\title{
Mreža slovenskih splošnih bolnišnic
}

Patricia Blatnik

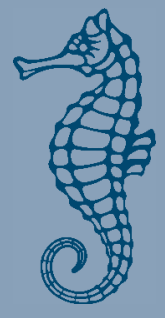


University of Primorska Press

Editorial Board

Gregor Pobežin

Maja Meško

Vito Vitrih

Silva Bratož

Aleksandra Brezovec

Ana Petelin

Janko Gravner

Krstivoje Špijunović

Miloš Zelenka

Jonatan Vinkler

Alen Ježovnik

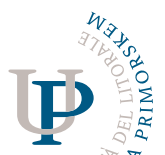

UNIVERT 


\section{Mreža slovenskih splošnih bolnišnic}

Patricia Blatnik

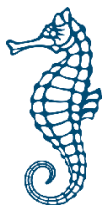


Mreža slovenskih splošnih bolnišnic

Patricia Blatnik

Recenzenta Alojz Ihan in Gaj Vidmar

Lektorirala . Anja Kolar

Prelom . Davorin Dukič

Izdala in založila . Založba Univerze na Primorskem

Titov trg 4, Koper · www.hippocampus.si

Glavni urednik . Jonatan Vinkler

Vodja založbe · Alen Ježovnik

(C) 2020 Univerza na Primorskem

Koper, december 2020

http://www.hippocampus.si/ISBN/978-96I-293-040-o.pdf

http://www.hippocampus.si/ISBN/978-96I-293-04I-7/index.html

https://doi.org/I0.26493/978-96I-293-040-O

Izid monografije je finančno podprla Javna agencija

za raziskovalno dejavnost Republike Slovenije iz sredstev

državnega proračuna iz naslova razpisa

za sofinanciranje znanstvenih monografij

(cc) BY-SA

Kataložni zapis o publikaciji (CIP) pripravili

v Narodni in univerzitetni knjižnici v Ljubljani

COBISS.SI-ID $=51484675$

ISBN 978-96I-293-040-O (pdf)

ISBN 978-96I-293-04I-7 (html) 


\section{Vsebina}

7 Slike

9 Preglednice

II Kratice

13 Uvod

17 Učinkovitost izvajalcev zdravstvene dejavnosti

I7 Teoretične iztočnice preučevanja učinkovitosti izvajalcev zdravstvene dejavnosti

I8 Opredelitev pojma učinkovitost znotraj ekonomske teorije

30 Opredelitev pojma učinkovitosti pri izvajalcih zdravstvene dejavnosti

37 Opredelitev pojma učinkovitosti znotraj mreže zdravstvenega varstva

38 Merjenje učinkovitosti izvajalcev zdravstvene dejavnosti

47 Pregled preučevanja učinkovitosti izvajalcev zdravstvene dejavnosti

5I Metodologija za izračun učinkovitosti izvajalcev zdravstvene dejavnosti

52 Ocenjevanje učinkovitosti z metodo SFA

67 Ocenjevanje učinkovitosti z metodo DEA

74 Opredelitev vzorca opazovanih bolnišnic

8o Rezultati ocenjevanja mer učinkovitosti izvajalcev zdravstvene dejavnosti

80 Rezultati ocenjevanja učinkovitosti z metodo SFA

92 Rezultati ocenjevanja učinkovitosti z metodo DEA

\section{Optimalna velikost izvajalcev zdravstvene dejavnosti}

II6 Teoretične iztočnice optimalne velikosti izvajalcev zdravstvene dejavnosti

II6 Optimalna velikost podjetjav ekonomski teoriji

135 Optimalna velikost izvajalcev zdravstvene dejavnosti 
I4I Metodologija za ocenjevanje optimalne velikosti izvajalca zdravstvene dejavnosti

150 Vzorec opazovanih bolnišnic

152 Podatki in spremenljivke opazovanih bolnišnic

I55 Rezultati ocenjevanja optimalne velikosti izvajalca zdravstvene dejavnosti

I62 Diskretna analiza optimalne velikosti izvajalca zdravstvene dejavnosti

I63 Zvezna analiza optimalne velikosti izvajalca zdravstvene dejavnosti

167 Grafična analiza optimalne velikosti izvajalca zdravstvene dejavnosti

I7I Optimalna lokacija izvajalcev zdravstvene dejavnosti

172 Teoretične iztočnice optimalne lokacije izvajalcev zdravstvene dejavnosti

172 Opredelitev pojma dostopnost do zdravstvenega varstva

174 Sinteza dostopnosti do zdravstvenega varstva

$\mathbf{1 7 7}$ Merjenje prostorske dostopnosti zdravstvenega varstva

190 Primeren potovalni čas do bolnišnice

194 Metodologija za preučevanje optimalnih lokacij izvajalcev zdravstvene dejavnosti

195 Modeli lokacija-alokacija

203 Podatki in spremenljivke modelov mreže sekundarne zdravstvene dejavnosti

206 Rezultati modelov mreže sekundarne zdravstvene dejavnosti

2 II Rezultati MI-modela

213 Rezultati MF-modela

216 Rezultati MC-modela

2 I8 Rezultati MA-modela

235 Ključne smernice postavitve optimalne mreže sekundarne zdravstvene dejavnosti

\section{Sklep}

\section{Literatura}

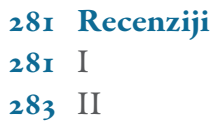




\section{Slike}

I9 Slika I: Tehnični učinkovitost in neučinkovitost, usmerjeni $\mathrm{k}$ inputom

2I Slika 2: Padajoči donosi obsega

22 Slika 3: Konstantni donosi obsega

22 Slika 4: Tehnični učinkovitost in neučinkovitost, usmerjeni k outputom

24 Slika 5: Alokacijski učinkovitost in neučinkovitost, usmerjeni k inputom

25 Slika 6: Alokacijski učinkovitost in neučinkovitost, usmerjeni k outputom

27 Slika 7: Stroškovna učinkovitost, usmerjena k inputom

29 Slika 8: Prihodkovna učinkovitost, usmerjena k outputom

I25 Slika 9: Funkcija TP, AP in MP

I28 Slika ı: Funkcija TC, VC, FC, AC, AVC, AFC in MC

130 Slika II: Funkcija STC, SAC, SMC in LTC, LAC in LMC

132 Slika I2: Kratkoročno ravnotežje popolnega konkurenta

134 Slika ı3: Dolgoročno ravnotežje popolnega konkurenta

I37 Slika I4: Optimalen obseg proizvodnje izvajalca zdravstvene dejavnosti

I40 Slika 15: Optimalna velikost izvajalca zdravstvene dejavnosti

I45 Slika I6: Linearna funkcija celotnih, povprečnih in mejnih stroškov

I47 Slika 17: Kvadratna funkcija celotnih, povprečnih in mejnih stroškov

I49 Slika I8: Kubična funkcija celotnih, povprečnih in mejnih stroškov

I50 Slika 19: Ocenjena funkcija dolgoročnih povprečnih stroškov

I6I Slika 20: Ocenjene funkcije dolgoročnih celotnih stroškov

I67 Slika 21: Ocenjena funkcija dolgoročnih celotnih stroškov

170 Slika 22: Ocenjena funkcija dolgoročnih povprečnih in dolgoročnih mejnih stroškov, ter premica cene

207 Slika 23: Razporeditev prebivalstva in lokacije obstoječih splošnih bolnišnic

208 Slika 24: Dostopnost do obstoječih splošnih bolnišnic v 30-minutnem časovnem intervalu 
209 Slika 25: Dostopnost do obstoječih splošnih bolnišnic v 45-minutnem časovnem intervalu

209 Slika 26: Dostopnost do obstoječih splošnih bolnišnic v 60-minutnem časovnem intervalu

210 Slika 27: Dostopnost do obstoječih splošnih bolnišnic brez časovne omejitve

212 Slika 28: MI-model pri 30-minutnem časovnem intervalu

213 Slika 29: MI-model pri 45-minutnem časovnem intervalu

214 Slika 30: MF-model pri 30-minutnem časovnem intervalu

215 Slika 3r: MF-model pri 60-minutnem časovnem intervalu

216 Slika 32: MC-model pri 30-minutnem časovnem intervalu

217 Slika 33: MC-model pri 45-minutnem časovnem intervalu

219 Slika 34: MA-model pri 30-minutnem časovnem intervalu

219 Slika 35: MA-model pri 45-minutnem časovnem intervalu

22I Slika 36: Primerjava obstoječih in optimalno lociranih splošnih bolnišnic znotraj 30-minutnega časovnega intervala

221 Slika 37: Primerjava pokritosti prebivalstva za obstoječe in optimalno locirane splošne bolnišnice znotraj 30-minutnega časovnega intervala

222 Slika 38: Primerjava obstoječih in optimalno lociranih splošnih bolnišnic znotraj 45-minutnega časovnega intervala

223 Slika 39: Primerjava pokritosti prebivalstva za obstoječe in optimalno locirane splošne bolnišnice znotraj 45-minutnega časovnega intervala

226 Slika 40: Optimalne lokacije devetih splošnih bolnišnic v 30-minutnem časovnem intervalu

227 Slika 41: Optimalne lokacije desetih splošnih bolnišnic v 30-minutnem časovnem intervalu

229 Slika 42: Optimalne lokacije štirih splošnih bolnišnic v 45-minutnem časovnem intervalu

230 Slika 43: Optimalne lokacije petih splošnih bolnišnic v 45-minutnem časovnem intervalu

232 Slika 44: Optimalni lokaciji dveh splošnih bolnišnic v 60-minutnem časovnem intervalu

248 Slika 45: Model raziskovanja mreže zdravstvenega varstva 


\section{Preglednice}

84 Preglednica r: Povprečna, minimalna in maksimalna tehnična učinkovitost splošnih bolnišnic, ocenjena z metodo SFA

85 Preglednica 2: Povprečna tehnična učinkovitost splošnih bolnišnic znotraj posameznih let, ocenjena z metodo SFA

89 Preglednica 3: Povprečna, minimalna in maksimalna stroškovna učinkovitost splošnih bolnišnic, ocenjena z metodo SFA

89 Preglednica 4: Povprečna stroškovna učinkovitost splošnih bolnišnice znotraj posameznih let, ocenjena z metodo SFA

95 Preglednica 5 : Povprečna, minimalna in maksimalna tehnična učinkovitost splošnih bolnišnic, ocenjena z metodo DEA

97 Preglednica 6: Povprečna tehnična učinkovitost splošnih bolnišnice znotraj posameznih let, ocenjena z metodo DEA

99 Preglednica 7: Povprečna, minimalna in maksimalna stroškovna učinkovitost splošnih bolnišnic, ocenjena z metodo DEA

IOI Preglednica 8: Povprečna stroškovna učinkovitost splošnih bolnišnice znotraj posameznih let, ocenjena z metodo DEA

I05 Preglednica 9: Povprečna, minimalna in maksimalna tehnična učinkovitost splošnih bolnišnic, ocenjena z metodo DEA

I06 Preglednica ıo: Povprečna tehnična učinkovitost splošnih bolnišnice znotraj posameznih let, ocenjena z metodo DEA

Io8 Preglednica II: Primerjava mer ekonomske učinkovitosti, ocenjene z metodo SFA in metodo DEA

II Preglednica I2: Povezanost mer ekonomske učinkovitosti ocenjene z metodo SFA in metodo DEA

II Preglednica I3: Povezava mer stroškovne, tehnične, alokacijske in učinkovitosti znotraj metode SFA 
II2 Preglednica I4: Povezava mer stroškovne, tehnične, alokacijske in učinkovitosti znotraj metode DEA

I58 Preglednica I5: Povzetek regresijskih modelov

158 Preglednica 16: Ocene parametrov regresijskih modelov

162 Preglednica 17: Podatki o outputu, celotnih in povprečnih stroških za leto 2014

205 Preglednica I8: Pripisane povprečne potovalne hitrosti na cestnem omrežju

206 Preglednica 19: Podatki o lokacijah obstoječih bolnišnic

207 Preglednica 20: Razporeditev prebivalstva po obstoječih bolnišnicah

225 Preglednica 21: Število splošnih bolnišnic in delež pokritosti prebivalcev znotraj 30-minutnega časovnega intervala

228 Preglednica 22: Število splošnih bolnišnic in delež pokritosti prebivalcev znotraj 45-minutnega časovnega intervala

23I Preglednica 23: Število splošnih bolnišnic in delež pokritosti prebivalcev znotraj 60-minutnega časovnega intervala 


\section{Kratice}

AJPES Agencija Republike Slovenije za javnopravne evidence in storitve

BDP Bruto domači proizvod

DEA Metoda podatkovne ovojnice

FTE Ekvivalent polne zaposlitve

GIC Geografski informacijski sistem

SFA Metoda stohastična mejne analize

SURS Statistični urad Republike Slovenije 



\section{Uvod}

Slovensko zdravstvo se srečuje $z$ vedno večjimi težavami. Na eni strani se podaljšujejo čakalne dobe, na drugi pa za zdravstveno varstvo namenjamo vedno več sredstev. V zadnjih letih imajo predvsem izvajalci na sekundarni ravni zdravstvene dejavnosti vedno večje težave z likvidnostjo sredstev, zato je osrednji izziv zagotoviti finančno vzdržnost sistema. Glede na vedno večje zahteve po restriktivni fiskalni politiki, ki je posledica predvsem finančne krize večine držav po svetu, se je treba lotiti reorganizacije in optimizacije slovenskega zdravstvenega sistema. Glede na dejstvo, da se za bolnišnično dejavnost namenja daleč največ sredstev znotraj zdravstvenega varstva in da se izvajalci na sekundarni ravni zdravstvene dejavnosti srečujejo z največjimi težavami, je smiselno preučevati pristope za optimizacijo izvajalcev sekundarne ravni zdravstvene dejavnosti. V tej luči je vpeljava ekonomskih mehanizmov za preučevanje učinkovitosti izvajalcev in optimalne velikosti, optimalnih lokacij ter optimalnega števila izvajalcev in posledično postavitev optimalne mreže sekundarne zdravstvene dejavnosti ključ do prihrankov oziroma učinkovitejšega zdravstvenega sistema.

Raziskovalci že vrsto leto poskušajo odgovoriti na vprašanje, kakšna je učinkovita mreža izvajalcev zdravstvene dejavnosti. Mreža zdravstvenega varstva je namreč ena izmed temeljnih iztočnic pri oblikovanju zdravstvene politike. Vprašanje pa ni pomembno samo z vidika oblikovalcev zdravstvene politike, ampak tudi z vidika družbe kot celote, saj mreža zdravstvenega varstva na eni strani oblikuje ponudbeno stran, na drugi strani pa vpliva tudi na povpraševanje po zdravstvenih storitvah. Pri oblikovanju mreže zdravstvene dejavnosti je treba slediti cilju maksi- 
miranja ekonomske učinkovitosti izvajalcev zdravstvene dejavnosti in cilju maksimiranja dostopnosti izvajalcev zdravstvenih storitev do posameznega bolnika. Pri zagotavljanju prvega cilja moramo upoštevati, da je eden izmed ključnih dejavnikov ekonomske učinkovitosti tudi velikost izvajalcev, ki je povezana $\mathrm{z}$ ustrezno stopnjo koncentracije zdravstvenih dejavnosti. Pri uresničevanju drugega cilja pa je treba zagotoviti, da se zdravstvene storitve čim bolj približajo posameznemu bolniku, pri čemer sta ključna dejavnika dostopnosti lokacija in število izvajalcev sekundarne zdravstvene dejavnosti. Skladno z obema ciljema mreže zdravstvenega varstva $\mathrm{v}$ monografiji preučujemo mere učinkovitosti izvajalcev sekundarne zdravstvene dejavnosti, njihovo optimalno velikost in optimalne lokacije ter število izvajalcev sekundarne zdravstvene dejavnosti, kar je podlaga za oblikovanje učinkovite mreže sekundarne zdravstvene dejavnosti.

Izdatki za zdravstvo v večini razvitih držav vse bolj naraščajo in predstavljajo pomemben delež v bruto domačem proizvodu - BDP. Zaradi staranja prebivalstva, večje ozaveščenosti ljudi, predvsem pa zaradi uvajanja sodobnejših zdravstvenih tehnologij se zdravstvo srečuje s potrebo po vedno večji porabi sredstev. $V$ zadnjih letih predstavlja glavni razlog za rast deleža zdravstvenih izdatkov v BDP-ju predvsem hiter napredek na področju zdravstvene tehnologije, pri čemer je pričakovati, da se bo v prihodnosti pritisk na rast zdravstvenih izdatkov samo še povečeval (Došenović Bonča 20I4). Ob predpostavki, da bodo zdravstvu namenjena sredstva vsaj še nekaj let ostala na enaki ravni, kar je posledica predvsem ekonomske krize in restriktivne fiskalne politike z omejevanjem proračunske porabe, je treba, če ne želimo zaustaviti napredka in razvoja na področju zdravstva, povečati učinkovitost zdravstvenega sistema. Med ukrepi, s katerimi lahko povečamo učinkovitost zdravstvenega sistema, je optimizacija mreže zdravstvenega varstva. Za učinkovit zdravstveni sistem je torej ključno odgovoriti na vprašanja o mreži zdravstvenega varstva.

$\mathrm{V}$ prihodnje bo torej za oblikovalce zdravstvene politike eden izmed ključnih izzivov postavitev učinkovite mreže zdravstvene dejavnosti. Mreža zdravstvenega varstva v razvitih tržnih gospodarstvih in v literaturi velja za enega ključnih nefinančnih mehanizmov selekcije in s tem tudi racionalnega obnašanja bolnikov kot porabnikov zdravstvenih storitev (Drummond idr. 2003; Nixon idr. 2004; Pouvourville idr. 2005). $\mathrm{V}$ monografiji se osredotočamo na bolnišnično dejavnost, pri čemer poskušamo prikazati možnosti za postavitev učinkovite mreže sekundarne zdravstvene dejavnosti. To izhaja iz ugotovitve, da se v večini držav za se- 
kundarno raven zdravstvene dejavnosti namenja največ sredstev, namenjenih izvajanju zdravstvenega varstva. Bolnišnična dejavnost bo kljub naraščajočemu pomenu primarne ravni zdravstvene dejavnosti tudi v prihodnje zahtevala velik delež finančnih sredstev, ki se namenjajo za zdravstveno varstvo. Skladno s tem je preučevanje delovanja bolnišnične dejavnosti še posebej pomembno, saj je z optimizacijo sekundarne zdravstvene dejavnosti mogoče ustvariti pomembne prihranke $\mathrm{v}$ celotnem sistemu zdravstvenega varstva.

Opredeljevanje mreže sekundarne zdravstvene dejavnosti je povezano $s$ funkcijo zdravstvenega varstva. Zdravstvena funkcija ima namreč specifično obliko in vsebuje tri korake. $\mathrm{V}$ teh treh korakih ugotavljamo učinkovitost in uspešnost zdravstvenega varstva. $\mathrm{V}$ prvem koraku se vzpostavlja odnos med inputi in outputi v obliki zdravstvenih storitev (Feldstein 20I I). Prav v tem odnosu se oblikuje ekonomska učinkovitost v obliki tehnične, alokacijske in stroškovne učinkovitosti (Debreu I95I; Koopmans 195 I; Farrell 1957; Coelli, Prasada Rao in Battese 1998; Zhu 2003; Coelli idr. 2005). Dejavniki teh učinkovitosti so različni, oblika mreže zdravstvenega varstva pa lahko vpliva nanje preko večje ali manjše stopnje koncentracije zdravstvenih dejavnosti. Ta namreč odloča o velikosti izvajalcev. Velikost izvajalcev tako predstavlja pomemben dejavnik njihove učinkovitosti. Tako $\mathrm{v}$ teoriji kot $\mathrm{v}$ praksi zato govorimo o optimalni velikosti izvajalcev (Pindyck in Rubinfeld 2013; Mankiw 2014). Ustrezna stopnja koncentracije zdravstvenih dejavnosti oziroma optimalna velikost zdravstvenih izvajalcev je torej povezana s prvim korakom zdravstvene funkcije. S tem korakom je tako povezan cilj doseganja ekonomske učinkovitosti izvajalcev v mreži zdravstvenega varstva.

Drugi korak zdravstvene funkcije je vezan na odnos med obsegom in vrsto zdravstvenih storitev ter zdravjem prebivalstva (Feldstein 201 I). Ekonomska učinkovitost tako ni povezana z drugim korakom zdravstvene funkcije, slednje pa velja tudi za tretji korak zdravstvene funkcije, ki vzpostavlja odnos med zdravjem prebivalstva in koristnostjo, ki jo to zdravje prinaša posamezniku (Zweifel, Breyer in Kifmann 2009). Sta pa drugi in zlasti tretji korak zdravstvene funkcije povezan s ciljem zdravstvene storitve čim bolj približati posameznemu prebivalcu in s tem doseči večjo stopnjo dostopnosti zdravstvenega varstva. To pomeni, da čim bližje so lokacijsko storitve zdravstvenega varstva bolniku, tem bolj lahko ob enakem obsegu in strukturi prispevajo $\mathrm{k}$ zdravju prebivalstva. Po drugi strani pa naj bi veljalo, da dostopnost zdravstvenih storitev prebivalstvu in zlasti bolnikom sama po sebi vpliva na koristnost, ki jo te storitve lahko izzovejo pri bolnikih. Domnevamo torej, da je dostopnost 
sama po sebi odvisna od ponudbe zdravstvenih storitev, ki vpliva na koristnost, ki jo zdravje daje posamezniku. Vpliv zdravstvenih storitev preko zdravja na koristnost bolnikov tako kaže uspešnost zdravstvenega varstva (Berndt 2000; Phelps 2012).

Razumljivo je, da ekonomska učinkovitost $\mathrm{v}$ prvem koraku zdravstvene funkcije sama po sebi še ne zagotavlja uspešnosti zdravstvenega varstva v drugem in tretjem koraku zdravstvene funkcije ter da so določene organizacijske oblike mreže zdravstvenega varstva, ki so učinkovite $\mathrm{v}$ prvem koraku, lahko neuspešne z vidika drugega in zlasti tretjega koraka zdravstvene funkcije. Organizacijska oblika, ki zagotavlja visoko stopnjo ekonomske učinkovitosti, na primer $\mathrm{v}$ vseh primerih ne zagotavlja tudi visoke stopnje koristnosti pri posameznem prebivalcu, če je takšna ponudba zdravstvenih storitev zelo oddaljena od posameznika in mu je zato tudi manj dostopna.

V monografiji preučujemo tehnično, alokacijsko in stroškovno učinkovitost v obliki ekonomske učinkovitosti, ki je definirana skladno z ožjo opredelitvijo zdravstvene funkcije. Ekonomska učinkovitost je povezana z velikostjo izvajalcev, zato je ključno vprašanje, kakšna je optimalna velikost izvajalcev zdravstvene dejavnosti. Pri definiranju optimalne velikosti bolnišnice smo sledili mikroekonomski teoriji, ki je v bistvu v ozadju tudi skoraj vseh drugih teorij o optimalni velikosti podjetja. Stopnja dostopnosti zdravstvenega varstva pa je povezana $\mathrm{z}$ drugim in tretjem korakom zdravstvene funkcije, kar pomeni, da smo pri določitvi števila bolnišnic in njihove optimalne lokacije sledili širši opredelitvi zdravstvene funkcije (Berndt 2000; Feldstein 2011; Phelps 2012). Posamezno zdravstveno storitev smo tako poskušali čim bolj geografsko približati vsakemu posameznemu prebivalcu, hkrati pa so ponudniki teh zdravstvenih storitev organizirani na način, da preko optimalne velikosti dosegajo tehnično, alokacijsko in stroškovno učinkovitost.

Postavitev mreže sekundarne zdravstvene dejavnosti je kompleksen problem in se dotika različnih področij ekonomskih in medicinskih ved pa tudi geodetskih znanosti. Temeljna značilnost dosedanjega preučevanja mreže zdravstvenega varstva je $\mathrm{v}$ tem, da raziskovalci v splošnem svojega preučevanja niso zasnovali na teoriji ali niso imeli namena povezati teoretičnih spoznanj z empiričnim preučevanjem. Predlagani model mreže sekundarne zdravstvene dejavnosti je tako izrazito aplikativne narave, hkrati nudi podlago za oblikovanje učinkovitega sistema zdravstvenega varstva tako v slovenskem kot tudi v svetovnem prostoru. 


\section{Učinkovitost izvajalcev zdravstvene dejavnosti}

Oblikovalci zdravstvene politike se pogosto srečujejo $\mathrm{z}$ vprašanjem oblikovanja mreže sekundarne ravni zdravstvenega varstva. Odgovori na vprašanja o mreži so ključni za celoten zdravstveni sistem, saj v svojem bistvu definirajo ponudbeno stran, hkrati pa vplivajo tudi na povpraševanje po zdravstvenih storitvah. Mrežo sekundarne zdravstvene dejavnosti sestavljajo izvajalci zdravstvenih storitev na sekundarni ravni. Eden izmed temeljnih dejavnikov mreže je učinkovitost izvajalcev zdravstvene dejavnosti. Od doseganja ekonomske učinkovitosti izvajalcev so odvisni izdatki za zdravstveno varstvo, kar vpliva na celotno obliko mreže sekundarne zdravstvene dejavnosti.

$\mathrm{V}$ tem delu monografije analiziramo učinkovitost izvajalcev sekundarne zdravstvene dejavnosti, ki se oblikuje v obliki tehnične, alokacijske in stroškovne učinkovitosti. Na podlagi ocenjevanja mer učinkovitosti opredelimo količnike posameznih mer učinkovitosti, kar predstavlja podlago pri definiranju ekonomsko najučinkovitejše slovenske splošne bolnišnice. $Z$ analiziranjem količnikov tehnične, alokacijske in stroškovne učinkovitosti želimo odgovoriti na vprašanje, kakšna učinkovita splošna bolnišnica naj deluje znotraj mreže sekundarne zdravstvene dejavnosti. Na ta način lahko identificiramo najučinkovitejšo slovensko splošno bolnišnico.

Teoretične iztočnice preučevanja učinkovitosti izvajalcev zdravstvene dejavnosti

Učinkovitost je eden izmed temeljnih pojmov, ki jih obravnavamo v sodobni ekonomski teoriji. V svojem bistvu ponazarja odnos med porablje- 
nimi inputi in outputi. $V$ primeru podjetja govorimo o razmerju med porabljenimi proizvodnimi dejavniki in obsegom proizvodnje. $S$ pojmom učinkovitost ponazarjamo ekonomsko učinkovitost, ki se kaže v obliki tehnične, alokacijske in stroškovne učinkovitosti. Iztočnice znotraj ekonomske teorije, ki govorijo o učinkovitosti podjetij, lahko uporabimo tudi pri definiranju učinkovitosti izvajalcev zdravstvene dejavnosti.

\section{Opredelitev pojma učinkovitost znotraj ekonomske teorije}

Prvo opredelitev pojma učinkovitost v ekonomski teoriji je podal Farrell (1957); ta temeljil na delu Debreua (195I) in Koopmansa (195I). Farrell je uvedel pojem relativne učinkovitosti, $\mathrm{v}$ katerem je učinkovitost osrednje enote za sprejemanje poslovnih odločitev (angl. decision making unit) lahko v primerjal z učinkovitostjo druge enote. Opredelil je tri vrste učinkovitosti - tehnično učinkovitost, alokacijsko učinkovitost in stroškovno oziroma ekonomsko učinkovitost. Farrell je v svojem besedilu za pojmovanje alokacijske učinkovitosti uporabil izraz »učinkovitost cen«, ekonomsko učinkovitost pa je opredelili kot »splošno učinkovitost «. Tehnična učinkovitost se nanaša na spodobnost proizvajalca, da dani obseg outputa proizvede z minimalnim obsegom inputov. Kot tehnično učinkovitega proizvajalca lahko opredelimo tudi tistega, ki z danimi inputi proizvede največji možen obseg outputov. Prva možnost je torej mera tehnične učinkovitosti, usmerjena $\mathrm{k}$ inputom, medtem ko drugo možnost imenujemo mera tehnične učinkovitosti, usmerjena $\mathrm{k}$ outputom. Alokacijsko učinkovitost proizvajalec doseže, če za proizvodnjo določenega obsega outputa uporablja ustrezno kombinacijo inputov glede na njihove relativne cene. Medtem ko lahko proizvajalec določeno raven outputa proizvede $\mathrm{z}$ različno kombinacijo inputov, je proizvajalec alokacijsko učinkovit le, če se inputi kombinirajo na način, ki omogoča proizvodnjo z najnižjimi možnimi stroški. Tehnična in alokacijska učinkovitost sta dve sestavini skupne stroškovne učinkovitosti, ki jo imenujemo tudi ekonomska učinkovitost (Farrell 1957). Stroškovna oziroma ekonomska učinkovitost je opredeljena kot produkt tehnične in alokacijske učinkovitosti. Proizvajalec je torej stroškovno učinkovit, če je hkrati tehnično in tudi alokacijsko učinkovit (Debreu 195 I; Farrell 1957; Coelli, Prasada Rao in Battese 1998; Coelli idr. 2005; Daraio in Simar 2007; Fried, Lovell in Schmidt 2008; Greene 2008).

\section{Tehnična učinkovitost}

Proizvajalci so tehnično učinkoviti, če proizvajajo določen obseg outputa v maksimalnem obsegu glede na razpoložljivo tehnologijo in razpoložlji- 
ve proizvodne dejavnike oziroma inpute. $\mathrm{Na}$ enak način lahko opredelimo proizvajalce kot tehnično učinkovite, ko pri proizvodnji določenega obsega outputa uporabljajo najmanjši možni obseg proizvodnih dejavnikov oziroma inputov skladno z razpoložljivo tehnologijo (Coelli, Prasada Rao in Battese 1998; Coelli idr. 2005; Fried, Lovell in Schmidt 2008; Greene 2008). Koopmans (I95 I) v svojem delu navaja, da je proizvajalec tehnično učinkovit, če mora ob povečanju posameznega outputa zmanjšati količino vsaj enega od preostalih outputov, ali v primeru, ko mora povečati količino vsaj enega od uporabljenih inputov. Koopmans (I95I) $\mathrm{v}$ nadaljevanju navaja, da je proizvajalec tehnično učinkovit, če mora ob zmanjšanju količine posameznega inputa povečati količino vsaj enega od preostalih inputov, ali v primeru, ko mora zmanjšati količino vsaj enega od proizvedenih outputov. Tehnično učinkovit proizvajalec lahko torej dano raven outputa proizvede $\mathrm{z}$ manjšo količino uporabljenih inputov, druga možnost pa je, da z dano količino inputov proizvede višjo raven outputa (Daraio in Simar 2007).

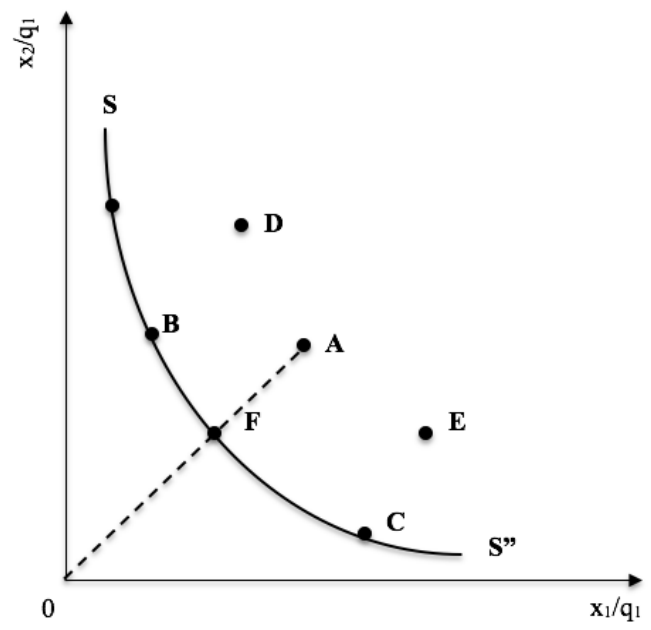

Slika I: Tehnični učinkovitost in neučinkovitost, usmerjeni k inputom

Vir: prirejeno po Coelli idr. (2005, 52).

Tehnično učinkovitost, kjer mora proizvajalec proizvajati dan obseg outputa z najmanjšim obsegom inputov, imenujemo mera tehnične učinkovitosti, usmerjena k inputom, ki sta jo Debreu (195I) in Farrell (1957) opredelila kot največje možno sorazmerno zmanjšanje inputov glede na dano raven outputa in razpoložljive tehnologije. Tehnično učinkoviti proizvajalci so torej tisti, ki uporabljajo najugodnejše razmerje med različnimi inputi. $V$ primerjavi s tehnično neučinkovitimi proizvajalci lahko 
tehnično učinkoviti proizvajalci proizvedejo enak obseg outputa z manjšo količino porabljenih inputov. Tehnično učinkovitost opredelimo na podlagi produkcijske funkcije, ki je v obliki izokvante. Primer produkcijske funkcije $s$ tehnično učinkovitimi in neučinkovitimi proizvajalci prikazuje slika $\mathrm{I}$.

Predpostavljamo, da imajo proizvajalci na voljo dva proizvodna dejavnika, input $x_{1}$ in input $x_{2}, s$ katerima proizvajajo določen obseg outputa $\mathrm{q}_{\mathrm{I}}$ ob predpostavki konstantnih donosov obsega. Poznavanje posameznih točk proizvodnje omogoča merjenje tehnične učinkovitosti. Proizvajalci na produkcijski funkciji, ki uporabljajo najugodnejšo kombinacijo inputov ob določenem outputu, so tehnično učinkoviti in se zato nahajajo se na izokvanti SS”. Proizvajalci, ki proizvajajo s takšnimi kombinacijami inputov, da se nahajajo izven izokvante SS", pa so tehnično neučinkoviti. $\mathrm{V}$ tem primeru namreč proizvajajo $\mathrm{z}$ večjim obsegom inputa od konkurentov. Pri takšnih kombinacijah inputov je namreč mogoče proizvesti večji obseg outputa.

Za proizvajalce $\mathrm{B}, \mathrm{F}$ in $\mathrm{C}$, ki jih prikazuje slika $\mathrm{I}$, torej velja, da so tehnično učinkoviti, saj ni proizvajalca, ki bi potreboval manj inputov. Njihova mera učinkovitosti je I. Za proizvajalce, ki proizvajajo s kombinacijami inputov, ki jih prikazujejo točke $\mathrm{D}, \mathrm{A}$ in $\mathrm{E}$, pa velja, da so tehnično neučinkoviti. Tehnična neučinkovitost je oddaljenost od produkcijske funkcije in je na sliki I prikazana kot razdalja od točke A do točke F. Tehnično učinkovitost proizvajalca torej definiramo kot (Coelli, Prasada Rao in Battese 1998; Coelli idr. 2005; Hollingsworth in Peacock 2008; Bogetoft in Otto 201 I):

$$
T E=0 F / 0 A \text {, }
$$

kar je enako:

$$
T E=1-F A / 0 A=1-d_{i}(x, q) .
$$

Razmerje 0F/0A je kazalnik stopnje tehnične učinkovitosti proizvajalca, ki zavzame vrednost med 0 in 1 . Vrednost 1 pomeni, da je proizvajalec $\mathrm{v}$ celoti tehnično učinkovit, če pa kazalnik zavzame vrednost manjšo od I, pa pomeni, da je proizvajalec tehnično neučinkovit. Razmerje $0 \mathrm{~F} / 0 \mathrm{~A}$ nam pove, za koliko odstotkov mora proizvajalec zmanjšati obseg porabljenih inputov, če želi postati tehnično učinkovit. Če je, na primer, tehnična učinkovitost proizvajalca A 0,75 , potem znaša njegova tehnična neučinkovitost 0,25 , kar pomeni 25 odstotkov. Proizvajalec $\mathrm{F}$ namreč potrebuje zgolj 75 odstotkov inputov od tehnično neučinkovitega proizvajalca A. 
Zgoraj omenjena $\mathrm{k}$ inputom usmerjana tehnična učinkovitost se ukvarja z vprašanjem, ki nam pove, za koliko se lahko količine inputov zmanjšajo, če ne želimo spreminjati količine outputa? Lahko pa postavimo tudi alternativno vprašanje: »Za koliko lahko povečamo količino outputa ob predpostavki, da ohranimo nespremenjene količine inputov?« (Coelli, Prasada Rao in Battese 1998; Coelli idr. 2005) V tem primeru dobimo mere tehnične učinkovitosti, usmerjene v outpute, ki so nasprotne od mer tehnične učinkovitosti, usmerjene $\mathrm{k}$ inputom. Mera tehnične učinkovitost, usmerjena v outpute, je enaka, če od vrednosti ena odštejemo največje možno sorazmerno zmanjšanje inputov glede na dano raven outputa in razpoložljivo tehnologijo. $\mathrm{Z}$ drugimi besedami - mera tehnične učinkovitosti je enaka maksimalnemu sorazmernemu povečanju vseh outputov, ki je možno ob dani ravni inputov in razpoložljivi tehnologiji (Debreu 195 1; Farrell 1957). Razliko med merami tehnične učinkovitosti, usmerjene $\mathrm{v}$ outpute in inpute lahko ponazorimo s pomočjo preprostega primera, ki vključuje input $X_{1}$ in output $q_{1}$. To je prikazano na sliki 2 , kjer je produkcijska funkcija s padajočimi donosi obsega označena z $f(x)$ in neučinkovitost proizvajalca s točko P.

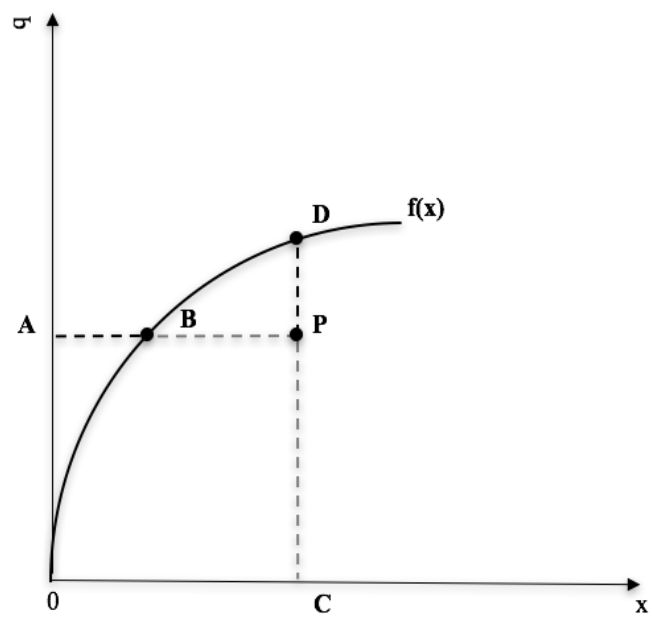

Slika 2: Padajoči donosi obsega

Vir: prirejeno po Coelli idr. $(2005,55)$.

Debreu-Farrellova mera tehnične učinkovitosti, usmerjena $\mathrm{k}$ inputom, je enake razmerju $A B / A P$, medtem ko mero tehnične učinkovitosti, usmerjeno k outputom, predstavlja razmerje $C P / C D$. Mere tehnične učinkovitosti, usmerjene $\mathrm{k}$ outputom, so enake meram tehnične učinkovitosti, usmerjenim $\mathrm{k}$ inputom zgolj v primeru, ko imamo v obeh prime- 
rih opravka s konstantnimi donosi obsega (Färe in Lovell 1978). Konstantne donose obsega prikazuje slika 3 , kjer za neučinkovitega proizvajalca $P$ velja, da je $A B / A P=C P / C D$.

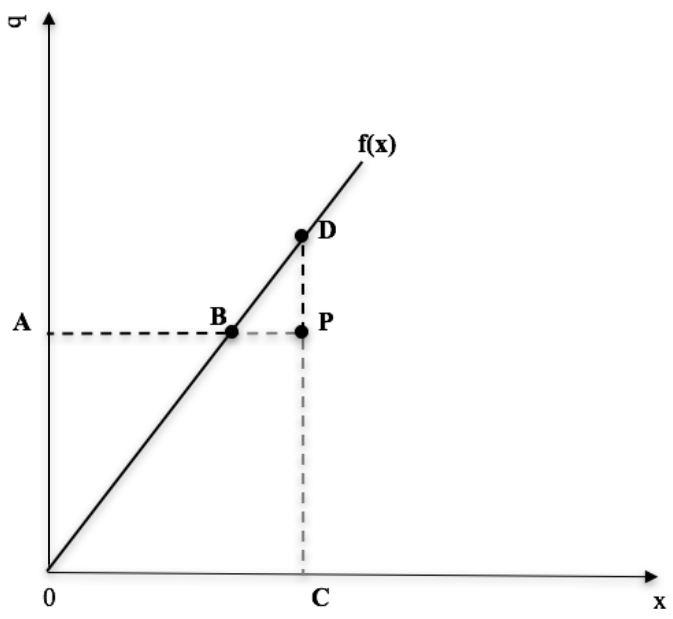

Slika 3: Konstantni donosi obsega

Vir: prirejeno po Coelli idr. (2005, 55).

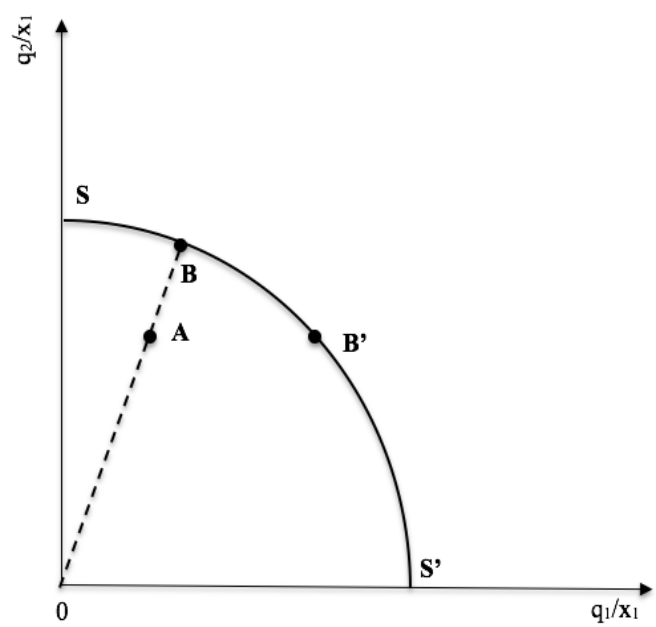

Slika 4: Tehnični učinkovitost in neučinkovitost, usmerjeni k outputom

Vir: prirejeno po Coelli idr. (2005, 55).

Sedaj lahko mere tehnične učinkovitosti, usmerjene k outputom, prikažemo na primeru, ko proizvajalec proizvaja dva outputa, $q_{1}$ in $q_{2}$, in 
input $X_{1}$. Če predpostavimo, da imamo opravka s konstantnimi donosi obsega, lahko prikažemo produkcijo funkcijo v dveh dimenzijah. Ta primer je prikazan na sliki 4 , kjer je krivulja produkcijska funkcija SS' in točka A ustreza tehnični neučinkovitosti proizvajalca. Pri tem je treba upoštevati, da tehnično neučinkovit proizvajalec A leži pod krivuljo, saj krivulja SS' predstavlja zgornjo mejo proizvodnih možnosti.

Debreu-Farrellova mera tehnične učinkovitosti, usmerjena k outputom, je opredeljena na način, ki ga ponazarja spodnje razmerje (Debreu I95 I; Farrell 1957; Färe, Grosskopf in Lovell 1985 in 1994). Na sliki 4 razdalja $A B$ ponazarja tehnično neučinkovitost, kar predstavlja vrednost, za katero bi lahko proizvajalec povečal output, ne da bi pri tem povečal obseg zaposlenih inputov. Mero tehnične učinkovitosti, usmerjeno k outputom, lahko torej ponazorimo z naslednjim razmerjem (Coelli, Prasada Rao in Battese I998; Coelli idr. 2005):

$$
T E=0 A / 0 B=d_{0}(x, q) .
$$

Razmerje 0 A/0 B je kazalnik stopnje tehnične učinkovitosti proizvajalca, ki zavzame vrednost med 0 in 1 . Vrednost 1 pomeni, da je proizvajalec $v$ celoti tehnično učinkovit, če pa kazalnik zavzame vrednost, ki je večja od 1 , to pomeni, da je proizvajalec tehnično neučinkovit.

\section{Alokacijska učinkovitost}

Pri alokacijski učinkovitosti si je treba zastaviti naslednja vprašanja: »Kakšna je optimalna kombinacija proizvodnih dejavnikov oziroma inputov, da proizvedemo output z minimalnimi možnimi stroški? Za koliko lahko povečamo dobiček, če izvedemo preprosto prerazporeditev inputov oziroma uporabimo drugačno kombinacijo inputov? « Pri alokacijski učinkovitosti mora torej proizvajalec izbrati kombinacijo inputov v pravih razmerjih glede na njihove cene, kar mu bo omogočilo, da bo output proizvajal z najnižjimi povprečnimi stroški. Če je proizvajalec alokacijsko učinkovit, doseže tudi maksimalen dobiček. V tem primeru bo namreč izbral takšno kombinacijo proizvodnih dejavnikov, pri katerih bodo stroški na enoto proizvoda najmanjši (Badunenko, Fritsch in Stephan 2006; Fried, Lovell in Schmidt 2008).

Alokacijsko učinkovitost lahko ocenjujemo, če poznamo cene inputov. Ocenjevanje alokacijske učinkovitosti brez cen inputov je namreč precej zahtevno. Nekateri znanstveniki, kot npr. Farrell (1957), so s tem namenom alokacijsko učinkovitost poimenovali učinkovitost cen, ki se nanaša na sposobnosti proizvajalca, da izbere optimalno kombinaci- 
jo inputov ob danih cenah. Če razpolagamo s podatki o cenah inputov in če proizvajalec sledi konceptu minimiranja stroškov in maksimiranja prihodkov, lahko določimo mere alokacijske učinkovitosti. Alokacijsko učinkovit proizvajalec pri izbiri inputov izbere ustrezno kombinacijo proizvodnih dejavnikov, na primer dela in kapitala, s katerimi lahko proizvede določeno količino proizvodov z najnižjimi povprečnimi stroški glede na cene surovin in delovne sile, ki prevladujejo (Daraio in Simar 2007).

Če želimo meriti alokacijsko učinkovitost, moramo v koordinatnem sistemu poleg produkcijske funkcije opredeliti še premico minimalnih stroškov. Grafično to pomeni, da moramo poleg izokvante vrisati še izokosto. Izokosta povezuje vse tiste točke, ki kažejo tiste kombinacije proizvodnih dejavnikov pri njihovih danih cenah, ki ohranjajo enako raven stroškov. Proizvajalec, ki želi minimirati svoje stroške, bo torej iskal točko, v kateri bodo stroški na enoto proizvoda najmanjši, kar prikazuje slika 5 .

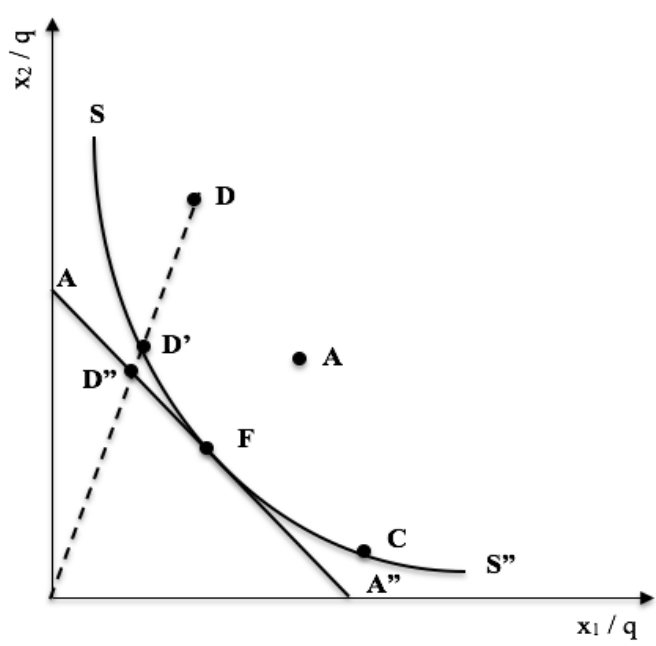

Slika 5: Alokacijski učinkovitost in neučinkovitost, usmerjeni k inputom Vir: prirejeno po Coelli idr. (2005, 52).

Alokacijska učinkovitost ocenjuje, ali proizvajalec uporablja različne proizvodne dejavnike oziroma inpute $\mathrm{v}$ najboljšem razmerju glede na njihove cene. Naklon premice enakih stroškov ali izokoste, ki je na grafu označena z AA", je enak razmerju cen med dvema proizvodnima dejavnikoma. Če želi biti proizvajalec alokacijsko učinkovit, mora uporabljati takšno razmerje inputov, da se bo nahajal v točki F. Z drugimi besedami - mora se nahajati v točki, kjer je premica enakih stroškov tangenta na produkcijsko funkcijo. $\mathrm{V}$ točki $\mathrm{F}$ je proizvajalec tako tehnično kot tudi 
alokacijsko učinkovit. Skladno s sliko 5 lahko alokacijsko učinkovitost matematično opredelimo kot razmerje (Coelli, Prasada Rao in Battese 1998; Coelli idr. 2005; Hollingsworth in Peacock 2008; Bogetoft in Otto 20II):

$$
A E=O D^{\prime \prime} / O D^{\prime},
$$

kar je enako:

$$
A E=1-D^{\prime \prime} D^{\prime} / 0 \text {. }
$$

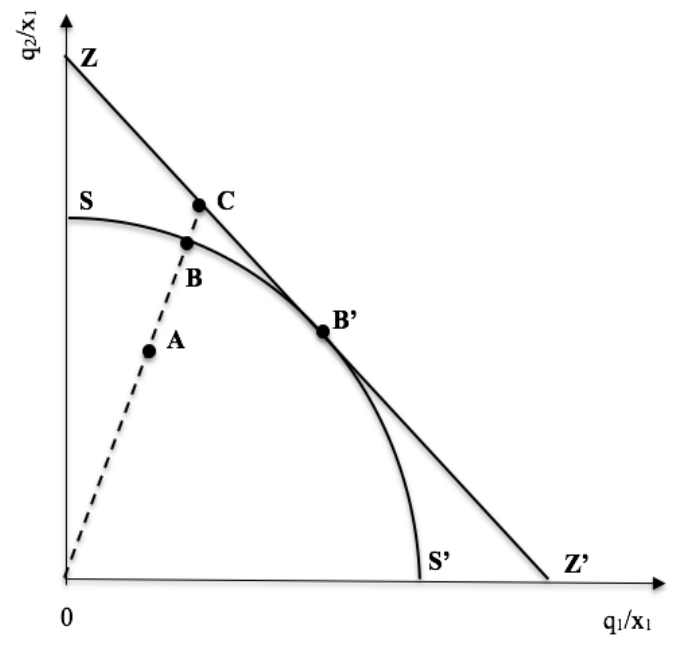

Slika 6: Alokacijski učinkovitost in neučinkovitost, usmerjeni k outputom

Vir: prirejeno po Coelli idr. (2005, 55$)$.

Ta enačba izhaja iz ugotovitve, da razdalja D’D” predstavlja znižanje proizvodnih stroškov, ki bi se pojavili, če bi proizvajalec prešel iz sicer tehnično učinkovite, vendar alokacijsko neučinkovite točke D' v tehnično in hkrati tudi alokacijsko učinkovito točko F. Proizvajalec bo alokacijsko neučinkovit tudi, če bo uporabljal sicer tehnično učinkovito kombinacijo inputov, vendar ta hkrati ne bo ustrezna glede na relativne cene inputov. Alokacijsko neučinkovitost proizvajalca lahko v tem primeru odpravimo $s$ prerazporeditvijo inputov in uporabo drugačne kombinacije inputov. Podobno kot pri tehnični učinkovitosti lahko alokacijsko učinkovitost ugotavljajmo tudi na primeru modela, usmerjenega v outpute. Mere alokacijske učinkovitosti, usmerjene k outputom, lahko prikažemo na pri- 
meru, ko proizvajalec proizvaja dva outputa, $q_{1}$ in $q_{2}$, in input $x_{1}$. Če predpostavimo, da imamo opravka s konstantnimi donosi obsega, lahko prikažemo mejo proizvodnih možnosti in funkcijo enakih prihodkov $\mathrm{v}$ dveh dimenzijah. V primeri, ko želimo meriti alokacijsko učinkovitost, moramo na produkcijsko funkcijo ZZ" vrisati tangento DD”. To prikazuje slika 6.

Alokacijsko učinkovitost lahko merimo, ko razpolagamo s podatki o cenah outputov. Na sliki 6 razdalja BC ponazarja alokacijsko neučinkovitost, kar predstavlja vrednost, za katero bi lahko proizvajalec povečal prihodek, ne da bi pri tem spremenil obseg razpoložljivih inputov. Proizvajalec bo alokacijsko neučinkovit, če bo uporabljal sicer tehnično učinkovito kombinacijo inputov, vendar ta hkrati ne bo ustrezna glede na relativne cene inputov. Alokacijsko neučinkovitost proizvajalca lahko v tem primeru odpravimo s prerazporeditvijo inputov in uporabo drugačne kombinacije inputov. Medtem ko je proizvajalec, ki ga označuje točka B tehnično učinkovit, ker leži na meji proizvodnih možnosti, bi lahko proizvajalec dosegel višji prihodek v točki B'. To je točka, kjer je mejna stopnja proizvodne transformacije enaka razmerju cen $\mathrm{p}_{2}$ in $\mathrm{p}_{\mathrm{r}}$. Če želi proizvajalec povečati prihodke, bo moral proizvajati več proizvoda $q_{1}$ in manj proizvoda $q_{2}$. Mero alokacijske učinkovitosti, usmerjeno k outputom, lahko ponazorimo z naslednjim razmerjem (Coelli, Prasada Rao in Battese 1998; Coelli idr. 2005; Hollingsworth in Peacock 2008; Bogetoft in Otto 2011):

$$
A E=0 B / 0 C .
$$

Razmerje 0 B/OC je kazalnik stopnje alokacijske učinkovitosti proizvajalca, ki zavzame vrednost med 0 in 1 . Vrednost 1 pomeni, da je proizvajalec v celoti alokacijsko učinkovit, če pa kazalnik zavzame vrednost, večjo od 1, pa pomeni, da je proizvajalec alokacijsko neučinkovit.

\section{Stroškovna učinkovitost}

Alokacijska in tehnična učinkovitost predstavljata skupno stroškovno učinkovitost, imenovano tudi ekonomska učinkovitost (Farrell 1957). Stroškovno oziroma ekonomsko učinkovitost opredelimo kot produkt med tehnično in alokacijsko učinkovitostjo. Proizvajalec ni tehnično in alokacijsko učinkovit, če za proizvodnjo določenega obsega outputa ne uporablja minimalne količine proizvodnih dejavnikov, hkrati pa pri tem tudi nima najnižjih možnih stroškov. To pomeni, da je stroškovna učinkovitost dosežena le, če proizvajalec uporablja najmanjšo možno količino 
inputov ter če se inputi kombinirajo na način, ki omogoča proizvodnjo določenega obsega outputa z najnižjimi možnimi stroški. Proizvajalci morajo torej poleg optimalne količine in kombinacije inputov proizvajati še z najnižjimi možnimi stroški (Coelli, Prasada Rao in Battese 1998; Coelli idr. 2005; Daraio in Simar 2007; Fried, Lovell in Schmidt 2008; Greene 2008).

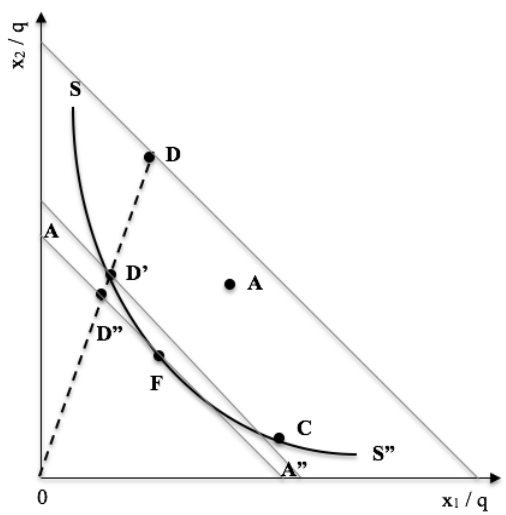

Slika 7: Stroškovna učinkovitost, usmerjena k inputom

Vir: prirejeno po Coelli idr. (2005, 52).

Proizvajalec je lahko stroškovno neučinkovit zaradi dveh razlogov. Prvič - v primeru tehnične neučinkovitosti, kar pomeni, da se ne nahaja na izokvanti (D). V tem primeru proizvajalec uporablja prevelike količine inputov za proizvodnjo določenega obsega outputa. Drugič - zaradi alokacijske neučinkovitosti, kar pomeni, da se ne nahaja na premici minimalnih stroškov (C). Proizvajalec bo stroškovno neučinkovit, če bo uporabljal sicer tehnično učinkovito kombinacijo inputov, vendar ta hkrati ne bo ustrezna glede na relativne cene inputov. To pomeni, da bo $\mathrm{v}$ tem primeru sicer dosegal tehnično učinkovitost, vendar na drugi strani ne bo dosegal alokacijske učinkovitosti. Skladno s tem lahko opredelimo, da obstajata dve sestavini skupne stroškovne učinkovitosti. Prva sestavina je tehnična učinkovitost, druga sestavina pa je alokacijska učinkovitost. Z drugimi besedami - obstaja več kot en sam vir stroškovne neučinkovitosti. Stroškovna neučinkovitost je lahko torej posledica tako tehnične kot tudi alokacijske neučinkovitosti (Fried, Lovell in Schmidt 2008; Greene 2008).

Alokacijska in tehnična učinkovitost sta elementa stroškovne učinkovitosti. Stroškovna učinkovitost je namreč opredeljena kot produkt tehnične in alokacijske učinkovitosti. To pomeni, da proizvajalec, ki ne bo hkrati tako tehnično kot tudi alokacijsko učinkovit, $\mathrm{v}$ nobenem pri- 
meru ne bo stroškovno učinkovit. Stroškovno učinkovitega proizvajalca prikazujemo na sliki 7 .

Proizvajalec F dosega oboje, in sicer tako tehnično kot tudi alokacijsko učinkovitost, zato je tudi stroškovno oziroma ekonomsko učinkovit. Mera stroškovne učinkovitosti je odvisna tako od mere tehnične kot tudi od mere alokacijske učinkovitosti. Za stroškovno učinkovitega proizvajalca velja, da je njegova mera učinkovitosti I. V primeru stroškovne neučinkovitosti pa velja, da je mera učinkovitosti proizvajalca manjša od I.

Krivulji SS" in AA" se stikata v točki F, v kateri je proizvajalec hkrati tehnično in tudi alokacijsko učinkovit, zato ga lahko opredelimo kot stroškovno učinkovitega proizvajalca. $V$ točki $C$ je proizvajalec sicer tehnično učinkovit, vendar je alokacijsko neučinkovit, zato ga ne moremo opredeliti kot stroškovno učinkovitega. Stroškovno neučinkovit pa je tudi proizvajalec D, ki ne dosega niti tehnične in niti alokacijske učinkovitosti. Za proizvajalca D lahko izračunamo mero stroškovne neučinkovitosti. To naredimo tako, da iz točke $\mathrm{D}$ potegnemo premico do koordinatnega izhodišča. V točki D” je višina stroškov enaka kot v točki F, zato lahko stroškovno učinkovitost opredelimo kot razdaljo od izhodišča do točke D" ter razdaljo od izhodišča do točke D (Coelli, Prasada Rao in Battese 1998; Coelli idr. 2005; Hollingsworth in Peacock 2008; Bogetoft in Otto 2OII):

$$
C E=O D^{\prime \prime} / O D \text {, }
$$

kar je enako:

$$
C E=1-D^{\prime \prime} D / O D \text {. }
$$

Stroškovna učinkovitost je oddaljenost proizvajalca od izokoste. Stroškovno neučinkovitost proizvajalca D lahko v tem primeru odpravimo tako, da dano raven outputa glede na produkcijsko funkcijo začnemo proizvajati z manjšo količino inputov, kar prikazuje točka D'. S tem odpravimo tehnično neučinkovitost proizvajalca. Nato pa moramo dano raven outputa začeti proizvajati še z najnižjimi povprečnimi stroški. V primeru, ko proizvajalec sicer uporablja tehnično učinkovito kombinacijo inputov, vendar ta hkrati ni ustrezna glede na relativne cene inputov, lahko z uporabo drugačne kombinacije inputov oziroma s prerazporeditvijo inputov doseže enak obseg proizvodnje pri nižjih stroških. S tem odpravimo še alokacijsko neučinkovitost.

Stroškovna oziroma ekonomska učinkovitost je opredeljena kot produkt tehnične in alokacijske učinkovitosti, zato lahko enačbo strokovne 
učinkovitosti opredelimo tudi matematično, in sicer kot (Coelli, Prasada Rao in Battese 1998; Coelli idr. 2005; Hollingsworth in Peacock 2008; Bogetoft in Otto 2011):

$$
C E=T E * A E,
$$

kar je enako:

$$
C E=\left(O D^{\prime} / O D\right) *\left(O D^{\prime \prime} / O D^{\prime}\right)=O D^{\prime \prime} / O D \text {. }
$$

Pri modelu, usmerjenem v outpute, pa lahko ekonomsko oziroma stroškovno učinkovitost opredelimo z mero prihodkovne učinkovitosti. $\mathrm{V}$ tem primeru torej nimamo več opravka s stroškovno učinkovitostjo, ampak s prihodkovno učinkovitostjo. Mere prihodkovne učinkovitosti, usmerjene k outputom, lahko prikažemo na primeru, ko proizvajalec proizvaja dva outputa, qI in q2, in input xı. Če imamo opravka s konstantnimi donosi obsega, lahko prikažemo mejo proizvodnih možnosti in funkcijo enakih prihodkov v dveh dimenzijah. To je razvidno iz slike 8 .

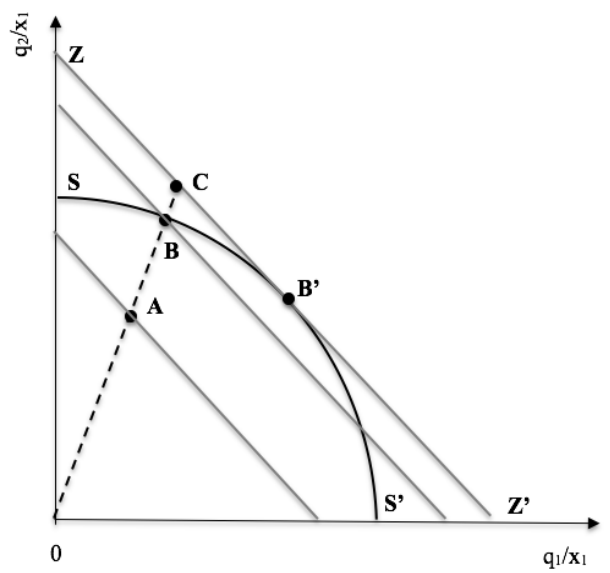

Slika 8: Prihodkovna učinkovitost, usmerjena k outputom

$\mathrm{V}$ primeru, ko je proizvajalec usmerjen $\mathrm{k}$ outputom, izhaja iz danega obsega inputov, kar pomeni, da so $\mathrm{v}$ tem primeru podani tudi stroški. Skladno s tem je mogoče cilj maksimiranja dobička uresničevati s ciljem maksimiranja prihodkov. Pri usmerjenosti v outpute je prihodkovna učinkovitost enaka razmerju med dejanskimi prihodki in maksimalnimi možnimi prihodki. Proizvajalec je lahko prihodkovno neučinkovit zaradi dveh razlogov. Prvič - v primeru tehnične neučinkovitosti, kar pomeni, da se ne nahaja na meji proizvodnih možnosti SS'. V tem primeru 
proizvajalec proizvaja premajhen obseg outputov glede na dano količino inputov. Drugič - zaradi alokacijske neučinkovitosti, kar pomeni, da se ne nahaja na krivulji maksimalnih prihodkov ZZ". Proizvajalec je alokacijsko neučinkovit tudi, če uporablja sicer tehnično učinkovito kombinacijo inputov, vendar ta hkrati ni ustrezna glede na relativne cene inputov. Proizvajalec lahko s proizvodnjo drugačne kombinacije outputov oziroma s prerazporeditvijo proizvodnje $\mathrm{z}$ uporabo enake količine inputov oziroma z enakimi stroški doseže višje prihodke, kar pomeni, da doseže tudi višji dobiček. Mero prihodkovne učinkovitosti lahko ponazorimo z naslednjim razmerjem (Coelli, Prasada Rao in Battese 1998; Coelli idr. 2005; Hollingsworth in Peacock 2008; Bogetoft in Otto 201 I):

$$
R E=O A / O C .
$$

Stroškovna oziroma ekonomska učinkovitost je opredeljena kot produkt tehnične in alokacijske učinkovitosti, zato lahko enačbo stroškovne učinkovitosti opredelimo tudi matematično, in sicer kot (Coelli, Prasada Rao in Battese 1998; Coelli idr. 2005; Hollingsworth in Peacock 2008; Bogetoft in Otto 201I):

$$
R E=T E * A E,
$$

kar je enako:

$$
R E=(O A / O B) *(O B / O C)=O A / O C .
$$

Razmerje $0 A / 0 B$ je kazalnik stopnje prihodkovne učinkovitosti proizvajalca, ki lahko zavzame vrednost med 0 in 1 . Vrednost 1 pomeni, da je proizvajalec $v$ celoti prihodkovno učinkovit, če pa kazalnik zavzame vrednost, manjšo od 1 , to pomeni, da je proizvajalec prihodkovno neučinkovit.

\section{Opredelitev pojma učinkovitosti pri izvajalcih zdravstvene dejavnosti}

Obstajata dva načina za merjenje outputa zdravstvenega varstva. Prvič storitve zdravstvenega varstva $(m)$ je mogoče opredeliti kot končni output, ki ga proizvajajo izvajalci zdravstvenih storitev. Zdravstvena funkcija $\mathrm{v}$ tem primeru prikazuje odnos med zdravstvenimi storitvami in proizvodnimi dejavniki oziroma inputi, s pomočjo katerih posamezni izvajalec zagotavlja zdravstvene storitve. Inpute lahko opredelimo v obliki inputa delo in inputa kapital. $\mathrm{V}$ primeru izvajalcev zdravstvenih storitev so $\mathrm{v}$ inputu delo zajeti zdravniki, medicinski sestre in drugi zdravstveni delav- 
ci, v inputu kapital pa bolniške postelje, oprema, medicinski material in podobno. Drugič - storitve zdravstvenega varstva ne obravnavamo kot končni output, temveč kot enega izmed inputov, ki prispevajo k ohranjanju in izboljševanju zdravstvenega stanja $(H)$. V tem primeru so torej storitve zdravstvenega varstva zgolj eden od inputov, ki vstopajo v zdravstveno funkcijo, ki kaže odnos med zdravjem oziroma zdravstvenim stanjem na eni strani ter zdravstvenimi storitvami in ostalimi inputi na drugi strani. To razmerje je moč prikazati z naslednjo enačbo (Feldstein 20 I; Došenović Bonča 20I4):

$$
H=f^{\prime}[m=f(\text { input })] .
$$

Če opazujemo zgornjo enačbo, vidimo, da je v zdravstveni ekonomiki zdravstvena funkcija definirana na poseben način in vsebuje več korakov. V prvem koraku se vzpostavlja odnos med inputi in outputi v obliki zdravstvenih storitev. Prav v tem odnosu se oblikuje ekonomska učinkovitost $\mathrm{v}$ obliki tehnične, alokacijske in stroškovne učinkovitosti. Če želimo preučevati učinkovitost izvajalcev zdravstvene dejavnosti, moramo torej upoštevati prvi korak oziroma ožjo opredelitev zdravstvene funkcije. Drugi korak oziroma širša opredelitev zdravstvene funkcije pa je vezana na odnos med obsegom in vrsto zdravstvenih storitev ter zdravjem prebivalstva. Učinkovitost izvajalcev zdravstvenega varstva ni povezana s širšo opredelitvijo zdravstvene funkcije. Če upoštevamo drugi korak zdravstvene funkcije, ki prikazuje odnos med zdravjem oziroma zdravstvenim stanjem in zdravstvenimi storitvami kot del inputov, lahko preučujemo uspešnost izvajalcev zdravstvenega varstva (Feldstein 20 I; Došenović Bonča 20I4).

Preučevanje odnosa med zdravstvenimi storitvami in inputi predstavlja osnovo za merjenje ekonomske učinkovitosti, ki se oblikuje v obliki tehnične, alokacijske in stroškovne učinkovitosti izvajalcev zdravstvene dejavnosti. Podobno kot za proizvajalce običajnih vrst dobrin velja tudi za izvajalce zdravstvenih storitev, da so tehnično učinkoviti, če proizvajajo določen obseg zdravstvenih storitev z zaposlitvijo minimalne količine proizvodnih dejavnikov oziroma inputov glede na razpoložljivo tehnologijo. Podobno lahko opredelimo izvajalce zdravstvene dejavnosti kot tehnično učinkovite $\mathrm{v}$ primeru, ko z danimi proizvodnimi dejavniki oziroma inputi in razpoložljivo tehnologijo proizvajajo maksimalen obseg zdravstvenih storitev. Tehnično učinkovit izvajalec zdravstvene dejavnosti tako uporablja najustreznejše razmerje med uporabljenimi inputi in outputi. V praksi to pomeni, da uporablja najugodnejše razmerje med 
številom zdravstvenega osebja, bolniških postelj, opreme in podobno ter številom pregledov ali številom operacij.

Alokacijsko učinkovitost pri izvajalcih zdravstvene dejavnosti lahko definiramo na enak način, kot smo definirali alokacijsko učinkovitost pri proizvajalcih znotraj ekonomske teorije. Alokacijsko učinkovitost izvajalec zdravstvene dejavnosti doseže, če za proizvodnjo določenega obsega zdravstvenih storitev uporablja ustrezno kombinacijo inputov glede na njihove relativne cene. Medtem ko je določen obseg zdravstvenih storitev mogoče proizvesti z različno kombinacijo inputov, je izvajalec zdravstvenih storitev alokacijsko učinkovit le, če zaposluje inpute v takšnem razmerju, ki omogočajo proizvodnjo zdravstvenih storitev z najnižjimi možnimi stroški. Feldstein (20II) navaja nekatere posebnosti pri proizvodnji zdravstvenih storitev. Med njimi so omejitve zaradi medsebojne zamenljivosti nekaterih proizvodnih dejavnikov, kot so zdravniki in medicinske sestre. Posebnost pri izvajalcih zdravstvenih storitev je tudi netržno oblikovanje cen proizvodnih dejavnikov in outputov, nepopolna konkurenca in odsotnost zasebne lastnine. Toda kljub navedenim posebnostim lahko mere alokacijske učinkovitosti izvajalcev zdravstvene dejavnosti opredelimo na enak način, kot je bilo to prikazano v razdelku »Opredelitev pojma učinkovitost znotraj ekonomske teorije «.

Stroškovno oziroma ekonomsko učinkovitost izvajalcev zdravstvene dejavnosti opredelimo kot produkt tehnične in alokacijske učinkovitosti izvajalcev zdravstvene dejavnosti. To pomeni, da sta tehnična in alokacijska učinkovitost dve sestavini skupne stroškovne učinkovitosti izvajalcev zdravstvene dejavnosti. Ta opredelitev je enaka opredelitvi stroškovne učinkovitosti pri proizvajalcih običajnih vrst dobrin. Izvajalec zdravstvenih storitev ni tehnično in alokacijsko učinkovit, če nima najnižjih stroškov pri proizvodnji določenega obsega zdravstvenih storitev. To pomeni, da je stroškovna učinkovitost dosežena le, če se inputi, ki jih pri izvajalcih zdravstvenih storitev izrazimo v obliki zdravstvenega osebja, zgradb, opreme bolniških postelj, medicinskega materialna, zdravil in drugih inputov, kombinirajo na način, ki omogoča proizvodnjo določenega obsega zdravstvenih storitev z najnižjimi možnimi stroški po enoti proizvodnje. Izvajalci zdravstvene dejavnosti morajo torej pri proizvodnji z najnižjimi možnimi stroški uporabiti optimalno kombinacije inputov.

Če opazujemo širšo opredelitev zdravstvene funkcije, vidimo, da prikazuje odnos med zdravstvenimi storitvami in zdravjem prebivalstva. $\mathrm{V}$ zdravstveni ekonomiki se preoblikovanje zdravstvenih storitev v zdravje obravnava kot standardna produkcijska funkcija. Potreba po zdravju, ki jo lahko opredelimo kot končni output, vodi k povpraševanju po različ- 
nih zdravstvenih storitvah $(m)$. Potreba po zdravstvenih storitvah je izpeljana in je odvisna od inputov, na primer cen, resnosti posameznikove bolezni in dojemanja učinkovitosti zdravljenja (Phelps 2012). Potreba po zdravju $(H)$ torej vodi do povpraševanja po zdravstvenih storitvah $(m)$, ki proizvaja oziroma »vrača zdravje $\ll$ :

$$
H=f(m) \text {. }
$$

Ker v ekonomiji ta postopek obravnavamo kot standardno produkcijsko funkcijo, lahko predpostavljamo, da je mejna produktivnost zdravstvenih storitev pozitivna in da se inkrementalni učinek zdravstvenih storitev na zdravje zmanjšuje s povečevanjem uporabe zdravstvenih storitev (Phelps 2012). Oba izida, torej tako zdravstvene storitve kot tudi zdravje prebivalstva, sta odvisna tudi od dejanske bolezni, ki jo ima posameznik. Zdravje tako lahko dojemamo kot funkcijo bolezni $(D)$ in zdravstvenih storitev $(m)$ :

$$
H=f(m, D)
$$

ali

$$
H=H 0-D+f(m) \text {. }
$$

$H, D$ in $m$ so vektorji velikih dimenzij, ki predstavljajo različne vidike zdravja, različne bolezni in različne oblike zdravljenja (Phelps 20I2). Funkcije zdravja na splošno merijo prispevek zdravstvenih storitev $\mathrm{k}$ zdravju, in sicer po količini posameznih komponent zdravstvenih storitev (na primer število zdravnikov in bolnišničnih postelj na tisoč prebivalcev), uporabi storitev (na primer število obiskov na zdravnika) ali po skupni potrošnji zdravstvenih storitev (Feldstein 20II).

Treba je omeniti še nekaj stvari. Prvič - kot že omenjeno, zdravstvene storitve $(m)$ ne morejo biti opisane kot homogena dejavnost. V praksi namreč poznamo številne medicinske posege in $\mathrm{v}$ okviru tehnološkega napredka njihova kompleksnost in raznolikost naraščata izredno hitro. Drugič - merjenje proizvodnje je težavno, ko je smrtnost le eden izmed mogočih izidov. Obolevnost, bolečina in trpljenje, funkcionalna in čustvena oslabitev ter kakovost življenja so še drugi vidiki odziva na zdravljenje (Berndt 2000). Številni postopki zdravljenja ne spreminjajo končne stopnje zdravja, na katero se posameznik vrne $s$ wpomočjo naravnega postopka ozdravitve, vendar pa ti postopki to pospešijo. Podobno pri neozdravljivih boleznih lahko zdravstvene storitve napredovanje bolezni le upočasnijo. Tretjič - zdravstvene storitve niso edini dejavnik, ki vpliva na zdravje. Življenjski slog posameznika lahko zmanjša stopnjo 
zdravja (na primer negativni učinki uživanja alkohola) ali prispeva (na primer zdrave prehranjevalne navade) $\mathrm{k}$ stopnji zdravja. Drugi inputi proizvodnje zdravja so še, na primer, znanje, čas in okolje (Berndt 2000). Če $X_{B}$ označuje skupek dobrin, ki imajo negativne učinke na zdravje, $X_{G} \mathrm{pa}$ skupek dobrin, ki k zdravju prispevajo, potem je mogoče funkcijo zdravja prikazati s spodnjo enačbo (Phelps 20I2):

$$
H=f\left(m, D, X_{B}, X_{G}\right) .
$$

Težave, povezane z merjenem zdravstvenega stanja oziroma zdravja prebivalstva, imajo v tem kontekstu pomembno vlogo. Na ravni celotne populacije oziroma na agregatni ravni se kot mere zdravja lahko uporabljajo stopnje umrljivosti, stopnje obolevnosti, stopnje splošnega zdravja, pričakovana življenjska doba in podobno. Sodobna literatura pa zdravje vse redkeje opredeljuje z zgoraj omenjenimi merami zdravja. V novejšem času se pri ugotavljanju zdravja in zdravstvenih izidov uporabljajo pristopi, po katerih bolniki ocenijo svoje zdravstveno stanje. Pri opredeljevanju se običajno definira fizično zdravje, mentalno zdravje, opravljanje vloge v družbi, dojemanje splošnega počutja, pojava simptomov, povezanih z boleznijo oziroma zdravljenjem (Bowling 2005).

Obstaja pa še tretji korak zdravstvene funkcije, ki vzpostavlja odnos med zdravjem prebivalstva in koristnostjo, ki jo to zdravje prinaša posamezniku. Pri najširši opredelitvi zdravstvene funkcije je torej poleg inputov, zdravstvenih storitev in zdravja prebivalstva smiselno upoštevati še koristnost, ki se pri posamezniku poveča skladno z izboljšanim zdravstvenim stanjem. Vpliv zdravstvenih storitev preko zdravja na koristnost bolnikov se prav tako kaže v uspešnosti zdravstvenega varstva (Tajnikar in Došenović Bonča 201 I):

$$
U=f^{\prime \prime}\left\{H=f^{\prime}[m=f(\text { input })]\right\} .
$$

Če opazujemo najširšo opredelitev zdravstvene funkcije, vidimo, da prikazuje odnos med zdravjem prebivalstva in koristnostjo. Koristnost posameznika je tako posledica izboljšanega zdravstvenega stanja oziroma zdravja posameznika. Potreba po izboljšanem zdravju vodi k povpraševanju po različnih zdravstvenih storitvah $(m)$. Potreba po zdravstvenih storitvah pa je izpeljana in je odvisna od inputov. Koristnost $(U)$ torej vodi do povpraševanja po izboljšanjem zdravju oziroma zdravstvenem stanju $(H)$ :

$$
U=f(H) .
$$


Pri tem je treba omeniti, da zdravje ni edini element funkcije koristnosti posameznika, medtem ko je mejna koristnost zdravja pozitivna. V funkcijo koristnosti posameznika poleg zdravja $(H)$ vstopa tudi nabor običajnih vrst blaga in storitev $(x)$, zato ima funkcija koristnosti naslednjo obliko:o

$$
U=f(H, x) .
$$

$\mathrm{Z}$ drugimi besedami - zdravje $(H)$ in običajne vrste dobrin $(x)$ so substituti in jih lahko $\mathrm{v}$ funkciji koristnosti med seboj zamenjujemo. Zato trditev, da bi se morali posamezniki izogniti porabi dobrin, ki negativno vpliva na njihovo zdravje, ni neizpodbitna. Končni cilj posameznega potrošnika namreč ni maksimiranje zdravja oziroma zdravstvenega stanja, ampak doseči maksimalno koristnost. To je jasno razvidno iz funkcije koristnosti, ki na eni strani sicer upošteva možnost, da potrošnja določenih vrst blaga ali storitev lahko negativno vpliva na zdravje oziroma zdravstveno stanje, vendar lahko na drugi strani kljub temu prispeva h koristnosti potrošnika (Došenović Bonča 20I4). Phelps (20I2) pri tem navaja, da lahko nabor dobrin $X_{B}$ predvidoma poveča koristnost posameznika. Ker zdravje sestavlja veliko različnih kategorij, kot so pričakovana življenjska doba $\left(H_{1}\right)$, odsotnost bolečine $\left(H_{2}\right)$ in mobilnosti $\left(\mathrm{H}_{3}\right)$, lahko funkcijo koristnosti zapišemo tudi v naslednji obliki (Phelps 2OI2):

$$
U=f\left(x, H_{1}, H_{2}, \ldots, H_{n}\right),
$$

ali natančneje:

$$
U=f\left(x, H_{1}, H_{2}, \ldots, H_{n}, \check{z} s, \mathrm{~s}, s i, o p\right),
$$

pri tem je žs - življenjski slog, $s$ - spol, $s i$ - stopnja izobrazbe in $o p-$ okolje in podobno.

Življenjski slog, spol, stopnja izobrazbe, okolje in drugi dejavniki neposredno vplivajo na koristnost in hkrati tudi posredno vplivajo na zdravje prek vpliva na zdravstveno stanje. Zavedati se je treba, da se lahko pojavi tudi negativen neposreden vpliv na koristnost posameznika, na primer, ko ima bolnik hude bolečine v procesu zdravljenja. Funkcija koristnosti ima medčasovne učinke potrošnje na koristnost. Potrošnja dobrin lahko vpliva na prihodnje zdravstveno stanje, hkrati pa prinaša tudi takojšen neposreden učinek na koristnost posameznika. Podoben učinek ima tudi potrošnja zdravstvenih storitev, ki vpliva na koristnost posame- 
znika in hkrati tudi na njegovo zdravje s časovnim zamikom. Prek vpliva na prihodnje možnosti potrošnje se lahko zgodi, da sedanji zdravstveni posegi vplivajo na možnosti prihodnje potrošnje (Berndt 2000).

Če povzamemo - v zdravstveni ekonomiki pojem učinkovitosti izvajalcev zdravstvene dejavnosti lahko preučujemo, če uporabljamo ožjo opredelitev zdravstvene funkcije, pri kateri so output storitve zdravstvenega varstva. V prvem koraku se vzpostavlja odnos med inputi in outputi v obliki zdravstvenih storitev. Prav v tem odnosu se oblikuje ekonomska učinkovitost v obliki tehnične, alokacijske in stroškovne učinkovitosti. Tehnična učinkovitost govori o maksimiranju odnosa med outputi in inputi, o ustrezni kombinaciji med inputi glede na njihove cene, ki minimira stroške, govori alokacijska učinkovitost, stroškovna pa zajema obe vrsti učinkovitosti. $S$ prvim korakom zdravstvene funkcije je tako povezan cilj doseganja ekonomske učinkovitosti izvajalcev zdravstvene dejavnosti.

Drugi korak zdravstvene funkcije je vezan na odnos med obsegom in vrsto zdravstvenih storitev ter zdravjem prebivalstva. Ekonomska učinkovitost izvajalcev zdravstvene dejavnosti ni povezana s tem korakom zdravstvene funkcije. Slednje velja tudi za tretji korak zdravstvene funkcije, ki vzpostavlja odnos med zdravjem prebivalstva in koristnostjo, ki jo to zdravje prinaša posamezniku. $\mathrm{Z}$ drugim korakom zdravstvene funkcije namreč maksimiramo zdravje oziroma zdravstveno stanje prebivalstva. V tretjem koraku zdravstvene funkcije pa poskušamo doseči čim večjo koristnost za posameznega potrošnika. Vpliv zdravstvenih storitev na zdravje, poleg tega pa tudi vpliv zdravstvenih storitev preko zdravja na koristnost bolnikov kaže uspešnost izvajalcev zdravstvene dejavnosti.

V praksi o uspešnem izvajalcu zdravstvene dejavnosti govorimo takrat, ko ta zagotavlja takšne zdravstvene storitve, ki v čim večji meri prispevajo $\mathrm{k}$ izboljšanju izidov zdravljenja obravnavanih bolnikov. $\mathrm{V}$ tem primeru so torej storitve zdravstvenega varstva zgolj eden od inputov, ki vstopajo $\mathrm{v}$ zdravstveno funkcijo, ki ponazarja odnos med zdravjem oziroma zdravstvenim stanjem na eni strani ter zdravstvenimi storitva$\mathrm{mi}$ in ostalimi inputi na drugi strani. Uspešnost izvajalca zdravstvene dejavnosti lahko opredelimo še širše. Velja namreč, da je ponudnik uspešen, če zagotavlja največjo možno koristnost za posameznega potrošnika. V zdravstveno funkcijo kot inputi vstopajo tako zdravje kot tudi zdravstvene storitve in proizvodni dejavniki oziroma ostali inputi, kar prikazuje odnos med koristnostjo na eni strani in zdravjem, zdravstvenimi storitvami ter ostalimi inputi na drugi strani (Došenović Bonča 2010; 2014). 


\section{Opredelitev pojma učinkovitosti znotraj mreže zdravstvenega varstua}

$\mathrm{V}$ prvem koraku zdravstvene funkcije se vzpostavlja odnos med inputi in outputi v obliki zdravstvenih storitev. V tem odnosu se oblikuje ekonomska oziroma stroškovna učinkovitost, in sicer v obliki tehnične, alokacijske in stroškovne učinkovitosti. Tehnična učinkovitost govori o pravem razmerju med obsegom inputov in outputov, o ustrezni kombinaciji med inputi glede na njihove cene, ki minimira stroške, govori alokacijska učinkovitost, stroškovna pa je produkt tehnične in alokacijske učinkovitosti. Dejavniki teh učinkovitosti so različni, oblika mreže zdravstvenega varstva pa lahko vpliva nanje preko večje ali manjše stopnje koncentracije in integracije zdravstvenih dejavnosti. Ta namreč odloča o velikosti izvajalcev, velikost izvajalcev pa je ključni dejavnik njihove učinkovitosti. Tako v teoriji kot $\mathrm{v}$ praksi zato govorimo o optimalni velikosti izvajalcev.

Ustrezna stopnja koncentracije in integracije zdravstvenih dejavno-

sti oziroma optimalna velikost zdravstvenih izvajalcev je torej povezana s prvim korakom zdravstvene funkcije. $S$ tem korakom je tako povezan cilj doseganja ekonomske učinkovitosti izvajalcev v mreži zdravstvenega varstva.

Drugi korak zdravstvene funkcije je vezan na odnos med obsegom in vrsto zdravstvenih storitev ter zdravjem prebivalstva. Ekonomska učinkovitost kot eden od dveh konfliktnih ciljev mreže zdravstvenega varstva ni povezana s tem korakom zdravstvene funkcije. Slednje velja tudi za tretji korak zdravstvene funkcije, ki vzpostavlja odnos med zdravjem prebivalstva in koristnostjo, ki jo to zdravje prinaša posamezniku. Je pa z drugim in zlasti tretjim korakom zdravstvene funkcije povezan cilj, da se zdravstvene storitve čim bolj približajo posameznemu prebivalcu in se $s$ tem doseže večja stopnja dostopnosti zdravstvenega varstva. Smiselno je upoštevati dve domnevi. Po prvi naj bi veljalo, da lokacijsko čim bližje so storitve zdravstvenega varstva bolniku, tem bolj lahko prispevajo ob enakem obsegu in strukturi k zdravju prebivalstva. Po drugi pa naj bi veljalo, da dostopnost zdravstvenih storitev prebivalstvu in zlasti bolnikom sama po sebi vpliva na koristnost, ki jo te storitve lahko izzovejo pri bolnikih. Domnevamo torej, da je dostopnost sama po sebi značilnost ponudbe zdravstvenih storitev, ki vpliva na koristnost, ki jo zdravje daje posamezniku. Vpliv zdravstvenih storitev preko zdravja na koristnost bolnikov kaže uspešnost zdravstvenega varstva.

Razumljivo je, da ekonomska učinkovitost $\mathrm{v}$ prvem koraku zdravstvene funkcije sama po sebi še ne zagotavlja uspešnosti zdravstvenega varstva $\mathrm{v}$ drugem in tretjem koraku zdravstvene funkcije ter da so določene organizacijske oblike mreže zdravstvenega varstva, ki so učinkovite 
$\mathrm{v}$ prvem koraku, lahko neuspešne $\mathrm{z}$ vidika drugega in zlasti tretjega koraka zdravstvene funkcije. Organizacijska oblika, ki zagotavlja visoko stopnjo ekonomske učinkovitosti, na primer, ne zagotavlja $\mathrm{v}$ vseh primerih tudi visoke stopnje koristnosti pri posameznem prebivalcu, če je takšna ponudba zdravstvenih storitev zelo oddaljena od posameznika in mu je zato tudi manj dostopna.

$\mathrm{Na}$ podlagi povedanega bi morali z mrežo zdravstvenega varstva doseči, da ob danih drugih dejavnikih zdravstvene funkcije ob danih inputi v zdravstveno varstvo dosežemo maksimalno koristnost za prebivalstvo. Pri tem pa izhajamo iz predpostavke, da je funkcija koristnosti prebivalstva istosmerno povezana $\mathrm{z}$ maksimiranjem dostopnosti do zdravstvenih storitev in optimalno velikostjo izvajalcev, zveza med dostopnostjo in velikostjo izvajalcev pa je obratnosmerna. Prav zaradi te obratnosmerne povezanosti med dostopnostjo in velikostjo izvajalcev ne gre za preprosto enosmerno maksimiranje zdravstvene funkcije $\mathrm{v}$ vseh treh korakih, pač pa gre za optimiranje te funkcije z oblikovanjem mreže zdravstvenega varstva. Verjetno bi lahko trdili, da bi dosegli teoretski optimum tedaj, ko bi bila posamezna zdravstvena storitev maksimalno geografsko približana vsakemu posameznemu prebivalcu v obliki, ki jo zdravstvena tehnologija omogoča, in kakovosti, ki jo prebivalec pričakuje, hkrati pa bi bili ponudniki teh zdravstvenih storitev organizirani na način, da bi preko optimalne velikost dosegali maksimalno tehnično in alokacijsko učinkovitost.

\section{Merjenje učinkovitosti izvajalcev z dravstvene dejavnosti}

V zdravstvenem varstvu lahko učinkovitost izvajalcev zdravstvene dejavnosti preučujemo z metodami primerjalne analize, ki definirajo učinkovitosti na podlagi primerjave kazalnikov med različnimi izvajalci zdravstvene dejavnosti. Kazalniki učinkovitosti so eden izmed najbolj uveljavljenih pripomočkov za spremljanje učinkovitosti delovanja enot za sprejemanje poslovnih odločitev. Kvantitativni kazalniki so namenjeni primerjavi med različnimi enotami za sprejemanje poslovnih odločitev (relativna števila) ali pa merijo učinkovitost nad posameznim parom spremenljivk (razmerje med outputom in inputom). Znotraj analize oziroma primerjave različnih kazalnikov je treba zagotoviti primerljivost podatkov posameznih izvajalcev, saj lahko v nasprotnem primeru heterogenost napačno interpretiramo kot posledico neučinkovitosti. Kot osnovo za primerjavo običajno določimo najučinkovitejšega izvajalca, lahko pa nam osnovo za primerjavo predstavlja tudi povprečna učinkovitost izvajalcev znotraj opazovanega vzorca (Ozcan 2008). 
Metoda primerjalne analize nam torej omogoča oceno učinkovitosti posameznega izvajalca glede na najboljšega izvajalca znotraj opazovanega vzorca ali pa oceno učinkovitosti posameznega izvajalca glede na povprečje celotnega opazovanega vzorca. Omenjena primerjalna analiza je najpreprostejša metoda merjenja ekonomske učinkovitosti znotraj zdravstvenega varstva. To metodo uporablja večina držav po svetu za statistično spremljanje kazalnikov učinkovitosti sistema zdravstvenega varstva. Posamezne bolnišnice oziroma države pripravljajo četrtletna poročila, ki jih zbirajo nekatere svetovne organizacije za primerjavo statističnih podatkov med različnimi državami sveta. $V$ tovrstne kazalnike uvrščamo na primer število umrlih na r.000 odpuščenih bolnikov, število bolniških postelj na I.000 prebivalcev, stopnjo hospitalizacije na I.000 bolnikov, povprečno ležalno dobo in podobno (Ersoy idr. 1997). Na podlagi vrednosti kazalnika, ki jo pripišemo najboljšemu izvajalcu, lahko analiziramo razmerje med stopnjo kazalnika posameznega izvajalca in stopnjo kazalnika najboljšega izvajalca (Ozcan 2008).

Kazalniki učinkovitosti torej predstavljajo razmerja med outputi in inputi posameznih enot za sprejemanje poslovnih odločitev, kar pomeni, da je učinkovitost opredeljena kot število enot outputa, ki jih izvajalec proizvede na enoto inputa. Uporaba enostavnih kazalnikov, ki v primerjalni analizi učinkovitosti izvajalcev kažejo razmerja med različnimi dejavniki, pogosto prikažejo nehomogene rezultate. V praksi to pomeni, da lahko tako dobljeni rezultati pogosto zavajajo managerje in odločevalce pri sprejemanju odločitev. Enačbo kazalnikov učinkovitosti primerjalne analize lahko zapišemo kot (Ozcan 2008):

$$
\text { Učinkovitost }=\frac{\text { Output }}{\text { Input }} .
$$

Druga pogosto uporabljena metoda za preučevanje učinkovitosti izvajalcev je metoda ocenjevanja funkcij s pomočjo metode najmanjših kvadratov. V zdravstvu je to metodo prvi uporabil Feldstein (1967). Pri tej metodi običajno ocenjujemo predvsem proizvodne funkcije. Feldstein (1967) je v svoji študiji ocenil proizvodne funkcije britanskih bolnišnic, pri čemer je to predstavljalo osnovo za nadaljnje preučevanje tehnične učinkovitosti bolnišnic. Na podlagi odklonov od ocenjenih regresij so bile določene posamezne mere tehnične učinkovitosti. Bolnišnice, ki so imele odklon opredeljen z ničelno vrednostjo, so bile opredeljene kot povprečno tehnično učinkovite bolnišnice. Bolnišnice, ki so imele negativen odklon, so bile interpretirane kot podpovprečno tehnično učinkovite bolnišnice. To pa pomeni, da so bile bolnišnice s pozitivnim odklonom, opredeljene kot nadpovprečno tehnično učinkovite bolnišnice. 
Lastnosti metode najmanjših kvadratov pri ocenjevanju funkcij imajo številne prednosti $\mathrm{v}$ primerjavi z enostavnimi kazalniki primerjalne analize. Metoda se namreč lahko uporablja za merjenje tehničnih sprememb z uporabo časovnih vrst. Prav tako pa se $s$ to metodo lahko ugotavlja tudi ekonomije obsega, ki se nanaša na dodatne prihranke pri stroških, ko proizvodnja večjega obsega outputa povzroči znižanje povprečnih stroškov pri proizvajalcu (Ozcan 2008). Kadar ugotovimo, da proporcionalnemu povečanju proizvodnih dejavnikov oziroma inputov sledi proporcionalno povečanje količine outputa, opredelimo konstantne donose obsega. Če proporcionalnemu povečanju inputov sledi nadproporcionalno povečanje količine outputa, opredelimo naraščajoče donose obsega. Če pa proporcionalnemu povečanju inputov sledi podproporcionalno povečanje količine proizvoda, opredelimo padajoče donose obsega (Street in Jacobs 2002).

Ocenjevanje učinkovitosti z metodo najmanjših kvadratov je sicer $\mathrm{z}$ ekonometričnega vidika dokaj preprosto, saj ne vključuje zahtevnih matematičnih operacij. Metoda najmanjših kvadratov pri opredeljevanju mer učinkovitosti kot osnovo upošteva povprečno učinkovitost izvajalcev znotraj opazovanega vzorca. Proizvodne funkcije, ki jih ocenjujemo s pomočjo metode najmanjših kvadratov, običajno tako niso v skladu s klasično ekonomsko teorijo. Proizvodna funkcije mora izražati maksimalen možen output, ki ga lahko izvajalci proizvedejo glede na razpoložljive proizvodne dejavnike in glede na dano tehnologijo. Metoda najmanjših kvadratov je omejena zaradi predpostavke o linearnosti vseh inputov in outputov, hkrati pa ne more razlikovati med učinkovitimi in neučinkovitimi izvajalci. Kljub možnosti vpogleda v razpon med bolj in manj učinkovitimi izvajalci s to metodo ni mogoče ugotoviti stopnje učinkovitosti posameznega izvajalca. Učinkovitost izvajalcev se ocenjuje na podlagi povprečne učinkovitosti vzorca in ne glede na možne mejne funkcije (Coelli in Lawrence 2006; Langabeer in Helton 2012).

Pri ocenjevanju funkcij $\mathrm{z}$ metodo najmanjših kvadratov se predpostavlja, da so izvajalci zdravstvenega varstva učinkoviti. Z njo ni mogoče opredeliti posameznih neučinkovitih enot, poleg tega pa je treba vnaprej opredeliti proizvodno funkcijo, ki je posledica njenega parametričnega oblikovanja. Kljub pomanjkljivostim je metoda najmanjših kvadratov pri ocenjevanju funkcij zelo priljubljena parametrijska analiza. Z metodo najmanjših kvadratov lahko ocenjujemo več različnih inputov in outputov, ob tem pa se predpostavlja tudi nepojasnjene slučajne ostanke $e$. Splošna formula za regresijo najmanjših kvadratov je (Ozcan 2008): 


$$
y=\beta_{0}+\beta_{1} x_{1}+\beta_{2} x_{2}+\ldots+\beta_{n} x_{n}+e .
$$

Pri tem predpostavljamo: (I) da za vsako vrednost $\mathrm{x}$, y, obstaja naključna spremenljivka $y / x=\beta_{0}+\beta_{1} x_{1}$; (2) da so vrednosti y neodvisne ena od druge; (3) da je srednja vrednost y ravna premica funkcije $x, y=\beta_{0}+\beta_{1} x_{1}+e$; (4) da je varianca y enaka za vse $\mathrm{x}$ in da ima y normalno porazdelitev za vsako vrednost $X$.

Tretja metoda za merjene učinkovitosti izvajalcev zdravstvene dejavnosti je metoda izračuna celotne faktorske produktivnosti. Ta metoda meri spremembe v učinkovitosti z uporabo indeksov, ki pri posameznem izvajalcu odražajo spremembe glede na obseg proizvedenih outputov in obseg porabljenih inputov znotraj dveh različnih časovnih obdobij. Pri merjenju sprememb se najpogosteje uporabljajo Laspeyresov, Paschejev, Fisherjev, Tornqvistovih in Malmquistov indeks. Razlika med Laspeyresovim in Paschejevim indeksov je v tem, ali se za utež uporablja osnovno število ali trenutno število količin. Fisherjev indeks poskuša odpraviti to razliko na način, da uporablja geometrično povprečje Laspeyresovega in Paschejevega indeksa, podobno velja tudi za Törnqvistov indeks, ki uporablja različna geometrijska povprečja za ceno in količino (Coelli idr. 2005; Fried, Lovell in Schmidt 2008; Ozcan 2008).

Indeksi Laspeyresa, Pascheja, Fisherja in Tornqvista so neparametrični pristopi, ki se lahko uporabljajo na presečnih ali panelnih podatkih za merjenje doseženih rezultatov dveh zdravstvenih organizacij v enem časovnem obdobju ali za učinkovitost ene zdravstvene organizacije $\mathrm{v}$ dveh časovnih obdobjih. Slabost te metodologije je, da je ni mogoče uporabljati, če želimo primerjati več kot dve zdravstveni organizaciji v istem časovnem obdobju ali za več časovnih obdobij. Znotraj metodologije skupne faktorske produktivnosti je najpogosteje uporabljen Malmquistov indeks, ki odpravlja nekatere pomanjkljivosti drugih indeksov, ki smo jih omenili zgoraj. Z Malmquistovim indeksom lahko raziskovalci znotraj zdravstvenega varstva primerjajo številne zdravstvene organizacije $v$ dveh časovnih obdobjih. Malmquistov indeks je mogoče dobiti z mejnim pristopom metode podatkovnih ovojnic ali metode stohastične mejne analize, ki ju predstavljamo v nadaljevanju. Prednost Malmquistovega indeksa je, da ne predpostavlja, da so izvajalci učinkoviti, hkrati pa ni treba opredeliti cene inputov in outputov (Coelli idr. 2005; Fried, Lovell in Schmidt 2008; Ozcan 2008).

Skupna faktorska produktivnost je $\mathrm{v}$ ekonomiji parameter, ki predstavlja izide enot za sprejemanje poslovnih odločitev z natančno definiranimi outputi, pri čemer se predpostavlja, da inputi na noben način niso 
povezani z outputi. Skupna faktorska produktivnost meri spremembo rezultata, ki ni posledica sprememb v obsegu inputov. Gre torej za opazovanje povečanja učinkovitosti zaradi tehnološke ali organizacijske inovativnosti in razvoja. Matematično lahko to opredelimo kot (Ozcan 2008):

$$
\operatorname{TFP}_{a b}=\frac{\sum_{i=1}^{N} p_{i b} q_{i b}}{\sum_{i=1}^{N} p_{i a} q_{i a}} .
$$

$\mathrm{V}$ formuli indeks $\mathrm{TFP}_{a b}$ meri spremembo vrednosti izbrane količine določenega števila outputov od obdobja $a$ do obdobja $b$; $a$ torej predstavlja prvo določeno obdobje, $b$ drugo določeno obdobje, $p$ cene outputov in $q$ količino outputov.

Četrta zelo pogosta metoda ocenjevanja učinkovitosti izvajalcev zdravstvene dejavnosti je metoda SFA. To metodo lahko delimo glede na to, ali imamo za ocenjevanje mejnih funkcij na voljo presečne podatke ali panelne podatke. Prvi model za analizo stohastičnih mejnih funkcij na podlagi presečnih podatkov so razvili Aigner, Lovell in Schmidt (1977) ter Meeusen in van den Broeck (1977), ki so ocenili mejno proizvodno funkcijo z metodo največjega verjetja. Ko se ocenjuje mejna stroškovna funkcija, je pristop popolnoma enak, saj je stroškovna funkcija $\mathrm{v}$ ekonomiji zrcalna slika proizvodne funkcije. Osnovni model deli celoten odklon $\varepsilon_{i}$ na dva dela. Prvi del celotnega odklona $\varepsilon_{i}$ imenujemo slučajna napaka ali beli šum, ki jo označujemo z $v_{i}$. Ta del predstavlja možnost izbire napačne funkcijske oblike, nenamerno opustitev ustreznih spremenljivk, napake pri podatkih in vpliv slučajnih dogodkov, na katere določen izvajalec znotraj opazovanega vzorca ne more vplivati. Drugi del celotnega odklona $\varepsilon_{i}$ pa ponazarja mero neučinkovitosti $u_{i}$, na katero izvajalec lahko vpliva.

$\mathrm{V}$ presečnih modelih stohastične mejne proizvodne funkcije se običajno predpostavlja, da je slučajna napaka $V_{i}$ neodvisno in identično porazdeljena normalna slučajna spremenljivka $\mathrm{z}$ ničelno srednjo vrednostjo in varianco $\sigma_{v}^{2}$, kar predstavlja predpostavko v omenjenih modelih. Slučajna spremenljivka neučinkovitosti $u_{i}$ je lahko porazdeljena na različne načine (Schmidt in Sickles 1984). Lahko uporabimo predpostavko o polovični normalni porazdelitvi, eksponentni porazdelitvi (Aigner, Lovell in Schmidt 1977; Meeusen in van den Broeck 1977), ali okrnjeni normalni porazdelitvi (Stevenson 1980). Poleg omenjenih predpostavk pa lahko uporabimo tudi predpostavko o dvoparametrični gama porazdelitvi (Stevenson 1980; Greene 1990). 
Pri merjenju učinkovitosti z metodo ocenjevanja mejnih proizvodnih in stroškovnih funkcij je pomembno vprašanje, kako definirati pojasnjevalne spremenljivke. Opredelitev modelov mejnih funkcij v prvem koraku zahteva opredelitev funkcijske oblike odnosa med inputi in outputi v proizvodnem procesu. Neoklasična ekonomska teorija pravi, da med pojasnjevalne spremenljivke običajno vključimo tiste spremenljivke, na katere izvajalci lahko vplivajo. $\mathrm{V}$ večini primerov lahko managerji vplivajo na spremenljivke, ki se nanašajo na obseg in cene porabljenih inputov (Jacobs, Smith in Street 2006). Med spremenljivke mejnih funkcij pa lahko uvrstimo tudi okoljske spremenljivke, na katere managerji v večini primerov ne morejo vplivati. Običajno med te spremenljivke uvrščamo lastništvo (javni ali zasebni izvajalci), značilnosti lokacije (območje goste ali redke poseljenosti), moč sindikatov, državno regulacijo in podobno (Coelli idr. 2005).

$\mathrm{V}$ primeru, ko pri ocenjevanju mejnih funkcij poleg pojasnjevalnih spremenljivk vključimo tudi okoljske spremenljivke, lahko domnevamo, da okoljske spremenljivke niso korelirane s slučajno stohastično napako $v_{i}$ in slučajno spremenljivko neučinkovitosti $u_{i}$. To je verjetno najenostavnejši način opredeljevanja okoljskih spremenljivk znotraj določene mejne funkcije. Učinkovitost posameznega izvajalca se v tem primeru spreminja glede na običajne vrste inputov in ne na podlagi okoljskih spremenljivk. V primeru presečnih podatkov to vodi do modela, ki ga lahko opredelimo z naslednjo obliko (Coelli, Perelman in Romano 1999; Coelli idr. 2005):

$$
\ln q_{i}=x_{i}^{\prime} \beta+z_{i}^{\prime} \gamma+v_{i}-u_{i},
$$

$Z_{i}^{\prime}$ pri tem predstavlja vektor okoljskih spremenljivk, $\gamma$ pa vektor neznanih parametrov.

Ko domnevamo, da so mere učinkovitosti povezane $\mathrm{z}$ variabilnostjo okoljskih spremenljivk, pa je treba mejne funkcije oceniti v dveh korakih (Pitt in Lee 198I). Prvi korak vključuje ocenjevanje mejnih funkcij tako, da mejne funkcije ocenimo zgolj s parametri neodvisnih spremenljivk, okoljske spremenljivke pa $\mathrm{v}$ tem koraku izpustimo. $\mathrm{V}$ drugem koraku rezultate, ki smo jih izračunali v prvem koraku, opredelimo kot odvisno spremenljivko, nato pa skladno s tem pojasnimo okoljske spremenljivke. Pristop, kjer ocenjujemo mejne funkcije $\mathrm{v}$ dveh korakih, ima številne pomanjkljivosti (Caudill, Ford in Gropper 1995; Wang in Schmidt 2002).

Kumbhakar, Ghost in McGuckin (199I) so, da bi odpravili pomanjkljivosti pristopa $\mathrm{v}$ dveh korakih, predlagali ocenjevanje mejnih funkcij na podlagi metode največjega verjetja, ki pojasnjuje odklon $u_{i} \mathrm{v}$ odnosu 
do okoljskih spremenljivk v enem koraku. Pri ocenjevanju mejnih funkcij je v tem primeru treba predpostaviti, da je del slučajne spremenljivke $u_{i}$ odvisen od okoljskih spremenljivk, drugi del pa neodvisen od okoljskih spremenljivk. Pregled pristopa ocenjevanja mejnih funkcij v enem koraku natančneje pojasnjujeta Kumbhakar in Lovell (2003). Model, ki obravnava opazovane okoljske spremenljivke, za katere se predpostavlja, da neposredno vplivajo na komponente mejnih funkcij, lahko opredelimo na naslednji način (Kumbhakar, Ghosh in McGuckin 1991):

$$
\ln q_{i}=x_{i}^{\prime} \beta+v_{i}-u_{i}
$$

in

$$
u_{i} \sim N^{*}\left(z_{i}^{\prime} \gamma, \sigma_{u}^{2}\right) .
$$

Učinki neučinkovitosti pri mejnih funkcijah imajo porazdelitev, ki se spreminja skladno z $Z_{i}{ }^{\prime}$, kar pomeni, da niso več enakomerno porazdeljeni. Ta model sta Battese in Coelli (1992 in 1995) kasneje nagradila tudi za primere, ko razpolagamo $s$ panelnimi podatki.

Schmidt in T.-F. Lin (1984) navajata, da lahko z uporabo panelnih podatkov odpravimo nekatere pomanjkljivosti modelov, ki uporabljajo presečne podatke. Ko ocenjujemo mejne funkcije s pomočjo stohastičnih modelov, moramo pri delitvi odklona $\varepsilon_{i}$ vedno predpostaviti tudi porazdelitev slučajne spremenljivke neučinkovitosti $u_{i}$. Če imamo na voljo panelne podatke, ki zajemajo večje število opazovanih enot $\mathrm{v}$ različnih časovnih obdobjih, pa se lahko z uporabo modela s stalnimi učinki izognemo definiranju predpostavk o porazdelitvi neučinkovitosti. Neodvisne spremenljivke pri ocenjevanju mejnih funkcij za presečne podatke običajno opredelimo kot spremenljivke, ki niso korelirane $s$ slučajno spremenljivko $u_{i}$. Če razpolagamo $s$ panelnimi podatki, ki vključujejo daljše časovno obdobje, predpostavke o korelaciji neodvisnih spremenljivk s slučajno spremenljivko $u_{i}$ ni treba opredeliti.

Pri uporabi panelnih podatkov in modela s stalnimi učinki velja, da se skrite individualne značilnosti oziroma skrita heterogenost opazovanih izvajalcev opredeli z oceno stalnega učinka. Prednost ocenjevanja mejnih funkcij s stalnimi učinki pa ima na drugi strani tudi slabost. $\mathrm{V}$ tem primeru so namreč stalni učinki v celoti pripisani posledici neučinkovitosti. Skupna pomanjkljivost vseh modelov je torej, da ocenjene mere učinkovitosti pogosto neustrezno odražajo dejanske mere neučinkovitosti izvajalcev znotraj opazovanega vzorca. Če ocenjene mejne proizvodne in mejne stroškovne funkcije ne upoštevajo skritih dejavnikov, so stalni 
učinki med drugim posledica neučinkovitosti in hkrati tudi skrite heterogenosti med izvajalci, kar z vidika analize običajno ni ustrezno. Za odpravo omenjenih pomanjkljivosti so nekateri avtorji poskušali izboljšati model s stalnimi učinki (Greene 2008). V nabor pojasnjevalnih spremenljivk so poskušali vključiti slamnate spremenljivke, ki so bile ocenjene z metodo največjega verjetja.

Peta in hkrati tudi najpogosteje uporabljena metoda za merjenje ekonomske učinkovitosti izvajalcev zdravstvene dejavnosti je metoda DEA. To metodo je prvi predstavil Farrell (1957), ki je v svoji študiji zapisal, da je njegov cilj poenotiti metodologijo merjenja učinkovitosti tako, da bo primerna za merjenje učinkovitosti katere koli produkcijske enote za sprejemanje poslovnih odločitev. Njegov pristop je temeljil na analizi dejavnosti, mero učinkovitosti pa je opredelil kot razmerje med inputi in outputi. DEA je metoda linearnega programiranja oziroma optimizacijska metoda, ki se lahko uporablja za merjenje tehnične, alokacijske in stroškovne učinkovitosti za več različnih outputov in inputov (Farrell 1957). Rezultat je ocenjena mera relativne učinkovitosti glede na najboljše razmerje med inputi in outputi, ki ga doseže posamezen izvajalec znotraj opazovanega vzorca.

Metoda DEA je primer neparametričnega pristopa izračunavanja učinkovitosti posameznih opazovanih enot, kar pomeni, da nam ne omogoča ločevanja med učinkom neučinkovitosti in učinkom slučajnih odklonov, zato se vsi odkloni od mejne funkcije pripišejo posledici neučinkovitosti enote za sprejemanje poslovnih odločitev. Farrellovo idejo merjenja učinkovitosti so nadgradili Charnes, Cooper in Rhodes (1978). Njihova študija je zajemala evalvacijo javnih programov, kjer so neparametrične mejne proizvodne funkcije izračunali na podlagi linearnega programiranja. Mere učinkovitosti so bile opredeljene kot relativne mera učinkovitosti enot poslovnega odločanja glede na podatkovno ovojnico. Relativno učinkovitost enot poslovnega odločanja merimo kot razmerje med inputi in outputi v proizvodnem procesu. Pri tem predpostavljamo, da so outputi in inputi vseh enot enako kakovostni in da znižanje ravni porabljenih proizvodnih dejavnikov oziroma inputov ne spremeni kakovosti proizvedenih outputov.

Od leta 1978 dalje je bilo z metodo DEA opravljenih veliko raziskav, kjer so za raziskovanje uporabljali veliko različnih kombinacij spremenljivk. Metoda DEA je posebej uporabna, kadar preučujemo različne izvajalce, ki pa uporabljajo podobne inpute za proizvodnjo homogenih outputov in kjer produkcijske funkcije ni mogoče jasno definirati (Sherman 1984). Metoda DEA je bila v zdravstvu največkrat uporabljena v raziska- 
vah in primerjavah učinkovitosti izvajalcev na sekundarni ravni zdravstvene dejavnosti ter izvajalcev na primarni ravni zdravstvene dejavnosti (Dash, Vaishnavi in Muraleedharan 2010).

$\mathrm{V}$ raziskavah je mogoče zaslediti predvsem dva pristopa merjenja učinkovitosti na podlagi metode DEA. Prvi pristop je $\mathrm{k}$ inputom usmerjen pristop, ki meri učinkovitost izvajalcev na način, da minimira inpute za doseganje danega obsega outputa. Drugi pristop pa je k outputom usmerjen pristop merjenja učinkovitosti, ki meri učinkovitost tako, da maksimira output ob danih inputih (Coelli idr. 2005). Na podlagi osnovnega modela metode podatkovne ovojnice so se razvili tudi različni pristopi, ki pa se med seboj razlikujejo glede na predpostavko o uporabljeni tehnologiji in glede na predpostavko o donosih obsega (Rouse, Harrison in Chen 2010). Najpogostejši modeli donosov obsega so modeli konstantnih donosov obsega, ki so jih pri preučevanju učinkovitosti v svoji študiji prvi uporabili Charnes, Cooper in Rhodes (1978). Poznamo tudi še drugo skupino donosov obsega, to so variabilni donosi obsega, ki jih je v svoji študiji prvi uporabil Afriat (1972). Variabilni donosi obsega so se kasneje uveljavili na podlagi študije Bankerja, Charnesa in Cooperja (1984). Poznamo pa še modele ne-naraščajočih donosov obsega in modele ne-upadajočih donosov obsega (Zhu 2003). Natančnejše so oba pristopa merjenja učinkovitosti metodološko opisali tudi Cooper, Seiford in Zhu (2004), C. Daraio in Simar (2007), Thanassoulis, M. C. S. Portela in Despić (2008).

$S$ predstavljenimi modeli metode DEA lahko na eni strani izračunamo mere tehnične, alokacijske in stroškovne oziroma ekonomske učinkovitosti na podlagi presečnih podatkov, na drugi strani pa tudi na podlagi panelnih podatkov. Panelni podatki znotraj metode DEA ne omogočajo tako širokega nabora pristopov, kot je to značilno pri ocenjevanju mer učinkovitosti s pomočjo metode SFA. Nekatere prednosti uporabe panelnih podatkov pri metodi SFA lahko uporabimo tudi znotraj metode DEA. Te prednosti so natančno opredelili Fried, Lovell in Schmidt (2008). Panelni podatki nam omogočajo oblikovanje skupnega vzorca, ki ga imenujemo tudi združeni vzorec opazovanih enot za sprejemanje poslovnih odločitev. Ta nam nato omogoča, da opredelimo eno množico in mejo proizvodnih možnosti. V primeru, ko panel zajema dolgo časovno obdobje, pa ta pristop ni primeren, saj se predpostavlja, da se meja proizvodnih možnosti, ki predstavlja najučinkovitejše kombinacije inputov in outputov, v času ne spreminja. Pri tem je glavna prednost omenjenega pristopa, da za vsako enoto za sprejemanje poslovnih odločitev lahko izraču- 
namo toliko mer učinkovitosti, kolikor je dolžina preučevanega obdobja (Došenović Bonča 2014).

V primeru, ko panel oblikujemo iz letnih podatkov o posameznem izvajalcu, nam to omogoča, da za določeno leto opredelimo množice mejnih proizvodnih možnosti. S primerjavo različnih mejnih proizvodnih možnosti v različnih letih lahko definiramo tudi tehnološki napredek. Če pride do sekanja mejnih proizvodnih možnosti, to pomeni, da je to lahko posledica tehnološkega napredka ali tehnološkega zaostanka znotraj posameznih območij proizvodnje. Slabost tega pristopa je, da se mere učinkovitosti med seboj precej razlikujejo. Panel je mogoče oblikovati tudi tako, da se oblikuje več združenih vzorcev, ki se medsebojno prekrivajo. Skladno s prvim in drugim pristopom ta pristop predstavlja vmesno alternativo, hkrati pa nam omogoča preučevanje sprememb v učinkovitosti skozi različna časovna obdobja, ki jih zajema posamezen združen vzorec. Ko razpolagamo s panelnimi podatki, obstaja možnost, da se prva meja oblikuje na podlagi podatkov prvega leta opazovanja, nato se druga meja oblikuje na podlagi podatkov drugega leta in tako dalje za vsa naslednja leta opazovanega obdobja. Znotraj tega pristopa ne obstaja možnost, da bi prišlo do tehnološkega zaostanka. Kot zadnji izmed pristopov pa je pristop, pri katerem vsakič posebej preučujemo dve zaporedni leti. Tako najprej preučujemo izvajalce na podlagi podatkov prvega in drugega leta, zatem preučujemo izvajalce na podlagi podatkov drugega in tretjega, nato opazujemo izvajalce na podlagi podatkov tretjega in četrtega leta in tako dalje vse do konca opazovanega obdobja (Fried, Lovell in Schmidt 2008).

\section{Pregled preučevanja učinkovitosti izvajalcev zdravstvene dejaunosti}

Prvi, ki so se začeli ukvarjati s preučevanjem učinkovitosti v zdravstvenem varstvu, so bili Charnes, Cooper in Rhodes (1978). Odločevalci na državni ravni in oblikovalci zdravstvene politike so se zaradi hitrega naraščanja finančnih izdatkov za zdravstveno varstvo začeli zavedati pomembnosti obvladovanja stroškov oziroma izdatkov za zdravstveno varstvo. To je spodbudilo številne raziskovalce, med njimi tudi Mortimerja (2002), da so pospešeno začeli razvijati metode, tehnike in pristope merjenja učinkovitosti izvajalcev zdravstvene dejavnosti. Večina raziskovalcev je največ pozornosti namenila izvajalcem na sekundarni ravni zdravstvenega varstva. To je skladno s tem, da se za bolnišnično dejavnost namenja daleč največ sredstev znotraj zdravstvenega varstva (Fryer, Antony in Ogden 2009). 
Raziskovalci so sprva ocenjevali učinkovitost poslovanja izvajalcev sekundarne zdravstvene dejavnosti na podlagi primerjalne analize različnih enostavnih kazalnikov učinkovitosti oziroma preprostih razmerij (Copeland in Jacobs 198I). Primerjalne analize so bile zaradi omejitev na preprosta razmerja z dvema spremenljivkama izdelane na podlagi več razmerij, zaradi česar so se tako raziskovalci kot tudi odločevalci srečevali s številnimi omejitvami. Uporaba te metode je pogosto podala mešane rezultate, kar pomeni, da so bili posamezni izvajalci zdravstvene dejavnosti na podlagi nekaterih kazalnikov povsem učinkoviti, medtem ko so drugi kazalniki odražali njihovo neučinkovitost (Ozcan 2008). Kljub omenjenim pomanjkljivostim pa primerjalno analizo zaradi njene enostavnosti oziroma preprostosti nekateri raziskovalci uporabljajo še v današnjem času (Berg idr. 2005; Linna, Häkkinen in Magnussen 2006). Konsenz o spremljanju določenih kazalnikov znotraj različnih držav omogoča primerjavo izvajalcev zdravstvene dejavnosti tudi med različnimi državami. Kazalniki se spremljajo na državni ravni za potrebe analize nekaterih točno določenih vidikov poslovanja. Na podlagi dobljenih rezultatov številne mednarodne institucije primerjajo zdravstvene sisteme različnih držav (Ministrstvo za zdravje Republike Slovenije 2010).

Znotraj primerjalne analize so se razvili notranji kazalniki, ki naj bi služili odločevalcem in managerjem izvajalcev zdravstvene dejavnosti za spremljanje in izboljšanje izidov poslovanja. Poleg notranjih kazalnikov poznamo znotraj primerjalne analize tudi zunanje dejavnike, ki služijo oblikovalcem zdravstvene politike, odločevalcem na državni ravni, plačnikom, bolnikom in drugim deležnikom zdravstvenega varstva, da čim laže ocenijo učinkovitost izvajanja zdravstvenih storitev, hkrati pa jih lahko primerjajo z ocenami zdravstvenih storitev drugih izvajalcev zdravstvene dejavnosti. Podrobneje so notranje in zunanje kazalnike opredelili Berg in sodelavci (2005), in sicer na podlagi naslednjih meril: pomembnost izida kazalnika, pomembnost obravnavanega področja in možnost potenciala za izboljšanje učinkovitosti poslovanja.

Skozi zgodovino so raziskovalci razvijali tudi kompleksnejše metode in pristope. Ena izmed prvih naprednejših metod za merjenje učinkovitosti znotraj javnega sektorja je bila metoda SFA (Aigner, Lovell in Schmidt I977). Ena izmed prvih študij, ki je poskušala metodo SFA tudi aplicirati na izvajalcih zdravstvene dejavnosti, je bila študija Hoflerja in Follanda (I99I). Avtorja navajata, da je metoda SFA najtočnejša metoda ocenjevanja učinkovitosti poslovanja bolnišnice in njenih stroškov. Po njunem mnenju naj bi bila pomanjkljivost drugih metod ta, da te ne omogočajo vključevanja minimalnih stroškov izvajalca skladno z ekonomsko teorijo. V svoji študiji sta dokazala, da strukturne razlike v stroških različnih 
bolnišnic temeljijo na naslednjih merilih: prvič - na lastništvu bolnišnic, torej glede na to, ali so bolnišnice javne ali zasebne; drugič - na statusu bolnišnice, to pomeni, da med seboj razlikujejo mestne in podeželske bolnišnice; tretjič - na številu opravljenih storitev oziroma glede na to, kolikšno število zdravstvenih storitev opravijo bolnišnice.

Zuckerman, Hadley in L. Iezzoni (1994) so uporabili presečni model stohastične mejne analize za izpeljavo posebne mere neučinkovitosti bolnišnic. Avtorji so ugotovili, da spodbujanje učinkovitosti, ki omogoča nagrajevanje bolnišnic, ki so sposobne proizvajati skladno z minimalnimi stroški, in kaznovanje tistih, ki imajo dejanske stroške višje od minimalnih, omogoča doseganje višje ravni učinkovitosti poslovanja bolnišnic. Veliko zanimanje med raziskovalci je povzročilo vprašanje, koliko prihrankov lahko ustvarimo z zmanjševanjem neučinkovitosti bolnišnic. V tej luči so preučevali učinkovitost bolnišnic številni avtorji, in sicer Linna (1998) na primeru finskih bolnišnic ter Prior in M. Solà (2000) na primeru španskih bolnišnic. R. Jacobs (200I) je v svoji študiji na primeru britanskih bolnišnic prav tako pokazala, da lahko z zmanjševanjem neučinkovitosti ustvarimo pomembne prihranke. Podobno navajajo tudi Li in Rosenman (200I) ter Rosko (200I), ki so preučevali učinkovitost ameriških bolnišnic, Blank in E. Eggink (2004) pa sta z metodo SFA preučevala učinkovitost nizozemskih splošnih bolnišnic.

Večina novejših študij, ki uporabljajo metodo SFA, se nanaša na ameriške bolnišnice. M. E. Deily in N. L. McKay (2006) sta v svoji študiji preučevali kakovost zdravstvene obravnave preko umrljivosti bolnikov v povezavi z učinkovitostjo bolnišnic. Povprečno učinkovitost bolnišnic sta izračunali s pomočjo hibridne funkcije za ameriške bolnišnice, ki zagotavljajo akutno obravnavo bolnikov. Ugotovili sta, da je povprečna učinkovitost bolnišnic znašala o,87. S. Yaisawarng in Burgess (2006) sta preučevala odnos med učinkovitostjo in dostopnostjo ter kakovostjo izvajalcev zdravstvenih storitev. Ugotovila sta, da povprečna učinkovitost bolnišnic znotraj opazovanega vzorca znaša 0,97 . Rosko (2004) je v svoji študiji s pomočjo metode SFA prav tako preučeval vpliv kakovosti na učinkovitost bolnišnic, vendar je ugotovil, da ima kakovost minimalen vpliv na učinkovitost izvajalcev zdravstvene dejavnosti. McKay, M. E. Deily in Dorner (2003) so ocenil učinkovitost ameriških bolnišnic na zelo velikem vzorcu. Učinkovitost so preučevali pri 4.075 ameriških bolnišnicah. Ugotovili so, da so najučinkovitejše tiste bolnišnice, ki imajo nepridobiten značaj, njihova povprečna mera učinkovitosti je znašala 0,86 , sledijo javne bolnišnice, pri katerih je povprečna mera učinkovitosti znašala 0,85 , in nato še bolnišnice $s$ pridobitnim značajem, pri katerih je bila povprečna mera učinkovitosti o,84. 
Linna, Häkkinen in Magnussen (2006) so ugotavljali učinkovitost finskih bolnišnic, ki so jih primerjali tudi z norveškimi bolnišnicami. B. Gannon (2005) je preučeval učinkovitost bolnišnic z uporabo različnih funkcijskih oblik. Pri tem je za ocenjevanje mejnih funkcij uporabil Cobb-Douglasovo funkcijsko obliko ter translogaritemsko funkcijsko obliko. Znotraj opazovanega vzorca, kjer je vključil irske bolnišnice, je ugotovil visoke stopnje neučinkovitosti. Street (2003) pa je ocenjeval mere učinkovitosti bolnišnic najprej z metodo SFA, nato pa rezultate primerjal še z rezultati, ki so bili pridobljeni z uporabo popravljene metode ocenjevanja funkcij s pomočjo metode najmanjših kvadratov. Ugotovil je, da sta obe metodi približno enako rangirali bolnišnice po njihovi učinkovitosti, pri čemer pa je metoda SFA postavila mejno funkcijo učinkovitosti bistveno više v primerjavi z metodo najmanjših kvadratov.

Metoda DEA je bila na podlagi zgodnjih del Farrella (1957) kasneje uporabljena tudi v zdravstvu. Za preučevanje učinkovitosti bolnišnic je prvi to metodo uporabil Nunamaker (1983), ki je preučeval učinkovitost storitev zdravstvene nege, in Sherman (1984), ki je preučeval učinkovitost vzorca ameriških bolnišnic. Njegov glavni namen je bil preizkusiti ustreznost mejnih modelov, predvsem metode podatkovne ovojnice v času, ki se je takrat uporabljala na področju zdravstvenega varstva. Od leta 1990 se je znotraj zdravstvene ekonomike pojavil velik interes za merjenje učinkovitosti bolnišnic in hkrati tudi za preučevanje dejavnikov učinkovitosti bolnišnic s pomočjo metode DEA. Področje raziskovanja se je razširilo tudi na druga področja zdravstvenega varstva.

Raziskovalci se tako niso več ukvarjali zgolj s preučevanjem bolnišnične dejavnosti, ampak so se začeli osredotočati tudi na druga področja znotraj sistema zdravstvenega varstva. Nyman in Bricker (1989) sta z metodo DEA preučevala učinkovitost domov za ostarele, Färe in sodelavci (1994) so ugotavljali produktivnost švedskih lekarn, Puig-Junoy (1998) je preučeval učinkovitost enot intenzivne nege, H. Ozgen in Ozcan (2002) pa sta ocenjevala učinkovitost dializnih centrov. Študije učinkovitosti bolnišnic so bile sprva usmerjene zgolj na določen tip bolnišnic, na primer na velike urbane bolnišnice (O'Neill I998), ali pa na univerzitetne bolnišnice, ki opravljajo raziskovalno in razvojno dejavnost (Grosskopf, Margaritis in Valdmanis 200I). Preučevanja večjega števila bolnišnic so se lotili šele leta 2004, ko so primerjali tehnično učinkovitosti ameriških bolnišnic v letu 1998 in tehnično učinkovitost bolnišnic v letu $200 \mathrm{I}$ (Harrison, Coppola in Wakefield 2004).

Kasneje je veliko število avtorjev z metodo DEA preučevalo vpliv lastnine bolnišnic, velikost bolnišnic, kakovost bolnišnic in podobno na 
njihove mere učinkovitosti. Nekatere študije navajajo, da so pridobitne bolnišnice manj učinkovite $\mathrm{v}$ primerjavi s tistimi, ki imajo nepridobiten značaj (Koop, Osiewalski in Steel 1997; Ozcan in Luke 1993). Na drugi strani pa Chang in sodelavci (2004) navajajo, da so pridobitne bolnišnice učinkovitejše v primerjavi z nepridobitnimi. Študija Gruce in D. Nath (200I) je pokazala, da različne velikosti bolnišnic niso korelirane z merami učinkovitosti, B. Watcharasriroj in Tang (2004) pa sta v svoji študiji ugotovila, da so bolnišnice večje velikosti zavzele višje vrednosti učinkovitosti. L. R. Mobley in Magnussen (2002) sta preučevala vpliv kakovosti storitev v bolnišnici na njihovo učinkovitost in na zadovoljstvo zaposlenih. Študija je prikazala precej presenetljive rezultate, ki kažejo, da je nizka kakovost zdravstvenih storitev povezana z nezadovoljstvom zaposlenih in hkrati tudi z neučinkovitostjo bolnišnic. Ferrando in sodelavci (2005) pa navajajo, da bi z ustreznimi smernicami lahko povečali učinkovitost bolnišnic, ne da bi to vplivalo na kakovost zdravstvene oskrbe.

\section{Metodologija za izračun učinkovitosti izvajalcev zdravstvene dejavnosti}

Pregled raziskav na področju zdravstva kaže, da sta najpogosteje uporabljena pristopa pri ocenjevanju učinkovitosti izvajalcev zdravstvene dejavnosti parametričen pristop ocenjevanja mejnih funkcij in neparametričen ali determinističen pristop ocenjevanja mejnih funkcij. Najpogosteje uporabljena metoda prvega pristopa je metoda SFA, $s$ katero ocenjujemo parametrične stohastične modele, najpogosteje uporabljena metoda drugega pristopa pa je metoda DEA, s katero ocenjujemo neparametrične ali deterministične modele. Metoda SFA in metoda DEA sodita v skupino analitičnih rigoroznih metod benchmarkinga, kjer se uporablja tako imenovana funkcija razdalje, ki meri učinkovitost posameznega izvajalca zdravstvene dejavnosti glede na učinkovitega izvajalca, ki se nahaja na mejni proizvodni ali stroškovni funkciji. Metodi se razlikujeta glede na uporabo različnih pristopov pri ocenjevanju mejnih funkcij. $\mathrm{Z}$ metodo SFA lahko izračunamo količnike mer učinkovitosti, ki temeljijo na ekonometričnem ocenjevanju stohastičnih mejnih funkcij, z metodo DEA pa lahko izračunamo količnike mer učinkovitosti, ki temeljijo na metodi linearnega programiranja. Pri definiranju meje proizvodnih možnosti obe metodi uporabljata različne predpostavke o slučajnih napakah oziroma belem šumu in neučinkovitosti.

Metodo SFA imenujemo stohastična metoda, ker omogoča ločevanje neučinkovitosti izvajalca od slučajnih napak oziroma belega šuma, ki nastane zaradi metodoloških napak. Med te napake uvrščamo na primer iz- 
biro napačne funkcijske oblike, vpliv spremenljivke, ki smo jo nenamerno izpustili znotraj modela, napake $\mathrm{v}$ podatkih in podobno (Simar in Wilson 2000; Farsi in Filippini 2004). Metodo DEA pa uvrščamo med neparametrične metode, kar pomeni, da pri njej ni mogoče razlikovati učinka učinkovitosti od učinka belega šuma (Fried, Lovell in Schmidt 2008), zato vse odklone od meje proizvodnih možnosti pripišemo neučinkovitosti izvajalcev. Avtorji najpogosteje navajajo, da je pri raziskavah merjenja učinkovitosti prednost metode DEA pred metodo SFA v tem, da ne zahteva opredelitve funkcijske oblike mejne funkcije, saj v tem primeru vse mejne funkcije ponazarjajo deterministične funkcije opazovanih vrednosti (Farsi in Filippini 2004). Metoda DEA je relativno nezahtevna za izvedbo, kar je razlog, da v literaturi pri preučevanju učinkovitosti izvajalcev zdravstvenega varstva najdemo številne raziskave $\mathrm{z}$ uporabo te metode.

Naša analiza temeljil na spoznanjih Bauerja in soavtorjev (1998), ki zagovarjajo tezo, da je pri izbiri metodologije treba uporabiti več različnih pristopov, kar pomeni, da ni treba sprejeti odločitve o najboljši metodi merjenja učinkovitosti. Glede na prvo postavljeno hipotezo smo v naši analizi učinkovitosti izvajalcev sekundarne zdravstvene dejavnosti uporabili obe metodi, torej tako metodo DEA kot tudi metodo SFA. Obe metodi sta nam omogočili izračun tehnične, alokacijske in stroškovne učinkovitosti. Izbrali smo ju z namenom, da bi na podlagi mer tehnične, alokacijske in stroškovne učinkovitosti opredelili ekonomsko najučinkovitejšo splošno bolnišnico, ki jo v nadaljevanju uporabimo kot osnovno enoto za postavitev mreže sekundarne zdravstvene dejavnosti. Ekonomsko najučinkovitejša splošna bolnišnica namreč predstavlja teoretičnega izvajalca sekundarne ravni zdravstvene dejavnosti, kar nam podaja odgovor na vprašanje, kakšnega izvajalca sekundarne zdravstvene dejavnosti potrebujemo znotraj mreže zdravstvene dejavnosti. Obe metodi uporabimo tudi z namenom preverjanja konsistentnosti rezultatov.

\section{Ocenjevanje učinkovitosti z metodo SFA}

Metoda SFA je ekonometrična metoda, ki vse odklone opazovane enote za sprejemanje poslovnih odločitev od mejne proizvodne funkcije ne pripiše izključno neučinkovitosti enote, ampak upošteva, da lahko odkloni nastanejo zaradi dejavnikov, na katere ni mogoče vplivati. Metoda SFA omogoča ločevanje neučinkovitosti enote od stohastične slučajne napake oziroma belega šuma, ki prav tako vpliva na proizvodnjo in stroške izvajalcev, vendar nanje managerji ne morejo vplivati. Sem uvrščamo na primer izbiro napačne funkcijske oblike, nenamerno opustitev ustreznih spremenljivk, napake pri podatkih, vpliv slučajnih dogodkov, kot so okvare delovnih sredstev, slabo vreme in podobno (Greene 2008). 
Prvi model stohastične mejne analize so uvedli Aigner, Lovell in Schmidt (1977) ter Meeusen in van den Broeck (1977) na podlagi presečnih podatkov. Na tej osnovi so bili nato opredeljeni številni modeli, ki so ocenjevali stohastične mejne funkcije in pomenijo prilagoditev oziroma nadgradnjo osnovnega modela za preučevanje učinkovitosti na podlagi baze panelnih podatkov. Obsežen pregled razvoja teh modelov so v svojih študijah podali številni raziskovalci (Bauer 1990; Forsund, Lovell in Schmidt 1980; Greene 2003; Kumbhakar in Lovell 2003; Greene 2008; Hollingsworth 2008).

V skladu z razpoložljivimi podatki tehnično učinkovitost izvajalcev zdravstvene dejavnosti ocenjujemo na osnovi presečnega modela stohastične mejne proizvodne funkcije z eno enačbo. Ker ne razpolagamo zgolj $\mathrm{z}$ informacijami o količinskem obsegu inputov in outputov, ampak imamo na voljo tudi podatke o cenah inputov in outputov, lahko ocenjujemo tudi stroškovno učinkovitost izvajalcev zdravstvene dejavnosti. Tudi $\mathrm{v}$ tem primeru stroškovno učinkovitost analiziramo na osnovi presečnega modela stohastične mejne stroškovne funkcije z eno enačbo, ki pa smo ga zaradi dualitete med proizvodno in stroškovno funkcijo izpeljali na podlagi prvega modela. Ocene tehnične in stroškovne učinkovitosti izvajalcev zdravstvene dejavnosti nam omogočajo tudi izračun njihove alokacijske učinkovitosti. Alokacijska učinkovitost je izračunana na podlagi primerjave tehnične in stroškovne učinkovitosti izvajalcev zdravstvene dejavnosti, in sicer na način, da je alokacijska učinkovitost izračunana kot razmerje med stroškovno in tehnično učinkovitostjo.

$\mathrm{Na}$ tem mestu moramo opozoriti še na eno dejstvo, ki se nanaša na preučevanje mer tehnične, alokacijske in stroškovne učinkovitosti. Ocena stohastične mejne proizvodne funkcije nam omogoča zgolj ocenjevanje mer tehnične učinkovitosti, medtem ko nam ocena stohastične mejne stroškovne funkcije omogoča ocenjevanje mer stroškovne, alokacijske in tudi tehnične učinkovitosti izvajalcev zdravstvene dejavnosti. Stroškovna učinkovitost je namreč sestavljena iz tehnične in alokacijske učinkovitosti, kar pomeni, da lahko stroškovno neučinkovitost razdelimo na njeni dve osnovni komponenti, pri čemer prva ponazarja tehnično neučinkovitost, druga pa alokacijsko neučinkovitost izvajalcev zdravstvene dejavnosti. Pri izračunu posameznih mer učinkovitosti uporabljamo program Shazam, ki ga je razvil Kenneth White (1993).

\section{Ocenjevanje stohastične mejne proizvodne funkcije}

Proizvodna funkcija ponazarja odnos med outputi in inputi. V ekonomski teoriji običajno izrazimo proizvodno funkcijo kot odnos med neodvisno spremenljivko in eno ali več pojasnjevalnimi spremenljivkami. To 
pomeni, da proizvodna funkcija običajno ponazarja odnos med enim outputom in več inputi. Matematično lahko to zapišemo v naslednji obliki:

$$
y=f\left(x_{1}, x_{2}, \ldots, x_{n}\right) ;
$$

y $\mathrm{v}$ tem primeru predstavlja odvisno spremenljivko, medtem ko $x_{n}(n=1, \ldots, N)$ predstavlja pojasnjevalne spremenljivke, $f($.$) pa ozna-$ čuje matematično funkcijo. Prvi korak pri ocenjevanju odnosa med odvisno in pojasnjevalnimi spremenljivkami je, da določimo algebraično obliko matematične funkcije $f($.$) .$

Različne algebrske oblike matematične funkcije $f($.$) omogočajo izbi-$ ro različnih funkcijskih oblik. $V$ študijah najpogosteje najdemo linearno funkcijo, Cobb-Douglasovo funkcijo (Cobb in Douglas 1928), kvadratno funkcijo, normalizirano kvadratno funkcijo, translogaritemsko funkcijo (Christensen, Jorgenson in Lau 1973), posplošeno Leontiefovo funkcijo (Diewert 197I), funkcijo konstantne elastičnosti zamenjave CES (McFadden 1963). Skupna značilnost vseh funkcijskih oblik je, da vsebujejo neznane parametre $\beta_{n}$ in $\beta_{n m}$, ki jih je treba oceniti. Pri izbiri med temi različnimi oblikami običajno dajemo prednost tistim, ki so fleksibilne, teoretično konsistentne, konsistentne glede na empirična dejstva, omogočajo konsistentno statistično ocenjevanje itd.

Cobb-Douglasovo funkcijsko obliko lahko zapišemo na naslednji način (Coelli idr. 2005):

$$
y=\beta_{0} \prod_{n=1}^{N} x_{n}^{\beta_{n}} .
$$

Translogaritemska funkcijska oblika pa ima naslednjo specifikacijo (Coelli idr. 2005):

$$
y=\exp \left(\beta_{0}+\sum_{n=1}^{N} \beta_{n} \ln x_{n}+\frac{1}{2} \sum_{n=1}^{N} \sum_{m=1}^{N} \beta_{n m} \ln x_{n} \ln x_{m}\right) .
$$

Če Cobb-Douglasovo funkcijsko obliko logaritmiramo, dobimo naslednji zapis:

$$
\ln y=A_{0}+\sum_{n=1}^{N} \beta_{n} \ln x_{n} k j e r A_{0}=\ln \beta_{0} .
$$

Če logaritmiramo translogaritemsko funkcijsko obliko, pa dobimo naslednjo specifikacijo: 


$$
\ln y=\beta_{0}+\sum_{n=1}^{N} \beta_{n} \ln x_{n}+\frac{1}{2} \sum_{n=1}^{N} \sum_{m=1}^{N} \beta_{n m} \ln x_{n} \ln x_{m} .
$$

Pri ocenjevanju proizvodnih funkcij možen vir napak ekonometričnih ocen predstavljajo izbira napačne funkcijske oblike ter nenamerna opustitev ustreznih spremenljivk, ki predstavljajo desno stran enačbe. Dodaten vir napak pa se nanaša na napake pri podatkih in vpliv slučajnih dogodkov, ki jih v ekonometričnem ocenjevanju proizvodnih funkcij opredelimo kot slučajno napako ali beli šum. Pri opredeljevanju proizvodnih funkcij je treba tako kombinirane učinke napak vključiti v obliki slučajnih spremenljivk. To prikazuje naslednja specifikacija (Coelli idr. 2005):

$$
y_{i}=x_{i}^{\prime} \beta+v_{i} i=1, \ldots, I
$$

$y_{i}$ pri tem označuje $i$ opazovanje odvisne spremenljivke, $x_{i}^{\prime}$ je vektor $K \times 1$ pojasnjevalnih spremenljivk, $\beta$ je povezana z vektorjem $K x 1$ neznanih parametrov, $v_{i}$ predstavlja slučajno napako, $I$ pa označuje število opazovanj v naboru podatkov. Glede na izbrano funkcijsko obliko, s katero ocenjujemo proizvodne funkcije, so lahko odvisne in pojasnjevalne spremenljivke $\mathrm{v}$ zgornji specifikaciji različne funkcije outputov in inputov. $\mathrm{V}$ primeru, da želimo pojasniti odnos med outputom $q_{i}$ in inputom $x_{1 i}, X_{2 i}$ in $X_{3 i}$ s translogaritemsko funkcijsko obliko, bomo dobili naslednjo specifikacijo:

$$
y_{i}=\ln q_{i}
$$

$$
x_{i}=\left[\begin{array}{c}
1 \\
\ln x_{1 i} \\
\ln x_{2 i} \\
\ln x_{3 i} \\
\frac{1}{2}\left(\ln x_{1 i}\right)^{2} \\
\ln x_{1 i} \ln x_{2 i} \\
\ln x_{1 i} \ln x_{3 i} \\
\frac{1}{2}\left(\ln x_{2 i}\right)^{2} \\
\ln x_{2 i} \ln x_{3 i} \\
\frac{1}{2}\left(\ln x_{2 i}\right)^{2}
\end{array}\right]
$$




$$
\beta=\left(\beta_{0} \beta_{1} \beta_{2} \beta_{3} \beta_{11} \beta_{12} \beta_{13} \beta_{22} \beta_{23} \beta_{33}\right)^{\prime} .
$$

Naša naslednja naloga je oceniti neznani parameter $\beta$. Poznamo dva glavna načina ocenjevanja regresijskega koeficienta $\beta$, to sta metoda največjega verjetja in metoda najmanjših kvadratov. Znotraj obeh metod je treba definirati napake, pri čemer metoda najmanjših kvadratov ne zahteva predpostavk o porazdelitvi napak, medtem ko je pri metodi največjega verjetja treba opredeliti predpostavko o porazdelitvi napak.

Najpogostejše predpostavke v zvezi z napakami so (Coelli idr. 2005):

$$
\begin{aligned}
& E\left(v_{i}\right)=0, \\
& E\left(v_{i}\right)=\sigma^{2},
\end{aligned}
$$

$$
E\left(v_{i} v_{s}\right)=0 \text { zavse } i \neq s \text {. }
$$

Regresijska enačba $y_{i}=x_{i}^{\prime} \beta+v_{i} \mathrm{i}$ in zgoraj omenjene predpostavke so znane kot klasičen linearni regresijski model. Tehnično gledano ta model vključuje tudi predpostavko, da spremenljivke $X_{i}$ niso naključne in natančno linearne, kar pomeni, da so na isti premici.

Metoda najmanjših kvadratov ocenjuje koeficient $\beta$ tako, da minimira vsoto deviacij med $y_{i} s$ in njihovo srednjo vrednostjo. Funkcijo, ki izraža vsoto kvadratov, lahko zapišemo kot funkcijo koeficienta $\beta$ na naslednji način:

$$
S(\beta)=\sum_{i=1}^{I}\left(y_{i}-E\left[y_{i}\right]\right)^{2}=\sum_{i=1}^{I}\left(y_{i}-x_{i}^{\prime} \beta\right)^{2} .
$$

Maksimiranje te funkcije v zvezi s koeficientom $\beta$ je enostavna računska operacija, ki vključuje določitev vektorja, ki ga odvajamo in enačimo z nič. Rešitev teh matematičnih pogojev predstavlja cenilko metode navadnih najmanjših kvadratov:

$$
b=\left(\sum_{i=1}^{I} x_{i} x_{i}^{\prime}\right)^{-1} \sum_{i=1}^{I} x_{i} y_{i} .
$$

Bistvo metode najmanjših kvadratov je, da gre pri njej za minimiranje kvadratov vsote odklonov pravih vrednosti od ocenjenih vrednosti. Pri njej torej iščemo tako vrednost, ki minimira neko funkcijo. Pri upo- 
rabi metode najmanjših kvadratov je treba definirati model in hkrati tudi napake, vendar pri tem ni treba opredeliti nobenih predpostavk o njihovi porazdelitvi. Pomanjkljivost te metode je, da z njeno uporabo ne izvemo ničesar o standardni napaki ocen koeficientov oziroma njihovi porazdelitvi. Kljub temu je mogoče porazdelitev predpostaviti, saj so ocene koeficientov linearne kombinacije spremenljivke y (Gauss 2004).

Metoda največjega verjetja pa je podprta z idejo, da določen vzorec opazovanj pogosteje pripada neki določeni porazdelitvi kot drugi. Če je n primer povprečna vrednost vzorca $\bar{y}=5,3$ pri nespremenjenih ostalih pogojih, je verjetneje, da ima vzorec porazdelitev s srednjo vrednostjo $\mu=5$, kot pa porazdelitev $\mu=100$. Metoda največjega verjetja oceni vrednost neznanega parametra tako, da maksimira verjetnost naključno določenega vzorca opazovanj.

Pri uporabi metode največjega verjetja za oceno parametrov klasičnega linearnega regresijskega modela moramo najprej opredeliti predpostavko o porazdelitvi standardnih napak. Najpogostejša predpostavka je, da so slučajne napake normalno porazdeljene. To lahko zapišemo v naslednji obliki (Coelli idr. 2005):

$$
v_{i} \sim \operatorname{iidN}\left(0, \sigma^{2}\right) .
$$

Zgornja specifikacija ponazarja, da so napake neodvisno in identično porazdeljene normalne slučajne spremenljivke z ničelno srednjo vrednostjo in varianco $\sigma^{2}$. Uporaba razmerja med $y_{i}$ in $v_{i}$ skupaj z znanimi lastnostmi običajnih slučajnih spremenljivk nam omogoča naslednji zapis:

$$
y_{i} \sim \operatorname{iidN}\left(x_{i}^{\prime} \beta, \sigma^{2}\right) .
$$

Skupno funkcijo gostote za vektor opazovanj $y=\left(y_{1}, y_{2}, \ldots, y_{I}\right)^{\prime}$ pa lahko zapišemo kot:

$$
L(y \mid \beta, \sigma)=\left(2 \pi \sigma^{2}\right)^{-\frac{1}{2}} \exp \left\{-\frac{1}{2 \sigma^{2}} \sum_{i=1}^{I}\left(y_{i}-x_{i}^{\prime} \beta\right)^{2}\right\} .
$$

Funkcija gostote skupne verjetnosti je znana tudi kot funkcija verjetja, ki izraža verjetnost opazovanja vzorca kot funkcijo neznanih parametrov $\beta$ in $\sigma^{2}$. Metoda največjega verjetja je cenilka koeficienta $\beta$, ki jo definiramo z maksimiranjem zgornje funkcije. Ekvivalentno jo je mogoče izračunati tudi z maksimiranjem logaritma funkcije verjetja: 


$$
\ln L=-\frac{I}{2} \ln (2 \pi)-\frac{I}{2} \ln \left(\sigma^{2}\right)-\frac{1}{2 \sigma^{2}} \sum_{i=1}^{I}\left(y_{i}-x_{i}^{\prime} \beta\right)^{2}
$$

Maksimiranje funkcije največjega verjetja je preprosta matematična operacija diferencialnega računa. Ko je desna stran enačbe enaka vsoti kvadratov v enačbi 2.47 , je maksimiranje funkcije največjega verjetja enako minimiranju vsote kvadratov. $\mathrm{V}$ posebnem primeru klasičnega linearnega regresijskega modela $z$ normalno porazdelitvijo napak je metoda največjega verjetja za ocenjevanje koeficienta $\beta$ enaka metodi najmanjših kvadratov.

Metoda največjega verjetja je v empiričnih študijah zelo želena, saj ima asimptotsko lastnost, to pomeni, da ponazarja značilnosti velikega vzorca. $Z$ večanjem velikosti vzorca $n$ proti neskončnosti se porazdelitev regresijskega koeficienta $\beta$ po metodi največjega verjetja približuje normalni porazdelitvi. Prednost metode največjega verjetja je, da je dosledna, hkrati pa je z metodo definiran tudi postopek izpeljave variance. Metoda sicer zahteva definiranje predpostavke o porazdelitvi napak, vendar nam poda asimptotsko porazdelitev omenjenih napak glede na pravo vrednost parametrov v populaciji (Rice 2009).

Če torej predpostavljamo, da imamo na voljo presečne podatke za $I$ izvajalcev, ki proizvajajo en output $q_{i}$, lahko ocenimo mejno proizvodno funkcij z linearno Cobb-Douglasovo funkcijsko obliko. V tem primeru lahko logaritem Cobb-Douglasove oblike zapišemo na naslednji način (Coelli idr. 2005):

$$
\ln q_{i}=x_{i}^{\prime} \beta+\varepsilon_{i} i=1, \ldots, I \text {. }
$$

Pri tem $q_{i}$ opredeljuje output $i$ podjetja, $x_{i}{ }^{\prime}$ je vektor $K \times 1$, ki ponazarja logaritem inputov, $\beta$ je vektor neznanih parametrov, $\varepsilon_{i}$ pa označuje odklon od mejne proizvodne funkcije in je povezan s tehnično neučinkovitostjo. V monografiji smo uporabili model Aignerja, Lovella in Schmidta (1977) ter Meeusna in van den Broecka (1977), ti so predlagali uporabo stohastične mejne proizvodne funkcije v naslednji obliki:

$$
\ln q_{i}=x_{i}^{\prime} \beta+v_{i}-u_{i} i=1, \ldots, I
$$

Ta funkcija je enaka funkciji 2.48, pri čemer je odklon od funkcije $\varepsilon_{i}$ razdeljen na del, ki se nanawša na slučajno napako $v_{i}$, in na del, ki se nanaša na tehnično neučinkovitost $u_{i}$ izvajalca $i$. Zgoraj opredeljen model definiramo kot stohastično mejno proizvodno funkcijo zato, ker so 
mere outputa omejene s stohastičnimi oziroma slučajnimi spremenljivkami $\exp \left(x_{i}^{\prime} \beta+v_{i}\right)$. Slučajna napaka $v_{i}$ je lahko pozitivna ali negativna, zato se stohastični mejni rezultati razlikujejo glede deterministični del modela $\exp \left(x_{i}^{\prime} \beta\right)$.

Pri tem je mogoče opredeliti različne vrste predstavljenega presečnega modela stohastične mejne proizvodne funkcije. Med seboj se razlikujejo glede na izbiro različnih funkcijskih oblik in porazdelitev slučajne napake $v_{i}$ in spremenljivko neučinkovitosti $u_{i}$. V monografiji predpostavljamo, da je slučajna spremenljivka $v_{i}$ identično porazdeljena normalna slučajna spremenljivka z ničelno srednjo vrednostjo in varianco $\sigma_{v}^{2}$, hkrati pa je skupaj s spremenljivko neučinkovitosti $u_{i}$ nekorelirana $v$ odnosu do pojasnjevalne spremenljivke $X_{i}$. Sprejeti je treba tudi predpostavko o porazdelitvi slučajne spremenljivke neučinkovitosti $u_{i}$, ki je lahko porazdeljena polovično normalno, eksponentno, okrnjeno normalno ali dvoparametrično gama. $V$ tem delu bomo sledili priporočilu Coellija in soavtorjev (2005), ki pravijo, da je predpostavko o porazdelitvi spremenljivke neučinkovitosti $u_{i}$ treba sprejeti na osnovi programa, ki ga uporabljamo znotraj metode stohastične mejne analize. Za potrebe testiranja hipotez uporabljamo programski paket Shazam, ki omogoča upoštevanje predpostavke, da je spremenljivka neučinkovitosti $u_{i}$ porazdeljena polovično normalno. Hkrati je to v literaturi tudi najpogosteje uporabljena predpostavka pri analizah merjenja učinkovitosti (Bauer 1990; Coelli 1995).

Tako smo znotraj modela sholastične mejne proizvodne funkcije $s$ polovično normalno porazdelitvijo sprejeli naslednje predpostavke:

- $\quad v_{i} \sim \operatorname{iidN}\left(0, \sigma_{v}^{2}\right)$,

- $\quad u_{i} \sim \operatorname{iidN}\left(0, \sigma_{v}^{2}\right)$ to je nenegativno polovična normalna porazdelitev in

- $\quad v_{i}$ in $u_{i}$ sta glede na pojasnjevalne spremenljivke med seboj porazdeljeni neodvisno.

Prva in tretja predpostavka sta klasični predpostavki, ki jih sprejemajo raziskovalci praktično v vseh študijah. Medtem ko je slučajna napaka $v_{i}$ identično porazdeljena normalna slučajna spremenljivka z ničelno srednjo vrednostjo, sta $v_{i}$ in $u_{i}$ glede na pojasnjevalne spremenljivke in hkrati tudi med seboj porazdeljeni neodvisno. Slučajna spremenljivka neučinkovitosti $u_{i}$ pa je identično porazdeljena nenegativna polovično normalna spremenljivka z ničelno srednjo vrednostjo in varianco $\sigma_{u}^{2}$. Pri tem predpostavljamo tudi, da ima slučajna napaka $v_{i}$ enake lastnosti, kot jih ima slučajna napaka $v_{i}$ pri klasičnem linearnem regresijskem modelu. 
Neznane pramatere $\beta_{i}$ pri mejni proizvodnji funkciji smo ocenjevali z metodo največjega verjetja. To je najpogosteje uporabljena metoda za ocenjevanje presečnih modelov stohastične mejne proizvodne funkcije, ki so jo predlagali že Aigner, Lovell in Schmidt (1977). Povedali smo, da lahko metodo največjega verjetja opredelimo tako, da maksimirano logaritem funkcije verjetja za $I$ vzorec izvajalcev. V tem primeru dobimo naslednjo specifikacijo.

$$
\begin{aligned}
& \ln L\left(q(y \mid \beta, \sigma, \lambda)=-\frac{1}{2} \ln \left(\frac{\pi \sigma^{2}}{2}\right)+\sum_{i=1}^{I} \ln \phi\left(-\frac{\varepsilon_{i} \lambda}{\sigma}\right)-\right. \\
& \frac{1}{2 \sigma^{2}} \sum_{i=11}^{I} \varepsilon_{i}^{2} .
\end{aligned}
$$

$\mathrm{V}$ tem primeru je $q$ vektor $\log$-outputov, $\varepsilon_{i}=v_{i}-u_{i}=\ln q_{i}-x_{i}^{\prime} \beta$ je sestavljena napaka oziroma odklon, $\phi(x)$ pa predstavlja kumulativno porazdelitveno funkcijo standardne slučajne napake, ovrednotene glede na $x$.

\section{Ocenjevanje stohastične mejne stroškovne funkcije}

Če imamo na voljo podatke o cenah inputov in outputov, hkrati pa sledimo konceptu minimiranja stroškov, lahko ocenimo ekonomske značilnosti proizvodne tehnologije in stroškovno učinkovitost opazovanega izvajalca. Ko imamo na voljo presečne podatke za izvajalca $i$, lahko mejno stroškovno funkcijo zapišemo na naslednji način:

$$
c_{i} \geq C\left(w_{1, i}, w_{2, i}, \ldots, w_{N, i}, q_{1, i}, q_{2, i}, \ldots, q_{M, i}\right) .
$$

Pri tem $c_{i}$ predstavlja strošek izvajalca $i, w_{n i}$ je cena inputa $n, q_{m i}$ je output $m$ in $c($.) je stroškovna funkcija, ki je nepadajoča, linearno homogena in konkavna v povezavi s cenami. Stroškovna funkcija prikazuje vse možne kombinacije, ki omogočajo proizvodnjo z najnižjimi možnimi stroški. Enačba 2.52 nam pove, da so opazovani stroški večji ali enaki minimalnim možnim stroškom.

Kot običajno je prvi korak pri opredelitvi mejne stroškovne funkcije pri ocenjevanju odnosa med inputi in outputi izbira funkcijske oblike $c($.). Pri merjenju učinkovitosti sta najbolj priporočeni funkcijski obliki Cobb-Douglasova funkcijska oblika in translogaritemska funkcijska oblika. Cobb-Douglasovo obliko mejne stroškovne funkcije lahko prikažemo na naslednji način: 
$\ln c_{i}=\ln \beta_{0}+\sum_{n=1}^{N} \beta_{n} \ln w_{n, i}+\sum_{m=1}^{M} \phi_{m} \ln q_{m, i}+v_{i}+u_{i}$

Če so parametri $\beta_{0}$ nenegativni in ustrezajo pogoju:

$$
\sum_{n=1}^{N} \beta_{n}=1
$$

lahko z upoštevanjem pogojev $\mathrm{v}$ enačbi 2.54, dobimo homogeno-omejitveno Cobb-Douglasovo mejno stroškovno funkcijo:

$$
\begin{aligned}
& \ln \left(c i / w_{N, i}\right)=\ln \beta_{0}+\sum_{n=1}^{N-1} \beta_{n} \ln \left(w n, i / w_{N, i}\right)+\sum_{m=1}^{M}{ }_{m} \ln q_{m, i}+ \\
& v_{i}+u_{i} .
\end{aligned}
$$

V tem primeru je $v_{i}$ slučajna spremenljivka, ki predstavlja beli šum oziroma napake merjenja, na katere izvajalec ne more vplivati, $u_{i}$ pa predstavlja nenegativno spremenljivko, ki predstavlja stroškovno neučinkovitost izvajalca. Ta funkcija je nepadajoča, linearno homogena in konkavna glede na inpute. Vidimo, da ima odklon $\varepsilon_{i} \mathrm{v}$ tem primeru drugačno obliko kot $\mathrm{v}$ primeru stohastične mejne proizvodne funkcije: $\varepsilon_{i}=v_{i}+u_{i}$, kar pomeni, da ima pozitiven naklon.

$\mathrm{Na}$ enak način lahko prikažemo tudi translogaritemsko obliko mejne stroškovne funkcije, ki ima naslednjo specifikacijo:

$$
\begin{aligned}
& \ln c_{i}=\beta_{0}+\sum_{n=1}^{N} \beta_{n} \ln w_{n i}+\beta_{q} \ln q_{i}+\frac{1}{2} \sum_{n=1}^{N} \sum_{m=1}^{N} \beta_{n m} \ln w_{n i} \\
& \ln w_{m i}+\sum_{m=1}^{N} \beta_{q m} \ln q_{i} \ln w_{n i}+\beta_{q q}\left(\ln q_{i}\right)^{2}+v_{i}+u_{i}
\end{aligned}
$$

Iz tega izhaja, da je $c_{i} i$ opazovanje stroškov, $w$ so cene inputov, $q_{i}$ pa predstavlja output. Mejna stroškovna funkcija se v ostalih značilnostih ne razlikuje $\mathrm{v}$ primerjavi $\mathrm{z}$ mejno proizvodno funkcijo, kar je logična posledica tega, da sta proizvodna in stroškovna funkcija med seboj dualiteteni. Pri ocenjevanju parametrov stohastične mejne stroškovne funkcije smo uporabljali enakew predpostavke, kot smo jih uporabljali pri stohastični mejni proizvodni funkciji.

Pri opredeljevanju presečnih modelov stohastične mejne stroškovne funkcije smo predpostavljali, da za način ocenjevanja regresijskega koeficienta $\beta$ uporabimo metodo največjega verjetja. Znotraj modela sto- 
hastične mejne stroškovne funkcije s polovično normalno porazdelitvijo smo sprejeli predpostavke, da je slučajna spremenljivka $v_{i}$ identično porazdeljena normalna slučajna spremenljivka $\mathrm{z}$ ničelno srednjo vrednostjo in varianco $\sigma_{v}^{2}$, hkrati pa je skupaj z nenegativno spremenljivko neučinkovitosti $u_{i}$ nekorelirana v odnosu do pojasnjevalnih spremenljivk. Sprejeli smo tudi predpostavko, da je slučajna spremenljivka neučinkovitosti $u_{i}$ identično porazdeljena nenegativna polovično normalna spremenljivka z ničelno srednjo vrednostjo in varianco $\sigma_{u}^{2}$.

\section{Ekonometrični model stohastične mejne proizvodne funkcije}

Pri vsaki opredelitvi ekonometričnega modela stohastične mejne proizvodne funkcije je vedno najprej treba sprejeti sklep o funkcijskem odnosu med outputi in inputi. Na podlagi klasične ekonomske, ekonometrične ter matematične teorije, na osnovi postavljenih hipotez in na podlagi zbranih podatkov smo se odločili, da bomo pri opredelitvi modela upoštevali, da izvajalci na sekundarni zdravstveni ravni proizvajajo en poslovni učinke oziroma output $(q)$ z dvema proizvodnima dejavnikoma, to sta delo $(L)$ in kapital $(K)$. Pri definiranju outputa smo upoštevali priporočila Coellija in soavtorjev (2005), ki navajajo, da je treba output izvajalcev opredeliti kot enoten agregiran poslovni učinek. Proizvodno funkcija $i$ izvajalca lahko tako opredelimo na naslednji način:

$$
q_{i}=q\left(L_{i}, K_{i}\right) .
$$

Za ocenjevanje te proizvodne funkcije $\mathrm{z}$ metodo stohastične mejne analize je treba opredeliti še funkcijsko obliko odnosa med neodvisno in pojasnjevalnimi spremenljivkami. Znotraj vsakega modela so funkcijski odnosi različni, zato se običajno tudi funkcijske oblike med seboj razlikujejo. Odločitev o izbiri funkcijske oblike ni nikoli vnaprej določena in zahteva temeljit premislek raziskovalcev. Odločitev mora temeljiti na potrebah empiričnega raziskovanja, kar pomeni, da moramo pri opredelitvi funkcijske oblike upoštevati namen, cilje in zastavljene hipoteze. Pravilo, ki bi definiralo pravo obliko proizvodne funkcije, ne obstaja, zato smo odločitev o izbiri oblike produkcijske funkcije sprejeli na podlagi konsistentne literature. Za namen naše analize smo sledili priporočilom, ki so jih opredelili Lau (1986) ter tudi Griffin, Montgomery in Rister (1987). Po njihovem mnenju se mora izbira nanašati na ekonomske, statistične in matematične značilnosti funkcijske oblike. Poleg tega pa je treba upoštevati tudi, da mora biti proizvodna funkcija konsistentna in fleksibilna. 
Pri analizi učinkovitosti smo uporabili dve različni funkcijski obliki, to sta Cobb-Douglasova proizvodna funkcija in translogaritemska proizvodna funkcija. Obe funkcijski obliki sta namreč v literaturi najpogosteje uporabljeni obliki proizvodne funkcije za merjenje učinkovitosti izvajalcev zdravstvene dejavnosti. Obe funkcijski obliki podajata različne mere učinkovitosti, kar pomeni, da je njuna primerjava z vidika naše raziskave zelo zanimiva. Cobb-Douglasova funkcijska oblika predpostavlja, da imajo izvajalci konstantne donose obsega, medtem ko pri translogaritemski proizvodni funkciji lahko upoštevamo ekonomije obsega, kar pomeni, da imajo izvajalci lahko tudi naraščajoče ali padajoče donose obsega. Značilnost obeh funkcijskih oblik je, da sta teoretično konsistentni, saj se predpostavlja, da sta obe funkciji linearno homogeni, poleg tega pa sta tudi konkavni, nepadajoči. Cobb-Douglasova funkcijska oblika torej ni lokalno fleksibilna, je pa zaradi svoje preprostosti uporabe in enostavnosti pri interpretaciji rezultatov zelo pogosto uporabljena pri študijah proizvodnih funkcij. Na drugi strani pa je translogaritemska proizvodne funkcija fleksibilnejša in nam omogoča opredelitev dodatnih značilnosti izvajalcev (Kumbhakar in Lovell 2003; Coelli idr. 2005; Fried, Lovell in Schmidt 2008).

$\mathrm{Za}$ enačbo proizvodne funkcije 2.57 smo torej opredelili dve funkcijski obliki, in sicer najprej Cobb-Douglasovo funkcijsko obliko, nato pa še translogaritemsko funkcijsko obliko. Pri prvem modelu smo predpostavljali, da obstaja $i$ izvajalcev sekundarne ravni zdravstvene dejavnosti, pri katerem determinističen del stohastične mejne proizvodne funkcije predstavljamo s Cobb-Douglasovo obliko proizvodne funkcije. Prvi model stohastične mejne proizvodne funkcije ima naslednjo specifikacijo:

$$
\ln q_{i}=\ln \beta_{0}+\beta_{L} \ln L_{i}+\beta_{K} \ln K_{i}+v_{i}-u_{i} .
$$

Pri tem modelu predpostavljamo, da imajo vsi izvajalci konstantne donose obsega. Enačba 2.58 vključuje Cobb-Douglasovo funkcijsko obliko, ki temelji na specifikaciji, ki smo jo opredelili z enačbo 2.57.

Pri drugem modelu stohastične mejne proizvodne funkcije smo prav tako predpostavljali, da obstaja $i$ izvajalcev sekundarne ravni zdravstvene dejavnosti, pri katerem pa determinističen del stohastične mejne proizvodne funkcije predstavljamo $s$ translogaritemsko funkcijsko obliko. Drugi model stohastične mejne proizvodne funkcije ima naslednjo specifikacijo: 


$$
\begin{aligned}
& \ln q_{i}=\beta_{0}+\beta_{L} \ln L_{i}+\beta_{K} \ln K_{i}+\frac{1}{2} \beta_{L, L} \ln L_{i} \ln L_{i}+ \\
& \frac{1}{2} \beta_{K, K} \ln K_{i} \ln K_{i}+\beta_{L, K} \ln L_{i} \ln K_{i}+v_{i}-u_{i}
\end{aligned}
$$

Pri tem modelu predpostavljamo variabilne donose obsega. S tem, ko smo definirali logaritemsko obliko funkcije, smo zadostili merilu linearnosti v parametrih. Enačba 2.59 vključuje translogaritemsko funkcijsko obliko in enako kot enačba 2.58 temelji na specifikaciji, ki smo jo opredelili z enačbo 2.57 .

Opredelili smo dva modela stohastične mejne proizvodne funkcije, ki se med seboj razlikujeta glede na funkcijsko obliko mejne proizvodne funkcije. Pri obeh modelih smo predpostavljali, da je slučajna spremenljivka neučinkovitosti $u_{i}$ polovično normalno porazdeljena in da je slučajna napak $v_{i}$, ki odraža beli šum, identično porazdeljena slučajna spremenljivka $\mathrm{z}$ ničelno srednjo vrednostjo in varianco $\sigma_{v}^{2}$. Parametri $\beta$ pa so bili $\mathrm{v}$ obeh modeli izračunani na podlagi metode največjega verjetja.

\section{Ekonometrični model stohastične mejne stroškovne funkcije}

Pri opredelitvi ekonometričnega modela stohastične mejne stroškovne funkcije smo najprej sprejeli sklep o funkcijskem odnosu med odvisno spremenljivko in pojasnjevalnimi spremenljivkami. Na podlagi zdravstvene ekonomike in klasične ekonomske teorije smo predpostavili, da izvajalci na sekundarni ravni zdravstvene dejavnosti proizvajajo enoten agregiran poslovni učinek $(q)$ z dvema proizvodnima dejavnikoma, to sta delo $(L)$ in kapital $(K)$. Predpostavili smo tudi, da so na dolgi rok vsi proizvodni dejavniki variabilni, kar pomeni, da lahko izvajalci izbirajo med različnimi kombinacijami dela in kapitala. Pri tem smo upoštevali, da izvajalci sledijo konceptu minimiranja stroškov oziroma da poskušajo proizvajati z minimalnimi povprečnimi stroški. Stroškovno funkcijo izvajalca $i$ lahko tako opredelimo na naslednji način:

$$
c_{i}=c\left(q_{i}, P_{L, i}, P_{K, i}\right) .
$$

V tem primeru $c_{i}$ predstavljajo skupne stroške izvajalca $i, q$ pa je agregiran poslovni učinek. Spremenljivka $P_{L}$ predstavlja ceno proizvodnega dejavnika delo, $P_{K}$ pa ceno proizvodnega dejavnika kapital.

Enako kot pri ocenjevanju stohastične mejne proizvodne funkcije smo se odločili, da bomo opredelili dve funkcijski obliki mejne stroškovne funkcije, to sta Cobb-Douglasova stroškovna funkcija in translogari- 
temska stroškovna funkcija. Za uporabo obeh funkcijskih oblik smo se odločili, ker Cobb-Douglasova funkcijska oblika ni lokalno fleksibilna, je pa najpogosteje uporabljena funkcijska oblika pri opredeljevanju mejnih stroškovnih funkcij. Na drugi strani pa je translogaritemska funkcijska oblika fleksibilnejša, vendar je zahtevnejša z vidika matematičnih računskih operacij (Kumbhakar in Lovell 2003; Coelli idr. 2005; Fried, Lovell in Schmidt 2008).

Za enačbo proizvodne funkcije 2.60 smo torej opredelili dve funkcijski obliki, in sicer najprej Cobb-Douglasovo funkcijsko obliko, nato pa še translogaritemsko funkcijsko obliko. Ob upoštevanju dualitete proizvodne funkcije in stroškovne funkcije, posledično pa tudi Cobb-Douglasove funkcijske oblike mejne proizvodne funkcije in Cobb-Douglasove funkcijske oblike mejne stroškovne funkcije, smo opredelili prvi model stohastične mejne stroškovne funkcije, ki ima naslednjo specifikacijo:

$$
\ln c_{i} / P_{K, i}=\ln \beta_{0}+\beta_{q} \ln q_{i}+\beta_{P_{L}} \ln P_{L, i} / P_{K, i}+v_{i}+u_{i} .
$$

Pri tem modelu predpostavljamo, da imajo vsi izvajalci konstantne donose obsega. Enačba 2.6I vključuje Cobb-Douglasovo funkcijsko obliko, ki temelji na specifikaciji, ki smo jo opredelili z enačbo 2.60 .

Pri drugem modelu stohastične mejne stroškovne funkcije smo upoštevali dualiteto translogaritemske funkcijske oblike mejne proizvodne funkcije in translogaritemske funkcijske oblike mejne stroškovne funkcije. Drugi model stohastične mejne stroškovne funkcije ima naslednjo specifikacijo:

$$
\begin{aligned}
& \ln c_{i} / P_{K, i}=\beta_{0}+\beta_{q} \ln q_{i}+\beta_{P_{L}} \ln P_{L, i} / P_{K, i}+\frac{1}{2} \beta_{q, q} \ln q_{i} \ln q_{i}+ \\
& \frac{1}{2} \beta_{P_{L}, P_{L}} \ln P_{L, i} / P_{K, i} \ln P_{L, i} / P_{K, i}+\beta_{q, P_{L}} \ln q_{i} \ln P_{L, i} / P_{K, i}+ \\
& v_{i}-u_{i}
\end{aligned}
$$

Izhajali smo iz predpostavke, da je stroškovna funkcija linearno homogena, poleg tega pa tudi konkavna glede na cene proizvodnih dejavnikov, kar nam omogoča uporabo translogaritemske linearne oblike stohastične mejne stroškovne funkcije. Poleg tega je stroškovna funkcija nepadajoča glede na cene inputov ter hkrati tudi dualitetna glede na translogaritemsko funkcijsko obliko proizvodne funkcije. Enačba 2.62 torej vključuje translogaritemsko funkcijsko obliko in enako kot enačba 2.6I temelji na specifikaciji, ki smo jo opredelili z enačbo 2.60 . 


\section{Ocenjevanje tehnične, alokacijske in stroškovne učin kovitosti}

Večina stohastičnih mejnih analiz je usmerjena v napovedovanje učinkov neučinkovitosti. Najpogostejša mera tehnične učinkovitosti je definirana kot razmerje med opazovanim outputom in ustreznim stohastičnim mejnim outputom. Mero tehnične učinkovitost torej lahko opredelimo na naslednji način:

$$
T E_{i}=\frac{q_{i}}{\exp \left(x_{i}^{\prime} \beta+v_{i}\right)}=\frac{\exp \left(x_{i}^{\prime} \beta+v_{i}-u_{i}\right)}{\exp \left(x_{i}^{\prime} \beta+v_{i}\right)}=\exp \left(-u_{i}\right) .
$$

V tem primeru mere tehnične učinkovitosti zavzamejo vrednost med o in I. Tehnično učinkovit izvajalec ima mero tehnične učinkovitosti I. Na podlagi zgornje specifikacije lahko vidimo, da tehnična učinkovitost meri output izvajalca $i$ v odnosu do outputa, ki ga proizvaja tehnično popolnoma učinkovit izvajalec. To je torej razmerje med opazovano vrednostjo proizvodnje izvajalca in maksimalno vrednostjo proizvodnje, ki je opredeljena s stohastično mejno proizvodno funkcijo.

$\mathrm{Na}$ enak način, kot smo opredelili mere tehnične učinkovitosti, lahko opredelimo tudi mere stroškovne učinkovitosti. Mere stroškovne učinkovitosti definiramo kot razmerje med minimalnimi možnimi stroški, ki jih ponazarja stohastična mejna stroškovna funkcija, in opazovanimi stroški. Mero stroškovne učinkovitosti lahko ponazorimo z naslednjim zapisom:

$$
C E_{i}=\frac{\exp \left(x_{i}^{\prime} \beta+v_{i}\right)}{c_{i}}=\frac{\exp \left(x_{i}^{\prime} \beta+v_{i}\right)}{\exp \left(x_{i}^{\prime} \beta+v_{i}+u_{i}\right)}=\exp \left(-u_{i}\right) .
$$

Tudi v tem primeru mere stroškovne učinkovitosti zavzamejo vrednosti med $\circ$ in $\mathrm{I}$. Za stroškovno učinkovitega izvajalca velja, da je njegova mere stroškovne učinkovitosti enaka I. Enačba 2.64 definira stroškovno učinkovitost kot razmerje med minimalnimi možnimi stroški, ki jih lahko izvajalec $i$ doseže v okolju, ki ga ponazarjajo neodvisne spremenljivke, in opazovanimi stroški izvajalca $i$. Stroškovna učinkovitost torej meri minimalne možne stroške v odnosu do dejanskih stroškov.

Alokacijsko učinkovitost pa smo definirali kot razmerje med stroškovno učinkovitostjo in tehnično učinkovitostjo. Alokacijska učinkovitost je torej izračuna kot:

$$
A E_{i}=\frac{C E_{i}}{T E_{i}} .
$$

V tem primeru vse vrednosti zavzamejo vrednosti med $\circ$ in I, pri čemer vrednost I predstavlja alokacijsko učinkovitega izvajalca, vrednosti, ki so manjše od I, pa alokacijsko neučinkovitega izvajalca. 


\section{Ocenjevanje ucinkovitosti z metodo DEA}

Za merjenje učinkovitosti bomo poleg metode stohastične mejne analize uporabili tudi metodo podatkovne ovojnice podatkov. V raziskavah je metoda DEA zelo pogosto uporabljena metoda, in sicer predvsem zaradi prednosti, ki smo jo omenili v poglavju 2.2. Bistvo metodologije DEA je, da omogoča preučevanje učinkovitosti tudi v primeru, ko razpolagamo z majhnim številom enot opazovanja. Poleg tega je bistvena prednost metode DEA, da nam omogoča, da opredelimo poslovni proces izvajalca $\mathrm{z}$ večjim številom outputov, poleg tega pa $\mathrm{z}$ večjim številom inputov. $\mathrm{V}$ monografiji smo uporabili metodo DEA, da bi preverili konsistentnost rezultatov, pridobljenih z metodo SFA.

Metoda DEA vključuje uporabo linearnih matematičnih metod programiranja za določitev neparametrične učinkovite meje ali izokvante. Mere učinkovitosti se nato izračunajo na podlagi oddaljenosti enote za sprejemanje poslovnih odločitev od podatkovne ovojnice. Obsežen pregled te metodologije so podali Färe, S. Grosskopf in Lovell (1985), Seiford in Thrall (1990), Lovell (1993), Charnes idr. (1995), Cooper, Seiford in Tone (2000) in Thanassoulis (2001), C. Daraio in Simar (2007), Fried, Lovell in Schmidt (2008), Greene (2008) in drugi.

Pristop določanja učinkovite meje ali izokvante, ki ga je predlagal Farrell (1957), je v kasnejših dveh desetletjih povzelo zgolj nekaj avtorjev. Shephard (1970) in Afriat (1972) sta predlagala matematične metode programiranja, ki so poskušale podati rešitve za določanje učinkovite meje proizvodnje. Študije niso prejele veliko pozornosti vse dokler niso Charnes, Cooper in Rhodes (1978) objavili svoje študije, v kateri so prvič uporabili izraz metoda ovojnice podatkov. $\mathrm{Na}$ osnovi njegovega dela je bilo potem objavljenih več sto člankov, $\mathrm{v}$ katerih so uporabili in tudi razširili metodologijo DEA.

Charnes, Cooper in Rhodes (1978) so predlagali model, ki je bil usmerjen $\mathrm{k}$ inputom, poleg tega pa je predpostavljal konstantne donose obsega. Model so poimenovalni model konstantnih donosov obsega, usmerjen $\mathrm{k}$ inputom. V kasnejših študijah so bili razviti tudi alternativni modeli, v katerih so predpostavljali variabilne donose obsega (Banker, Chames in Cooper 1984; Färe, Grosskopf in Lovell 1985). Metoda DEA v preteklosti ni bila tako pogosto uporabljena metoda merjenja učinkovitosti kot metoda SFA. Večje pozornosti je bila deležna šele v zadnjih desetletjih, ko so jo avtorji začeli uporabljati na različnih področjih, v logistiki, šolstvu in zdravstvu in drugje (Zhu 2003).

Metoda DEA omogoča izračun relativne učinkovitosti homogenih enot glede na podatkovno ovojnico. Te enote se imenujejo enote za spre- 
jemanje poslovnih odločitev. V našem primeru enote za sprejemanje poslovnih odločitev predstavljajo izvajalci na sekundarni ravni zdravstvene dejavnosti oziroma bolnišnice. DEA je metoda linearnega programiranja, zato nam omogoča izračun učinkovitosti na podlagi preučevanja odnosa med inputi oziroma proizvodnimi dejavniki ter outputi. Pri tem predpostavljamo, da so vsi izvajalci v opazovanem vzorcu enake kakovosti, hkrati pa tudi, da zmanjšanje obsega inputov ne spremeni kakovosti proizvedenih outputov.

Oblikovali smo dva modela za merjenje učinkovitosti izvajalcev. Prvi je model konstantnih donosov obsega, usmerjen $\mathrm{k}$ inputom, drugi pa se imenuje model variabilnih donosov obsega, usmerjen $\mathrm{k}$ outputom. $S$ prvim modelom bomo izračunali tako tehnično, alokacijsko kot tudi stroškovno učinkovitost splošnih bolnišnic. $Z$ drugim modelom pa bomo izračunali zgolj tehnično učinkovitost splošnih bolnišnic. Za izračun različnih mer učinkovitosti namreč uporabljamo programski paket Deap, ki ga je razvil Tomothy Coelli, kar nam znotraj k outputom usmerjenega modela omogoča zgolj izračun mer tehnične učinkovitosti (Coelli 1996). Pri prvem modelu smo predpostavili usmerjenost k inputom glede na dejstvo, da je obseg outputov vsako leto dogovorjen vnaprej, in sicer na podlagi splošnega ter področnega dogovora med plačnikom in izvajalcem zdravstvene dejavnosti. V tem primeru imajo izvajalci output opredeljen od zunaj, kar pomeni, da lahko vplivajo zgolj na obseg porabljenih inputov. Predpostavljali smo tudi konstantne donose obsega, saj smo pri tem modelu želeli definirati najučinkovitejše izvajalce ne glede na njihovo velikost. $V$ tem primeru smo upoštevali, da bi lahko določen neučinkovit izvajalec dosegel višjo učinkovitost s prilagoditvijo in prerazporeditvijo uporabljenih inputov, kot tudi s prilagoditvijo svoje velikosti glede na največjo produktivnost. $\mathrm{Na}$ ta način smo definirali učinkovite izvajalce tako po uporabi inputov kot tudi po velikosti.

$\mathrm{V}$ drugem modelu pa smo predpostavljali usmerjenost k outputom, in sicer na podlagi dejstva, da večina managerjev v zdravstveni dejavnosti ne želi zmanjševati oziroma spreminjati obsega zaposlenosti inputov. $V$ tem primeru smo dobili odgovor na vprašanje, za koliko odstotkov bi morali neučinkoviti izvajalci povečati obseg proizvodnje outputov, če bi želeli postati učinkoviti. V outpute usmerjen model predstavlja podlago za vsakoletna pogajanja s plačnikom zdravstvenih storitev, kjer se za vsakega izvajalca posebej vnaprej opredeli obseg proizvedenih outputov. Rezultati naše analize torej managerjem povedo, koliko storitev bi lahko opazovani izvajalci opravili z razpoložljivi inputi oziroma za koliko odstotkov bi lahko z danimi inputi povečali število opravljenih zdravstvenih storitev. To je torej tudi osnova pri sprejemanju odločitev o krajšanju čakal- 
nih vrst. $V$ drugem modelu smo predpostavljali variabilne donose obsega, kar pomeni, da smo iz mer neučinkovitosti izključili neučinkovitost, ki je posledica neučinkovitosti obsega. To pomeni, da smo predpostavljali, da niso vsi izvajalci enake velikosti in da lahko določena mera neučinkoviti izhaja iz dejstva, da nekateri opazovani izvajalci niso optimalne velikosti. $\mathrm{Z}$ upoštevanjem variabilnih donosov smo tako ločili neučinkovitost obsega od čiste neučinkovitosti oziroma zmanjšali heterogenost med izvajalci, ki je posledica različne velikosti izvajalcev.

\section{Model konstantnih donosov obsega, usmerjen k inputom}

Model konstantnih donosov obsega, usmerjen $\mathrm{k}$ inputom, so prvi uvedli Charnes, Cooper in Rhodes (1978). V tem primeru predvidevamo, da imamo na razpolagamo podatke za $N$ inpute in $M$ outpute za $I$ število izvajalcev. Vsak izvajalec $i$ je predstavljen $s$ stolpcem vektorja $X_{i}$ in $q_{i}$. $N \times I$ matrika inputov, $X$, in $M \times I$ matrika outputov, $Q$, predstavljajo podatke za vse izvajalce $I$.

Osnovni model DEA lahko predstavimo preko matematične oblike, ki odraža razmerje inputov in outputov. V tem primeru za vsakega posameznega izvajalca želimo ponazoriti razmerje vseh outputov preko vseh inputov. To naredimo tako, da prikažemo razmerje $u^{\prime} q_{i} / v^{\prime} x_{i}$, kjer je $u$ vektor uteži outputa $M \times I, v$ pa je vektor uteži inputa $N \times 1$. Optimalne uteži dobimo z matematičnim programiranjem po zgledu Coellija idr. (2005):

$$
\begin{aligned}
& \max _{u, v}\left(u^{\prime} q_{i} / v^{\prime} x_{i}\right), \\
& \text { St } \frac{u^{\prime} q_{i}}{v^{\prime} x_{j}} \leq 1, j=1,2, \ldots, I, \\
& u, v \geq 0 .
\end{aligned}
$$

$S$ tem določimo vrednosti $u$ in $v$. V tem primeru maksimiramo količnik učinkovitosti za izvajalca $i$, pri čemer velja omejitev, da morajo biti vse mere učinkovitosti manjše ali enake I. Problem specifikacije tega razmerja je, da ima neskončno število rešitev. Da bi se izognili temu problemu, lahko zapišemo omejitev $v^{\prime} x i=1$, kar pomeni, da dobimo naslednjo specifikacijo (Coelli idr. 2005):

$$
\begin{aligned}
& \max _{\mu, v}\left(\mu^{\prime} q_{i}\right), \\
& \operatorname{St} v^{\prime} x_{j}=1, \\
& \mu^{\prime} q_{j}-v^{\prime} x_{j} \leq 0, j=1,2, \ldots, I, \\
& \mu, v \geq 0 .
\end{aligned}
$$


Pri tem je pri spremembi zapisa iz $u$ in $v_{\mathrm{v}} \mu$ in $v$ treba poudariti, da je to drugačen problem linearnega programiranja. Oblika DEA modela, ki smo ga opredelili z enačbo 2.67 , je opredeljena v multiplikatorski obliki. $\mathrm{Z}$ uporabo dualnosti v linearnem programiranju je mogoče izpeljati ekvivalentno obliko rešitve omenjenega problema (Coelli idr. 2005):

$$
\begin{aligned}
& \min _{\theta, \lambda} \theta, \\
& S t-q_{i}+Q \lambda \geq 0, \\
& \theta x_{i}-X \lambda \geq 0, \\
& \lambda \geq 0 .
\end{aligned}
$$

V tem primeru je $\theta$ skalar in $\lambda$ je $I x 1$ vektor konstant. Ta oblika vključuje manj omejitev kot multiplikatorska oblika $N+M<I+1$ in v splošnem je to ključna prednost. Vrednost $\theta$ je količnik učinkovitosti izvajalca $i$. To zadostuje pogoju $\theta<1$, pri čemer vrednost I označuje točko na meji in s tem tehnično učinkovitega izvajalca skladno s Farrellovo (1957) opredelitvijo. Upoštevati je treba, da mora biti problem linearnega programiranja rešen za $I$ časovna obdobja, in sicer za vsako podjetje v opazovanem vzorcu. Na ta način dobimo vrednost $\theta$ za vsakega posameznega izvajalca.

Učinkovita meja tega sklopa predstavlja izokvanto, ki je določena na podlagi vseh podatkovnih točk oziroma opazovanih izvajalcev znotraj vzorca. Prikazani model omogoča izračun mer tehnične neučinkovitosti z ugotavljanjem oddaljenosti opazovanega izvajalca od učinkovite meje oziroma podatkovne ovojnice podatkov. Na ta način lahko opredelimo mere tehnične učinkovitosti, hkrati pa prikažemo tudi zglede za izvajalce, ki želijo postati tehnično učinkoviti. Ta model se imenuje tudi Farrellov model, saj skalar $\theta$ predstavlja Debreu-Farrellovo mero tehnične učinkovitosti (Cooper, Seiford in Zhu 2004).

Stroškovno učinkovitost izvajalcev lahko definiramo na podoben način kot tehnično učinkovitost. V primeru modela konstantnih donosov obsega, usmerjenega $\mathrm{k}$ inputom, lahko na podlagi enačbe 2.68 , ki prikazuje tehnično učinkovitost izvajalcev, opredelimo tudi model, konstantnih donosov obsega, usmerjen $\mathrm{k}$ inputom, ki ponazarja stroškovno učinkovitost izvajalcev:

$$
\begin{aligned}
& \min _{\lambda, x_{i}^{*}} w_{i}^{\prime}, x_{i}^{*}, \\
& S t-q_{i}+Q \lambda \geq 0, \\
& x_{i}^{*}-X \lambda \geq 0, \\
& \lambda \geq 0 .
\end{aligned}
$$


$V$ tem primeru $w_{i}$ prikazuje $N x 1$ vektor cen inputov za izvajalca $i$, $x_{i}$ je vektor stroškovnega minimiranja količin inputov za izvajalca $i$ glede na dane cene inputov $w_{i}$ in raven outputa $q_{i}$.

Skupno stroškovno učinkovitost izvajalca $i$ lahko torej izračunamo, kot navajajo Coelli idr. (2005):

$$
C E=\frac{w_{i}^{\prime}, x_{i}^{*}}{w_{i}^{\prime}, x_{i}} .
$$

Stroškovna učinkovitost predstavlja razmerje med minimalnimi stroški in dejanskimi stroški izvajalca $i$.

Ko razpolagamo s cenami inputov, lahko izračunamo tudi alokacijsko učinkovitost. Alokacijsko učinkovitost izvajalcev lahko opredelimo kot razmerje med stroškovno učinkovitostjo modela konstantnih donosov obsega, usmerjenega $\mathrm{k}$ inputom, in tehnično učinkovitostjo modela konstantnih donosov obsega, usmerjenega $\mathrm{k}$ inputom. Alokacijsko učinkovitost modela konstantnih donosov obsega, usmerjenega $\mathrm{k}$ inputom, torej matematično opredelimo na naslednji način (Coelli idr. 2005):

$$
A E=\frac{C E_{i}}{T E_{i}} .
$$

Vse mere alokacijske učinkovitosti zavzamejo vrednosti med $\circ$ in I. $\mathrm{Za}$ alokacijsko učinkovitega izvajalca velja, da je njegova mera alokacijske učinkovitosti enaka I, za alokacijsko neučinkovitega izvajalca pa velja, da je njegova mera alokacijske učinkovitosti manjša od I.

\section{Model variabilnih donosov obsega, usmerjen k outputom}

Podobno, kot smo opredelili model konstantnih donosov obsega, usmerjen $\mathrm{k}$ inputom, lahko opredelimo tudi model variabilnih donosov obsega, usmerjen k outputom. Predpostavka o konstantnih donosih obsega je primerna, ko nas zanima definiranje učinkovitosti izvajalcev ne glede na njihovo velikost oziroma v ko želimo ugotoviti, kateri izvajalci so neučinkoviti tako zaradi velikostne neučinkovitosti kot tudi zaradi čiste neučinkovitosti. Predpostavko o konstantnih donosih obsega torej uporabimo, ko nas zanima, kateri izvajalci so učinkoviti tako po velikosti kot tudi po obsegu porabljenih proizvodnih dejavnikov pri tej velikosti. V praksi pa nas pogosto zanima, kateri izvajalci so učinkoviti zgolj glede na razmerje med obsegom proizvedenega outputa in obsegom uporabljenih inputov. To pomeni, da izključimo heterogenost med izvajalci oziroma njihovo različno velikost. 
Različni avtorji, kot so Afriat (1972), Färe, S. Grosskopf in Logan (1983) ter Banker, Charnes in Cooper (1984), so predlagali prilagoditev modela konstantnih donosov obsega, ki prevzame značilnosti modela variabilnih donosov obsega. Uporaba predpostavke konstantnih donosov obsega definira rezultate merjenja tehnične učinkovitosti, ki vključujejo tudi učinke velikostne učinkovitosti. Uporaba modela variabilnih donosov obsega pa omogoča izračun tehnične učinkovitosti, ki ne zajame učinkov velikostne učinkovitosti. Na osnovi modela konstantnih donosov obsega je mogoče problem linearnega programiranja zapisati tudi za primer variabilnih donosov obsega. To naredimo tako, da v enačbo 2.68 uvedemo omejitev o konveksnosti $I 1^{\prime} \lambda=1$ po zgledu Coellija idr. (2005):

$$
\begin{aligned}
& \min _{\theta, \lambda} \theta, \\
& S t-q_{i}+Q \lambda \geq 0, \\
& \theta x_{i}-X \lambda \geq 0, \\
& I 1^{\prime} \lambda=1, \\
& \lambda \geq 0 .
\end{aligned}
$$

$\mathrm{V}$ tem primeru je $I 1$ označba za vektor $I x 1$. Ta pristop vključuje konveksno obliko podatkovne ovojnice, ki se tesneje prilagaja podatkovnim točkam kot linearna oblika podatkovne ovojnice, ki je značilna za konstantne donose obsega. V primeru variabilnih donosov obsega so mere tehnične učinkovitosti običajno višje ali enake kot v primeru konstantnih donosov obsega.

Upoštevati je treba, da konveksnost oblike $I 1^{\prime} \lambda=1$. v bistvu zagotavlja, da neučinkovitega izvajalca primerjamo zgolj z izvajalcem, ki je podobne velikosti. V tem primeru je podatkovna ovojnica sestavljena iz konveksne kombinacije opazovanih izvajalcev. Ta omejitev konveksnosti pa $\mathrm{v}$ primeru konstantnih donosov obsega ni uvedena, zato $\mathrm{v}$ tem modelu opazovanega izvajalca primerjamo z izvajalci, ki so lahko bistveno večji ali tudi bistveno manjši od njega. $V$ tem primeru je vsota uteži $\lambda$ večja ali manjša od ena.

Do sedaj smo prikazali modele, ki so opredelili učinkovitost izvajalcev kot sorazmerno zmanjšanje uporabe inputov glede na dano raven outputa. To je skladno z Debreu-Farrellovo mero tehnične učinkovitosti, usmerjeno v inpute. Mero tehnične učinkovitosti je mogoče definirati kot sorazmerno povečanje outputa glede na dano raven inputov. 
$\mathrm{V}$ primeru konstantnih donosov obsega ta dva načina zavzameta enake vrednosti mer tehnične učinkovitosti. V primeru variabilnih donosov obsega pa se mere tehnične učinkovitosti razlikujejo glede na usmerjenost $\mathrm{k}$ inputom ali $\mathrm{k}$ outputom. $\mathrm{V}$ večini študij izberejo usmerjenost $\mathrm{k}$ inputom, ker predpostavljajo, da imajo izvajalci večji vpliv na inpute, kar pomeni, da količine inputov $\mathrm{v}$ tem primeru predstavljajo odvisne spremenljivke. V nekaterih panogah pa imajo izvajalci podano določeno raven inputa in si zato prizadevajo za proizvodnjo maksimalnega obseg outputa. Kljub temu je znano dejstvo, da izbira usmerjenosti v inpute ali outpute le neznatno vpliva na mere tehnične učinkovitosti (Coelli in Perelman 1999).

Na podoben način, kot smo prikazali model variabilnih donosov obsega, usmerjenega $\mathrm{k}$ inputom, lahko prikažemo še model variabilnih donosov obsega, usmerjenega $\mathrm{k}$ outputom. DEA model, usmerjen $\mathrm{v}$ outpute, je zelo podoben DEA modelu, usmerjenemu v inpute. $\mathrm{K}$ outputom usmerjen modela variabilnih donosov tako lahko prikažemo na naslednji način (Coelli idr. 2005):

$$
\begin{aligned}
& \min _{\theta, \lambda} \phi, \\
& S t-\phi q_{i}+Q \lambda \geq 0, \\
& x_{i}-X \lambda \geq 0, \\
& I 1^{\prime} \lambda=1, \\
& \lambda \geq 0 .
\end{aligned}
$$

$\mathrm{V}$ tem primeru $1 \leq \phi<\infty$ in $\phi-1$ ponazarja sorazmerno povečanje outputa, ki ga lahko izvajalec $i$ doseže, če ima podano določeno raven inputov. Upoštevati je treba, da $1 / \phi$ opredeljuje rezultat mere tehnične učinkovitosti, ki variira med $\circ$ in 1 . To imenujemo mera učinkovitosti, usmerjena v outpute.

V primeru definiranja modela variabilnih donosov obsega, usmerjenega k outputom, nam programski paket, ki smo ga izbrali za izračun mer učinkovitosti, ne omogoča izračuna prihodkovne in alokacijske učinkovitosti. Prihodkovno oziroma stroškovno in alokacijsko učinkovitost splošnih bolnišnic lahko tako izračunamo zgolj pri modelu, ki je usmerjen k inputom. Izvajalce, ki so neučinkoviti zaradi svoje velikostne neučinkovitosti, lahko tako definiramo zgolj na podlagi primerjave tehnične učinkovitosti modela, usmerjenega $v$ inpute, in tehnične učinkovitosti izvajalcev, usmerjenih v outpute. 


\section{Opredelitev vzorca opazovanih bolnišnic}

V Sloveniji delujejo univerzitetne bolnišnice, splošne bolnišnice in specialne bolnišnice, med katerimi so nekateri izvajalci v državni lasti, drugi pa v zasebni lasti. Zasebni izvajalci so po velikosti v primerjavi z javnimi bolnišnicami bistveno manjši, hkrati pa opravljajo zelo majhen in ozek nabor dejavnosti, zato jih v opazovani vzorec nismo vključili. V Sloveniji deluje šestindvajset bolnišnic, med katerimi sta dve univerzitetni bolnišnici, deset je splošnih bolnišnic in štirinajst je specialnih bolnišnic. $\mathrm{V}$ monografiji preučujemo mrežo sekundarne zdravstvene dejavnosti, kar pomeni, da analiziramo učinkovitost zgolj slovenskih splošnih bolnišnic, medtem ko specialnih bolnišnic v vzorec ne vključujemo. Pri preučevanju učinkovitosti je namreč znotraj vzorca treba zagotoviti čim večjo homogenost opazovanih enot. V nasprotnem primeru se lahko zgodi, da heterogenost izvajalcev zamenjamo za neučinkovitost, kar pomeni, da dobljeni rezultati ne ponazarjajo ustreznih mer učinkovitosti posameznih izvajalcev. Na to opozarjajo številni avtorji, med katerimi omenjeno problematiko posebej izpostavljata B. Watcharasriroj in Tang (2004). Metoda SFA in metoda DEA vključujeta predpostavko, da imajo vsi opazovani izvajalci enako tehnologijo, kar pomeni, da se za njih predpostavlja enotna mejna proizvodna funkcija. Na to opozarjajo tudi Chen, Hwang in Shao (2005), ki zaradi omenjenih razlogov v svoji analizi učinkovitosti zajamejo zgolj nekatere splošne bolnišnice. To je posledica dejstva, da obstajajo tehnološke razlike med različnimi bolnišnicami, kar pomeni, da v vzorec ni mogoče zajeti vseh bolnišnic, saj v tem primeru ni mogoče dobiti ustreznih ocen učinkovitosti izvajalcev. Skladno s povedanim smo tudi mi v vzorec zajeli zgolj slovenske splošne in univerzitetne bolnišnice.

Pri analizi učinkovitosti smo ocenjevali tehnično, alokacijsko in stroškovno učinkovitost dvanajstih slovenskih splošnih bolnišnic. Iz nabora podatkov smo izključili specialne bolnišnice tako znotraj metode SFA kot tudi znotraj metode DEA, saj obe metodi zahtevata homogenost opazovanih enot. Pri tem bi lahko izključili še dve univerzitetni bolnišnici, vendar zaradi majhnega nabora števila opazovanih enot to ni bilo smiselno. Poleg tega določen obseg terciarne ravni zdravstvene dejavnosti opravljajo tudi ostale splošne bolnišnice, zato je bilo $\mathrm{z}$ vidika naše analize $\mathrm{v}$ nabor podatkov smiselno vključili tudi oba univerzitetna klinična centra. Vzorec slovenskih splošnih bolnišnic tako predstavlja dvanajst bolnišnic, in sicer Splošna bolnišnica Brežice, Splošna bolnišnica Celje, Splošna bolnišnica Izola, Splošna bolnišnica Jesenice, Splošna bolnišnica Murska Sobota, Splošna bolnišnica Nova Gorica, Splošna bolnišnica Novo mesto, Splošna bolnišnica Ptuj, Splošna bolnišnica Slovenj Gradec, Splošna bol- 
nišnica Trbovlje, Univerzitetni klinični center Ljubljana in Univerzitetni klinični center Maribor.

Znotraj analize učinkovitosti smo uporabili podatke dvanajstih analiziranih splošnih bolnišnic v desetletnem obdobju, in sicer med letom 2005 in letom 20I4. Pri preučevanju učinkovitosti slovenskih splošnih bolnišnic tako uporabljamo panelne podatke, ki predstavljajo kombinacijo presečnih podatkov in časovnih vrst. Prednost panelnih podatkov je, da upoštevajo spremembe spremenljivk skozi čas in po posameznih izvajalcih. Na ta način razpolagamo s stodvajsetimi opazovanji, kar je skladno z dejstvom, da smo opazovali dvanajst slovenskih splošnih bolnišnic skozi desetletno obdobje. Na ta način znotraj metode DEA in metode SFA razpolagamo z zadostnim številom opazovanih enot. Podatke o inputih, ki smo jih uporabili za ocenjevanje učinkovitosti posameznih splošnih bolnišnic, smo pridobili iz računovodskih izkazov oziroma letnih poročil, ki jih zbirata Agencija Republike Slovenije za javnopravne evidence in storitve - AJPES in Združenje zdravstvenih zavodov Slovenije. Eden izmed temeljih virov podatkov o obsegu outputov so nam predstavljali podatki, ki jih zbira Nacionalni inštitut za javno zdravje. Relevantnost podatkov, ki jih zbira Nacionalni inštitut za javno zdravje smo preverili tudi s podatki, ki jih zbira Zavod za zdravstveno zavarovanje Slovenije.

\section{Podatki in opredelitev spremenljivk opazovanih bolnišnic}

Metodo SFA in metodo DEA smo uporabili za izračun tehnične, alokacijske in stroškovne učinkovitosti dvanajstih opazovanih splošnih bolnišnic. Pri izračunu tehnične učinkovitosti smo potrebovali podatke o količinskem obsegu proizvedenih outputov in podatke o količinskem obsegu porabljenih inputov. Pri alokacijski in stroškovni učinkovitosti pa smo poleg podatkov o količinskem obsegu inputov potrebovali še podatke o cenah inputov. Skladno s tem smo najprej opredelili vrste dejavnosti, ki jih opravljajo slovenske splošne bolnišnice, nato pa še njihov količinski obseg v posameznih letih znotraj opazovanega obdobja. Poleg podatkov o obsegu porabljenih inputov pa smo definirali še cene izbranih inputov v obdobju med letom 2005 in letom 2014.

Podatke o količinskem obsegu proizvedenih outputov smo pridobili od Nacionalnega inštituta za javno zdravje in Zavoda za zdravstveno zavarovanje Slovenije, s katerim bolnišnice sklenejo pogodbe znotraj splošnega in področnega dogovora o obsegu programa posameznih zdravstvenih storitev in hkrati tudi o njihovih cenah. Temeljne dejavnosti opazovanih slovenskih splošnih bolnišnic so v skladu z določili Splo- 
šnega dogovora za bolnišnice (Zavod za zdravstveno zavarovanje Slovenije 2014) razdeljene v več skupin. Osnovni dve vrsti dejavnosti, ki jih opravljajo bolnišnice, sta specialistična ambulantna dejavnost in specialistična hospitalna dejavnost. Poleg tega nekatere bolnišnice opravljajo tudi dializno dejavnost, terciarno dejavnost in druge zdravstvene dejavnosti. Skladno s tem smo opredelili več vrst outputov, ki jih proizvajajo opazovane splošne bolnišnice. Podatki o obsegu programa zdravstvenih storitev se na ravni bolnišnice zbirajo ločeno, in sicer glede na posamezno vrsto dejavnosti.

Za izračun tehnične, alokacijske in stroškovne učinkovitosti uporabljamo metodologijo SFA in metodologijo DEA, pri čemer je treba znotraj metode SFA kot output vključiti enoten poslovni učinek, medtem kot znotraj metode DEA lahko vključimo večje število ločenih outputov. Pri tem je treba upoštevati, da večje število outputov zahteva tudi večje število spremenljivk, ki jih vključimo v posamezne modele. Ker razpolagamo s podatki zgolj dvanajstih slovenskih splošnih bolnišnic, je treba posamezne vrste outputa vključiti v analizo kot agregirane kazalnike outputa. Pri tem upoštevamo priporočila Golanya in Rolla (1989) ter Dysona idr. (200I), ki navajajo, da je treba pri določitvi števila outputov upoštevati, da moramo razpolagati vsaj z dvakrat večjim številom opazovanih enot od zmnožka skupnega števila inputov in outputov. Ko uporabimo dve vrsti inputa, lahko $\mathrm{v}$ analizo učinkovitosti vključimo maksimalno tri različne outpute. Omenjeno pravilo velja, ko uporabimo presečne podatke, hkrati pa velja enako tudi pri uporabi panelnih podatkov.

$\mathrm{V}$ ta namen smo znotraj analize učinkovitosti omejili število outputov, in sicer na način, da smo določene vrste dejavnosti, ki jih nekatere bolnišnice opravljajo, izključili iz nabora outputov. Outpute bolnišnic lahko porazdelimo znotraj petih skupin. Prvo skupino predstavlja output, ki obsega specialistično ambulantno dejavnost, drugi output zajema specialistično hospitalno dejavnost, tretji output odraža dializno dejavnost, četrti output obsega terciarno dejavnost in peti output zajema druge zdravstvene dejavnosti, ki jih opravljajo bolnišnice. Znotraj analize učinkovitosti smo uporabili dve vrsti outputa, to sta output specialistične ambulantne dejavnosti in output specialistične hospitalne dejavnosti, output dializne dejavnosti, output terciarne dejavnosti in output drugih dejavnosti pa smo iz analize izključili. Prvi output smo tako definirali kot output ambulante dejavnosti, drugi output pa kot output hospitalne dejavnosti. Pri definiranju outputa smo kot ključno merilo uporabili vrsto obravnave bolnikov. Output ambulantne obravnave namreč ne 
zahteva hospitalizacije bolnikov, medtem ko se pri outputu hospitalne dejavnosti predvideva, da pri bolnikih poteka hospitalizacija, kar pomeni, da ostanejo v bolnišnici običajno več dni.

Način spremljanja podatkov nam omogoča, da lahko za potrebe naše analize izrazimo output ambulante dejavnosti na način, da pri opredelitvi količinskega obsega outputa ambulantne dejavnosti uporabimo podatke $\mathrm{v}$ obliki števila primerov ambulante dejavnosti, ki ga izrazimo $s$ številom obravnavanih bolnikov. Število primerov tako izraža skupno število vseh obiskov bolnikov, ki so potrebovali ambulanto obravnavo. V tem primeru velja, da vsak ambulantni obisk upoštevamo kot dodaten primer ambulantne dejavnosti, ne glede na dejstvo, da lahko posamezno ambulanto isti bolnik obišče večkrat. Sem torej uvrščamo tako prve obiske kot tudi ponovne obiske bolnikov. Če je na primer bolnik določeno ambulanto obiskal trikrat, se šteje, da so bili obravnavani trije bolniki. To pomeni, da se kljub temu, da gre za istega bolnika, pri definiranju količinskega obsega outputa upošteva, da gre v tem primeru za tri nove bolnike.

Drugi output za preučevane splošne bolnišnice smo definirali kot output hospitalne dejavnosti. Za potrebe opredelitve količinskega obsega outputa hospitalne dejavnosti smo uporabili število akutno odpuščenih bolnikov. Za vse slovenske splošne bolnišnice je mogoče pridobiti podatke o številu akutno odpuščenih bolnikov glede na posamezne skupine primerljivih primerov. Podatki po skupinah primerljivih primerov vključujejo tudi heterogenost med posameznimi obravnavami, vendar so ti podatki z vidika naše analize preveč podrobni. Zaradi majhnega števila opazovanih enot smo tako pri združevanju različnih outputov upoštevali skupno število vseh skupin primerljivih primerov, kar je v našem primeru ekvivalentno številu akutno odpuščenih bolnikov.

Metoda DEA nam omogoča, da v analizo vključimo več vrst outputov, zato smo v tem primeru za vse opazovane bolnišnice vključili dve vrsti outputa, in sicer output ambulantne dejavnosti in output hospitalne dejavnosti. Za potrebe metode SFA pa je bilo treba različne outpute agregirati v enoten poslovnih učinek, kar pomeni, da je bilo treba output ambulantne dejavnosti in output hospitalne dejavnosti agregirati v enoten kazalnik outputa. Output ambulantne dejavnosti in output hospitalne dejavnosti smo združili preko števila obravnavanih bolnikov. To je skladno z dejstvom, da je znotraj literature agregiran poslovni učinek najpogosteje opredeljen v obliki skupnega števila bolnikov, ki jih bolnišnice obravnavajo $\mathrm{v}$ posameznem letu (Ozcan 2008). Tudi vse novejše 
študije, ki preučujejo učinkovitost bolnišnic, običajno kot output bolnišnice definirajo število vseh obravnavanih bolnikov (Yang in Zeng 2014; Kinyanjui, Gachanja in Muchai 2015; Samer 2016). Znotraj metode SFA je torej output definiran v obliki števila obravnavanih bolnikov, ki predstavlja seštevek bolnikov, ki so jih bolnišnice obravnavale znotraj specialistične ambulantne dejavnosti in znotraj specialistične hospitalne dejavnosti. Agregiran output je torej vsota outputa ambulantne dejavnosti in outputa hospitalne dejavnosti.

Poleg podatkov o obsegu outputov pa za analizo učinkovitosti potrebujemo tudi podatke o obsegu porabljenih inputov. Za analizo tehnične, alokacijske in stroškovne učinkovitosti potrebujemo podatke tako o količinskem obsegu inputov kot tudi podatke o cenah porabljenih inputov. Podatke o posameznih vrstah inputov smo pridobili iz računovodskih izkazov oziroma letnih poslovnih in strokovnih poročil opazovanih bolnišnic, ki jih zbira AJPES, in iz podatkov o poslovanju zdravstvenih zavodov, ki jih zbira Združenje zdravstvenih zavodov.

$\mathrm{Za}$ analizo učinkovitosti smo oblikovali dve vrsti inputa, in sicer skladno s klasično ekonomsko teorijo smo inpute opredelili v obliki inputa delo in inputa kapital. Input delo smo izrazili s povprečnim številom zaposlenih, ocenjenim na podlagi opravljenih ur. Ta mera je v primerjavi $s$ klasično mero proizvodnega dejavnika delo, ki opredeljuje število zaposlenih konec koledarskega leta, primernejša. Povprečno število zaposlenih, ocenjenih na podlagi opravljenih ur, namreč upošteva razlike med tistimi, ki so zaposleni za poln delovni čas, in med tistimi, ki so zaposleni za krajši delovni čas. Poleg tega znotraj opazovanih bolnišnic upošteva tudi nadurno delo oziroma dežurstva. To je hkrati v analizah učinkovitosti tudi najpogosteje uporabljena mera proizvodnega dejavnika delo (Coelli idr. 2005). Obseg inputa delo v obliki povprečnega števila zaposlenih, ocenjenega na podlagi opravljenih ur, smo izračunali kot razmerje med številom delovnih ur v opazovanem letu in številom možnih ur v opazovanem letu.

Za izračun tehnične učinkovitosti izvajalcev poleg podatkov o količinskem obsegu inputa delo potrebujemo tudi podatke o količinskem obsegu inputa kapital. Obseg inputa kapital smo izrazili v obliki vrednosti opredmetenih osnovnih sredstev, ki so izražene v evrih. V računovodskih izkazih so namreč opredeljene vrednosti vseh posameznih osnovnih sredstev, ki jih uporabljajo bolnišnice, med katerimi smo uporabili podatke o vrednosti nepremičnin in opreme ter drugih opredmetenih osnovnih sredstev. $\mathrm{Z}$ uporabo podatkov o vrednosti opredmetenih osnovnih 
sredstev smo zanemarili vpliv stopnje odpisanosti opreme. Obseg inputa kapital je tako izračunan kot vsota vrednosti nepremičnin in opreme ter ostalih opredmetenih osnovnih sredstev. Pri opredelitvi vrednosti opredmetenih osnovnih sredstev je treba zagotoviti primerljivost podatkov za celotno opazovano obdobje, zato smo vse vrednosti osnovnih opredmetenih sredstev deflacionirali. Nakupne vrednosti opredmetenih osnovnih sredstev se namreč v času spreminjajo, zato so vse vrednosti deflacionirane na začetno leto opazovanja, torej na leto 2005. Pri tem smo vrednosti nepremičnin deflacionirali na podlagi indeksa cen stanovanjih nepremičnin, vrednosti opreme in drugih opredmetenih osnovnih sredstev pa smo deflacionirali na podlagi indeksa cen življenjskih proizvodov za zdravila in medicinske izdelke.

Poleg podatkov o obsegu porabljenih inputov pa za izračun alokacijske in stroškovne učinkovitosti potrebujemo podatke o ceni inputov. Ceno inputa delo smo izračunali kot razmerje med letnim stroškom dela posamezne bolnišnice in povprečnim številom zaposlenih, izračunanim na podlagi števila opravljenih ur. Cena dela nam tako pove, kolikšen je povprečen letni strošek dela za posamezno bolnišnico na zaposlenega, izražen v evrih. Ker opazujemo bolnišnice znotraj daljšega časovnega obdobja, je pri izračunu cene dela treba upoštevati realne stroške dela. Realne vrednosti stroškov dela smo izračunali tako, da smo nominalne vrednosti stroškov dela deflacionirali z ustreznim deflatorjem. Pri tem smo uporabili indeks cen življenjskih potrebščin, s pomočjo katerega smo lahko izračunali realno vrednost cene dela posamezne bolnišnice, ki ponazarja realen strošek dela na posameznega zaposlenega. Skladno s tem smo pri izračunu cene dela nominalne stroške dela deflacionirali na začetno analizirano leto, torej na leto 2005 .

Cena kapitala je odvisna od definiranja obsega inputa kapitala. Pri analizi učinkovitosti smo obseg inputa kapital definirali v obliki osnovnih opredmetenih sredstev, s katerimi razpolagajo posamezne bolnišnice. Skladno $s$ tem smo podatke o ceni inputa kapitala, izražene $\mathrm{v}$ evrih, izračunali tako, da smo vsoto stroškov amortizacije in odhodkov iz financiranja delili z vrednostjo osnovnih opredmetenih sredstev. $\mathrm{Za}$ osnovna opredmetena sredstva je namreč značilno, da se amortizirajo, kar pomeni, da nastanejo stroški amortizacije, njihov nakup pa lahko bolnišnice financirajo z lastniškim ali dolžniškim kapitalom. V primeru nakupa osnovnih sredstev z dolžniškim kapitalom nastanejo na ta račun odhodki iz financiranja, zato smo pri izračunu cene kapitala upoštevali tako stroške amortizacije kot tudi odhodke iz financiranja. Tudi v 
tem primeru je treba opredeliti realno vrednost cene kapitala, kar je mogoče na način, da vrednosti v števcu in imenovalcu deflacioniramo $\mathrm{z}$ istim deflatorjem. Cena kapitala predstavlja razmerje med vsoto stroškov amortizacije in odhodkov za financiranja ter vrednostjo osnovnih opredmetenih sredstev, kar pomeni da lahko ceno kapitala izračunamo tudi tako, da uporabimo kar nominalne vrednosti, ki jih imamo $\mathrm{v}$ števcu in imenovalcu.

\section{Rezultati ocenjevanja mer učinkovitosti izvajalcev zdravstvene dejavnosti}

Mere tehnične, alokacijske in stroškovne učinkovitosti ocenjujemo z dvema alternativnima metodama, $\mathrm{z}$ ekonometrično in parametrično stohastično mejno analizo SFA in neparametrično metodo linearnega programiranja DEA. Obe metodi, tako SFA kot tudi DEA, sta analitični strogi metodi primerjalne analize, ki izkoriščata funkcije razdalje za merjenje učinkovitosti izvajalcev zdravstvene dejavnosti glede na mejne funkcije. Za oba pristopa so značilne različne tehnike ocenjevanja mejnih funkcij, pri čemer uporabljata različne predpostavke o statističnih napakah oziroma belemu šumu in strukturi proizvodne tehnologije (Kumbhakar in Lovell 2003; Coelli idr. 2005; Fried, Lovell in Schmidt 2008). SFA je stohastična metoda, ki omogoča razlikovanje neučinkovitosti od učinkov belega šuma, kar omogoča osnovo za statistično sklepanje. DEA je po drugi strani neparametrična metoda, ki omogoča, da pri ocenjevanju učinkovitosti ni treba sprejeti predpostavke o funkcijski obliki, s čimer se izognemo morebitnim negativnim učinkom napačne izbire funkcijske oblike mejnih funkcij. Metoda DEA ima sicer pomanjkljivost, da pri njej ni mogoče ločevati med učinkom neučinkovitosti in učinkom belega šuma, vendar pa ima to prednost, da nima stroge zahteve glede uporabljenih podatkov, kar pomeni, da je v analizo mogoče vključiti manjše število opazovanih enot (Farsi in Filippini 2004). SFA metoda ima na drugi strani pomanjkljivost, ki izhaja iz zahteve po rigorozni predpostavki glede oblike mejnih funkcij, hkrati je treba zagotoviti tudi večje število opazovanj (Fried, Lovell in Schmidt 2008).

\section{Rezultati ocenjevanja ucinkovitostiz metodo SFA}

Za preučevanje učinkovitosti splošnih bolnišnic smo znotraj metode SFA izbrali dve funkcijski obliki proizvodne in stroškovne funkcije, Cobb-Douglasovo in translogaritemsko funkcijsko obliko. Rezultati učinko- 
vitosti, ki smo jih dobili na podlagi translogaritemske funkcijske oblike, kažejo, da je glede na uporabljene podatke primernejša uporaba Cobb-Douglasove funkcijske oblike. Pri translogaritemski funkcijski obliki je namreč zahtevana ocena večjega števila spremenljivk, ki vplivajo na manjšo učinkovitost statistične metode. Poleg tega pa lahko interakcije, ki so vključene v model, povzročijo multikolinearnost, kar pomeni, da se lahko zgodijo velike napake pri ocenjevanju in tudi lahko pride do neskladnosti samih rezultatov. Značilnost translogaritemskega modela je, da definira lokalni približek okoli določene točke, običajno okoli mediane. Skladno $s$ tem se model na eni strani zelo dobro prilega opazovanjem, ki so v okolici mediane, na drugi strani pa definira bistveno manj natančen približek za opazovanja, ki so daleč od mediane.

Rezultati ocenjevanja učinkovitosti s translogaritemskim modelom sicer kažejo, da se podatki bolje prilegajo translogaristemski kot Cobb-Douglasovi funkcijski obliki, kar se odraža tudi v višjih merah učinkovitosti, kljub temu pa rezultati ponazarjajo nestabilnost mer učinkovitosti splošnih bolnišnic, kar pomeni, da je translogaritemska funkcijska oblika manj primerna z vidika naše analize. Skladno s tem smo se odločili, da ocenjevanje učinkovitosti splošnih bolnišnic podrobneje ponazorimo na primeru Cobb-Douglasove proizvodne in stroškovne funkcije. Ta funkcijska oblika je preprostejša za uporabo, hkrati pa zahteva oceno bistveno manjšega števila spremenljivk, kar je praktična prednost, ko imamo v vzorcu vključeno manjše število opazovanj. Kot smo že omenili, imamo v slovenskem prostoru zgolj dvanajst splošnih bolnišnic, kar nam omogoča opazovanje manjšega števila enot, ki jih rešujemo z uporabo panelnih podatkov, zato je uporaba Cobb-Douglasove funkcijske oblike z vidika naše analize še toliko primernejša. Poleg tega je interpretacija rezultatov pri tej funkcijski obliki bistveno enostavnejša za razumevanje, saj ne vsebuje interakcijskih vplivov neodvisnih spremenljivk.

Mere tehnične, alokacijske in stroškovne učinkovitosti so pri metodi SFA ocenjene na podlagi ekonometričnih ocen proizvodne in stroškovne funkcije. Kot je znano, so pri ekonometričnih ocenah stohastične mejne funkcije napake merjenja sestavljene iz dveh delov (Kumbhakar in Lovell 2003; Fried, Lovell in Schmidt 2008). Prvi se nanaša na normalno porazdeljeno stohastično napako $\mathrm{z}$ ničelno sedanjo vrednostjo, drugi pa je posledica neučinkovitosti ostanka. Mejna proizvodna funkcija tako kaže maksimalen možen obseg outputa glede na določeno raven inputov. Mejna stroškovna funkcija pa opredeljuje minimalne možne stroške glede na določen obseg outputa, cene proizvodnih dejavnikov in obstoječo proizvodno tehnologijo. Pri proizvodni funkciji 
je neučinkovitost označena z nedoseganjem mejne proizvodne funkcije, pri stroškovni funkciji pa je neučinkovitost posledica nedoseganja mejne stroškovne funkcije. Odstopanja posameznega izvajalca zdravstvenih storitev od mejne proizvodne ali mejne stroškovne funkcije so vsota normalno porazdeljene stohastične napake $\mathrm{z}$ ničelno sedanjo vrednostjo in neučinkovitosti ostanka, ki je v primeru stroškovne funkcije pozitiven, v primeru proizvodne funkcije pa zavzame negativno vrednost. Pri neučinkovitosti lahko sicer sprejmemo različne predpostavke o njeni porazdelitvi, vendar se pri spremenljivki neučinkovitosti običajno predpostavlja polovična normalna porazdelitev, kar velja tudi v primeru naše analize.

$\mathrm{Na}$ tem mestu moramo opozoriti še na eno dejstvo, ki se nanaša na preučevanje mer tehnične, alokacijske in stroškovne učinkovitosti. Ocena mejne proizvodne funkcije nam omogoča zgolj ocenjevanje mer tehnične učinkovitosti, medtem ko nam ocena mejne stroškovne funkcije omogoča ocenjevanje mer stroškovne, alokacijske in tudi tehnične učinkovitosti izvajalcev zdravstvene dejavnosti. Stroškovna učinkovitost je namreč sestavljena iz tehnične in alokacijske učinkovitosti, kar pomeni, da lahko stroškovno neučinkovitost razdelimo na njeni dve komponenti, pri čemer prva ponazarja tehnično neučinkovitost, druga pa alokacijsko neučinkovitost izvajalce zdravstvene dejavnosti.

Rezultate ocenjevanja tehnične učinkovitosti smo izpeljali na podlagi ocene mejne stroškovne funkcije oziroma stroškovne učinkovitosti. Mere tehnične učinkovitosti, ocenjene z metodo SFA, kažejo, da se znotraj posameznih bolnišnic v opazovanem obdobju količniki tehnične učinkovitosti niso bistveno spreminjali. Skladno s tem imajo splošne bolnišnice z najvišjimi količniki učinkovitosti v povprečju skozi celotno obdobje visoke mere tehnične učinkovitosti. Na drugi strani pa imajo splošne bolnišnice z najnižjimi količniki učinkovitosti nizke mere tehnične učinkovitosti v vseh letih opazovanja. Ocene mere tehnične učinkovitosti so tako na podlagi metode SFA konsistentne v celotnem opazovanem obdobju, kar kaže na to, da je določena splošna bolnišnica, ki je bila tehnično neučinkovita $\mathrm{v}$ prvem letu opazovanja, tehnično neučinkovita tudi v preostalih devetih letih opazovanja.

Splošna bolnišnica Brežice ima vrednosti tehnične učinkovitosti med 0,805 in 0,976 , pri čemer v začetnem obdobju opazovanja dosega visoke mere tehnične učinkovitosti, ki v kasnejšem obdobju upadajo, $\mathrm{v}$ zadnjih letih pa se kaže trend ponovnega naraščanja. Pri Splošni bolnišnici Celje se količniki tehnične učinkovitosti gibljejo med o,934 in 
0,979, pri tem je ta bolnišnica zaradi relativno konstantnih mer učinkovitosti definirana kot tehnično najučinkovitejša splošna bolnišnica. Splošna bolnišnica Izola zavzame vrednosti tehnične učinkovitosti med $0,78 \mathrm{I}$ in 0,896 . Njeni količniki tehnične učinkovitosti v prvih letih opazovanja v povprečju naraščajo, v zadnjem obdobju pa je opazno ponovno upadanje mer tehnične učinkovitosti. Splošna bolnišnica Jesenice je tehnično najučinkovitejša v letih 2008, 2013 in 2014, najnižjo mero tehnične učinkovitosti pa doseže v letu 2006, ko njen količnik tehnične učinkovitosti znaša 0,725 . Univerzitetni klinični center Ljubljana je tehnično najbučinkovitejši v letu 2013, ko njegova mera tehnične učinkovitosti znaša 0,891 , tehnično najmanj učinkovit pa je v letu 2009, ko je njegov količnik tehnične učinkovitosti o,619. Pri Univerzitetnem kliničnem centru Maribor se mere tehnične učinkovitosti gibljejo med 0,549 in 0,619 , pri tem pa najvišjo mero tehnične učinkovitosti doseže v letu 2005. Splošna bolnišnica Murska Sobota je tehnično najučinkovitejša v letih 20IO, $201 \mathrm{I}$ in $20 \mathrm{I}$ 2, pri čemer v letu $20 \mathrm{Io}$ doseže najvišjo mero tehnične učinkovitosti, ki znaša 0,990 , v letih 201 I in 2012 pa njen količnik tehnične učinkovitosti zavzame vrednost 0,976 . Splošna bolnišnica Nova Gorica zavzame vrednosti tehnične učinkovitosti med 0,5 I 8 in 0,614 , pri tem se njeni količniki v začetnem obdobju znižujejo, v zadnjih letih opazovanja pa se ponovno zvišujejo. Splošna bolnišnica Novo mesto je najučinkovitejša v letih 2005 in 2006 , kar pomeni, da doseže najvišje vrednosti tehnične učinkovitosti $\mathrm{v}$ začetnem obdobju, z leti pa se njene mere tehnične učinkovitosti v povprečju znižujejo. Pri Splošni bolnišnici Ptuj se količniki tehnične učinkovitosti gibljejo med o,630 in 0,695, pri tem pa je ta bolnišnica tehnično najučinkovitejša v letu 2007. Splošna bolnišnica Slovenj Gradec najvišje mere tehnične učinkovitosti doseže v letih 20I2, 2013 in 2014, pri čemer njena najvišja mera tehnične učinkovitosti znaša 0,517 . Splošna bolnišnica Trbovlje je tehnično najučinkovitejša v letu 2013, ko je njen količnik tehnične učinkovitosti 0,822 , najnižjo vrednost tehnične učinkovitosti pa doseže ravno v začetku opazovanega obdobja, to je v letu 2005, ko je njen količnik tehnične učinkovitosti znašal o,630.

$\mathrm{Za}$ ponazoritev povzetka rezultatov ocenjevanja tehnične učinkovitosti, ki smo jih izpeljali na podlagi ocene mejne stroškovne funkcije, predstavljamo preglednico I, ki prikazuje povprečne vrednosti količnikov tehnične učinkovitosti posamezne splošne bolnišnice ter njihove minimalne in maksimalne vrednosti količnikov tehnične učinkovitosti, ki so jih splošne bolnišnice dosegle v celotnem obdobju opazovanja. 
Preglednica I: Povprečna, minimalna in maksimalna tehnična učinkovitost splošnih bolnišnic, ocenjena z metodo SFA

\begin{tabular}{cccc} 
Bolnišnica & $\begin{array}{c}\text { Povprečna tehnična } \\
\text { učinkovitost }\end{array}$ & $\begin{array}{c}\text { Minimalna tehnična } \\
\text { učinkovitost }\end{array}$ & $\begin{array}{c}\text { Maksimalna tehnična } \\
\text { učinkovitost }\end{array}$ \\
SBB & 0,883 & 0,805 & 0,976 \\
\hline SBC & 0,963 & 0,934 & 0,979 \\
\hline SBI & 0,834 & 0,781 & 0,896 \\
\hline SBJ & 0,780 & 0,725 & 0,816 \\
\hline UKL LJ & 0,727 & 0,619 & 0,891 \\
\hline UKCMB & 0,585 & 0,549 & 0,619 \\
\hline SBMS & 0,909 & 0,852 & 0,990 \\
\hline SB NG & 0,562 & 0,518 & 0,614 \\
\hline SBNM & 0,789 & 0,716 & 0,936 \\
\hline SBP & 0,659 & 0,630 & 0,695 \\
\hline SB SG & 0,461 & 0,378 & 0,517 \\
\hline SBT & 0,763 & 0,822 & 0,630 \\
\hline
\end{tabular}

Podatki mer tehnične učinkovitosti kažejo, da so v letu 2005 tehnično najučinkovitejše Splošna bolnišnica Brežice, Splošna bolnišnica Celje in Splošna bolnišnica Novo mesto. Najnižjo tehnično učinkovitost ima Splošna bolnišnica Slovenj Gradec, Splošna bolnišnica Nova Gorica in Univerzitetni klinični center Maribor. V letu 2006 so tehnično najučinkovitejše Splošna bolnišnica Brežice, Splošna bolnišnica Celje in Splošna bolnišnica Murska Sobota. Med tehnično najmanj učinkovite splošne bolnišnice pa spadajo Splošna bolnišnica Slovenj Gradec, Splošna bolnišnica Nova Gorica in oba univerzitetna klinična centra. V letu 2007 lahko na eni strani zaznamo spremembo pri Splošni bolnišnici Novo mesto, ki ima opazno nižjo mero tehnične učinkovitosti, na drugi strani pa imata v tem letu višjo mero tehnične učinkovitosti Splošna bolnišnica Izola in Splošna bolnišnica Trbovlje. V letu 2008 velja, da imajo ponovno najvišje mere tehnične učinkovitosti Splošna bolnišnica Brežice, Splošna bolnišnica Celje in Splošna bolnišnica Murska Sobota. V tem letu je opazno izboljšala svoj rezultat tudi Splošna bolnišnica Jesenice. Z visokimi merami tehnične neučinkovitosti še vedno izstopajo Splošna bolnišnica Slovenj Gradec, Splošna bolnišnica Ptuj, Splošna bolnišnica Nova Gorica in oba univerzitetna klinična centra. V letu 2009 je svojo mero tehnične učinkovitosti izboljšala Splošna bolnišnica Izola, ki se tako poleg Splošne bolnišnice Brežice, Splošne bolnišnice Celje in Splošne bolnišnice Murska Sobota uvršča v skupino tehnično najučinkovitejših slovenskih splošnih bolnišnic. Situacija v 
letu 2010 je ostala praktično nespremenjena, kar pomeni, da imajo najvišje in najnižje mere tehnične učinkovitosti iste splošne bolnišnice kot v letu 2009. V letu 20 I sta tehnično najučinkovitejši Splošna bolnišnica Celje in Splošna bolnišnica Murska Sobota, na drugi strani pa imata izjemno nizke količnike tehnične učinkovitosti Splošna bolnišnica Slovenj Gradec in Splošna bolnišnica Nova Gorica. Znotraj leta 2012 ni opaznih večjih sprememb, kar pomeni, da so v skupini najučinkovitejših slovenskih splošnih bolnišnic še vedno Splošna bolnišnica Brežice, Splošna bolnišnica Celje in Splošna bolnišnica Murska Sobota. Splošna bolnišnica Slovenj Gradec ima v tem letu sicer višjo mero tehnične učinkovitosti, vendar je hkrati še vedno splošna bolnišnica $\mathrm{z}$ najnižjo mero tehnične učinkovitosti. Za leto 2013 je značilno, da največ splošnih bolnišnic dosega svoje najvišje mere tehnične učinkovitosti, kar pomeni, da je za leto 2013 značilna tudi najvišja povprečna mera tehnične učinkovitosti. V letu 2014 najvišje mere tehnične učinkovitosti dosežejo Splošna bolnišnica Brežice, Splošna bolnišnica Celje, Univerzitetni klinični center Ljubljana in Splošna bolnišnica Murska Sobota. Na drugi strani pa v tem letu z visokimi merami tehnične neučinkovitosti še vedno izstopa Splošna bolnišnica Slovenj Gradec, hkrati pa tudi Univerzitetni klinični center Maribor.

Povzetka rezultatov ocenjevanja tehnične učinkovitosti, ki smo jih izpeljali na podlagi ocene mejne stroškovne funkcije, predstavljamo v preglednici 2, ki prikazuje povprečne vrednosti količnikov tehnične učinkovitosti vseh splošnih bolnišnic skupaj znotraj posameznega leta. Količnike povprečne tehnične učinkovitosti prikazujemo za celotno opazovano obdobje, kar pomeni od leta 2005 do leta 2014.

Preglednica 2: Povprečna tehnična učinkovitost splošnih bolnišnic znotraj posameznih let, ocenjena z metodo SFA

\begin{tabular}{cc} 
Leto & Povprečna tehnična učinkovitost \\
\hline 2005 & 0,752 \\
\hline 2006 & 0,736 \\
\hline 2007 & 0,735 \\
\hline 2008 & 0,729 \\
\hline 2009 & 0,735 \\
\hline 2010 & 0,748 \\
\hline 2011 & 0,738 \\
\hline 2012 & 0,743 \\
\hline 2013 & 0,759 \\
\hline 2014 & 0,755 \\
\hline
\end{tabular}


Metoda SFA nam pokaže, da je skozi celotno opazovano obdobje tehnično najučinkovitejša slovenska splošna bolnišnica Splošna bolnišnica Celje, ki ima povprečno vrednost tehnične učinkovitosti 0,963 . Sledi ji Splošna bolnišnica Murska Sobota s povprečnim količnikom tehnične učinkovitosti 0,909 in Splošna bolnišnica Brežice s povprečno mero tehnične učinkovitosti $\circ, 883$. Takoj za njima ima najvišjo povprečno vrednost tehnične učinkovitosti Splošna bolnišnica Izola z mero tehnične učinkovitosti 0,834 , Splošna bolnišnica Novo mesto s povprečnim količnikom tehnične učinkovitosti 0,789 in Splošna bolnišnica Jesenice s povprečno mero tehnične učinkovitosti 0,780 . Najnižjo vrednost tehnične učinkovitosti skozi vsa leta opazovanja ima Splošna bolnišnica Slovenj Gradec, pri kateri znaša povprečna vrednost tehnične učinkovitosti 0,46r. Če bi Splošna bolnišnica Slovenj Gradec želela postati tehnično učinkovita splošna bolnišnica, bi morala $\mathrm{v}$ povprečju zmanjšati obseg zaposlenosti proizvodnih dejavnikov za 53,9 odstotka ob nespremenjenem obsegu outputa. Splošna bolnišnica Nova Gorica je v podobnem položaju, saj njena povprečna mera tehnične učinkovitosti znaša 0,562 , kar pomeni, da je $\mathrm{v}$ primerjavi $\mathrm{z}$ ostalimi slovenskimi splošnimi bolnišnicami tehnično manj učinkovita. V takem primeru bi morala Splošna bolnišnica Nova Gorica zmanjšati obseg zaposlenosti proizvodnih dejavnikov za 43,8 odstotka, če bi želela poslovati na meji proizvodnih zmožnosti.

Rezultati stroškovne učinkovitosti kažejo, da se stroškovna učinkovitost Splošne bolnišnice Brežice giblje med o,703 in o,824, pri čemer je njena stroškovna učinkovitost $\mathrm{v}$ prvih letih opazovanja najvišja, v zadnjem obdobju pa najnižja. Pri Splošni bolnišnici Celje se količniki stroškovne učinkovitosti gibljejo med o,834 in o,879, kar pomeni, da je bila njena stroškovna učinkovitost skozi celotno opazovano obdobje relativno konstantna; to jo uvršča v kategorijo stroškovno najučinkovitejše slovenske splošne bolnišnice. Splošna bolnišnica Izola zavzame vrednosti stroškovne učinkovitosti med 0,708 in 0,80 I. Če primerjamo njene mere stroškovne učinkovitosti od začetka do konca opazovanega obdobja, vidimo, da se stroškovna učinkovitost Splošne bolnišnice Izola v povprečju z leti izboljšuje. Splošna bolnišnica Jesenice zavzame vrednosti stroškovne učinkovitosti med 0,760 in $0,88 \mathrm{I}$, pri čemer v prvem obdobju njene mere stroškovne učinkovitosti naraščajo, nato v letu 2009 opazno padejo, $\mathrm{v}$ zadnjem obdobju pa ponovno naraščajo. Univerzitetni klinični center Ljubljana je stroškovno najučinkovitejši v letih 2013 in 2014, ko njegova mera stroškovne učinkovitosti znaša 0,766 oziroma 0,758 , stroškovno naj- 
manj učinkovit pa je v letu 2009, ko je njegov količnik stroškovne učinkovitosti 0,503. Pri Univerzitetnem kliničnem centru Maribor se mere stroškovne učinkovitosti gibljejo med 0,469 in 0,560 , pri čemer nekoliko višje mere stroškovne učinkovitosti dosega v zadnjih letih opazovanja. Splošna bolnišnica Murska Sobota je stroškovno najučinkovitejša v letu 2oro, ko znaša njena mera stroškovne učinkovitosti o,88I, stroškovno najmanj učinkovita pa je v letu 2007, ko znaša njen količnik stroškovne učinkovitosti 0,760 . Splošna bolnišnica Nova Gorica zavzame vrednosti stroškovne učinkovitosti med 0,457 in 0,539 , pri tem pa je ta bolnišnica stroškovno najučinkovitejša v letu 20I4. To je skladno z dejstvom, da rezultati kažejo, da njene mere stroškovne učinkovitosti od začetka do konca opazovanega obdobja v povprečju z leti naraščajo. Splošna bolnišnica Novo mesto je stroškovna najučinkovitejša v letu 2005, ko njena vrednost stroškovne učinkovitosti znaša 0,856 , v kasnejšem obdobju pa rezultati kažejo, da se njene mere stroškovne učinkovitosti postopno znižujejo. Pri Splošni bolnišnici Ptuj se mere stroškovne učinkovitosti gibljejo med 0,547 in 0,615, pri čemer do leta $2010 \mathrm{v}$ povprečju naraščajo, v letu $201 \mathrm{I}$ opazno padejo, v zadnjem obdobju pa začnejo postopoma spet naraščati. Splošna bolnišnica Slovenj Gradec najvišje mere stroškovne učinkovitosti doseže v prvem letu opazovanja ter $\mathrm{v}$ zadnjih treh letih opazovanja, pri tem pa njena najvišja mera stroškovne učinkovitosti znaša 0,459 . Splošna bolnišnica Trbovlje je stroškovno najučinkovitejša v letu 2013, ko je njen količnik stroškovne učinkovitosti o,691, najnižjo vrednost stroškovne učinkovitosti pa doseže ravno v začetku opazovanega obdobja, to je v letu 2005, ko njen količnik stroškovne učinkovitosti znaša 0,526.

Za ponazoritev povzetka rezultatov ocenjevanja stroškovne učinkovitosti, ki smo jih izpeljali na podlagi ocene mejne stroškovne funkcije, predstavljamo preglednico 3 , ki prikazuje povprečne vrednosti količnikov stroškovne učinkovitosti posamezne splošne bolnišnice ter njihove minimalne in maksimalne vrednosti količnikov stroškovne učinkovitosti, ki so jih splošne bolnišnice dosegle v celotnem obdobju opazovanja.

Podatki mer stroškovne učinkovitosti kažejo, da so v letu 2005 stroškovno najučinkovitejše Splošna bolnišnica Brežice, Splošna bolnišnica Celje in Splošna bolnišnica Novo mesto. Najnižjo stroškovno učinkovitost dosežejo Splošna bolnišnica Slovenj Gradec, Splošna bolnišnica Nova Gorica in Univerzitetni klinični center Maribor. V letu 2006 sta na eni strani stroškovno najučinkovitejši Splošna bolnišnica Brežice in Splošna bolnišnica Celje, na drugi strani pa najnižje mere stroškovne učinkovitosti zavzamejo Splošna bolnišnica Slovenj Gradec, Splo- 
šna bolnišnica Nova Gorica in oba univerzitetna klinična centra. V letu 2007 je Splošna bolnišnica Brežice poslabšala svoj rezultat, kar pomeni, da ima nižjo mero stroškovne učinkovitosti kot v letu 2006, hkrati pa je svojo mero stroškovne učinkovitosti izboljšala Splošna bolnišnica Izola, ki jo tako v letu 2007 uvrščamo v kategorijo stroškovno najučinkovitejših splošnih bolnišnic. V letu 2008 se situacija ni bistveno spremenila, kar pomeni, da so stroškovno najučinkovitejše iste splošne bolnišnice kot v letu 2007, hkrati pa imajo najnižje količnike stroškovne učinkovitosti ponovno Splošna bolnišnica Slovenj Gradec, Splošna bolnišnica Nova Gorica in oba univerzitetna klinična centra. V letu 2009 je stroškovno najučinkovitejša Splošna bolnišnica Celje, vse ostale splošne bolnišnice pa dosegajo precej nižje količnike stroškovne učinkovitosti. Še najopaznejše povečanje mere stroškovne učinkovitosti v primerjavi z letom poprej se je zgodilo pri Splošni bolnišnici Ptuj. V letu 2010 je svojo mero stroškovne učinkovitosti precej izboljšal Univerzitetni klinični center Ljubljana, ki ga tako ne uvrščamo več v skupino stroškovno najmanj učinkovitih splošnih bolnišnic. $V$ tej kategoriji ostajajo Splošna bolnišnica Slovenj Gradec, Splošna bolnišnica Nova Gorica in Univerzitetni klinični center Maribor. V letu 20 I sta stroškovno najučinkovitejši Splošna bolnišnica Celje in Splošna bolnišnica Murska Sobota, ostale splošne bolnišnice pa so stroškovno precej manj učinkovite, pri čemer najnižje rezultate stroškovne učinkovitosti ponovno dosežejo Splošna bolnišnica Slovenj Gradec, Splošna bolnišnica Nova Gorica ter Univerzitetni klinični center Maribor. V letu 2012 je opazna sprememba pri Splošni bolnišnici Izola, ki je svojo mero stroškovne učinkovitosti opazno poslabšala glede na leto 20 I I, poleg tega pa vidimo, da je Splošna bolnišnica Nova Gorica sicer svojo mero stroškovne učinkovitosti izboljšala, vendar še vedno sodi v skupino splošnih bolnišnic z najnižjimi merami stroškovne učinkovitosti. V letu 2013 ni opaznih večjih sprememb, kar pomeni, da so stroškovno najučinkovitejše in najmanj učinkovite iste splošne bolnišnice kot $\mathrm{v}$ preteklem obdobju. Je pa v tem letu bistveno izboljšal svoje mero stroškovne učinkovitosti Univerzitetni klinični center Ljubljana, ki se $\mathrm{v}$ tem letu približa stroškovno najučinkovitejšim slovenskim splošnim bolnišnicam. V letu 2014 najvišje mere stroškovne učinkovitosti dosežejo Splošna bolnišnica Brežice, Splošna bolnišnica Celje in Splošna bolnišnica Murska Sobota. Na drugi strani pa v tem letu z visokimi merami stroškovne neučinkovitosti še vedno izstopa Splošna bolnišnica Slovenj Gradec, hkrati pa tudi Univerzitetni klinični center Maribor. 
Preglednica 3: Povprečna, minimalna in maksimalna stroškovna učinkovitost splošnih bolnišnic, ocenjena z metodo SFA

\begin{tabular}{cccc} 
Bolnišnica & $\begin{array}{c}\text { Povprečna stroškovna } \\
\text { učinkovitost }\end{array}$ & $\begin{array}{c}\text { Minimalna stroškovna } \\
\text { učinkovitost }\end{array}$ & $\begin{array}{c}\text { Maksimalna stroškovna } \\
\text { učinkovitost }\end{array}$ \\
SBB & 0,762 & 0,703 & 0,824 \\
\hline SBC & 0,862 & 0,834 & 0,879 \\
\hline SBI & 0,761 & 0,708 & 0,801 \\
\hline SBJ & 0,697 & 0,654 & 0,722 \\
\hline UKL LJ & 0,621 & 0,503 & 0,766 \\
\hline UKCMB & 0,531 & 0,469 & 0,560 \\
\hline SBMS & 0,812 & 0,760 & 0,881 \\
\hline SBNG & 0,496 & 0,457 & 0,539 \\
\hline SB NM & 0,703 & 0,634 & 0,856 \\
\hline SBP & 0,578 & 0,547 & 0,615 \\
\hline SB SG & 0,410 & 0,338 & 0,459 \\
\hline SBT & 0,643 & 0,459 & 0,691 \\
\hline
\end{tabular}

Povzetek rezultatov ocenjevanja stroškovne učinkovitosti, ki smo jih izpeljali na podlagi ocene mejne stroškovne funkcije, predstavljamo v preglednici 4, ki prikazuje povprečne vrednosti količnikov stroškovne učinkovitosti vseh splošnih bolnišnic skupaj znotraj posameznega leta. Količnike povprečne stroškovne učinkovitosti prikazujemo za celotno opazovano obdobje, torej od leta 2005 do leta 2014.

Preglednica 4: Povprečna stroškovna učinkovitost splošnih bolnišnice znotraj posameznih let, ocenjena z metodo SFA

\begin{tabular}{cc} 
Leto & Povprečna stroškovna učinkovitost \\
\hline 2005 & 0,663 \\
\hline 2006 & 0,651 \\
\hline 2007 & 0,647 \\
\hline 2008 & 0,644 \\
\hline 2009 & 0,646 \\
\hline 2010 & 0,661 \\
\hline 2011 & 0,660 \\
\hline 2012 & 0,661 \\
\hline 2013 & 0,667 \\
\hline 2014 & 0,665 \\
\hline
\end{tabular}


Metoda SFA nam pokaže, da je skozi celotno opazovano obdobje stroškovno najučinkovitejša slovenska splošna bolnišnica Splošna bolnišnica Celje, ki ima povprečno vrednost stroškovne učinkovitosti o,862. Ta podatek ni presenetljiv glede na dejstvo, da je Splošna bolnišnica Celje hkrati tudi tehnično najučinkovitejša slovenska splošna bolnišnica. Sledi ji Splošna bolnišnica Murska Sobota s povprečnim količnikom stroškovne učinkovitosti o,812 in Splošna bolnišnica Brežice s povprečno mero stroškovne učinkovitosti 0,762 . Takoj za njima ima najvišjo povprečno vrednost stroškovne učinkovitosti Splošna bolnišnica Izola z mero stroškovne učinkovitosti o,76I, sledita Splošna bolnišnica Novo mesto s povprečnim količnikom stroškovne učinkovitosti 0,703 in Splošna bolnišnica Jesenice s povprečno mero stroškovne učinkovitosti 0,697 . Najnižjo vrednost stroškovne učinkovitosti skozi vsa leta opazovanja ima Splošna bolnišnica Slovenj Gradec, pri kateri znaša povprečna vrednost stroškovne učinkovitosti o,4Io. Splošna bolnišnica Slovenj Gradec je neučinkovita zaradi prevelike količine porabe inputov, poleg tega pa zaradi dejstva, da ne proizvaja z minimalnimi povprečnimi stroški. To pomeni, da mora uporabiti manjše količine in hkrati drugačno kombinacijo inputov, če želi postati stroškovno učinkovita splošna bolnišnica. Splošna bolnišnica Nova Gorica je v podobnem položaju, saj njena povprečna mera stroškovne učinkovitosti znaša 0,496 , kar pomeni, da lahko stroškovno neučinkovitost odpravi tako, da dano raven outputa začne proizvajati z manjšo količino inputov, hkrati pa mora dano raven outputa začeti proizvajati še z najnižjimi možnimi stroški.

Alokacijsko učinkovitost $\mathrm{v}$ našem primeru predstavlja razmerje med količniki stroškovne in tehnične učinkovitosti splošnih bolnišnic, kar pomeni, da je alokacijska učinkovitost izvajalcev zdravstvene dejavnosti posledica njihove tehnične in stroškovne učinkovitosti. Metoda SFA nam pokaže, da najvišje mere alokacijske učinkovitosti dosega Splošna bolnišnica Izola, ki ima povprečno vrednost alokacijske učinkovitosti 0,913. Sledi ji Univerzitetni klinični center Maribor s povprečnim količnikom alokacijske učinkovitosti 0,907 in Splošna bolnišnica Celje s povprečno mero alokacijske učinkovitosti o,895. Takoj za Splošno bolnišnico Celje imata najvišjo mero alokacijske učinkovitosti Splošna bolnišnica Jesenice in Splošna bolnišnica Murska Sobota, ki obe zavzameta vrednost alokacijske učinkovitosti 0,893 . Rezultati kažejo, da ima najnižji količnik alokacijske učinkovitosti Splošna bolnišnica Trbovlje, pri kateri znaša povprečna vrednost alokacijske učinkovitosti o,843. Če bi Splošna bolnišnica Trbovlje želela postati alokacijsko učinkovita splošna bolnišnica, bi morala v povprečju znižati stroške proizvodnih dejavnikov za I5,7 od- 
stotka ob nespremenjenem obsegu outputa. Podobno velja za Univerzitetni klinični center Ljubljana, ki ima povprečno mero alokacijske učinkovitosti o,853, kar pomeni, da bi moral zmanjšati svoje dejanske stroške proizvodnih dejavnikov za I 4,7 odstotka, če bi želel poslovati na premici minimalnih stroškov.

Do sedaj smo ponazorili rezultate ocenjevanja mer tehnične, alokacijske in stroškovne učinkovitosti na podlagi ocene stohastične mejne stroškovne funkcije. Na osnovi razpoložljivih podatkov o cenah proizvodnih dejavnikov ter na podlagi domneve, da izvajalci zdravstvene dejavnosti minimirajo svoje stroške smo ocenili ekonomske značilnosti proizvodne tehnologije in definirali stroškovno učinkovitost na podlagi mejne stroškovne funkcije. Poleg tega smo razpolagali tudi s podatki o količinskem obsegu proizvodnih dejavnikov, kar nam je omogočalo, da smo stroškovno učinkovitost razčlenili na njeni dve osnovni komponenti, to sta tehnična in alokacijska učinkovitost. Mejna stroškovna funkcija je bila tako ocenjena z namenom napovedovanja mer stroškovne neučinkovitosti, ki grafično predstavljajo inverz razdalje med opazovano splošno bolnišnico in ocenjeno mejno stroškovno funkcijo. Pri tem so bile vse mere stroškovne ter iz nje izpeljane mere tehnične in alokacijske učinkovitosti usmerjene $\mathrm{k}$ inputom, kar pomeni, da je bila vključena predpostavka, da vsi izvajalci zdravstvene dejavnosti lahko spreminjajo svoje inpute pri danem obsegu outputa.

Tehnično učinkovitost izvajalcev zdravstvene dejavnosti smo ocenili tudi na podlagi ocene stohastične mejne proizvodne funkcije, kar vključuje predpostavko, da vsi izvajalci zdravstvene dejavnosti maksimirajo svoj output glede na določeno raven inputov. Ocenjevanje stohastične mejne proizvodne funkcije zahteva podatke o količinskem obsegu proizvedenega outputa in količinskem obsegu uporabljenih inputov posameznih izvajalcev zdravstvene dejavnosti. Skladno s tem nam ocena mejne proizvodne funkcije omogoča izračun zgolj tehnične učinkovitosti izvajalcev zdravstvene dejavnosti, medtem ko alokacijske in stroškovne učinkovitosti na osnovi mejne proizvodne funkcije ni mogoče preučevati. Mejna proizvodna funkcije je tako ocenjena $\mathrm{z}$ namenom napovedovanja mer tehnične neučinkovitosti izvajalcev zdravstvene dejavnosti, ki grafično predstavljajo razdaljo med opazovano splošno bolnišnico in ocenjeno mejno proizvodno funkcijo. Pri tem so vse mere tehnične učinkovitosti usmerjene k outputom, kar pomeni, da je vključena predpostavka, da vsi izvajalci zdravstvene dejavnosti lahko spreminjajo obseg proizvedenega outputa, ne morejo pa vplivati na raven uporabljenih inputov. 
Rezultate ocenjevanja tehnične učinkovitosti smo izpeljali na podlagi ocene mejne proizvodne funkcije. Metoda SFA nam pokaže, da so mere tehnične učinkovitosti izvajalcev zdravstvene dejavnosti ocenjene na podlagi mejne proizvodne funkcije zelo podobne meram tehnične učinkovitosti, ki smo jih izpeljali na podlagi mejne stroškovne funkcije. To je logična posledica dejstva, da gre v obeh primerih za ocenjevanje razmerja med količino proizvedenega outputa in količino uporabljenih inputov. Edina razlika $\mathrm{v}$ merah tehnične učinkovitosti je $\mathrm{v}$ tem, da v prvem primeru govorimo o merah tehnične učinkovitosti, usmerjene $\mathrm{k}$ inputom, $\mathrm{v}$ drugem primeru pa govorimo o merah tehnične učinkovitosti, usmerjene k outputom. Skladno s tem so tudi rezultati obeh mer tehnične učinkovitosti zelo podobni, pri čemer pa so mere tehnične učinkovitosti, usmerjene k outputom, nekoliko višje, kar je posledica dejstva, da govorimo o $\mathrm{k}$ outputom usmerjenem modelu. Za posamezne splošne bolnišnice tako veljajo enake zakonitosti znotraj obeh modelov, zato rezultatov na tem mestu ne bomo podrobneje opisovali.

\section{Rezultati ocenjevanja ucinkovitostiz metodo DEA}

DEA je neprametrična metoda linearnega programiranja, ki preučuje odnos med inputi, ki vstopajo v proizvodni proces, in outputom, ki je rezultat tega procesa. $\mathrm{Z}$ metodo DEA preučujemo tehnično, alokacijsko in stroškovno učinkovitost posameznih izvajalcev zdravstvene dejavnosti $v$ primerjavi z drugimi izvajalci zdravstvene dejavnosti znotraj panoge. $\mathrm{V}$ prvem koraku metoda DEA definira proizvodne enote, to so $\mathrm{v}$ našem primeru slovenske splošne bolnišnice, ki proizvajajo maksimalen obseg outputa glede na določeno raven inputov (Zhu 2003). Ta pristop tako ocenjuje deterministične mejne funkcije na podlagi opazovanih enot, pri čemer odstopanja od mejne funkcije predstavljajo mere neučinkovitosti. To pomeni, da DEA metoda ne omogoča razlikovanja neučinkovitosti od slučajne napake merjenja, kar se šteje kot pomanjkljivost metode DEA v primerjavi z metodo SFA.

Ko razpolagamo s cenami proizvodnih dejavnikov, lahko s pomočjo metode DEA preučujemo tudi odstopanja dejanskih stroškov posameznih izvajalcev zdravstvene dejavnosti glede na njihove minimalne možne stroške, kar je posledica uporabe neoptimalnega razmerja inputov glede na relativne cene proizvodnih dejavnikov. Alokacijska učinkovitost tako odraža sposobnost izvajalca zdravstvene dejavnosti, da uporablja inpute $\mathrm{v}$ pravem razmerju glede na njihove cene in proizvodno tehnologijo. Tehnična in alokacijska učinkovitost sta dve sestavini skupne 
stroškovne učinkovitosti, kar pomeni, da se stroškovna učinkovitost kaže tako v obliki tehnične kot tudi alokacijske učinkovitosti izvajalcev zdravstvene dejavnosti.

\section{Rezultati DEA modela konstantnih donosov obsega}

Pri DEA modelu konstantnih donosov obsega, usmerjenega $\mathrm{k}$ inputom, obstaja predpostavka, da izvajalci zdravstvene dejavnosti ne morejo povečevati oziroma spreminjati obsega proizvodnje, kar pomeni, da je output $\mathrm{v}$ tem primeru za splošne bolnišnice dan. To je skladno z dejstvom, da je obseg outputa za posamezne izvajalce zdravstvene dejavnosti vsako leto vnaprej dogovorjen na podlagi pogodbe med izvajalcem in plačnikom zdravstvenih storitev. Posledično to pomeni, da splošne bolnišnice lahko vplivajo zgolj na obseg porabljenih inputov, ne morejo pa spreminjati obsega outputa. Predpostavka o konstantnih donosih obsega nam omogoča, da definiramo učinkovite izvajalce ne glede na njihovo velikost. Rezultati modela konstantnih donosov obsega, usmerjenega $\mathrm{k}$ inputom, tako definirajo, katere splošne bolnišnice so učinkovite tako po velikosti in tudi po porabi inputov. $V$ tem primeru je upoštevano, da lahko določena neučinkovita splošna bolnišnica doseže višjo mero učinkovitosti tako s prilagoditvijo svoje velikosti kot tudi s prerazporeditvijo uporabljenih proizvodnih dejavnikov.

Pri tem prikazujemo najprej rezultate ocenjevanja tehnične učinkovitosti modela konstantnih donosov obsega, usmerjenega $\mathrm{k}$ inputom. Količniki tehnične učinkovitosti, ocenjeni z metodo DEA, kažejo, da se posamezne mere tehnične učinkovitosti z leti bistveno bolj spreminjajo znotraj posameznih bolnišnic kot $\mathrm{v}$ primeru količnikov tehnične učinkovitosti, ocenjenih z metodo SFA. Pri tem velja, da so pri metodi DEA, kljub bistveno večjemu variiranju mer tehnične učinkovitosti, bolnišnice $\mathrm{z}$ najvišjimi merami še vedno definirane kot tehnično najučinkovitejše splošne bolnišnice v vseh letih opazovanja. Podobna situacija velja za splošne bolnišnice z najnižjimi merami učinkovitosti, pri katerih se rezultati tehnične učinkovitosti sicer z leti spreminjajo, vendar imajo pri tem skozi celotno obdobje status najmanj učinkovitih splošnih bolnišnic.

Mere tehnične učinkovitosti izvajalcev zdravstvene dejavnosti kažejo, da količniki tehnične učinkovitost sicer z leti variirajo znotraj posameznih splošnih bolnišnic, pri čemer pa so splošne bolnišnice z najvišjimi merami učinkovitosti v povprečju tehnično učinkovite skozi celotno obdobje. Podobna situacija velja za splošne bolnišnice z najnižjimi mera- 
mi učinkovitosti, pri katerih se rezultati tehnične učinkovitosti sicer z leti spreminjajo, vendar so pri tem še vedno definirane kot najmanj učinkovite splošne bolnišnice.

Splošna bolnišnica Brežice je definirana kot tehnično učinkovita splošna bolnišnica skozi celotno obdobje, saj so njene mere tehnične učinkovitosti v vseh letih opazovanja enake I. Pri Splošni bolnišnici Celje se količniki tehnične učinkovitosti gibljejo med 0,884 in 0,983 , pri čemer je ta bolnišnica tehnično najučinkovitejša v letu 2009. Pri Splošni bolnišnici Izola se mere tehnične učinkovitosti gibljejo med o,886 in r. V letih 2007,2008 in 2009 ta bolnišnica velja za tehnično učinkovito bolnišni$\mathrm{co}, \mathrm{v}$ preostalih letih pa so zanjo značilne različne mere tehnične neučinkovitosti. Splošna bolnišnica Jesenice velja za tehnično učinkovito v letu 2014, najnižjo mero tehnične učinkovitosti pa zavzame v letu 20Io, ko njen količnik tehnične učinkovitosti znaša 0,85 I. Univerzitetni klinični center Ljubljana je tehnično najučinkovitejši v letu 2013, ko njegova mera tehnične učinkovitosti znaša 0,664 , tehnično najmanj učinkovit pa je v letu 2007, ko je njegov količnik tehnične učinkovitosti 0,525. Pri Univerzitetnem kliničnem centru Maribor se mere tehnične učinkovitosti gibljejo med o,640 in 0,748 , pri čemer najvišjo mero tehnične učinkovitosti doseže v letu 2005. Splošna bolnišnica Murska Sobota je tehnično učinkovita v letih 2010 in 201 I, najnižja mera tehnične učinkovitosti pa je zanjo značilna v letu 2005, ko njen količnik tehnične učinkovitosti znaša o,883. Pri Splošni bolnišnici Nova Gorica se količniki tehnične učinkovitosti gibljejo med 0,749 in $0,85 \mathrm{I}$, pri čemer je ta bolnišnica tehnično najučinkovitejša v letu 2013. Splošna bolnišnica Novo mesto je učinkovita v letih 2005 in 2006, najnižjo mero tehnične učinkovitosti pa zavzame v letu 20ı, in sicer 0,797. Splošna bolnišnica Ptuj najvišjo mero tehnične učinkovitosti doseže v letu 2006, ko njena mera tehnične učinkovitosti znaša 0,995 , najnižja mera tehnične učinkovitosti pa je zanjo značilna v letu 20ı, ko njen količnik tehnične učinkovitosti zavzame vrednost o,831. Pri Splošni bolnišnici Slovenj Gradec se količniki tehnične učinkovitosti gibljejo med 0,615 in 0,913 , pri čemer je ta bolnišnica tehnično najučinkovitejša v letu 2013. Splošna bolnišnica Trbovlje je tehnično učinkovita v letih med 2007 in 2014, najnižjo vrednost tehnične učinkovitosti pa doseže ravno v začetku opazovanega obdobja, to je v letu 2005, ko njen količnik tehnične učinkovitosti znaša 0,938 .

Za ponazoritev povzetka rezultatov ocenjevanja tehnične učinkovitosti, ki smo jih izpeljali na podlagi ocene modela konstantnih donosov obsega, usmerjenega $\mathrm{k}$ inputom, predstavljamo preglednico 5, ki prika- 
zuje povprečne vrednosti količnikov tehnične učinkovitosti posamezne splošne bolnišnice ter njihove minimalne in maksimalne vrednosti količnikov tehnične učinkovitosti, ki so jih splošne bolnišnice dosegle v celotnem obdobju opazovanja.

Preglednica 5: Povprečna, minimalna in maksimalna tehnična učinkovitost splošnih bolnišnic, ocenjena z metodo DEA

\begin{tabular}{cccc} 
Bolnišnica & $\begin{array}{c}\text { Povprečna tehnična } \\
\text { učinkovitost }\end{array}$ & $\begin{array}{c}\text { Minimalna tehnična učinko- } \\
\text { vitost }\end{array}$ & $\begin{array}{c}\text { Maksimalna tehnična } \\
\text { učinkovitost }\end{array}$ \\
\hline SBB & 1,000 & 1,000 & 1,000 \\
\hline SBC & 0,915 & 0,884 & 0,983 \\
\hline SBI & 0,949 & 0,886 & 1,000 \\
\hline SBJ & 0,900 & 0,851 & 1,000 \\
\hline UKL LJ & 0,587 & 0,525 & 0,661 \\
\hline UKCMB & 0,683 & 0,640 & 0,748 \\
\hline SBMS & 0,936 & 0,883 & 1,000 \\
\hline SB NG & 0,822 & 0,749 & $0,85 \mathrm{I}$ \\
\hline SB NM & 0,879 & 0,797 & 1,000 \\
\hline SBP & 0,895 & 0,831 & 0,995 \\
\hline SB SG & 0,845 & 0,615 & 0,913 \\
\hline SBT & 0,991 & 0,938 & 1,000 \\
\hline
\end{tabular}

Če primerjamo podatke splošnih bolnišnic po posameznih letih, vidimo, da sta v letu 2005 tehnično učinkoviti Splošna bolnišnica Brežice in Splošna bolnišnica Novo mesto. Z nekoliko nižjo mero tehnične učinkovitosti jima sledijo Splošna bolnišnica Ptuj, Splošna bolnišnica Trbovlje in Splošna bolnišnica Izola. Najnižjo tehnično učinkovitost imajo Splošna bolnišnica Slovenj Gradec in oba univerzitetna klinična centra. V letu 2006 se situacija ni bistveno spremenila. Nekoliko višje mere tehnične učinkovitosti sta dosegli le Splošna bolnišnica Murska Sobota in Splošna bolnišnica Slovenj Gradec. Pri tem imata še vedno oba univerzitetna klinična centra nižje količnike tehnične učinkovitosti v primerjavi z ostalimi splošnimi bolnišnicami. V letu 2007 je opazna sprememba pri Splošni bolnišnici Novo mesto, ki ni več tehnično učinkovita, sta pa v tem letu mesto tehnično učinkovite splošne bolnišnice zavzeli Splošna bolnišnica Izola in Splošna bolnišnica Trbovlje. V letu 2008 velja, da so tehnično učinkovite Splošna bolnišnica Brežice, Splošna bolnišnica Slovenj Gradec in Splošna bolnišnica Trbovlje. Z nekoliko nižjo mero 
tehnične učinkovitosti jim sledijo Splošna bolnišnica Celje, Splošna bolnišnica Ptuj, Splošna bolnišnica Jesenice in Splošna bolnišnica Murska Sobota. Z visokimi merami tehnične neučinkovitosti pa še vedno izstopata Univerzitetni klinični center Ljubljana in Univerzitetni klinični center Maribor. Situacija v letu 2009 je ostala praktično nespremenjena, kar pomeni, da so tehnično učinkovite in tehnično neučinkovite iste splošne bolnišnice kot v letu 2008. Znotraj leta 2010 je na eni strani opazna sprememba pri Splošni bolnišnici Murska Sobota, ki je postala tehnično učinkovita, na drugi strani pa merila tehnično učinkovite splošne bolnišnice ne dosega več Splošna bolnišnica Izola. Znotraj leta 20 I I so še vedno tehnično učinkovite Splošna bolnišnica Brežice, Splošna bolnišnica Murska Sobota in Splošna bolnišnica Trbovlje. Višjo mero tehnične učinkovitosti v primerjavi z letom 2010 zavzamejo Splošna bolnišnica Jesenice, Splošna bolnišnica Nova Gorica, Splošna bolnišnica Novo mesto, Splošna bolnišnica Ptuj in Splošna bolnišnica Slovenj Gradec. Nekoliko višjo vrednost tehnične učinkovitosti ima tudi Univerzitetni klinični center Maribor, medtem ko ima Univerzitetni klinični center Ljubljana količnik tehnične učinkovitosti nižji. V letu 2012 je edina večja sprememba opazna pri Splošni bolnišnici Murska Sobota, ki je izgubila status tehnično učinkovite splošne bolnišnice. Za leto 2013 je značilno, da največ splošnih bolnišnic dosega svoje najvišje mere tehnične učinkovitosti. V primerjavi z ostalimi leti svoj najvišji količnik tehnične učinkovitosti dosegata Splošna bolničina Nova Gorica in Splošna bolnišnica Slovenj Gradec. Poleg tega svojo najvišjo vrednost tehnične učinkovitosti dosega tudi Univerzitetni klinični center Ljubljana, čeprav je v primerjavi z ostalimi slovenskimi splošnimi bolnišnicami v tem letu še vedno tehnično najmanj učinkovit. V letu 2014 so tehnično učinkovite tri splošne bolnišnice, in sicer Splošna bolnišnica Brežice, Splošna bolnišnica Jesenice in Splošna bolnišnica Trbovlje. V tem letu je torej Splošna bolnišnica Jesenice povečala svojo mero tehnične učinkovitosti in ima tako status tehnično učinkovite splošne bolnišnice. Enako kot v vseh preostalih letih pa z visokimi merami tehnične neučinkovitosti še vedno izstopata Univerzitetni klinični center Ljubljana in Univerzitetni klinični center Maribor.

Povzetek rezultatov ocenjevanja tehnične učinkovitosti, ki smo jih izpeljali na podlagi modela konstantnih donosov obsega, usmerjenega $\mathrm{k}$ inputom, predstavljamo v preglednici 6 , ki prikazuje povprečne vrednosti količnikov tehnične učinkovitosti vseh splošnih bolnišnic skupaj znotraj posameznega leta. Količnike povprečne tehnične učinkovitosti prikazujemo za celotno opazovano obdobje, kar pomeni od leta 2005 do leta 2014. 
Preglednica 6: Povprečna tehnična učinkovitost splošnih bolnišnice znotraj posameznih let, ocenjena z metodo DEA

\begin{tabular}{cc}
\hline Leto & Povprečna tehnična učinkovitost \\
\hline 2005 & 0,858 \\
\hline 2006 & 0,882 \\
\hline 2007 & 0,872 \\
\hline 2008 & 0,883 \\
\hline 2009 & 0,868 \\
\hline 2010 & 0,845 \\
\hline 2011 & 0,867 \\
\hline 2012 & 0,871 \\
\hline 2013 & 0,862 \\
\hline 2014 & 0,862 \\
\hline
\end{tabular}

DEA model konstantnih donosov obsega, usmerjen $\mathrm{k}$ inputom, torej pokaže, da je bila skozi celotno opazovano obdobje tehnično učinkovita Splošna bolnišnica Brežice, kar pomeni, da v vseh letih zavzame vrednost I. Sledita ji Splošna bolnišnica Trbovlje s povprečno vrednostjo tehnične učinkovitosti 0,99I in Splošna bolnišnica Izola s količnikom o,949. Takoj za njima imata najvišjo povprečno vrednost tehnične učinkovitosti Splošna bolnišnica Murska Sobota z mero tehnične učinkovitosti 0,936 in Splošna bolnišnica Celje $s$ količnikom tehnične učinkovitosti o,915. Najnižjo vrednost tehnične učinkovitosti skozi vsa leta opazovanja ima Univerzitetni klinični center Ljubljana, pri katerem znaša povprečna vrednost tehnične učinkovitosti 0,587 . To pomeni, da bi moral Univerzitetni klinični center, če želi doseči tehnično učinkovitost, v povprečju zmanjšati obseg zaposlenosti dela in kapitala za 4I,3 odstotka ob nespremenjenem obsegu outputa. Podobna situacija je pri Univerzitetnem kliničnem centru Maribor, ki je v primerjavi z ostalimi bolnišnicami tehnično manj učinkovit. Njegova povprečna vrednost tehnične učinkovitosti znaša 0,683 . V takem primeru bi moral Univerzitetni klinični center Maribor zmanjšati obseg zaposlenosti proizvodnih dejavnikov za 31,7 odstotka, če bi želel poslovati na meji proizvodnih možnosti, kar bi pomenilo, da je tehnično učinkovit.

Rezultati kažejo, da je Splošna bolnišnica Brežice stroškovno učinkovita skoraj skozi celotno obdobje opazovanja. Edina izjema so leta 20I2, 2013 in 2014, ko je njena stroškovna učinkovitost nekoliko nižja. Pri Splošni bolnišnici Celje se količniki stroškovne učinkovitosti gibljejo med 
0,559 in 0,807 , pri čemer je ta bolnišnica stroškovno najučinkovitejša $\mathrm{v}$ letu 2014. Pri Splošni bolnišnici Izola se mere stroškovne učinkovitosti gibljejo med 0,550 in 0,787 . Če pogledamo njene mere stroškovne učinkovitosti od začetka do konca opazovanega obdobja, vidimo, da se stroškovna učinkovitost Splošne bolnišnice Izola v povprečju z leti povečuje. Splošna bolnišnica Jesenice velja za stroškovno učinkovito v letu 20 I4, najnižjo mero stroškovne učinkovitosti pa zavzame v letu 2006, ko je njen količnik stroškovne učinkovitosti 0,659 . Univerzitetni klinični center Ljubljana je stroškovno najučinkovitejši v letu 20I 4, ko njegova mera stroškovne učinkovitosti znaša o,6I I, stroškovno najmanj učinkovit pa je v letu 2009, ko je njegov količnik stroškovne učinkovitosti 0,394. Pri Univerzitetnem kliničnem centru Maribor se mere stroškovne učinkovitosti gibljejo med 0,423 in 0,502, pri čemer najvišjo mero stroškovne učinkovitosti doseže v letu 2005. Splošna bolnišnica Murska Sobota je stroškovno najučinkovitejša v letu 2010 , ko znaša njena mera stroškovne učinkovitosti 0,88 I, stroškovno najmanj učinkovita pa je v letu 2007, ko znaša njen količnik stroškovne neučinkovitosti 0,387 . Pri Splošni bolnišnici Nova Gorica se količniki stroškovne učinkovitosti gibljejo med o,576 in o,830, pri čemer je ta bolnišnica stroškovno najučinkovitejša v letu 20I4. To je skladno z dejstvom, da se njene mere stroškovne učinkovitosti od začetka do konca opazovanega obdobja v povprečju z leti povečujejo. Splošna bolnišnica Novo mesto je stroškovna najučinkovitejša v letu 2005, ko njena vrednost stroškovne učinkovitosti znaša 0,748 , najnižjo mero stroškovne učinkovitosti pa zavzame v letu 2013, ko njen količnik stroškovne učinkovitosti znaša o,600. Splošna bolnišnica Ptuj najvišjo mero stroškovne učinkovitosti doseže v letu 20I4, ko je njena mera stroškovne učinkovitosti $\circ, 8 \circ 8$, najnižja mera stroškovne učinkovitosti pa je zanjo značilna $\mathrm{v}$ letu 2007, ko je njen količnik stroškovne učinkovitosti 0,597. Pri Splošni bolnišnici Slovenj Gradec se količniki stroškovne učinkovitosti gibljejo med o,408 in 0,694, pri čemer je ta bolnišnica stroškovno najučinkovitejša v letu 20 I I. Splošna bolnišnica Trbovlje je stroškovno učinkovita v letih med 2009 in 2014, najnižjo vrednost stroškovne učinkovitosti pa doseže prav v začetku opazovanega obdobja, to je v letu 2005, ko njen količnik stroškovne učinkovitosti znaša o,850.

Za ponazoritev povzetka rezultatov ocenjevanja stroškovne učinkovitosti, ki smo jih izpeljali na podlagi ocene modela konstantnih donosov obsega, usmerjenega k inputom, predstavljamo preglednico 7, ki prikazuje povprečne vrednosti količnikov stroškovne učinkovitosti posamezne splošne bolnišnice ter njihove minimalne in maksimalne vrednosti količ- 
nikov stroškovne učinkovitosti, ki so jih splošne bolnišnice dosegle v celotnem obdobju opazovanja.

Preglednica 7: Povprečna, minimalna in maksimalna stroškovna učinkovitost splošnih bolnišnic, ocenjena z metodo DEA

\begin{tabular}{cccc} 
Bolnišnica & $\begin{array}{c}\text { Povprečna stroškovna } \\
\text { učinkovitost }\end{array}$ & $\begin{array}{c}\text { Minimalna stroskovna } \\
\text { učinkovitost }\end{array}$ & $\begin{array}{c}\text { Maksimalna stroškovna } \\
\text { učinkovitost }\end{array}$ \\
\hline SBB & 0,986 & 0,904 & 1,000 \\
\hline SBC & 0,647 & 0,559 & 0,807 \\
\hline SBI & 0,677 & 0,550 & 0,787 \\
\hline SBJ & 0,808 & 0,659 & 1,000 \\
\hline UKL LJ & 0,510 & 0,525 & 0,661 \\
\hline UKCMB & 0,448 & 0,640 & 0,748 \\
\hline SB MS & 0,724 & 0,613 & $0,88 \mathrm{I}$ \\
\hline SB NG & 0,671 & 0,576 & 0,830 \\
\hline SBNM & 0,666 & 0,600 & 0,748 \\
\hline SBP & 0,649 & 0,597 & 0,808 \\
\hline SB SG & 0,585 & 0,408 & 0,694 \\
\hline SBT & 0,957 & 0,850 & 1,000 \\
\hline
\end{tabular}

Podatki mer stroškovne učinkovitosti kažejo, da je v letu 2005 stroškovno učinkovita Splošna bolnišnica Brežice, z nekoliko nižjo mero stroškovne učinkovitosti ji sledi Splošna bolnišnica Trbovlje. Najnižjo stroškovno učinkovitost imajo Splošna bolnišnica Slovenj Gradec in oba univerzitetna klinična centra. V letu 2006 je nekoliko višjo mero stroškovne učinkovitosti dosegla Splošna bolnišnica Slovenj Gradec, kar pomeni, da imata v tem letu najnižje mere stroškovne učinkovitosti Univerzitetni klinični center Ljubljana in Univerzitetni klinični center Maribor. V letu 2007 se situacija ni bistveno spremenila, je pa opazno dodatno znižanje količnikov obeh univerzitetnih kliničnih centrov, ki dosežeta najnižje vrednosti stroškovne učinkovitosti med vsemi slovenskimi splošnimi bolnišnicami. V letu 2008 je stroškovno učinkovita Splošna bolnišnica Brežice, relativno visoko mero stroškovne učinkovitosti ima tudi Splošna bolnišnica Trbovlje, ostale splošne bolnišnice pa dosegajo bistveno nižje količnike stroškovne učinkovitosti. Še najopaznejše povečanje mere stroškovne učinkovitosti v primerjavi z letom poprej se je zgodilo pri Splošni bolnišnici Jesenice. V letu 2009 so se v povprečju količniki mer stroškovne učinkovitosti povečali skoraj 
pri vseh opazovanih splošnih bolnišnicah. V primerjavi z letom 2008 so svoj rezultat izboljšale Splošna bolnišnica Celje, Splošna bolnišnica Izola, Splošna bolnišnica Jesenice, Splošna bolnišnica Murska Sobota, Splošna bolnišnica Nova Gorica, Splošna bolnišnica Slovenj Gradec in Splošna bolnišnica Trbovlje. Ima pa v tem letu presenetljivo najnižjo mero stroškovne učinkovitosti glede na vsa ostala leta Univerzitetni klinični center Ljubljana, kar pomeni, da je svoj rezultat v primerjavi s preteklim letom poslabšal. V letu 20 ro sta stroškovno učinkoviti Splošna bolnišnica Brežice in Splošna bolnišnica Trbovlje. Ostale splošne bolnišnice so stroškovno neučinkovite, pri čemer najnižje rezultate stroškovne učinkovitosti dosežeta ponovno oba univerzitetna klinična centra. $V$ letu 20 I se situacija ni bistveno spremenila, še vedno ostajata stroškovno učinkoviti Splošna bolnišnica Brežice in Splošna bolnišnica Trbovlje. So pa v tem letu svojo mero stroškovne učinkovitosti izboljšale Splošna bolnišnica Celje, Splošna bolnišnica Izola, Splošna bolnišnica Jesenice, Splošna bolnišnica Nova Gorica in Splošna bolnišnica Slovenj Gradec. V letu 2012 je status stroškovno učinkovite splošne bolnišnice izgubila Splošna bolnišnica Brežice, kar pomeni, da je edina bolnišnica, ki posluje z minimalni možni stroški zgolj Splošna bolnišnica Trbovlje. Rezultati kažejo tudi, da ima Splošna bolnišnica Slovenj Gradec v primerjavi z letom poprej opazno nižjo mero stroškovne učinkovitosti. V letu 2013 se je edina večja sprememba pri merah stroškovne učinkovitosti zgodila pri Splošni bolnišnici Slovenj Gradec, ki je svojo mero stroškovne učinkovitosti v primerjavi z letom 2012 še dodatno poslabšala. V letu 2014 sta stroškovno učinkoviti dve splošni bolnišnici, in sicer Splošna bolnišnica Jesenice in Splošna bolnišnica Trbovlje. V tem letu je torej Splošna bolnišnica Jesenice bistveno izboljšala svoje poslovanje in ima tako status stroškovno učinkovite splošne bolnišnice. Enako kot v vseh preostalih letih pa z visokimi merami stroškovne neučinkovitosti še vedno izstopata Univerzitetni klinični center Ljubljana in Univerzitetni klinični center Maribor.

Povzetek rezultatov ocenjevanja stroškovne učinkovitosti, ki smo jih izpeljali na podlagi modela konstantnih donosov obsega, usmerjenega $\mathrm{k}$ inputom, predstavljamo $\mathrm{v}$ preglednici 8 , ki prikazuje povprečne vrednosti količnikov stroškovne učinkovitosti vseh splošnih bolnišnic skupaj znotraj posameznega leta. Količnike povprečne stroškovne učinkovitosti prikazujemo za celotno opazovano obdobje, torej od leta 2005 do leta 2014. 
Preglednica 8: Povprečna stroškovna učinkovitost splošnih bolnišnice znotraj posameznih let, ocenjena z metodo DEA

Leto

\begin{tabular}{ll}
2005 & 0,648 \\
\hline 2006 & 0,641 \\
\hline 2007 & 0,642 \\
\hline 2008 & 0,699 \\
\hline 2009 & 0,699 \\
\hline 2010 & 0,735 \\
\hline 2011 & 0,732 \\
\hline 2013 & 0,697 \\
\hline 2014 & 0,680 \\
\hline
\end{tabular}

Povprečna stroškovna učinkovitost

DEA model konstantnih donosov obsega, usmerjen $\mathrm{k}$ inputom, pokaže, da je glede na celotno opazovano obdobje stroškovno najučinkovitejša Splošna bolnišnica Brežice, ki ima povprečno vrednost stroškovne učinkovitosti 0,986 , sledi ji Splošna bolnišnica Trbovlje s povprečno vrednostjo stroškovne učinkovitosti o,957. Takoj za njima imata najvišjo povprečno vrednost stroškovne učinkovitosti Splošna bolnišnica Jesenice s količnikom o,8०8 in Splošna bolnišnica Murska Sobota z mero stroškovne učinkovitosti 0,724 . Najnižje vrednosti stroškovne učinkovitosti pretežno vsa leta opazovanja sta imela Univerzitetni klinični center Maribor in Univerzitetni klinični center Ljubljana, pri čemer ima slednji v primerjavi z Univerzitetnim kliničnim centrom Maribor, še nižjo povprečno vrednost stroškovne učinkovitosti. Pri Univerzitetnem kliničnem centru Maribor ta znaša o,446, pri Univerzitetnem kliničnem centru Ljubljana pa 0,5 Io. To pomeni, da je Univerzitetni klinični center Maribor stroškovno neučinkovit zaradi prevelike količine porabe inputov, poleg tega pa zaradi dejstva, da ne proizvaja z minimalnimi povprečnimi stroški. Enako velja za Univerzitetni klinični center Ljubljana, ki lahko svojo stroškovno neučinkovitost odpravi tako, da dano raven outputa začne proizvajati z manjšo količino inputov, hkrati pa mora dano raven outputa začeti proizvajati še z najnižjimi možnimi stroški.

Alokacijsko učinkovitost $\mathrm{v}$ našem primeru predstavlja razmerje med količniki stroškovne in tehnične učinkovitosti splošnih bolnišnic, kar pomeni, da je alokacijska učinkovitost izvajalcev zdravstvene dejavnosti posledica njihove tehnične in stroškovne učinkovitosti. DEA model kon- 
stantnih donosov obsega, usmerjen $\mathrm{k}$ inputom, pokaže, da najvišje mere alokacijske učinkovitosti dosega Splošna bolnišnica Brežice, ki ima povprečno vrednost alokacijske učinkovitosti 0,965 . Sledita ji Splošna bolnišnica Trbovlje s povprečnim količnikom alokacijske učinkovitosti 0,965 in Splošna bolnišnica Jesenice s povprečno mero alokacijske učinkovitosti 0,896 . Takoj za njima imata najvišjo mero alokacijske učinkovitosti Univerzitetni klinični center Ljubljana s povprečnim količnikom alokacijske učinkovitosti o,866 in Splošna bolnišnica Nova Gorica s povprečno mero alokacijske učinkovitosti o,8 18. Rezultati kažejo, da ima najnižji količnik alokacijske učinkovitosti Univerzitetni klinični center Maribor, pri katerem znaša povprečna vrednost alokacijske učinkovitosti o,657. Če bi Univerzitetni klinični center Maribor želel postati alokacijsko učinkovita splošna bolnišnica, bi moral v povprečju znižati stroške proizvodnih dejavnikov za 34,3 odstotka ob nespremenjenem obsegu outputa. Podobno velja za Splošno bolnišnico Izola, ki ima povprečno mero alokacijske učinkovitosti 0,7 I2, kar pomeni, da bi morala zmanjšati svoje dejanske stroške proizvodnih dejavnikov za 28,8 odstotka, če bi želela poslovati na premici minimalnih stroškov.

\section{Rezultati DEA modela variabilnih donosov obsega}

Pri DEA modelu variabilnih donosov obsega, usmerjenem $\mathrm{k}$ outputom, obstaja predpostavka, da izvajalci zdravstvene dejavnosti ne morejo zmanjševati oziroma spreminjati obsega zaposlitve svojih proizvodnih dejavnikov, kar pomeni, da so inputi za izvajalce zdravstvene dejavnosti dani. Rezultati nam tako povedo, za koliko odstotkov bi morale neučinkovite splošne bolnišnice povečati obseg proizvodnje svojih outputov, če bi želele postati tehnično učinkovite. V luči okolja, v katerem poslujejo splošne bolnišnice, je to zelo pomembna informacija tako za managerje kot tudi za oblikovalce zdravstvene politike, predvsem za plačnika zdravstvenih storitev, ki se odloča o količini storitev, ki jih priznava in plačuje izvajalcem zdravstvene dejavnosti. DEA model variabilnih donosov obsega, usmerjen k outputom, nam torej pove, koliko storitev lahko posamezna splošna bolnišnica opravi z razpoložljivi inputi oziroma za koliko odstotkov lahko z danimi inputi poveča število opravljenih zdravstvenih storitev. S predpostavko o variabilnih donosih obsega smo iz mer neučinkovitosti izključili neučinkovitost, ki je posledica neučinkovitosti obsega. To pomeni, da je upoštevano, da niso vsi izvajalci enako veliki in da lahko določena mera neučinkovitosti izhaja iz dejstva, da niso vsi izvajalci optimalne velikosti. $Z$ upoštevanjem variabilnih donosov obsega smo 
tako zmanjšali heterogenost med splošnimi bolnišnicami, ki je posledica različne velikosti.

Količniki tehnične učinkovitosti na podlagi modela variabilnih donosov obsega, usmerjenega $\mathrm{k}$ outputom, so $\mathrm{v}$ primerjavi z modelom konstantnih donosov obsega, usmerjenega $\mathrm{k}$ inputom, višji. To je logična posledica dejstva, da smo v primeru modela variabilnih donosov obsega, usmerjenega k outputom, izključili neučinkovitost, ki izhaja iz neučinkovitosti obsega. Mere tehnične neučinkovitosti v tem primeru ponazarjajo zgolj neučinkovitost, ki je posledica neučinkovitega razmerja med obsegom proizvedenega outputa in obsegom porabljenih proizvodnih dejavnikov. Mere tehnične učinkovitosti izvajalcev zdravstvene dejavnosti kažejo, da količniki tehnične učinkovitost sicer z leti variirajo znotraj posameznih splošnih bolnišnic, pri čemer pa so splošne bolnišnice z najvišjimi merami učinkovitosti v povprečju tehnično učinkovite skozi celotno obdobje. Podobna situacija velja za splošne bolnišnice z najnižjimi merami učinkovitosti, pri katerih se rezultati tehnične učinkovitosti sicer z leti spreminjajo, vendar so pri tem še vedno definirane kot najmanj tehnično učinkovite splošne bolnišnice.

Splošna bolnišnica Brežice je definirana kot tehnično učinkovita splošna bolnišnica skozi celotno obdobje, saj so njene mere tehnične učinkovitosti v vseh letih opazovanja enake r. Enako velja za Splošno bolnišnico Celje, ki je skozi vsa opazovana leta tehnično učinkovita splošna bolnišnica s povprečno mero tehnične učinkovitosti i. Če primerjamo te podatke $\mathrm{z}$ rezultati modela konstantnih donosov obsega, usmerjenega $\mathrm{k}$ inputom, vidimo, da je tehnična neučinkovitost Splošne bolnišnice Celje pri prvem modelu posledica zgolj velikostne neučinkovitosti, saj rezultati kažejo, da uporablja pravo razmerje med obsegom outputa in obsegom porabljenih proizvodnih dejavnikov. Pri Splošni bolnišnici Izola se mere tehnične učinkovitosti znotraj modela variabilnih donosov obsega, usmerjenega k outputom, gibljejo med o,934 in $\mathrm{r}$. V obdobju med letom 2007 in letom 2010 ter v letu 2014 ta bolnišnica velja za tehnično učinkovito splošno bolnišnico, v preostalih letih pa so zanjo značilne različne mere tehnične neučinkovitosti. Splošna bolnišnica Jesenice velja za tehnično učinkovito v obdobju med letom 2008 in letom 2014, najnižjo mero tehnične učinkovitosti pa zavzame na začetku opazovanega obdobja, to je v letu 2005, ko njen količnik tehnične učinkovitosti znaša 0,929. Pri Univerzitetnem kliničnem centru Ljubljana rezultati pokažejo enako kot v primeru Splošne bolnišnice Celje. Univerzitetni klinični center Ljubljana je skozi celotno opazovano obdobje tehnično učinkovita splošna bolnišnica s povprečno mero tehnične učinkovitosti $\mathrm{r}$. V prime- 
ru modela konstantnih donosov obsega, usmerjenega $\mathrm{k}$ inputom, je tako njegova tehnična neučinkovitost posledica zgolj neučinkovitosti obsega, kar pomeni, da je njegova velikost prevelika. Rezultati modela variabilnih donosov obsega, usmerjenega k outputom, namreč kažejo, da uporablja pravo razmerjem med obsegom outputa in obsegom porabljenih inputov. Pri Univerzitetnem kliničnem centru Maribor se mere tehnične učinkovitosti gibljejo med 0,915 in I, pri čemer najnižjo mero tehnične učinkovitosti zavzame v letu 2013, ko njegov količnik tehnične učinkovitosti znaša 0,915 . Splošna bolnišnica Murska Sobota je tehnično učinkovita v obdobju med letom 2006 in 2008 ter v obdobju med letom 2010 in letom 2013, najnižja mera tehnične učinkovitosti pa je zanjo značilna v letu 2005, ko njen količnik tehnične učinkovitosti znaša 0,939. Pri Splošni bolnišnici Nova Gorica se količniki tehnične učinkovitosti gibljejo med 0,850 in 0,992 , pri čemer je ta bolnišnica tehnično najučinkovitejša v letu 2014. Splošna bolnišnica Novo mesto je učinkovita v obdobju med letom 2005 in letom 2008 , najnižjo mero tehnične učinkovitosti pa zavzame v letu 2013, ko znaša njen količnik tehnične učinkovitosti 0,903. Pri Splošni bolnišnici Ptuj se mere tehnične učinkovitosti znotraj modela variabilnih donosov obsega, usmerjenega k outputom, gibljejo med o,858 in I. Splošna bolnišnica Ptuj je tehnično učinkovita zgolj v letu $2006, \mathrm{v}$ preostalih letih pa so zanjo značilne različne mere tehnične neučinkovitosti. Splošna bolnišnica Slovenj Gradec ima znotraj modela variabilnih donos obsega, usmerjenega $\mathrm{k}$ outputom, med vsemi splošnimi bolnišnica najnižje količnike tehnične učinkovitosti. Boljši rezultati znotraj modela konstantnih donosov obsega, usmerjenega $\mathrm{k}$ inputom, kažejo na dejstvo, da je Splošna bolnišnica Slovenj Gradec sicer velikostno učinkovita, hkrati pa ne proizvaja maksimalnega obsega outputa glede na razpoložljiv obseg proizvodnih dejavnikov. Splošna bolnišnica Trbovlje je tehnično učinkovita v letih med 2007 in 2014, najnižjo vrednost tehnične učinkovitosti pa doseže ravno $\mathrm{v}$ začetku opazovanega obdobja, to je v letu 2005, ko njen količnik tehnične učinkovitosti znaša 0,945 .

Za ponazoritev povzetka rezultatov ocenjevanja tehnične učinkovitosti, ki smo jih izpeljali na podlagi ocene modela variabilnih donosov obsega, usmerjenega k outputom, predstavljamo preglednico 9, ki prikazuje povprečne vrednosti količnikov tehnične učinkovitosti posamezne splošne bolnišnice ter njihove minimalne in maksimalne vrednosti količnikov tehnične učinkovitosti, ki so jih splošne bolnišnice dosegle v celotnem obdobju opazovanja. 
Preglednica 9: Povprečna, minimalna in maksimalna tehnična učinkovitost splošnih bolnišnic, ocenjena z metodo DEA

\begin{tabular}{cccc} 
Bolnišnica & $\begin{array}{c}\text { Povprečna tehnična } \\
\text { učinkovitost }\end{array}$ & $\begin{array}{c}\text { Minimalna tehnična } \\
\text { učinkovitost }\end{array}$ & $\begin{array}{c}\text { Maksimalna tehnična } \\
\text { učinkovitost }\end{array}$ \\
\hline SBB & $\mathrm{I}, 000$ & $\mathrm{I}, 000$ & $\mathrm{I}, 000$ \\
\hline SBC & $\mathrm{I}, 000$ & $\mathrm{I}, 000$ & $\mathrm{I}, 000$ \\
\hline SBI & 0,979 & 0,934 & $\mathrm{I}, 000$ \\
\hline SBJ & 0,985 & 0,929 & $\mathrm{I}, 000$ \\
\hline UKL LJ & $\mathrm{I}, 000$ & $\mathrm{I}, 000$ & $\mathrm{I}, 000$ \\
\hline UKCMB & 0,970 & 0,915 & $\mathrm{I}, 000$ \\
\hline SBMS & 0,992 & 0,939 & 0,992 \\
\hline SB NG & 0,934 & 0,850 & $\mathrm{I}, 000$ \\
\hline SB NM & 0,969 & 0,903 & $\mathrm{I}, 000$ \\
\hline SBP & 0,921 & 0,858 & 0,999 \\
\hline SB SG & 0,913 & 0,616 & $\mathrm{I}, 000$ \\
\hline SBT & 0,992 & 0,945 &
\end{tabular}

Če primerjamo podatke splošnih bolnišnic po posameznih letih, vidimo, da so v letu 2005 tehnično učinkoviti Splošna bolnišnica Brežice, Splošna bolnišnica Celje, oba univerzitetna klinična centra in Splošna bolnišnica Novo mesto. Najnižjo tehnično učinkovitost dosega Splošna bolnišnica Slovenj Gradec, sledi pa ji Splošna bolnišnica Nova Gorica. V letu 2006 so tehnično učinkovite Splošna bolnišnica Brežice, Splošna bolnišnica Celje, Univerzitetni klinični center Ljubljana, Splošna bolnišnica Murska Sobota in Splošna bolnišnica Ptuj. Splošna bolnišnica Nova Gorica je v tem letu svoj rezultat izboljšala, Splošna bolnišnica Slovenj Gradec pa je še vedno tehnično najmanj učinkovita splošna bolnišnica. V letu 2007 je učinkovitih osem izmed dvanajstih splošnih bolnišnic, pri čemer Splošna bolnišnica Slovenj Gradec ostaja tehnično najmanj učinkovita splošna bolnišnica. V letu 2008 je znotraj modela variabilnih donosov obsega, usmerjenega k outputom, tehnično učinkovitih kar devet splošnih bolnišnic, kar pomeni, da večina splošnih bolnišnic proizvaja maksimalen možen obseg outputa pri dani količini obsega proizvodnih dejavnikov. V letu 2009 so tehnično neučinkoviti Univerzitetni klinični center Maribor, Splošna bolnišnica Murska Sobota, Splošna bolnišnica Nova Gorica, Splošna bolnišnica Novo mesto, Splošna bolnišnica Ptuj in Splošna bolnišnica Slovenj Gradec. Med njimi ima najnižji količnik tehnične učinkovitosti Splošna bolnišnica Ptuj. V letu 20 io so bile vse splo- 
šne bolnišnice tehnično učinkovite, razen Splošne bolnišnice Nova Gorica, Splošne bolnišnica Novo mesto, Splošne bolnišnice Ptuj in Splošne bolnišnice Slovenj Gradec. V letu 20 I i ima tako kot v prejšnjih dveh letih ponovno najvišji količnik tehnične neučinkovitosti Splošna bolnišnica Ptuj, sledi pa ji Splošna bolnišnica Nova Gorica. V letu 2012 so tehnično učinkovite Splošna bolnišnica Brežice, Splošna bolnišnica Celje, Splošna bolnišnica Jesenice, Univerzitetni klinični center Ljubljana in Splošna bolnišnica Murska Sobota. V območju najnižje tehnične učinkovitosti sta še vedno Splošna bolnišnica Ptuj in Splošna bolnišnica Nova Gorica. V letu 2013 je učinkovitih pet izmed dvanajstih splošnih bolnišnic, pri čemer Splošna bolnišnica Ptuj ostaja tehnično najmanj učinkovita splošna bolnišnica. V letu 2014 so tehnično neučinkoviti Univerzitetni klinični center Maribor, Splošna bolnišnica Murska Sobota, Splošna bolnišnica Nova Gorica, Splošna bolnišnica Novo mesto, Splošna bolnišnica Ptuj in Splošna bolnišnica Slovenj Gradec. Med njimi ostaja tehnično najmanj učinkovita Splošna bolnišnica Ptuj.

Povzetek rezultatov ocenjevanja tehnične učinkovitosti, ki smo jih izpeljali na podlagi modela variabilnih donosov obsega, usmerjenega $\mathrm{k}$ outputom, predstavljamo $\mathrm{v}$ preglednici ıo, ki prikazuje povprečne vrednosti količnikov tehnične učinkovitosti vseh splošnih bolnišnic skupaj znotraj posameznega leta. Količnike povprečne tehnične učinkovitosti prikazujemo za celotno opazovano obdobje, kar pomeni od leta 2005 do leta 2014.

Preglednica ıo: Povprečna tehnična učinkovitost splošnih bolnišnice znotraj posameznih let, ocenjena z metodo DEA

\begin{tabular}{cc}
\hline Leto & Povprečna tehnična učinkovitost \\
\hline 2005 & 0,934 \\
\hline 2006 & 0,969 \\
\hline 2007 & 0,982 \\
\hline 2008 & 0,985 \\
\hline 2009 & 0,971 \\
\hline 2010 & 0,979 \\
\hline 2011 & 0,970 \\
\hline 2012 & 0,972 \\
\hline 2013 & 0,973 \\
\hline 2014 & 0,979 \\
\hline
\end{tabular}

DEA model variabilnih donosov obsega, usmerjen k outputom, torej pokaže, da so bili skozi celotno opazovano obdobje tehnično učin- 
koviti Splošna bolnišnica Brežice, Splošna bolnišnica Celje in Univerzitetni klinični Center Ljubljana, kar pomeni, da v vseh letih opazovanja zavzamejo mero tehnične učinkovitosti $\mathrm{I}$. Takoj za njimi imata najvišjo povprečno vrednost tehnične učinkovitosti Splošna bolnišnica Trbovlje in Splošna bolnišnica Murska Sobota, ki obe zavzameta vrednost 0,992. Sledijo Splošna bolnišnica Jesenice, ki ima povprečno vrednost tehnične učinkovitosti 0,985 , Splošna bolnišnica Izola s povprečno mero tehnične učinkovitosti 0,979 in Univerzitetni klinični center Maribor s povprečnim količnikom tehnične učinkovitosti o,970. Najnižjo vrednost tehnične učinkovitosti ima Splošna bolnišnica Slovenj Gradec, pri kateri znaša povprečna vrednost tehnične učinkovitosti 0,913 . To pomeni, da bi morala Splošna bolnišnica Slovenj Gradec, da bi dosegla tehnično učinkovitost, $\mathrm{v}$ povprečju povečati obseg proizvedenih outputov za 8,7 odstotka ob nespremenjenem obsegu proizvodnih dejavnikov. Podobna situacija je pri Splošni bolnišnici Ptuj, ki je v primerjavi z ostalimi splošnimi bolnišnicami tehnično manj učinkovita. Njena povprečna vrednost tehnične učinkovitosti znaša 0,921 . V takem primeru bi morala Splošna bolnišnica Ptuj povečati obseg proizvedenih outputov za 7,9 odstotka, če bi želela poslovati na meji proizvodnih možnosti, kar bi pomenilo, da je tehnično učinkovita splošna bolnišnica.

\section{Primerjava rezultatov metode SFA in metode DEA}

Rezultati merjenja učinkovitosti se razlikujejo glede na to, ali uporabimo parametrično ali neparametrično oziroma deterministično tehniko ocenjevanja učinkovitosti. Metoda SFA je najpogosteje uporabljena metoda prvega pristopa, metoda DEA pa je najpogosteje uporabljena metoda drugega pristopa. Pri tem SFA ocenjuje mere učinkovitosti na osnovi ekonometričnega ocenjevanja stohastičnih mejnih funkcij, DEA pa ocenjuje mere učinkovitosti na podlagi linearnega programiranja. Rezultati, pridobljeni na podlagi metode SFA, kažejo, da se povprečne mere ekonomske učinkovitosti splošnih bolnišnic v obdobju med letom 2005 in letom 2014 gibljejo med 0,644 in 0,667 , pri metodi DEA pa so povprečne mere ekonomske učinkovitosti v razponu med $0,64 \mathrm{I}$ in 0,778 . Praktično $\mathrm{v}$ vseh primerih so rezultati ocenjevanja mer učinkovitosti $\mathrm{z}$ metodo SFA nižji od rezultatov ocenjevanja mer učinkovitosti z metodo DEA. To pomeni, da so mere neučinkovitosti oziroma odmiki od meje proizvodne in stroškovne funkcije znotraj metode SFA višji v primerjavi z metodo DEA. Mere ekonomske učinkovitost splošnih bolnišnic, ocenjene z metodo SFA in metodo DEA, prikazujemo v preglednici I I. 
Preglednica I I: Primerjava mer ekonomske učinkovitosti, ocenjene z metodo SFA in metodo DEA

\begin{tabular}{ccc} 
Leto & $\begin{array}{c}\text { Mere ekonomske učinkovitosti ocenjene z } \\
\text { metodo SFA }\end{array}$ & $\begin{array}{c}\text { Mere ekonomske učinkovitosti ocenjene z } \\
\text { metodo DEA }\end{array}$ \\
\hline 2005 & 0,663 & 0,648 \\
\hline 2006 & 0,651 & 0,641 \\
\hline 2007 & 0,647 & 0,642 \\
\hline 2008 & 0,644 & 0,699 \\
\hline 2009 & 0,646 & 0,699 \\
\hline 2010 & 0,661 & 0,735 \\
\hline 2011 & 0,660 & 0,732 \\
\hline 2012 & 0,661 & 0,697 \\
\hline 2013 & 0,667 & 0,680 \\
\hline 2014 & 0,665 & 0,778 \\
\hline
\end{tabular}

Splošna raven ekonomske učinkovitosti pri metodi SFA je torej nižja v primerjavi z metodo DEA v vseh desetih letih opazovanja. Ta rezultat sicer ni v skladu s pričakovanji glede na tehnike merjenja učinkovitosti vsake posamezne metode. Metoda DEA namreč uporablja determinističen pristop, kar pomeni, da odstopanje določene opazovane enote od mejne funkcije v celoti pripiše neučinkovitosti. Metoda SFA pa na drugi strani uporablja stohastičen pristop, kar pomeni, da odmik opazovane enote od mejne funkcije razdeli na dva dela, in sicer na stohastično napako in mero neučinkovitosti. Skladno s tem bi pričakovali, da metoda SFA oceni višje mere učinkovitosti opazovanih izvajalcev.

Kljub temu so podobne rezultate mer učinkovitosti dobili tudi v številnih drugih študijah (Ferrier in Lovell r990; Hjalmarsson, Kumbhakar in Heshmati 1996; Chirikos in Sear 2000; Giuffrida in Gravelle 2001; Jacobs 200I). Razlika v rezultatih je v našem primeru posledica dejstva, da ocenjena stohastična mejna funkcija, opredeljena znotraj metode SFA, leži nad ovojnico podatkov oziroma nad mejno funkcijo, določeno z metodo DEA. Očitno je torej, da se stohastična mejna funkcija, ki smo jo definirali znotraj metode SFA, manj prilega podatkom, kot je to značilno za mejno funkcijo, ki jo določi metoda DEA. Znotraj metode SFA smo namreč sami izbrali funkcijsko obliko mejne proizvodne in mejne stroškovne funkcije, medtem ko pri metodi DEA te predpostavke ni bilo treba sprejeti, kar pomeni, da je metoda DEA sama določila mejno proizvodno in mejno stroškovno funkcijo. 
Rezultati mer učinkovitosti, ocenjenih s pomočjo metode DEA, kažejo, da se večina splošnih bolnišnic nahaja na mejni funkciji ali v njeni neposredni bližini. Skladno s tem sta znotraj opazovanega obdobja vsako leto popolnoma učinkoviti običajno dve slovenski splošni bolnišnici. Rezultati tako niso popolnoma $\mathrm{v}$ skladu z merami učinkovitosti, izračunanimi na podlagi metode SFA. Pri metodi SFA namreč nobena izmed opazovanih splošnih bolnišnic ni popolnoma učinkovita oziroma ne dosega mere učinkovitosti I, kar pomeni, da nobena splošna bolnišnica ne laži na stohastični mejni funkciji. To je posledica razlik v načinu definiranja mejne funkcije znotraj obeh metod. V metodi DEA se namreč dejanska opazovanja uporabijo za določitev ovojnice podatkov, kar pomeni, da bo vedno vsaj ena splošna bolnišnica ležala na mejni funkciji. V tem primeru se torej ne moremo izogniti dejstvu, da bo najmanj ena splošna bolnišnica ocenjena kot popolnoma učinkovita oziroma z mero učinkovitosti I. V metodi SFA pa opazovanja služijo zgolj kot pomoč pri definiranju stohastične mejne funkcije.

Med rezultati, ocenjenimi s pomočjo metode SFA in metode DEA, obstaja še ena pomembna razlika. Mere učinkovitosti znotraj metode DEA bistveno bolj variirajo glede na mere učinkovitosti, ocenjene s pomočjo metode SFA. Slednja namreč omogoča oceno stohastične napake, ki ponazarja metodološke napake, kamor uvrščamo napačno izbiro funkcijske oblike, vpliv spremenljivke, ki smo jo nenamerno izpustili, napake $\mathrm{v}$ podatkih, okoljske dejavnike in podobno. Skladno s tem imajo rezultati, ki smo jih dobili s pomočjo metode DEA, večjo variabilnost glede na rezultate, pridobljene s pomočjo metode SFA. Kot smo že povedali, je znotraj metode SFA v merah neučinkovitosti izključena neučinkovitost, ki je posledica slučajne napake oziroma belega šuma.

Sta pa obe metodi pokazali približno enake trende naraščanja in padanja mer učinkovitosti v posameznih letih. Količniki ekonomske učinkovitosti, izračunani $\mathrm{z}$ metodo SFA, v prvih šestih letih opazovanja $\mathrm{v}$ povprečju naraščajo, in tako $\mathrm{v}$ letu 2010 zavzamejo vrednost $0,66 \mathrm{I}$, kar pomeni, da so na ravni 66, I odstotka učinkovitosti učinkovitih splošnih bolnišnic. Podobno velja za količnike ekonomske učinkovitosti, izračunane z metodo DEA, ki v prvih šestih letih opazovanja v povprečju naraščajo, pri čemer v letu 2010 dosežejo vrednost 0,735 , torej so $v$ tem letu na ravni 73,5 odstotka povprečne učinkovitosti učinkovitih splošnih bolnišnic. V naslednjih dveh letih mere ekonomske učinkovitosti, izračunane $\mathrm{z}$ metodo $S F A$, v povprečju padajo, $\mathrm{v}$ letu 2013 pa se ponovno povišajo in tako dosežejo najvišjo vrednost, ki znaša o,667. V letu 2014 se količniki ekonomske učinkovitosti praktično ne spremenijo, kar pomeni, da osta- 
nejo na približno enaki ravni, torej pri 66,5 odstotkih učinkovitosti učinkovitih splošnih bolnišnic. Podobno velja za mere ekonomske učinkovitosti, izračunane z metodo DEA, ki po letu 2010 začnejo padati, nato pa $\mathrm{v}$ zadnjem letu opazovanja dosežejo svojo najvišjo vrednost, ki je na ravni 77,8 odstotka učinkovitosti učinkovitih splošnih bolnišnic.

Primerjava količnikov obeh metod ocenjevanja učinkovitosti splošnih bolnišnic tako kaže, kako pomembno je, da ne uporabimo zgolj enega pristopa merjena učinkovitosti, ampak poskušamo ocenjevati količnike učinkovitosti splošnih bolnišnic z uporabo več različnih pristopov. Naša analiza torej potrjuje spoznanja Bauerja in soavtorjev (1998), ki zagovarjajo tezo, da je pri izbiri metodologije treba uporabiti več različnih pristopov, kar pomeni, da ni treba sprejeti odločitve o najboljši metodi merjenja učinkovitosti. Na ta način preverimo konsistentnost rezultatov, kar nam predstavlja dobro podlago pri nadaljnjem raziskovanju.

Preglednica I2: Povezanost mer ekonomske učinkovitosti ocenjene z metodo SFA in metodo DEA

\begin{tabular}{|c|c|c|c|c|c|c|}
\hline & TE SFA & AESFA & CE SFA & TE DEA & AE DEA & CE DEA \\
\hline TESFA & 1,000 & & & & & \\
\hline AESFA & 0,014 & 1,000 & & & & \\
\hline CESFA & $0,983^{*}$ & 0,169 & 1,000 & & & \\
\hline TEDEA & $0,605^{*}$ & 0,157 & $0,565^{*}$ & 1,000 & & \\
\hline AEDEA & $0,229^{*}$ & $0,464^{*}$ & 0,138 & $0,225^{*}$ & 1,000 & \\
\hline CEDEA & $0,468^{*}$ & $0,295^{\circ}$ & $0,404^{*}$ & $0,713^{*}$ & $0,771^{*}$ & 1,000 \\
\hline
\end{tabular}

*Povezanost je statistično značilna

Za preverjanje konsistentnosti rezultatov metode SFA in metode DEA smo izvedli Spearmanov korelacijski test, ki preverja povezanost med ordinalnimi spremenljivkami. Spearmanov korelacijski test pred izračunom korelacije podatke oziroma vrednosti učinkovitosti izvajalcev zdravstvene dejavnosti preoblikuje $\mathrm{v}$ rang, nato pa pri končnem izračunu uporabi razliko med rangi različnih vrednosti. Ko je znotraj Spearmanovega koeficienta korelacije rangov statistična značilnost enaka ali manjša od o,oo5, govorimo o statistični povezanosti spremenljivk, ko je stopnja značilnosti večja od o,o05, pa povezanost med spremenljivkami ni statistično značilna (Lawrence 2013). Spearmanov korelacijski test smo uporabili, ker temelji na korelaciji rangov, kar pomeni, da je v primerjavi z nekaterimi ostalimi korelacijskimi testi robustnejši. Spearmanov korelacijski koeficient je neparametrijski koeficient, kar je pomembno zlasti 
ob dejstvu, da metoda DEA uporablja neparametričen pristop izračunavanja učinkovitosti posameznih opazovanih enot. Poleg tega predpostavljamo, da povezanost med rezultati metode SFA in metode DEA ni linearna.

V preglednici I2 so prikazani korelacijski koeficienti učinkovitosti, dobljeni z metodama SFA in DEA. Primerjava koeficientov, dobljenih z obema metodama, kaže na stopnjo njune podobnosti. Dobljene korelacije so srednje velikosti. Tehnična učinkovitost, ocenjena z metodo SFA, korelira s tehnično učinkovitostjo, dobljeno na podlagi metode DEA, o,6r. Korelacija med alokacijsko učinkovitostjo znotraj metode SFA ter metode DEA je nižja in znaša o,46. Korelacija med mero stroškovne učinkovitosti, ocenjene $\mathrm{z}$ metodo SFA, in mero stroškovne učinkovitosti, ocenjene z metodo DEA, pa znaša 0.40 . Če bi bili primerljivi koeficienti zelo visoki, bi to pomenilo, da sta metodi enaki, kar pomeni, da nima smisla uporabiti obeh pristopov. $V$ tem primeru bi namreč ena metoda podala popolnoma enake odgovore kot druga. Če bi bili korelacijski koeficienti nizki oziroma zanemarljivi, bi to pomenilo, da metodi nista podobni in ju zato ne smemo razumeti kot ekvivalenten način raziskovanja našega problema. Ker so koeficienti korelacije med obema metodama srednje visoki, to pravzaprav pomeni, da z obema metodama dobimo podobne rezultate, ki pa niso popolnoma enaki, zato je pravzaprav smiselno pri analizi učinkovitosti uporabiti oba pristopa, če želimo problem raziskati čim natančneje. Srednje visoki koeficienti potrjujejo skladnost obeh metod, hkrati pa potrjujejo tudi, da metodi nista identični in zato skupaj ponujata več informacij kot zgolj posamezna metoda. Ti koeficienti potrjujejo pravilnost odločitve, da pri iskanju odgovorov preverjamo mere ekonomske učinkovitosti izvajalcev zdravstvene dejavnosti z obema metodama.

Poleg povezanosti mer ekonomske učinkovitosti, ocenjene z metodo SFA in metodo DEA, pa nas je zanimala tudi povezava med merami tehnične, alokacijske in stroškovne učinkovitosti znotraj metode SFA in znotraj metode DEA. V preglednici I3 predstavljamo analizo korelacijskih vplivov za koeficiente učinkovitosti, dobljene z metodo SFA. Analiza je pokazala visoko povezanost med stroškovno in tehnično učinkovitostjo, ki znaša I,००, kar pomeni, da je bil vrstni red izvajalcev zdravstvene dejavnosti po velikosti koeficienta stroškovne učinkovitosti povsem enak vrstnemu redu izvajalcev zdravstvene dejavnosti glede na koeficient tehnične učinkovitosti. Po drugi strani pa alokacijska učinkovitost nizko in nepomembno korelira tako s tehnično učinkovitostjo kot tudi s stroškovno učinkovitostjo. 
Preglednica 13: Povezava mer stroškovne, tehnične, alokacijske in učinkovitosti znotraj metode SFA

\begin{tabular}{cccc} 
& TE & AE & CE \\
\hline TE & 1,000 & & \\
\hline AE & 0,224 & 1,000 & \\
\hline CE & $1,000^{*}$ & 0,224 & 1,000 \\
\hline
\end{tabular}

*Povezanost je statistično značilna

Preglednica I4: Povezava mer stroškovne, tehnične, alokacijske in učinkovitosti znotraj metode DEA

\begin{tabular}{cccc} 
& TE & AE & CE \\
\hline TE & 1,000 & & \\
\hline AE & 0,392 & 1,000 & \\
\hline CE & $0,825^{*}$ & $0,720^{*}$ & 1,000 \\
\hline
\end{tabular}

*Povezanost je statistično značilna

Nekoliko drugačne rezultate pokaže analiza koeficientov učinkovitosti, dobljene z metodo DEA, ki jih prikazujemo v preglednici i 4. Korelacijski koeficient med tehnično učinkovitostjo in stroškovno učinkovitostjo je nekoliko nižji kot v primeru koeficientov znotraj metode SFA in znaša 0,83 , pri čemer velja, da je statistično značilen. Prav tako obstaja visoka korelacija med stroškovno učinkovitostjo in alokacijsko učinkovitostjo, ki znaša 0,72 in je tudi statistično značilna. Nizka in neznačilna pa je povezanost $s$ tehnično učinkovitostjo in alokacijsko učinkovitostjo, kar je seveda tudi pričakovano, saj gre za dve ločeni meri učinkovitosti, ki temeljita na različnih pristopih. Vsekakor lahko potrdimo izjemno visoko povezanost med stroškovno in tehnično učinkovitostjo, medtem ko se je povezanost med stroškovno in alokacijsko učinkovitostjo znotraj metode DEA izkazala za visoko in pomembno, znotraj metode SFA pa korelacija ni pomembna.

Rezultati merjenja učinkovitosti slovenskih splošnih bolnišnic z metodo SFA in metodo DEA so uporabno orodje, ki lahko pomaga managerjem in plačnikom zdravstvenih storitev pri boljšem razumevanju ekonomske učinkovitosti izvajalcev zdravstvene dejavnosti. Skladno s tem se udeleženci laže odločajo o nadaljnjem poslovanju splošnih bolnišnic, pri čemer so jim na voljo najboljše prakse splošnih bolnišnic, ki so se znotraj analize izkazale kot najučinkovitejše splošne bolnišnice. Analiza mer učinkovitosti slovenskih splošnih bolnišnic pa je še posebej uporabno 
orodje tudi za oblikovalce zdravstvene politike, predvsem $\mathrm{v}$ tistem delu, ki se navezuje na oblikovanje mreže sekundarne zdravstvene dejavnosti. Poznavanje mer učinkovitosti splošnih bolnišnic in njihovo spreminjanje $\mathrm{v}$ času lahko predstavlja osnovo pri zagotavljanju virov za poslovanje splošnih bolnišnic ter pri oblikovanju ponudbene strani znotraj mreže sekundarne zdravstvene dejavnosti. 



\section{Optimalna velikost izvajalcev zdravstvene dejavnosti}

Ekonomska učinkovitost izvajalcev zdravstvene dejavnosti je povezana z obsegom proizvodnje, zato je ključno vprašanje, kako velike splošne bolnišnice potrebujemo za oblikovanje učinkovite mreže sekundarne zdravstvene dejavnosti. Mreža zdravstvenega varstva mora biti definirana na način, da določa velikost izvajalcev, ta pa vpliva potem tako na ponudbeno stran kot tudi na stran povpraševanja po zdravstvenih storitvah. Tako $\mathrm{v}$ teoriji kot $\mathrm{v}$ praksi zato govorimo o optimalni velikosti izvajalcev zdravstvene dejavnosti. Optimalna velikost izvajalcev zdravstvene dejavnosti zajema ustrezno stopnjo koncentracije izvajalcev zdravstvenih dejavnosti, kar vpliva na njihovo ekonomsko učinkovitost delovanja. $Z$ opredelitvijo optimalne velikosti izvajalcev zagotovimo možnost za njihovo racionalno obliko delovanja.

V tem delu monografije poskušamo definirati ekonomsko najučinkovitejšo splošno bolnišnico ne samo na podlagi analiz mer učinkovitosti, ampak tudi z opredelitvijo njene optimalne velikosti. S tem ne odgovorimo zgolj na vprašanje, kakšna učinkovita splošna bolnišnica naj deluje znotraj mreže sekundarne zdravstvene dejavnosti, ampak podajamo tudi odgovor na vprašanje, koliko storitev mora splošna bolnišnica proizvajati, če želimo zagotoviti možnost za njihovo racionalno obliko delovanja. $\mathrm{Na}$ ta način lahko definiramo optimalno velikost najučinkovitejše slovenske splošne bolnišnice. 


\section{Teoretične iztočnice optimalne velikosti izvajalcev zdravstvene dejavnosti}

Izvajalci v javni lasti se obnašajo racionalno in minimirajo stroške in maksimirajo prihodke, kar je ključno za opredelitev njihove optimalne velikosti. Ker gre pri razpravi o velikosti podjetja vedno za problem minimiranja stroškov, kar vodi do maksimiranja dobička, javna lastnina izvajalcev zdravstvene dejavnosti in njihov nepridobitni značaj ne spreminja opisanih iztočnic. Prav tako je pomembno, da izvajalec znotraj mreže javnega zdravstva ne glede na lastninsko strukturo deluje ob danih cenah, saj cene zdravstvenih storitev postavlja plačnik javnega zdravstva. To pomeni, da vsaj na teoretski ravni ni razlogov, da ne bi domnevali, da se javni izvajalec sekundarne zdravstvene dejavnosti ne bi obnašal enako, kot domnevamo za podjetje znotraj ekonomske teorije. Pri definiranju optimalne velikosti izvajalca zdravstvene dejavnosti tako izhajamo iz teorije optimalne velikosti podjetja. V ekonomski teoriji o optimalni velikosti podjetja govorijo mikroekonomska teorija, teorija transakcijskih stroškov, teorija industrijske organizacije in teorija dinamičnih modelov rasti podjetja. V monografiji smo pri definiranju optimalne velikosti izvajalca zdravstvene dejavnosti sledili mikroekonomski teoriji, ki je v bistvu v ozadju tudi skoraj vseh drugih teorij.

\section{Optimalna velikost podjetja v ekonomski teoriji}

$\mathrm{V}$ tem poglavju se bomo ukvarjali s temeljnim vprašanjem, ki pojasnjuje optimalno velikost podjetij. Velikost podjetij se spreminja s spreminjanjem proizvodnih zmogljivosti, to pomeni s številom delovnih strojev in velikostjo proizvodnih prostorov, ki jih uporabljajo v podjetju. Ko se lastniki in upravljavci odločajo o velikosti podjetja, morajo pri definiranju velikosti podjetja upoštevati notranje dejavnike, ki so specifični za posamezno podjetje. Pri tem je treba biti pozoren in upoštevati zlasti tehnologijo, stroške in posledično tudi dobiček, ki se odražajo v odnosu med proizvodnimi značilnostmi podjetja na eni strani in tržnimi značilnostmi na drugi strani. Skladno s tem ekonomska teorija definira, da podjetje dosega optimalno velikost tako, da na eni strani upošteva notranje dejavnike podjetja, hkrati pa na drugi strani sledi načelu maksimiranja dobička (Tajnikar 2006a; 2006b). V ekonomski teoriji tako podjetje povečuje svoj obseg proizvodnje in posledično proizvodne dejavnike do točke, ki vodi do maksimiranja dobička. $\mathrm{V}$ točki, ko ugotovi, da povečevanje velikosti podjetja povzroči zmanjševanje dobička, obsega proizvodnje ni več smiselno povečevati (You I995; Tajnikar 2006b; Penrose 2013). 
Podjetje torej dosega optimalno velikost $\mathrm{z}$ odločitvami o povečanju ali zmanjšanju proizvodnih zmogljivosti oziroma obsega proizvodnje. $\mathrm{V}$ ozadju optimalne velikosti podjetja je pridobitni motiv, pri tem pa maksimalnega dobička ni mogoče doseči s povečevanjem podjetja čez vse meje. $\mathrm{V}$ ekonomski teoriji pravimo, da ima podjetje svojo optimalno velikost $\mathrm{v}$ točki, pri kateri doseže maksimalen dobiček (Tajnikar 2006a; 2006b). Pri tem je ključno, da je ta velikost povezana z značilnostjo povprečnih stroškov, ki z večanjem podjetja nekaj časa padajo, v kasnejši fazi pa začnejo naraščati. Če želimo opredeliti optimalno velikost podjetja, moramo najprej spoznati, kateri so dejavniki, ki vplivajo na optimalno velikost. Te dejavnike pojasnjujejo štiri teorije o velikosti podjetja (You 1995). Njihova spoznanja nam omogočajo, da ugotovimo, zakaj so nekatera podjetja velika ali srednje velika, druga pa majhna. Poleg tega omenjene teorije pojasnjujejo, katera je tista velikost podjetja in kateri so tisti dejavniki, ki vplivajo na velikost, pri katerih podjetje z vidika trga in lastnika postane najučinkovitejše. Štiri temeljne teorije, ki govorijo o velikosti podjetja, so teorija transakcijskih stroškov, teorija industrijske organizacije, teorija dinamičnih modelov rasti podjetja in klasična mikroekonomska teorija velikosti podjetja (You 1995).

\section{Teorija transakcijskih stroškov}

Teorija transakcijskih stroškov je znana kot temeljna teorija, ki pojasnjuje obstoj podjetja (Hicks I935; Coase 1937; 1960). S teorijo transakcijskih stroškov ne pojasnjujemo zgolj obstoja podjetja, ampak lahko podamo tudi zanimive iztočnice o tem, kako veliko naj bi bilo podjetje. Osnova teorije transakcijskih stroškov je spoznanje, da je posamezno podjetje zgolj alternativa tržnemu mehanizmu, ki se ukvarja $\mathrm{z}$ alokacijo proizvodnih dejavnikov in vodenjem poslovnih transakcij. Razlika med podjetjem in tržnim mehanizmom je v tem, da znotraj podjetja zaposleni v okviru vodenja podjetja sprejemajo odločitve, kar imenujemo administrativna ali poslovodstvena alokacija, na trgu pa cene povzročajo tržno alokacijo (Coase 1937; 1960; Williamson 1985; Wallis in North 1986; Williamson in Winter 1991; Barzel in Kochin 1992; Medema 1997).

Vodenje znotraj podjetja in tržni mehanizem povzročata gospodarskim subjektom določene stroške. Z vidika teorije transakcijskih stroškov je ključno, da so v nekaterih primerih tržni transakcijski stroški višji kot transakcijski stroški, ki nastanejo znotraj podjetja. To spoznanje je ključno za pojasnjevanje smiselnosti obstoja podjetja. Skladno s tem teorija transakcijskih stroškov pravi, da naj bi podjetje obstajalo zato, ker je tržni mehanizem v določenih primerih dražji kot vodenje znotraj podje- 
tja (Coase 1937; 1960; Barzel in Kochin 1992; Dixit 1996; Williamson 1985; Wallis in North 1986; Williamson in Winter 1991; Rao 2003; Tajnikar 2006b; Dietrich 2008). Z drugimi besedami - glavni razlog obstoja podjetja je dejstvo, da je smiselno, da podjetje obstaja, ko lahko znotraj samega podjetja izvede neko transakcijo po nižjih stroških glede na obstoječe tržne stroške.

Eno izmed pomembnih vprašanj je, zakaj je tržni mehanizem v nekaterih primerih dražji oziroma neučinkovit $\mathrm{v}$ primerjavi z izvajanjem transakcij znotraj podjetja. Tržni transakcijski stroški nastajajo pri subjektih, ki vstopajo $v$ tržne odnose, in so povezani z možnostjo pridobivanja ustreznih informacij, potrebnih za njihovo odločanje, in $s$ pravilnostjo njihovih odločitev. Pridobivanje teh informacij gospodarskim subjektom povzroča določene stroške. Premajhno število informacij, nezmožnost oblikovanja ustreznih odločitev na osnovi teh informacij in nesposobnost vstopanja $\mathrm{v}$ večje število tržnih transakcij je tisto, kar povzroča, da so tržni transakcijski stroški višji od transakcijskih stroškov znotraj (Coase 1937; 1960; Williamson 1985; Wallis in North 1986; Williamson in Winter 1991; Barzel in Kochin 1992; Dixit 1996; Rao 2003; Tajnikar 2006b; Dietrich 2008).

Skladno s tem ločimo tri izvore tržnih transakcijskih stroškov (Williamson in Winter 1991; You 1995; Tajnikar 2006b; Stiglitz 2009):

- Prvi so povezani z omejeno racionalnostjo, $s$ katero ponazarjamo možnost pridobivanja ustreznih informacij, njihovega analiziranja in preoblikovanja v ustrezne odločitve. Pravimo, da je na trgu tako veliko informacij, da je posameznik informacijsko preveč obremenjen, da bi lahko te informacije pravilno presojal in na tej osnovi oblikoval ustrezne odločitve. $V$ določenih primerih potrebuje informacije, ki jih ni moč pridobiti, ne da bi pri tem opustil nekatere druge pridobitne dejavnosti. To pa povzroči nastajanje oportunitetnih stroškov informacij. Veliko število informacij na trgu in njihova slaba preglednost povzročita tudi težave pri sprejemanju poslovnih odločitev.

- Na nastajanje transakcijskih stroškov vpliva tudi asimetrija informacij. Tržni partnerji pogosto nimajo enakega dostopa do informacij, kar pomeni, da obstajajo večje ali manjše možnosti informiranosti. Večjo ali manjšo informiranost tržnih partnerjev tako posamezniki izkoristijo za pridobivanje svojih premoženjskih koristi, ki pa povzročajo stroške ne le njihovim tržnim partnerjem, ampak tudi neučinkovito alokacijo proizvodnih dejavnikov in neučinkovite tržne odločitve. 
- $\quad$ Z asimetrijo informacij je pogosto povezano tudi vprašanje oportunističnega obnašanja. Omejena racionalnost na eni strani in asimetrija informacij na drugi strani omogočata, da tržni partnerji pridobivajo določene prednosti, ki njihovim partnerjem povzročajo stroške oziroma škodo, velikokrat tudi kot posledica goljufij in zvijač.

Obstoj podjetja tako temelji na domnevi, da je potreben obseg transakcij, ki jih je treba nadzorovati znotraj podjetja, bistveno manjši kot na trgu. Znotraj podjetja je na voljo večje število izbranih informacij, ki ne povzročajo posebnih stroškov pri pridobivanju in ki omogočajo tudi natančnejše usmerjanje $\mathrm{k}$ pravim odločitvam. Pri tem zaposleni v podjetju ne razpolagajo z zelo različnimi informacijami, poleg tega pa je različno informiranost znotraj podjetja bistveno teže izkoriščati (Williamson in Winter 1991; You 1995; Tajnikar 2006b; Stiglitz 2009). To pomeni, da je v vsakem primeru znotraj podjetja smiselno organizirati vsaj del dejavnosti, pri tem pa vodenje teh dejavnosti, medsebojno usklajevanje, sprejemanje odločitev in nadzor temeljijo zgolj na poslovodstvenih odnosih.

Teorija transakcijskih stroškov navaja, da je mogoče v določenih primerih učinkoviteje voditi poslovne dejavnosti, če se posamezniki organizirajo znotraj podjetja, pri tem pa ne pride do posredovanja tržnih odnosov. Toda s tem še nismo odgovorili na vprašanje, kako veliko naj bo podjetje. Ključno je spoznanje, da so pri tem odločilnega pomena poslovodstveni stroški oziroma stroški, ki nastanejo z vodenjem dejavnosti v okviru samega podjetja. Običajno v teoriji transakcijskih stroškov domnevamo, da z rastjo podjetja poslovodstveni stroški naraščajo. Takšno naraščanje običajno pojasnjujejo z dvema skupinama razlogov (You i995; Tajnikar 2006b):

- V prvo skupino uvrščamo vse tiste, ki so posledica zamenjave močnih tržnih spodbud, ki običajno temeljijo na pridobitnih motivih z bistveno šibkejšimi vodstvenimi spodbudami in prisilami, značilnimi za poslovodstvene odnose znotraj podjetja. $\mathrm{Na}$ trgu sta prisila konkurence in nagrada dobička tista, ki silita posameznika, da se obnaša racionalno. Znotraj podjetja pa zelo redko nastanejo takšne prisile, saj se večina prisil običajno izoblikuje v hierarhičnih odnosih med nadrejenimi in podrejenimi. Takšne prisile in spodbude so bistveno šibkejše in zato vodijo $\mathrm{k}$ manj racionalnemu obnašanju parterjev v poslovodstvenih odnosih. 
- V drugo skupino razlogov za rast poslovodstvenih stroškov pa štejemo tiste, ki izhajajo iz sprememb samih tržnih spodbud, nastalih z organiziranjem podjetja. Te spremembe so običajno povezane $\mathrm{z}$ vlogo lastnine $\mathrm{v}$ tržnih odnosih. Nadpovprečni dobiček, ki izvira iz učinkovitega gospodarjenja na trgu, seveda tudi v primeru organiziranja podjetja spodbuja lastnika podjetja ali pa managerje k učinkovitemu gospodarjenju. Drugače pa je z običajnim zaposlenim, do katerega omenjene tržne spodbude ne sežejo, saj je njihova racionalnost in učinkovitost $\mathrm{v}$ največji meri dosežena s poslovodstveno prisilo nadrejenih. Če bi se tako eni kot drugi pojavljali na trgu, bi čutili tržne spodbude neposredno, hkrati pa bi bili tako lastniki kot zaposleni spodbujeni na enak način. Čim večje je podjetje, tem večja je hierarhičnost, kompleksnost in razvejanost poslovodstvenih odnosov in teže je nadzorovati prisile, ki uravnavajo takšne odnose. Hkrati posamezniki z večanjem podjetja postajajo vse bolj oddaljeni od tržnih spodbud, kar pomeni, da postajajo vse manj pomembne za racionalno sodelovanje posameznika $\mathrm{v}$ proizvodnem procesu in transakcijah znotraj podjetja.

Bistvo teorije transakcijskih stroškov je torej teza, da bo podjetje obstajalo v primeru, ko bodo za enako opravljeno transakcijo stroški znotraj podjetja nižji, kot znašajo stroški tržne alokacije oziroma tržnega mehanizma. Pri tem se pojavi vprašanje, v katerih primerih bo podjetje veliko ter kdaj bo podjetje majhno. You (1995) pravi, da bo podjetje raslo v primerih, ko bo organiziralo dodane transakcije, pri čemer bo njihovo vodenje znotraj podjetja še vedno cenejše kot v primeru tržnega mehanizma. Na drugi strani pa se bo podjetje zmanjševalo, če bo prihajalo do opuščanja transakcij, kar se bo zgodilo, ko bo določena transakcija na trgu cenejša. Skladno s tem bo torej optimalna velikost podjetja v točki, kjer se bodo transakcijski stroški znotraj podjetja izenačili s transakcijskimi stroški tržnega mehanizma.

\section{Teorija industrijske organizacije}

$S$ teorijo industrijske organizacije pojasnjujemo velikost podjetja na podlagi trditve, da je velikost podjetja povezana $\mathrm{z}$ učinki nepopolne konkurence (You 1995). Značilnost industrijske organizacije kot vede v sodobni ekonomiki je, da predvideva, da sodobna konkurenca na eni strani ni nepopolna, hkrati pa na drugi strani tudi ni povsem monopolna, ampak je sestavljena iz različnih konkurenčnih oblik, ki jih s skupnim imenom 
poimenujemo nepopolna konkurenca. $\mathrm{V}$ takih razmerah torej zasledimo velika, srednje velika ali mala podjetja, kar je posledica dejstva, da trg sestavljajo najrazličnejše tržne strukture $\mathrm{z}$ različno velikostjo in različno konkurenčnostjo. Na ta način si podjetja pridobijo različno tržno moč in različen tržni delež, kar pa posledično vpliva na to, kako velika postanejo podjetja (You 1995; Tommaso in Dubbini 2000; Tajnikar 2006b).

Nepopolna konkurenca je skupni pojem različnih tržnih struktur, kar pomeni, da jo sestavljajo različne oblike konkurence (Bojnec idr. 2007; Samuelson in Nordhaus 2010; Pindyck in Rubinfeld 2013). Mala podjetja lahko v panogi preživijo, če blaga ne diferencirajo z reklamo, kakovostjo in prodajnimi potmi. To je posledica dejstva, da velika podjetja, ki delujejo v razmerah nepopolne konkurence, zaradi svojega monopolnega položaja ne postavljajo cene $\mathrm{v}$ minimumu povprečnih stroškov. To pa omogoča, da na trgu preživijo tudi manjša in stroškovno manj učinkovita podjetja. Tak je primer cenovnega vodstva, kjer lahko nekaj velikih oligopolističnih podjetij deluje skupaj z malimi podjetji na ta način, da tako eni kot drugi maksimirajo svoj dobiček. Prav tako je tak primer možen tedaj, ko velika monopolistična podjetja dovoljujejo manj učinkovitim malim podjetjem, da preživijo, ker lahko obstoj malih podjetij, še posebej v razmerah cikličnega gibanja trga, omogoča tudi dolgoročno maksimiranje dobičkov velikih podjetij (Weis 1979; You 1995; Tajnikar 2006a; 2006b).

Še nazornejša razlaga razlik v velikosti podjetij v različnih sektorjih in tudi znotraj neke dejavnosti je prisotna $\mathrm{v}$ primeru, ko blago ni diferencirano s pomočjo reklame, ko podjetja ne ponujajo različno kakovostnih proizvodov ter ko podjetja ne prodajajo blaga na različne načine. $\mathrm{V}$ teh primerih trg razpade na tako imenovane tržne segmente, ki jih pogosto definiramo kot nišne trge. Takšna tržna segmentacija vodi do številnih in med seboj različnih trgov, ki zahtevajo različno tehnologijo, pri tem pa se pojavlja tudi različno veliko povpraševanje. Zaradi poslovodnih stroškov in pogosto tudi zaradi neustrezne tehnologije na takšnih tržnih segmentih velikokrat velika podjetja ne morejo izoblikovati ustrezne ponudbe. Posledično $\mathrm{v}$ teh primerih na trgih prevladujejo manjša podjetja (Weis 1979; You 1995; Tajnikar 2006b).

Diferenciacija $\mathrm{v}$ vseh navedenih primerih nastane predvsem $\mathrm{z}$ investiranjem $\mathrm{v}$ reklamo, kakovost in prodajne poti, kar posledično pomeni, da postane problem optimalnega investiranja v diferenciacijo blaga povezan z velikostjo podjetja. Če se pri oglaševanju pojavijo ekonomije obsega, lahko take ekonomije obsega vodijo do večjih podjetij. To zelo nazor- 
no ponazarja primer, ko manjša podjetja niso sposobna ustvariti lastnih blagovnih znamk (You 1995).

V primeru, ko imamo opravka z nepopolno konkurenco, na velikost podjetja ne vplivajo zgolj dejavniki, ki jih pripisujemo tržni segmentaciji in nepopolni konkurenci. Pri tem je smiselno opredeliti vsaj še štiri dejavnike, ki govorijo v prid malim podjetjem (You 1995; Tajnikar 2006b):

- V primeru visoke segmentacije trgov je zelo pomembna fleksibilnost podjetij, ki pa je pri večjih podjetjih običajno bistveno manjša v primerjavi z manjšimi podjetji. Fleksibilnost je povezana tako s tehnologijo kot tudi z organizacijo. Visoka stopnja tržne negotovosti in spreminjajoče se povpraševanje na posameznih trgih ne omogočata obstoja velikih podjetij, saj niso dovolj fleksibilna, da bi se jim prilagajala.

- Velikost podjetij je povezana tudi z nekonkurenčnimi oblikami nastajanja cen proizvodnih dejavnikov, ki v primeru nepopolne konkurence niso enake za vse kupce. Nizke plače tako običajno spodbujajo nastanek manjših podjetij, saj so nizke plače običajno povezane s šibko močjo sindikatov. Manjša podjetja so pogosto soočena tudi z visokimi stroški kapitala zaradi manjše vloge majhnih podjetjih na kapitalskih trgih.

- Tržna segmentacija povzroči nastajanje velikega števila tržnih niš, pri katerih je povpraševanje običajno majhno in kratkotrajno. $V$ tem kontekstu so edino mala podjetja sposobna učinkovito pokrivati takšne tržne niše.

- V procesu deindustrializacije in povečevanja razvoja storitvenih dejavnosti se pogosto oblikujejo trgi, ki zahtevajo v večji meri podjetja manjše velikosti, ki so hkrati tudi delovno intenzivnejša.

\section{Teorija dinamičnih modelov}

V okviru teorije dinamičnih modelov lahko najdemo več razlag o velikosti podjetij. Tako imenovane stohastične teorije o velikostni distribuciji izhajajo iz Gibratovega zakona, ki pravi, da stopnja rasti podjetja ni odvisna od sedanje velikosti in od njegove pretekle rasti (Gibrat 1931; Simon in Bonini 1958; You 1995). Po tem zakonu je velikost podjetij rezultat slučajnosti in ne tehnologije, transakcijskih stroškov ali tržne segmentacije. Ta teorija torej pravi, da velikosti podjetij ne določa noben sistematični dejavnik. 
Kljub temu pa v kasnejšem obdobju You (1995) najava, da naj bi na takšno slučajno distribucijo velikosti podjetja vplivali vsaj trije dejavniki, ki modificirajo splošno obliko Gibratovega zakona. Prvi dejavnik so vstopi in izstopi v določeno dejavnost. Drugi dejavnik je ugotovitev, da obstaja negativna povezava med starostjo podjetja in stopnjo rasti podjetja, kar pomeni, da starejše kot je podjetje, nižja je njegova stopnja rasti. Tretji dejavnik pa je povezan s spoznanjem, da velika podjetja rastejo stabilneje.

$\mathrm{Na}$ tej osnovi bi lahko sklepali, da je velikost podjetja sicer slučajna spremenljivka, vendar ima gospodarstvo $z$ večjim številom novih nastalih podjetij več manjših podjetij z višjo stopnjo rasti, hkrati pa tudi z manj stabilno stopnjo rasti (Vining 1976; Evans 1987; You 1995; Garnsey idr. 2004).

Ta ugotovitev je delno povezana s spoznanjem, da lahko v tem okviru govorimo o življenjskem ciklusu podjetja (Marshall 2013). Življenjski ciklus podjetja je tako v veliki meri podlaga za pojasnjevanje podjetniške rasti. Po tej teoriji velja, da mlada podjetja običajno laže propadejo, medtem ko naj bi starejša podjetja poslovala varneje in stabilneje (You I995; Tajnikar 2006b; Marshall 2013).

Ta spoznanja temeljijo na teoriji učenja, ki predpostavlja, da nova nastala podjetja postanejo učinkovita šele v kasnejšem obdobju, ko si pridobijo ustrezne izkušnje, starejša podjetja pa so prav zaradi obsežnih izkušenj učinkovitejša, kar pomeni, da posledično niso v taki meri izpostavljena nevarnostim propada (Jovanovic 1982). Starejša podjetja imajo tako običajno stabilnejšo stopnjo rasti, ki pa je v večini primerov nižja kot pri mladih podjetjih. Posledično to pomeni, da so mlada podjetja po opredelitvi manjša, ki še niso dosegla optimalne velikosti in šele z učenjem pridobivajo konkurenčnost in velikost. Na velikost podjetij pomembno vpliva tudi dejstvo, da podjetja propadajo in tako omogočajo prostor novim nastalim podjetjem (Jovanovic 1982; You 1995; Tajnikar 2006b).

$\mathrm{Na}$ podobno razlago naletimo tudi v okviru modelov o tako imenovanem inovacijskem ciklu (Schumpeter 2008). V teh modelih podjetja niso v statičnem ravnotežju, poleg tega tudi ne obstajajo dinamični procesi, ki bi omogočili prilagoditev takemu ravnotežju. Podjetje naj bi bilo ves čas pod vplivom tehnoloških in organizacijskih sprememb, s katerimi naj bi utrjevalo svoj položaj na trgu. Inovacije tako na eni strani zaostrujejo konkurenco, na drugi strani pa konkurenca zahteva vse intenzivnejše inoviranje v podjetju. Kljub temu pa možnosti za inoviranje znotraj podjetja niso enake. $V$ zelo inovativnih panogah so manjša podjetja bistveno primernejša za inovacije, vendar so hkrati v zgodnjih fazah življenjskega cikla. Za inoviranje $\mathrm{v}$ tehnološko zrelejših panogah, ki zahtevajo 
več denarnih sredstev in več investicij v inoviranje, pa so primernejša velika podjetja (You 1995; Tajnikar 2006b; Schumpeter 2008). Na ta način lahko razložimo pojav malih in velikih podjetij v različnih gospodarskih panogah.

\section{Klasična mikroekonomska teorija velikosti podjetja}

Klasična mikroekonomska teorija velikosti podjetja temelji na mikroekonomskih načelih (Panzar i989). Po tej teoriji velja, da posamezno podjetje išče določeno ravnotežje, pri katerem doseže maksimalni dobiček. Ta teorija velja v primeru popolne konkurence, kar pomeni, da se podjetja vsaj v začetku analize zgolj prilagajajo cenam na trgu, in da na značilnosti podjetniškega okolja ne morejo vplivati. Skladno s to teorijo je podjetje treba upravljati na način, da proizvaja takšen obseg proizvodnje in zaposluje takšen obseg proizvodnih dejavnikov, da doseže maksimalni dobiček (Tajnikar 2006b; Mas-Colell, Whinston in Green 2012; Krugman in Wells 2013; Pindyck in Rubinfeld 2013; Besanko, Mankiw 2014; Braeutigam in Rockett 2015).

Ključno za razumevanje mikroekonomske teorije velikosti podjetja je poznavanje nekaj temeljnih pojmov mikroekonomije. Na tem mestu je treba poudariti, da stroške preučuje teorija stroškov, ta pa temelji na teoriji proizvodnje. Stroški namreč nastajajo z uporabo proizvodnih dejavnikov v proizvodnem procesu. Ker proizvodnja poteka v znotraj posameznih podjetij, je $\mathrm{v}$ teoriji stroškov in proizvodnje pozornost usmerjena $\mathrm{k}$ preučevanju posameznega podjetja.

\section{Kratkoročna analiza teorije proizvodnje}

Osnova kratkoročne teorije proizvodnje je dejstvo, da lahko analiziramo proizvodnjo posameznega podjetja ob predpostavki, da je mogoče v podjetju spreminjati obseg zaposlitve zgolj enega proizvodnega dejavnika. Ta dejavnik se imenuje variabilni proizvodni dejavnik. Ker je obseg uporabe ostalih proizvodnih dejavnikov v tem času nespremenjen, je to tipična kratkoročna analiza. Za kratkoročno analizo je namreč značilno, da je vsaj en proizvodni dejavnik fiksen in s tem določa razpoložljive proizvodne zmogljivosti podjetja. Kratkoročna analiza je torej analiza pri danih proizvodnih zmogljivostih (Tajnikar 2006a; 2006b; Samuelson in Nordhaus 20ı0; Jain in Khanna 201 I; Mas-Colell, Whinston in Green 2012; Krugman in Wells 2013; Pindyck in Rubinfeld 2013; Mankiw 2014; Besanko, Braeutigam in Rockett 2015). 
S spreminjanjem obsega zaposlitve variabilnega proizvodnega dejavnika lahko opredelimo celotne, povprečne in mejne proizvode, kar prikazuje slika 9.

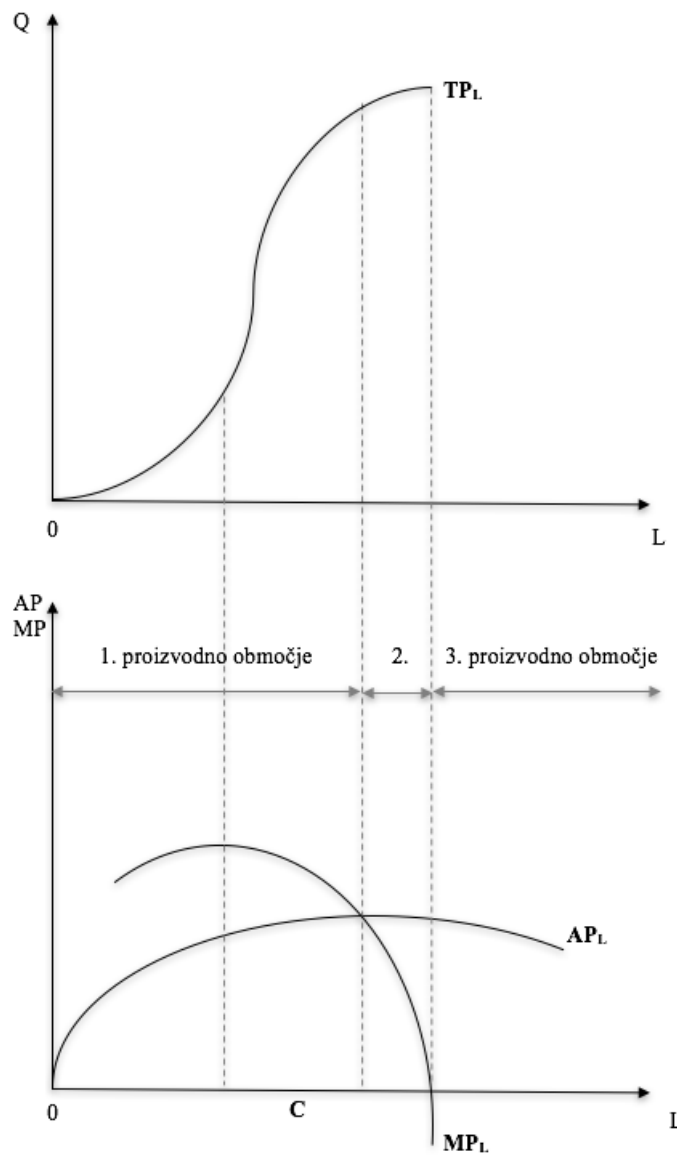

$\mathrm{TP}_{\mathrm{L}}$ - celotni proizvod, $\mathrm{AP}_{\mathrm{L}}$ - povprečni proizvod, $\mathrm{MP}_{\mathrm{L}}$ - mejni proizvod

\section{Slika 9: Funkcija TP, AP in MP}

Vir: prirejeno po Jain in Khanna (20 1 1, 190).

Te kategorije so povezane s pojmom proizvodna funkcija, ki ponazarja enolično opredeljen odnos med količino proizvodnih dejavnikov, to sta delo in kapital, ter količinskim obsegom proizvodnje. To pomeni, da so tako proizvodni dejavniki kot tudi proizvodnja merjeni $s$ količinski$\mathrm{mi}$ in ne $\mathrm{z}$ denarnimi enotami. $\mathrm{S}$ spreminjanem obsega zaposlitve variabilnega proizvodnega dejavnika lahko torej opredelimo odnos med vari- 
abilnim proizvodnim dejavnikom in količinskim obsegom proizvodnje. Takšen odnos odraža proizvodna funkcija (Tajnikar 2006a; 2006b; Samuelson in Marks 20ıо; Jain in Khanna 20ı I; Mas-Colell, Whinston in Green 2012; Krugman in Wells 2013; Pindyck in Rubinfeld 2013; Mankiw 2014).

Takšne oblike krivulj proizvodnje izražajo tako imenovani zakon padajočih donosov. Zakon padajočih donosov pravi, da se donosi posameznih enot uporabljenega variabilnega proizvodnega dejavnika spreminjajo glede na odnos med količino variabilnega proizvodnega dejavnika in količino uporabljenega fiksnega proizvodnega dejavnika. Pri manjši količini variabilnega proizvodnega dejavnika in velikih količinah fiksnega proizvodnega dejavnika donos dodatno uporabljenih enot variabilnega proizvodnega dejavnika narašča. To ponazarja naraščajoči del funkcije mejnega proizvoda. Toda z uporabo dodatnih enot variabilnega proizvodnega dejavnika hitro dosežemo točko, ko dodatno uporabljene enote ob dani količini enot fiksnega proizvodnega dejavnika vse manj vplivajo na povečevanje proizvodnje. To pa povzroči, da začne mejni proizvod padati. Zakon o padajočih donosih se tako kaže v funkciji mejnega proizvo$\mathrm{da}$, in sicer od tiste točke dalje, ko začne mejni proizvod padati. Če to funkcijo opazujemo na sliki 9, lahko vidimo, da jo v prvem delu oblikuje zakon naraščajočih donosov, v najvišji točki na krivulji pa prevlada zakon padajočih donosov. Ob tem je treba poudariti, da zakon padajočih donosov velja ob predpostavki, da je vsaj en proizvodni dejavnik fiksen oziroma nespremenljiv (Tajnikar 2006a; 2006b; Rebernik 2008; Jain in Khanna 20I I; Mas-Colell, Whinston in Green 20r2; Krugman in Wells 2013; Pindyck in Rubinfeld 2013; Besanko, Braeutigam in Rockett 2015).

\section{Dolgoročna analiza proizvodnje funkcije}

Razlikovati moramo med donosi, ki opredeljujejo obliko kratkoročne proizvodne funkcije, imenujemo jih tudi donosi variabilnega proizvodnega dejavnika, ter tako imenovanimi donosi obsega. Donosi obsega so kategorija, ki je povezana z dolgoročno analizo in kaže spreminjanje obsega proizvodnje, ko se sorazmerno spreminja količina vseh uporabljenih proizvodnih dejavnikov. Poznamo konstantne, naraščajoče in padajoče donose obsega. Za konstantne donose obsega je značilno, da se proizvodnja poveča za enak odstotek kot uporaba vseh proizvodnih dejavnikov. Če se uporaba proizvodnih dejavnikov na primer poveča za deset odstotkov, se tudi proizvodnja poveča za deset odstotkov. O naraščajočih donosih obsega govorimo takrat, ko je povečanje proizvodnje nad sorazmerjem, o padajočih donosih obsega pa govorimo takrat, ko je povečanje proizvodnje pod so- 
razmerno s povečanjem uporabljenih proizvodnih dejavnikov (Žižmond idr. 2005; Tajnikar 2006a; 2006b; Bojnec idr. 2007; Rebernik 2008; Jain in Khanna 2011; Krugman in Wells 2013; Pindyck in Rubinfeld 2013).

$\mathrm{V}$ gospodarstvu srečamo vse tri donose obsega. Konstantni donosi obsega nastanejo, ko dva delavca z dvema enakima strojema proizvedeta dvakrat več kot en delavec z enim strojem. Naraščajoči donosi obsega so običajno posledica povečanja proizvodnje, ki omogoča večjo delitev dela in specializacijo pa tudi uveljavljanje produktivnejših in bolj specializiranih strojev. Padajoči donosi obsega pa najpogosteje nastanejo zaradi tega, ker povečan obseg proizvodnje onemogoči učinkovito upravljanje podjetij in usklajevanje številnih postopkov in oddelkov znotraj podjetja. Število komunikacijskih kanalov postane vse večje, število sestankov, količina administrativnega dela, število telefonskih klicev se povečujejo s povečanjem obsega dejavnosti. Vse teže je nadzorovati upravljavske odločitve, zato učinkovitost posla pada in zato pride do padajočih donosov obsega. Razlogi za naraščajoče, konstantne in padajoče donose variabilnega proizvodnega dejavnika se razlikujejo od razlogov za naraščajoče, konstantne in padajoče donose obsega. Tako lahko domnevamo, da so padajoči donosi na kratek rok skladni tako s konstantnimi, naraščajočimi in padajočimi donosi obsega na dolgi rok (Tajnikar 2006a; 2006b; McGuigan, Moyer in Harris 2008; Rebernik 2008; Mas-Colell, Whinston in Green 2012; Krugman in Wells 2013; Pindyck in Rubinfeld 2013).

\section{Kratkoročna analiza teorije stroškov}

Stroške posameznega podjetja lahko preučujemo na podlagi poznavanja proizvodnje funkcije in cen proizvodnih dejavnikov. Stroške uvajamo v analizo s pomočjo stroškovnih funkcij. Poznamo več vrst stroškov. Fiksni stroški so tisti stroški, ki niso odvisni od obsega proizvodnje in nastanejo s porabo fiksnih proizvodnih dejavnikov. Takšni stroški so najemnine, obresti, nekateri davki na premoženje, nekatera zavarovanja in podobno. Druga skupina stroškov so variabilni stroški, ki se spreminjajo z obsegom proizvodnje in nastanejo s porabo variabilnih proizvodnih dejavnikov. Tipični variabilni stroški so materialni stroški, različne vrste dela, nekateri davki in podobno. Celotni stroški pa so denarno ovrednoteni potroški proizvodnih dejavnikov, ki jih dobimo tako, da seštejmo skupne fiksne in skupne variabilne stroške. Poleg teh stroškov poznamo tudi tri skupine povprečnih stroškov. Povprečni stroški so vsota povprečnih fiksnih stroškov in povprečnih variabilnih stroškov. Povprečni fiksni stroški so fiksni stroški na enoto proizvodnje, povprečni variabilni stroški pa so variabilni stroški na enoto proizvodnje. Pri tem poznamo še mej- 
ne stroške, ki merijo, za koliko se spremenijo celotni stroški, če podjetje proizvede dodatno enoto proizvoda (Žižmond idr. 2005; Tajnikar 2006a; 2006b; Bojnec idr. 2007; Rebernik 2008; Samuelson in Marks 2010; Samuelson in Nordhaus 2010; Jain in Khanna 2011; Mas-Colell, Whinston in Green 2012; Krugman in Wells 2013; Pindyck in Rubinfeld 2013; Mankiw 2014; Besanko, Braeutigam in Rockett 2015).
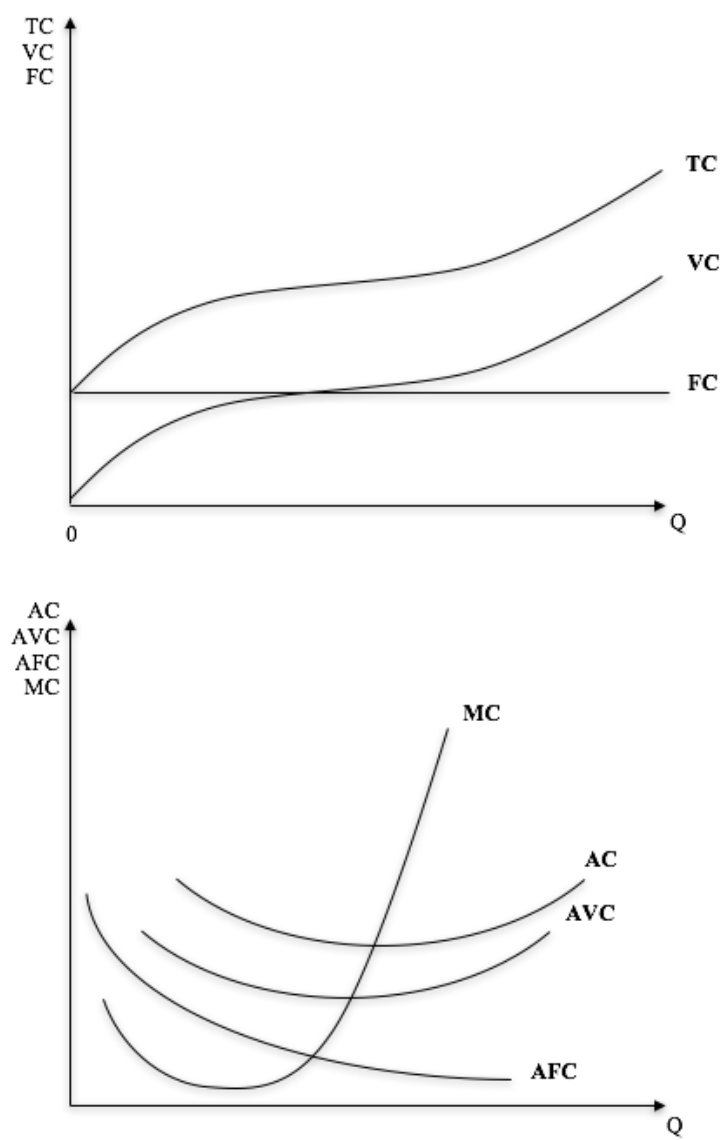

$\mathrm{TC}$ - celotni stroški, VC - variabilni stroški, FC - fiksni stroški, AC - povprečni stroški, AVC - povprečni variabilni stroški, $\mathrm{AFC}$ - povprečni fiksni stroški, MC mejni stroški

Slika ı: Funkcija TC, VC, FC, AC, AVC, AFC in MC

Vir: prirejeno po Jain in Khanna (201 1, 235-241).

Z grafično analizo lahko opredelimo povezavo med različnimi vrstami skupnih, povprečnih in mejnih stroškov, kar prikazujemo v sliki ı. Povprečne stroške kaže naklonski kot premice, ki teče iz koordinatnega 
izhodišča do posameznih točk na funkciji celotnih stroškov. Tako lahko vidimo, da padajoča funkcija povprečnih fiksnih stroškov izvira iz dane velikosti fiksnih stroškov, ki je neodvisna od obsega proizvodnje. U oblika povprečnih variabilnih stroškov je povezana z znano obliko variabilnih stroškov, po kateri variabilni stroški najprej naraščajo s padajočo stopnjo rasti, potem pa začnejo naraščati vse hitreje, tako da se stopnja rasti skupnih variabilnih stroškov zvišuje. Mejne stroške grafično izrazimo $s$ tangento na funkcijo celotnih stroškov. U oblika mejnih stroškov pojasnjuje tudi že opisano obliko variabilnih stroškov in celotnih stroškov (Johnston 1960; Tajnikar 2006a; 2006b; McGuigan, Moyer in Harris 2008; Rebernik 2008; Jain in Khanna 201 I; Mas-Colell, Whinston in Green 2012; Krugman in Wells 2013; Pindyck in Rubinfeld 2013; Besanko, Braeutigam in Rockett 2015).

\section{Dolgoročna analiza teorije stroškov}

Dolgoročne povprečne stroške moramo opazovati ob predpostavki, da so vsi proizvodni dejavniki variabilni. Oblika krivulje dolgoročnih celotnih stroškov je zrcalna slike krivulje dolgoročnega celotnega proizvoda in je posledica učinkov zakona donosov obsega. Nanjo najprej vplivajo naraščajoči, kasneje pa padajoči donosi obsega. Iz take funkcije dolgoročnih celotnih stroškov lahko izpeljemo tudi funkcijo dolgoročnih povprečnih stroškov in njej ustrezno funkcijo dolgoročnih mejnih stroškov, kar prikazuje slika I I (Johnston 1960; Koutsoyiannis 1987; Tajnikar 2006a; 2006b; McGuigan, Moyer in Harris 2008; Rebernik 2008; Henderson 20 I; Jain in Khanna 2011; Krugman in Wells 2013; Messner 2013; Pindyck in Rubinfeld 2013; Mankiw 2014; Besanko, Braeutigam in Rockett 2015).

Pomenska razlika med kratkoročno in dolgoročno analizo stroškov je $\mathrm{v}$ tem, da proizvajalec lahko na dolgi rok spreminja velikost podjetja ali, z drugim besedami, obseg proizvodnih zmogljivosti. Ko smo prikazali kratkoročne krivulje povprečnih stroškov in mejnih stroškov, smo predvidevali, da ima podjetje dane proizvodne zmogljivosti, to pa posledično pomeni, da lahko za vsako proizvodno zmogljivost določimo posebni krivulji povprečnih in mejnih stroškov. $\mathrm{Z}$ drugimi besedami - proizvajalec ima toliko različnih povprečnih in mejnih stroškov, kolikor ima na voljo različnih proizvodnih zmogljivosti. Dolgoročne stroškovne funkcije potem grafično dobimo na način, da upoštevamo vse možne proizvodne zmogljivosti, to je vse možne velikosti podjetja, ali da združimo v eno skico vse možne povprečne in mejne stroške. Ker ti povprečni in mejni stroški ustrezajo posameznim proizvodnim zmogljivostim, jih imenuje- 
mo kratkoročni povprečni in mejni stroški. To pomeni, da so tudi dolgoročni povprečni stroški in dolgoročni mejni stroški le kratkoročni povprečni stroški in kratkoročni mejni stroški, ki jih proizvajalec izbere iz celotnega sklada kratkoročnih povprečnih in mejnih stroškov, ki so zanj prek različnih proizvodnih zmogljivosti dosegljivi. Tako dolgoročni povprečni stroški niso nič drugega kot ovojnica kratkoročnih povprečni stroškov (Johnston 1960; Koutsoyiannis 1987; Tajnikar 2006a; 2006b; McGuigan, Moyer in Harris 2008; Rebernik 2008; Henderson 20I I; Jain in Khanna 2011; Krugman in Wells 2013; Messner 2013; Pindyck in Rubinfeld 2013; Mankiw 2014; Besanko, Braeutigam in Rockett 2015).
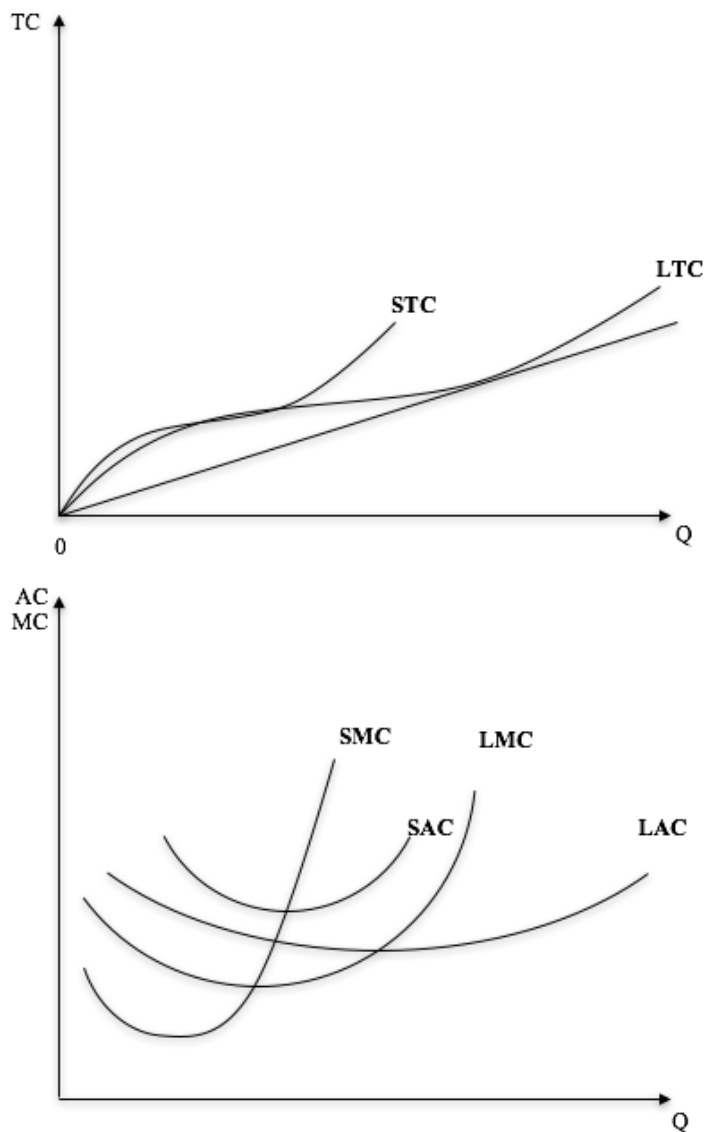

STC - kratkoročni celotni stroški, LTC - dolgoročni celotni stroški, SAC kratkoročni povprečni stroški, LAC - dolgoročni povprečni stroški, SMC kratkoročni mejni stroški, LMC - dolgoročni mejni stroški 


\section{Kratkoročno ravnotežje podjetja pripopolni konkurenci}

Pri popolni konkurenci se posamezni proizvajalec odloča za takšen obseg proizvodnje, s katerim izpolni mejno načelo, kar pomeni, da je dana cena na trgu enaka mejnim stroškom. $\mathrm{V}$ tem primeru ustvari maksimalen dobiček.

Za popolno konkurenco je značilno, da posamezen ponudnik ne more vplivati na tržno ceno, to pa pomeni, da se lahko tržni ceni prilagaja zgolj z obsegom svoje proizvodnje in prodaje blaga. Tako je zanj tržna cena dana ne glede na to, kakšen je obseg njegove proizvodnje. Takšne razmere določajo tudi njegovo funkcijo prihodka, ki je zmnožek proizvedene in prodane količine ter cene blaga, funkcija pa je premica, ki teče iz koordinatnega izhodišča, saj je pri prodaji nič tudi njegov prihodek nič. Nagib njegove funkcije prihodka pa je odvisen od cene blaga. Čim višja je cena, tem bolj je funkcija celotnega prihodka strma (Tajnikar 2006a; 2006b; Rebernik 2008; Jain in Khanna 2011; Krugman in Wells 2013; Pindyck in Rubinfeld 2013; Mankiw 2014).

Podjetje doseže ravnotežje pri tistem obsegu proizvodnje, pri katerem je dobiček največji. Ker je dobiček enak razliki me celotnimi prihodki in celotnimi stroški, funkciji celotnih prihodkov in celotnih stroškov pa smo že opredelili, je optimalni obseg proizvodnje $\left(Q_{0}\right)$, pri katerem podjetje doseže največji možni dobiček, tisti, pri katerem je razlika med celotnimi prihodki in celotni stroški največja. Točko, pri katerem postanejo celotni prihodki večji od celotnih stroškov, imenujemo točka indiferentnosti oziroma točka preloma (Tajnikar 2006a; 2006b; McGuigan, Moyer in Harris 2008; Rebernik 2008; Jain in Khanna 20 I; Mas-Colell, Whinston in Green 2012; Krugman in Wells 2013; Pindyck in Rubinfeld 2013; Mankiw 2014).

$Z$ vidika teorije cen je precej značilnejši način opredeljevanja ravnotežja podjetja na podlagi povprečnih in mejnih količin. Za opredelitev ravnotežja podjetja potrebujemo poleg povprečnih stroškov in mejnih stroškov še tako imenovano premico cene. Za popolno konkurenco je značilno, da je cena $\left(P_{\circ}\right)$ za popolnega ponudnika dana $\mathrm{z}$ ravnotežjem na trgu. Po tej ceni lahko prodajo katero koli količino blaga. Premica, ki to ceno kaže grafično, je premica cene. To je hkrati krivulja povpraševanja po proizvodih posameznega popolnega konkurenta (Johnston 1960; Tajnikar 2006a; 2006b; McGuigan, Moyer in Harris 2008; Rebernik 2008; Mas-Colell, Whinston in Green 2012; Krugman in Wells 2013; Pindyck in Rubinfeld 2013; Mankiw 2014; Besanko, Braeutigam in Rockett 2015). Kratokoročno ravnotežje popolnega konkurenta grafično prikazujemo v sliki $\mathbf{2} 2$. 


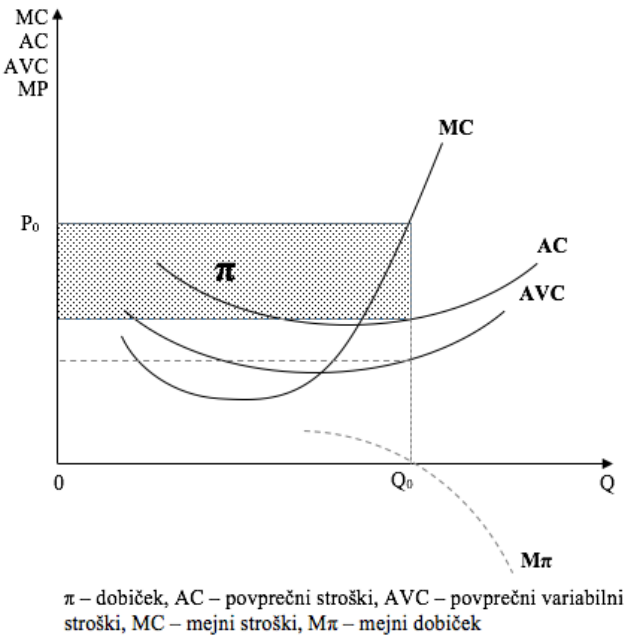

Slika I2: Kratkoročno ravnotežje popolnega konkurenta

Vir: prirejeno po Jain in Khanna (20 I I, 32 I).

Tudi v tem primeru skušamo najprej opredeliti količino proizvodnje, pri kateri bo popoln konkurent kar najbolj povečal svoj dobiček. Že vnaprej lahko rečemo, da je to tista količina proizvodnje, pri kateri se bodo mejni stroški izenačili s ceno blaga na trgu. To domnevo imenujemo mejno načelo, ki ga lahko utemeljimo na naslednji način. Mejni stroški pomenijo dodatne stroške, ki nastanejo s proizvodnjo dodatne enote outputa, cena pa je zaslužek, ki ga proizvajalec doseže s prodajo dodatne enote. Vse dokler je cena višja od mejnih stroškov, to pa je do presečišča mejnih stroškov s premico cene, so zaslužki s prodajo dodatnih enot blaga večji kot stroški proizvodnje teh enot. To pa pomeni, da povečanje obsega proizvodnje in prodaje v tem primeru povečuje tudi celoten dobiček.

Vsaka dodatno proizvedena in prodana enota blaga poveča celoten dobiček podjetja, kar ponazarja funkcija mejnega dobička. Ko pa so mejni stroški večji od cene dodatno proizvedene enote blaga, proizvajalca dodatno proizvedene enote stanejo več, kot je njegov prihodek od prodaje teh enot na trgu. Zato dodatno proizvedene enote zmanjšujejo celoten dobiček. To se zgodi v primeru, ko je mejni dobiček negativen, kar pome$\mathrm{ni}$, da nastane $\mathrm{z}$ dodatno proizvedeno enoto mejna izguba. To pa pomeni, da se celotni dobiček zmanjšuje. Maksimalen dobiček je torej dosežen pri tistem obsegu proizvodnje, pri katerem se mejni stroški izenačijo z dano tržno ceno blaga (Žižmond idr. 2005; Tajnikar 2006a; 2006b; McGuigan, Moyer in Harris 2008; Rebernik 2008; Jain in Khanna 20I I; Mas-Colell, Whinston in Green 2012; Krugman in Wells 2013; Pindyck in Rubinfeld 2013; Mankiw 2014; Besanko, Braeutigam in Rockett 2015). 
Ali je celoten dobiček, ki ga s približevanjem presečišču mejnih stroškov s ceno blaga maksimiramo, pozitiven ali negativen, je odvisno od funkcij povprečnih stroškov. Če je funkcija povprečnih stroškov takšna, da pri ravnotežnem obsegu proizvodnje cena presega povprečne stroške, je dobiček pozitiven, če pa je cena nižja od povprečni stroškov, pa je celoten dobiček negativen (Žižmond idr. 2005; Tajnikar 2006a; 2006b; McGuigan, Moyer in Harris 2008; Rebernik 2008; Jain in Khanna 20II; Mas-Colell, Whinston in Green 2012; Krugman in Wells 2013; Pindyck in Rubinfeld 2013; Mankiw 2014; Besanko, Braeutigam in Rockett 2015).

Na kratek rok bo proizvajalec proizvajal tudi, če je cena nižja od povprečnih skupnih stroškov, vendar mora biti hkrati višja od povprečnih variabilnih stroškov. $V$ tem primeru se s celotnimi prihodki pokrijejo vsi variabilni stroški in tudi del fiksnih stroškov. Njegova izguba je potem enaka razliki med skupnimi fiksnimi stroški in pokritim delom teh stroškov. Če proizvajalec v tem primeru ne bi proizvajal, bi pri njem še vedno nastajali fiksni stroški, kar pomeni, da bi bila izguba posledično večja, kot če proizvaja. Zato je najnižja cena, pri kateri je smiselno, da popoln konkurent še proizvaja, tista, ki je na ravni minimuma povprečnih variabilnih stroškov. Skozi to najnižjo točko teče tudi funkcija mejnih stroškov. Prav ravnotežna količina proizvodnje pa lahko ustreza tudi točki, kjer se sekajo premica cena, funkcija mejnih stroškov in funkcija povprečnih variabilnih stroškov. Tako točko imenujemo točka indiferentnosti (Žižmond idr. 2005; Tajnikar 2006a; 2006b; McGuigan, Moyer in Harris 2008; Rebernik 2008; Jain in Khanna 20I I; Mas-Colell, Whinston in Green 2012; Krugman in Wells 2013; Pindyck in Rubinfeld 2013; Mankiw 2014; Besanko, Braeutigam in Rockett 2015).

\section{Dolgoročno ravnotežje pri popolni konkurenci}

Dolgoročno ravnotežje popolnega konkurenta temelji na domnevi, da so vsi proizvodni dejavniki variabilni. To pa pomeni, da lahko spreminjamo tudi obseg uporabe tistih proizvodnih dejavnikov, ki so bili na kratek rok fiksni. Ker so to tisti proizvodni dejavniki, ki določajo velikost podjetja, je na dolgi rok odločilno vprašanje, kako veliko naj bo podjetje. Ko smo govorili o dolgoročnih povprečnih stroških in dolgoročni proizvodni funkciji, smo spoznali, da so dolgoročni povprečni stroški opredeljeni prav s spreminjajočimi se donosi obsega, ki nastanejo ob različnih velikostih posameznih podjetij (Johnston 1960; Koutsoyiannis 1987; Tajnikar 2006a; 2006b; McGuigan, Moyer in Harris 2008; Rebernik 2008; Henderson 2011; Krugman in Wells 2013; Messner 2013; Pindyck in Rubin- 
feld 2013; Mankiw 2014; Besanko, Braeutigam in Rockett 2015). Dolgoročno ravnotežje popolnega konkurenta grafično prikazujemo v sliki I3.

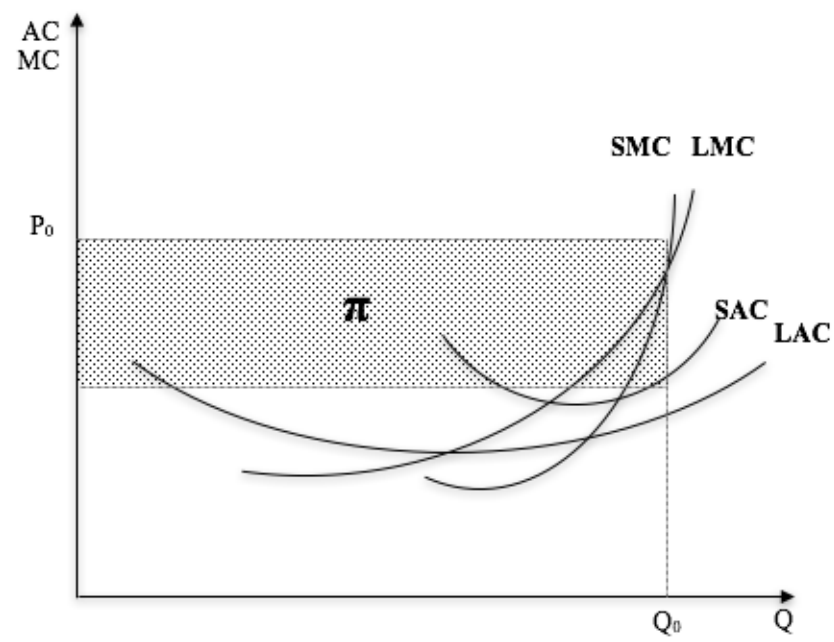

Slika I3: Dolgoročno ravnotežje popolnega konkurenta

Vir: prirejeno po Jain in Khanna (201 1, 324).

Tako se mora podjetje na dolgi rok najprej odločiti, kako veliko naj bo oziroma kakšno proizvodno zmogljivost bo izbralo, potem pa mora znotraj te odločitve opredeliti tudi svoje kratkoročno ravnotežje. To je ravnotežje, ki ga podjetje išče pri danih proizvodnih zmogljivostih s spreminjanem obsega uporabe variabilnega proizvodnega dejavnika. Nobenega razloga ni, zakaj se podjetje tudi na dolgi rok ne bi ravnalo po povprečnih in mejnih stroških. $V$ tem primeru mora seveda upoštevati dolgoročne povprečne stroške, dolgoročne mejne stroške in ceno blaga na trgu, ki jo poznamo že iz kratkoročne analize ravnotežja popolnega konkurenta. Dolgoročno ravnotežje posameznega popolnega konkurenta je doseženo pri tistem obsegu proizvodnje, pri katerem se dolgoročni mejni stroški izenačijo $s$ ceno blaga na trgu. Ta obseg proizvodnje najprej določa velikost podjetja oziroma izbrano proizvodno zmogljivost (Johnston 1960; Koutsoyiannis 1987; Tajnikar 2006a; 2006b; McGuigan, Moyer in Harris 2008; Rebernik 2008; Pindyck in Rubinfeld 2013; Mankiw 2014; Besanko, Braeutigam in Rockett 2015).

Ker bo popoln konkurent, ki si prizadeva k maksimiranju dobička, izbral tako proizvodno zmogljivost, ki mu bo pri dolgoročni optimalni količini proizvodnje hkrati zagotavljala kratkoročno ravnotežje, mora skozi točko, v kateri se sekata premica cena in krivulja dolgoročnih mej- 
nih stroškov, teči tudi krivulja kratkoročnih mejnih stroškov. V tej točki so torej kratkoročni in dolgoročni mejni stroški enaki. Samo v primeru, da kratkoročna krivulja mejnih stroškov teče skozi to točko, je pri dolgoročnem ravnotežju zagotovljeno tudi kratkoročno ravnotežje med ceno in kratkoročnimi mejnimi stroški. Če pa so v tej točki kratkoročni in dolgoročni mejni stroški enaki, mejni stroški pa določajo spremembe povprečnih stroškov, se morajo pri dolgoročno optimalni količini proizvodnje popolnega konkurenta spremeniti kratkoročni povprečni stroški enako, kot se spreminjajo dolgoročni povprečni stroški. V sliki 13 moramo to izrazit z enako nagnjenostjo krivulj kratkoročnih povprečnih stroškov in dolgoročnih povprečnih stroškov. To pa je možno samo takrat, ko se krivulja kratkoročnih povprečnih strokov dotika dolgoročnih povprečnih stroškov. Zato je za dolgoročno optimalno velikost podjetja oziroma dolgoročno optimalno proizvodno zmogljivost značilno, da mejni stroški te zmogljivosti tečejo skozi točko presečišča premice cene in dolgoročnih mejnih stroškov, kratkoročni povprečni stroški pa se pri tej količini dotikajo funkcije dolgoročnih povprečnih stroškov (Johnston 1960; Koutsoyiannis 1987; Tajnikar 2006a; 2006b; McGuigan, Moyer in Harris 2008; Rebernik 2008; Pindyck in Rubinfeld 2013; Mankiw 2014; Besanko, Braeutigam in Rockett 2015).

\section{Optimalna velikost izvajalcev zdravstvene dejaunosti}

Ugotovili smo, da obstajajo vsaj štiri teorije optimalne velikosti podjetij, v našem primeru izvajalcev zdravstvene dejavnosti. Skladno s predstavljenimi teoretičnimi iztočnicami štirih različnih teorij optimalne velikosti podjetja bomo pri definiranju optimalne velikosti izvajalcev sekundarne zdravstvene dejavnosti uporabili mikroekonomsko teorijo, ki je v bistvu v ozadju tudi skoraj vseh drugih teorij. Optimalno velikost splošne bolnišnice bomo tako poskušali definirati na teoretičnih iztočnicah dolgoročne analize teorije proizvodnje in dolgoročne analize teorije stroškov. Pri tem se bomo osredotočili predvsem na dolgoročno ravnotežje izvajalcev sekundarne zdravstvene dejavnosti.

$\mathrm{Z}$ vidika mikroekonomske teorije se optimalne velikosti podjetij bistveno razlikujejo glede na tip konkurence, v kateri podjetja delujejo. Ta ugotovitev je tudi iztočnica teorije industrijske organizacije, ki govori o optimalni velikosti podjetja. Teoretično lahko tako opazujemo optimalno velikost podjetja v razmerah popolne in nepopolne konkurence. Pri tem ključne razlike med definiranjem optimalne velikosti $\mathrm{v}$ obeh tipih konkurence izhajajo iz načina oblikovanja cen, $s$ katerimi se sooča ponudnik. $V$ razmerah popolne konkurence so cene za ponudnika dane na 
trgu in se lahko prilagaja le s količino ponudbe, pri čemer s svojo količino ponudbe ni sposoben spreminjati tržnih cen. V razmerah nepopolne konkurence pa lahko posplošeno domnevamo, da ponudnik s svojo ponudbo oblikuje tudi tržne cene in da lahko proda večjo količino blaga le tako, da zniža svoje ponudbene cene (Koutsoyiannis 1987; You 1995; Tajnikar 2006a; 2006b; Rebernik 2008; Krugman in Wells 2013; Pindyck in Rubinfeld 2013; Mankiw 2014; Besanko, Braeutigam in Rockett 2015).

Ključno za določitev optimalne velikost izvajalca zdravstvene dejavnosti je poznavanje osnovnih zakonitosti mikroekonomske teorije podjetja, ki veljajo tudi za izvajalca sekundarne zdravstvene dejavnosti. Kratkoročna analiza tako temelji na domnevi, da izvajalec zdravstvene dejavnosti posluje v razmerah, ko so vsaj nekateri dejavniki po obsegu fiksni in nespremenljivi. Tako predpostavljamo, da so proizvodne zmogljivosti v obliki operacijskih dvoran, zgradb, zemlje in podobno za izvajalca zdravstvene dejavnosti dane. Ob fiksnih proizvodnih dejavnikih pa naj bi obstajali tudi variabilni proizvodni dejavniki. Pri tem predpostavljamo, da je ključen variabilni proizvodni dejavnik v osnovi delo, ki ga v splošni bolnišnici predstavljajo zdravniki, medicinske sestre in drugo zdravstveno ter nezdravstveno osebje. Za kratkoročno analizo je tako značilno, da izvajalec zdravstvene dejavnosti vodi in opravlja bolnišnico ob danih proizvodnih zmogljivostih in spremenljivih možnostih zaposlovanja dela. Ta analiza temelji tudi na domnevi o tako imenovanih naraščajočih in padajočih donosih variabilnega proizvodnega dejavnika. Ta domneva pomeni, da se produktivnost izvajalcev najprej povečuje, če ob fiksnem proizvodnem dejavniku zdravstvene dejavnosti zaposlujejo vse več in več variabilnega proizvodnega dejavnika, po določeni točki pa je količina fiksnega proizvodnega dejavnika takšna, da učinkovito povečanje variabilnega proizvodnega dejavnika ni več mogoče.

Naraščajoči in padajoči donosi variabilnega proizvodnega dejavnika se tako pri izvajalcih zdravstvene dejavnosti izrazijo v tipični U-obliki povprečnih stroškov. Ob vse večjem zaposlovanju variabilnega proizvodnega dejavnika ob danih proizvodnih zmogljivostih povprečni stroški najprej padajo, dosežejo svoj minimum, potem pa začnejo naraščati. Spremembe povprečnih stroškov izražajo tako imenovani mejni stroški. Ti nam povedo, za koliko se spremenijo celotni stroški, če zaposlimo dodatno enoto variabilnega proizvodnega dejavnika. Dokler so mejni stroški manjši od povprečnih, se povprečni stroški zmanjšujejo, ko pa mejni stroški postanejo večji od povprečnih, se začnejo povprečni stroški povečevati. Mejni stroški izvajalcev zdravstvene dejavnosti imajo prav tako značilno U-obliko, tečejo pa na tako, da sekajo povprečne stroške skozi njihovo 
minimalno vrednost, in sicer od spodaj navzgor. Optimalen obseg proizvodnje izvajalca zdravstvene dejavnosti grafično prikazujemo v sliki i 4 .

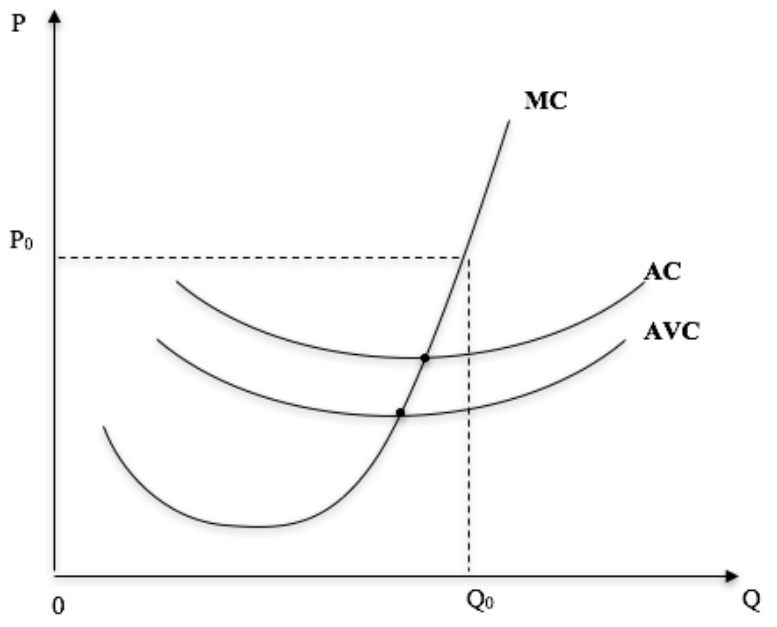

Slika I4: Optimalen obseg proizvodnje izvajalca zdravstvene dejavnosti

Po mejnem načelu je torej za izvajalca zdravstvene dejavnosti smiselno povečevati zaposlovanje variabilnega proizvodnega dejavnika, s tem pa tudi povečevanje obsega proizvodnje do tiste količine, ko se mejni stroški izenačijo s tržno ceno. Prav s to količino so $\mathrm{z}$ dodatno prodano enoto zaslužili več, kot jih je stala. Po tej količini so stroški dodatne enote večji, kot lahko z njo zaslužijo na trgu. Zato je celoten prihodek maksimalen $\mathrm{v}$ točki, kjer se mejni stroški izenačijo z dano tržno ceno. Za managerje je torej smiselno, da povečujejo obseg proizvodnje in jo omejijo na količino, pri kateri so mejni stroški enaki ceni na trgu. $V$ tem primeru bo namreč dosežen maksimalen dobiček.

$S$ tem še nismo določili, kako naj bi izvajalec sekundarne zdravstvene dejavnosti ravnal, ko se odloča o optimalni velikosti proizvodnje. Do sedaj smo razložili, kaj se zgodi na kratek rok, če izvajalec zdravstvene dejavnosti maksimira dobiček. Ker domnevamo, da so kratkoročni povprečni stroški naraščajoči oziroma da rastejo $\mathrm{z}$ večanjem obsega proizvodnje ob danih proizvodnih zmogljivosti, padajoči donosi variabilnega proizvodnega dejavnika povzročajo, da za izvajalca zdravstvene dejavnosti ni smiselno, da povečuje obseg proizvodnje do skrajne meje proizvodnih zmogljivosti. Vendar v okviru kratkoročne analize še ne moremo govoriti o velikosti izvajalca zdravstvene dejavnosti, saj v tem primeru domnevamo, da so proizvodne zmogljivosti dane, s tem pa je posredno opredeljena tudi velikost. 
Razprava o optimalni velikosti izvajalca zdravstvene dejavnosti tako spada v razpravo o njegovem dolgoročnem ravnotežju. Velikost izvajalca namreč lahko spreminjamo le, če domnevamo, da noben proizvodni dejavnik ni za bolnišnico fiksen, kar je definicija dolgega roka. Šele v dolgoročni analizi torej domnevamo, da se lahko spreminjajo tudi proizvodne zmogljivosti. Dolgoročna analiza je v osnovi opredeljena kot analiza razmer, v katerih so vsi proizvodni dejavniki variabilni, kar pomeni, da jih ponudnik lahko poljubno spreminja $\mathrm{z}$ vidika njihove velikosti. V praksi to pomeni, da lahko bolnišnica ne le zaposluje dodatne delavce, kupuje več materiala, porabi več elektrike, pač pa lahko kupi tudi nove stroje, gradi večje zgradbe, pridobi patente in podobno.

Pri povečevanju vseh dejavnikov nastajajo določeni donosi, ki jih v tem primeru imenujemo donosi obsega. Sestavljeni so iz tako imenovanih ekonomij obsega in disekonomij obsega. Ekonomije obsega so posledica spoznanja, da dolgoročni povprečni stroški padajo, če povečujemo vse proizvodne dejavnike, torej tako tiste, ki so v kratkoročni analizi fiksni, kot tudi tiste, ki so v kratkoročni analizi variabilni. Ta domneva naj bi bila povezana $\mathrm{z}$ učinki tehnologije. $Z$ večanjem podjetja prihaja do podrobnejše delitve dela, do večje specializacije in s tem tudi do večje učinkovitosti vseh proizvodnih dejavnikov, ki sodelujejo v proizvodnem procesu. Hkrati je takšna delitev dela povezana tudi z določenimi učinki tako imenovane družbene delitve dela, to je delitve dela med ponudniki, ki prav tako vpliva na povečanje učinkovitosti podjetniških dejavnikov. Običajno domnevamo, da te ekonomije sprva delujejo zelo izrazito, potem pa se njihova moč z velikostjo izvajalca zmanjšuje in zato pri določeni velikosti podjetja prenehajo delovati (Johnston 1960; Tajnikar 2006a; 2006b; Rebernik 2008; Henderson 20II; Messner 2013; Pindyck in Rubinfeld 2013).

V okviru mikroekonomske teorije podjetja oziroma znotraj dolgoročne analize izpostavljamo poseben dejavnik, ki ne pride pretirano do izraza pri kratkoročni analizi, in ki vsaj v kratkoročni analizi ni sestavni del podjetja. To so poslovne in podjetniške sposobnosti upravljanja, nadzora in sprejemanja tveganja. Prav ti dejavniki dolgoročnega poslovanja naj bi bili v dolgoročni analizi edini fiksen dejavnik, ki ga ni mogoče spreminjati, kar pomeni, da povzročajo disekonomije obsega. Sposobnosti vodenja in podjetništva vplivajo na učinkovitost organizacije znotraj podjetja (Johnston 1960; Tajnikar 2006a; 2006b; Rebernik 2008; Henderson 2011; Messner 2013; Pindyck in Rubinfeld 2013). To pomeni, da dolgoročno splošne bolnišnice ne smemo upravljati zgolj kot množico delavcev in opreme, pač pa moramo razumeti, da je splošna bolnišnica pred- 
vsem družbena organizacija, ki jo je treba upravljati. Na upravljanje take družbene organizacije pa je vezan omejen dejavnik vodstvenih in podjetniških sposobnosti. Prav upravljanje, ki obsega odločanje, uresničevanje odločitev, nadzor in sprejemanje ter razumevanje številnih informacij znotraj bolnišnice, sproža nastajanje njihovih disekonomij obsega. To pomeni, da, čim večji bo izvajalec zdravstvene dejavnosti, tem teže ga bo učinkovito upravljati kot družbeno organizacijo. To pa potem posledično vpliva na nastajanje padajočih donosov obsega in naraščanje dolgoročnih povprečnih stroškov.

Optimalna velikost izvajalca sekundarne zdravstvene dejavnosti je potem vsaj v osnovi opredeljena s točko, pri kateri kombiniranje ekonomij obsega in disekonomij obsega vodi do dolgoročnih minimalnih povprečnih stroškov. Dolgoročni minimalni povprečni stroški pa niso nič drugega kot povprečni stroški tistega obrata in tipa obrata, ki dajejo hkrati tudi kratkoročne minimalne povprečne stroške. Znotraj mikroekonomske teorije trg pripelje do take velikosti, če konkurenca zniža cene na raven dolgoročnih minimalnih povprečnih stroškov popolnega konkurenta in če ta maksimira dobiček. Maksimiranje dobička zahteva izenačitev njegovih dolgoročnih mejnih stroškov z dano ceno na trgu. To pa se zgodi pri dolgoročnih minimalnih povprečnih stroških, ko je cena na ravni najnižjih dolgoročnih povprečnih stroškov popolnega konkurenta (Johnston 1960; Koutsoyiannis 1987; Posnett 2002; Tajnikar 2006a; 2006b; McGuigan, Moyer in Harris 2008; Rebernik 2008; Henderson 2011; Kristensen idr. 2013; Messner 2013; Pindyck in Rubinfeld 2013; Mankiw 2014; Besanko, Braeutigam in Rockett 2015). Enako torej velja tudi za izvajalca zdravstvene dejavnosti. Optimalna velikost splošne bolnišnice je torej pri minimumu njenih dolgoročnih povprečnih stroškov, če plačnik zdravstvenih storitev postavi ceno na raven dolgoročnih minimalnih povprečnih stroškov in če splošna bolnišnica sledi cilju minimiranja stroškov ter maksimiranja prihodkov. Če je cena na trgu nad minimalnimi dolgoročnimi povprečnimi stroški, sta optimalen obseg proizvodnje in ustrezna velikost splošne bolnišnice večja, saj mejni stroški naraščajo s količino ponudbe. Optimalno velikost izvajalca zdravstvene dejavnosti grafično prikazujemo v sliki is.

Teoretične iztočnice optimalne velikosti podjetja znotraj mikroekonomske teorije lahko torej uporabimo tudi kot podlago za definiranje optimalne velikosti izvajalca sekundarne zdravstvene dejavnosti. To je skladno s predpostavko, da se izvajalci v javni lasti obnašajo racionalno in minimirajo stroške oziroma maksimirajo prihodke, kar je ključno za opredelitev optimalne velikosti. Ker gre pri razpravi o velikosti ponu- 
dnika, kot smo pokazali, vedno za problem minimiranja stroškov in maksimiranja prihodkov, javna lastnina izvajalcev in njihov nepridobitni značaj ne spreminjata opisanih iztočnic. To pomeni, da vsaj na teoretski ravni ni razlogov, da ne bi domnevali, da se javni izvajalec sekundarne zdravstvene dejavnosti ne bi obnašal enako, kot domnevamo za podjetje v mikroekonomski teoriji.

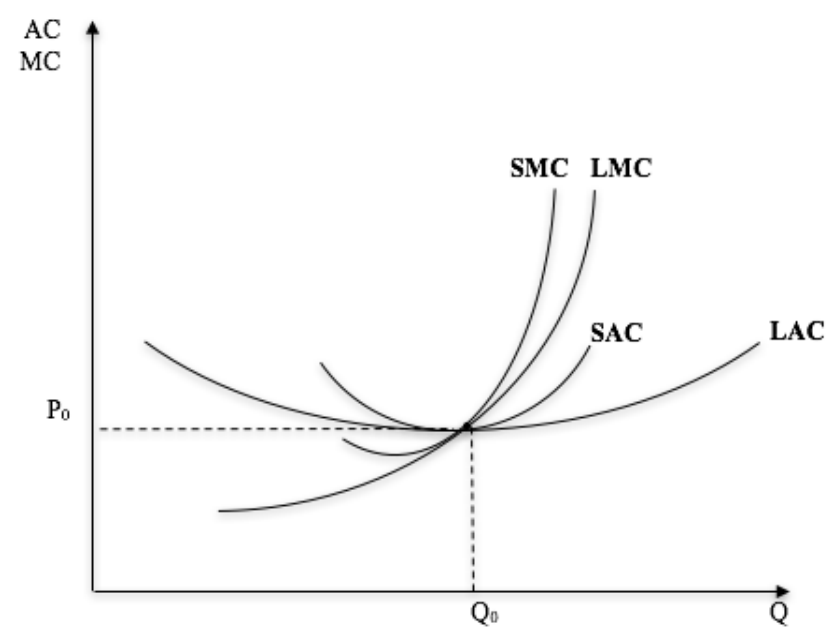

Slika is: Optimalna velikost izvajalca zdravstvene dejavnosti

Prav tako je pomembno, da izvajalec znotraj mreže javnega zdravstva ne glede na lastninsko strukturo deluje ob danih cenah, saj cene zdravstvenih storitev postavlja plačnik javnega zdravstva. Pri zdravstvenem varstvu gre namreč za regulirani trg, kjer je cena na trgu dana - določa jo plačnik -, kar pomeni, da izvajalec zdravstvene dejavnosti ne more vplivati na ceno storitev, ki jih ponuja na trgu. To pa pomeni, da se posamezen izvajalec zdravstvene dejavnosti lahko tržni ceni prilagaja zgolj z obsegom svoje proizvodnje oziroma s količino zdravstvenih storitev. Pri tem je pomembno dejstvo, da je zanj tržna cena dana ne glede na to, kakšen je obseg njegove proizvodnje. Na teoretski ravni torej lahko predpostavljamo, da za izvajalca zdravstvene dejavnosti veljajo podobne razmere kot za podjetje v primeru popolne konkurence, za katerega je značilno, da sprejema dano tržno ceno, pri tem pa se trgu prilagaja zgolj z obsegom proizvodnje. Iztočnice, ki govorijo o optimalni velikosti podjetja, zato veljajo tudi za izvajalca zdravstvenega varstva v okviru mreže javnega zdravstva. 
Metodologija za ocenjevanje optimalne velikosti izvajalca zdravstvene dejavnosti

$\mathrm{Na}$ podlagi opredelitve optimalne velikosti izvajalca zdravstvene dejavnosti lahko $\mathrm{z}$ večjo gotovostjo definiramo ekonomsko najučinkovitejšo slovensko splošno bolnišnico. Glede na ugotovitev, da znotraj metode SFA in metode DEA nima ista bolnišnica najvišje mere ekonomske učinkovitosti, lahko odločitev o ekonomsko najučinkovitejši splošni bolnišnici sprejmemo, če preko dolgoročnih funkcij opredelimo tudi optimalno velikost splošne bolnišnice. V nadaljevanju smo tako preverjali, ali katera izmed splošnih bolnišnic, ki zavzame najvišje mere ekonomske učinkovitosti, dosega tudi dolgoročno ravnotežje. To pomeni, da analiziramo, ali se nahaja na točki optimalne velikosti bolnišnice. To smo ugotovili s pomočjo analize stroškovnih funkcij splošnih bolnišnic, pri čemer smo se osredotočili na Splošno bolnišnico Celje, ki ima najvišje mere ekonomske učinkovitosti znotraj metode SFA, in Splošno bolnišnico Brežice, ki dosega najvišje mere ekonomske učinkovitosti znotraj metode DEA.

Pri izpeljavi in analizi stroškovnih funkcij izvajalca sekundarne zdravstvene dejavnosti se je treba zavedati, da razprava o optimalni velikosti splošne bolnišnice spada v razpravo o njenem dolgoročnem ravnotežju. Velikost splošne bolnišnice lahko spreminjamo le, če domnevamo, da noben proizvodni dejavnik ni za bolnišnico fiksen, kar je definicija dolgega roka. To pomeni, da lahko določimo optimalno velikost splošne bolnišnice, če analiziramo njene dolgoročne stroškovne funkcije. Na dolgi rok krojijo dolgoročne povprečne stroške ekonomije obsega, ki v smeri zniževanja dolgoročnih povprečnih stroškov izvirajo iz delitve dela in so pogojene s tehnologijo v sektorju, v smeri njihovega povečevanja pa izvirajo iz problemov upravljanja ter vodenja. Če je vsaj en dejavnik fiksen, bolnišnica ne more več izbirati svoje velikosti, saj je ta določena z obsegom fiksnega proizvodnega dejavnika, in lahko izbira le optimalen obseg proizvodnje oziroma dejavnosti ob dani velikosti.

Ključno za določitev optimalne velikosti splošne bolnišnice je izračun posameznih analitičnih konceptov dolgoročne stroškovne funkcije, pri čemer je izračun odvisen od tega, v kakšni obliki je funkcija podana. Lahko jo namreč predstavimo v obliki zapisa v preglednici, v obliki matematične specifikacije ali v grafični obliki. Skladno s tem je optimalna velikost izvajalca sekundarne zdravstvene dejavnosti analizirana z diskretnimi, zveznimi in grafičnimi analizami. Diskretna analiza nam omogoča, da predstavimo podatke o dolgoročnih celotnih stroških in količini proizvodnje v tabelarični obliki. V prvem koraku smo tako z diskretno ana- 
lizo najprej opredelili dolgoročno stroškovno funkcijo splošne bolnišnice, ki prikazuje razmerje med celotnimi stroški in obsegom proizvodnje na dolgi rok. Na podlagi dolgoročnih celotnih stroškov smo ugotovili, kakšni denarni izdatki so potrebni za proizvodnjo določene količine outputa. Dolgoročni celotni stroški predstavljajo vsoto vseh stroškov izvajalca zdravstvene dejavnosti, torej stroškov dela in stroškov kapitala.

V drugem koraku smo uporabili zvezno analizo, ki nam je omogočila, da opredelimo zvezo med dolgoročnimi celotnimi stroški in obsegom proizvodnje $\mathrm{z}$ matematično funkcijo. $S$ pomočjo regresijskega modela smo podatke iz diskretne analize preoblikovali v konkretne matematične specifikacije ocen dolgoročnih stroškovnih funkcij. Na ta način smo funkcijo dolgoročnih celotnih stroškov opredelili še v obliki zvezne analize, ki nam je omogočila, da smo dobljene rezultate primerjali še z vrednostmi, pridobljenimi iz diskretnih zapisov. Zavedamo se, da uporaba regresijske analize ni popolnoma primerna metoda glede na dejstvo, da imamo na razpolago majhno število enot opazovanja. V Sloveniji deluje dvanajst splošnih bolnišnic, zato smo lahko znotraj regresijskega modela uporabili zgolj dvanajst opazovanih enot v različnih časovnih obdobjih. Skladno s tem so tudi rezultati ocenjenega nelinearnega regresijskega modela interpretirani s previdnostjo.

$\mathrm{Na}$ podlagi dolgoročne stroškovne funkcije smo z matematičnimi operacijami izračunali funkcijo dolgoročnih povprečnih stroškov. Dolgoročni povprečni stroški nam povedo, koliko znaša $\mathrm{v}$ denarju ovrednotena poraba proizvodnih dejavnikov pri proizvodnji ene enote proizvoda. $\mathrm{Na}$ ta način smo opredelili, koliko bolnišnico v povprečju stane proizvodnja ene enote outpuwta. Dolgoročni povprečni stroški tako predstavljajo stroške na enoto proizvedenega proizvoda, kar pomeni, da dolgoročne povprečne stroške izračunamo tako, da dolgoročne celotne stroške delimo sštevilom proizvedenih enot:

$$
\text { Dolgoročni povprečni stroški }=\frac{L T C}{Q}=L A C \text {. }
$$

$\mathrm{Na}$ enak način, kot smo izračunali funkcijo dolgoročnih povprečnih stroškov, smo izračunali tudi funkcijo dolgoročnih mejnih stroškov. S tem smo definirali, za koliko se spremenijo dolgoročni celotni stroški, če proizvedemo dodatno enoto proizvoda. Mejni stroški so eden od ključnih pojmov ekonomije in so posebna analitična vrsta stroškov. Dolgoročni mejni stroški tako označujejo dodatne stroške pri proizvodnji ene dodatne enote outputa. Matematično jih zapišemo kot:

$$
\text { Dolgoročni povprečni stroški }=\frac{L T C}{Q}=L A C \text {, }
$$


oziroma pri zvezni analizi kot:

Dolgoročni mejni stroški $=\frac{\partial L T C}{\partial Q}=L M C$.

Če upoštevamo mikroekonomsko teorijo o velikosti podjetja in jo apliciramo na izvajalce zdravstvenih storitev, ugotovimo, da je optimalna velikost splošne bolnišnice pri velikosti, ki daje minimalne dolgoročne povprečne stroške. Trg namreč pripelje do take velikosti, če plačnik zdravstvenih storitev zniža cene na raven minimalnih dolgoročnih povprečnih stroškov posamezne splošne bolnišnice in če ta minimira stroške ter maksimira prihodke. Minimum dolgoročnih povprečnih stroškov smo matematično izračunali tako, da smo dolgoročne povprečne stroške najprej odvajali, nato pa smo odvod enačili z nič. Matematično to zapišemo kot:

$$
\frac{\partial L A C}{\partial Q}=0 .
$$

Minimiranje stroškov ter maksimiranje prihodkov zahteva izenačitev bolnišničnih dolgoročnih mejnih stroškov z dano ceno na trgu. Če je cena na trgu nad minimalnimi dolgoročnimi povprečnimi stroški izvajalca, sta optimalen obseg proizvodnje in ustrezna velikost splošne bolnišnice večja, saj mejni stroški naraščajo s količino ponudbe. Poleg dolgoročnih povprečnih stroškov in dolgoročnih mejnih stroškov smo tako potrebovali še premico cene. Premico cene smo določili tako, da smo izračunali povprečno ceno, ki jo plačnik zdravstvenih storitev plača posamezni bolnišnici za opravljeno storitev. Presečišče funkcije dolgoročnih mejnih stroškov in premice cene smo matematično izračunali kot:

$$
P=L M C \text {. }
$$

V tretjem koraku smo uporabili grafično analizo, ki nam je omogočila predstaviti funkcijsko povezanost med dolgoročnimi celotnimi stroški in obsegom proizvodnje še grafično v ustreznem koordinatnem sistemu. $\mathrm{Z}$ uporabo podatkov iz diskretne in zvezne analize funkcije dolgoročnih celotnih stroškov, dolgoročnih povprečnih stroškov, dolgoročnih mejnih stroškov in premice smo torej izdelali še grafično analizo omenjenih vrst stroškov. Grafično smo določili tudi presečišče dane tržne cene in mejnih stroškov. Na ta način smo opredelili optimalen obseg proizvodnje oziroma optimalno velikost izvajalcev sekundarne zdravstvene dejavnosti. Iz grafične analize smo lahko odčitali, ali je velikost bolnišnice optimalna, ko je mejni strošek enak tržni ceni v minimumu povprečnih stroškov. 
Za oceno dolgoročnih stroškovnih funkcij smo uporabili regresijski model. Postopek regresijske analize smo uporabili z namenom opredelitve matematične specifikacije dolgoročnih stroškovnih funkcij splošnih bolnišnic. Regresijska analiza je namreč ena izmed najpogosteje uporabljenih ekonometričnih metod za ocenjevanje posameznih vrst funkcij znotraj teorije proizvodnje in teorije stroškov. Bistvo regresijske analize je, da preučuje odnos med eno odvisno spremenljivko in eno ali več neodvisnimi spremenljivkami, in sicer $\mathrm{z}$ namenom ocenjevanja vrednosti odvisne spremenljivke ob danih vrednostih neodvisne spremenljivke (Gujarati in Porter 2010). Pri tem se zavedamo, da nam uporaba regresijskega modela zaradi majhnega števila enot opazovanja ne omogoča sprejemanja rezultatov z veliko gotovostjo oziroma posploševanja dobljenih rezultatov na sploh na vse izvajalce zdravstvene dejavnosti, saj je v modelih zajeta zgolj populacija slovenskih splošnih bolnišnic, zato so tudi rezultati interpretirani s previdnostjo.

Pri uporabi regresijskega modela je treba določiti funkcijsko obliko regresijske enačbe, ki ima pomembne posledice za oceno različnih krivulj dolgoročnih stroškov. Pri analizi ocenjevanja dolgoročne stroškovne funkcije poznamo tri najpogosteje uporabljene funkcijske oblike, to so kubična, kvadratna in linearna funkcijska oblika. Vsaka izmed njih ponazarja različno obliko krivulje dolgoročnih stroškov. Poznamo tudi druge funkcijske oblike stroškovnih funkcij, na primer Cobb-Douglasovo funkcijsko obliko, vendar se v statističnih raziskavah najpogosteje uporabljajo kubična, kvadratna in linearna funkcijska oblika (Petersen in Lewis 1994; McGuigan, Moyer in Harris 2008; Henderson 201 I). Ekonomisti morajo pri analizah, ki ponazarjajo razmerje med dolgoročnimi stroški in obsegom proizvodnje, izbrati eno izmed naštetih oblik funkcij.

$\mathrm{V}$ primeru, ko je razmerje med stroški in outputom linearne oblike, ima funkcijska oblika linearne funkcije celotnih stroškov naslednji zapis (Petersen in Lewis 1994; Henderson 2011):

$$
L T C=b_{0}+b_{1} Q .
$$

Na ta način ocenimo statistična parametra $b_{0}$ in $b_{1}$. Linearna funkcijska oblika celotnih stroškov nam omogoča zapis linearne funkcijske oblike povprečnih stroškov (Petersen in Lewis 1994; Henderson 201 I):

$$
L A C=\frac{b_{0}}{Q}+Q .
$$


$\mathrm{Na}$ tej osnovi je mogoče $\mathrm{v}$ naslednjem koraku definirati tudi linearno funkcijsko obliko mejnih stroškov (Petersen in Lewis 1994; Henderson 2OII):

$$
L M C=b_{1} .
$$

Krivulje celotnih, povprečnih in mejnih stroškov, ki so v skladu z linearnim modelom, so prikazane na sliki 16 . Te funkcije imajo naslednje lastnosti: celotni stroški naraščajo sorazmerno z obsegom proizvodnje, povprečni stroški na začetku padajo, nato pa se vse bolj približujejo vrednostim mejnih stroškov, mejni stroški pa so konstantni pri vrednosti parametra $b_{1}$.
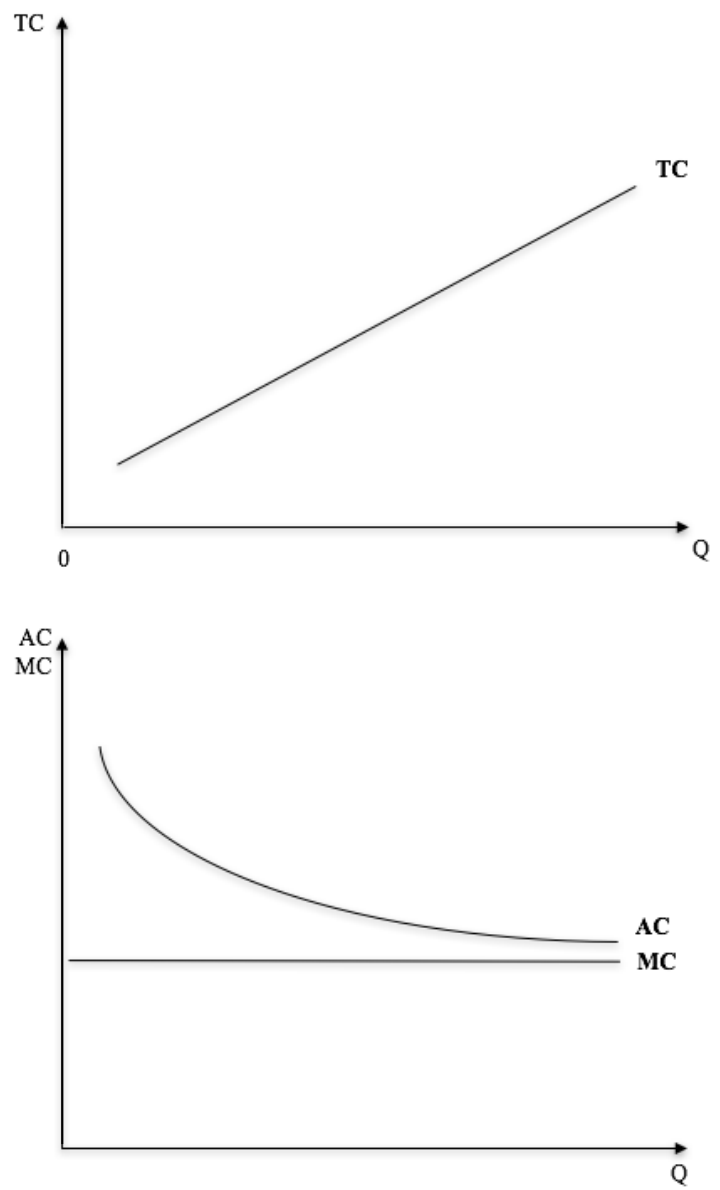

Slika 16: Linearna funkcija celotnih, povprečnih in mejnih stroškov Vir: prirejeno po Petersen in Lewis $(1994,243)$. 
Lahko se zgodi, da se izmerjeni podatki najbolje prilegajo kakšni nelinearni funkcij, kar pomeni, da odnos med stroški in outputi ne ponazarja linearnega razmerja. $\mathrm{V}$ tem primeru govorimo o nelinearni regresiji. Ko je odnos med neodvisno in odvisno spremenljivko polinomski, ima torej regresijski model naslednjo obliko:

$$
\begin{aligned}
& y_{i}=\beta_{0}+\beta_{1} x_{i}+\beta_{2} x_{i}{ }^{2} \ldots+\beta_{k} x_{i}{ }^{k}+\varepsilon_{i} i=1, \ldots, \operatorname{Iin} k>1, \\
& I>k+1
\end{aligned}
$$

Pri tem $\varepsilon_{i}$ predstavlja napako ocene, ki je normalno porazdeljena naključna spremenljivka, za katero je značilno matematično upanje $E(\varepsilon i)=0$ in varianca $V(\varepsilon i)=0$.

Če je zveza med odvisno in neodvisno spremenljivko kvadratna, ima model naslednjo obliko:

$$
y_{i}=\beta_{0}+\beta_{1} x_{i}+\beta_{2} x_{i}^{2}+\varepsilon_{i} .
$$

Zveza med odvisno in neodvisno spremenljivko je v veliki večini primerov tudi kubična in takrat ima model naslednjo obliko:

$$
y_{i}=\beta_{0}+\beta_{1} x_{i}+\beta_{2} x_{i}^{2}+\beta_{3} x_{i}^{3}+\varepsilon_{i} .
$$

Parametre $b_{0}, b_{1}, b_{2}, b_{3}$ poiščemo z metodo najmanjših kvadratov, tako da minimiramo funkcijo:

$$
\begin{aligned}
& f\left(\beta_{0}, \beta_{1}, \beta_{2}, \beta_{3}\right)= \\
& \sum_{i=1}^{I}\left(y_{i}-\beta_{0}-\beta_{1} x_{i}-\beta_{2} x_{i}{ }^{2}-\beta_{3} x_{i}{ }^{3}-\varepsilon_{i}\right)^{2} .
\end{aligned}
$$

Minimiranje lahko izvedemo $\mathrm{z}$ iskanjem stacionarne točke, nato pa dobimo linearen sistem enačb za koeficiente $\beta$.

Če smo torej ugotovili, da izmerjeni podatki ne ustrezajo linearni funkcijski obliki, moramo izbrati eno izmed nelinearnih funkcij, ki se kar najbolje prilega parom merjenja. Če se opazovane enote kar najbolje prilegajo kvadratni funkcijski obliki, lahko v tem primeru funkcijo celotnih stroškov definiramo v obliki kvadratne funkcijske oblike (Petersen in Lewis 1994; McGuigan, Moyer in Harris 2008; Henderson 201 I):

$$
L T C=c_{0}+c_{1} Q+c_{2} Q^{2} .
$$


Pari merjenja pa se pogosto še bolje prilegajo kubični funkcijski obliki, kar matematično zapišemo kot (Henderson 20ı I; McGuigan, Moyer in Harris 2008; Petersen in Lewis 1994):

$$
L T C=d_{0}+d_{1} Q+d_{2} Q^{2}+d_{3} Q^{3} .
$$

Kvadratna in kubična funkcijska oblika sta pogosto uporabljeni funkcijski obliki, saj predpostavljata nelinearno razmerje ocenjevanih spremenljivk. Parametre v enačbah 3.13 in 3.14 običajno ocenimo neposredno po metodi regresije najmanjših kvadratov. Enačba 3.14 je nelinearna v spremenljivkah $Q, Q^{2} Q^{3}$, hkrati pa je linearna v parametrih $d_{0}, d_{2}, d_{3}$, zato lahko metodo najmanjših kvadratov uporabimo brez preoblikovanja enačbe.
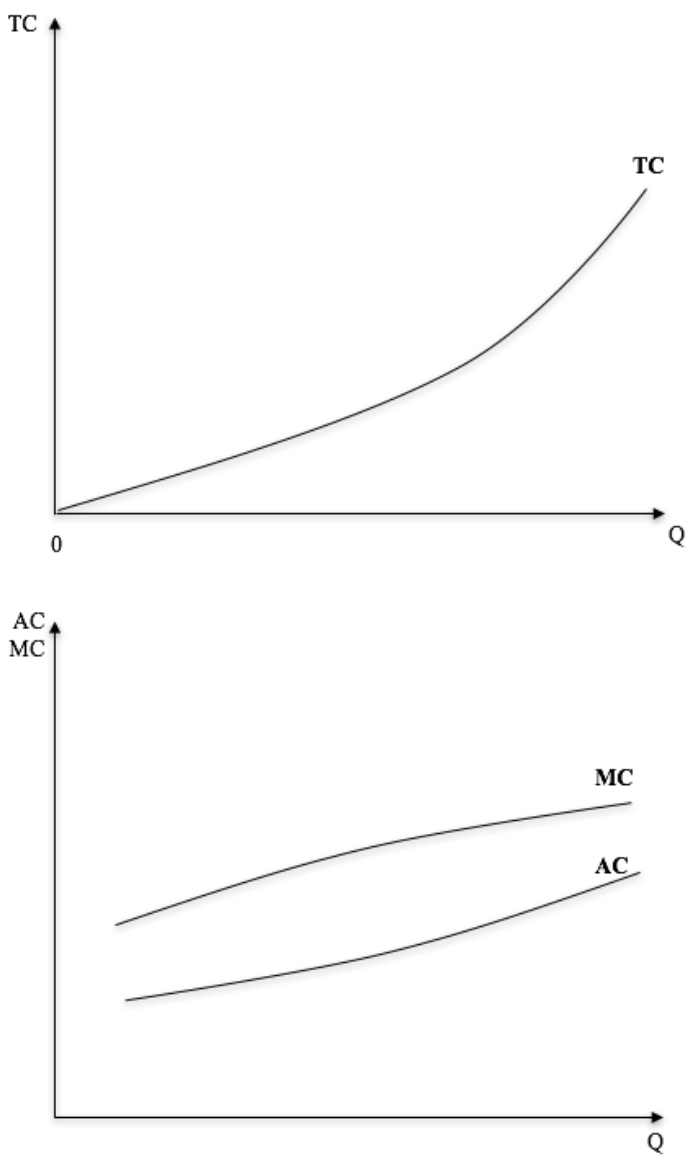

Slika 17: Kvadratna funkcija celotnih, povprečnih in mejnih stroškov

Vir: prirejeno po Petersen in Lewis $(1994,244)$. 
Čeprav je oblika kvadratne ali kubične funkcije odvisna od ocenjenih parametrov, tipična oblika stroškovne funkcije temelji na funkcijskih oblikah, ki jih prikazujemo v sliki 17 in sliki 18 . Kvadratna funkcija ima naslednje lastnosti: celotni stroški naraščajo po vedno višji stopnji, povprečni stroški naraščajo nelinearno, mejni stroški pa naraščajo linearno glede na output. Povprečne stroške izračunamo tako, da funkcijo celotnih stroškov delimo s količino proizvodnje (Petersen in Lewis 1994; McGuigan, Moyer in Harris 2008; Henderson 201I):

$$
L A C=\frac{C_{0}}{Q}+C_{1}+C_{2} Q .
$$

Mejne stroške izračunamo kot prvi odvod funkcije celotnih stroškov. To pomeni, da jih zapišemo kot (Petersen in Lewis 1994; McGuigan, Moyer in Harris 2008; Henderson 201 I):

$$
L M C=\frac{\partial L T C}{\partial Q}=c_{1}+2 c_{2} Q .
$$

Tipična oblika celotnih stroškov, povprečnih stroškov in mejnih stroškov temelji na kubični funkcijski obliki, ki jo prikazujemo v sliki ı 8 . Kubična funkcija ima naslednje lastnosti: celotni stroški najprej naraščajo po vedno nižji stopnji, nato pa naraščajo po vedno višji stopnji, povprečni in mejni stroški pa imajo tipično U-funkcijsko obliko. Povprečne stroške tako definiramo kot (Petersen in Lewis 1994; McGuigan, Moyer in Harris 2008; Henderson 201 I):

$$
L A C=\frac{d_{0}}{Q}+d+d_{2} Q+d_{3} Q^{2} .
$$

Mejne stroške lahko zapišemo kot (Petersen in Lewis 1994; McGuigan, Moyer in Harris 2008; Henderson 201 I):

$$
L M C=\frac{\partial L T C}{\partial Q}=d_{1}+2 d_{2} Q+3 d_{3} Q^{2} .
$$

Z izrisom celotnih stroškov $\mathrm{v}$ odvisnosti od količinskega obsega proizvodnje je mogoče ugotoviti, katera od navedenih treh funkcijskih oblik najbolje predstavlja razmerje, ki obstaja med dvema spremenljivkama. To pa predstavlja ključen podatek pri odločanju o funkcijski obliki stroškovnih funkcij.

$\mathrm{Na}$ tem mestu moramo izpostaviti še eno dejstvo. Oblika dolgoročnih povprečnih stroškov je odvisna od ekonomij in disekonomij obsega, 
zato je kubična funkcijska oblika, ki je v skladu z ekonomijami in disekonomija obsega, običajno najprimernejša funkcijska oblika pri ocenjevanju stroškovnih funkcij.
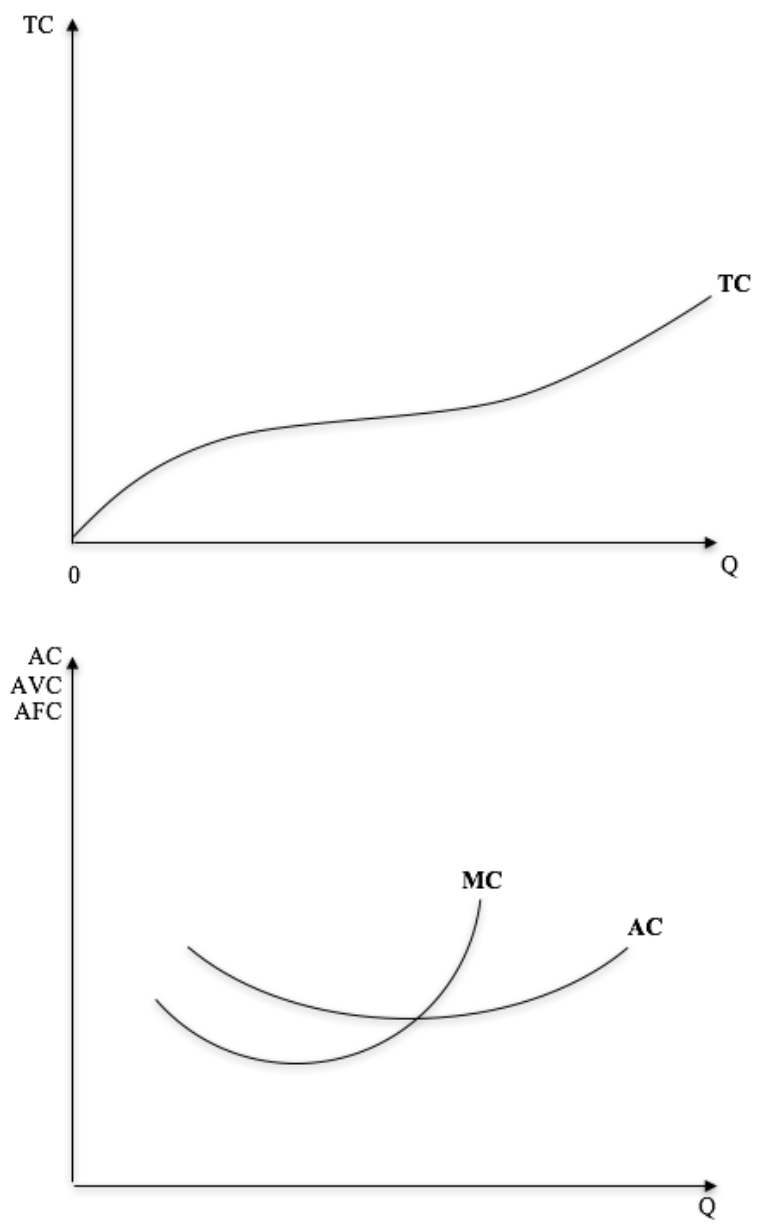

Slika I 8: Kubična funkcija celotnih, povprečnih in mejnih stroškov

Vir: prirejeno po Petersen in Lewis (1994, 245).

Eden izmed problemov pri analizi stroškovnih funkcij na podlagi presečnih podatkov je, da se lahko zgodi, da ocenjena funkcija dolgoročnih povprečnih stroškov in popolnoma enaka aktualni dolgoročni funkciji povprečnih stroškov (Johnson 1972). To prikazujemo na sliki I9, kjer so opredeljene štiri krivulje kratkoročnih povprečnih stroškov $\left(S A C_{1}, S A C_{2}, S A C_{3}, S A C_{4}\right)$. Iz mikroekonomske teorije vemo, da dol- 
goročne stroškovne funkcije grafično dobimo na način, da upoštevamo vse možne proizvodne zmogljivosti, to je vse možne velikosti ponudnika, ali da združimo v eno skico vse možne kratkoročne povprečne stroške. Tako dolgoročni povprečni stroški niso nič drugega kot ovojnica različnih kratkoročnih povprečnih stroškov.

Pri analizi stroškovnih funkcij na podlagi presečnih podatkov je vključena predpostavka, da ponudniki proizvajajo na točki optimalnega obsega proizvodnje, torej na tisti točki svoje $S A C$ krivulje, ki je del njihove $L A C$ krivulje. Če torej želimo natančno oceniti $L A C$ krivuljo, morajo ponudniki, ki imajo svoje kratkoročne povprečne stroške opredeljene $s$ krivuljami $S A C_{1}, S A C_{2}, S A C_{3}, S A C_{4}$, proizvajati v točkah $A^{\prime \prime}, C^{\prime \prime}, G^{\prime \prime}$, $R^{\prime \prime}$. Če v resnici ponudniki proizvajajo v točkah $A^{*}, C^{*}, G^{*}, R^{*}$, potem se ocenjena dolgoročna krivulja povprečnih stroškov razlikuje od aktualne krivulje dolgoročnih povprečnih stroškov.

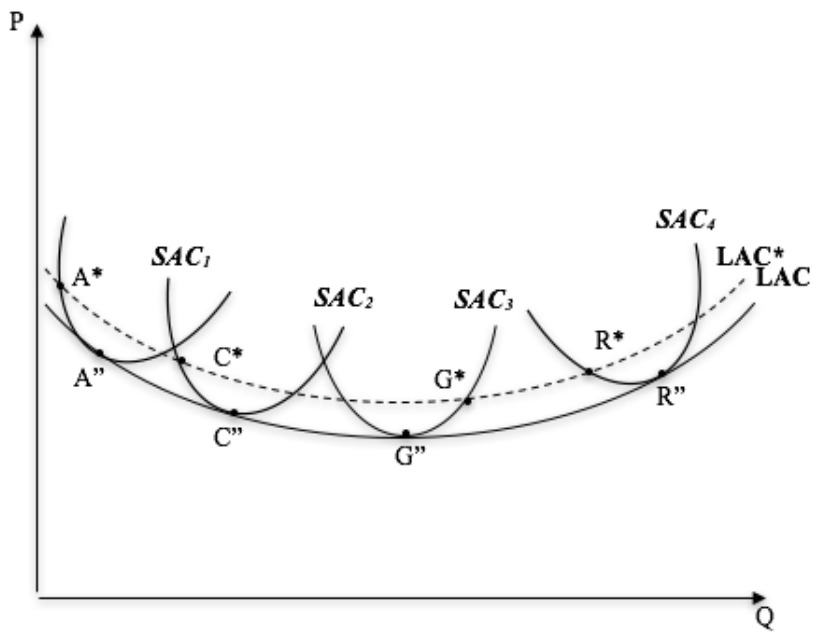

Slika ı 9: Ocenjena funkcija dolgoročnih povprečnih stroškov

\section{Vzorec opazovanib bolnišnic}

Situacija znotraj slovenskega zdravstvenega sistema metodološko omogoča iskanje dolgoročne stroškovne funkcija izvajalca zdravstvene dejavnosti na osnovni obstoječih splošnih bolnišnic. Dobra stran tega modela je, da ne gre za vzorec splošnih bolnišnic, pač pa kar za populacijo vseh slovenskih splošnih bolnišnic, kar pomeni, da so posploševanja na naše splošne bolnišnice neomejena. Seveda pa se zavedamo, da pri tem ne moremo govoriti o rezultatih, ki veljajo nasploh. To je skladno z dejstvom, da nas zanima predvsem optimalna velikost izvajalca zdravstvene dejavnosti, ki 
izhaja iz značilnosti in ob pogojih, ki jih je mogoče doseči znotraj slovenskega zdravstvenega sistema.

V Sloveniji deluje šestindvajset bolnišnic, med katerimi sta dve univerzitetni bolnišnici, deset je splošnih bolnišnic in štirinajst je specialnih bolnišnic. $V$ tem delu preučujemo optimalno velikost slovenske splošne bolnišnice, kar pomeni, da analiziramo zgolj slovenske splošne bolnišnice, medtem ko specialnih bolnišnic v vzorec ne vključujemo. Znotraj vzorca je namreč treba zagotoviti čim večjo homogenost opazovanih enot. Pri tem smo iz analize izključili Univerzitetni klinični center Ljubljana, saj je za potrebe ocene dolgoročne stroškovne funkcije treba zagotoviti, da imajo vsi proizvodni obrati v preučevanem vzorcu enako tehnologijo. Univerzitetni klinični center Ljubljana je terciarna zdravstvena ustanova, ki obravnava najtežje bolnike in skladno s tem se tudi njegova tehnologija razlikuje v primerjavi z ostalimi slovenskimi splošnimi bolnišnicami. Iz nabora podatkov bi lahko sicer izključili tudi Univerzitetni klinični center Maribor, vendar se je ta nedavno preoblikoval iz splošne bolnišnice v univerzitetno, kar pomeni, da je njegova proizvodna tehnologija primerljiva s tehnologijo preostalih splošnih bolnišnic. V nabor podatkov smo tako vključili deset splošnih bolnišnic in eno univerzitetno bolnišnico.

Za potrebe regresijske analize smo pridobili podatke za enajst splošnih bolnišnic, ki delujejo znotraj mreže sekundarne zdravstvene dejavnosti v Sloveniji. Vzorec slovenskih splošnih bolnišnic tako predstavlja enajst bolnišnic, in sicer Splošna bolnišnica Brežice, Splošna bolnišnica Celje, Splošna bolnišnica Izola, Splošna bolnišnica Jesenice, Splošna bolnišnica Murska Sobota, Splošna bolnišnica Nova Gorica, Splošna bolnišnica Novo mesto, Splošna bolnišnica Ptuj, Splošna bolnišnica Slovenj Gradec, Splošna bolnišnica Trbovlje in Univerzitetni klinični center Maribor.

Pri ocenjevanju optimalne velikosti slovenske splošne bolnišnice smo uporabili podatke iz letnih in strokovnih poročil enajstih analiziranih splošnih bolnišnic v desetletnem obdobju, in sicer med letom 2005 in letom 20I4. Prvi temeljni vir podatkov o stroških posameznih bolnišnic so nam predstavljali računovodski izkazi oziroma letna poročila, ki jih zbirata AJPES in Združenje zdravstvenih zavodov Slovenije. Drugi temeljni virov podatkov o obsegu outputov so nam predstavljali podatki, ki jih zbira Nacionalni inštitut za javno zdravje. Relevantnost podatkov, ki jih zbira Nacionalni inštitut za javno zdravje smo preverili tudi s podatki, ki jih zbira Ministrstvo za zdravje. 


\section{Podatki in spremenljivke opazovanib bolnišnic}

Pri statističnem ocenjevanju dolgoročnih stroškovnih funkcij lahko uporabljamo regresijsko analizo tako na podlagi časovnih vrst kot tudi na podlagi presečnih podatkov. $V$ primeru časovnih vrst običajno opazujemo posameznega izvajalca $\mathrm{v}$ daljšem časovnem obdobju, kar pomeni, da imamo na voljo podatke o stroških in obsegu proizvodnje za več različnih let. Presečne podatke pa uporabljamo, ko opazujemo več različnih izvajalcev ob nekem točno določenem času. Presečni podatki nam podajajo informacije o stroških in obsegu outputa več različnih izvajalcev v istem časovnem trenutku (Johnston I961; Johnson 1972; Koutsoyiannis 1987).

Pri ocenjevanju dolgoročnih stroškovnih funkcij na podlagi časovnih vrst pridobimo podatke o stroških in outputih posameznega izvajalca, ki je imel v opazovanem obdobju različno velike proizvodne obrate. Ko za analizo uporabljamo časovne vrste, se običajno srečujemo s problemom, kako zagotoviti, da se ostali dejavniki, ki vplivajo na output, v času ne bodo spreminjali. Glede na to, da se s časom tehnologija v podjetju skoraj vedno spreminja, je ocenjevanje dolgoročnih stroškovnih funkcij na podlagi časovnih vrst precej težavno (Johnston 1961; Johnson 1972; Koutsoyiannis 1987).

Zgoraj navedeni razlogi pri ocenjevanju dolgoročnih stroškovnih funkcij utemeljujejo uporabo presečnih podatkov. Pri tem je treba zbrati podatke različnih proizvodnih obratov oziroma izvajalcev, ki se nanašajo na določeno raven outputa, in podatke o stroških, ki nastajajo znotraj proizvodnega procesa v vsakem obratu. Podatki morajo biti zbrani tako, da preprečijo napake merjenja, kar pomeni, da se morajo nanašati na dejansko raven ali stopnjo proizvodnje $\mathrm{v}$ tem obdobju in hkrati tudi na dejansko višino stroškov, ki morajo biti povezani z ravnijo proizvodnje $\mathrm{v}$ vsakem opazovanem obratu (Christensen in Greene 1976; Koutsoyiannis 1987; McGuigan, Moyer in Harris 2008; Samuelson in Marks 2010).

Ključna prednost ocenjevanja dolgoročnih stroškovnih funkcij na podlagi presečnih podatkov je, da se izognemo problemu spreminjanja tehnologije, saj imamo na voljo podatke o stroških in outputih različno velikih obratov oziroma različno velikih izvajalcev v nekem točno določenem trenutku. Skladno s priporočili A. Koutsoyiannis (1987) smo se tudi mi odločili, da preučujemo dolgoročne stroškovne funkcije z regresijsko analizo, ki temelji na presečnih podatkih.

Pri ocenjevanju dolgoročnih stroškovnih funkcij v okviru presečnih podatkov smo predvidevali:

- da vsaka splošna bolnišnica prilagodi svoje poslovanje tako, da posluje skladno z optimalnim obsegom proizvodnje; 
- da je med splošnimi bolnišnicami tehnologija naključno porazdeljena, kar pomeni, da imajo nekatere manjše bolnišnice staro tehnologijo, druge imajo naprednejšo tehnologijo, in enako velja tudi za velike bolnišnice;

- da je podjetniška sposobnost naključno povezana z različnimi velikostmi splošnih bolnišnic.

Presečni podatki so nam omogočili izdelavo opisnih in sklepnih statistik. Da bi dosegli cilje ocenjevanja dolgoročnih stroškovnih funkcij, smo uporabili opisno statistiko, vključno z mediano, odstotki in povprečji. Regresijsko analizo smo uporabili za oceno različnih stroškovnih funkcij na dolgi rok. Obstaja več razlogov za sprejetje tega postopka v okviru ocenjevanja dolgoročnih stroškovnih funkcij. $V$ prvi vrsti presečni podatki prihajajo iz različnih bolnišnic z različno velikostjo proizvodnih obratov, drugič, vsi podatki so zbrani v istem časovnem trenutku, kar pomeni, da ni mogoče, da bi se tehnologija spreminjala, tretjič, ni potrebe po obravnavanju sprememb cen.

Dolgoročno stroškovno funkcijo izvajalca zdravstvene dejavnosti smo ocenili na podlagi presečnih podatkov, pri čemer se zavedamo, da regresijska analiza ni popolnoma primerna metoda, saj razpolagamo z majhnim številom enot opazovanja, zato smo pri ocenjevanju dolgoročnih stroškovnih funkcij definirali deset različnih regresijskih modelov, ki se nanašajo na podatke o izvajalcih za obdobje od leta 2005 do leta 2014. To pomeni, da so v prvem regresijskem modelu vključeni podatki splošnih bolnišnic za leto 2005 , v drugem so zajeti podatki za leto 2006 , v tretjem so podatki za leto $2007, \mathrm{v}$ četrtem so vključeni podatki za leto 2008 , $\mathrm{v}$ petem so zajeti podatki za leto 2009 , $\mathrm{v}$ šestem so podatki za leto $20 \mathrm{ro}$, $\mathrm{v}$ sedmem so vključeni podatki za leto $20 \mathrm{I}$, v osmem so zajeti podatki za leto 2012 , v devetem so podatki za leto 2013 in v desetem so vključeni podatki splošnih bolnišnic za leto 20I4. Najlaže bi ustrezno dolgoročno stroškovno funkcijo izvajalca zdravstvene dejavnosti seveda pridobili na osnovi presečnih podatkov večjega števila splošnih bolnišnic, kar pa je mogoče zgolj v državah, kjer znotraj sistema zdravstvenega varstva deluje večje število splošnih bolnišnic.

Posamičen regresijski model in iz njega izhajajoča dolgoročna stroškovna funkcija sicer veliko povesta o zakonitostih gibanja funkcije $\mathrm{v}$ opazovanem letu, vendar pa lahko posamezni specifični dejavniki, ki se odražajo v poslovanju splošnih bolnišnic znotraj tega leta, pomembno vplivajo na obliko dolgoročne stroškovne funkcije. Temu smo se izognili tako, da smo poiskali deset dolgoročnih stroškovnih funkciji, ki temelijo na podatkih desetih različnih let, pri čemer smo poskušali opredeliti 
najznačilnejšo obliko dolgoročne stroškovne funkcije izvajalca zdravstvene dejavnosti. Takšna ocena je smiselna predvsem zato, da dobimo zanesljivejši vpogled na dolgoročno stroškovno funkcijo izvajalca zdravstvene dejavnosti.

Pridobljeni podatki zajemajo vrednosti o stroških ter o outputu opazovanih splošnih bolnišnic. Podatke o stroških splošnih bolnišnic smo pridobili s strani AJPES-a ter Združenja zdravstvenih zavodov, podatke o outputu splošnih bolnišnic pa so nam omogočili na Nacionalnem inštitutu za javno zdravje in Ministrstvu za zdravje. Pri tem smo se posebej osredotočili na podatke o stroških in obsegu outputa Splošne bolnišnice Celje, ki dosega najvišje mere učinkovitosti znotraj metode SFA, in Splošne bolnišnice Brežice, ki dosega najvišje vrednosti učinkovitosti znotraj metode DEA. Podatke o stroških in outputu po posameznih dejavnostih, ki veljajo za Splošno bolnišnico Celje in Splošno bolnišnico Brežice, smo tako preverili na podlagi njihovih internih dokumentov.

Dolgoročna analiza stroškovnih funkcij predvideva oceno celotnih stroškov opazovanih izvajalcev. Za potrebe opredelitve celotnih stroškov smo uporabili podatke o vseh stroških, ki jih imajo posamezne opazovane splošne bolnišnice znotraj določenega leta. Celotni stroški skladno z izkazi prihodkov in odhodkov vključujejo stroške blaga, materiala in storitev, stroške dela, stroške amortizacije, druge stroške, finančne odhodke, druge odhodke in prevrednotene poslovne odhodke. Celotni stroški predstavljajo denarne izdatke splošnih bolnišnic, zato so skladno z ekonomsko teorijo opredeljeni kot seštevek stroškov dela in stroškov kapitala, izraženih v evrih. Glede na to, da znotraj posameznih regresijskih modelov uporabljamo presečne podatke, so celotni stroški v vseh regresijskih modelih izraženi v nominalnih vrednostih. Celotni stroški so povezani $s$ stroški, ki nastajajo znotraj dveh vrst dejavnosti, ki jih opravljajo izvajalci zdravstvene dejavnosti.

Pri dolgoročni analizi stroškovnih funkcij potrebujemo tudi oceno količinskega obsega proizvedenega outputa. Količinski obseg outputa smo skladno s priporočili Dranoveja (1998) definirali v obliki števila bolnikov na leto. To je torej tisto število bolnikov, ki jih posamezna bolnišnica sprejme in obravnava v enem letu. Količinski obseg proizvedenega outputa v našem primeru vključuje dve vrsti outputa, ki zajemata različne vrste zdravstvenih dejavnosti. Način spremljanja podatkov nam namreč omogoča, da za potrebe naše analize izrazimo količinski obseg outputa skladno z dejavnostmi, ki jih opravljajo izvajalci sekundarne zdravstvene dejavnosti. 
Splošne bolnišnice opravljajo dejavnosti, ki niso povezane s hospitalizacijo in zahtevajo ambulantno obravnavo bolnika, imenujemo jih specialistične zunaj-bolnišnične zdravstvene dejavnosti. Poleg tega splošne bolnišnice opravljajo tudi dejavnosti, pri katerih je prisotna hospitalizacija, kar imenujemo specialistična hospitalna dejavnost. Količinski obseg specialistične zunaj-bolnišnične zdravstvene dejavnosti je $\mathrm{v}$ našem primeru opredeljen v obliki števila primerov ambulante dejavnosti, ki ga izrazimo s številom obravnavanih bolnikov. Število ambulantnih primerov ponazarja tako prve obiske kot tudi ponovne obiske bolnikov. Za potrebe opredelitve količinskega obsega specialistične hospitalne dejavnosti pa smo uporabili podatke o številu akutno odpuščenih bolnikov, ki izvirajo iz skupin primerljivih primerov. Agregiran količinski obseg proizvedenega outputa je tako definiran kot seštevek bolnikov, ki so jih izvajalci obravnavali znotraj specialistične zunaj-bolnišnične oziroma ambulante zdravstvene dejavnosti in specialistične oziroma akutne hospitalne obravnave.

Pri definiranju optimalne velikosti izvajalca zdravstvene dejavnosti je treba izpeljati tudi funkcijo dolgoročnih povprečnih stroškov Pri izpeljavi funkcije dolgoročnih povprečnih stroškov smo uporabili podatke o celotnem proizvodu in podatke o povprečnih stroških, pri čemer so povprečni stroški izraženi kot stroški na enoto proizvedenega outputa. Za izpeljavo funkcije dolgoročnih mejnih stroškov smo uporabili podatke o celotnem proizvodu ter podatke o mejnih stroških, kjer mejni stroški predstavljajo stroške, ki nastanejo s proizvodnjo dodatne enote outputa. Za določitev presečišča mejnih stroškov in dane cene smo opredelili tudi ceno storitev, ki jo plačnik zdravstvenih storitev plačuje izvajalcem zdravstvene dejavnosti.

\section{Rezultati ocenjevanja optimalne velikosti izvajalca zdravstvene dejavnosti}

Pri ocenjevanju optimalne velikosti izvajalca zdravstvene dejavnosti smo preverjali tri najbolj priljubljene funkcijske oblike ocenjevanja dolgoročnih stroškovnih funkcij, linearno, kvadratno in kubično funkcijsko obliko. Funkcija dolgoročnih celotnih stroškov ponazarja odnos med stroški in dejavniki, ki nanje vplivajo. Ključni dejavniki, ki dolgoročno vplivajo na rast stroškov posameznega proizvajalca, so velikost proizvodnega obrata, raven outputa, cene inputov, tehnologija, učinkovitost vodstva in podobno. V matematični obliki lahko funkcijo stroškov zapišemo kot:

$$
C=f(x .) \text {. }
$$


$C$ ponazarja stroške, ki so lahko opredeljeni kot stroški na enoto ali skupni stroški, $X$ pa predstavljen raven proizvodnje oziroma količinski obseg outputa. Raven proizvodnje in celotni stroški so pozitivno povezani, kar pomeni, da v primeru povečanja proizvodnje celotni stroški naraščajo, v primeru zmanjšanja proizvodnje pa celotni stroški padajo. To je posledica dejstva, da povečana raven proizvodnje zahteva tudi večjo porabo materiala, elektrike, delovne sile in podobno. Na dolgi rok pa se z naraščanjem proizvodnje ne povečujejo zgolj variabilni proizvodni dejavniki, ampak tudi tisti proizvodni dejavniki, ki so na kratek rok fiksni. To pomeni, da bodo na dolgi rok poleg naraščanja materialnih stroškov, stroškov elektrike in stroškov dela naraščali tudi stroški, ki so povezani z nakupom novih zgradb, naprav in opreme. V praksi je uporabnost katere koli funkcije stroškov, torej tako funkcije celotnih stroškov, funkcije povprečnih stroškov in funkcije mejnih stroškov, odvisna predvsem od pravilne izbire funkcijske oblike.

$\mathrm{Na}$ podlagi determinacijskih koeficientov se je izkazalo, da kubična funkcijska oblika stroškovne funkcije najbolje ponazarja odnos med celotnimi stroški in outputom v vseh letih opazovanja. Povzetek regresijskih modelov korelacijskih koeficientov $-\mathrm{R}$ in determinacijskih koeficientov $\mathrm{R}^{2}$ oziroma popravljenih determinacijskih koeficientov - popravljeni $\mathrm{R}^{2}$ za vseh deset let kaže, da največ pojasnjene skupne variance ponazarja kubična funkcijska oblika. Že linearna funkcijska oblika omogoča zanesljivo napovedovanje, popravljeni determinacijskih koeficienti se gibljejo med $0,895 \mathrm{v}$ letu $201 \mathrm{I}$ in $0,923 \mathrm{v}$ letu 2005 , vendar lahko pri tem več skupne pojasnjene variance ponazorimo z uporabo kvadratne funkcijske oblike - popravljeni determinacijski koeficienti se gibljejo $0,896 \mathrm{v}$ letu 2014 in $0,929 \mathrm{v}$ letu 2005 . Še največ pojasnjene skupne variance pa lahko opredelimo znotraj kubične funkcijske oblike, kjer se popravljeni determinacijski koeficienti gibljejo med 0,906 v letu 2014 in $0,954 \mathrm{v}$ letu 2006. Pri tem veljajo enake zakonitosti tudi pri korelacijskih koeficientih, ki so prav tako najvišji pri opredelitvi kubične funkcijske oblike in se tako gibljejo med 0,962 in 0,983 . Za opredelitev dolgoročne stroškovne funkcije izvajalca zdravstvene dejavnosti je tako najprimernejša kubična funkcijska oblika.

Popravljeni determinacijski koeficient znotraj vseh regresijskih modelov je visok, kar pomeni, da gre večina skupne variance na račun pojasnjevalne spremenljivke, zato so omenjeni modeli zadovoljivi za napovedovanje, še posebej ker ne govorimo o vzorcu splošnih bolnišnic, pač pa kar o populaciji vseh slovenskih splošnih bolnišnic. Ob upoštevanem razmerju ena proti deset med odvisno in pojasnjevalnimi spremenljivkami ter visokem popravljenem determinacijskem koeficientu nam prika- 
zani regresijski modeli, ki temeljijo na kubični funkcijski obliki, omogočajo oceno funkcij dolgoročnih celotnih stroškov izvajalcev sekundarne zdravstvene dejavnosti.

Domnevo linearne regresije torej lahko zavrnemo, saj nam rezultati kažejo, da so primernejši nelinearni modeli regresije. Skladno z opisanimi rezultati smo se torej za potrebe naše analize odločili, da bomo dolgoročno funkcijo celotnih stroškov izvajalca zdravstvene dejavnosti ocenili na podlagi kubične funkcijske oblike. To je posledica dejstva, da se izmerjeni podatki najbolje prilagajajo kubični funkcijski obliki. Hkrati je to skladno tudi z ekonomsko teorijo dolgoročne teorije stroškov. Zveza med neodvisno in odvisno spremenljivko je torej kubična, zato lahko poenostavljeno obliko kubične funkcijske oblike dolgoročne stroškovne funkcije zapišemo kot:

$$
T C=\left(x_{i}, x_{i}^{2}, x_{i}^{3}\right),
$$

splošno obliko kubične funkcijske oblike dolgoročne stroškovne funkcije pa kot:

$$
L T C=\beta_{1} x_{i}+\beta_{2} x_{i}^{2}+\beta_{3} x_{i}^{3}+e_{i},
$$

kjer so:

- $\quad$ LTC = dolgoročni celotni stroški,

- $\quad x=$ število obravnavanih bolnikov na leto,

- $\epsilon_{i}=$ slučajna spremenljivka.

Izračunali smo vse vrednosti nelinearnih regresijskih modelov, kar nam je bila osnova za matematične zapise funkcij dolgoročnih celotnih stroškov, ki temeljijo na kubični funkcijski obliki. Pri tem smo opredelili regresijske modele za vsa opazovana leta. Povzetek regresijskih modelov in ocene njihovih parametrov prikazujemo v preglednici is in preglednici 16.

V naslednjem koraku smo želeli preveriti, ali so regresijski modeli kot celota ustrezni, torej ali jih je sploh smiselno uporabiti za nadaljnjo razlago. Za testiranje statističnih značilnosti posameznega regresijskega modela smo uporabili test analize variance za vsako leto opazovanja, kar ponazarjajo F-testi. Iz preglednice is lahko razberemo, da so vrednosti Sig., ki označujejo točno stopnjo značilnosti, $\mathrm{v}$ vseh primerih manjše od 0,05 , to pa pomeni, da ima količinski obseg outputa statistično značilen vpliv na spreminjanje celotnih stroškov. Vrednosti Sig. v vseh letih znašajo o,০oo, kar pomeni, da statistična značilnost velja za celotno obdobje opazovanja. 
Mreža slovenskih splošnih bolnišnic

Preglednica I s: Povzetek regresijskih modelov

\begin{tabular}{ccccccc}
\hline Leto & $\begin{array}{c}\text { Stevilo } \\
\text { opazovanj }\end{array}$ & R & $R^{2}$ & Popravljeni R & F & Sig. \\
\hline 2005 & II & 0,980 & 0,959 & 0,944 & 63,111 & 0,000 \\
\hline 2006 & II & 0,983 & 0,966 & 0,954 & 76,826 & 0,000 \\
\hline 2007 & II & 0,976 & 0,953 & 0,935 & 53,583 & 0,000 \\
\hline 2008 & II & 0,979 & 0,958 & 0,943 & 61,477 & 0,000 \\
\hline 2009 & II & 0,978 & 0,957 & 0,941 & 59,016 & 0,000 \\
\hline 2010 & II & 0,982 & 0,965 & 0,951 & 72,584 & 0,000 \\
\hline 2011 & II & 0,965 & 0,932 & 0,906 & 36,295 & 0,000 \\
\hline 2012 & II & 0,976 & 0,953 & 0,936 & 54,490 & 0,000 \\
\hline 2014 & II & 0,961 & 0,924 & 0,904 & 32,585 & 0,000 \\
\hline
\end{tabular}

Preglednica ı: Ocene parametrov regresijskih modelov

\begin{tabular}{cccc}
\hline Leto & Vrednost parametra Q & Vrednost parametra Q & Vrednost parametra Q \\
\hline 2005 & 431,915 & $-0,003$ & $5,887 \mathrm{E}-9$ \\
\hline 2006 & 469,704 & $-0,003$ & $6,873 \mathrm{E}-9$ \\
\hline 2007 & 466,312 & $-0,003$ & $6,235 \mathrm{E}-9$ \\
\hline 2008 & 532,042 & $-0,003$ & $6,617 \mathrm{E}-9$ \\
\hline 2009 & 558,725 & $-0,003$ & $6,418 \mathrm{E}-9$ \\
\hline 2010 & 621,771 & $-0,004$ & $7,8888 \mathrm{E}-9$ \\
\hline 2011 & 546,112 & $-0,003$ & $6,057 \mathrm{E}-9$ \\
\hline 2012 & 567,183 & $-0,003$ & $6,383 \mathrm{E}-9$ \\
\hline 2013 & 338,670 & $-0,001$ & $2,261 \mathrm{E}-9$ \\
\hline 2014 & 316,379 & $-0,001$ & $1,878 \mathrm{E}-9$ \\
\hline Povprečje & $484,88 \mathrm{1}$ & $-0,003$ & $5,65 \mathrm{E}-09$ \\
\hline
\end{tabular}

Preglednica 16 prikazuje, da v letu 2005 ocene parametrov zavzamejo naslednje vrednosti: $\widehat{\beta_{1}}=431,915, \widehat{\beta_{2}}=-0,00255$, $\widehat{\beta_{3}}=0,00000000589$. To pomeni, da lahko ocenjeno funkcijo dolgoročnih celotnih stroškov na podlagi podatkov za leto 2005 zapišemo kot:

$$
L T C=431,915 Q-0,00255 Q^{2}+0,00000000589 Q^{3} \text {. }
$$


Vletu 2006 znašajo ocene parametrov: $\widehat{\beta_{1}}=469,704, \widehat{\beta_{2}}=-0,00292$ in $\widehat{\beta_{3}}=0,00000000687$. Ocenjeno funkcijo dolgoročnih celotnih stroškov na podlagi podatkov za leto 2006 lahko zapišemo kot:

$$
L T C=469,704 Q-0,00292 Q^{2}+0,00000000687 Q^{3} .
$$

$\mathrm{V}$ letu 2007 ocene parametrov zavzamejo naslednje vrednosti: $\widehat{\beta_{1}}=466,312, \widehat{\beta_{2}}=-0,00272, \widehat{\beta_{3}}=0,00000000624$. To pomeni, da lahko ocenjeno funkcijo dolgoročnih celotnih stroškov na podlagi podatkov za leto 2007 zapišemo kot:

$$
L T C=466,312 Q-0,00272 Q^{2}+0,00000000624 Q^{3} .
$$

V letu 2008 znašajo ocene parametrov: $\widehat{\beta_{1}}=532,042, \widehat{\beta_{2}}=-0,00302$ in $\widehat{\beta_{3}}=0,00000000662$. Ocenjeno funkcijo dolgoročnih celotnih stroškov na podlagi podatkov za leto 2008 lahko zapišemo kot:

$$
L T C=532,042 Q-0,00302 Q^{2}+0,00000000662 Q^{3} .
$$

V letu 2009 ocene parametrov zavzamejo naslednje vrednosti: $\widehat{\beta_{1}}=558,725, \widehat{\beta_{2}}=-0,00306$ in $\widehat{\beta_{3}}=0,00000000642$. To pomeni, da lahko ocenjeno funkcijo dolgoročnih celotnih stroškov na podlagi podatkov za leto 2009 zapišemo kot:

$$
L T C=558,725 Q-0,00306 Q^{2}+0,00000000642 Q^{3} .
$$

V letu 2010 znašajo ocene parametrov: $\widehat{\beta_{1}}=621,771, \widehat{\beta_{2}}=-0,00372$ in $\widehat{\beta_{3}}=0,00000000789$. Ocenjeno funkcijo dolgoročnih celotnih stroškov na podlagi podatkov za leto 20 ro lahko zapišemo kot:

$$
L T C=621,771 Q-0,00372 Q^{2}+0,00000000789 Q^{3} .
$$

$\mathrm{V}$ letu 20I I ocene parametrov zavzamejo naslednje vrednosti: $\widehat{\beta_{1}}=546,112, \widehat{\beta_{2}}=-0,00284, \widehat{\beta_{3}}=0,00000000606$. To pomeni, da lahko ocenjeno funkcijo dolgoročnih celotnih stroškov na podlagi podatkov za leto 20 I z zapišemo kot:

$$
L T C=546,112 Q-0,00284 Q^{2}+0,00000000606 Q^{3} .
$$

V letu 2012 znašajo ocene parametrov: $\widehat{\beta_{1}}=567,183, \widehat{\beta_{2}}=-0,0031$ in $\widehat{\beta_{3}}=0,00000000638$. Ocenjeno funkcijo dolgoročnih celotnih stroškov na podlagi podatkov za leto 20 I 2 lahko zapišemo kot: 


$$
L T C=567,183 Q-0,0031 Q^{2}+0,00000000638 Q^{3} .
$$

$\mathrm{V}$ letu 2013 ocene parametrov zavzamejo naslednje vrednosti: $\widehat{\beta_{1}}=338,67, \widehat{\beta_{2}}=-0,000902, \widehat{\beta_{3}}=0,00000000226$. To pomeni, da lahko ocenjeno funkcijo dolgoročnih celotnih stroškov na podlagi podatkov za leto 2013 zapišemo kot:

$$
L T C=338,67 Q-0,000902 Q^{2}+0,00000000226 Q^{3} .
$$

Vletu 20I 4znašajo ocene parametrov: $\widehat{\beta_{1}}=316,379, \widehat{\beta_{2}}=-0,000706$ in $\widehat{\beta_{3}}=0,00000000188$. Ocenjeno funkcijo dolgoročnih celotnih stroškov na podlagi podatkov za leto 2014 lahko zapišemo kot:

$$
L T C=316,379 Q-0,000707 Q^{2}+0,00000000188 Q^{3} .
$$

Za prikaz povprečnih ocen parametrov regresijskih modelov smo izračunali tudi povprečje vrednosti parametrov $\widehat{\beta}_{1}, \widehat{\beta}_{2}$ in $\widehat{\beta}_{3}$. Rezultati izračunov kažejo, da znaša povprečni koeficient $\widehat{\beta}_{1}=484,881$, povprečni koeficient $\widehat{\beta_{2}}=-0,003$ in povprečni koeficient $\widehat{\beta_{3}}=0,00000000565$.

Posamičen presečni regresijski model in iz njega izhajajoča dolgoročna stroškovna funkcija sicer veliko povesta o zakonitostih gibanja celotnih stroškov in obsega proizvodnje v opazovanem letu, vendar lahko potencialne posebnosti pri poslovanju bolnišnice znotraj opazovanega leta pomembno vplivajo na obliko dolgoročne stroškovne funkcije. Da bi ugotovili, ali znotraj opazovanega obdobja obstajajo morebitna odstopanja, smo poiskali deset dolgoročnih stroškovnih funkcij za deset let, pri čemer smo poskušali opredeliti neko najznačilnejšo obliko dolgoročne stroškovne funkcije. To grafično prikazujemo v sliki 20. Takšna ocena je smiselna predvsem zato, da dobimo zanesljivejši vpogled v dolgoročno stroškovno funkcijo izvajalca zdravstvene dejavnosti, ki je manj pod vplivov morebitnih specifičnih dejavnikov poslovanja, ki lahko izvirajo na primer iz nakazila določenega zneska denarja posamezni splošni bolnišnici za pokritje njenih preteklih izgub.

Iz slike 20 vidimo, da so vse dolgoročne funkcije celotnih stroškov precej podobne. Opazno pa je, da sta regresijska modela, ki sta opredeljena na podlagi podatkov izvajalcev zdravstvene dejavnosti za leto 2013 in 2014 , nekoliko drugačna od preostalih modelov. Kubična funkcijska oblika obeh regresijskih modelov se precej bolj približuje linearni funkcijski obliki. To pomeni, da znotraj omenjenih dveh modelov ekonomije in disekonomije obsega delujejo bistveno manj izrazito, kot to velja pri preo- 
stalih dolgoročnih funkcijah celotnih stroškov. Kljub temu vsi regresijski modeli kažejo podobne zakonitosti gibanja funkcij, kar pomeni, da nam opredelitev optimalne velikosti izvajalca na podlagi funkcije dolgoročnih celotnih stroškov, ki izvira iz presečnih podatkov za eno leto, lahko omogoči relevantno oceno okvirne točke optimalnega obsega proizvodnje oziroma optimalne velikosti izvajalca zdravstvene dejavnosti.

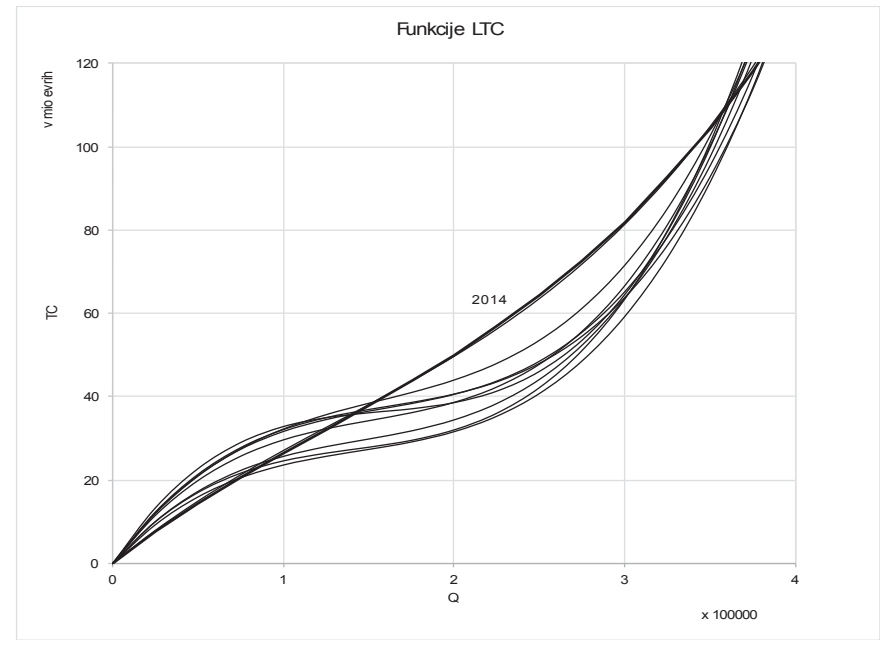

Slika 2o: Ocenjene funkcije dolgoročnih celotnih stroškov

Za definiranje optimalne velikosti izvajalca sekundarne zdravstvene dejavnosti je seveda smiselno podrobneje analizirati zadnje opazovano leto oziroma funkcijo dolgoročnih celotnih stroškov, ki izhaja iz zadnjega leta, za katerega so podatki na voljo. To je namreč krivulja celotnih stroškov izvajalcev zdravstvene dejavnosti na dolgi rok, ki je najaktualnejša glede na opazovano obdobje. Skladno s tem v nadaljevanju podrobneje prikažemo postopek definiranja optimalne velikosti izvajalca sekundarne zdravstvene dejavnosti na osnovi dolgoročne stroškovne funkcije, ki je opredeljena na podlagi podatkov o celotnih stroških in količinskem obsegu outputa splošnih bolnišnic za leto 2014.

$\mathrm{V}$ nadaljevanju torej predstavljamo rezultate empirične in grafične analize dolgoročne stroškovne funkcije za izvajalca sekundarne zdravstvene dejavnosti, ki se nanaša na podatke splošnih bolnišnic za leto 2014. Empirično analizo smo razdelili v dva dela. V prvem delu smo v okviru diskretne analize ugotavljali vrednosti dolgoročnih povprečnih stroškov in dolgoročnih mejnih stroškov, ki so bile izračunane na podlagi nume- 
ričnih vrednosti, podanih v obliki tabele. $V$ drugem delu pa smo za potrebe zvezne analize izpeljali matematične specifikacije funkcije dolgoročnih povprečnih stroškov in dolgoročnih mejnih stroškov. Na podlagi matematičnih zapisov smo lahko izračunali količino proizvodnje oziroma količinski obseg outputa, pri katerem ima izvajalec sekundarne zdravstvene dejavnosti optimalno velikost. $V$ okviru grafične analize pa smo ugotavljali obnašanje krivulj dolgoročnih celotnih stroškov, dolgoročnih povprečnih stroškov in dolgoročnih mejnih stroškov ter premice cene. Preverjali smo osnovne ekonomske zakonitosti in grafično odčitali, ali je optimalna velikost izvajalca sekundarne zdravstvene dejavnosti v minimumu dolgoročnih povprečnih stroškov.

\section{Diskretna analiza optimalne velikosti izvajalca zdravstvene dejavnosti}

Diskretna analiza ponazarja dolgoročno stroškovno funkcijo v tabelarični obliki. V ekonomski teoriji je to običajen način predstavitve stroškovnih funkcij, saj nam opazovanja nekega izvajalca običajno ponazarjajo različne kombinacije količin outputa in celotnih stroškov, ki jih ima ponudnik, v našem primeru izvajalec sekundarne zdravstvene dejavnosti, zaradi porabe proizvodnih dejavnikov. Podatke o outputu, celotnih in povprečnih stroških za leto $20 \mathrm{I} 4$ prikazujemo v preglednici 17.

Preglednica I7: Podatki o outputu, celotnih in povprečnih stroških za leto 2014

\begin{tabular}{cccc} 
Opazovanje & $\begin{array}{c}\text { Output }(\mathbf{Q} \text { vobliki števila } \\
\text { obravnavanih bolnikov }\end{array}$ & $\begin{array}{c}\text { Celotni stroški (TC) } \\
\text { v evrih }\end{array}$ & $\begin{array}{c}\text { Povprečni stroški (AC) } \\
\text { v evrih }\end{array}$ \\
\hline I & 76.552 & 14.748 .124 & 192,655 \\
\hline 2 & 396.428 & 90.845 .914 & 229,161 \\
\hline 3 & 156.791 & 39.627 .853 & 252,743 \\
\hline 4 & 130.131 & 31.634 .285 & 243,096 \\
\hline 5 & 393.285 & 171.519 .001 & 436,119 \\
\hline 6 & 207.562 & 43.030 .130 & 207.312 \\
\hline 7 & 140.942 & 41.286 .450 & 292,932 \\
\hline 8 & 193.941 & 50.391 .518 & 259,829 \\
\hline 9 & 85.318 & 23.316 .024 & 273,284 \\
\hline IO & 109.436 & 38.111 .431 & 2258,253 \\
\hline II & 65.658 & 14.798 .157 & \\
\hline
\end{tabular}


Celotni stroški nam torej povedo, kakšni denarni izdatki so potrebni za proizvodnjo določene količine outputa (Žižmond idr. 2005; Bojnec idr. 2007; Samuelson in Nordhaus 2010). Dolgoročni celotni stroški so zrcalna slika dolgoročnega celotnega proizvoda in so posledica učinkov zakona donosov obsega. Najprej na celotne stroške vplivajo naraščajoči, kasneje pa padajoči donosi obsega (Tajnikar 2006a; Rebernik 2008; Samuelson in Nordhaus 20I0). Dolgoročni celotni stroški torej najprej naraščajo po padajočih stopnji, pri večjem obsegu proizvodnje pa po naraščajočih stopnjah.

Povprečni stroški izbrane ravni outputa merijo, koliko v povprečju stane proizvedena enota outputa (Žižmond idr. 2005; Bojnec idr. 2007; Samuelson in Nordhaus 2010). V primeru, ko se nahajamo na območju naraščajočih donosov obsega in so cene inputov enake, dolgoročni povprečni stroški upadajo. $\mathrm{V}$ tem primeru imamo opravka z ekonomijami obsega. Če se nahajamo na območju naraščajočih dolgoročnih povprečnih stroškov, pa govorimo o disekonomijah obsega (Tajnikar 2006a; Bojnec idr. 2007; Rebernik 2008; Samuelson in Nordhaus 2010).

Mejni stroški merijo, za koliko se spremenijo celotni stroški, če ponudnik proizvede dodatno (mejno) enoto outputa (Žižmond idr. 2005; Bojnec idr. 2007; Samuelson in Nordhaus 2010). Dolgoročni mejni stroški so nižji od dolgoročnih povprečnih stroškov, dokler ti padajo, pri vrednosti, pri kateri so dolgoročni povprečni stroški minimalni, imajo dolgoročni mejni stroški enako vrednost, ko dolgoročni povprečni stroški naraščajo, pa so dolgoročni mejni stroški višji (Tajnikar 2006a; Rebernik 2008; Samuelson in Nordhaus 2010).

\section{Zvezna analiza optimalne velikosti izvajalca zdravstvene dejavnosti}

Rezultati diskretne analize so primerni za praktično uporabo, vendar izračuni pogosto niso natančni. $V$ tem primeru lahko vrednosti posameznih analitičnih konceptov izračunamo zgolj na podlagi diskretnih vrednosti o celotnih stroških in obsegu proizvodnje. Mejne stroške lahko tako izračunamo zgolj za dodatno enoto outputa, ne moremo pa jih izračunati za infinitezimalno majhno spremembo.

Za potrebe zahtevnejše analize je tako primernejšaa uporaba zvezne analize. $\mathrm{Za}$ uporabo te metode smo potrebovali dolgoročno stroškovno funkcijo, ki je podana v obliki zvezne matematične funkcije. $S$ pomočjo nelinearnega regresijskega modela smo prišli do ocenjene dolgoročne funkcije celotnih stroškov, ki temelji na podatkih o celotnih stroških in količinskem obsegu proizvodnje izvajalcev zdravstvene dejavnosti v letu 
2014. Dolgoročna stroškovna funkcija, ki velja za izvajalca sekundarne zdravstvene dejavnosti, ima naslednjo kubično funkcijsko obliko:

$$
L T C=316,379 Q-0,000707 Q^{2}+0,00000000188 Q^{3} .
$$

Dolgoročni celotni stroški v tem primeru niso podani z diskretno vrednostjo, ampak so izraženi kot funkcija količinskega obsega proizvodnje. $Q$ predstavlja output v obliki števila obravnavanih pacientov in določa višino dolgoročnih celotnih stroškov.

Če želimo izračunati dolgoročno funkcijo povprečnih stroškov, moramo najprej opredeliti splošno formulo dolgoročnih povprečnih stroškov, ki pravi, da je treba dolgoročne celotne stroške deliti s spremenljivko, ki meri obseg proizvodnje:

$$
L A C=\frac{L T C}{Q} .
$$

$\mathrm{V}$ našem primeru smo dolgoročne povprečne stroške izračunali na naslednji način:

$$
\begin{aligned}
& L A C=\frac{316,379 Q-0,000707 Q^{2}+0,00000000188 Q^{3}}{Q} \\
& L A C=316,379-0,000707 Q+0,00000000188 Q^{2} .
\end{aligned}
$$

Zvezna analiza nam omogoča izračun dolgoročnih mejnih stroškov kot odvod funkcije dolgoročnih celotnih stroškov po spremenljivki, ki meri obseg proizvodnje. Splošni definicijski obrazec za izračun dolgoročnih mejnih stroškov pri zvezni analizi je torej:

$$
L M C=\frac{\partial L T C}{\partial Q} .
$$

V našem primeru smo dolgoročne mejne stroške izračunali tako, da smo odvajali dolgoročno funkcijo celotnih stroškov po spremenljivki $Q$ :

$$
\begin{aligned}
& L M C=\frac{\partial\left(316,379 Q-0,000707 Q^{2}+0,00000000188 Q^{3}\right)}{\partial Q} \\
& L M C=316,379-0,00141 Q+0,00000000564 Q^{2} .
\end{aligned}
$$

Povedali smo, da je optimalna velikost izvajalcev zdravstvene dejavnosti pri velikosti, ki daje minimalne dolgoročne povprečne stroške. To velja v primeru, ko je tržna cena postavljena na raven minimalnih dolgoročnih povprečnih stroškov splošne bolnišnice in če ta minimira stroške 
ter maksimira prihodke. Če želimo izračunati optimalno velikost splošne bolnišnice, moramo torej izračunati še minimum dolgoročnih povprečnih stroškov. To naredimo tako, da funkcijo dolgoročnih povprečnih stroškov najprej odvajamo, nato pa jo enačimo z 0 :

$$
\begin{aligned}
& \frac{\partial L A C}{\partial Q}=-0,000707+0,00000000376 Q \\
& -0,000707+0,00000000376 Q=0 \\
& Q=188031,915 .
\end{aligned}
$$

Rezultat nam pokaže, da je optimalna velikost slovenske splošne bolnišnice pri 188.032 bolnikih letno. To je raven proizvodnje, pri kateri so ekonomije obsega največje. Povprečna cena storitve, ki jo plačuje plačnik zdravstvenih storitev, znaša v opazovanem obdobju 309,6I evrov. To pomeni, da je cena na trgu nad minimalnimi dolgoročnimi povprečnimi stroški bolnišnice, zato je tudi optimalna velikost bolnišnice ustrezno večja, saj mejni stroški naraščajo s količino ponudbe. Če želimo izračunati, kje je točka maksimalnega dobička oziroma optimalne velikosti bolnišnice, moramo izenačiti bolnišnične dolgoročne mejne stroške $\mathrm{z}$ dano ceno na trgu. Če povprečno ceno na storitev izenačimo z dolgoročnimi mejni stroški, dobimo:

$$
\begin{aligned}
& L M C=316,379-0,00141 Q+0,00000000564 Q^{2} \\
& 316,379-0,00141 Q+0,00000000564 Q^{2}=309,61 \\
& Q=245103,383 .
\end{aligned}
$$

Vidimo torej, da je glede na obstoječe stanje optimalna velikost splošne bolnišnice pri večjem obsegu proizvodnje in ne na ravni minimalnih dolgoročnih povprečnih stroškov. To je posledica dejstva, da je plačnik zdravstvenih storitev postavil povprečno ceno storitve na višjo raven. Takšen rezultat dobimo tako $\mathrm{v}$ primeru ocenjevanja optimalne velikosti izvajalca sekundarne zdravstvene dejavnosti na podlagi podatkov splošnih bolnišnic za leto 20I4, kot tudi pri ocenjevanju optimalne velikosti izvajalca na podlagi podatkov splošnih bolnišnic za vsa preostala leta. $Z$ vidika vodenja splošne bolnišnice sta za vodstvo pomembna oba prikazana rezultata, na eni strani je ključna informacija tista, ki pove, pri kateri količini proizvodnje ima splošna bolnišnica najnižje stroške na enoto proizvedenega outputa, na drugi strani pa je pomemben tudi rezultat, ki opredeli točko maksimalnega dobička oziroma optimalne velikosti splošne bolnišnice. 
Če dobljene rezultate primerjamo s podatki o količini proizvedenega outputa posameznih izvajalcev zdravstvene dejavnosti, vidimo, da se nobena od slovenskih splošnih bolnišnic ne nahaja natanko na točki optimalne velikosti. Se pa izmed vseh splošnih bolnišnic optimalni velikosti najbolj približata Splošna bolnišnica Celje in Splošna bolnišnica Murska Sobota. Ostale splošne bolnišnice odstopajo bistveno bolj od obsega proizvodnje, ki omogoča doseganje maksimalnega dobička. Če pri tem upoštevamo rezultate, ki smo jih dobili z analizo SFA in analizo DEA, lahko ugotovimo, da se rezultati opredelitve optimalne velikosti izvajalca zdravstvene dejavnosti bistveno bolj skladajo z rezultati, ki jih je podala metoda SFA. Skladno z metodo SFA namreč najvišje mere učinkovitosti dosega Splošna bolnišnica Celje, pri čemer pa vidimo, da Splošna bolnišnica Celje spada tudi v skupino bolnišnic, ki se na podlagi ocenjevanja dolgoročnih stroškovnih funkcij najbolj približajo optimalni velikosti. Skladno z metodo DEA najvišje mere učinkovitosti dosega Splošna bolnišnica Brežice, pri čemer pa se ta bolnišnica na podlagi ocenjevanja dolgoročnih stroškovnih funkcij ne nahaja v bližini točke optimalne velikosti bolnišnice.

Pri regresijskih modelih smo uporabili presečne podatke za slovenske splošne bolnišnice, pri čemer smo definiranje optimalne velikosti izvajalca sekundarne zdravstvene dejavnosti podrobneje prikazali na osnovi dolgoročne funkcije celotnih stroškov, ki je ocenjena na podlagi podatkov splošnih bolnišnic za leto 20I4. Zaradi majhnega števila enot opazovanja ne moremo s popolno gotovostjo trditi, da je točka optimalne velikosti izvajalca zdravstvene dejavnosti natanko pri obravnavi $245.83 \mathrm{I}$ bolnikov letno. Za potrditev te trditve bi morali razpolagati z večjim številom splošnih bolnišnic, vendar znotraj slovenskega zdravstvenega sistema deluje zgolj dvanajst splošnih bolnišnic, kar nam ne omogoča opazovanja večjega števila enot.

$\mathrm{Za}$ večjo relevantnost rezultatov smo opredelili regresijske modele ocenjevanja dolgoročnih stroškovnih funkcij za vseh deset let opazovanj; ti kažejo zelo podobne trende naraščanja in padanja posameznih delov funkcij. Optimalno velikost izvajalca sekundarne zdravstvene dejavnosti smo tako definirali tudi na osnovi dolgoročnih funkcij celotnih stroškov, ki niso ocenjene zgolj na podlagi podatkov splošnih bolnišnic za leto 2014 , ampak so ocenjene tudi na podlagi podatkov splošnih bolnišnic za vsa preostala leta opazovanja. Glede na podobne trende gibanja različnih stroškovnih funkcij je tudi optimalna velikost izvajalca sekundarne zdravstvene dejavnosti v ostalih primerih pri podobnem obsegu proizvodnje. Optimalna velikost splošne bolnišnice se tako skladno z različnimi ocenami dolgoročnih stroškovnih funkcijah giblje med 245.83 I in 274.992 enotami outputa. Skladno s tem lahko sklepamo, da je točka 
opredelitve optimalne velikosti izvajalca sekundarne zdravstvene dejavnosti povsem skladna z našim namenom. Na tem mestu smo namreč želeli pokazati zgolj nekatere zakonitosti, ki veljajo pri ocenjevanju dolgoročnih stroškovnih funkcij, poleg tega pa so nam dobljeni rezultati zgolj v pomoč pri definiranju ekonomsko najučinkovitejše slovenske splošne bolnišnice.

\section{Grafična analiza optimalne velikosti izvajalca zdravstvene dejavnosti}

Z grafično analizo lahko vizualno predstavimo zakonitosti bodisi z uporabo podatkov iz diskretne analize bodisi $\mathrm{z}$ uporabo podatkov zvezne analize. Ker daje zvezna analiza natančnejše podatke, smo za izpeljavo grafične analize uporabili te podatke. Grafična analiza stroškovnih funkcij vizualno predstavlja zakonitosti spreminjanja posameznih konceptov stroškov v odvisnosti od količinskega obsega proizvodnje. S pomočjo grafične analize smo pojasnili tudi ključne zakonitosti, ki veljajo v mikroekonomski teoriji podjetja. V slikah $2 \mathrm{I}$ in 22 je prikazano gibanje dolgoročnih celotnih stroškov, dolgoročnih povprečnih stroškov, dolgoročnih mejnih stroškov in premica cene, ki temeljijo na podatkih splošnih bolnišnic v letu 2014.

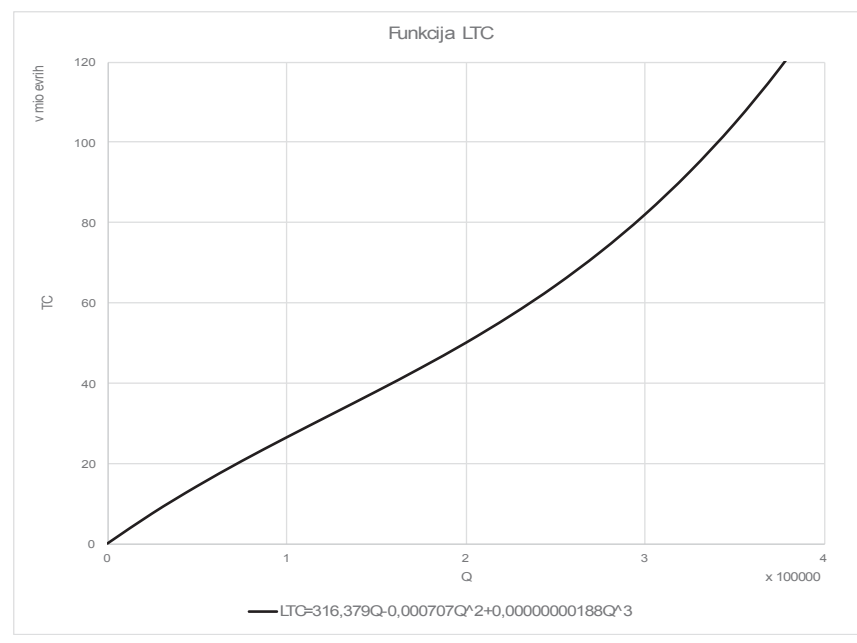

Slika 21: Ocenjena funkcija dolgoročnih celotnih stroškov

Gibanje funkcije celotnih stroškov je v skladu z izpeljavo kubične funkcijske oblike dolgoročnih celotnih stroškov opazovane bolnišnice. Za krivuljo dolgoročnih povprečnih stroškov je značilno, da je inverzna slika krivulje dolgoročnega celotnega proizvoda ter da je posledica učinkov zakona donosa obsega. Nanjo najprej vplivajo naraščajoči donosi obsega, kar se kaže z naraščanjem stroškov po padajoči stopnji rasti, kasneje 
pa nanjo vplivajo padajoči donosi obsega, kar pomeni, da stroški začnejo naraščati vse hitreje. To je razvidno tudi iz krivulje gibanja dolgoročnih celotnih stroškov, kjer imamo opravka z naraščajočimi donosi obsega do vrednosti približno I 80.000 enot outputa, od te vrednosti dalje pa celotni stroški naraščajo po vedno višji stopnji, kar je posledica padajočih donosov obsega.

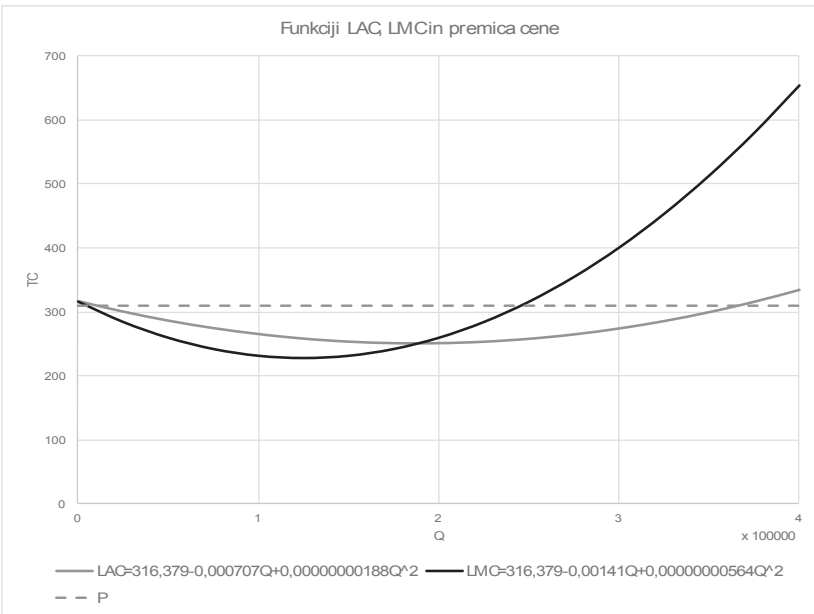

Slika 22: Ocenjena funkcija dolgoročnih povprečnih in dolgoročnih mejnih stroškov, ter premica cene

Iz funkcije dolgoročnih celotnih stroškov lahko izpeljemo funkcijo dolgoročnih povprečnih stroškov. Dolgoročni povprečni stroški se zmanjšujejo, dokler so dolgoročni mejni stroški nižji od njih, saj nižji mejni stroški kažejo, da vsaka dodatna enota outputa stane bolnišnico manj, kot so v povprečju stali do te enote proizvedeni outputi. Na dolgi rok se torej povprečni stroški zmanjšujejo do obravnave $\mathrm{i} 88.032$ bolnikov letno, kar smo izračunali že v zvezni analizi dolgoročnih povprečnih stroškov. Dolgoročni povprečni stroški potem naraščajo, ko so dolgoročni mejni stroški višji od njih, saj tedaj dodatno proizvedene enote outputa stanejo več, kot so v povprečju stale do teh enot proizvedene enote outputa, to pomeni od obravnave 188.032 bolnikov naprej. V primeru, ko splošna bolnišnica obravnava I 88.032 bolnikov letno, znašajo njeni dolgoročnimi povprečnimi stroški približno 250 evrov, kar pomeni, da bolnišnico ena obravnava bolnika v povprečju stane približno 250 evrov.

Mejni stroški se grafično izrazijo s tangento na funkcijo dolgoročnih celotnih stroškov. Oblika dolgoročnih mejnih stroškov je podobna obliki dolgoročnih povprečnih stroškov. Dolgoročni mejni stroški tako v za- 
četku padajo, dosežejo svoj minimum, nato pa začnejo naraščati. Ker je prevojna točka pri funkciji dolgoročnih mejnih stroškov pri manjših količinah proizvedenega outputa, kot so količine, pri katerih premica s koordinatnega izhodišča doseže svoj položaj tangente na funkcijo dolgoročnih povprečnih stroškov, je najmanjša vrednost funkcije dolgoročnih mejnih stroškov pri manjših količinah outputa kot najmanjša vrednost dolgoročnih povprečnih stroškov. To je razvidno tudi iz grafa gibanja krivulje dolgoročnih mejnih stroškov, kjer vidimo, da funkcija dolgoročnih mejnih stroškov doseže svoj minimum pri približno I 25.000 bolnikih letno. Pri tej količini obravnave bolnikov dolgoročni mejni stroški znašajo približno 282 evrov.

Grafično lahko pogledamo še presečišče dane tržne cene in mejnih stroškov. Za izvajalca zdravstvene dejavnosti je značilno, da deluje ob danih cenah, saj cene zdravstvenih storitev postavlja plačnik javnega zdravstva. Pri zdravstvenemu varstvu gre namreč za reguliran trg, kjer ceno na trgu določi plačnik, kar pomeni, da izvajalec zdravstvene dejavnosti ne more vplivati na ceno storitev, ki jih ponuja na trgu. Pri tem je pomembno dejstvo, da je zanj tržna cena dana ne glede na to, kakšen je obseg njegove proizvodnje. Premica, ki to ceno kaže grafično, je premica cene. Iz grafa lahko vidimo, da je ta cena postavljena na raven pri približno 3 ro evrih.

Premica cene je pomembna, ker lahko na podlagi njene vrednosti definiramo količino proizvodnje, pri kateri bo bolnišnica dosegla maksimalen dobiček. Mejni stroški pomenijo dodatne stroške, ki nastanejo s proizvodnjo ene dodatne enote outputa, cena pa je zaslužek, ki ga bolnišnica doseže s prodajo dodatne enote outputa. Vse dokler je cena višja od dolgoročnih mejnih stroškov, to pa je do presečišča krivulj dolgoročnih mejnih stroškov in premice cene, so prihodki bolnišnice s prodajo dodatnih enot outputa večji kot stroški proizvodnje teh enot. Ko so dolgoročni mejni stroški višji od cene dodatno proizvedene enote outputa, pa bolnišnico dodatno proizvedena enota outputa stane več, kot je njen prihodek s prodajo teh enot. Maksimalen dobiček bolnišnice je torej pri količini outputa, pri kateri so dolgoročni mejni stroški enaki ceni outputa. Že pri zvezni analizi dolgoročne funkcije mejnih stroškov smo izračunali, da je to vrednost, kjer bolnišnica letno obravnava 245.83 I bolnikov, kar je nazorno potrjuje tudi slika 22.

Ne glede na omejitve, ki izhajajo iz analize optimalne velikosti izvajalca zdravstvene dejavnosti, je dolgoročna stroškovna funkcija lahko eno od koristnih orodjih pri vodenju splošne bolnišnice. Ocene dolgoročnih stroškovnih funkcij lahko vodstvo splošnih bolnišnice uporabi predvsem pri sprejemanju odločitev o prihodnjem poslovanju. $\mathrm{V}$ procesu odloča- 
nja mora manager jasno razumeti odnos med inputi in količinskim obsegom proizvodnje na eni strani ter med proizvodnjo in stroški na drugi strani. Skladno s tem obstaja za vodstvo splošnih bolnišnic možnost, da na osnovi predstavljenih ocen dolgoročnih stroškovnih funkcij povečajo svoj dobiček, in sicer na način, da zmanjšajo svoje proizvodne stroške, kar povzroči tudi večjo učinkovitost posamezne splošne bolnišnice.

Moramo pa na tem mestu opozoriti še na eno dejstvo, in sicer, da so ocene dolgoročnih stroškovnih funkcij zgolj matematične ocene, ki ponazarjajo odnos med količino proizvodnje in posameznimi vrstami stroškov, zanemarjajo pa druge dejavnike, ki prav tako lahko vplivajo na obseg proizvodnje. Lahko se torej zgodi, da posamezni splošni bolnišnici zaradi vpliva drugih dejavnikov in ne zgolj zaradi proizvodnih stroškov ne bo uspelo doseči izračunane optimalne ravni proizvodnje. $V$ tem primeru je torej smiselno, da bolnišnica količino proizvodnje ustrezno spremeni glede na specifične dejavnike, ki so značilne za posamezen proizvodni obrat. Ocene dolgoročnih stroškovnih funkcij predstavljajo zgolj eno izmed orodij, kar pomeni, da mora vodstvo kljub vsemu upoštevati tudi določene posebnosti znotraj posamezne splošne bolnišnice. 


\section{Optimalna lokacija izvajalcev zdravstvene dejavnosti}

V tem delu monografije se ukvarjamo z določitvijo optimalnih lokacij izvajalcev sekundarne zdravstvene dejavnosti. V drugem delu monografije smo za potrebe oblikovanja učinkovite mreže sekundarne zdravstvene dejavnosti analizirali mere učinkovitosti splošnih bolnišnic, v tretjem delu smo opredelili njihovo optimalno velikost, rezultat četrtega dela monografije pa je opredelitev optimalnih lokacij in števila izvajalcev sekundarne zdravstvene dejavnosti. S tem odgovorimo na vprašanje, kje morajo biti splošne bolnišnice locirane in koliko splošnih bolnišnic potrebujemo znotraj mreže sekundarne zdravstvene dejavnosti. Na ta način lahko prikažemo možne projekcije postavitve mreže sekundarne zdravstvene dejavnosti v Sloveniji.

Pri oblikovanju mreže zdravstvene dejavnosti smo sledili cilju maksimiranja dostopnosti do posameznega bolnika. To pomeni, da je bilo treba zagotoviti, da se zdravstvene storitve čim bolj približajo posameznemu bolniku, pri čemer je ključni dejavnik dostopnosti lokacija izvajalcev. Pri oblikovanju mreže pa nismo sledili zgolj cilju maksimiranja dostopnosti do posameznega bolnika, temveč smo upoštevali tudi cilj maksimiranja učinkovitosti izvajalcev ob upoštevanju njihove optimalne velikosti, ki smo ju podrobno razdelali v drugem in tretjem delu monografije.

Skladno s tem smo oblikovali mrežo sekundarne zdravstvene dejavnosti, ki dosega dva cilja, ki sta že na prvi pogled konfliktna. Po eni strani smo mrežo sekundarne zdravstvene dejavnosti oblikovali na način, da smo zagotovili visoko stopnjo geografske dostopnosti, na drugi strani pa smo zagotovili tudi racionalno obliko delovanja izvajalcev zdravstvenih storitev. Konfliktnost med obema ciljema ni omogočala istočasnega ma- 
ksimiranja obeh. Oblikovana mreža sekundarne zdravstvene dejavnosti tako vzpostavlja ravnotežje med čim večjo dostopnostjo do zdravstvenih storitev na eni strani ter ustrezno stopnjo koncentracije zdravstvenih dejavnosti, ki z doseganjem optimalne velikosti izvajalcev zagotavljata njihovo učinkovitost na drugi strani.

\section{Teoretične iztočnice optimalne lokacije izvajalcev zdravstvene dejavnosti}

Učinkovito mrežo zdravstvenega varstva lahko dosežemo, če z danimi inputi za zdravstveno varstvo dosežemo maksimalno korist za prebivalstvo. Pri tem izhajamo iz predpostavke, da je koristnost istosmerno povezana z maksimiranjem dostopnosti do zdravstvenih storitev. Maksimalno koristnost lahko torej dosežemo z opredelitvijo optimalnih lokacij izvajalcev zdravstvenih storitev, ki se morajo v čim večji meri približati posameznim prebivalcem. Definiranje optimalnih lokacij pa od nas zahteva poznavanje teoretičnih izhodišč dostopnosti do zdravstvenega varstva, možne načine merjenja prostorske dostopnosti, poznavanje primernih potovalnih časov do izvajalcev zdravstvene dejavnosti in poznavanje možnih modelov ocenjevanja optimalnih lokacij.

\section{Opredelitev pojma dostopnost do zdravstvenega varstva}

Khan in Bhardwaj (1994) pravita, da ima pojem dostopnost do zdravstvenega varstva več definicij, zato se njegov pomen $v$ danem kontekstu pogosto predpostavlja. $\mathrm{Na}$ različne pomene pojma dostopnosti je opozoril tudi Guagliardo (2004), ki je predlagal upoštevanje različnih stopenj in dimenzij dostopnosti. Dve najširši stopnji sta potencial izvršitve zdravstvene oskrbe (angl. potential for care delivery), ki mu sledi realizirana izvršitev zdravstvene oskrbe (angl. realized delivery of care). Potencial zdravstvene oskrbe obstaja v primeru, ko je povpraševanje prisotno $v$ istem času in prostoru kot sistem nudenja zdravstvene oskrbe. Realizirana zdravstvena oskrba pa sledi, ko so vse ovire za njeno zagotovitev premagane. Številne ovire lahko pogosto onemogočajo napredovanje iz potenciala v realizirano zdravstveno oskrbo.

Penchansky in Thomas (198I) sta ovire združila v pet različnih dimenzij: razpoložljivost, dostopnost, dosegljivost, sprejemljivost in prilagojenost. Podobno v novejši literaturi navajajo tudi drugi avtorji (Peters idr. 2008; Levesque, Harris in Russell 2013). Največ pozornosti je običajno namenjene zadnjim trem dimenzijam, ki odražajo ureditev financiranja zdravstvenega varstva. Razpoložljivost in dostopnost sta po naravi 
prostorski dimenziji. Razpoložljivost odraža število lokacij zdravstvenih storitev, med katerimi lahko bolniki izbirajo. Dostopnost pa se nanaša na razdaljo ali potovalni čas, ki ga potrebujejo bolniki do najbližjega izvajalca zdravstvenih storitev. Razlikovanje med pojmom razpoložljivost in dostopnost je v nekaterih primerih nujno potrebno, vendar se moramo po drugi strani zavedati, da je treba v primeru, ko imamo na voljo več različnih zdravstvenih storitev na istem območju, dimenziji razpoložljivost in dostopnost obravnavati hkrati. Skupen izraz, ki zajema obe dimenziji in se je $\mathrm{v}$ zadnjem času precej dobro uveljavil tako v zdravstveni geografiji kot tudi zdravstveni ekonomiki, je pojem prostorska dostopnost (Luo in Wang 2003a; Guagliardo idr. 2004; Luo 2004).

V splošnem se povpraševanje prebivalstva ne ujema s prostorsko porazdelitvijo izvajalcev zdravstvene dejavnosti (Parker in Campbell 1998; Luo in Wang 2003b; Guagliardo idr. 2004). Cilj zmanjšanja neenakosti pri dostopu do zdravstvenih storitev še zdaleč ni dosežen. Rosenberg in Hanlon (1996) navajata, da imajo posamezniki z višjimi dohodki boljši dostop do družinskih zdravnikov, poleg tega pa ohranjajo višji zdravstveni status in se bolj poslužujejo preventivnega zdravljenja. S. McLafferty in Wang (2009) navajata, da pri prebivalcih z nižjim socialno-ekonomskim položajem odkrijejo posamezne vrste raka v bistveno poznejši fazi. Zdravje prebivalstva, ki imajo višje dohodke, se izboljšuje hitreje, kar pomeni, da prebivalci iz različnih socialno-ekonomskih skupin skrbijo za svoje zdravstveno stanje v različni meri. Izobrazba, zaposlenost, dohodek in socialna varnost vplivajo na življenjski slog posameznika, ta pa vliva na zdravje prebivalcev. Poleg tega uporaba zdravil in zdravstvenih storitev vpliva na obolevnost, umrljivost in pričakovano življenjsko dobo (Wang, Rosenberg in Lo 2008; McLafferty in Wang 2009; Meliker, Goovaerts idr. 2009; Meliker, Jacquez idr. 2009). Na dostopnost do zdravstvenega varstva torej močno vpliva okolje, zato ni presenetljivo, da pomanjkanje ponudbe zdravstvenega varstva še posebej prizadene podeželje in revne mestne skupnosti (Rosenblatt in Lishner 1991; Shen 1998; Rosenthal, Zaslavsky in Newhouse 2005).

Pri razumevanju tega pojava je torej zelo pomembno, da raziskovanje prostorske dostopnosti poteka $\mathrm{v}$ skladu $\mathrm{z}$ večdimenzionalnim konceptom pogojene interakcije med različnimi prostorskimi dejavniki (geografska lokacija, potovalna razdalja) in drugimi dejavniki (socialno-ekonomski status, starost, spol in etična pripadnost) (Joseph in Bantock 1984; Meade in Earickson 2000; Wang 2012). Teoretično bi torej morali biti izvajalci zdravstvenih storitev locirani glede na potencialno povpraševanje, torej predvsem na območjih, kjer so potrebe ljudi po zdravstvenem varstvu 
največje. V realnosti pa se dogaja, da ravno območja, kjer obstaja največje povpraševanje po določenih zdravstvenih storitvah, pogosto ne zagotavljajo pokritosti z izvajalci. Shi in soavtorji (2OI2) so tako v svoji študiji opredelili področja, kjer prebivalci nimajo dostopa do večjih izvajalcev zdravstvenih storitev, ki se ukvarjajo z zdravljenjem rakavih obolenj. V ZDA so na primer na območju, kjer je zaznano največje povpraševanje po onkološkem zdravljenju, odkrili največje nepokrito območje z izvajalci, ki zdravijo rakava obolenja. Prostorsko neskladje med različnimi geografskimi lokacijami zdravstvenih izvajalcev na eni strani in povpraševanjem prebivalcev na drugi strani predstavlja za oblikovalce zdravstvene politike ključen izziv pri zagotavljanju dostopnosti do zdravstvenega varstva.

\section{Sinteza dostopnosti do zdravstvenega varstva}

Oddaljenost izvajalca zdravstvenih storitev je predstavljala pomembno oviro za dostop do zdravstvenega varstva že v i9. stoletju (Jarvis I852; Hunter, Shannon in Sambrook 1986). Do leta 1970 je bilo veliko poskusov merjenja prostorske dostopnosti storitev zdravstvenega varstva, opredelitev področij pomanjkanja izvajalcev zdravstvenih storitev in razkritja socialnih razlik v dostopnosti do storitev zdravstvenega varstva glede na mestna in podeželska območja (Ciocco in Altman 1954; Morrill, Earickson in Rees 1970; Elesh in Schollaert 1972; Wennberg in Gittelsohn 1973; Shannon in Dever 1974). To so bila že v tistem času dnevno politična vprašanja. Poročilo U.S. National Advisory Commission on Health Manpower (1967) navaja, da imajo premožne soseske bistveno večje število zdravstvenih delavcev v primerjavi z revnejšimi predeli. Vse to je spodbudilo, da se je zdravstvena politika začela osredotočati tudi na podeželska in mešana podeželska območja, kljub pomanjkanju konsenza o tem, kako je najbolje opredeliti prostorsko dostopnost izvajalcev zdravstvenih storitev (Joseph in Bantock 1982; Connor, Hillson in Krawelski 1995; Goodman idr. 1997; Fryer idr. 1999; Shi idr. 1999; Fortney, Rost in Warren 2000; Luo in Wang 2003a). V istem obdobju je bilo gorivo zelo velika ovira, kar je povzročilo nastanek redkeje poseljenih območij, ki pa so bila povezana tudi z upadanjem zdravja prebivalstva in upadanjem zdravstvene delovne sile (Salsberg in Forte 2002).

Zaskrbljenost zaradi slabe dostopnosti do zdravstvenih storitev na podeželskih območjih je še vedno visoka (Council on Graduate Medical Education 1998; Heinrich 200I). Dostopnosti do izvajalcev zdravstvenih storitev na podeželskih območjih, z nekaj izjemami (McGuirk in Porell 1984; Gesler in Meade 1988), analitično niso preučevali vse do sredine sedemdesetih let preteklega stoletja. Eden od razlogov je, da so intuitivni 
prostorski indikatorji nedvomno primernejši za redkeje poseljena območja, medtem ko pri gosteje naseljenih mestnih območjih nimajo tako pomembne vloge. Ironično je, da upadanje raziskav s področja dostopnosti do zdravstvenih storitev sovpada $\mathrm{z}$ večjo razpoložljivostjo zmogljive programske in strojne opreme, ki je potrebna za relevantnejše študije. Razlog lahko iščemo v tem, da je lokacije obstoječih izvajalcev zdravstvene dejavnosti težko spreminjati, predvsem pa je pri tem potrebne veliko politične volje, kar raziskovalce običajno odvrača, da bi se lotevali temeljitih analiz dostopnosti do zdravstvenih storitev.

V novejši literaturi obstajajo jasni dokazi o socialni nepravičnosti v prostorski razporeditvi izvajalcev zdravstvenega varstva (Guagliardo idr. 2004). Kljub temu pa obstaja zelo malo študij, ki so testirale vpliv večje dostopnosti do zdravstvenih storitev na zdravje prebivalstva. V dveh študijah so Fortney in sodelavci (1995 in 1999) pokazali, da sta razdalja in potovalni čas do najbližjega izvajalca zdravstvenih storitev pozitivno vplivala na odvajanje od prepovedanih drog in na verjetnost zdravljenja zaradi duševnih bolezni. Athas in sodelavci (2000) ter A. B. Nattinger in sodelavci (200I) so ugotovili, da je daljši potovalni čas do najbližjega izvajalca zdravstvenih storitev povezan z zmanjšanim odstotkom žensk, ki so se odločile za zdravljenje raka dojke. Podobno navajajo tudi Meden in sodelavci (2002), ki so ugotovili, da obstaja statistična korelacija med bližino izvajalcev onkološkega obsevanja in oceno primernosti radikalne metode mastektomije, pri čemer obe metodi dajeta enake rezultate zdravljenja raka dojke. Bolnice, ki so bližje zdravstvenim ustanovam, ki izvajajo onkološka obsevanja, so bistveno nižje ovrednotile manj zaželeno in radikalno zdravljenje raka, ki se konča s kirurško odstranitvijo celotne dojke. Goodman idr. (I994; 1997) poročajo, da je večja oddaljenost od bolnišnice povezana z manjšo verjetnostjo za sprejem diskrecijskih pogojev.

Študija Buchmuellerja, M. Jacobson in C. Wold (2006) je pokazala, da ima večja razdalja do bolnišnice za posledico višje stopnje smrtnosti zaradi srčnih napadov in nenamernih poškodb. Druga študija, ki so jo opravili Arcury in sodelavci (2005), kaže, da lahko krajše razdalje med bolniki in zdravniki povečajo pogostost rednih obiskov zdravnikov na primarni ravni zdravstvene dejavnosti. Tudi druge študije potrjujejo, da je zgodnje odkrivanje bolezni in zdravljenje negativno povezano s povečevanjem razdalje oziroma podaljševanjem potovalnega časa med bolniki in zdravstvenimi storitvami (Campbell idr. 2000; Monnet idr. 2006; Onega idr. 2008; Meyer 20I2). Oddaljenost oziroma razdalja med bolniki in izvajalci zdravstvenih storitev je temeljni vidik merjenja prostorske 
dostopnosti, ki se razlikuje glede na različne klinične prakse in zdravstvene potrebe. Pri bolnikih s kardiovaskularnimi obolenji je na primer ključno, da pridejo do zdravstvene oskrbe $\mathrm{v}$ čim krajšem času oziroma $\mathrm{v}$ kratkem časovnem intervalu (Hare in Barcus 2007; Busingye, Pedigo in Odoi 20II). Kadar gre za redne zdravstvene preglede, obstaja veliko manj omejitev in bolniki so pripravljeni sprejeti daljše razdalje oziroma potovalne čase pri dostopu do izvajalcev zdravstvenih storitev (Lovett, Sunnenberg in Haynes 2004).

Vse zgoraj omenjene študije navajajo, da prostorska dostopnost vpliva na verjetnost zdravljenja posameznih vrst bolezni. Bistveno manj študij pa preučuje, kako se prostorska dostopnost do izvajalcev zdravstvenih storitev neposredno odraža na zdravju prebivalstva. Študija J. Basu in Friedmana (200r) je pokazala, da so otroci, ki živijo na območjih s slabšo pokritostjo primarnega zdravstva, pripravljeni dalj časa potovati do bolnišničnih storitev. Rezultati njihovega zdravstvenega stanja so bistveno slabši v primerjavi z rezultati zdravstvenega stanja otrok, ki imajo boljšo dostopnost do zdravstvenih storitev. Določene bolezni so namreč običajno odkrite v kasnejših fazah, kar povzroči, da so tudi rezultati zdravljenja nekaterih vrst bolezni bistveno slabši. J. Basu, Friedman in H. Burstin (2002) ter Parchman in Culler (1999) so podobne študije opravili na odrasli populaciji. Ugotovil so, da je slabša dostopnost primarnega zdravstvenega sistema povezana $\mathrm{z}$ bistveno večjim odstotkom sprejemov bolnikov na sekundarni ravni. Britanska raziskava, ki jo je opravil Gulliford (2002), je pokazala, da so območja, kjer primanjkuje splošnih zdravnikov, povezana z višjimi stopnjami hospitalizacije, ki pa bi se jim lahko s primerno zdravstveno oskrbo v večini primerov izognili. Nazadnje pa je študija umrljivosti v ZDA pokazala, da je umrljivost bistveno manjša na območjih, kjer deluje večje število zdravnikov (Shi in Starfield 200I).

Pomanjkanje zdravstvene oskrbe na poselitvenih območjih, ki se nahajajo na bistveno bolj oddaljenih lokacijah, negativno vpliva na zdravje tamkajšnjih prebivalcev. Toda kljub desetletnim prizadevanjem obstaja presenetljivo malo informacij in študij o učinku prostorske dostopnosti zdravstvenih storitev na zdravje prebivalstva. Najosnovnejši problem je, da ne vemo, kaj je najuporabnejše merilo prostorske dostopnosti. Izbira merila se v raziskavah razlikuje glede na poseljenost določenega območja, rasne ali etnične sestave in ekonomskega statusa prebivalstva. Pri tem je smiselno domnevati, da prostorska dostopnost vpliva na zdravje prebivalstva, in sicer na neki določeni točki povečanja razpoložljivosti zdravstvenih virov. Kljub vsemu pa še vedno ni znano, kje ta točka dejansko je 
(Wennberg, Freeman in Culp 1987; Goodman idr. 1996; Weinstein, Goodman in Wennberg 1998; Goodman idr. 2001).

Prav tako še ne vemo, kako se učinek povečevanja dostopnosti do zdravstvenega varstva razlikuje glede na posamezne vrste bolezni. Na primer, ali ima povečanje dostopnosti do zdravstvenega varstva večji učinek na bolnike, ki se zdravijo zaradi astme, ali ima večji učinek na bolnike z boleznimi srca in ožilja. Literatura pri tem vprašanju ni enotna. Nekatere študije namreč kažejo, da se izboljšanje zdravja prebivalstva ob povečanju dostopnosti do zdravstvenega varstva razlikuje glede na posamezno vrsto bolezni, medtem ko druge navajajo, da se vse vrste bolezni na povečanje dostopnosti do zdravstvenega varstva odzivajo enako (Basu in Friedman 2001; Basu, Firedman in Burstin 2002).

Dodatna težava je, da ni znano, katera raven zdravstvene dejavnosti je najpomembnejša pri povečevanju dostopnosti do zdravstvenega varstva. $\mathrm{Z}$ drugimi besedami, ali je optimalna prostorska dostopnost pomembnejša pri primarni ravni zdravstvene dejavnosti, ali ima optimalna prostorska dostopnost večji pomeni pri sekundarni ravni zdravstveni dejavnosti. Poleg tega pa tudi ni znano, kako je povečevanje dostopnosti do zdravstvenega varstva povezano z drugimi dimenzijami dostopnosti, torej z dosegljivostjo, sprejemljivostjo in prilagojenostjo (Guagliardo 2004).

$\mathrm{Na}$ tem mestu je treba poudariti, da še vedno ne obstajajo relevantne študije, ki bi ugotavljale, kakšen latentni učinek na zdravje prebivalstva povzroči povečanje dostopnosti do zdravstvenega varstva. Z drugimi besedami, po kolikšnem času je opazno izboljšanje ali poslabšanje zdravja prebivalstva. Dokler ne bomo poznali odgovora na to vprašanje, moramo biti previdni pri razlagi odnosa med povečanjem dostopnosti do zdravstvenega varstva in zdravstvenim stanjem prebivalstva. Izboljšanje zdravja prebivalstva je namreč lahko posledica tudi nekaterih drugih okoliščin in ne zgolj povečanja dostopnosti do zdravstvenega varstva, kar je treba upoštevati pri interpretaciji rezultatov omenjenih vrst študij.

\section{Merjenje prostorske dostopnosti zdravstvenega varstva}

V tem poglavju se bomo osredotočili na temeljna vprašanja, ki se pojavljajo pri merjenju prostorske dostopnosti storitev zdravstvenega varstva. Pri tem bo poudarek na metodah merjenja prostorske dostopnosti, ki se uporabljajo predvsem za določitev prostorske dostopnosti izvajalcev zdravstvene dejavnosti v gosteje poseljenih območjih. Večina obstoječih meril za merjenje prostorske dostopnosti temelji na potencialni interakciji med izvajalci zdravstvenih storitev, na primer med zdravniki na primarni ravni zdravstvene dejavnosti, bolnišnicami in prebivalci, ki potrebujejo 
zdravstveno oskrbo oziroma, z drugimi besedami, med ponudbo in povpraševanjem (Guagliardo 2004; Higgs 2005; Wang 20I2). Na področju zdravstvene geografije je kompleksno in celovito prostorsko analizo, ki je merila prostorske dostopnosti zdravstvenega varstva, prvi objavil Gesler (1986), ki je prispeval razvrstitev v štiri kategorije. Prva kategorija je oskrbno razmerje, ki predstavlja razmerje med številom izvajalcev in številom prebivalstva, druga kategorija je potovalna upornost, ki ponazarja razdaljo ali čas med bolnikom in izvajalcem zdravstvenih storitev, tretja kategorija je povprečna potovalna upornost, ki opredeljuje povprečno razdaljo do niza izvajalcev zdravstvenih storitev, četrta kategorija pa predstavlja gravitacijski model vpliva izvajalcev.

\section{Oskrbno razmerje}

Oskrbno razmerje oziroma razmerje med številom izvajalcev in številom prebivalstva se uporablja predvsem za omejena območja znotraj nekega določenega ozemlja. Oskrbno razmerje je najbolj priljubljeno merilo prostorske dostopnosti, saj njegova uporaba temelji na intuitivnem pristopu, hkrati pa so viri podatkov raziskovalcem običajno enostavno dostopni. Poleg tega za njegovo izračunavanje ne potrebujemo geografskega informacijskega sistema - GIS, ki je računalniško podprt podatkovno procesni sistem za učinkovito zajemanje, shranjevanje, vzdrževanje, obdelavo, analize, porazdeljevanje in prikazovanje prostorskih (geografskih) podatkov. $\mathrm{V}$ literaturi se oskrbno razmerje uporablja za meritve tako na primarni kot tudi na sekundarni in terciarni ravni zdravstvene dejavnosti. Oskrbna razmerja se izračunavajo za omejena območja, kot so države, okrožja, velemesta, mesta ali območja zdravstvenih storitev. Rezultati analize so izraženi v geografskih enotah. Števec je pokazatelj zmogljivosti sistema zdravstvenega varstva, kamor uvrščamo število zdravnikov, število bolnišnic ali število bolnišničnih postelj, imenovalec pa določa velikost populacije znotraj območja, ki ponazarja število oseb, ki v določenem času sestavljajo populacijo. $\mathrm{V}$ kasnejših fazah se na omejenih območjih pogosto analizira tudi povezanost oskrbnega razmerja z nekaterimi kazalci izkoriščenosti zdravstvenega sistema ali kazalci zdravstvenega stanja prebivalstva (Khan 1992; Perry in Gesler 2000; Radke in Mu 2000; Guagliardo 2004; Cervigni idr. 2008).

Oskrbna razmerja kot razmerja med številom izvajalcev in številom prebivalstva so zelo uporabna v primerih, ko analiziramo velika geografska območja. Uporabljajo se za določitev minimalnih standardov zdravstvene oskrbe in identifikacijo slabše pokritih geografskih območij (Schonfeld, Heston in Falk 1972; Connor, Hillson in Krawelski 1995). 
Oskrbna razmerja pa imajo nekatere pomanjkljivosti; med njimi se srečamo z omejenostjo območij z upravnimi oziroma političnimi mejami. Poleg tega ne upoštevajo možnega prehajanja bolnikov preko meja, kar je še posebej izrazito pri manjših geografskih območjih, kot so občine ali določeni predeli posameznega mesta (Guagliardo 2004; Higgs 2005; Cromley in McLafferty 2012; Wang 2012). Oskrbna razmerja prav tako ne zaznajo sprememb dostopnosti znotraj meja določenega območja, poleg tega pa ne upoštevajo meril za razdalje oziroma potovalno upornost. Rezultati in interpretacije različnih študij se zato močno razlikujejo glede na velikost, število in usmeritev študije prostorske dostopnosti. Ta problem je zelo dobro znan številnim geografom in analitikom prostorske dostopnosti, ki se zavedajo statističnih pristranskosti, ki lahko pomembno vplivajo na rezultate študij in statističnih hipotez (Openshaw 1984).

Potovalna upornost

Potovalna upornost do najbližjega izvajalca je merilo prostorske dostopnosti, ki prav tako kot oskrbno razmerje temelji na intuitivnem pristopu. Običajno se meri od bolnikovega stalnega prebivališča oziroma od geografskega središča prebivalstva, ali pa od centroida območja, kar je odvisno od razpoložljivosti podatkov, pa do najbližjega izvajalca zdravstvenih storitev. Potovalno upornost lahko opredelimo na več različnih načinov. Potovalna upornost se lahko nanaša na višino potnih stroškov, ki jih ocenimo glede na razdaljo med bolnikom in izvajalcem. Potovalno upornost lahko opredelimo tudi kot evklidsko razdaljo, to je geometrična razdalja $\mathrm{v}$ večrazsežnostnem prostoru oziroma običajna razdalja med dvema točkama (Guagliardo 2004). V novejši literaturi se običajno namesto evklidske razdalje uporablja razdalja ali čas potovanja po kategoriziranem cestnem omrežju (Brabyn in Beere 2006; Pearce, Witten in Bartie 2006; Dai 2010; Cheng, Wang in Rosenberg 2012; Shi idr. 2012; Delmelle idr. 2013; Wan idr. 2013).

Merilo potovalne upornosti do najbližjega izvajalca je uporabno predvsem za podeželska območja oziroma za območja, ki so redkeje poseljena. Na teh predelih je namreč verjetnost povpraševanja po najbližjemu izvajalcu daleč največja. Kljub temu pa so Fryer in sodelavci (1999) v svojih študijah predložili dokaze o nasprotnem. Kljub primernosti za podeželska območja tega merila ne moremo uporabiti na gosteje poseljenih območjih. Merilo potovalne upornosti je namreč bistveno slabše uporabno na območjih, kjer obstaja niz izvajalcev zdravstvenih storitev na podobni oddaljenosti. Za določitev prostorske dostopnosti je torej treba upoštevati tudi druga merila prostorske dostopnosti in ne zgolj potovalno upor- 
nost. Potovalna upornost je namreč slab pokazatelj razpoložljivosti, zato je za pravilno razumevanje prostorske dostopnosti treba kombinirati tako potovalno upornost, ki določa dostopnost, kot tudi oskrbno razmerje, ki določa razpoložljivost zdravstvenega varstva (Fryer idr. 1999; Guagliardo 2004).

\section{Povprečna potovalna upornost}

Povprečna potovalna upornost do najbližjega izvajalca je zanimiva zato, ker predstavlja kombinirano merilo tako razpoložljivosti kot tudi dostopnosti sistema zdravstvenega varstva. Tudi ta se meri od točke prebivališča katerega koli bolnika ali geografskega sedišča prebivalstva. V naslednjem koraku seštejemo potovalne upornosti do vseh izvajalcev zdravstvenih storitev znotraj omejenega območja, nato pa glede na dobljeno vsoto izračunamo še njeno povprečje. Pri tem $\mathrm{v}$ analizo kot omejeno območje običajno vključimo določeno mesto ali občino. Povprečna potovalna upornost je $\mathrm{v}$ študijah prostorske dostopnosti storitev zdravstvenega varstva zelo redko uporabljeno merilo (Dutt idr. 1986). To izhaja iz dejstva, da ima povprečna potovalna upornost do niza izvajalcev dve ključni pomanjkljivosti. Prvič, vpliv perifernih izvajalcev je precenjen. Ti namreč povečujejo potovalno upornost za bolnike iz nasprotne periferije, kljub temu da izbirajo storitve zdravstvenega varstva sebi bližjih izvajalcev zdravstvenih storitev. Dodaten problem pa se nanaša na prehajanje preko meja. Podobno kot pri oskrbnem razmerju do najbližjega izvajalca bolniki namreč pogosto prečkajo geografska območja in tako poiščejo bližnje zdravstvene storitve zunaj omejenih območij (Guagliardo 2004).

\section{Gravitacijski modeli}

Gravitacijski model vpliva izvajalcev je prav tako, kot tudi povprečna potovalna upornost do niza izvajalcev, kombinirano merilo, ki vključuje tako razpoložljivost kot tudi dostopnost zdravstvenega varstva. Spremenjena različica Newtonovega zakona gravitacije je bila sprva razvita za napovedovanje potovanj (Reilly 193I) in za pomoč pri načrtovanju rabe zemljišč (Hansen 1959). Gravitacijski model je najveljavnejše merilo prostorske dostopnosti, ki se lahko uporablja tako za podeželska območja kot tudi za gosteje poseljena območja. Njegova prednost je, da upošteva potencialno interakcijo med posameznim bolnikom in vsakim izvajalcem zdravstvenih storitev. Zaradi upoštevanja vseh izvajalcev zdravstvene dejavnosti gravitacijski model včasih označujemo kot kumulativno oportunitetno merilo prostorske dostopnosti (Guagliardo 2004). 
Poznamo gravitacijske modele, ki merijo prostorsko dostopnost izvajalcev zdravstvenih storitev $\mathrm{z}$ vidika dostopnosti do elektivnih zdravstvenih storitev, in gravitacijske modele, ki merijo prostorsko dostopnost izvajalcev zdravstvenih storitev do nujne zdravstvene oskrbe. Po elektivnih zdravstvenih storitvah bolniki posežejo, ko jim njihovo zdravstveno stanje omogoča, da se prosto odločajo, ali bodo izbrali določeno storitev zdravstvenega varstva in hkrati tudi katero vrsto zdravstvene storitve bodo izbrali. Za storitve nujne zdravstvene oskrbe pa je značilno, da jih je treba izvesti zaradi nujnih stanj življenjske ogroženosti ali nenadnih poslabšanj zdravstvenega stanja, kar pomeni, da se bolniki ne morejo prosto odločati, ali bodo izbrali določeno zdravstveno storitev.

\section{Gravitacijski modeli do elektivnih zdravstvenih storitev}

V primeru, ko bolnik zazna določene bolezenske znake oziroma zdravstveno potrebo, se lahko odloči, ali bo sploh povpraševal po zdravstvenih storitvah, ali pa si bo pomagal sam. Če se odloči za povpraševanje po zdravstvenih storitvah, se nato nadalje odloči, po kateri storitvi in v okviru katerega zdravstvenega sistem bo povpraševal. Pri tem ima na izbiro javni, zasebni ali pa alternativni sistem zdravstvenega varstva. Po izbiri vrste zdravstvene storitve in trga prosto izbere izvajalca, pri čemer omejitve izhajajo iz izvajalčeve zmogljivosti. Skladno s to odločitvijo nato pri izbranem izvajalcu zdravstvenih storitev prosto izbere čas storitve, vendar pri tem obstajajo določene omejitve, $\mathrm{k}$ izhajajo iz izvajalčeve obremenjenosti. Čakalne dobe torej vplivajo na to, kdaj bo izbrano storitev izbranega izvajalca zdravstvenih storitev dejansko tudi uporabil (Pps Medico 2012).

Bolniki se lahko odločajo med javnim in zasebnim zdravstvenim sistemom, med uradno medicino na eni strani in alternativnim zdravstvenim sistemom na drugi strani. Globina, do katere lahko bolnik prosto izbira, je odvisna od sistema, v katerem bolnik povprašuje po storitvah zdravstvenega varstva. $V$ javnem sistemu zdravstvenega varstva prosta izbira seže do izbire ponudnika primarnega zdravstva. Šele v kasnejši fazi, ko se zdravnik na primarni ravni zdravstvene dejavnosti odloči, da bo bolnika napotil na sekundarno raven zdravstvene dejavnosti, se ta lahko odloči o naslednji izbiri izvajalca. Pri tem se moramo zavedati, da tudi tukaj takoj naleti na omejitve dostopa zaradi zmogljivosti in obremenjenosti ciljnega izvajalca storitev zdravstvenega varstva (Pps Medico 20 I2).

Vzrok je v pravilih financiranja javnega zdravstva. V javnem zdravstvenem sistemu tržni regulator ponudbe in povpraševanja ni cena, zato to vlogo prevzema omejevanje dostopa, ki se odraža preko omejevanja iz- 
bire in čakalnih dob. Potrebe ljudi oziroma potrebe po zdravstveni oskrbi so bistveno večje od ponudbe, zato se omejevanju dostopnosti do zdravstvenih storitev ni mogoče izogniti. $\mathrm{Na}$ trgu imajo to vlogo cene, pri politiki, ki oblikuje sistem zdravstvenega varstva, pa cene ne smejo omejevati potreb. Namesto cen omenjeni sistemi uporabljajo kot način omejevanja čakalne dobe, kar prisili bolniki, da čakajo tedne, mesece za kakršno koli raven zdravstvene oskrbe (Pps Medico 20I2; Miller, Benjamin in North 2014).

Zasebni in tudi alternativni zdravstveni sistem temeljita na samoplačnikih, kar pomeni, da imajo pri njih omejevalno vlogo cene. $V$ tem primeru so torej omejitve izbire manjše in bolnik lahko prosto izbira med vrstami in ravnmi storitev. V vsaki vrsti in na vsaki ravni lahko izbira med več oziroma vsemi ponudniki, pri čemer je tudi zelo verjetno, da bo na omejitve zaradi zmogljivosti in obremenjenosti ciljnih izvajalcev naletel bistveno pozneje, kot to velja za javni sistem zdravstvenega varstva (Pps Medico 20I 2; Miller, Benjamin in North 20I4).

Nujen pogoj za elektivnost oziroma za izbiro vrste zdravstvenih storitev, izvajalca, kraja in časa zdravstvenih storitev je, da bolniku zdravstveno stanje sploh omogoča odločanje in izbiro. To pomeni, da elektivne zdravstvene storitve niso nujne, poleg tega pa mora biti omogočeno, da elektivne zdravstvene storitve izvajajo izvajalci v stacionarnih obratih, ki pomenijo vozlišča v mreži zdravstvene infrastrukture. Stacionarnost v smislu lokacijske stalnosti in lokacijske pogojenosti elektivnih zdravstvenih storitev je tudi podlaga za relevantnost analiz in meritev prostorske dostopnosti zdravstvene infrastrukture oziroma izvajalcev zdravstvenih storitev, ki so dosegljivi na posameznih lokacijah v mreži zdravstvene dejavnosti (Pps Medico 2012).

Najpreprostejša formula enostavnega gravitacijskega modela, ki ga lahko uporabimo v primeru elektivnih zdravstvenih storitev, ima naslednjo obliko (Hansen 1959):

$$
A_{i}=\sum_{j} \frac{S_{j}}{d_{i j}^{\beta}} .
$$

$A_{i}$ predstavlja prostorsko dostopnost s populacijske točke i, ki je lahko stalno prebivališče bolnika ali centroid območja. $S_{j}$ izraža storitveno zmogljivost izvajalca zdravstvenih storitev na določeni lokaciji. Običajno je merjena kot ekvivalent polne zaposlitve zdravstvenega delavca, ali pa kot število bolnišničnih postelj, ki jih ima izvajalec zdravstvenih storitev. Lahko pa se uporabi tudi morebitno drugo merilo, ki odraža zmoglji- 
vost izvajalca zdravstvene dejavnosti. $d$ označuje potovalno upornost, ki je razdalja ali čas med točkama $i$ in $j . \beta$ je koeficient upadanja težavnosti potovanja, včasih ga imenujemo tudi koeficient potovalne vztrajnosti. $\beta$ predstavlja spremembo težavnosti potovanja zaradi spremembe potovalnega časa ali razdalje. Prostorska dostopnost je boljša, ko narašča število izvajalcev zdravstvene dejavnosti v števcu, ali pa takrat, ko se zmanjšuje potovalna upornost.

Gravitacijske vrednosti lahko uporabimo na več načinov. Na primer, če je vrednost $A_{i}$ ocenjena za številna geografska področja znotraj določenega območja, ki ga analiziramo, potem je mogoče izdelati tridimenzionalni površinski model dostopnosti na podlagi omenjenih gravitacijskih točkovnih vrednosti $A_{i}$. Območja z nizkimi vrednostmi tako ustrezajo območjem z relativno slabo dostopnostjo zdravstvenega varstva, območja z visokimi vrednostmi pa predstavljajo območja, na katerih se nahaja prekomerno število izvajalcev zdravstvene dejavnosti. Vrednosti $A_{i}$ so lahko ocenjene tudi kot geografsko reprezentativne točke za posamezna mesta znotraj opazovanega območja in jih kot take lahko primerjamo s povprečno vrednostjo $A_{i}$ za opazovano območje.

Kljub vsesplošni uporabnosti pa ima enostaven gravitacijski model vsaj dve večji pomanjkljivosti. Prvič, $A_{i}$ ne temelji na intuitivnem pristopu, kar otežuje delo oblikovalcem zdravstvene politike. Uporabniki meril običajno raje razmišljajo o oskrbnem razmerju ali preprosto določeni oddaljenosti od ponudnika zdravstvenih storitev, in to kljub prej omenjeni težavi, da to merilo ni primerno za gosteje poseljena območja. Drugič, gravitacijski model obravnava samo ponudbo, ne pa tudi povpraševanja. $A_{i}$, ki predstavlja razdaljo med dvema različnima izvajalcema zdravstvenih storitev, je lahko enaka kljub temu, da en izvajalec lahko oskrbuje 5.000 bolnikov, drugi izvajalec pa zgolj ı.000 bolnikov. V tem primeru je namreč jasno, da oba izvajalca zdravstvenih storitev nista enako dostopna (Guagliardo 2004).

Joseph in Bantock (1982) sta predlagala rešitev za omenjeni problem. Dodala sta faktor prilagoditve populacijskega povpraševanja $V_{j}$, ki povpraševanje prostorsko razporedi na enak način, kot osnovni gravitacijski model razporeja ponudbo:

$$
V_{j}=\sum_{j} \frac{P_{k}}{d_{k j}^{\beta}} .
$$

$P_{k}$ ponazarja število prebivalcev na populacijski točki $k$, ki je lahko na primer centroid območja, $d$ pa je razdalja med populacijsko točko $k$ in 
lokacijo ponudbe $j$. Povpraševanje na lokaciji izvajalca $j$ je torej izračunano kot vsota gravitacijskega vpliva vseh populacijskih točk in vseh razdalj do najbližjega izvajalca zdravstvenih storitev.

Josephov in Bantockov (1982) izboljšan gravitacijski model je tako izražen kot:

$$
A_{i}=\sum_{j} \frac{S_{j}}{d_{i j}^{\beta} V_{j}} .
$$

Omenjeni model dostopnosti, ki temelji na gravitacijskih načelih, je v bistvu razmerje med ponudbo in povpraševanjem (Huff 2000; Luo in Qi 2009; Wang 20I2). Predstavljeni gravitacijski model nam omogoča preučitev geografskih razlik $\mathrm{v}$ dostopnosti do izvajalcev zdravstvenih storitev. Kljub svoji uporabnosti njegova uporaba ni enostavna za oblikovalce zdravstvene politike in strokovnjake na področju javnega zdravstva, in sicer predvsem v tistem delu, ki se navezuje na razlago in izvajanje. Problem običajno predstavljajo tudi velike količine podatkov, geografsko kodirani podatki posameznih lokacij prebivalstva in lokacij izvajalcev zdravstvene dejavnosti, ki so potrebni za izvedbo analize. Izboljšan gravitacijski model pogosto zahteva velik napor raziskovalcev pri računanju in programiranju (Taaffe, Gauthier in O'Kelly 1996; Luo in Whippo 2012).

Razumevanje tega modela je izziv za nove študije prostorske dostopnosti. Naslednji problem je, da je koeficient $\beta$ običajno raziskovalcem neznan in lahko tako vključuje veliko različnih matematičnih oblik. Oblika in velikost koeficienta se razlikujeta glede na vrsto storitve in populacijo, ki je zajeta v študiji (Talen in Anselin 1998). Empirične raziskave zahtevajo oceno koeficienta , ki jih je v številnih primerih težko opredeliti, zato se oblikovalci zdravstvene politike običajno izogibajo uporabi omenjenega modela. Ne glede na nekatere pomanjkljivosti je izboljšani gravitacijskih model lahko zelo koristen in uporaben pri študijah prostorske dostopnosti izvajalcev zdravstvene dejavnosti.

Poznejše raziskave so poskušale še nadalje izboljšati Josephov in Bantockov (1982) gravitacijski model. Luo in Wang (2003a in 2003b) sta razvila metodo dvostopenjskega prekrivanja gravitacijskega območja, ki jo je prvi v svoji študiji uporabil Peng (1997), ki pa je raziskoval dostopnost delovnih mest za prebivalstvo. Metoda dvostopenjskega prekrivanja gravitacijskega območja se začne $z$ določitvijo primernega potovalnega časa do izvajalca zdravstvenih storitev. Lee (1991) je predlagal, da primeren čas do najbližjega izvajalca zdravstvenih storitev ne sme biti daljši od 30-minutne avtomobilske vožnje po kategoriziranem cestnem omrežju. Luo 
in Wang (2003a in 2003b) v nujnem dvostopenjskem procesu navajata, da je treba najprej opredeliti oskrbno razmerje za vsako lokacijo izvajalca zdravstvenih storitev, to pa dobimo tako, da število zdravnikov delimo $s$ številom prebivalcev, ki živi znotraj meja 30-minutnega potovalnega časa. Oskrbna razmerja je treba opredeliti za celotno območje, ki ga zajemamo $\mathrm{v}$ študiji, in ne zgolj samo za lokacijo enega izvajalca zdravstvenih storitev. Rezultat so izdelane geografske karte, ki prekrivajo območja centroidov vseh izvajalcev zdravstvenih storitev. Karta torej omogoča prikaz prekrivanja enih in praznine med drugimi gravitacijskimi območji, ki so navidezno nepreskrbljena.

V drugem koraku je poudarek na populacijskih točkah. Populacijske točke lahko vključujejo stalna prebivališča, naselja s številom prebivalstva ali pa centroide poštnih številk, kar je odvisno od razpoložljivosti omenjenih podatkov. Za vsako populacijsko točko izračunamo količino prostorske dostopnosti tako, da seštejemo oskrbna razmerja, ki smo jih izračunali $\mathrm{v}$ prvem koraku in prekrivajo populacijsko točko. $\mathrm{Na}$ ta način vsaka populacijska točka dobi svojo vrednost prostorske dostopnosti. Prostorska dostopnost se sešteva zgolj na tisti področjih, ki se med seboj prekrivajo (Luo in Wang 2003a; 2003b).

V prvem koraku torej za vsako lokacijo izvajalca j poiščemo vse populacijske točke $k$ znotraj časovnega dosega $d_{0}$, nato pa za omejeno območje $j$ izračunamo oskrbno razmerje $R_{j} . P_{k}$ so populacijske točke ali lokacije stalnega prebivališča ljudi, ki živijo znotraj območja, za katerega velja, da je $d_{k j} \leq d_{0}$. $S_{j}$ predstavlja število polno zaposlenih zdravstvenih delavcev oziroma število zdravnikov na lokaciji $j, d_{k j}$ pa je potovalni čas med lokacijama $k$ in $j$ (Luo in Wang 2003a; Wang 20I2):

$$
R_{j}=\frac{S_{j}}{\sum_{k \epsilon\left(d_{k j} \leq d_{0}\right)} P_{k}} .
$$

V drugem koraku nato za vsako populacijsko lokacijo $i$ poiščemo vse lokacije izvajalcev $j$, ki so znotraj omejenega časa potovanja $d_{0}$, nato pa seštejemo vsa oskrbna razmerja na tistih območjih, ki se med seboj prekrivajo (Luo in Wang 2003a; Wang 20I2):

$$
A_{i}=\sum_{j \in\left(d_{i j} \leq d_{0}\right)} R_{j}=\sum_{j \in\left(d_{i j} \leq d_{0}\right)} \frac{S_{j}}{\sum_{k \epsilon\left(d_{k j} \leq d_{0}\right)} P_{k}} .
$$

Pri tem velja, da za vsakega prebivalca lahko izračunamo prostorsko dostopnost do storitev zdravstvenega varstva. Posredno lahko na ta na- 
čin izdelamo tudi karto dostopnosti znotraj neke določene regije ali države. Dostopnost na posamezni populacijski točki $\left(A_{i}\right)$, ki ima v dosegu 30-minutnega časovnega intervala možnost dostopa zgolj do enega izvajalca zdravstvenih storitev, je enaka oskrbnemu razmerju območja izvajalca $j\left(R_{j}\right)$. Kadar sta na območju populacijske točke $i$ dostopna dva izvajalca ali je dostopnih več izvajalcev, pa $A_{i}$ izračunamo kot seštevek oskrbnih razmerij za območja vseh izvajalcev, ki so dostopni v 30-minutnem časovnem intervalu. Večja vrednost $A_{i}$ kaže na boljšo dostopnost posamezne lokacije.

Pri omenjenem modelu so vrednosti prostorske dostopnosti izražene v enotah, ki so enake kot pri oskrbnih razmerjih. Luo in Wang (2003a in $2003 \mathrm{~b}$ ) sta matematično dokazala, da je njuna metoda $v$ bistvu poseben primer Josephovega in Bantockovega (1982) izboljšanega gravitacijskega modela. Navajata tudi, da je pomanjkljivost metode dvostopenjskega prekrivnega gravitacijskega območja prehajanje bolnikov preko meja določenega območja. Zavedata se, da je po eni strani njuno delo mogoče izboljšati, po drugi strani pa predstavlja dobro podlago za raziskovalce, ki se ukvarjajo z raziskovanjem prostorske dostopnosti (Luo in Wang 2003a; 2003b).

Metoda dvostopenjskega prekrivanja gravitacijskih območjih je postala zelo priljubljena in je bila zato uporabljena $\mathrm{v}$ številnih novejših študijah (Yang, Goerge in Mullner 2006; McGrail in Humphreys 2009; Dai 2010; Ngui in Apparicio 201 I; Cheng, Wang in Rosenberg 2012; Shi idr. 20I2; Wan idr. 2013). Metoda sicer omogoča zanesljivejše merjenje prostorske dostopnosti $\mathrm{v}$ kategorijah oskrbnega razmerja, ne odpravlja pa problema navidezne enakovrednosti prostorske dostopnosti znotraj vsakega oskrbnega območja. Skladno s tem v literaturi zasledimo tudi nekatere poskuse izboljšanja predstavljenih gravitacijskih modelov.

Dai (2010) je tako v svojem gravitacijskem modelu uporabili Gaussovo funkcijo, ki je odpravila nekatere pomanjkljivosti predhodnih metod. Te so namreč v svojih gravitacijskih modelih običajno zajele tiste prebivalce, ki so imeli od svojega prebivališča do izvajalca zdravstvenih storitev maksimalen čas potovanja 30 minut. Znotraj teh modelov pa ni bilo upoštevano, da so na eni strani nekateri prebivalci do najbližjega izvajalca potrebovali zgolj pet minut, na drugi strani pa so bili nekateri oddaljeni 30 minut. Zavedati se je treba, da se prostorska dostopnost s povečevanjem razdalje zmanjšuje, zato ne more biti enaka za tiste prebivalce, ki imajo do izvajalca pet minut, in za tiste prebivalce, ki imajo do izvajalca 30 minut. Prostorska dostopnost znotraj omejenih območji se razlikuje tudi glede na vrsto izvajalca zdravstvenih storitev ali glede na tip 
naselij (Yang, Goerge in Mullner 2006). Za upoštevanje učinka upadanja prostorske dostopnosti s povečevanjem razdalje sta Luo in Qi (2009) za prostorsko dostopnost znotraj omejenega območja definirala uteži, ki so omogočile razlikovanje med različnimi časovnimi intervali potovanja.

McGrail in Humphreys (2009) sta predlagala enotno utež za desetminutno obdobje, utež z vrednostjo o zunaj 6o-minutnega časovnega intervala in vmesne vrednosti uteži, ki so se gibale med $\mathrm{I}$ in o za preostale časovne intervale. Za posplošitev učinka upadanja prostorske dostopnosti s povečevanjem razdalje, kar predstavlja $f$, lahko sintetiziramo že prej omenjene formule (McGrail in Humphreys 2009; Wang 20I2):

$$
A_{i}=\sum_{j=1}^{n}\left[\frac{S_{j} f\left(d_{i j}\right)}{\sum_{k=1}^{m} P_{k} f\left(d_{i j}\right)}\right] .
$$

Formula je podobna kot v primeru izboljšanega gravitacijskega modela in modela dvostopenjskega prekrivanja gravitacijskega območja.

\section{Gravitacijski modeli do nujne zdravstvene oskrbe}

Poleg elektivnih zdravstvenih storitev bolniki povprašujejo tudi po takšnih zdravstvenih storitvah, ki jih je treba izvesti zaradi nujnih stanj življenjske ogroženosti. $\mathrm{V}$ takih okoliščinah se bolnik praviloma ni sposoben prosto odločati, ali sploh bo izbral neko določeno storitev, katera zdravstvena storitev bo to, kdaj in kje oziroma katerega izvajalca zdravstvenih storitev bo izbral. Ko gre za ohranitev življenja oziroma sprejemljivega zdravstvenega stanja, mora sprejeti nujne zdravstvene storitve takoj, in sicer od prvega, najbližjega ali edinega izvajalca zdravstvenih storitev, in to na lokaciji, kjer ga je nujno zdravstveno stanje doletelo. To pomeni doma, na delu, na poti, v začasnem prebivališču itd. Zdravstvene storitve, ki jih bolnik potrebuje $\mathrm{v}$ okoliščinah, ko do nujne medicinske pomoči ne more pripotovati sam, obsegajo potovanje usposobljenega in ustrezno opremljenega zdravstvenega osebja na kraj, kjer se bolnik nahaja, izvedbo nekaterih zdravstvenih storitev na krajem samem, lahko pa tudi med prevozom v najbližjo zdravstveno ustanovo, običajno je to bolnišnica.

Pri elektivnih zdravstvenih storitvah, ki jih nudi zgolj stacionarna zdravstvena oskrba, potovalna upornost upošteva samo čas, razdaljo in stroške poti od bolnika do izbranega izvajalca zdravstvenih storitev. Pri nujnih primerih pa se srečujemo z mobilno zdravstveno oskrbo, ki jih uveljavljeni modeli prostorske dostopnosti ne zajemajo. Bistvena razlika med stacionarnimi in mobilnimi zdravstvenimi storitvami se kaže v tem, 
da je potovalna upornost pri mobilnih zdravstvenih storitvah vsota potovalne upornosti med lokacijo prehospitalne enote $l$ ter aktualno lokacijo bolnika $m$ in potovalne upornosti med lokacijo bolnika $m$ ter lokacijo bolnišnice $j$.

Enostavni gravitacijski model, ki ga je razvil Hansen (1959), brez izboljšave Josephove in Bantockove (1982) predstavlja prostorsko dostopnost do poljubne ravni zdravstvene oskrbe, torej tako do primarne kot tudi do sekundarne ali terciarne ravni zdravstvenega varstva:

$$
A_{i}=\sum_{j} \frac{S_{j}}{d_{i j}^{\beta}} .
$$

Hansenov (1959) gravitacijski model lahko uporabimo kot osnovo za enostavni gravitacijski model do nujne zdravstvene oskrbe. Slednji se razlikuje $\mathrm{v}$ imenovalcu, ki mu je treba dodati potovalno upornost med lokacijo prehospitalne enote in lokacijo bolnika, ki ga je doletelo nujno zdravstveno stanje. Enostavni gravitacijski model do nujne zdravstvene oskrbe predstavlja naslednja formula (Pps Medico 20I2):

$$
A_{m}=\sum_{j} \frac{S_{j}}{d_{l m}^{\alpha}+d_{m j}^{\beta}} .
$$

$A_{m}$ predstavlja prostorsko dostopnost z aktualne lokacije bolnika $m$, ki potrebuje nujno zdravstveno oskrbo, $d_{l m}$ označuje potovalno upornost med lokacijo prehospitalne enote $l$ in lokacijo bolnika $m$. To je torej razdalja ali čas med točkama $l$ in $m . d_{m j}$ pa označuje potovalno upornost med aktualno lokacijo bolnika $m$ in lokacijo bolnišnice $j$. Povedano drugače - to je razdalja ali čas med točko $m$ in točko $j$. $\alpha$ je koeficient upadanja težavnosti potovanja oziroma koeficient potovalne vztrajnosti med lokacijama $l$ in $m, \beta$ pa predstavlja količnik potovalne vztrajnosti med lokacijama $m$ in $j$.

Nujno zdravstveno oskrbo lahko $v$ istem trenutku potrebuje večje število bolnikov, kar omejuje izvedljivost in uporabnost zgornjega enostavnega modela. Možnost velikega števila lokacij $m$ zahteva prilagoditev modela prostorske dostopnosti oziroma mreže izvajalcev zdravstvene dejavnosti. Kljub temu, da lahko nujno zdravstveno stanje posameznega bolnika nastopi kjer koli, je za analizo dejanskih mrež zdravstvene dejavnosti, za načrtovanje njihovih izboljšav in za geografsko oziroma statistično primerljivost podatka $A_{m}$ primerno upoštevati $A_{m}=A_{i}$. To pomeni, da se modelira prostorska dostopnost do nujnih zdravstvenih storitev od lokacije prebivalstva, določene $s$ centroidom poselitve $i$, in potoval- 
no upornostjo med lokacijami $l$ in $m$, ter $m$ in $j$, kakor izhaja iz naslednje formule (Pps Medico 2012):

$$
A_{i}=\sum_{j} \frac{S_{j}}{d_{l i}^{\alpha}+d_{i j}^{\beta}} .
$$

Tudi pri modelu prostorske dostopnosti do nujnih zdravstvenih storitev, enako kot pri modelu elektivnih zdravstvenih storitev, je treba upoštevati faktor prilagoditve populacijskega povpraševanja $V_{i}$ iz Josephovega in Bantockovega (1982) modela. To pomeni, da dobimo formulo z naslednjo obliko (Pps Medico 2012):

$$
A_{i}=\sum_{j} \frac{S_{j}}{\left(d_{l i}^{\alpha}+d_{i j}^{\beta}\right) V_{i}} .
$$

Naslednja poenostavitev se nanaša na količnika potovalne vztrajnosti $\alpha$ in $\beta$. Pri prostorski dostopnosti do elektivnih zdravstvenih storitev potovalna vztrajnost pomembno ponderira potovalno razdaljo oziroma čas, zato velja, da $\alpha \neq \beta \neq 1$. Pri dostopanju do nujnih zdravstvenih storitev pa se sme predpostaviti, da je relevanten čas zgolj absoluten oziroma realen potovalni čas, kar pomeni, da je $\alpha=\beta=1$. Če to upoštevamo pri modelu prostorske dostopnosti do nujnih zdravstvenih storitev, dobimo formulo z naslednjo obliko (Pps Medico 20 I 2):

$$
A_{i}=\sum_{j} \frac{S_{j}}{\left(d_{l i}+d_{i j}\right) V_{i}} .
$$

Pogosto se stalna lokacija prehospitalne enote nahaja na isti lokaciji, kot se nahaja najbližja bolnišnica za bolnika, ki potrebuje nujno zdravstveno oskrbo. V takih primerih lahko formulo prostorske dostopnosti do nujnih zdravstvenih storitev zapišemo z naslednjo obliko (Pps MediCO 2OI2):

$$
A_{i}=\sum_{j} \frac{S_{j}}{2 d_{l i} V_{i}} .
$$

Predstavitev teoretičnih gravitacijskih modelov merjenja prostorske dostopnosti je predvsem predlog možne izbire matematičnih modelov, ki jih lahko uporabimo znotraj analiz prostorske dostopnosti. Ti modeli predstavljajo za raziskovalce dobro teoretično osnovno, njihova izbira pa je odvisna od raziskovalnega problema, ki ga obravnavajo. Gravitacijski modeli so vsestransko uporabi, kar pomeni, da jih lahko uporabljamo za 
različna področja merjenja prostorske dostopnosti. Skladno s tem tudi v slovenskem prostoru najdemo raziskave, ki uporabljajo gravitacijske modele za analize prostorske dostopnosti določenih ciljev, sicer na drugem področju, kot je tukaj obravnavano, pa vendar $\mathrm{v}$ podobnem kontekstu (Drozg 2005).

Drozg (2005) je tako analiziral regionalizacijo Slovenije v kontekstu policentričnega razvoja. Ugotovil je, da je bila pri izbiri regionalnih središč v različnih zasnovah policentričnega prostorskega razvoja v Sloveniji upoštevana velikost njihovih gravitacijskih območij in opremljenost z osrednjimi dejavnostmi. Za izbiro regionalnih središč pa je bistveno dvoje. Prvič, opremljenost z osrednjimi dejavnostmi, prvenstveno z upravo, nato pa še z zdravstvom, šolstvom in kulturo. Drugič, z dostopnostjo do naselij, ki imajo največ kvartarnih dejavnosti. Drozg (2005) je ugotovil, da bi bilo ob upoštevanju 30-minutne dostopnosti v Sloveniji potrebnih I6 regionalnih središč, in sicer Ljubljana, Maribor, Celje, Koper, Kranj, Murska Sobota, Novo mesto, Nova Gorica, Ptuj, Slovenj Gradec, Brežice, Trbovlje, Postojna, Kočevje, Idrija in Tolmin. Za so-minutno dostopnost do regionalnih središč pa bi bilo dovolj osem središč. Ta bi bila Ljubljana, Maribor, Celje, Koper, Kranj, Murska Sobota, Novo mesto in Nova Gorica.

\section{Primeren potovalni čas do bolnišnice}

Prvi, ki so se ukvarjali z dostopnostjo do zdravstvenega varstva, so bili Bosanac, R. C. Parkinson in Hall (1976). V svoji študiji so predlagali kot standard geografske dostopnosti do sekundarne zdravstvene dejavnosti 30 minut trajajoče potovanje. Po njihovem mnenju je določitev geografske dostopnosti do sistema zdravstvenega varstva predpogoj za načrtovanje zdravstvene politike. Kot merilo so nekoč uporabljali razdaljo do najbližjega izvajalca zdravstvenih storitev, čeprav je danes znano, da je zaradi spremenljivih topografskih in prometnih vzorcev bistveno relevantnejše merilo potovalni čas. V svoji raziskavi so analizirali skoraj trideset različnih virov, ki so bili objavljeni med leti 1954 in 1975 . Strinjali so se, da je vse popularnejši standard potovalnega časa, ki so ga opredelili kot 30-minutno potovanje do najbližje bolnišnice, primernejše za določanje geografske dostopnosti do zdravstvenih storitev. Pri analizi dostopnosti oziroma preskrbljenosti prebivalstva $\mathrm{v}$ svojem območju so ugotovili, da poligoni 30-minutnih potovalnih časov do akreditiranih bolnišnic zajamejo skoraj 90 odstotkov prebivalcev. To pomeni, da več kot eden od desetih prebivalcev ni imel omenjene dostopnosti do sekundarne zdravstvene dejavnosti.

Bosanac, R. C. Parkinson in Hall (1976) niso poskušali postaviti ciljnega populacijskega deleža, ki naj bi imel 30-minutno dostopnost. V svo- 
ji analizi so postavili nekaj vprašanj glede načinov, kako dostopnost še izboljšati, vendar pri tem nanje niso odgovorili. So pa v diskusiji izpostavili še za današnji čas aktualno dilemo, ki pravi, da se tisti, ki se ukvarjajo z dostopnostjo in dosegom zdravstvenih storitev, soočajo z vprašanji o vlogi majhnih bolnišnic na podeželskih območjih. Pri tem izpostavljajo problem majhnih bolnišnic predvsem zaradi njihove vprašljive ekonomske učinkovitosti. Bosanac, R. C. Parkinson in Hall (1976) navajajo, da primerjava z nacionalnimi standardi pokaže, da območje, ki ga v svoji študiji analizirajo, podpira nesorazmerno veliko število majhnih bolnišnic. Približno tretjina prebivalcev države se namreč nahaja znotraj 30-minutnega potovalnega časa do majhne bolnišnice.

Večina avtorjev je $\mathrm{v}$ svojih študijah zavzela stališče, da je primeren potovalni čas do najbližje bolnišnice 30-minutni časovni interval (Mehrez idr. 1996; Fortney, Rost in Warren 2000). Tudi Messina in sodelavci (2006) so v analizi geografske dostopnosti bolnišnic oziroma preskrbljenosti prebivalstva s storitvami sekundarne zdravstvene dejavnosti zavzeli stališče, da je najdaljši potovalni čas do najbližje bolnišnice 30 minut, pri čemer je treba upoštevati kategorije cest oziroma omejitve hitrosti na njih. Zavzeli so stališče, da so slabše preskrbljena tista območja, kjer se določeno poštno območje nahaja povsem ali delno zunaj 30-minutnega intervala dostopnosti, hkrati pa znotraj posameznega poštnega območja prebiva več kot 50.000 prebivalcev.

Ministrstvo za zdravje v ZDA (U.S. Department of Health and Human Services 2002) je oblikovalo smernice v zvezi z dostopom do zdravstvene oskrbe. V svojem programu so navedli, da je za primarno raven zdravstvene dejavnosti primeren potovalni čas 30 minut. Vse, kar presega 30-minutni časovni interval, pa kaže na slabo dostopnost do zdravstvenih storitev. Pri dostopnosti do zobozdravstvenih storitev in do zdravstvenih ustanov, ki skrbijo za duševno zdravje prebivalstva, pa je ta interval nekoliko daljši. V tem primeru naj bi potovalni čas od bolnika do izvajalca zdravstveni storitev znašal 40 minut. Pri tem poudarjajo, da je treba upoštevati, da večina velemest in gosteje poseljenih območij uporablja javni prevoz. Številne mestne četrti, za katere je značilna visoka stopnja revščine, so namreč povsem odvisne od javnega prevoza, zato je posledično treba upoštevati potovalni čas, ki ga omogoča javni prevoz. Na območjih, za katera je značilna nizka stopnja revščine, pa se prebivalci lahko izognejo javnemu prevozu, zato se pri analizah dostopnosti upošteva potovalni čas, ki ga bolniki potrebujejo za potovanje z osebnim vozilom do najbližjega izvajalca zdravstvenih storitev. 
Ministrstvo za zdravje v zvezni državi Michigan (Michigan Department of Community Health 2015) je opredelilo omejeno območje kot tisto geografsko območje, v katerem prebiva vsaj 50.000 prebivalcev. Akreditirana bolnišnica se mora nahajati znotraj 30-minutnega časovnega intervala dostopnosti. Enak standard pri njih velja tudi za nujno zdravstveno oskrbo. Storitve morajo biti bolnikom na voljo 24 ur na dan in sedem dni v tednu. Pri definiranju območij znotraj 30-minutnega časovnega intervala je treba upoštevati najkrajšo pot in najnižjo omejitev hitrosti za potovanje po cestnem omrežju.

British Columbia (Ministry of Health - Province of British Columbia 2002) je določila standard dostopnosti do urgentnih središč. Vsi prebivalci omenjene province naj bi imeli zagotovljeno nujno zdravstveno oskrbo, do katere se je z osebnim avtomobilom mogoče pripeljati v eni uri. Standard za dostopnost do splošnih bolnišnic znaša dve uri trajajoče potovanje od bolnikovega prebivališča do najbližjega izvajalca zdravstvenih storitev na sekundarni ravni zdravstvene dejavnosti. Pri storitvah specialistične dejavnosti pa so kot standard dostopnosti opredelili časovni interval štirih ur.

V dokumentu o strategiji dostopnosti 2010-2013 je mestni svet v Plymouthu (Plymouth City Council and Plymouth Hospitals NHS Trust 20ro) v Veliki Britaniji sprejel izhodišče, da je pri dostopnosti do storitev zdravstvenega varstva treba upoštevati 30-minutni potovalni čas. Pri tem je treba upoštevati potovalni čas, ki ga prebivalcem zagotavlja javni prevoz. Na tem območju namreč 54 odstotkov prebivalcev ni lastnikov osebnih avtomobilov, posledično to pomeni, da uporaba javnega prevoza poveča potovalni čas za približno deset minut v primerjavi z osebnim avtomobilom.

Daljši potovalni čas od prebivališča do najbližjega izvajalca zdravstvenih storitev poveča tveganje za umrljivost in povzroči neželene zaplete pri zagotavljanju zdravstvene oskrbe (Lyon idr. 2004; Souza in Strachan 2005; Karanicolas idr. 2006; Turrell, Kavanagh in Subramanian 2006; Probst idr. 2007; Wei idr. 2008). Dejavnost ginekologije pa je drugo področje, pri katerem lahko potovalni čas vpliva na izid zdravstvene oskrbe. Dostop do ginekološke oskrbe je pogosto omejena na podeželju oziroma na redkeje poseljenih območjih. V zvezi s tem problemom je bilo opravljenih zelo malo študij (Parker, Dickinson in Morton-Jones 2000; Dummer in Parker 2004). Nobena od njih ni pokazala vpliva potovalnega časa na umrljivost ob porodu. Na tem področju so A. C. Ravelli in soavtorji (20I I) ugotovili, da je potovalni čas od doma do najbližje porodnišnice, ki presega 20 minut vožnje $z$ osebnim avtomobilom, povezan s povečanjem tveganjem smrti in neželenih izidov pri porodnicah na Nizozemskem. 
Nemški Zvezni inštitut za gradbeno, urbanistično in prostorsko raziskovanje (Bundesinstitut für Bau-, Stadt- und Raumforschung 20I I) je objavil poročilo o dostopnosti do bolnišnic. V dokumentu navajajo, da tudi za zdravstveno infrastrukturo velja, da je dostopnost pravo merilo za oceno stopnje preskrbljenosti prebivalstva. Čas vožnje z osebnim avtomobilom iz njihovega modela dostopnosti je natančno ocenjena količina, ki je ni mogoče, tako kot v primeru dostopnosti šol, šteti samo za približno vrednost lokacijske primernosti in dejanskih dolžin poti. Pri njih je na splošno stopnja preskrbljenosti tudi na podeželskih območjih dobra. Le redka območja so pod 20-minutnim pragom dostopnosti.

V Nemčiji je bila leta 2010 med prebivalci izvedena anketa (Pabst Science Publishers 20I0), ki je analizirala odnos prebivalcev do dolgih potovalnih časov do bolnišnic. Rezultati ankete, ki je zajela 6.000 anketirancev, so pokazali, da se je tri petine prebivalcev pripravljenih peljati do bolnišnice pol ure ali še dalj časa, ena petina bi vzela v zakup eno uro, preostalih 20 odstotkov pa celo več kot eno uro trajajoče potovanje. Anketa je tudi pokazala, da je izbira porodnišnice bistveno odvisna od razloga za sprejem. Sedem od desetih nosečnic si je pred porodom ogledalo porodnišnico, za izbiro pa so se odločile glede na to, kako so se tam počutile. Enako število pa jih je prav zaradi bližine odklonilo neko porodnišnico. Za 62 odstotkov bolnikov s kroničnimi boleznimi je bila odločilna specializiranost bolnišnice, za 60 odstotkov pa priporočilo lečečega zdravnika. Vsak šesti vprašani je navedel, da za načrtovanje elektivnega obiska bolnišnice uporablja internetni vir. Med več kot 60 let starimi uporabniki jih je celo 23 odstotkov iskalo primerno bolnišnico prav po internetu. Rezultati so relativizirali stališče o pomenu bližine prebivališča, ki ga vedno znova ponavljajo oblikovalci zdravstvene politike pri oblikovanju mreže bolnišnic.

$\mathrm{Na}$ drugi strani pa Fortney in soavtorji (20 I ) navajajo, da je najpomembnejši vidik dostopa do izvajalca zdravstvenih storitev njegova lokacija. Njihova študija je pokazala, da se pacienti običajno odločijo za tistega izvajalca zdravstvenih storitev, ki je dostopen v 30-minutnem časovnem intervalu. Poleg časovnega intervala dostopnosti je zanje pomembna tudi cestna infrastruktura, ki naj bi zadovoljevala potrebe po varnem, hitrem in udobnem prevozu. V svoji študiji opozarjajo, da so možnosti dostopa do izvajalcev zdravstvenih storitev še posebej pomembne za podeželsko prebivalstvo, čeprav je to vprašanje pomembno tudi za preobremenjena mestna območja in za tiste, ki nimajo osebne oblike prevoza.

Raziskave so torej ugotovile nekatere povezave med potovalnimi časi do bolnišnic. V zvezi s tem obstaja tudi določena meja soglasja glede časovnih intervalov dostopnosti. Kljub temu ni mogoče zaobiti dejstva, da je odločitev o tem, kakšni potovalni časi naj bi bili sprejemljivi kot meri- 
lo za oblikovanje mreže zdravstvene dejavnosti, še vedno na strani oblikovalcev zdravstvene politike.

V nadaljevanju ugotavljamo, ali lahko opisane teoretične iztočnice, ki govorijo o dostopnosti izvajalcev zdravstvenih storitev, uporabimo tudi na primeru slovenskih splošnih bolnišnic. Zanima nas torej, ali lahko s pomočjo opredeljenih teoretičnih modelov preučujemo dostopnost izvajalcev sekundarne zdravstvene dejavnosti, ali lahko opredelimo tudi optimalne lokacije in število izvajalcev, kar predstavlja osnovo oblikovanja mreže sekundarne zdravstvene dejavnosti. Skladno s tem v nadaljevanju predstavljamo metodologijo za preučevanje optimalnih lokacij izvajalcev zdravstvene dejavnosti.

\section{Metodologija za preučevanje optimalnih lokacij izvajalcev zdravstvene dejavnosti}

Za določitev optimalnih lokacij izvajalcev sekundarne zdravstvene dejavnosti smo najprej izvedli analizo obstoječega stanja prostorske dostopnosti. Analizirali smo obstoječe lokacije splošnih bolnišnic, ki se nahajajo znotraj obstoječe mreže sekundarne zdravstvene dejavnosti v Sloveniji. V ta namen smo definirali območja pokritosti, s katerih se je do obstoječih splošnih bolnišnic mogoče pripeljati z osebnim avtomobilom v različnih časovnih intervalih. Izračunali smo število prebivalcev, ki gravitira k posamezni splošnih bolnišnici, in delež prebivalstva, ki ga bolnišnica pokrije znotraj svojega območja. Na podlagi naselij s številom prebivalstva in na podlagi obstoječih lokacij splošnih bolnišnic je bilo z orodjem najbližjega objekta izračunano, h kateri bolnišnici gravitira določeno naselje, ob pogoju, da gravitira $\mathrm{k}$ najbližji splošni bolnišnici. Za vsako gravitacijsko območje je bilo izračunano, koliko prebivalcev živi znotraj določenega območja. Naš namen merjenja prostorske dostopnosti je bil predvsem pojasniti relevantnost in objektivnost raziskav s področja prostorske dostopnosti in ne predstaviti predlog matematičnega modela za analizo prostorske dostopnosti obstoječih splošnih bolnišnic in za določanje optimalnih hipotetičnih lokacij slovenskih splošnih bolnišnic.

$\mathrm{V}$ ta namen smo v nadaljevanju uporabili eno samo merilo, in sicer potovalno upornost oziroma potovalni čas pri uporabi osebnega motornega vozila na kategoriziranem cestnem omrežju, in sicer od centroida naselja do centroida obstoječe ali hipotetične lokacije splošne bolnišnice. V tem okviru ni bila izdelana primerjalna analiza dostopnosti z namenom ugotavljanja razlik $\mathrm{v}$ preskrbljenosti prebivalstva na različnih gravitacijskih območjih z zdravstvenimi storitvami. Skladno s tem je torej upoštevanje storitvene zmogljivosti izvajalcev zdravstvene dejavnosti, ki je bila v navedenih formulah podana s številom za polni čas zaposlenih 
zdravnikov ali številom bolnišničnih postelj, brez pomena. $V$ našem primeru smo namreč izdelali analizo do istovrstne, enako kakovostne in enako zmogljive zdravstvene infrastrukture, kar pomeni, da v tem okviru zadošča zgolj analiza časovne razdalje oziroma potovalnega časa.

Modeli, ki smo jih uporabili za izračun časovnih razdalj in lokacij, se imenujejo modeli lokacija-alokacija. Pri tem smo znotraj analize uporabili različne modele lokacija-alokacija. Naš namen je bil namreč preveriti, kateri izmed modelov najbolje pojasnjuje in opredeljuje potencialno mrežo sekundarne zdravstvene dejavnosti v Sloveniji.

\section{Modeli lokacija-alokacija}

Pri določanju optimalnih lokacij imamo opravka z lokacijskimi problemi, ki so klasični optimizacijski modeli, ki se zelo pogosto uporabljajo na številnih področjih in ne zgolj pri določanju optimalnih lokacij izvajalcev zdravstvene dejavnosti. Lokacijo nekega objekta je zaradi različnih komunikacijskih, transportnih ter drugih pogojev treba zelo skrbno izbrati, pri čemer je treba upoštevati mnogo meril. Na področju zdravstvenega varstva je še posebej zelo pomembno, kje so izvajalci zdravstvenih storitev locirani. V primeru, ko so zmogljivosti izvajalcev premalo izkoriščene, ali v primeru, ko so izvajalci locirani na napačni lokaciji, je zdravstveno stanje prebivalstva na tem območju bistveno slabše. Posledice se kažejo $\mathrm{v}$ obliki povečane umrljivosti in obolevnosti prebivalstva. Na področju zdravstvenega varstva je torej lociranje izvajalcev zdravstvenih storitev še toliko pomembneje kot na drugih področjih.

Študije so pokazale, da lahko modeli lokacija-alokacija zagotavljajo znanstveno podporo pri načrtovanju in določanju optimalnih lokacij potencialnih objektov (Spaulding in Cromley 2007; Church in Murray 2009; Cromley in McLafferty 2012; Tomintz idr. 2013). Z zmanjševanjem celotne tehtane razdalje oziroma časa modeli rešujejo lokacijske probleme, hkrati pa določajo učinkovite lokacije objektov. Pri tem se osredotočajo na tista geografska območja, na katerih se pojavi povpraševanje in potencial za zagotavljanje ponudbe (Spaulding in Cromley 2007; Church in Murray 2009). Obstaja več različnih modelov lokacija-alokacija, ki se med seboj razlikujejo glede na različne matematične operacije in glede na način iskanja možnih rešitev. Pri tem so različne matematične operacije povezane predvsem s potekom postopka reševanja problemov znotraj posameznih modelov. To pomeni, da pri enakem lokacijskem problemu modeli predlagajo različne možne rešitve.

Modeli lokacija-alokacija so bili preučevani na številnih področjih vse od leta 1960 dalje. Največkrat so bili uporabljeni na področju geografije, ekonomije, industrije in javne uprave (Teixeira in Antunes 2008; 
Cromley in McLafferty 20I2). V literaturi obstajajo različne klasifikacije modelov lokacija-alokacija (Daskin 2008; Church in Murray 2009; Cromley in McLafferty 20I2). Mi smo v analizi optimalnih lokacij splošnih bolnišnic uporabili tiste modele, ki se uporabljajo v povezavi z GIS orodjem, kar pomeni, da so vsebinsko in postopkovno sorodni. Skladno s tem smo uporabili štiri modele lokacija-alokacija: model minimalne upornosti - MI-model (angl. minimise impedance model), model minimiranja števila objektov - MF-model (angl. minimise facilities model), model maksimalnega pokritja - MC-model (angl. maximise coverage model) in model maksimalne obiskanosti - MA-model (angl. maximise attendance model).

\section{MI-model}

196 Prvo opredelitev MI-modela p-mediane je predlagal Hakiwmi (1964), ki navaja: $\gg$ Želimo poiskati lokacijo policijske postaje ${ }^{p}$ tako, da je maksimalna razdalja od točke ${ }^{p}$ minimum.« MI-model je bil eden izmed prvih razvitih matematičnih modelov, ki se je ukvarjal z minimiranjem tehtane razdalje med lokacijami ponudbe in povpraševanja (Hakimi 1964; Teitz in Bart 1968). Bistvo modela je, da stremi k umeščanju določenega števila objektov, in sicer tako, da sta povprečna razdalja in čas, ki ga uporabniki potrebujejo, da pridejo do posameznega objekta, čim krajša (Church in Sorensen 1994; Church in Murray 2009). MI-model je dvociljni model: eden od ciljev je kar najbolj zmanjšati agregat časa potovanja med poselitvenim vozliščem in objektom, drugi pa je določiti razdaljo, ki uporabnike ločuje do najbližjega objekta (Narula, Ogbu in Samuelsoson 1977). Da bi dosegli ta cilj, lahko uporabimo naslednjo formulo (Teitz in Bart 1968; Cromley in McLafferty 2012):

Minimizacija $Z=\sum_{i \in I} \sum_{j \in J} a_{i} d_{i j} x_{i j}$

Pri tem je treba upoštevati naslednje omejitve:

- objekt mora biti dodeljen različnim mestom povpraševanja:

$x_{i j} \leq x_{j j}$ zavse $(i j)$;

- odprt objekt je treba razvrstiti glede na povpraševanje:

$$
\sum_{j \in J} x_{i j}=1 \text { za vse } i
$$

- locirati je treba zgolj $p$ objekte: 
$\sum_{j \in J} x_{j j}=p$ zavse $j$,

pri čemer je:

$x_{i j}=(0,1)$ za vse $i \in j$.

$Z$ predstavlja ciljno funkcijo. $I$ je množica točk povpraševanja, ki so v večini primerov vozlišča v omrežju skupaj z indeksom $i$, ki pa predstavlja določeno točko povpraševanja. $J$ ponazarja množico potencialnih objektov, ki so običajno vozlišča $\mathrm{v}$ omrežju skupaj z indeksom $j$, ki označuje določeno lokacijo potencialnega objekta. $a_{i}$ je število ljudi, ki so prisotni na kraju povpraševanja $i$. $x_{i j}$ je enak $\mathrm{I}$, ko povpraševanju na kraju $i$ pripišemo objekt $j$. V primeru, ko lokacija povpraševanja $i$ ni enaka lokaciji potencialnega objekta $j$, pa je $X_{i j}$ enak $0 . p$ predstavlja število potencialnih objektov, ki jih je treba locirati.

GIS orodje ponuja številne možnosti pri uporabi modelov lokacija-alokacija. Na podlagi MI-modela lahko v GIS orodju pregledujemo in ocenjujemo prostorske razporeditve, hkrati pa ugotavljamo tudi dostopnost do posameznih storitev. E. K. Cromley in S. L. McLafferty (20I2) sta predstavila MI-model prav na področju zdravstvenih storitev, kjer sta določila tako točke povpraševanje kot tudi obseg povpraševanja. Mitropoulos in sodelavci (2006) so predstavili nekaj novih predlogov za povečanje povpraševanja po izvajalcih na primarni ravni zdravstvene dejavnosti. V svoji študiji navajajo, da se je pri bolnikih pojavil povečan obseg povpraševanja po bolnišničnih storitvah, kar povzroča problem preobremenjenosti sekundarne ravni zdravstvene dejavnosti. Oblikovali so model, ki temelji na MI-modelu in mešanem celoštevilskem programiranju.

Pri uporabi MI-modela je treba upoštevati določene omejitve. Osnovna omejitev je ta, da obstaja določen proračun za financiranje izvajalcev zdravstvenih storitev ter da je za vse izvajalce zdravstvenih storitev treba zagotoviti enako količino finančnih sredstev za njihove naložbe in širitev dejavnosti. MI-model lahko predstavlja osnovo za vse raziskovalce, ki želijo analizirati dostopnost do storitev ob upoštevanju določenih omejitev. Obstajajo pa primeri, ko je uporaba MI-modela manj primerna. Ta model običajno ne ustreza sistemom, ki so hierarhične narave (Hodgson 1988). Rahman in Smith (2000) navajata, da ima uporaba MI-modela na področju zdravstvenega varstva nekatere pomanjkljivosti. Kakovost zdravstvenih storitev oziroma izidi zdravljenja se lahko hitro poslabšajo, ko čas potovanja preseže neko kritično vrednost. V tem primeru torej MI-model vodi do nesprejemljivih rešitev. Kljub temu je najpomembnejša prednost 
tega modela, da ima MI-model zmožnost, da se zmanjša agregat razdalje med ponudbo in povpraševanjem.

\section{MF-model}

Cilj modelov prekrivanja, kamor uvrščamo tudi MF-model, je, kako zagotoviti popolno pokritost, maksimalno pokritost, ali pa delno pokritost točk povpraševanja, in sicer na podlagi razdalje ali časa potovanja (Church in Murray 2009).

MF-model išče načine, kako z minimalnim številom izvajalcev pokriti potrebe uporabnikov znotraj določene razdalje ali časovnega intervala (ReVelle in Hogan 1989a; Schilling, Jayaraman in Barkhi 1993). Rešitev tega problema se razlikuje od drugih, ki iščejo način, kako postaviti omejeno število izvajalcev za zadovoljitev potreb uporabnikov. MF-model določi minimalno število objektov, ki lahko ustrezajo tako omejitvam razdalje kot tudi časovnim omejitvam. Od leta 1970 je kar nekaj raziskovalcev poskušalo opredeliti MF-model, s katerimi bi rešili probleme lociranja izvajalcev. Prvi tak model so postavili Toregas in sodelavci (I97I), s katerim so poskušali določiti maksimalen čas in razdaljo med uporabniki in lokacijo urgentnih središč. Gleason (1975) je uporabil MF-model, da bi izračunal minimalno število avtobusnih postaj na neki določeni relaciji, in sicer ob določitvi maksimalnega števila korakov, ki jih človek sme narediti iz katere koli točke povpraševanja do najbližje avtobusne postaje.

Matematično funkcijo za MF-model lahko zapišemo kot (Schilling, Jayaraman in Barkhi 1993; Cromley in McLafferty 2012):

$$
\text { Minimizacija } Z=\sum_{j \in J} x_{j}
$$

Za obseg posameznega mesta povpraševanja je ključnega pomena razdalja ali časovni interval od točke povpraševanja do lokacije potencialnega objekta.

$$
\sum_{j \in N_{i}} x_{j} \geq 1 \text { za vsei. }
$$

Objekt je lahko na potencialni lokaciji j ustanovljen, ali pa tudi ne. V odvisnosti od tega zavzamejo vrednost 0 ali 1 .

$$
x_{j}=(0,1) \text { zavse } j \text {. }
$$

$x_{j}$ zavzame vrednost o, če objekt ni ustanovljen na lokaciji $j . V$ primeru, ko je objekt ustanovljen na lokaciji j , pa $x_{j}$ zavzame vrednost I. $N_{i}$ predstavlja množico objektov, ko je razdalja med točko povpraševanja $i$ 
in lokacijo potencialnega objekta $j$ manjša od definirane razdalje ali potovalnega časa, kar zapišemo kot $d_{i j}<s$. Pri tem se $d_{i j}$ nanaša na razdaljo med točko povpraševanja $i$ in lokacijo potencialnega objekta $j . s$ pa ponazarja simbol za maksimalno razdaljo ali časovni interval dostopnosti.

Kritiki so temu modelu kot glavni slabosti očitali, da niso vključili možnosti, da je izvajalec zaseden ali ni dosegljiv. V primeru iskanja bolnišničnih urgentnih središč je možno, da je nek izvajalec namreč zaseden (Marianov in ReVelle 1994). V naslednjih letih je bilo predlaganih nekaj modificiranih MF-modelov, ki so poskušali odpravili omejitve potencialne zasedenosti izvajalca. ReVelle in K. Hogan (1989a) sta v svojem modelu poskušala oceniti zasedenost izvajalcev, in sicer v okviru geografske pokritosti okoli vozlišča. Z MF-modelom običajno določamo optimalne lokacije potencialnih izvajalcev, ki niso vnaprej določene (Straitiff in Cromley 2010). MF-model se torej v glavnem uporablja zato, da bi definiral najmanjše število izvajalcev, ki lahko pokrijejo povpraševanje na nekem geografskem območju. MF-modeli so bili zelo pogosto uporabljeni, da bi definirali zdravstvene storitve. Bili so tudi eni prvih modelov, ki so odgovarjali na vprašanje, kako definirati minimalno število izvajalcev, da bi pokrili povpraševanje znotraj določene razdalje ali časovnega okvira.

\section{MC-model}

V MF-modelu se predpostavlja, da skušamo pokriti vse potrebe uporabnikov. V praksi pa se je pokazalo, da so viri vedno omejeni, zato so raziskovalci oblikovali MC-model (Church in ReVelle 1974; Spaulding in Cromley 2007; Murawski in Church 2009), ki poskuša maksimirati pokritje potreb, ali z drugimi besedami delež prebivalstva, ki mu je storitev dostopna, in sicer v določenem časovnem intervalu ali razdalji. Seveda se lahko zgodi, da določeni deli ozemlja ali območja v takem modelu niso pokrita s storitvami. MC-model je uporaben takrat, ko obstaja majhno število izvajalcev, $s$ katerimi je treba pokriti čim večje število ljudi, ki potrebujejo določene storitve (Church in Murray 2009; Gu, Wang in McGregor 2010). Postopki reševanja lokacijskih problemov se torej v MC-modelu razlikujejo od načina reševanja iste težave v MF-modelu. V smislu izbire lokacij objektov MC-model ne želi minimirati števila potencialnih objektov, ki pokrivajo vse točke povpraševanja znotraj določene razdalje ali časovnega intervala. MC-model ponuja rešitev, kako pokriti čim večje območje povpraševanja, in sicer glede na razdaljo ali časovni okvir med točko povpraševanja in točko ponudbe.

Matematična funkcija MC-modela je bila zapisana v številnih študijah (Church in ReVelle 1974; Murawski in Church 2009; Cromley in McLafferty 2012): 
Minimiranje $Z=\sum_{j \in J} a_{i} y_{i}$,

pri čemer velja:

$\sum_{j \in N_{i}} x_{j}+y_{i} \geq 1$ za vse $i \in I$.

Minimiranje Z je odvisno od:

$\sum_{j \in J} x_{j}=p$

pri čemer je:

$x_{j}=(0,1)$ zavse $j \in J$,

$y_{i}=(0,1)$ zavse $i \in I$.

V novejšem času sta Spaulding in Cromley (2007) predstavila novo opredelitev modela maksimalnega pokritja, in sicer $\mathrm{z}$ namenom locirati niz trgovin v 75 mestih v ZDA. Pri tem sta uporabila reprezentativne podatke in možnosti, ki jih omogoča GIS orodje. Alexandris in Giannikos (20I0) pa sta predstavila model, ki prav tako temelji na možnostih, ki jih ponuja GIS orodje. Model sta oblikoval z namenom predstavitve povpraševanja po bančnih poslovalnicah v Atenah. Glavna prednost MC-modela je uporaba poligonov namesto diskretnih točk v smislu predstavljanja potreb uporabnikov. Kar nekaj avtorjev je uporabilo MC-model za izboljšanje dostopnosti do zdravstvenih storitev znotraj geografskih območij, in sicer skozi prilagoditve obstoječih izvajalcev ali z dodajanjem novih izvajalcev na območjih, na katerih je dostopnost do zdravstvenih storitev slaba. Po drugi strani so nekateri ponujali tudi drugačne rešitve. L. Murawski in Church (2009) sta na primer predlagala izboljšanje transportnih poti za izboljšanje dostopnosti do zdravstvenih storitev v Gani.

MC-model je v glavnem uporabljen za definiranje maksimalnega geografskega pokritja uporabnikov znotraj določene razdalje od ponudnika oziroma izvajalca. $Z$ njim lahko dosežemo povečanje geografske pokritosti in ponujanje možnih alternativnih rešitev, kadar je izvajalec zaseden. Ta model pomeni pomembno možnost za distribucijo storitev zdravstvenega varstva. Čeprav MC-model nudi dobro podporo prostorskemu načrtovanju različnih zmogljivosti izvajalcev, pa mnogi izzivi še vedno ostajajo nerešeni. Sem uvrščamo posebej tiste, ki so vezani na razdaljo. Za boljše razumevanje problema v MC-modelu so tako v MA-mo- 
del vnesli različno upoštevanje razdalje med ponudnikom in točkami povpraševanja.

\section{MA-model}

Drugi soroden model je model MA, ki želi maksimirati obiskanost izvajalca znotraj nekega časovno dostopnega območja. Utež oziroma ponder za vsako točko povpraševanja ni enak; večji je tam, kjer je večja poseljenost, saj je tam tudi večje povpraševanje (Holmes, Williams in Brown 1972; Algharib 201 I). MA-model je ena vrsta modelov prekrivanja, pri katerem se matematične operacije razlikujejo glede na predhodne predstavljene modele. To je tudi ključna razlika med MA- in MC-modelom. Model MA namreč zahteva različno razmerje povpraševanja oziroma različno obtežitev točke povpraševanja glede na razdaljo, ki jo ima uporabnik do izvajalca. Razdalja je torej ključni dejavnik za ponder, ki ga pripišemo vsaki geografski točki povpraševanja. Ta ponder se znižuje sorazmerno s povečevanjem razdalje med izvajalcem in uporabnikom (Church in ReVelle 1974; ReVelle in Hogan 1989b; Spaulding in Cromley 2007; Murawski in Church 2009).

Cilj MA-modela je določitev lokacije izvajalcev, ki bodo omogočile njihovo maksimalno obiskanost. Ta model naj bi povečal količino točk povpraševanja, ki jih lahko posamezen izvajalec pokrije glede na določeno razdaljo ali časovno omejitev. MA-model predpostavlja, da se možnost za interakcijo med lokacijami izvajalcev in lokacijami povpraševanja zmanjšuje z naraščajočo razdaljo. To pomeni, da verjetnost obiskanosti izvajalca pada linearno, ko se povečuje razdalja. To je razlog, da ta model poišče možnosti za lociranje izvajalcev, ki so blizu večine prebivalstva (Algharib 20I I). Z drugimi besedami - optimalne lokacije izvajalcev v MA-modelih bodo v neposredni bližini največjega števila točk povpraševanja.

Matematično funkcijo tega modela so zapisali Holmes, Williams in Brown (1972):

$$
Z=\sum_{i=0}^{n} \sum_{j=0}^{n} a_{i}\left(S-d_{i j}\right) x_{i j} .
$$

Denimo, da obstajajo povpraševanje oziroma potrebe v i-ti ploskovni enoti, nato $i=1,2, \ldots n$ predstavlja skupno število ljudi. Pri tem predpostavimo, da $j=1,2, \ldots n$ določa razdaljo med ploskovno enoto $i$ in $j$, ki je lahko izmerjena z različnimi merskimi enotami. $S$ predstavlja razdaljo, ki mora biti znotraj definiranega praga območja. Pri odločitvah uporabimo naslednje spremenljivke, ki morajo biti znotraj naslednjih intervalov: 
- $\quad x_{i j}=0$, ko ploskovna enota $i$ ne pokriva svojih potreb z izvajalcem $j$,

- $\quad 0<d_{i j} \leq 1$, ko ploskovna enota $i$ pokriva svoje potrebe z izvajalcem $j$.

Model MA predpostavlja, da je verjetnost uporabe storitve pri uporabnikih tem manjša, čim daljši potovalni čas imajo ti do storitve. Posledično to pomeni, da se količina povpraševanja zmanjšuje z oddaljenostjo od izvajalcev. Povpraševanje je večje tam, kjer je poseljenost prebivalstva večja. Izvajalci, ki bodo locirani na gosteje poseljenem območju, bodo torej bolj obiskani, kot če bi bili locirani na obrobju nekega naselja, kjer je poseljenost običajno manjša. Za MA-model je značilno, da povpraševanju, ki se pojavi zunaj omejenega območja, ni dodeljen nobeden izvajalec in točke povpraševanja ostanejo nepokrite. V primeru, ko je točka povpraševanja znotraj omejenega območja, pa ji dodelimo utež oziroma ponder, in sicer glede na oddaljenost od izvajalca. Pri tem je treba upoštevati, da se posamezni točki povpraševanja dodeli ponder zgolj na podlagi razdalje do najbližjega izvajalca storitve.

Za namene analize optimalnih lokacij in števila splošnih bolnišnic smo uporabili štiri klasične modele lokacija-alokacija, ki so nam podali informacijo, kolikšno je najmanjše število izvajalcev, ki lahko pokrijejo potrebe prebivalcev po storitvah zdravstvenega varstva znotraj določenega območja. To so model MI, model MF, model MC in model MA. Pri tem smo definirali različne časovne intervale, ki opredeljujejo maksimalen potovalni čas od točke povpraševanja do najbližjega izvajalca zdravstvenih storitev. $\mathrm{Na}$ ta način smo določili število izvajalcev, s katerimi smo poskušali pokriti čim večji delež prebivalcev, ki potrebujejo zdravstvene storitve znotraj določenega časovnega intervala dostopnosti.

Naš namen je bil predstaviti možne projekcije postavitve mreže sekundarne zdravstvene dejavnosti, pri čemer nismo sledili cilju preoblikovanja obstoječe mreže, temveč cilju postavitve povsem nove mreže sekundarne zdravstvene dejavnosti. Predstavljene projekcije torej obstoječo mrežo sekundarne zdravstvene dejavnosti redefinirajo. Obstoječa mreža sekundarne zdravstvene dejavnosti v osnovi ne omogoča učinkovitega izvajanja zdravstvenih storitev, zato njeno preoblikovanje $\mathrm{v}$ tem okviru ne bi bilo smiselno. Skladno s tem smo tudi izbrali modele lokacija-alokacija, ki poskušajo minimirati število izvajalcev zdravstvene dejavnosti, ki so potrebni, da pokrijejo čim večje število točk povpraševanja na podlagi časa potovanja. Modeli lokacija-alokacija ne izbirajo lokacij glede na obstoječe stanje izvajalcev, temveč določijo optimalne lokacije povsem na novo. 
$\mathrm{Na}$ tej točki je bilo treba za potrebe analize optimalnih lokacij in števila izvajalcev sekundarne zdravstvene dejavnosti sprejeti še eno odločitev. Ta odločitev se nanaša na primeren potovalni čas, ki ga posamezen bolnik potrebuje do najbližjega izvajalca. Maksimalen potovalni čas do najbližje bolnišnice mora biti opredeljen tako, da izvajalcem omogoča zagotavljanje dobrih zdravstvenih izidov. V literaturi in med oblikovalci zdravstvene politike ni enotnega mnenja, kolikšen je primeren potovalni čas do najbližje bolnišnice, zato smo se odločili, da bomo definirali tri različne časovne intervale, ki jih v teoriji najpogosteje omenjajo. Kot prvi časovni interval je opredeljeno 30 minut trajajoče potovanje z osebnim avtomobilom. Drugi interval je vključeval 45-minutno časovno obdobje, tretji interval je predstavljal 6o-minutno časovno obdobje. To pomeni, da smo kot rezultat dobili tri različne možne rešitve.

Znotraj metode lokacija-alokacija smo torej definirali različne modele, ki smo jih uporabili skupaj z orodjem ArcGIS za mrežne analize (angl. Network Analyst), ki ga je razvilo podjetje Esri (2008). S pomočjo ArcGIS orodja smo izdelali geografske karte, ki prikazujejo optimalne hipotetične lokacije bolnišnic, do katerih lahko bolniki dostopajo z osebnim avtomobilom v različnih časovnih intervalih. Rezultata analize sta dva. Najprej smo opredelili hipotetične lokacije optimalno lociranih bolnišnic, ki omogočajo dostop do najbližjih bolnišnic v 30-minutnem, 45-minutnem, 6o-minutnem časovnem intervalu. Drugi rezultat pa prikazuje število optimalnih lokacij oziroma hipotetično število bolnišnic, ki bi zagotavljale zdravstveno oskrbo osemdesetim odstotkom celotnega prebivalstva Slovenije v navedenih časovnih intervalih.

\section{Podatki in spremenljivke modelov mreže sekundarne zdravstvene dejaunosti}

Pri analizi optimalnih lokacij in števila slovenskih splošnih bolnišnic smo uporabili podatke o lokacijah naselij z njihovim številom prebivalcev in podatke o cestni mreži Slovenije, na podlagi katere smo definirali povprečne potovalne hitrosti na kategoriziranem cestnem omrežju. Za potrebe analize različnih modelov lokacija-alokacija pa smo opredelili lokacije naselij z več kot 5.000 prebivalci. Poleg tega smo uporabili tudi različne časovne intervale, $\mathrm{v}$ katerih lahko bolniki dostopajo do najbližjega izvajalca zdravstvene dejavnosti z osebnim avtomobilom. Za analizo prostorske dostopnosti obstoječih splošnih bolnišnic smo uporabili podatke o lokacijah obstoječih slovenskih splošnih bolnišnic. Na podlagi omenjenih podatkov smo tako v prvem koraku najprej analizi- 
rali obstoječe stanje, kjer smo opredelili pokritost prebivalstva s storitvami zdravstvenega varstva glede na obstoječe lokacije slovenskih splošnih bolnišnic. V drugem koraku smo na podlagi opredeljenih podatkov opredelili optimalne lokacije in število hipotetičnih splošnih bolnišnic. $\mathrm{Na}$ ta način smo definirali tri različne modele mreže sekundarne zdravstvene dejavnosti.

\section{Lokacije naselij s številom prebivalstva}

V ArcGis orodje smo vključili podatke o številu prebivalcev po različnih administrativnih enotah in na hierarhični mreži enako velikih celic. To nam je omogočalo označevanje in povezovanje poljubne prostorske enote ter pregledovanje statističnih podatkov o številu prebivalcev znotraj kartografske podloge. Za definiranje števila prebivalstva smo izbrali prostorsko raven $500 \mathrm{~m}$ x $500 \mathrm{~m}$. To nam je omogočalo, da smo neposredno prevzete podatke povezali s cestno mrežo, kar nam je omogočalo analiziranje prostorske dostopnosti v nadaljevanju. $\mathrm{V}$ tem delu je bilo treba izvesti minimalne popravke centroidov naselij, če so bili ti predaleč od cestne mreže. Vsi podatki so zadnji javno dostopni podatki, kar pomeni, da smo uporabili podatke, ki se nanašajo na leto 2015.

\section{Cestna mreža Slovenije}

Preko digitalnega zemljevida OpenStreetMap (OpenStreetMap Wiki Contributors 2016), ki se uporablja pri vse več analizah prostorske dostopnosti, smo v ArcGis orodje vključili osnovne podatke o cestnem omrežju. OpenStreetMap se razlikuje od ostalih ponudnikov zemljevidov predvsem $\mathrm{v}$ hitrosti objave posodobitev, saj so spremembe na zemljevidih dnevno posodobljene. $\mathrm{Na}$ tem mestu smo za potrebe naše analize nekatere podatke o cestnem omrežju, pridobljene $\mathrm{z}$ digitalnim zemljevidom OpenStreetMap, dopolnili in preoblikovali. Iz nabora podatkov smo izključili določene kategorije, to so peš poti, kolesarske poti, konjske poti, avtobusne postaje in podobno, kar z vidika naše analize ni relevantno. Poleg tega smo v zemljevid vključili določene cestne odseke, ki so znotraj digitalnega zemljevida OpenStreetMap izpuščeni. V naslednjem koraku smo v cestno omrežje vnesli podatke o povprečnih potovalnih hitrostih. Uporabljena je bila uradna klasifikacija državnih cest 2012 (»Uredba o kategorizaciji državnih cest « 20I2). Pripisane povprečne potovalne hitrosti podajamo v preglednici 18. 
Preglednica i 8: Pripisane povprečne potovalne hitrosti na cestnem omrežju

Tip ceste

\begin{tabular}{|c|c|}
\hline \multicolumn{2}{|c|}{ Priključne ceste } \\
\hline Avtocesta & 100 \\
\hline Hitra cesta & 90 \\
\hline Glavna cesta I. reda in 2. reda & 80 \\
\hline Regionalna cesta 1 . reda in 2 . reda & 70 \\
\hline Regionalna cesta 3 . reda in 4 . reda & 60 \\
\hline Ostale neklasificirane ceste izven naselja & 50 \\
\hline Ulica v spalnem naselju & 40 \\
\hline \multicolumn{2}{|c|}{ Priključne ceste } \\
\hline Servirne ceste & 40 \\
\hline Avtocesta-priključki & 100 \\
\hline Hitra cesta - priključki & 70 \\
\hline Cesta, rezervirana za motorna vozila - priključki & 60 \\
\hline Pomembna (medkrajevna) cesta - priključki & 30 \\
\hline Manjša cesta z delilno črto - priključki & 30 \\
\hline
\end{tabular}

Hitrost $\mathrm{v} \mathrm{km/h}$ . 


\section{Lokacije obstoječih splošnih bolnišnic}

Za potrebe analize prostorske dostopnosti obstoječih splošnih bolnišnic smo potrebovali podatke o njihovih točnih lokacijah. V analizo smo, kot že omenjeno, zajeli vse splošne bolnišnice in dva univerzitetna klinična centra. Podatke, ki so bili vneseni za analizo prostorske dostopnosti v orodju ArcGis, predstavljamo v preglednici 19.

Preglednica 19: Podatki o lokacijah obstoječih bolnišnic

\begin{tabular}{|c|c|c|c|}
\hline Št. & Bolnišnica & Ulica in hišna števila & Kraj \\
\hline I & Splošna bolnišnica Brežice & Černelčeva cesta is & 8250 Brežice \\
\hline 2 & Splošna bolnišnica Celje & Oblakova ulica 5 & 3000 Celje \\
\hline 3 & Splošna bolnišnica Izola & Polje 40 & 6310 Izola \\
\hline 4 & Splošna bolnišnica Jesenice & Cesta maršala Tita ıı & 4270 Jesenice \\
\hline 5 & Univerzitetni klinični center Ljubljana & Zaloška cesta 2 & 1000 Ljubljana \\
\hline 6 & Univerzitetni klinični center Maribor & Ljubljanska ulica 5 & 2000 Maribor \\
\hline 7 & Splošna bolnišnica Murska Sobota & Ulica dr. Vrbnjaka 6 & 9000 Murska Sobota \\
\hline 8 & Splošna bolnišnica Nova Gorica & Ulica padlih borcev rza & 5290 Šempeter pri Gorici \\
\hline 9 & Splošna bolnišnica Novo mesto & Šmihelska cesta I & 8000 Novo mesto \\
\hline 10 & Splošna bolnišnica Ptuj & Potrčeva cesta 23 & 2250 Ptuj \\
\hline II & Splošna bolnišnica Slovenj Gradec & Gosposvetska cesta I & 2380 Slovenj Gradec \\
\hline 12 & Splošna bolnišnica Postojna & Rudarska cesta 9 & 1420 Trbovlje \\
\hline
\end{tabular}

\section{Rezultati modelov mreže sekundarne zdravstvene dejavnosti}

V prvem koraku predstavljamo razporeditev prebivalstva oziroma gostoto poseljenosti ter lokacije obstoječih slovenskih splošnih bolnišnic. Že na prvi pogled vidimo, da je gostota poseljenosti v Sloveniji neenakomerna, kar se kaže v večjem številu prebivalcev, ki živijo v vzhodnem in osrednjem delu Slovenije, medtem kot je zahodni del Slovenije redkeje poseljen. Obstoječe stanje kaže, da imamo v vzhodnem delu Slovenije sedem splošnih bolnišnic in en univerzitetni klinični center, v osrednji Sloveniji je en univerzitetni klinični center, v zahodni Sloveniji pa imamo tri splošne bolnišnice, kar prikazuje slika 23.

$\mathrm{V}$ nadaljevanju prikazujemo razporeditev prebivalstva oziroma delež prebivalstva, ki gravitira k posamezni obstoječi splošni bolnišnici. Pri tem smo v analizi zajeli merilo, pri katerem se lahko prebivalci pripeljejo do najbližjega izvajalca zdravstvenih storitev v časovnem intervalu do 30 minut, $v$ časovnem intervalu od 30 do 45 minut, v časovnem intervalu od 45 do 60 minut in v obdobju brez časovnih omejitev. Razporeditev 
prebivalstva, ki gravitira $\mathrm{k}$ posamezni bolnišnici, prikazujemo $\mathrm{v}$ preglednici 20.

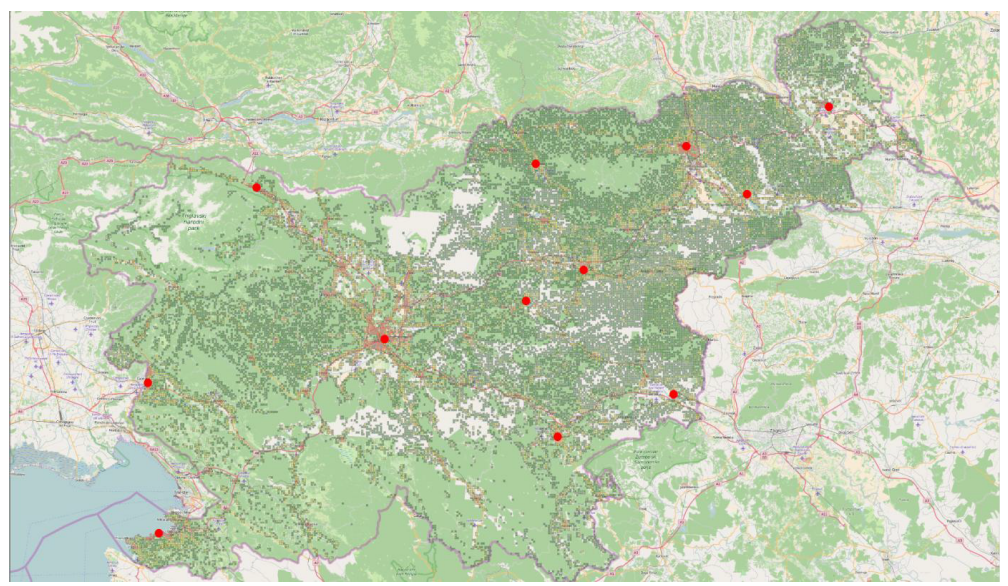

Slika 23: Razporeditev prebivalstva in lokacije obstoječih splošnih bolnišnic

Preglednica 20: Razporeditev prebivalstva po obstoječih bolnišnicah

\begin{tabular}{|c|c|c|c|c|c|c|c|c|}
\hline \multirow[t]{2}{*}{ Bolnišnica } & \multicolumn{2}{|c|}{ Do $30 \mathrm{~min}$} & \multicolumn{2}{|c|}{$\mathrm{Od}_{30} \mathrm{do}_{45} \mathrm{~min}$} & \multicolumn{2}{|c|}{$\mathrm{Od}_{45} \mathrm{do} 60 \mathrm{~min}$} & \multicolumn{2}{|c|}{ Brez omejitev } \\
\hline & Št. preb. & $\begin{array}{l}\text { Delež } \\
\text { preb. } \\
(\mathrm{v} \%)\end{array}$ & Št. preb. & $\begin{array}{l}\text { Delež } \\
\text { preb. } \\
(\mathrm{v} \%)\end{array}$ & Št. preb. & $\begin{array}{l}\text { Delež } \\
\text { preb. } \\
(\mathrm{v} \%)\end{array}$ & Št. preb. & $\begin{array}{c}\text { Delež } \\
\text { preb. } \\
(\mathrm{v} \%)\end{array}$ \\
\hline / & 323.092 & 15,66 & 95.752 & 4,64 & 24.310 & $\mathrm{I}, \mathrm{I} 8$ & 7.048 & 0,34 \\
\hline SBB & $55 \cdot 44^{2}$ & 2,69 & 67.462 & 3,27 & 67.462 & 3,27 & 67.462 & 3,27 \\
\hline SBC & 208.611 & IO,II & 241.756 & 11,72 & 244.662 & II,86 & 245.026 & II, 88 \\
\hline SBI & 92.606 & 4,49 & 106.614 & 5,17 & 117.118 & 5,68 & 118.926 & 5,77 \\
\hline SBJ & 85.143 & 4,13 & 93.632 & 4,54 & 93.977 & 4,56 & 96.248 & 4,67 \\
\hline UKL LJ & 588.629 & 28,53 & 662.164 & 32,10 & 693.748 & 33,63 & 700.711 & 33,97 \\
\hline UKCMB & 219.227 & 10,63 & 228.290 & 11,07 & 228.889 & $\mathrm{II}, \mathrm{IO}$ & 228.889 & $\mathrm{II}, \mathrm{IO}$ \\
\hline SB MS & 108.559 & 5,26 & 119.169 & 5,78 & 119.169 & 5,78 & 119.169 & 5,78 \\
\hline SB NG & $8 \mathrm{I} .453$ & 3,95 & 100.893 & 4,89 & 107.428 & 5,21 & 110.706 & 5.37 \\
\hline SB NM & 92.203 & 4,47 & 115.743 & 5,61 & 133.484 & 6,47 & 136.030 & 6,59 \\
\hline SBP & 84.107 & 4,08 & 93.383 & 4,53 & 93.459 & 4,53 & 93.459 & 4,53 \\
\hline SB SG & 60.552 & 2,94 & 68.331 & 3,31 & 69.085 & 3,35 & 69.117 & 3,35 \\
\hline SBT & 63.250 & 3,07 & 69.685 & 3,38 & 70.083 & 3,40 & 70.083 & 3,40 \\
\hline Skupaj & 2.062 .874 & 100,00 & 2.062 .874 & 100,00 & 2.062 .874 & 100,00 & 2.062 .874 & 100,00 \\
\hline
\end{tabular}

Podatke iz preglednice grafično prikazujemo tudi v slikah 24, 25, 26 in $27 . \mathrm{Na}$ sliki 24 vidimo območja, $s$ katerih lahko bolniki dostopajo do 
najbližjih splošnih bolnišnic v 30-minutnem časovnem intervalu. $\mathrm{V}$ tem primeru obstoječe lokacije splošnih bolnišnic omogočajo dostop 84,34 odstotka prebivalstva, kar pomeni, da zdravstvene storitve na sekundarni ravni zdravstvene dejavnosti $v$ 30-minutnem časovnem intervalu niso zagotovljene 323.092 prebivalcem. V obstoječem stanju največji delež prebivalstva gravitira $\mathrm{k}$ Univerzitetnemu kliničnemu centru Ljubljana, in sicer 28,53 odstotka celotnega prebivalstva, najmanjši delež prebivalstva pa zajame Splošna bolnišnica Brežice, h kateri gravitira zgolj 2,69 odstotka prebivalstva. Univerzitetni klinični center Ljubljana lahko torej v 30-minutnem časovnem intervalu oskrbi 588.629 bolnikov, Splošna bolnišnica Brežice pa 55.442 bolnikov.

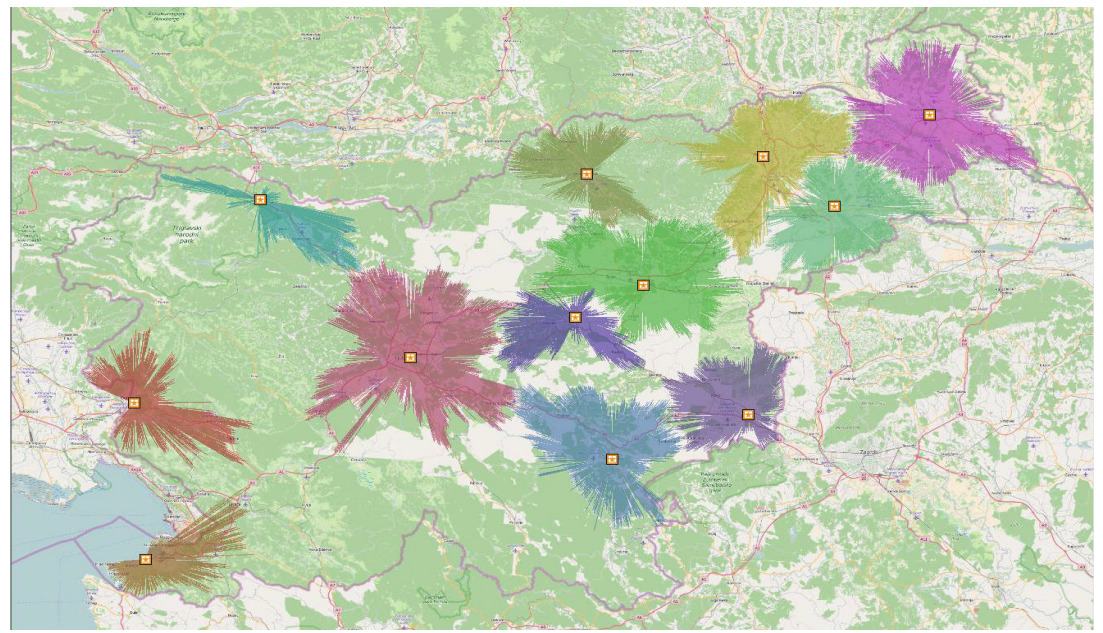

Slika 24: Dostopnost do obstoječih splošnih bolnišnic v 30-minutnem časovnem intervalu

V sliki 25 prikazujemo območja, s katerih se lahko bolniki pripeljejo do najbližje splošne bolnišnice z osebnim avtomobilom v 45-minutnem časovnem intervalu. Rezultati nam pokažejo, da je $\mathrm{v}$ tem primeru delež pokritosti območij večji v primerjavi z deležem pokritosti na sliki 24. Znotraj 45-minutnega časovnega intervala do obstoječih splošnih bolnišnic ne more dostopati 4,65 odstotka prebivalstva, kar pomeni, da zdravstvene storitve na sekundarni ravni zdravstvene dejavnosti v 45-minutnem okviru niso dosegljive 95.752 prebivalcem. Največji delež prebivalstva pokrije Univerzitetni klinični center Ljubljana, h kateremu gravitira 662.164 prebivalcev. Naša največja splošna bolnišnica lahko v osrednji Sloveniji znotraj 45-minutnega časovnega intervala oskrbi 32,10 odstotka prebivalcev. Zanimiv je podatek, da je na drugem mestu po deležu pokri- 
tosti prebivalstva Splošna bolnišnica Celje, ki pa je po velikosti bistveno manjša od Univerzitetnega kliničnega centra Maribor. Do Splošne bolnišnice Celje lahko v 45-minutnem časovnem intervalu dostopa I I,72 odstotka prebivalcev, kar pomeni, da lahko znotraj omenjenega časovnega okvira zagotovijo zdravstvene storitve 241.756 prebivalcev.

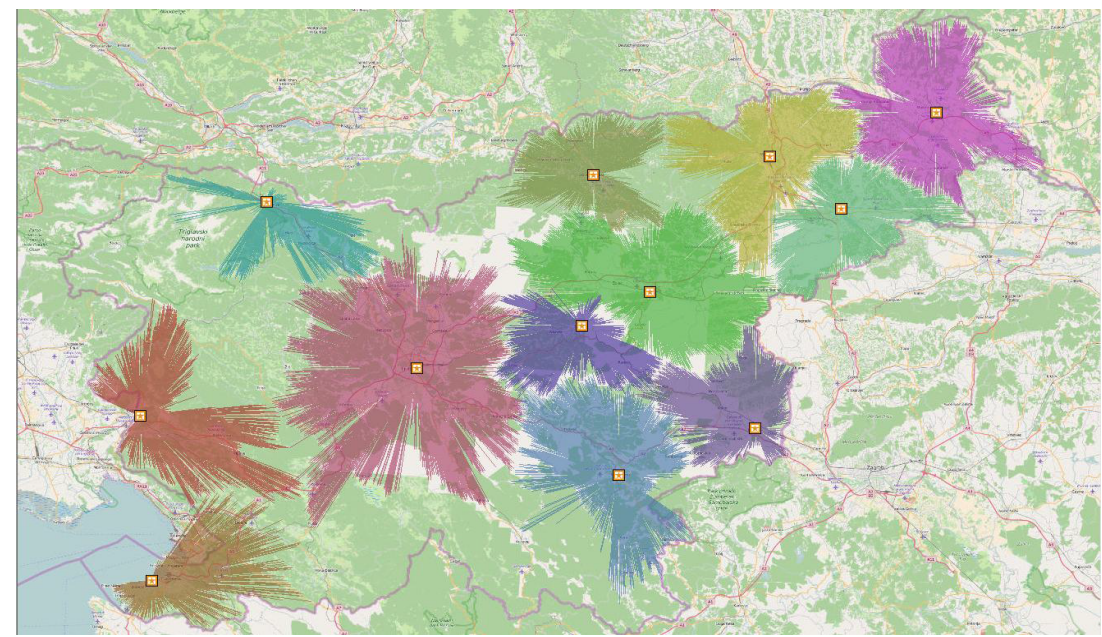

Slika 25: Dostopnost do obstoječih splošnih bolnišnic v 45-minutnem časovnem intervalu

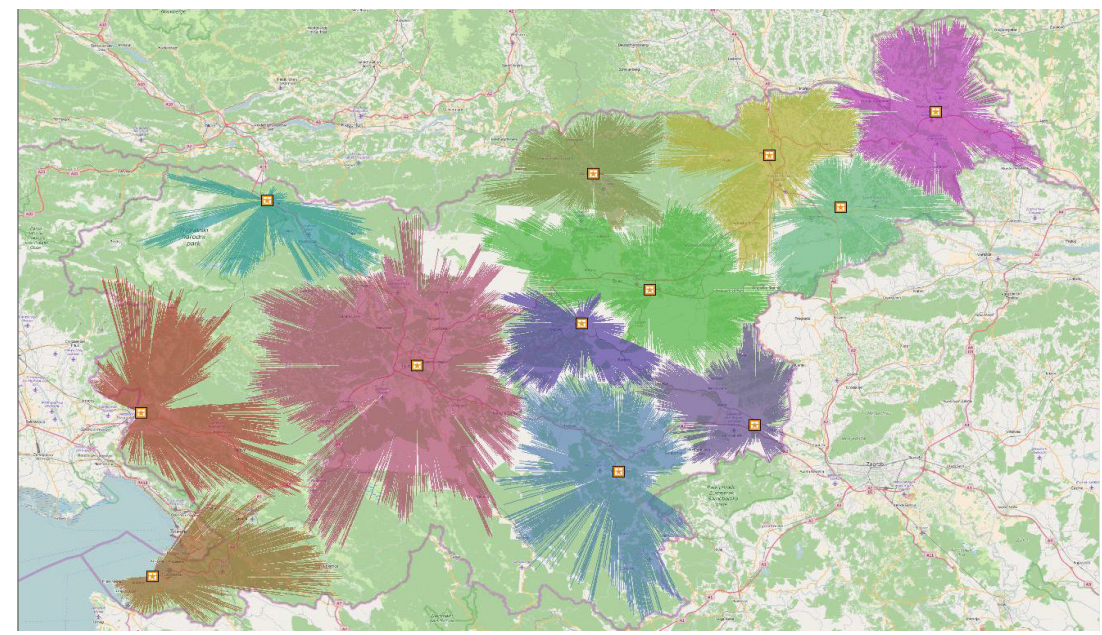

Slika 26: Dostopnost do obstoječih splošnih bolnišnic v 60-minutnem časovnem intervalu

V sliki 26 prikazujemo območja, $s$ katerih se lahko bolniki pripeljejo do najbližje splošne bolnišnice z osebnim avtomobilom v 60 minutah. Re- 
zultati kažejo, da je v tem primeru delež pokritosti prebivalstva že zelo visok. Na podlagi izrisanega zemljevida pokritosti vidimo, da je zelo malo praznega prostora med posameznimi gravitacijskimi območji, kar pomeni, da relativno majhen delež prebivalstva ne more dostopati do obstoječih splošnih bolnišnic v 60-minutnem časovnem intervalu. V 60-minutnem časovnem intervalu obstoječih dvanajst splošnih bolnišnic ne pokrije I,I 8 odstotka celotnega prebivalstva. Zanimiv je podatek, da k Splošni bolnišnici Slovenj Gradec gravitira 3,35 odstotka prebivalstva, k Splošni bolnišnici Trbovlje, ki je po velikosti približno dvakrat manjša splošna bolnišnica v primerjavi s Splošni bolnišnico Slovenj Gradec, pa gravitira celo večji delež prebivalstva, to je 3,4 odstotka. Do Splošne bolnišnice Trbovlje se tako v 60-minutnem časovnem intervalu lahko pripelje 70.083 bolnikov.

V sliki 27 prikazujemo območja pokritosti, ki jih zajamejo obstoječe splošne bolnišnice, če pri tem ni vključene nobene časovne omejitve. Podatki se ne razlikujejo bistveno od podatkov, ki jih dobimo, če v analizo vključimo merilo 6o-minutnega časovnega intervala. Delež prebivalstva, ki ne gravitira k nobenemu območju, je o,34 odstotka, kar pomeni, da nima dostopa do storitev na sekundarni ravni zdravstvene dejavnosti 7.048 prebivalcev. Če primerjamo deleže prebivalstva, ki jih obstoječe bolnišnice pokrijejo brez časovne omejitve, s podatki, ko je vključen 6o-minutni časovnih interval, vidimo, da se delež prebivalstva, ki gravitira k Splošni bolnišnici Brežice, Univerzitetnemu kliničnemu centru Maribor, Splošni bolnišnici Murska Sobota, Splošni bolnišnici Ptuj, Splošni bolnišnici Slovenj Gradec in Splošni bolnišnici Trbovlje, ne spremeni.

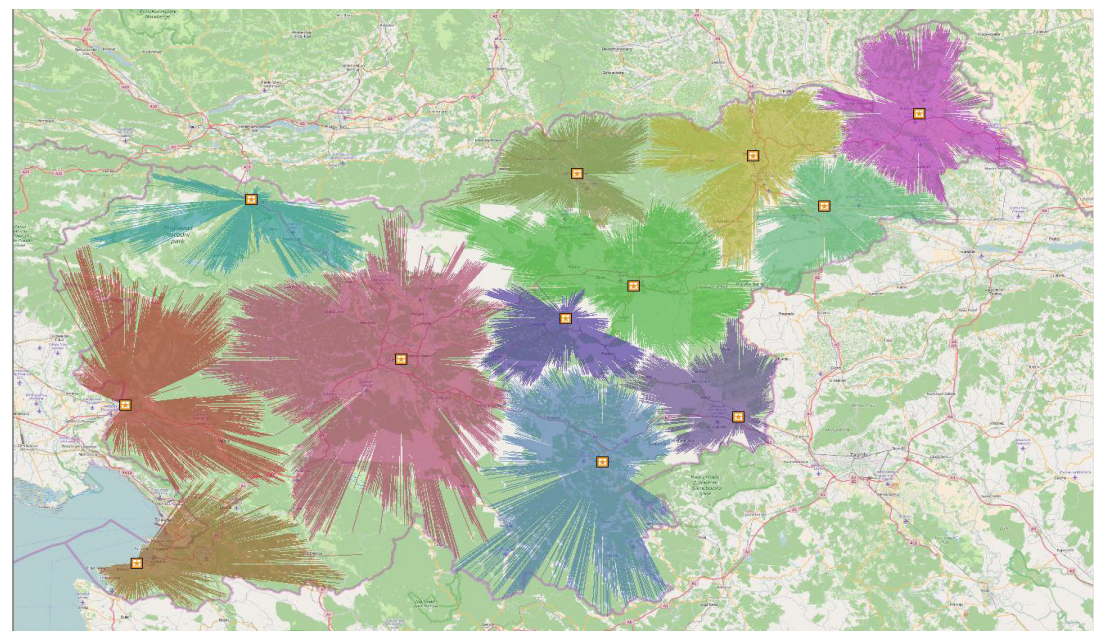

Slika 27: Dostopnost do obstoječih splošnih bolnišnic brez časovne omejitve 
Analiza obstoječega stanja slovenskih splošnih bolnišnic nam pokaže, kolikšen delež prebivalstva gravitira $\mathrm{k}$ posamezni splošni bolnišnici $\mathrm{v}$ različnih časovnih intervalih. Na podlagi prikazanih rezultatov lahko sklepamo, da je delež pokritosti prebivalstva s storitvami na sekundarni ravni zdravstvene dejavnosti zelo visok. Večina prebivalstva lahko dostopa do obstoječih splošnih bolnišnic že v 30-minutnem časovnem intervalu, kar kaže, da je z vidika zagotavljanja ravnotežja med dvema ciljema, torej na eni strani med maksimiranjem ekonomske učinkovitosti izvajalcev zdravstvene dejavnosti, na drugi strani pa med maksimiranjem dostopnosti do zdravstvenih storitev, tehtnica nagnjena v prid drugemu cilju.

V nadaljevanju predstavljamo rezultate analiz modelov lokacija-alokacija, ki prikazujejo potencialno mrežo sekundarne zdravstvene dejavnosti. Nekateri med njimi so praktično zelo uporabni in predstavljajo dobro podlago za oblikovalce zdravstvene politike.

\section{Rezultati MI-modela}

Prvi model, na podlagi katerega lahko določimo optimalne lokacije slovenskih splošnih bolnišnic, je MI-model p-mediane oziroma model minimalne upornosti. Pri tem modelu stremimo $\mathrm{k}$ umeščanju določenega števila objektov na način, da sta povprečna razdalja ali čas, ki ga bolnik potrebuje, da pride do posameznega izvajalca zdravstvene storitve, čim krajši. MI-model je sicer za naš raziskovalni problem manj primeren, saj nas v okviru problema ne zanimajo minimalen povprečni časi razdalj potovanja vseh pacientov do splošnih bolnišnic, pač pa zgolj časovne omejitve, v okviru katerih naj bi bile splošne bolnišnice dosegljive čim večjemu številu prebivalcev. MI-model zahteva, da znotraj analize že vnaprej definiramo določeno število objektov, ki jih želimo locirati. V našem primeru smo tako definirati, da želimo poiskati optimalne lokacije dvanajstih splošnih bolnišnic. Za dvanajst splošnih bolnišnic smo se odločili skladno z dejstvom, da tudi znotraj obstoječe mreže sekundarne zdravstvene dejavnosti deluje dvanajst splošnih bolnišnic. Rezultati MI-modela nam tako omogočajo neposredno primerjavo optimalnih lokacij dvanajstih splošnih bolnišnic in lokacij obstoječih splošnih bolnišnic.

$\mathrm{V}$ nadaljevanju prikazujemo sliki 28 in 29 , ki ponazarjata optimalno lociranih dvanajst splošnih bolnišnic v dveh različnih časovnih intervalih dostopnosti. MI-modela definira, da so optimalne lokacije splošnih bolnišnic znotraj 30-minutnega časovnega intervala v Novi Gorici, Kopru, Logatcu, Kranju, Grosuplju, Ravnah na Koroškem, Zagorju ob Savi, Novem mestu, Celju, Krškem, Mariboru in Murski Soboti. Če primerjamo te podatke z obstoječimi lokacijami slovenskih splošnih bolnišnic, vi- 
dimo, da se lokacija Splošne bolnišnice Nova Gorica ne spremeni. Lokacija Splošne bolnišnice Izola se prestavi v Koper, namesto Univerzitetnega kliničnega centra Ljubljana dobimo dve novi lokaciji splošnih bolnišnic, in sicer v Logatcu ter Grosuplju. Lokacija Splošne bolnišnice Jesenice se nadomesti z lokacijo v Kranju, Splošna bolnišnica Trbovlje je na novo locirana v Zagorju ob Savi, lokacija Splošne bolnišnice Slovenj Gradec se prestavi v Ravne na Koroškem, lokacija Splošne bolnišnice Brežice pa se nadomesti z lokacijo v Krškem. Splošna bolnišnica Novo mesto, Splošna bolnišnica Celje, Univerzitetni klinični center Maribor in Splošna bolnišnica Murska Sobota ostanejo locirane na istih lokacijah. Lokacija Splošne bolnišnice Ptuj pa znotraj tega modela ni nadomeščena z drugo lokacijo.

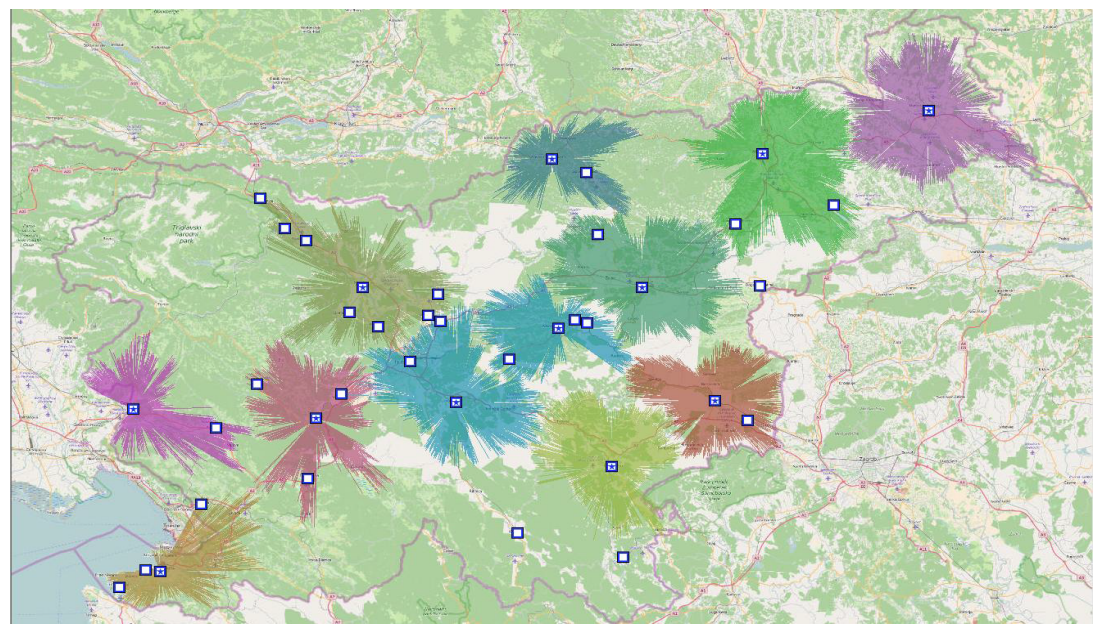

Slika 28: MI-model pri 30-minutnem časovnem intervalu

$\mathrm{Na}$ podlagi prikazanih rezultatov znotraj slike 29 opazimo, da je pri 45-minutnem časovnem intervalu pokritost območja precej večja, kar pomeni, da potencialne lokacije splošnih bolnišnic zajamejo večje število prebivalstva. Skladno s tem se spremenijo tudi nekatere lokacije splošnih bolnišnic, ki so bile v modelu, ki je vključeval 30-minutni časovni interval, locirane v drugih krajih. MI-model definira, da so optimalne lokacije splošnih bolnišnic znotraj 45-minutnega časovnega intervala v Novi Gorici, Kopru, Idriji, Radovljici, Postojni, Kamniku, Kočevju, Slovenj Gradcu, Hrastniku, Novem mestu, Slovenski Bistrici in Murski Soboti.

Predstavljen MI-model služi zgolj za vzorec, ko razmišljamo v smeri raziskovanja optimalnih lokacij znotraj sistema zdravstvenega varstva. Cilj MI-modela je namreč zagotoviti rešitve, ki zmanjšujejo celotno pov- 
prečno razdaljo med objekti in točkami povpraševanja. Znotraj tega modela je treba izbrati število lociranih objektov in razdaljo, če kot merilo uporabimo maksimalno razdaljo. V naši analizi smo kot merilo sicer izbrali časovni interval dostopnosti. Uporabnost MI-modela je lahko na drugih področjih zdravstvenega varstva večja, kot je pri definiranju optimalnih lokacij splošnih bolnišnic. MI-model bi se izkazal kot koristen, če bi želeli poiskati optimalne lokacije zdravstvenih domov, kjer bi želeli minimirati potne stroške obiskov na domu, ali če bi želeli poiskati optimalne lokacije osrednjih skladišč, od koder bi razvažali zdravila in medicinski material posameznim izvajalcem zdravstvene dejavnosti.

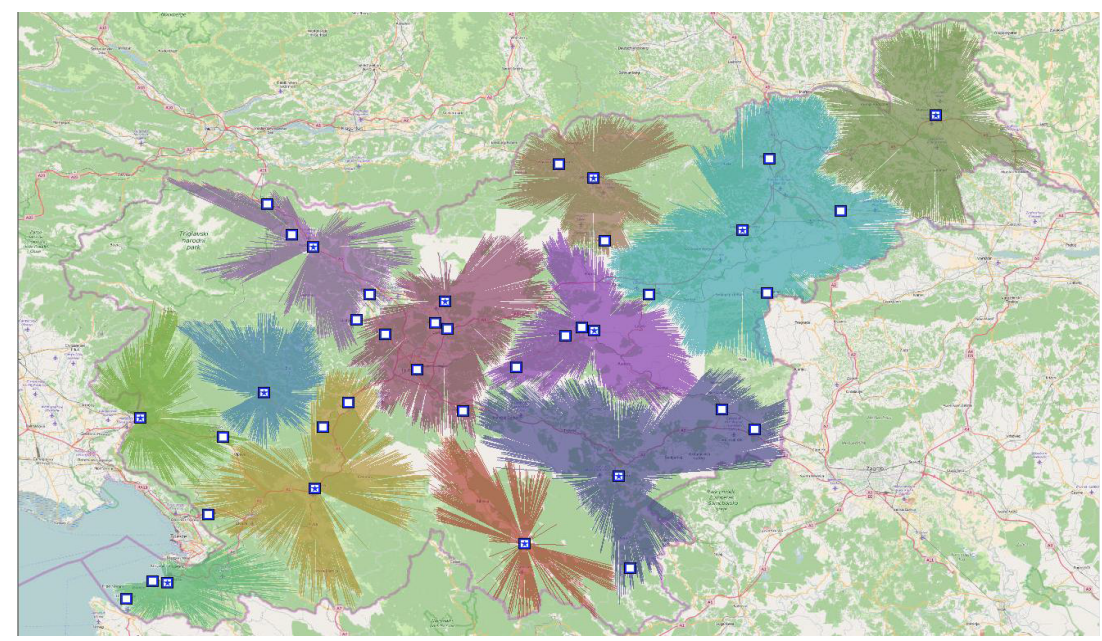

Slika 29: MI-model pri 45-minutnem časovnem intervalu

\section{Rezultati MF-modela}

MF-model ali model minimalnega števila objektov nam ponuja zanimivo rešitev, kjer iščemo načine, kako z minimalnim številom izvajalcev pokriti potrebe prebivalstva. Ta model je posebno učinkovit takrat, ko nimamo vnaprej določenega števila potencialnih izvajalcev. Uporaben je za lociranje najmanjšega potrebnega števila različnih nujno potrebnih zdravstvenih storitev v praznem geografskem prostoru. Od drugih modelov lokacija-alokacija se razlikuje po tem, da ne išče, kam postaviti omejeno število izvajalcev za zadovoljitev potreb uporabnikov, ampak poskuša znotraj mreže minimirati število izvajalcev. Za potrebe naše analize to pomeni, da znotraj modela ni treba vnaprej definirati števila splošnih bolnišnic, ki jih želimo locirati. 
Čeprav se zdi, da je MF-model še najprimernejši za reševanje našega znanstvenega problema, pa vsebuje omenjena rešitev nekaj predpostavk, ki njeno zanimivost zmanjšujejo. Model predpostavlja, da je treba pokriti vse potrebe prebivalstva, kar pomeni, da analizira optimalne lokacije ob predpostavki ıoo-odstotne pokritosti prebivalstva. To pa je tudi razlog, da omenjeni model ni najustreznejši za naš raziskovalni problem. Rešitve, ki jih ponudi MF-model, z vidika naše raziskave niso najbolj pragmatične, saj ne omogočajo iskanja ekonomsko upravičenih kompromisnih rešitev, kjer bi ugotavljali optimalne lokacije splošnih bolnišnic ob določenem odstotku pokritosti prebivalstva. Model na eni strani sicer izračuna minimalno število splošnih bolnišnic, ki ustrezajo časovnim omejitvam, vendar na drugi strani v model ni mogoče vključiti tudi merila pokritosti prebivalstva.

Rezultati MF-modela so prikazani v sliki 30, ki ponazarja optimalne lokacije splošnih bolnišnic znotraj 30-minutnega časovnega intervala. Primerjava modelov s 30-minutnim časovnim intervalom ter modela s 6o-minutnim časovnim intervalom nam pokaže nekatere razlike. MF-model je znotraj 30-minutnega časovnega intervala definiral, da je treba za zadovoljitev vseh potreb prebivalstva locirati 3 I splošnih bolnišnic. Optimalne lokacije 3 I splošnih bolnišnic so v Novi Gorici, Kopru, Sežani, Ajdovščini, Idriji, Jesenicah, Bledu Radovljici, Postojni, Vrhnika, Škofji Loki, Kranju, Kamniku, Grosuplju, Litiji, Kočevju, Ravnah na Koroškem, Slovenj Gradcu, Velenju, Zagorju ob Savi, Hrastniku, Novem mestu, Črnomlju, Celju, Krškem, Brežicah, Slovenski Bistrici, Rogaški Slatini, Mariboru, Ptuju in Murski Soboti.

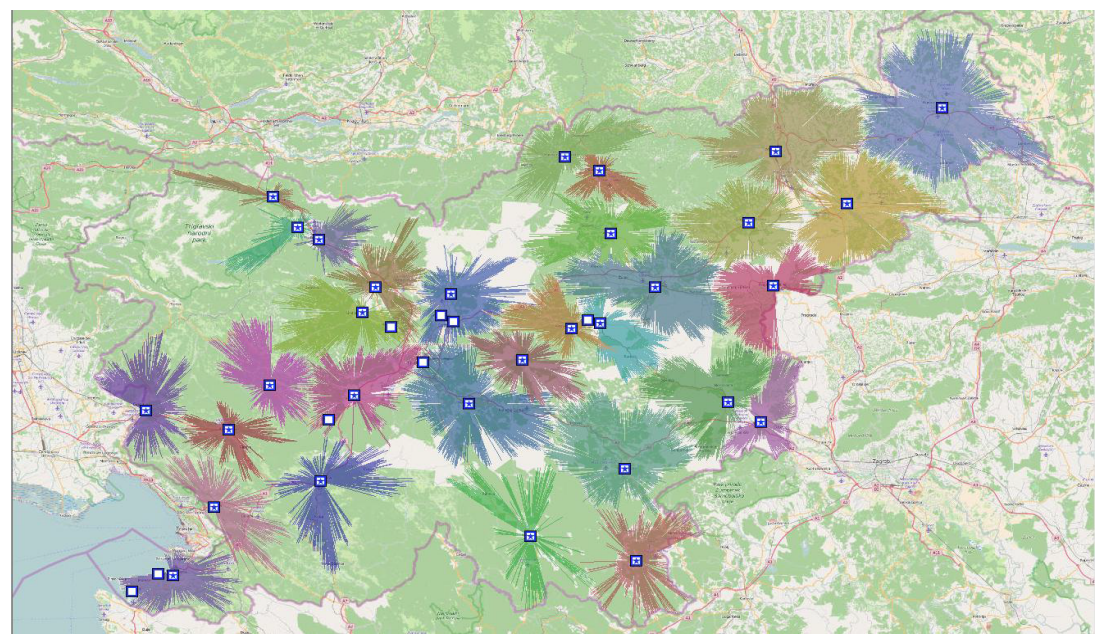

Slika 30: MF-model pri 3o-minutnem časovnem intervalu 
Na podlagi prikazanih rezultatov v sliki 3 I opazimo, da je pri 6o-minutnem časovnem intervalu pokritost območja ostala enaka kot pri 30-minutnem časovnem intervalu, se je pa spremenilo število splošnih bolnišnic. Pri povečanju časovnega intervala s 30 na 60 minut se je število minimalno potrebnih bolnišnic bistveno zmanjšalo. MF-model je definiral, da je minimalno število izvajalcev, ki lahko pokrijejo vse potrebe prebivalcev znotraj 60-minutnega časovnega intervala, I3. MF-model nam pokaže, da so optimalne lokacije 13 splošnih bolnišnic v Novi Gorici, Jesenicah, Idriji, Postojni, Ljubljani, Kočevju, Ravnah na Koroškem, Zagorju ob Savi, Velenju, Črnomlju, Krškem, Mariboru in Murski Soboti.

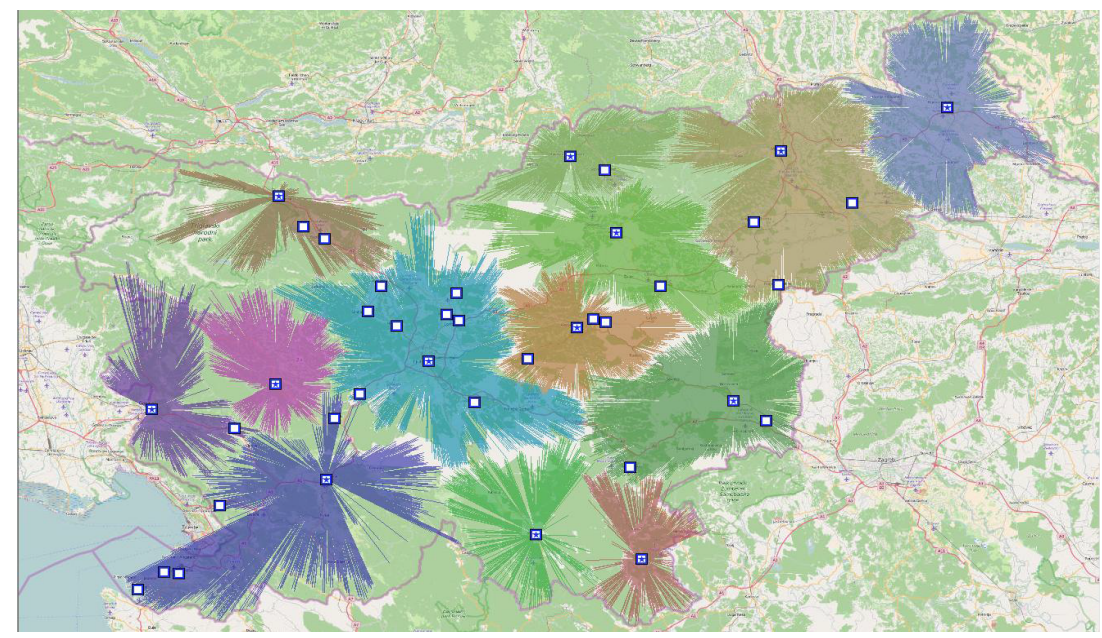

Slika 31: MF-model pri 60-minutnem časovnem intervalu

Rezultati MF-modela nam pokažejo, da se ta model razlikuje od ostalih modelov lokacija-alokacija, ki želijo locirati neko določeno število objektov na območju povpraševanja. MF-model poskuša definirati minimalno število splošnih bolnišnic, ki jih potrebujemo za zadovoljitev vseh potreb po bolnišničnih storitvah. Model je sicer podoben ostalim prikazanim modelom $\mathrm{v}$ tistem koraku, ki se navezuje na alociranje točk povpraševanja, vendar se od njih razlikuje $\mathrm{v}$ številu izvajalcev, ki jih poskuša locirati. MF-model bi lahko bil znotraj zdravstvenega varstva učinkovit pri iskanju optimalnih lokacij najmanjšega števila urgentnih centrov ali ambulant $\mathrm{z}$ osebnimi zdravniki, torej pri tistih izvajalcih zdravstvenih storitev, pri katerih je treba zagotoviti popolno pokritje točk povpraševanja. 


\section{Rezultati MC-modela}

MC-model ali model maksimalnega pokritja poskuša maksimirati potrebe uporabnikov oziroma delež prebivalstva, ki mu je določena storitev dostopna v nekem določenem časovnem obdobju. $\mathrm{V}$ tem primeru model omogoča, da znižujemo merilo pokritosti območja, pri tem pa je še vedno mogoče opredeliti časovni interval dostopnosti, ki definira maksimalen čas od točke povpraševanja do točke izvajalca. Znotraj MC-modela je treba opredeliti število objektov, ki jih želimo locirati, zato smo za potrebe naše analize definirali, da želimo poiskati optimalne lokacije dvanajstih splošnih bolnišnic. To nam je omogočilo, da smo optimalne lokacije potencialnih splošnih bolnišnic lahko primerjali z lokacijami obstoječih splošnih bolnišnic. MI-model omogoča izračun določenih relevantnih rešitev, na podlagi katerih bi lahko oblikovali učinkovito mrežo sekundarne zdravstven dejavnosti.

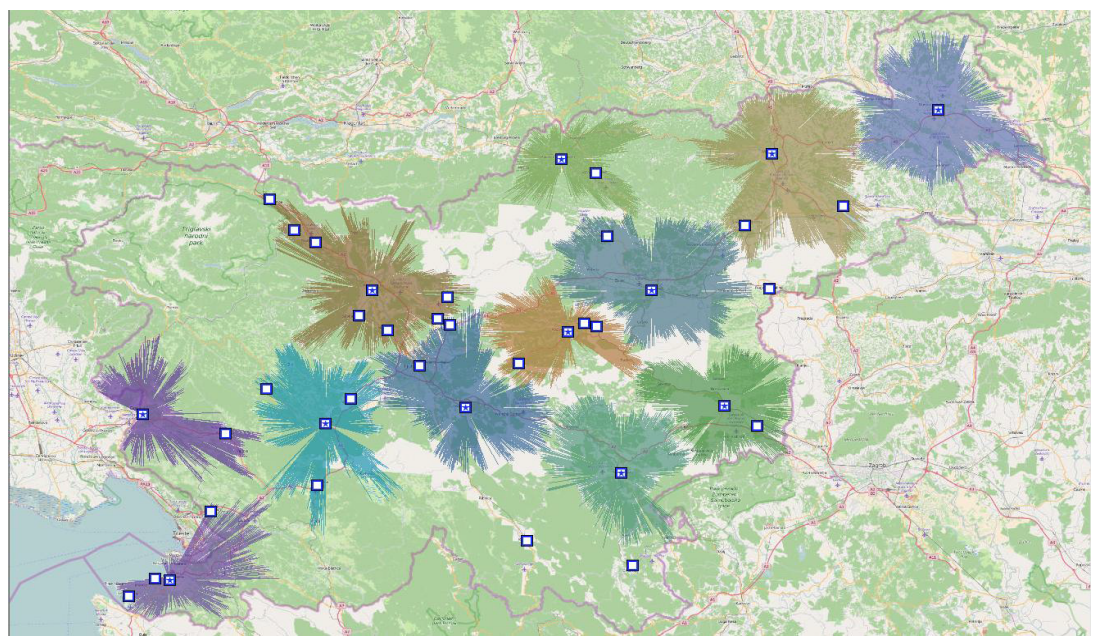

Slika 32: MC-model pri 30-minutnem časovnem intervalu

Prikazujemo sliki 32 in 33, kjer smo z MC-modelom poiskali optimalne lokacije dvanajstih splošnih bolnišnic $\mathrm{v}$ dveh različnih časovnih intervalih dostopnosti. MC-model definira, da je dvanajst optimalnih lokacij slovenskih splošnih bolnišnic znotraj 30-minutnega časovnega intervala v Novi Gorici, Kopru, Logatcu, Kranju, Grosuplju, Ravnah na Koroškem, Zagorju ob Savi, Novem mestu, Celju, Krškem, Mariboru in Murski Soboti. Če primerjamo te podatke z obstoječimi lokacijami slovenskih splošnih bolnišnic, vidimo, da se lokacija Splošne bolnišnice Nova Gorica ne spremeni. Lokacija Splošne bolnišnice Izola se prestavi v 
Koper, namesto Univerzitetnega kliničnega centra Ljubljana dobimo dve novi lokaciji splošnih bolnišnic, in sicer v Logatcu ter Grosuplju. Lokacija Splošne bolnišnice Jesenice se nadomesti z lokacijo v Kranju, Splošna bolnišnica Trbovlje je na novo locirana v Zagorju ob Savi, lokacija Splošne bolnišnice Slovenj Gradec se prestavi v Ravne na Koroškem, lokacija Splošne bolnišnice Brežice pa se nadomesti z lokacijo v Krškem. Splošna bolnišnica Novo mesto, Splošna bolnišnica Celje, Univerzitetni klinični center Maribor in Splošna bolnišnica Murska Sobota ostanejo locirane na istih lokacijah. Lokacija Splošne bolnišnice Ptuj pa znotraj tega modela ni nadomeščena z drugo lokacijo.

Primerjava slik 32 in 33 nam pokaže, da obstajajo razlike med optimalnimi lokacijami znotraj 30-minutnega časovnega intervala in znotraj 45-minutnega časovnega intervala. Znotraj slike 33 opazimo, da je pri 45-minutnem časovnem intervalu pokritost območja precej večja, kar pomeni, da potencialne lokacije splošnih bolnišnic znotraj 45-minutnega časovnega intervala zajamejo večji delež celotnega prebivalstva. Skladno $\mathrm{s}$ tem se spremenijo tudi nekatere lokacije splošnih bolnišnic, ki so bile $\mathrm{v}$ modelu, ki je vključeval 30-minutni časovni interval, locirane $\mathrm{v}$ drugih krajih. MC-model definira, da so optimalne lokacije splošnih bolnišnic znotraj 45-minutnega časovnega intervala v Novi Gorici, Kopru, Idriji, Radovljici, Postojni, Kamniku, Kočevju, Slovenj Gradcu, Hrastniku, Novem mestu, Slovenski Bistrici in Murski Soboti.

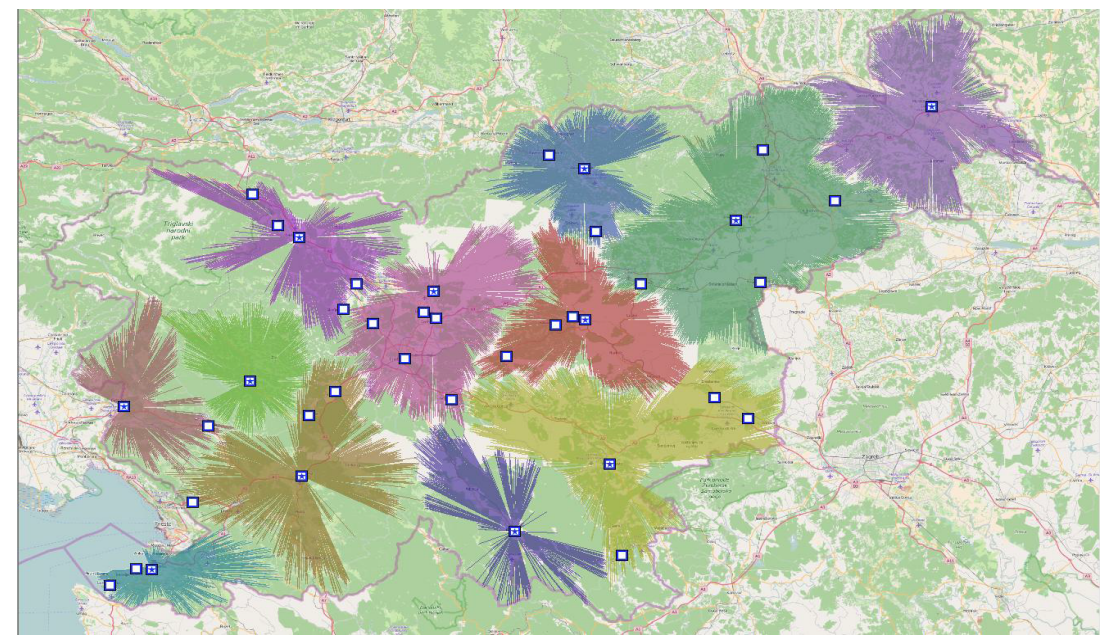

Slika 33: MC-model pri 45-minutnem časovnem intervalu 
Namen modela MC je doseči čim večjo pokritost prebivalstva z zdravstvenimi storitvami na podlagi časovnega intervala, ki velja od lokacije potencialnega bolnika do lokacije splošne bolnišnice. Rezultati MC-modela prikazujejo optimalne lokacije dvanajstih splošnih bolnišnic na način, da poskušajo maksimirati pokritje točk povpraševanja. Uporabnost MC-modela se kaže v primerih, ko obstaja majhno število izvajalcev, ki morajo v čim večji meri pokriti potrebe prebivalstva. Pri tem se je treba zavedati, da vse potrebe prebivalstva z omenjenim modelom ne bodo pokrite, kar se sklada z ekonomskim načelom, ki pravi, da je treba neomejene potrebe ljudi zaradi redkosti dobrin omejiti. To velja tudi znotraj sistema zdravstvenega varstva, kjer so potrebe po zdravstveni oskrbi bistveno večje od ponudbe, zato je omejevanje dostopnosti do zdravstvenih storitev neizogibno. $\mathrm{V}$ ekonomski teoriji to vlogo odigrajo sicer cene na trgu, znotraj zdravstvenega sistema pa lahko to vlogo prevzame mreža zdravstvene dejavnosti, ki preko optimalno lociranih izvajalcev zdravstvene dejavnosti oblikuje ponudbo.

\section{Rezultati MA-modela}

MA-model je v osnovi podoben MC-modelu, s tem da pri definiranju optimalnih lokacij različno ponderira točke povpraševanja. MA-model ponderira točke povpraševanja glede na razdaljo, ki jo ima uporabnik do najbližjega izvajalca, ponder pa se znižuje sorazmerno s povečevanjem razdalje med izvajalcem in točko povpraševanja. To je skladno z dejstvom, da v tem modelu predpostavljamo, da se možnost za obiskanost določenega izvajalca zmanjšuje s povečevanjem razdalje uporabnika do najbližjega izvajalca. Posledično to pomeni, da je povpraševanje večje tam, kjer je poseljenost gostejša. V primerjavi z ostalimi modeli lokacija-alokacija MA-model locira izvajalce na gosteje poseljenih območjih.

To je razvidno tudi iz slik 34 in 35 , ki prikazujeta optimalne lokacije dvanajstih splošnih bolnišnic v 30- in 45-minutnem časovnem intervalu. Rezultati MA-modela, ki vključujejo optimalne lokacije splošnih bolnišnic znotraj 30-minutnega časovnega intervala, se razlikujejo od rezultatov MC-modela, kjer smo prav tako opredelili optimalne lokacije dvanajstih splošnih bolnišnic znotraj 30-minutnega časovnega intervala. MA-model definira, da bi splošne bolnišnice morale biti locirane v Novi Gorici, Kopru, Kranju, Ljubljani, Zagorju ob Savi, Velenju, Novem mestu, Celju, Krškem, Mariboru, Ptuju in Murski Soboti.

V sliki 35 pa prikazujemo optimalne lokacije dvanajstih splošnih bolnišnic, dostopnih v 45-minutnem časovnem intervalu. Tudi v tem prime- 
ru se rezultati MA-modela razlikujejo od rezultatov, ki smo jih predstavili znotraj MC-modela. Če bi želeli bolniki dostopati do storitev na sekundarni ravni zdravstvene dejavnosti, bi morale biti splošne bolnišnice locirane v Novi Gorici, Kopru, Logatcu, Kranju, Ljubljani, Ravnah na Koroškem, Zagorju ob Savi, Novem mestu, Celju, Krškem, Mariboru in Murski Soboti. V tem primeru torej govorimo o optimalnih lokacijah dvanajstih splošnih bolnišnic.

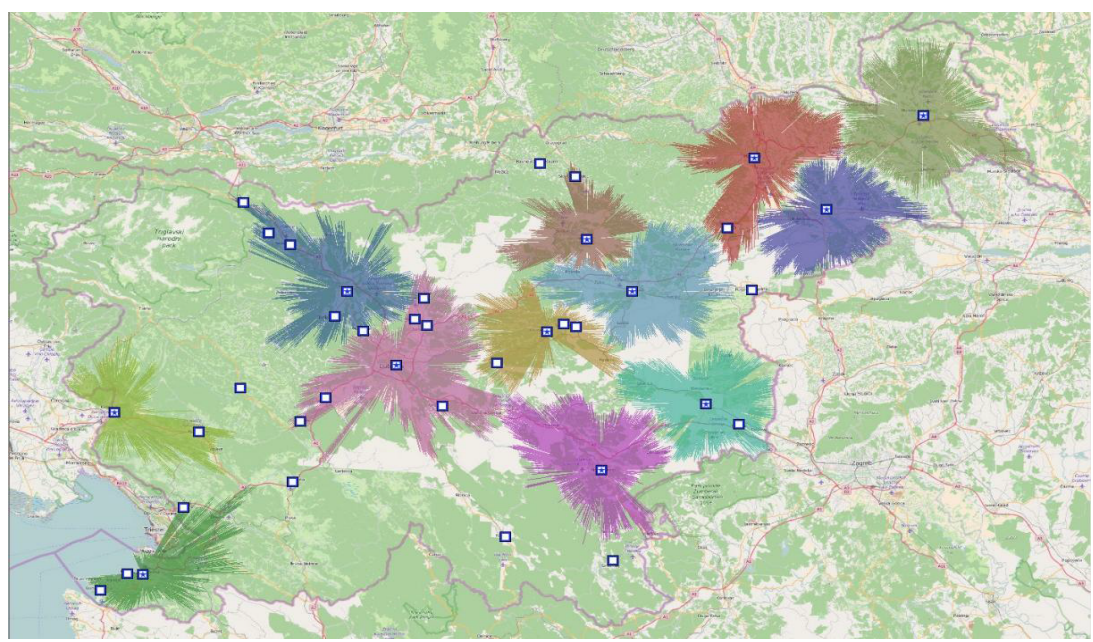

Slika 34: MA-model pri 30-minutnem časovnem intervalu

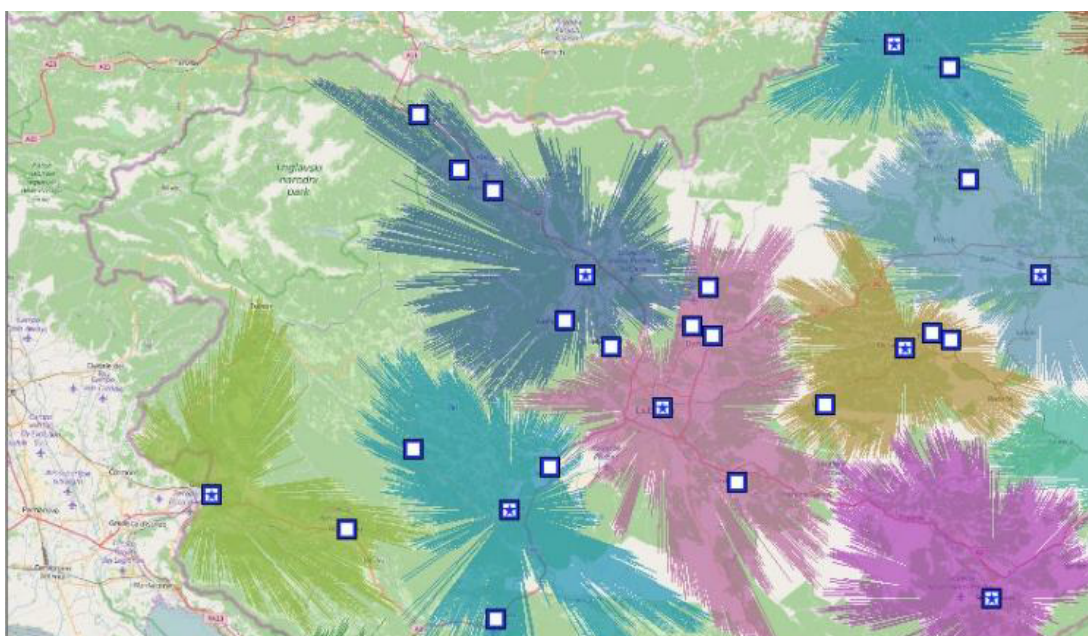

Slika 35: MA-model pri 45-minutnem časovnem intervalu 
Uporaba modela MA nam omogoča maksimiranje obiskanosti posamezne splošne bolnišnice, hkrati pa nam omogoča minimiranje celotne razdalje med splošnimi bolnišnicami in potencialnimi bolniki. Znotraj modela MA je treba izbrati število objektov, ki jih želimo locirati, in maksimalno časovno oddaljenost od splošne bolnišnice do posameznega prebivalca. Če primerjamo rezultate, dobljene z MA-modelom, vidimo, da se model razlikuje od ostalih modelov lokacija-alokacija $v$ tem, da določi optimalne lokacije splošnih bolnišnic v večjih oziroma gosteje poseljenih krajih, kar je posledica dejstva, da model MA locira objekte na območjih, kjer živi največ potencialnih bolnikov. S tem zagotovimo, da bodo novo locirane splošne bolnišnice maksimalno obiskane, saj delujejo na območjih največjega povpraševanja. Rezultati MA-modela so torej relevantni z vidika raziskovalnega problema, ki ga obravnavamo, zato v nadaljevanju podrobneje prikazujemo primerjavo obstoječih dvanajstih bolnišnic in optimalno lociranih dvanajstih bolnišnic.

\section{Rezultati MA-modela pri primerjavi obstoječih in optimalno lociranih splošnih bolnišnic}

V sliki 34 smo že prikazali rezultate, ki nam jih ponuja MA-model, če iščemo optimalne lokacije dvanajstih splošnih bolnišnic znotraj 30-minutnega časovnega intervala. Če primerjamo te rezultate z lokacijami obstoječih dvanajstih splošnih bolnišnic, ki so prikazane v sliki 24, vidimo, da se lokacija Splošne bolnišnica Izola nadomesti z lokacijo v Kopru, Splošna bolnišnica Jesenice je na novo locirana v Kranju, Splošna bolnišnica Trbovlje se prestavi v Zagorje ob Savi, lokacija Splošne bolnišnice Slovenj Gradec se nadomesti z lokacijo v Velenju, Splošna bolnišnica Brežice pa je na novo locirana v Krškem. Pri tem je pomembno izpostaviti, da smo znotraj MA-modela v primeru, da v mestu še ni splošne bolnišnice, lokacije splošnih bolnišnic $\mathrm{v}$ mestih umestili tako, da so te $\mathrm{v}$ bližini vpadnic, kar nam omogoča dobro povezljivost z okoliškimi naselji. Primerjavo lokacij dvanajstih obstoječih splošnih bolnišnic in optimalno lociranih splošnih bolnišnic podajamo v sliki 36 .

V nadaljevanju nas je zanimalo, kolikšno pokritost prebivalstva dosežemo z obstoječo mrežo splošnih bolnišnic in kolikšen delež pokritosti prebivalstva dosežemo s potencialno mrežo dvanajstih optimalno lociranih splošnih bolnišnic, ki nam jih definira MA-model. Podatke o številu pokritosti prebivalstva znotraj 30-minutnega časovnega intervala predstavljamo v sliki 37. 


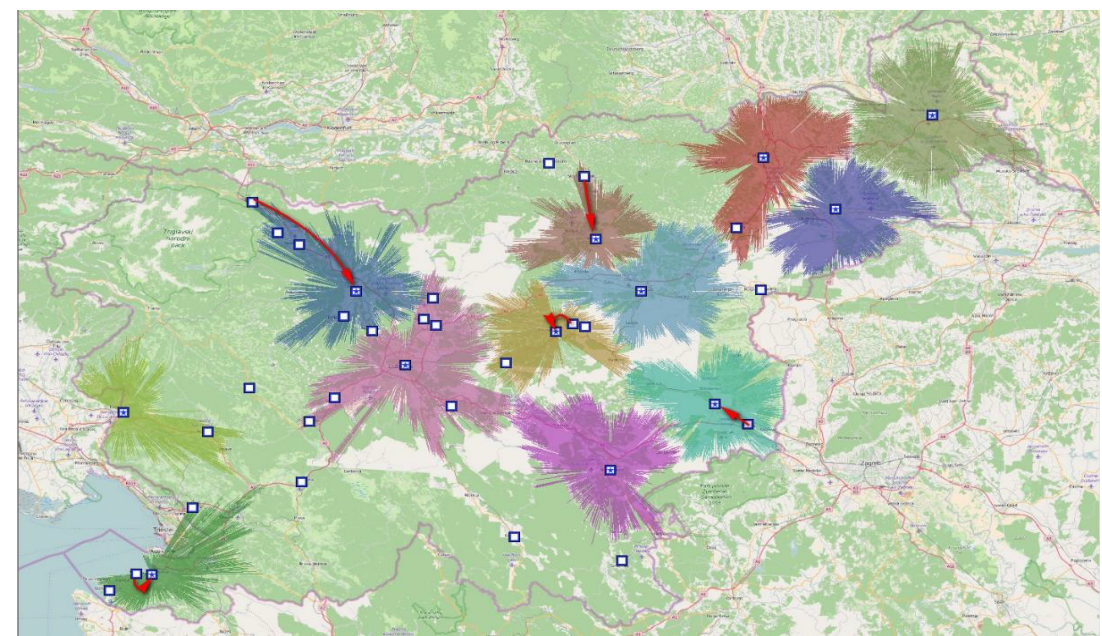

Slika 36: Primerjava obstoječih in optimalno lociranih splošnih bolnišnic znotraj 30-minutnega časovnega intervala

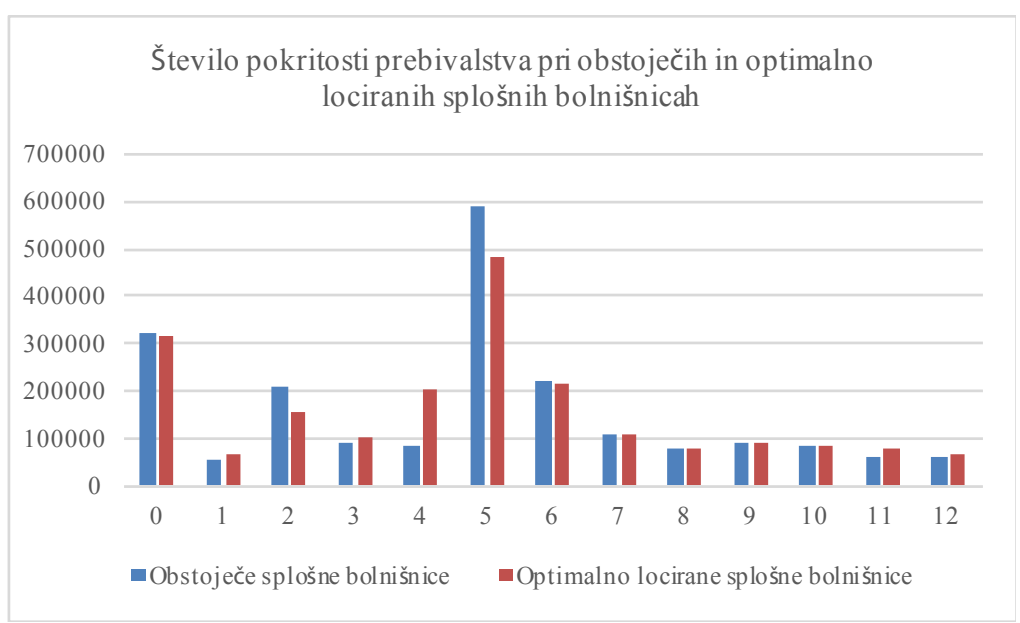

Slika 37: Primerjava pokritosti prebivalstva za obstoječe in optimalno locirane splošne bolnišnice znotraj 30-minutnega časovnega intervala

Delež prebivalstva, ki ga pokrivajo obstoječe splošne bolnišnice, in delež prebivalstva, ki ga pokrivajo optimalno locirane bolnišnice, je zelo podoben. Z obstoječimi lokacijami splošnih bolnišnic znotraj 30-minutnega časovnega intervala pokrijemo 84,34 odstotka prebivalstva, z optimalno lociranimi splošnimi bolnišnicami pa znotraj 30-minutnega časovnega intervala pokrijemo 84,56 odstotka prebivalstva. $V$ tem primeru 
bi torej s potencialno mrežo sekundarne zdravstvene dejavnosti zagotovili storitve na sekundarni ravni zdravstvene dejavnosti 4.627 prebivalcem več. Dvanajst optimalno lociranih splošnih bolnišnic ima v primerjavi z obstoječimi dvanajstimi bolnišnicami višje število prebivalcev, ki gravitirajo $\mathrm{k}$ splošni bolnišnici z najmanjšim zaledjem. Znotraj obstoječe mreže je to Splošna bolnišnica Brežice, v primeru potencialne mreže pa bi bila to splošna bolnišnica v Krškem. Poleg tega ima dvanajst optimalno lociranih splošnih bolnišnic nižje število prebivalcev, ki gravitirajo k Univerzitetnemu kliničnemu centru Ljubljana oziroma splošni bolnišnici z največjim zaledjem. Splošna bolnišnica Celje ima manj zaledja na račun splošne bolnišnice, ki bi bila locirana v Velenju. Splošna bolnišnica, ki bi bila locirana v Kranju, pa bi pobrala velik del zaledja tudi na račun Univerzitetnega kliničnega centra Ljubljana.

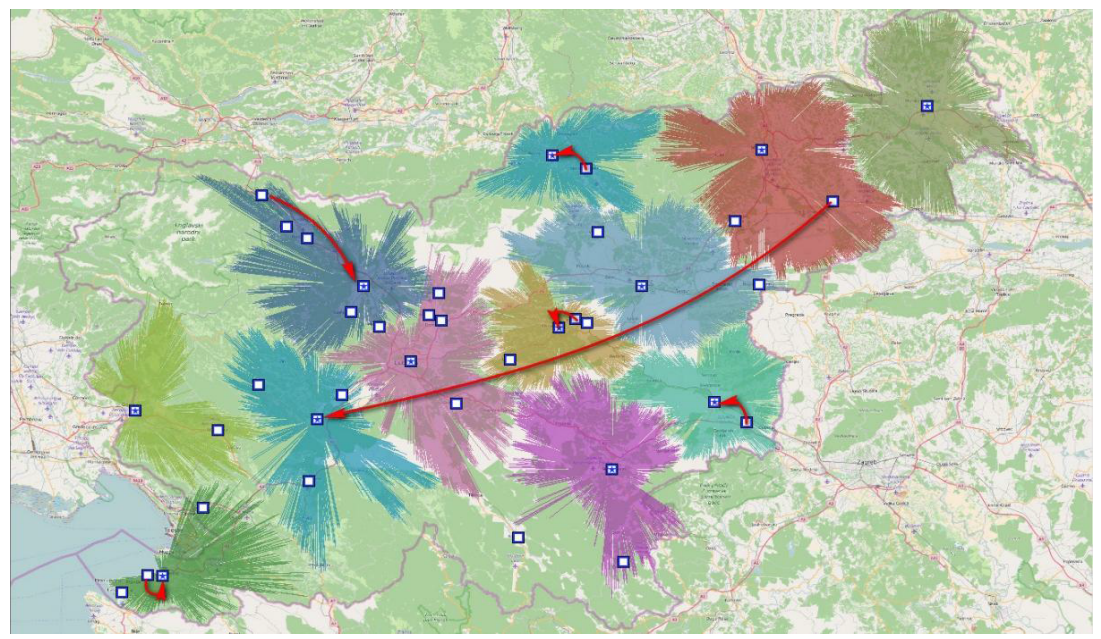

Slika 38: Primerjava obstoječih in optimalno lociranih splošnih bolnišnic znotraj 45-minutnega časovnega intervala

Podobne rezultate dobimo, če primerjamo dvanajst obstoječih bolnišnic z dvanajstimi optimalno lociranimi bolnišnicami znotraj 45-minutnega časovnega intervala. V sliki 35 smo prikazali rezultate, ki nam jih ponuja MA-model, če iščemo optimalne lokacije dvanajstih splošnih bolnišnic znotraj 45-minutnega časovnega intervala. Če primerjamo te rezultate z lokacijami obstoječih dvanajstih splošnih bolnišnic, ki so prikazane v sliki 25, vidimo, da se lokacija Splošne bolnišnica Izola nadomesti z lokacijo v Kopru, Splošna bolnišnica Jesenice je na novo locirana v Kranju, Splošna bolnišnica Trbovlje se prestavi v Zagorje ob Savi, lokacija Splošne bolnišnice Slovenj Gradec se nadomesti z lokacijo v Ravnah na 
Koroškem, Splošna bolnišnica Brežice pa je na novo locirana v Krškem. Pri tem je treba še izpostaviti, da je znotraj modela na eni strani ukinjena Splošna bolnišnica Ptuj, na drugi strani pa nam je model na novo definiral bolnišnico, bi mora biti locirana $v$ Logatcu. Lokacije optimalnih splošnih bolnišnic $\mathrm{v}$ mestih smo $\mathrm{v}$ primeru, da $\mathrm{v}$ tem mestu še ni bolnišnice, umestili tako, da so te v bližini vpadnic. To nam omogoča dobro povezljivost z okoliškimi naselji. Primerjavo lokacij dvanajstih obstoječih splošnih bolnišnic in optimalno lociranih splošnih bolnišnic podajamo v sliki 38.

V sliki 39 prikazujemo pokritost prebivalstva, ki velja za obstoječo mrežo sekundarne zdravstvene dejavnosti, torej za obstoječe splošne bolnišnice in pokritost prebivalstva znotraj potencialne mreže sekundarne zdravstvene dejavnosti. Na podlagi MA-modela torej prikazujemo podatke o pokritosti prebivalstva $\mathrm{v}$ okviru 45-minutnega časovnega intervala.

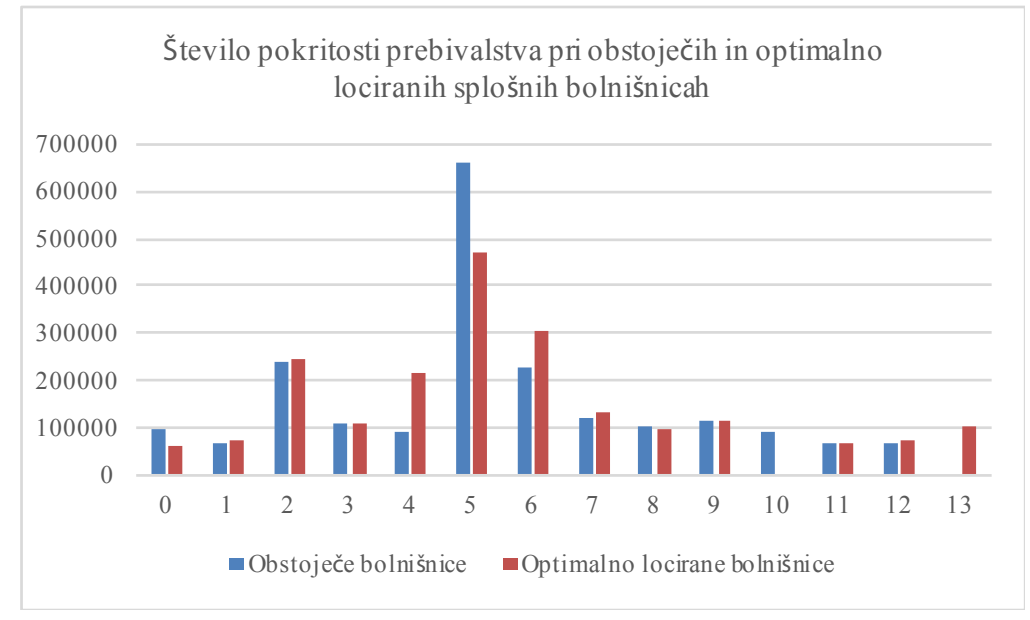

Slika 39: Primerjava pokritosti prebivalstva za obstoječe in optimalno locirane splošne bolnišnice znotraj 45-minutnega časovnega intervala

Delež prebivalstva, ki ga pokrivajo obstoječe splošne bolnišnice, je $\mathrm{v}$ primerjavi z deležem prebivalstva, ki ga pokrivajo optimalno locirane bolnišnice, nekoliko višji. $Z$ obstoječimi lokacijami splošnih bolnišnic znotraj 45-minutnega časovnega intervala pokrijemo 95,36 odstotka prebivalstva, z optimalno lociranimi splošnimi bolnišnicami pa znotraj 45-minutnega časovnega intervala pokrijemo 96,91 odstotka prebivalstva. $\mathrm{V}$ tem primeru bi torej s potencialno mrežo sekundarne zdravstvene dejavnosti lahko zagotovili zdravstvene storitve dodatnim 3 I.949 prebivalcem. Rezultati kažejo, da v določenih delih Slovenije prihaja do 
manjših sprememb lokacij bolnišnic znotraj regij. Večja sprememba je, da Splošna bolnišnica Ptuj v 45-minutnem časovnem intervalu ni bila izbrana kot optimalna lokacija. Njeno vlogo je prevzela bolnišnica, ki mora biti locirana v Logatcu. Skladno s tem optimalna bolnišnica v Logatcu zajema večji delež prebivalstva v primerjavi z deležem prebivalstva, ki ga pokriva Splošna bolnišnica Ptuj. Poleg tega ima dvanajst optimalno lociranih splošnih bolnišnic nižje število prebivalcev, ki gravitirajo k Univerzitetnemu kliničnemu centru Ljubljana, ta delež namreč prevzemata bolnišnici v Kranju in Logatcu. Univerzitetnemu kliničnemu centru Maribor pa se poveča zaledje zaradi ukinitve Splošne bolnišnice Ptuj.

Model MA se je izkazal kot najučinkovitejši model za določitev optimalne mreže sekundarne zdravstvene dejavnosti. Na podlagi tega modela najlaže sledimo cilju opredelitve optimalnih lokacij in števila izvajalcev sekundarne zdravstvene dejavnosti ob predpostavki iskanja ravnotežja med maksimiranjem ekonomske učinkovitosti izvajalcev zdravstvene dejavnosti in maksimiranjem dostopnosti do zdravstvenih storitev. Povedali smo že, da lahko dosežemo teoretski optimum tedaj, ko se posamezna splošna bolnišnica maksimalno geografsko približa vsakemu posameznemu prebivalcu, hkrati pa mora biti organizirana na način, da preko optimalne velikosti dosega tudi maksimalno ekonomko učinkovitost.

To pomeni, da moramo pri iskanju lokacij in števila splošnih bolnišnic upoštevati dejstvo, da bolnišnic ni mogoče locirat na način, ki bi omogočal pokritje vseh potreb prebivalstva. $S$ tem bi namreč zadostili zgolj cilju maksimiranja dostopnosti, hkrati pa bi zanemarili cilj doseganja tudi ekonomske učinkovitosti izvajalcev zdravstvene dejavnosti. V tej luči je torej iskanje določenega števila splošnih bolnišnic, ki poskušajo $\mathrm{v}$ čim večji meri zagotoviti delež pokritosti prebivalstva z bolnišničnimi storitvami, najustreznejši način iskanja optimalne mreže sekundarne zdravstvene dejavnosti. Minimalno število splošnih bolnišnic znotraj različnih časovnih intervalov smo torej iskali s predpostavko osemdesetodstotne pokritosti prebivalstva. To je delež pokritosti, ki je najpogosteje omenjen kot merilo pokritosti prebivalstva z bolnišničnimi storitvami za večino držav po svetu (World Health Organization 20I4).

$\mathrm{V}$ nadaljevanju torej prikazujemo, kako smo s pomočjo MA-modela poiskali optimalne lokacije slovenskih splošnih bolnišnic ob osemdesetodstotni pokritosti prebivalstva v različnih časovnih intervalih. $V$ zvezi s primernimi potovalnimi časi do splošnih bolnišnic sicer obstaja tudi določena meja soglasja glede nekaterih časovnih intervalov dostopnosti. Pri tem pa ni mogoče zaobiti dejstva, da je odločitev o tem, kakšni potovalni časi naj bi bili sprejemljivi kot merilo za oblikovanje mreže zdravstvene dejavnosti, še vedno na strani oblikovalcev zdravstvene politike. Skla- 
dno s tem smo tudi mi oblikovali tri možne projekcije postavitve mreže sekundarne zdravstvene dejavnosti, ki zajemajo 30-, 45- in 60-minutni interval dostopnosti. Odločitev o izbiri mreže je tako na strani oblikovalcev zdravstvene politike.

\section{Rezultati MA-model pri minimiranju števila splošnih bolnišnic}

Znotraj MA-modela lahko poiščemo minimalno število izvajalcev, ki je potrebno za zagotovitev osemdesetodstotne pokritosti prebivalstva $\mathrm{v}$ različnih časovnih intervalih. V prvem koraku tako analiziramo optimalne lokacije in število splošnih bolnišnic, ki je potrebno za zagotovitev osemdesetodstotne pokritosti ob predpostavki, da je maksimalen čas, ki ga potrebuje posamezen bolnik do najbližje splošne bolnišnice, 30 minut. Znotraj MA-modela lahko ugotovimo, kolikšno je minimalno število splošnih bolnišnic za zagotovitev določenih potreb prebivalstva na način, da postopno zmanjšujemo število izvajalcev, pri čemer vzporedno ugotavljamo, za koliko se na ta račun zmanjša delež pokritosti prebivalstva.

Preglednica 2 I: Število splošnih bolnišnic in delež pokritosti prebivalcev znotraj
30-minutnega časovnega intervala

\begin{tabular}{|c|c|c|c|c|}
\hline \multirow[b]{2}{*}{ Bolnišnica } & \multicolumn{2}{|c|}{9 optimalno lociranih bolnišnic } & \multicolumn{2}{|c|}{ Io optimalno lociranih bolnišnic } \\
\hline & Število prebivalcev & $\begin{array}{c}\text { Delež prebivalcev } \\
(\mathbf{v} \%)\end{array}$ & Śtevilo prebivalcev & $\begin{array}{l}\text { Delež prebivalcev } \\
(\mathbf{v} \%)\end{array}$ \\
\hline Celje & 220.370 & 10,68 & 209.607 & $\mathrm{IO}, \mathrm{I} 6$ \\
\hline Murska Sobota & 108.637 & 5,27 & 108.637 & 5,27 \\
\hline Ljubljana & 482.380 & 23,38 & $479.67 \mathrm{I}$ & 23,25 \\
\hline Kranj & 205.165 & 9,95 & 205.165 & 9,95 \\
\hline Ptuj & 84.113 & 4,08 & 84.113 & 4,08 \\
\hline Maribor & 218.664 & 10,60 & 218.664 & 10,60 \\
\hline Velenje & / & / & / & / \\
\hline Nova Gorica & 81.453 & 3,95 & 81.453 & 3,95 \\
\hline Koper & 101.980 & 4,94 & 101.980 & 4,94 \\
\hline Zagorje ob Savi & l & / & 67.710 & 3,28 \\
\hline Krško & / & / & / & / \\
\hline Novo mesto & 108.523 & 5,26 & 108.488 & 5,26 \\
\hline Skupaj & 1.611 .285 & 78, II & 1.665 .488 & 80,74 \\
\hline
\end{tabular}

MA-model nam pokaže, da merilu osemdesetodstotne pokritosti znotraj 30-minutnega časovnega intervala zadostimo z desetimi opti- 
malno lociranimi splošnimi bolnišnicami. $\mathrm{Na}$ ta način dosežemo, da so zdravstvene storitve na sekundarni ravni zdravstvene dejavnosti v 30-minutnem časovnem intervalu dostopne 80,74 odstotka celotnega prebivalstva. Skladno s tem bi imelo dostop do splošnih bolnišnic v 30-minutnem časovnem intervalu I.665.488 prebivalcev Slovenije. Če zmanjšamo število splošnih bolnišnic še za enega izvajalca, pade delež pokritosti prebivalstva na 78, I I odstotka. Z devetimi optimalno lociranimi splošnimi bolnišnicami tako zagotovimo dostop do izvajalcev na sekundarni ravni zdravstvene dejavnosti 1.61 I.285 prebivalcev Slovenije. Podatke o številu splošnih bolnišnic in deležu prebivalcev, ki gravitirajo k posamezni optimalni lokaciji splošne bolnišnice znotraj 30-minutnega časovnega intervala, prikazujemo v preglednici 2 I.

V sliki 40 in sliki 4I prikazujemo rezultate MA-modela, ki ponazarjajo optimalne lokacije splošnih bolnišnic ob predpostavki osemdesetodstotne pokritosti prebivalstva. Sliki ponazarjata projekciji prostorske dostopnosti optimalno lociranih splošnih bolnišnic znotraj 30-minutnega časovnega intervala. Slika 40 ponazarja devet optimalnih lokacij slovenskih splošnih bolnišnic znotraj 30-minutnega časovnega intervala, $s$ katerimi pokrijemo 78, I I odstotka prebivalstva. V tem primeru MA-model izvzame splošno bolnišnico, ki je bila v začetnem stanju locirana v Velenju, splošno bolnišnico, ki je bila v Zagorju ob Savi, in splošno bolnišnico, ki je bila v Krškem. Optimalne lokacije splošnih bolnišnic bi bile znotraj mreže sekundarne zdravstvene dejavnosti tako v Celju, Murski Soboti, Ljubljani, Kranju, Ptuju, Mariboru, Novi Gorici, Kopru in Novem mestu.

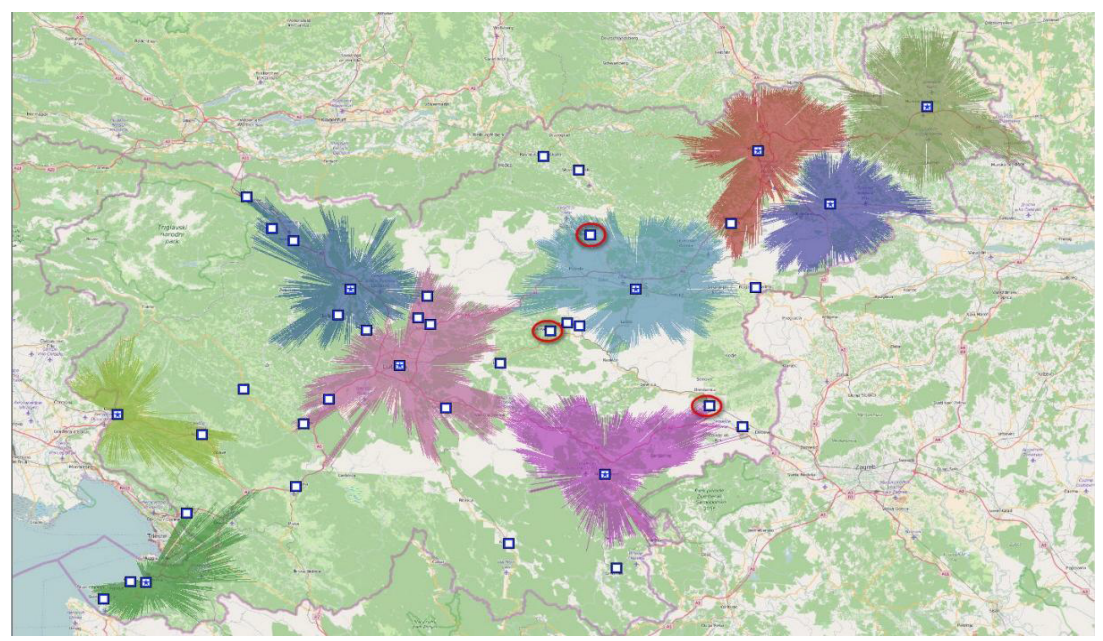

Slika 40: Optimalne lokacije devetih splošnih bolnišnic v 30-minutnem časovnem intervalu 


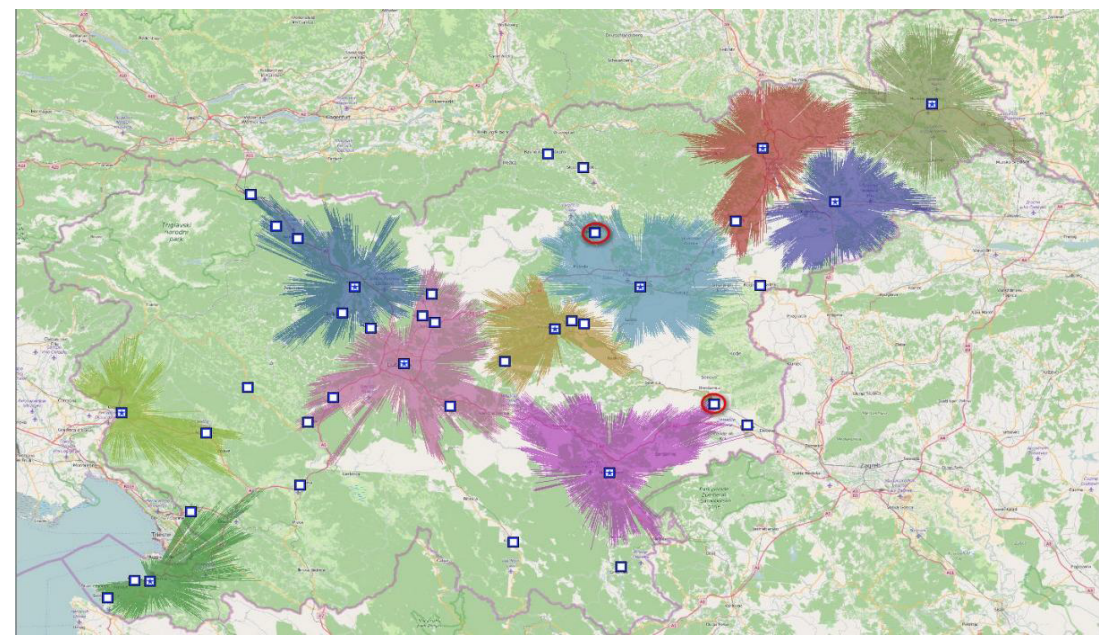

Slika 41: Optimalne lokacije desetih splošnih bolnišnic v 30-minutnem časovnem intervalu

Slika 4I ponazarja deset optimalnih lokacij slovenskih splošnih bolnišnic znotraj 30-minutnega časovnega intervala, s katerimi pokrijemo 80,74 odstotka prebivalstva. V tem primeru torej zadostimo merilu osemdesetodstotne pokritosti prebivalstva, kar je bil naš zastavljeni cilj. Rezultati nam pokažejo, da je izvzeta splošna bolnišnica, ki je bila v začetnem stanju znotraj MA-modela locirana v Velenju, in splošna bolnišnica, ki je bila locirana v Krškem. Optimalne lokacije splošnih bolnišnic bi bile znotraj mreže sekundarne zdravstvene dejavnosti tako locirane v Celju, Murski Soboti, Ljubljani, Kranju, Ptuju, Mariboru, Novi Gorici, Kopru, Zagorju ob Savi in Novem mestu. Na tem mestu je treba izpostaviti kraje, do katerih bolniki ne morejo dostopati znotraj 30-minutnega časovnega intervala, kar pomeni, da je njihov potovalni čas do najbližjega izvajalca zdravstvene dejavnosti daljši. Na severozahodnem delu Slovenije znotraj 30-minutnega časovnega intervala ne morejo dostopati prebivalci v Kranjski Gori, Bovcu, Kobaridu in Tolminu. V južni in jugozahodni Sloveniji so taki kraji Pivka, Ilirska Bistrica, Cerknica, Ribnica, Kočevje in Črnomelj. V severnem delu Slovenije pa znotraj 30-minutnega časovnega intervala do splošne bolnišnice ne morejo dostopati prebivalci v Mežici, Črni na Koroškem, Ravnah na Koroškem in Dravogradu.

Če povišamo interval dostopnosti, kar pomeni, da je maksimalen čas, ki ga potrebujejo bolniki od točke, kjer se pojavi potreba po zdravstvenih storitvah, do najbližje splošne bolnišnice 45 minut, se število splošnih bolnišnic opazno zmanjša. Merilu osemdesetodstotne pokritosti prebivalstva znotraj 45-minutnega časovnega intervala zadostimo $\mathrm{z}$ alocira- 
njem petih splošnih bolnišnic. Na ta način dosežemo, da so zdravstvene storitve na sekundarni ravni zdravstvene dejavnosti v 45-minutnem časovnem intervalu dostopne 84,35 odstotka celotnega prebivalstva. Skladno s tem bi imelo dostop do splošnih bolnišnic v 45-minutnem časovnem intervalu 1.740 .072 prebivalcev Slovenije. V primeru zmanjšanja števila splošnih bolnišnic še za enega izvajalca se delež pokritosti prebivalstva zmanjša na 77,65 odstotka. To pomeni, da s štirimi splošnimi bolnišnicami znotraj 45-minutnega časovnega intervala lahko zagotovimo dostop do zdravstvenih storitev na sekundarni ravni zdravstvene dejavnosti 1.601.793 prebivalcem Slovenije. To prikazujemo v preglednici 22, ki ponazarja podatke o številu splošnih bolnišnic in deležu prebivalcev, ki gravitirajo k posamezni optimalni lokaciji splošne bolnišnice znotraj 45-minutnega časovnega intervala.

Preglednica 22: Število splošnih bolnišnic in delež pokritosti prebivalcev znotraj 45 -minutnega časovnega intervala

\begin{tabular}{|c|c|c|c|c|}
\hline \multirow[b]{2}{*}{ Bolnišnica } & \multicolumn{2}{|c|}{4 optimalno locirane bolnišnice } & \multicolumn{2}{|c|}{5 optimalno lociranih bolnišnic } \\
\hline & Število prebivalcev & $\begin{array}{l}\text { Delež prebivalcev } \\
(\mathrm{v} \%)\end{array}$ & Število prebivalcev & $\begin{array}{l}\text { Delež prebivalcev } \\
(\mathrm{v} \%)\end{array}$ \\
\hline Celje & 315.598 & 15,30 & 314.736 & 15,26 \\
\hline Murska Sobota & / & / & / & / \\
\hline Logatec & / & / & I & 1 \\
\hline Ljubljana & 766.845 & 37,17 & $736.90 \mathrm{O}$ & 35,72 \\
\hline Kranj & 1 & / & / & \\
\hline Ravne na Koroškem & / & / & / & / \\
\hline Maribor & 380.107 & 18,43 & 380.107 & 18,43 \\
\hline Nova Gorica & 1 & 1 & / & / \\
\hline Koper & 139.243 & 6,75 & 139.243 & 6,75 \\
\hline Zagorje ob Savi & l & l & / & / \\
\hline Krško & 1 & 1 & 1 & 1 \\
\hline Novo mesto & / & / & 169.085 & 8,20 \\
\hline Skupaj & 1.601 .793 & 77,65 & 1.740 .072 & 84,35 \\
\hline
\end{tabular}

V nadaljevanju prikazujemo projekciji prostorske dostopnosti optimalno lociranih splošnih bolnišnic znotraj 45-minutnega časovnega intervala. Sliki 42 in 43 prikazujeta rezultate MA-modela, ki ponazarjajo optimalne lokacije splošnih bolnišnic ob predpostavki osemdesetodstotne pokritosti prebivalstva. Slika 42 ponazarja štiri optimalne lokacije slovenskih splošnih bolnišnic znotraj 45-minutnega časovnega intervala, 
s katerimi pokrijemo 77,65 odstotka prebivalstva. $\mathrm{V}$ tem primeru MA-model iz mreže izvzame splošno bolnišnico, ki je bila v začetnem stanju locirana v Murski Soboti, splošno bolnišnico, ki je bila v Logatcu, splošno bolnišnico, ki je bila postavljena v Kranju, splošno bolnišnico, ki je bila locirana v Ravnah na Koroškem, prav tako odpade prej locirana splošna bolnišnica v Novi Gorici, splošna bolnišnica, ki je bila v Zagorju ob Savi, splošna bolnišnica, ki je bila postavljena v Krškem, in splošna bolnišnica v Novem mestu. Optimalne lokacije splošnih bolnišnic bi bile znotraj mreže sekundarne zdravstvene dejavnosti locirane $\mathrm{v}$ štirih večjih krajih po Sloveniji, to so Celje, Ljubljana, Maribor in Koper.

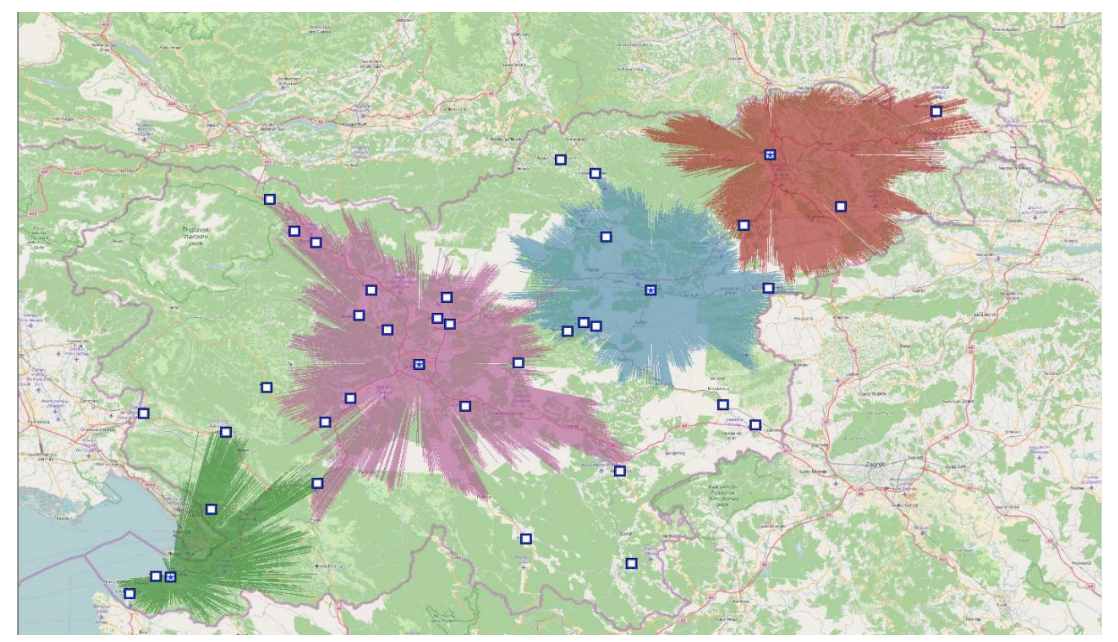

Slika 42: Optimalne lokacije štirih splošnih bolnišnic v 45-minutnem časovnem intervalu

Slika 43 ponazarja pet optimalnih lokacij slovenskih splošnih bolnišnic znotraj 45-minutnega časovnega intervala, s katerimi pokrijemo 84,35 odstotka prebivalstva. V tem primeru torej merilo osemdesetodstotne pokritosti prebivalstva celo presežemo, kar je v prid večji dostopnosti in posledično tudi koristnosti za bolnike, ki potrebujejo bolnišnično oskrbo. Rezultati nam pokažejo, da je izvzeta splošna bolnišnica, ki je bila v začetnem stanju znotraj MA-modela locirana v Murski Soboti, splošna bolnišnica, ki se je nahajala v Logatcu, splošna bolnišnica, ki je bila postavljena v Kranju, splošna bolnišnica, ki je bila locirana v Ravnah na Koroškem, odpade prej locirana splošna bolnišnica v Novi Gorici, splošna bolnišnica, ki se je nahajala v Zagorju ob Savi, in splošna bolnišnica, ki je bila postavljena v Krškem. Optimalne lokacije splošnih bolnišnic bi bile znotraj mreže sekundarne zdravstvene dejavnosti locirane v petih večjih krajih po Sloveniji, to so Celje, Ljubljana, 
Maribor, Koper in Novo mesto. V tem primeru znotraj 45-minutnega časovnega intervala do zdravstvene dejavnosti ne morejo dostopati prebivalci v Kranjski Gori, Bovcu, Kobaridu in Tolminu. V južni in jugozahodni Sloveniji so taki kraji Ilirska Bistrica in Kočevje. V severnem in severovzhodnem delu Slovenije pa znotraj 45-minutnega časovnega intervala do zdravstvene dejavnosti ne morejo dostopati prebivalci v Mežici, Črni na Koroškem, Ravnah na Koroškem, Dravogradu, Lendavi in Črenšovcih.

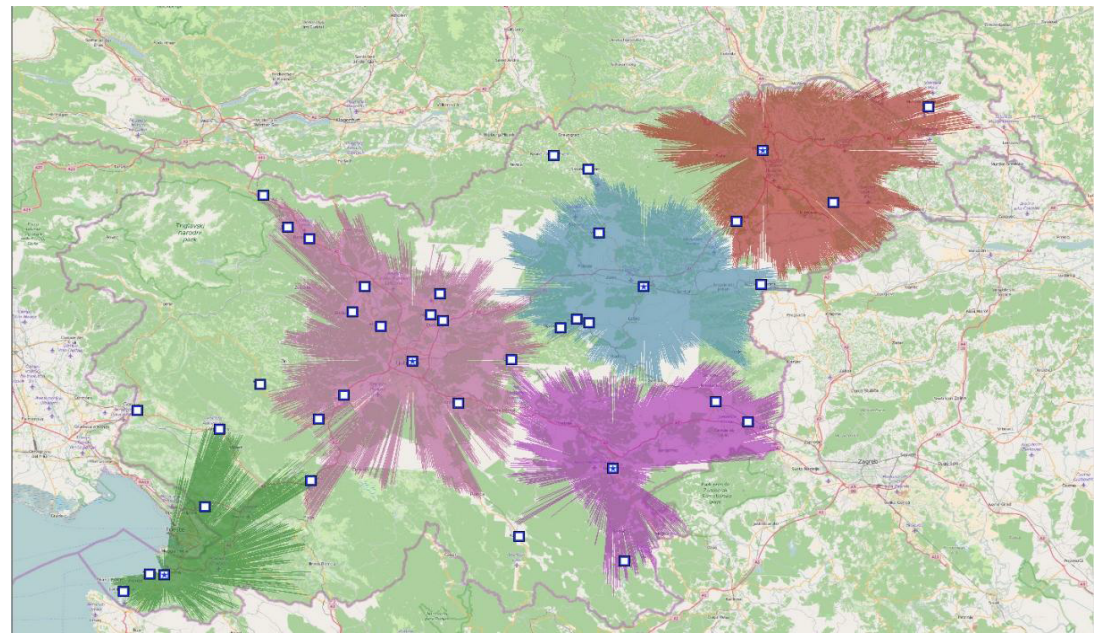

Slika 43: Optimalne lokacije petih splošnih bolnišnic v 45-minutnem časovnem intervalu

Če povišamo interval dostopnosti na 60 minut dolg potovalni čas, se število splošnih bolnišnic občutno zmanjša. Merilu osemdesetodstotne pokritosti prebivalstva znotraj 60-minutnega časovnega intervala zadostimo z alociranjem zgolj dveh splošnih bolnišnic. $V$ tem primeru so bolnišnične storitve v 6o-minutnem časovnem intervalu dostopne 8I,45 odstotka celotnega prebivalstva. Skladno s tem bi na sekundarni ravni v 6o-minutnem časovnem intervalu imelo dostop do zdravstvenih storitev 1.680.207 vseh prebivalcev Slovenije. V primeru dodatnega zmanjšanja enega izvajalca, se delež pokritosti prebivalstva zmanjša na 55,49 odstotka, kar je z vidika postavitve optimalne mreže sekundarne zdravstvene dejavnosti prenizek delež. $V$ tem primeru bi z eno splošno bolnišnico omogočili dostop v okviru 6o-minutnega časovnega intervala zgolj I.I44.725 prebivalcev Slovenije. To prikazujemo v preglednici 23 , ki ponazarja podatke o številu splošnih bolnišnic in deležu prebivalcev, ki gravitirajo $\mathrm{k}$ posamezni optimalni lokaciji splošne bolnišnice znotraj 60-minutnega časovnega intervala. 
Preglednica 23: Število splošnih bolnišnic in delež pokritosti prebivalcev znotraj 6o-minutnega časovnega intervala

\begin{tabular}{|c|c|c|c|c|}
\hline \multirow{2}{*}{ Bolnišnica } & \multicolumn{2}{|c|}{ I optimalno locirana bolnišnica } & \multicolumn{2}{|c|}{2 optimalno locirani bolnišnici } \\
\hline & Śtevilo prebivalcev & $\begin{array}{c}\text { Delež prebivalcev } \\
(\mathrm{v} \%)\end{array}$ & Śtevilo prebivalcev & $\begin{array}{c}\text { Delež prebivalcev } \\
(\mathrm{v} \%)\end{array}$ \\
\hline Celje & / & / & / & / \\
\hline Murska Sobota & 1 & 1 & 1 & I \\
\hline \multicolumn{5}{|l|}{ Logatec } \\
\hline Ljubljana & I.144.725 & 55,49 & 973.523 & 47,19 \\
\hline Kranj & / & I & / & I \\
\hline Ravne na Koroškem & / & I & / & / \\
\hline Maribor & / & / & l & / \\
\hline Nova Gorica & / & I & / & I \\
\hline Koper & / & / & / & / \\
\hline Zagorje ob Savi & / & / & / & / \\
\hline Krško & / & / & / & / \\
\hline Slovenska Bistrica & 1 & / & 706.684 & 34,26 \\
\hline Novo mesto & / & / & I & I \\
\hline Skupaj & I.1444.725 & 55,49 & 1. 680.207 & 81,45 \\
\hline
\end{tabular}

V nadaljevanju v sliki 44 prikazujemo rezultate MA-modela, ki ponazarja optimalne lokacije slovenskih splošnih bolnišnic ob predpostavki osemdesetodstotne pokritosti prebivalstva. Pri tem prikazujemo projekcijo prostorske dostopnosti z zgolj dvema optimalno lociranima splošnima bolnišnicama, projekcije prostorske dostopnosti z eno optimalno locirano splošno bolnišnico pa ne prikazujemo, saj taka mreža sekundarne zdravstvene dejavnosti z vidika doseganja cilja primerne pokritosti prebivalstva z bolnišničnimi storitvami ne bi bila učinkovita. Slika 44 prikazuje mrežo optimalno lociranih splošnih bolnišnic znotraj 6o-minutnega časovnega intervala. $\mathrm{Z}$ dvema optimalno lociranima splošnima bolnišnicama zagotovimo $8 \mathrm{I}, 45$ odstotka pokritost prebivalstva. V tem primeru MA-model iz mreže izvzame splošno bolnišnico, ki je bila v začetnem stanju locirana v Celju, splošno bolnišnico, ki je bila v Murski Soboti, splošno bolnišnico, ki je bila postavljena v Logatcu, splošno bolnišnico, ki je bila v Kranju, splošno bolnišnico, ki je bila locirana v Ravnah na Koroškem, splošno bolnišnico, ki se je nahajala v Mariboru, splošno bolnišnico, ki je bila postavljena v Novi Gorici, splošno bolnišnico, ki je bila v Kopru, splošno bolnišnico, ki je bila 
locirana v Zagorju ob Savi, splošno bolnišnico, ki je bila v Krškem, in splošno bolnišnico v Novem mestu. Optimalni lokaciji splošnih bolnišnic bi bili znotraj mreže sekundarne zdravstvene dejavnosti locirani v Ljubljani in Slovenski Bistrici. V tem primeru ni mogoče zagotoviti dostopnosti prebivalcem v nekaterih krajih vzhodne Slovenije, med katere spadajo Nova Gorica, Šempeter pri Novi Gorici, Vrtojba, Solkan in Tolmin. Prav tako ostanejo nepokriti nekateri kraji jugozahodne Slovenije, to so Koper, Izola, Lucija, Piran in Portorož. V vzhodnem in jugovzhodnem delu Slovenije znotraj 60-minutnega časovnega intervala ne morejo do izvajalcev zdravstvene dejavnosti dostopati prebivalci Brežic in Metlike.

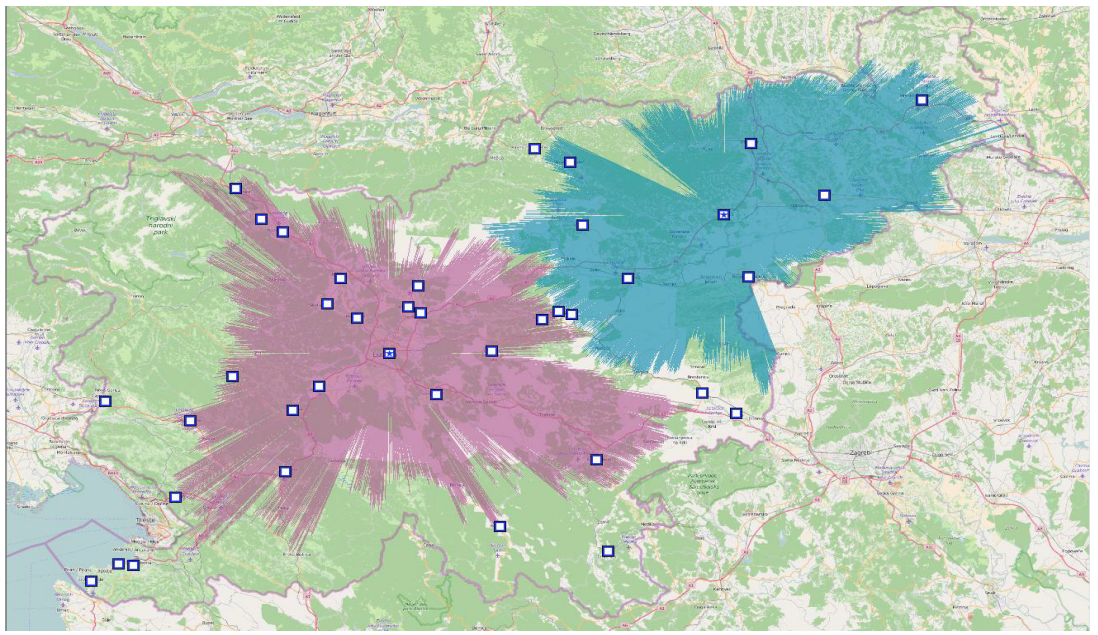

Slika 44: Optimalni lokaciji dveh splošnih bolnišnic v 60-minutnem časovnem intervalu

Skladno s cilji četrtega dela monografije smo tako oblikovali vse tri možne projekcije postavitve mreže sekundarne zdravstvene dejavnosti, ki zajemajo 30-, 45-in 60-minutni interval dostopnosti. Ugotovili smo, da je mogoče v Sloveniji oblikovati mrežo sekundarne zdravstvene dejavnosti znotraj 30-minutnega časovnega intervala $\mathrm{z}$ desetimi optimalno lociranimi splošnimi bolnišnicami ob osemdesetodstotni pokritosti prebivalstva. Če kot interval dostopnosti določimo 45 minut trajajoče potovanje, lahko mrežo sekundarne zdravstvene dejavnosti oblikujemo s petimi optimalno lociranimi splošnimi bolnišnicami ob osemdesetodstotni pokritosti. V primeru 6o-minutnega časovnega intervala pa bi v Sloveniji zadostovali za oblikovanje učinkovite mreže sekundarne zdravstvene de- 
javnosti zgolj dve optimalno locirani splošni bolnišnici ob predpostavki osemdesetodstotne pokritosti prebivalstva. 



\section{Ključne smernice postavitve optimalne mreže sekundarne zdravstvene dejavnosti}

V uvodnem delu smo izpostavili, da je oblikovanje mreže sekundarne zdravstvene dejavnosti v bistvu iskanje optimalnega stanja med dvema konfliktnima ciljema. Po eni strani naj bi se izvajalci sekundarne zdravstvene dejavnosti v čim večji meri približali posameznim bolnikom, po drugi strani pa naj bi z ustrezno koncentracijo izvajalcev sekundarne zdravstvene dejavnosti dosegli tudi racionalno obliko njihovega delovanja. To pomeni, da naj bi optimizacija vzpostavila ravnotežje med čim večjo dostopnostjo prebivalstva do zdravstvenih storitev, kar vodi do tem večje geografske razpršitve izvajalcev in maksimiranja njihovega števila na eni strani, ter ob upoštevanju povpraševanja do doseganja ekonomske učinkovitosti preko optimalne velikosti izvajalcev na drugi strani. Ker je mreža sekundarne zdravstvene dejavnosti vedno v osnovi postavljena kot mreža javnega zdravstva, javni sistem zdravstvenega varstva pa za posamezne izvajalce ne glede na njihovo lastninsko strukturo ustvarja razmere poslovanja, ki je zelo podobne razmeram, $\mathrm{v}$ katerih deluje podjetje znotraj mikroekonomske teorije, moramo pričeti definiranje mreže javnega zdravstva z definiranjem ekonomske učinkovitosti izvajalcev zdravstvene dejavnosti, ki je povezana z njihovo optimalno velikostjo. Če tako upoštevamo različne kategorije učinkovitosti izvajalcev sekundarne zdravstvene dejavnosti, njihovo priporočeno optimalno velikost in razporeditev prebivalstva, lahko definiramo mrežo sekundarne zdravstvene dejavnosti, $s$ katero uresničimo geografsko dostopnost in hkrati ekonomsko učinkovitost izvajalcev sekundarne zdravstvene dejavnosti.

Prvi korak pri definiranju optimalne mreže sekundarne zdravstvene dejavnosti je tako preučevanje odnosa med inputi in outputi v obliki 
zdravstvenih storitev. Prav v tem odnosu se oblikuje ekonomska učinkovitost $\mathrm{v}$ obliki tehnične, alokacijske in stroškovne učinkovitosti. Tehnična učinkovitost govori o maksimiranju odnosa med količinskim obsegom outputa in količinskim obsegom inputov, o ustrezni kombinaciji med inputi glede na njihove cene, ki minimizira stroške, govori alokacijska učinkovitost, stroškovna pa zajema obe učinkovitosti. Skladno $s$ tem smo v drugem delu monografije preučevali tehnično, alokacijsko in stroškovno učinkovitost izvajalcev sekundarne zdravstvene dejavnosti z dvema alternativnima metodama, z ekonometrično in parametrično stohastično mejno analizo SFA in neparametrično metodo linearnega programiranja DEA. Obe metodi, tako SFA kot tudi DEA, sta analitični strogi metodi primerjalne analize, ki izkoriščata funkcije razdalje za merjenje učinkovitosti izvajalcev zdravstvene dejavnosti glede na mejne funkcije.

Rezultati metode SFA pokažejo, da je skozi celotno opazovano obdobje stroškovno najučinkovitejša Splošna bolnišnica Celje, ki ima povprečno vrednost stroškovne učinkovitosti 0,862 . Ta podatek ni presenetljiv glede na dejstvo, da je Splošna bolnišnica Celje hkrati tudi tehnično najučinkovitejša slovenska splošna bolnišnica. Sledi ji Splošna bolnišnica Murska Sobota s povprečnim količnikom stroškovne učinkovitosti o,8 I 2 in Splošna bolnišnica Brežice s povprečno mero tehnične učinkovitosti 0,762 . Takoj za njima ima najvišjo povprečno vrednost stroškovne učinkovitosti Splošna bolnišnica Izola z mero stroškovne učinkovitosti o,76I, Splošna bolnišnica Novo mesto s povprečnim količnikom stroškovne učinkovitosti 0,703 in Splošna bolnišnica Jesenice s povprečno mero stroškovne učinkovitosti o,697. Najnižjo vrednost stroškovne učinkovitosti skozi vsa leta opazovanja ima Splošna bolnišnica Slovenj Gradec, pri kateri znaša povprečna vrednost stroškovne učinkovitosti o,4Io. Splošna bolnišnica Nova Gorica je v podobnem položaju, saj njena povprečna mera stroškovne učinkovitosti znaša 0,496 .

Rezultati metode DEA pokažejo, da je glede na celotno opazovano obdobje stroškovno najučinkovitejša Splošna bolnišnica Brežice, ki ima povprečno vrednost stroškovne učinkovitosti o,986, sledi ji Splošna bolnišnica Trbovlje s povprečno vrednostjo stroškovne učinkovitosti 0,957 . Takoj za njima ima najvišjo povprečno vrednost stroškovne učinkovitosti Splošna bolnišnica Jesenice $s$ količnikom $0,8 \circ 8$ in Splošna bolnišnica Murska Sobota z mero stroškovne učinkovitosti o,724. Najnižje vrednosti stroškovne učinkovitosti pretežno vsa leta opazovanja sta imela Univerzitetni klinični center Ljubljana in Univerzitetni klinični center Maribor, pri čemer ima slednji v primerjavi z Univerzitetnim kliničnim 
centrom Ljubljana še nižjo povprečno vrednost stroškovne učinkovitosti. Pri Univerzitetnem kliničnem centru Maribor ta znaša o,448, pri Univerzitetnem kliničnem centru Ljubljana pa o, 5 ro.

Rezultati mer učinkovitosti splošnih bolnišnic potrjujejo, da je izvajalec, ki dosega najvišje mere tehnične, alokacijske in stroškovne učinkovitosti, tudi ekonomsko najučinkovitejši izvajalec sekundarne zdravstvene dejavnosti. Ekonomska učinkovitost se namreč oblikuje v obliki tehnične, alokacijske in stroškovne učinkovitosti. To je skladno z dejstvom, da tehnična in alokacijska učinkovitost splošnih bolnišnic predstavljata skupno stroškovno učinkovitost, kar pomeni, da sta tehnična in alokacijska učinkovitost dve sestavini stroškovne učinkovitosti. To potrjujejo tudi rezultati mer stroškovne učinkovitosti, ki ponazarjajo, da je stroškovna učinkovitost produkt tehnične in alokacijske učinkovitosti. Če torej pomnožimo količnike tehnične učinkovitosti splošnih bolnišnic z njihovimi količniki alokacijske učinkovitosti, ugotovimo, da dobljeni rezultat predstavlja stroškovno učinkovitost. Splošna bolnišnica, ki ni hkrati tako tehnično kot tudi alokacijsko učinkovita, $v$ nobenem primeru ni stroškovno učinkovita. Posledično to pomeni, da ima splošna bolnišnica z najvišjimi merami tehnične in alokacijske učinkovitosti tudi najvišje mere stroškovne učinkovitosti. Splošno bolnišnico, ki dosega najvišjo raven stroškovne učinkovitosti, tako lahko definiramo kot ekonomsko najučinkovitejšo slovensko splošno bolnišnico.

Dejavniki tehnične, alokacijske in stroškovne učinkovitosti so različni, oblika mreže zdravstvene dejavnosti pa lahko vpliva nanje preko večje ali manjše stopnje koncentracije zdravstvenih dejavnosti. Ta namreč odloča o velikosti izvajalcev. Velikost izvajalcev je torej eden izmed dejavnikov njihove učinkovitosti. Tako $\mathrm{v}$ teoriji kot $\mathrm{v}$ praksi govorimo zato o optimalni velikosti izvajalcev sekundarne zdravstvene dejavnosti. Pri definiranju ekonomsko učinkovite splošne bolnišnice je torej smiselno poznati tudi njeno optimalno velikost.

Teoretične iztočnice optimalne velikosti podjetja znotraj mikroekonomske teorije lahko uporabimo tudi kot podlago za definiranje optimalne velikosti izvajalca sekundarne zdravstvene dejavnosti. V tem primeru velja, da so cene za izvajalca dane na trgu in se je mogoče prilagajati le s količino ponudbe, pri čemer s svojo količino ponudbe ni sposoben spreminjati tržnih cen. To so razmere, ki so značilne tudi za izvajalce sekundarne zdravstvene dejavnosti. Ceno zdravstvenih storitev namreč postavlja plačnik, kar pomeni, da se izvajalec lahko prilagaja trgu le s količino ponudbe, pri čemer s svojo količino ne more spreminjati cen zdravstvenih storitev. Razprava o optimalni velikosti izvajalcev sekundarne zdravstve- 
ne dejavnosti spada $v$ razpravo o njihovem dolgoročnem ravnotežju podjetij. Velikost podjetja namreč lahko spreminjamo le, če domnevamo, da noben proizvodni dejavnik ni za podjetje fiksen, kar je v mikroekonomski teoriji definicija dolgega roka. Prav tako je pomembno, da mikroekonomska opredelitev optimalne velikosti izvajalca sekundarne zdravstvene dejavnosti upošteva domnevo, da izvajalci minimizirajo stroške ter maksimirajo prihodke.

Optimalna velikost je v takih razmerah pri minimalnih dolgoročnih povprečnih stroških, če cene, ki jih priznava plačnik, težijo k tem stroškom. Minimalni dolgoročni povprečni stroški pa so določeni z učinki delitve dela in tehnologije ter problemi upravljanja ter vodenja. Delitev dela in tehnologija dajeta ekonomijo obsega in zahtevata večji obseg dejavnosti, problemi upravljanja in vodenja pa so v ozadju tako imenovanih disekonomij obsega in omejujejo velikost izvajalca. Splošna bolnišnica je tipična organizacija, ki ji spodnjo mejo velikosti opredeljuje značaj njene dejavnosti. Ta zahteva velike investicije $\mathrm{v}$ zgradbe in opremo, tehnološko pa je znotraj njih uveljavljena visoka stopnja delitve dela, ki se izraža v oddelčni organizaciji, pri tem pa vsaj na sploh oddelkov ni mogoče osamosvojiti in razdvojiti, in sicer zaradi tokov bolnikov, ki tečejo med različnimi oddelki. Zato so za splošno bolnišnico dolgoročno značilne izrazite ekonomije obsega. Ob tem pa so dokaj strogo postavljene tudi zgornje meje velikosti splošne bolnišnice, ki onemogočajo njeno učinkovitost pri velikih obsegih dejavnosti. To izvira iz pomena dejavnika dela, ki ga je težko učinkovito voditi ob prevelikih obsegih enot, zato v bolnišnici hitro nastajajo disekonomije obsega, če se število zaposlenih v posameznih oddelkih povečuje preko meja.

Ključen za določitev optimalne velikosti splošne bolnišnice je izračun posameznih analitičnih konceptov dolgoročne stroškovne funkcije, pri čemer je izračun odvisen od tega, $v$ kakšni obliki je funkcija podana. Lahko jo namreč predstavimo v obliki zapisa v tabeli, v obliki matematične specifikacije ali $v$ grafični obliki. Skladno s tem smo optimalno velikost izvajalca sekundarne zdravstvene dejavnosti analizirali z diskretnimi, zveznimi in grafičnimi analizami, pri čemer smo uporabili več različnih regresijskih modelov. Posamičen regresijski model in iz njega izhajajoča dolgoročna stroškovna funkcija sicer veliko povesta o zakonitostih gibanja funkcije v opazovanem letu, vendar pa lahko posamezni specifični dejavniki, ki se odražajo v poslovanju splošnih bolnišnic znotraj tega leta, pomembno vplivajo na obliko dolgoročne stroškovne funkcije. Skladno s tem smo poiskali deset dolgoročnih stroškovnih funkciji, ki temeljijo na podatkih desetih različnih let, pri čemer smo poskušali oprede- 
liti najznačilnejšo obliko dolgoročne stroškovne funkcije izvajalca zdravstvene dejavnosti. Takšna ocena je smiselna predvsem zato, da dobimo zanesljivejši pogled na dolgoročno stroškovno funkcijo izvajalca zdravstvene dejavnosti.

Optimalna velikost izvajalcev zdravstvene dejavnosti je pri velikosti, ki daje minimalne dolgoročne povprečne stroške. To velja v primeru, ko je tržna cena postavljena na raven minimalnih dolgoročnih povprečnih stroškov splošne bolnišnice in če ta minimizira stroške ter maksimira prihodke. Če izračunamo optimalno velikost izvajalca sekundarne zdravstvene dejavnosti skladno z minimumom dolgoročnih povprečnih stroškov, nam rezultat pokaže, da ima optimalna splošna bolnišnica najnižje stroške na enoto proizvodnje pri 188.032 bolnikih letno. To velja v primeru podatkov splošnih bolnišnic za leto 20r4. Če upoštevamo rezultate, ki temeljijo na podatkih splošnih bolnišnic za celotno opazovano obdobje, torej od leta 2005 do leta 2014 , pa vidimo, da se najnižji stroški na enoto proizvodnje gibljejo od I 88.032 do 242.947 obravnav bolnikov letno. To je raven proizvodnje, pri kateri so ekonomije obsega največje.

Ob upoštevanju dejstva, da je povprečna cena storitve, ki jo plačnik zdravstvenih storitev plačuje izvajalcem zdravstvene dejavnosti, nad minimalnimi dolgoročnimi povprečnimi stroški, je optimalna velikost splošne bolnišnice na podlagi podatkov splošnih bolnišnic za leto 2014 pri večjem obsegu proizvodnje, to je pri $245.83 \mathrm{I}$ bolnikih letno. To je posledica dejstva, da dolgoročni mejni stroški naraščajo $s$ količino ponudbe. Izračun točke maksimalnega dobička oziroma optimalne velikosti splošne bolnišnice na podatkih splošnih bolnišnic za vseh deset opazovanih let pa kaže, da se ob izenačitvi bolnišničnih dolgoročnih mejnih stroškov z dano ceno na trgu optimalna velikost splošne bolnišnice giblje med $245.83 \mathrm{I}$ in 274.992 obravnav bolnikov letno. $Z$ vidika vodenja splošne bolnišnice sta za vodstvo pomembni obe informaciji, torej tako informacija, ki pove, pri kateri količini proizvodnje ima splošna bolnišnica najnižje stroške na enoto proizvodnje, kot tudi informacija, ki opredeli točko maksimalnega dobička oziroma optimalne velikosti splošne bolnišnice.

Rezultati diskretnih zapisov sicer pokažejo, da se nobena izmed slovenskih splošnih bolnišnic ne nahaja natanko na točki optimalne velikosti, se pa izmed vseh splošnih bolnišnic optimalni velikost najbolj približata Splošna bolnišnica Celje in Splošna bolnišnica Murska Sobota. Če pri tem upoštevamo rezultate, ki smo jih dobili znotraj analize SFA in analize DEA, lahko ugotovimo, da se rezultati opredelitve optimalne velikosti izvajalca zdravstvene dejavnosti skladajo z rezultati, ki jih je po- 
dala metoda SFA. Znotraj metode SFA namreč najvišje mere učinkovitosti dosegata Splošna bolnišnica Celje in Splošna bolnišnica Murska Sobota. Obe splošni bolnišnici pa spadata tudi v skupino bolnišnic, ki se na podlagi ocenjevanja dolgoročnih stroškovnih funkcij najbolj približa optimalni velikosti izvajalca zdravstvene dejavnosti. Na drugi strani je metoda DEA definirala, da najvišje mere učinkovitosti dosega Splošna bolnišnica Brežice, pri čemer pa se ta bolnišnica na podlagi ocenjevanja dolgoročnih stroškovnih funkcij ne nahaja v bližini točke optimalne velikosti splošne bolnišnice. Skladno s tem vidimo, da so v našem primeru na podlagi definiranja optimalne velikosti izvajalca zdravstvene dejavnosti relevantnejši z metodo SFA dobljeni rezultati. To je tudi podlaga pri naši odločitvi, ko smo se odločili, da kot ekonomsko najučinkovitejšo slovensko splošno bolnišnico definiramo Splošno bolnišnico Celje.

$Z$ vidika ekonomske učinkovitosti je smiselno, da splošna bolnišnica proizvaja tisto količino proizvodnje, pri kateri ima najnižje stroške na posameznega obravnavanega bolnika. Skladno s tem je tudi racionalna odločitev plačnika zdravstvenih storitev, da postavi ceno na raven minimalnih dolgoročnih stroškov, kar izvajalce prisili, da proizvajajo $\mathrm{v}$ točki, kjer imajo najnižje stroške na posamezno proizvedeno enoto. Pretekli poslovni rezultati izvajalcev sekundarne zdravstvene dejavnosti v Sloveniji kažejo, da večina izvajalcev posluje $\mathrm{v}$ bližini točke ničelnega dobička. Skladno s tem smo predvidevali, da je plačnik zdravstvenih storitev postavil ceno na raven minimalnih dolgoročnih povprečnih stroškov, kar pomeni, da je točka optimalne velikost ob pogoju presečišča dolgoročnih mejnih stroškov in premice cene ravno v minimumu dolgoročnih povprečnih stroškov. Zvezna in grafična analiza ocenjevanja dolgoročnih stroškovnih funkcij sta nam pokazali, da optimalna velikost izvajalca sekundarne zdravstvene dejavnosti ni v minimumu dolgoročnih povprečnih stroškov, saj je cena zdravstvenih storitev postavljena višje, skladno $s$ tem pa je tudi presečišče dolgoročnih mejnih stroškov in premice cene, ki določa optimalno velikost izvajalca zdravstvene dejavnosti, pri večjem obsegu proizvodnje.

Kot ekonomsko najučinkovitejšo slovensko splošno bolnišnico smo opredelili Splošno bolnišnico Celje. Naša odločitev je posledica dejstva, da na ta način definiramo ekonomsko najučinkovitejšo splošno bolnišnico ne samo na podlagi analiz mer tehnične, alokacijske in stroškovne učinkovitosti, ampak tudi z opredelitvijo njene optimalne velikosti. $S$ tem ne odgovorimo zgolj na vprašanje, kakšna učinkovita splošna bolnišnica naj deluje znotraj mreže sekundarne zdravstvene dejavnosti, ampak podajamo tudi odgovor na vprašanje, koliko storitev mora splošna 
bolnišnica proizvajati, če želi slediti ekonomskim načelom. S tem zadostimo dvema ciljema monografije, torej na eni strani identificiramo ekonomsko najučinkovitejšo slovensko splošno bolnišnico, hkrati pa definiramo tudi njeno optimalno velikost. Kot ekonomsko najučinkovitejša slovenska splošna bolnišnica je torej definirana Splošna bolnišnica Celje, ki ima optimalno velikost pri obravnavi med 245.83 I in 274.992 bolnikov letno. Splošna bolnišnica Celje predstavlja teoretičnega izvajalca sekundarne ravni zdravstvene dejavnosti, ki ima najvišjo mero tehnične, alokacijske in stroškovne učinkovitosti, hkrati pa se nahaja tudi v bližini točke optimalne velikosti. $S$ tem dosežemo prvi cilj mreže sekundarne zdravstvene dejavnosti, ki je z ustrezno koncentracijo izvajalcev sekundarne zdravstvene dejavnosti zagotoviti racionalno obliko njihovega delovanja. To pomeni, da z doseganjem optimalne velikosti splošne bolnišnice zagotavljamo njihovo ekonomsko učinkovitost znotraj mreže sekundarne zdravstvene dejavnosti.

Ekonomska učinkovitost ima obratnosmerno povezavo $\mathrm{z}$ dostopnostjo izvajalcev sekundarne zdravstvene dejavnosti, kar pomeni, da je treba poiskati teoretski optimum na način, da je posamezna zdravstvena storitev maksimalno geografsko približana vsakemu posameznemu prebivalcu v obliki, ki jo zdravstvena tehnologija omogoča, in kakovosti, ki jo prebivalec pričakuje, hkrati pa so ponudniki teh zdravstvenih storitev organizirani na način, da preko optimalne velikost dosegajo maksimalno tehnično, alokacijsko in stroškovno učinkovitost. To je mogoče doseči tako, da definiramo tudi optimalne lokacije in število izvajalcev sekundarne zdravstvene dejavnosti, ki se poskušajo v čim večji meri približati posameznemu prebivalcu oziroma ki poskušajo zagotoviti čim večjo dostopnost zdravstvenih storitev prebivalstvu.

Za namene analize optimalnih lokacij in števila splošnih bolnišnic smo uporabili klasične modele lokacija-alokacija, ki so nam v prvem koraku podali informacijo, kje morajo biti locirane splošne bolnišnice znotraj mreže sekundarne zdravstvene dejavnosti. Izdelali smo geografske karte, ki prikazujejo optimalne hipotetične lokacije bolnišnic, do katerih lahko bolniki dostopajo $\mathrm{z}$ osebnim avtomobilom $\mathrm{v}$ različnih časovnih intervalih. Pri tem ni mogoče zaobiti dejstva, da je odločitev o tem, kakšni potovalni časi naj bi bili sprejemljivi kot merilo za oblikovanje mreže zdravstvene dejavnosti, še vedno na strani oblikovalcev zdravstvene politike. Maksimalen potovalni čas do najbližje bolnišnice mora biti opredeljen tako, da izvajalcem omogoča zagotavljanje dobrih zdravstvenih izidov. V literaturi in med oblikovalci zdravstvene politike ni enotnega mnenja, kolikšen je primeren potovalni čas do najbližje bolnišnice, zato smo se od- 
ločili, da bomo definirali tri različne časovne intervale, ki jih v teoriji najpogosteje omenjamo. Kot prvi časovni interval je opredeljeno 30 minut trajajoče potovanje z osebnim avtomobilom. Drugi interval je vključeval 45-minutno časovno obdobje, tretji interval je predstavljal 60-minutno časovno obdobje. To pomeni, da smo kot rezultat dobili tri različne možne rešitve.

Različne modele lokacija-alokacija smo uporabili skupaj z orodjem ArcGIS za mrežne analize. Modeli lokacija-alokacija nam niso podali zgolj informacije, kje morajo biti locirane splošne bolnišnice, ampak so nam v drugem koraku odgovorili tudi na vprašanje, kolikšno je najmanjše število izvajalcev, ki lahko pokrije potrebe prebivalcev po storitvah zdravstvenega varstva znotraj določenega območja. Na ta način smo določili tudi število izvajalcev, s katerimi smo poskušali pokriti čim višji delež prebivalstva, ki potrebuje zdravstvene storitve. Število splošnih bolnišnic se enako kot v primeru opredelitve optimalnih lokacij splošnih bolnišnic razlikuje glede na različne časovne intervale. Projekcije prostorske dostopnosti izvajalcev sekundarne zdravstvene dejavnosti tako prikazujejo dva rezultata, pri čemer prvi rezultat predstavlja hipotetične lokacije optimalno lociranih splošnih bolnišnic, drugi rezultat pa ponazarja število takšnih lokacij oziroma hipotetično število splošnih bolnišnic, ki osemdesetim odstotkom prebivalstva zagotavljajo dostopnost do bolnišničnih storitev v različnih časovnih intervalih. Rezultati, ki se kažejo $\mathrm{v}$ različnih lokacijah in različnem številu splošnih bolnišnic, so posledica razlik med tremi časovnimi intervali dostopnosti. Ti predstavljajo povprečen potovalni čas z osebnim avtomobilom, ki ga bolniki potrebujejo za potovanje od točke, kjer se pojavi potreba po zdravstvenih storitvah, do najbližje splošne bolnišnice.

Znotraj prve projekcije prostorske dostopnosti smo kot maksimalen časovni interval dostopnosti, ki ga potrebujejo bolniki do najbližje splošne bolnišnice, definirali 30 minut dolgo potovanje z osebnim avtomobilom. V tem primeru so rezultati pokazali, da lahko zagotovimo dostopnost osemdesetim odstotkom prebivalstva z desetimi optimalno lociranimi bolnišnicami. Optimalne lokacije splošnih bolnišnic bi bile znotraj mreže sekundarne zdravstvene dejavnosti locirane v Celju, Murski Soboti, Ljubljani, Kranju, Ptuju, Mariboru, Novi Gorici, Kopru, Zagorju ob Savi in Novem mestu. V primerjavi z obstoječim stanjem bi se torej zmanjšalo število izvajalcev na sekundarni ravni zdravstvene dejavnosti za dve bolnišnici. Poleg tega pa bi bile splošne bolnišnice locirane na drugih lokacijah. Znotraj obalno-kraške regije bi se lokacija Splošne bolnišnice Izole prestavila v Koper, znotraj zasavske regije pa bi se lokacija 
Splošne bolnišnice Trbovlje zamenjala z lokacijo v Zagorju ob Savi. V posavski regiji bi bila izločena Splošna bolnišnica Brežice, v koroški regiji pa Splošna bolnišnica Slovenj Gradec.

$\mathrm{V}$ drugi projekciji prostorske dostopnosti smo kot maksimalen časovni interval dostopnosti, ki ga potrebujejo bolniki za potovanje do najbližje splošne bolnišnice, definirali 45 minut dolgo potovanje z osebnim avtomobilom. Skladno z daljšim časovnim intervalom dostopnosti bi v tem primeru potrebovali pet splošnih bolnišnic za pokritje potreb osemdesetih odstotkov prebivalstva. Optimalno locirane bolnišnice bi bile v petih večjih krajih v Sloveniji, to so Celje, Ljubljana, Maribor, Koper in Novo mesto. Glede na obstoječo mrežo sekundarne zdravstvene dejavnosti bi imeli znotraj potencialne mreže sekundarne zdravstvene dejavnosti sedem splošnih bolnišnic manj. Na ta način bi bila znotraj posavske regije izločena Splošna bolnišnica Brežice, znotraj gorenjske regije ne bi bilo več Splošne bolnišnice Jesenice, v pomurski regiji bi se izognili Splošni bolnišnici Murska Sobota, v goriški regiji bi bila izločena Splošna bolnišnica Nova Gorica, v podravski regiji ne bi bilo več Splošne bolnišnice Ptuj, v koroški regiji bi se izognili Splošni bolnišnici Slovenj Gradec, v zasavski regiji pa bi bila izločena Splošna bolnišnica Trbovlje. V območju obalno-kraške regije bi se lokacija Splošne bolnišnice Izola prestavila v Koper.

$\mathrm{V}$ tretji projekciji prostorske dostopnosti smo kot maksimalen časovni interval dostopnosti, ki ga potrebujejo bolniki do najbližje splošne bolnišnice, definirali 60 minut dolgo potovanje $\mathrm{z}$ osebnim avtomobilom. $\mathrm{V}$ tem primeru bi, da bi dosegli osemdeset odstotno pokritost prebivalstva znotraj omenjenega časovnega intervala, potrebovali zgolj dve splošni bolnišnici. Potencialno mrežo sekundarne zdravstvene dejavnosti bi tako sestavljali zgolj dve optimalno locirani splošni bolnišnici. Prva splošna bolnišnica bi bila locirana znotraj osrednjeslovenske regije, natančneje v Ljubljani, druga splošna bolnišnic pa bi bila locirana v podravski regiji, in sicer v Slovenski Bistrici. Splošna bolnišnica Brežice, Splošna bolnišnica Celje, Splošna bolnišnica Izola, Splošna bolnišnica Jesenice, Univerzitetni klinični center Maribor, Splošna bolnišnica Murska Sobota, Splošna bolnišnica Nova Gorica, Splošna bolnišnica Novo mesto, Splošna bolnišnica Ptuj, Splošna bolnišnica Slovenj Gradec in Splošna bolnišnica Trbovlje pa bi bile iz mreže sekundarne zdravstvene dejavnosti izvzete.

Skladno z dobljenimi rezultati smo lahko preverili hipotezo 3 , kjer smo predvidevali, da so optimalne lokacije slovenskih splošnih bolnišnic odvisne od lokacij naselij s številom prebivalstva, povprečne potovalne hitrosti na kategoriziranem cestnem omrežju in časovnega intervala dostopnosti. Skladno z rezultati analize projekcij postavitve optimalne mreže 
sekundarne zdravstvene dejavnosti smo z definiranjem merila, ki govori o maksimalnem intervalu dostopnosti, ki je z vidika koristnosti še sprejemljiv za bolnika, definirali optimalne lokacije slovenskih splošnih bolnišnic. Pri tem smo upoštevali tako gostoto prebivalstva, lokacije naselij s številom prebivalstva, kot tudi povprečne potovalne hitrosti na kategoriziranem cestnem omrežju. Rezultati variirajo glede na opisana merila, pri čemer smo posebej prikazali, kako se spreminjajo optimalne lokacije splošnih bolnišnic s spreminjanjem časovnega intervala dostopnosti. $\mathrm{V}$ različnih modelih smo $\mathrm{z}$ definiranjem maksimalnega potovalnega časa podrobneje prikazali možne oblike mreže sekundarne zdravstvene dejavnosti. S tem smo pokazali, kako so optimalne lokacije slovenskih splošnih bolnišnic odvisne od lokacij naselij s številom prebivalstva, povprečne potovalne hitrosti na kategoriziranem cestnem omrežju in časovnega intervala dostopnosti. Hipotezo 3 smo tako na osnovi rezultatov sprejeli.

$\mathrm{Z}$ definiranjem optimalnih lokacij in števila splošnih bolnišnic znotraj različnih časovnih intervalov smo opredelili tri najrelevantnejše projekcije postavitve izvajalcev znotraj mreže sekundarne zdravstvene dejavnosti, ki zagotavljajo dostopnost do zdravstvenih storitev $\mathrm{v}$ posameznem časovnem okviru osemdesetim odstotkom prebivalstva. S tem odgovorimo na vprašanje, kje morajo biti splošne bolnišnice locirane in koliko splošnih bolnišnic potrebujemo znotraj mreže sekundarne zdravstvene dejavnosti. Na ta način zadostimo cilju monografije, ki je prikazati različne možne projekcije postavitve mreže sekundarne zdravstvene dejavnosti v Sloveniji. Če se oblikovalci zdravstvene politike torej odločijo, da je treba vse storitve sekundarne ravni zdravstvene dejavnosti zagotoviti prebivalcem znotraj 30-minutnega časovnega intervala, v Sloveniji potrebujemo deset splošnih bolnišnic. Če se v okviru zdravstvene politike sprejme sklep, da se slovenskemu zdravstvenemu sistemu nameni manj finančnih sredstev ter da je dovolj, da so bolnišnične storitve prebivalcem dostopne znotraj 45-minutnega časovnega intervala, potem v Sloveniji potrebujemo pet splošnih bolnišnic. Če pa se oblikovalci zdravstvene politike odločijo, da bodo zagotovili storitve na sekundarni ravni zdravstvene dejavnosti prebivalcem zgolj znotraj 60-minutnega časovnega intervala, potem sta v Sloveniji dovolj zgolj dve splošni bolnišnici.

$\mathrm{Z}$ definiranjem optimalnih lokacij in števila splošnih bolnišnic dosežemo drugi cilj mreže sekundarne zdravstvene dejavnosti, ki je zagotoviti, da se storitve na sekundarni ravni zdravstvene dejavnosti čim bolj približajo posameznemu prebivalcu, kar pomeni, da je mogoče ob danih pogojih doseči večjo stopnjo dostopnosti zdravstvenega varstva. Pri tem se je treba zavedati, čim bližje so storitve zdravstvenega varstva bolniku, tem 
bolj lahko prispevajo ob enakem obsegu in strukturi k zdravju prebivalstva. Posledično to pomeni, da dostopnost zdravstvenih storitev prebivalstvu in zlasti bolnikom sama po sebi vpliva na koristnost, ki jo te storitve lahko izzovejo pri bolnikih. Domnevamo torej, da je dostopnost sama po sebi značilnost ponudbe zdravstvenih storitev, ki vpliva na koristnost, ki jo zdravje daje posamezniku. Vpliv zdravstvenih storitev preko zdravja na korist bolnikov kaže uspešnost zdravstvenega varstva.

Razumljivo je, da ekonomska učinkovitost izvajalcev sekundarne zdravstvene dejavnosti sama po sebi še ne zagotavlja uspešnosti zdravstvenega varstva ter da so določene organizacijske oblike mreže sekundarne zdravstvene dejavnosti, ki zagotavljajo zgolj ekonomsko učinkovitost izvajalcev sekundarne ravni zdravstvene dejavnosti, neuspešne $\mathrm{z}$ vidika zagotavljanja koristi za prebivalce oziroma bolnike. To pomeni, da na primer organizacijska oblika, ki zagotavlja visoko stopnjo ekonomske učinkovitosti, ne zagotavlja $\mathrm{v}$ vseh primerih tudi visoke stopnje koristnosti pri posameznem prebivalcu, če je takšna ponudba zdravstvenih storitev zelo oddaljena od posameznika in mu je zato tudi manj dostopna.

$\mathrm{Na}$ podlagi povedanega moramo mrežo sekundarne zdravstvene dejavnosti oblikovati tako, da ob danih inputih $\mathrm{v}$ zdravstveno varstvo dosežemo maksimalno koristnost za prebivalstvo. Teoretski optimum torej lahko dosežemo tedaj, ko so ponudniki zdravstvenih storitev organizirani na način, da preko optimalne velikost dosegajo maksimalno tehnično, alokacijsko in stroškovno učinkovitost, hkrati pa je posamezna zdravstvena storitev maksimalno geografsko približana vsakemu posameznemu prebivalcu. Na podlagi dobljenih rezultatov lahko zaključimo, da teoretski optimum dosežemo, ko so znotraj mreže sekundarne zdravstvene dejavnosti splošne bolnišnice organizirane na način, da letno opravijo od 245.83 I do 274.992 obravnav bolnikov, hkrati pa je znotraj mreže sekundarne zdravstvene dejavnosti alociranih deset splošnih bolnišnic, s katerimi zagotovimo dostopnost do zdravstvenih storitev osemdesetim odstotkom prebivalstva v okviru 30-minutnega potovalnega časa.

Znotraj mreže sekundarne zdravstvene dejavnosti je smiselno multiplicirati splošno bolnišnico, ki maksimira odnos med količinskim obsegom outputa in količinskim obsegom inputov, s čimer zagotovimo tehnično učinkovitost ponudnikov. Primer takšne bolnišnice je Splošna bolnišnica Celje, ki hkrati uporablja tudi ustrezno kombinacijo med inputi glede na njihove cene. Če so znotraj mreže sekundarne zdravstvene dejavnosti organizirane bolnišnice, ki so podobne Splošne bolnišnici Celje, s tem dosežemo tudi alokacijsko učinkovitost ponudnikov. Splošna bolnišnica Celje je posledično tudi stroškovno najučinkovitejša slovenska 
splošna bolnišnica, kar pomeni, da poleg optimalne kombinacije količinskega obsega outputa in inputov proizvaja tudi z minimalnimi možnimi stroški. Če znotraj mreže sekundarne zdravstvene dejavnosti delujejo bolnišnice, podobne Splošni bolnišnici Celje, zagotovimo maksimalno tehnično, alokacijsko in stroškovno učinkovitost ponudnikov zdravstvenih storitev. Splošne bolnišnice bi morale biti organizirane na način, da dosegajo optimalno velikost, kar pomeni, da morajo letno opraviti od $245.83 \mathrm{I}$ do 274.992 zdravstvenih storitev. Pri definiranju optimalnega modela mreže sekundarne zdravstvene dejavnosti sta tako pomembni dve informaciji. Prvič, znotraj mreže morajo biti organizirane bolnišnice, ki so podobne Splošni bolnišnici Celje, drugič, bolnišnice morajo letno obravnavati od 245.83 I do 274.992 bolnikov. Učinkovitost delovanja ponudnikov znotraj mreže sekundarne zdravstvene dejavnosti namreč zagotovimo z ustrezno stopnjo koncentracije in integracije ponudnikov zdravstvenih storitev oziroma $\mathrm{z}$ doseganjem njihove optimalne velikosti.

$\mathrm{Na}$ drugi strani mora biti znotraj mreže sekundarne zdravstvene dejavnosti organiziranih deset splošnih bolnišnic, ki omogočajo dostop osemdesetim odstotkom prebivalstva $\mathrm{v}$ 30-minutnem časovnem intervalu. V tem primeru morajo biti splošne bolnišnice locirane v Celju, Murski Soboti, Ljubljani, Kranju, Ptuju, Mariboru, Novi Gorici, Kopru, Zagorju ob Savi in Novem mestu. Izmed treh predlaganih modelov, ki prikazujejo projekcije prostorske dostopnosti izvajalcev sekundarne zdravstvene dejavnosti znotraj 30-, 45- in 60-minutnega časovnega intervala, smo izbrali model, ki omogoča dostop do splošnih bolnišnic osemdesetim odstotkom prebivalstva v okviru 30 minut dolgega potovalnega časa iz dveh razlogov. Izmed predlaganih modelov projekcije prostorske dostopnosti ta model zagotavlja maksimalno koristnost za posameznika, ki povprašuje po zdravstvenih storitvah, saj zajema najkrajši časovni interval, ki ga bolniki potrebujejo, da pridejo do najbližjega izvajalca zdravstvenih storitev. Hkrati s tem modelom ob upoštevanju optimalne velikosti oziroma optimalnega števila zdravstvenih storitev, ki bi jih morale splošne bolnišnice opraviti, zagotovimo, da izvajalci pokrijejo potrebe prebivalstva po bolnišničnih storitvah. Znotraj izbranega optimalnega modela mreže sekundarne zdravstvene dejavnosti bi namreč izvajalci opravili približno enako število zdravstvenih storitev, kot jih opravijo vse splošne bolnišnice znotraj obstoječe mreže sekundarne zdravstvene dejavnosti. Z desetimi splošnimi bolnišnicami, ki letno opravijo od 245.83 I do 274.992 obravnav bolnikov, tako zagotovimo približno enako število zdravstvenih storitev kot z obstoječimi dvanajstimi splošnimi bolnišnicami. 
S tem smo pokazali, kako lahko v Sloveniji oblikujemo teoretični model mreže sekundarne zdravstvene dejavnosti, s katerim je mogoče celovito in na spoznanjih sodobne ekonomske teorije o učinkovitosti, mikroekonomske teorije podjetja in teorije lokacije pojasniti dejavnike mreže sekundarne zdravstvene dejavnosti ter $\mathrm{s}$ tem prispevati $\mathrm{k}$ poglobljenemu razumevanju mreže zdravstvenega varstva. $\mathrm{Na}$ ta način smo zadostili osrednjemu cilju monografije, ki je bil izoblikovati in preizkusiti model mreže sekundarne zdravstvene dejavnosti. Pri tem se je treba zavedati, da so odgovori na vprašanja o mreži zdravstvenega varstva ključni za naš zdravstveni sistem, saj ne definirajo le ponudbene strani v našem zdravstvu, pač pa odločilno vplivajo tudi na racionalnost povpraševanja po zdravstvenih storitvah. Mreža zdravstvenega varstva povsod po svetu in $v$ literaturi velja za enega ključnih nefinančnih mehanizmov selekcije in $s$ tem tudi racionalnega obnašanja bolnikov kot porabnikov zdravstvenih storitev, kar pomeni, da lahko z oblikovanjem optimalnega modela mreže sekundarne zdravstvene dejavnosti ustvarimo pomembne prihranke ne samo znotraj sekundarne zdravstvene dejavnosti, ampak tudi v celotnem sistemu zdravstvenega varstva.

Postavitev mreže zdravstvene dejavnosti je kompleksen problem in se dotika različnih področij ekonomskih in medicinskih ved pa tudi geodetskih znanosti. Temeljna značilnost dosedanjega preučevanja mreže zdravstvenega varstva je $\mathrm{v}$ tem, da raziskovalci v splošnem svojega preučevanja niso temeljili na teoriji ali niso imeli namena povezati teoretičnih spoznanj z empiričnim preučevanjem. Predlagani optimalni model mreže sekundarne zdravstvene dejavnosti je tako izrazito aplikativne narave, hkrati pa nudi podlago za oblikovanje učinkovitega sistema zdravstvenega varstva tako v slovenskem kot tudi v svetovnem prostoru.

Skladno z opredelitvijo teoretičnega modela mreže sekundarne zdravstvene dejavnosti želimo na tem mestu pokazati možen model raziskovanja mreže zdravstvenega varstva, ki je koristno orodje pri vseh nadaljnjih raziskovanjih na področju zdravstva, predvsem pa na tistih področjih, ki se nanašajo na učinkovitost izvajalcev zdravstvene dejavnosti, njihovo optimalno velikost in optimalne lokacije ter števila izvajalcev zdravstvene dejavnosti. Model raziskovanja je uporaben za vse oblikovalce zdravstvene politike in tiste, ki želijo preučevati ter oblikovati mrežo zdravstvenega varstva celovito oziroma na podlagi večjega števila dejavnikov, ki nanjo neposredno vplivajo. Oblikovan je skladno z dejavniki in rezultati analiz, ki smo jih izvedli v okviru monografije. V modelu raziskovanja so zajeti tudi tisti dejavniki, ki jih v monografiji nismo preučevali, hkrati pa prestavljajo pomemben vidik mreže zdravstvenega varstva. 
Omenjeni dejavniki namreč niso neposredno povezani z ekonomskimi vedami, ampak vključujejo predvsem znanje s področja medicinskih ved, zato to presega namen monografije.

Zaradi lažje predstave model raziskovanja mreže zdravstvenega varstva predstavljamo tudi v slikovni obliki, kar ponazarja slika 45.

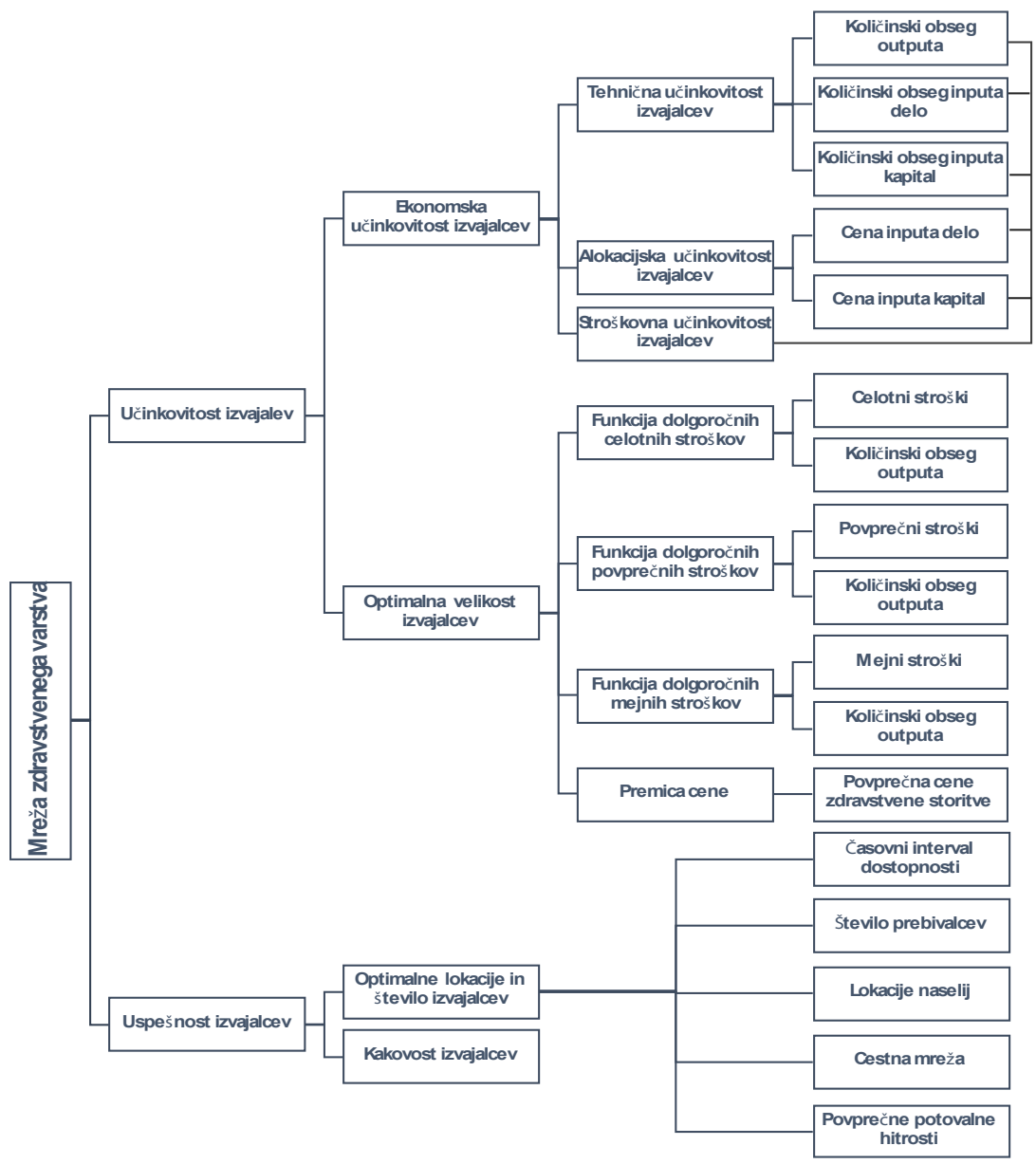

Slika 45: Model raziskovanja mreže zdravstvenega varstva

Na podlagi prikazanega modela raziskovanja je mogoče oblikovati teoretičen model mreže zdravstvenega varstva ne zgolj za sekundarno raven zdravstvene dejavnosti, ampak tudi za primarno in terciarno raven zdravstvene dejavnosti. Omenjeni model raziskovanja je lahko dobra podlaga tudi za vse raziskovalce in oblikovalce zdravstvene politike, ki jih zani- 
majo specifični dejavniki mreže zdravstvenega varstva, kar pomeni, da se lahko osredotočijo zgolj na posamezen del prikazanega modela, ki ponazarja možen način raziskovanja posameznih vrst dejavnikov. Model raziskovanja mreže zdravstvenega varstva je zasnovan tako, da ga je mogoče uporabiti kot celoto, hkrati pa je mogoče uporabiti zgolj njegove posamezne dele, ki ponazarjajo možen način raziskovanja posamezne skupine dejavnikov mreže zdravstvenega varstva.

Mrežo zdravstvenega varstva je mogoče oblikovati na način, da preučujemo učinkovitost in uspešnost zdravstvenega varstva. $\mathrm{V}$ prvem koraku je treba preučevati odnos med inputi in outputi v obliki zdravstvenih storitev, o čemer govori ekonomska učinkovitost izvajalcev zdravstvenega varstva. Ekonomska učinkovitost se oblikuje v obliki tehnične, alokacijske in stroškovne učinkovitosti. Tehnična učinkovitost govori o maksimiranju odnosa med količinskim obsegom outputa in količinskim obsegom inputov. Alokacijska učinkovitost govori ustrezni kombinaciji med inputi glede na njihove cene, pri čemer je treba inpute kombinirati na način, da omogočajo proizvodnjo z najnižjimi možnimi stroški. $V$ tem primeru bo proizvajalec izbral takšno kombinacijo proizvodnih dejavnikov, da bodo stroški na enoto proizvoda najmanjši. Stroškovna učinkovitost je opredeljena kot produkt med tehnično in alokacijsko učinkovitostjo. Stroškovna učinkovitost je dosežena le, če proizvajalec uporablja najmanjšo možno količino inputov ter če inpute kombinira tako, da omogoča proizvodnjo določenega obsega outputa z najnižjimi možnimi stroški.

$\mathrm{V}$ drugem koraku je pri raziskovanju mreže zdravstvenega varstva smiselno opredeliti optimalno velikost izvajalcev zdravstvene dejavnosti. Pri tem je glede na lastninsko strukturo in razmere, $v$ katerih delujejo izvajalci zdravstvene dejavnosti, smiselno uporabili mikroekonomsko teorijo, ki je v bistvu v ozadju tudi skoraj vseh drugih teorij optimalne velikosti. Optimalno velikost izvajalcev zdravstvene dejavnosti je treba opredeliti na teoretičnih iztočnicah dolgoročne analize teorije proizvodnje in dolgoročne analize teorije stroškov. Razprava o optimalni velikosti ponudnikov namreč spada $\mathrm{v}$ razpravo o dolgoročnem ravnotežju izvajalcev zdravstvene dejavnosti. Velikost ponudnika je mogoče spreminjati le, če se domneva, da noben proizvodni dejavnik ni za podjetje fiksen, kar je v mikroekonomski teoriji definicija dolgega roka. Če je vsaj en dejavnik fiksen, ponudnik ne more več izbirati svoje velikosti, saj je ta določena z obsegom fiksnega dejavnika, in lahko izbira le optimalen obseg proizvodnje oziroma dejavnosti ob dani velikosti. Prav tako je pomembno, da mikroekonomska razlaga optimalne velikosti upošteva domnevo, da ponudniki maksimirajo svoj dobiček. 
$\mathrm{V}$ tretjem koraku je pri raziskovanju mreže zdravstvenega varstva smiselno opredeliti tudi uspešnost izvajalcev zdravstvene dejavnosti, ki se kaže v obliki odnosa med zdravstvenimi storitvami in koristnostjo, ki jo te zdravstvene storitve prinašajo posamezniku. Maksimalno koristnost je mogoče doseči, če se posamezna zdravstvena storitev maksimalno geografsko približa vsakemu posameznemu prebivalcu v obliki, ki jo zdravstvena tehnologija omogoča. To je mogoče doseči na način, da definiramo optimalne lokacije in število izvajalcev zdravstvene dejavnosti, ki se poskušajo v čim večji meri približati posameznemu prebivalcu oziroma ki poskušajo prebivalcem zagotoviti čim večjo dostopnost do zdravstvenih storitev.

Za določitev optimalnih lokacij izvajalcev zdravstvene dejavnosti je najpogosteje uporabljeno eno samo merilo, to je potovalna upornost oziroma potovalni čas pri uporabi osebnega motornega vozila na kategoriziranem cestnem omrežju, in sicer od centroida naselja do centroida hipotetične lokacije izvajalca zdravstvene dejavnosti. Z variiranjem različnih časovnih intervalov, ki predstavljajo potovalno pot, ki jo potrebujejo bolniki do najbližjega izvajalca zdravstvene dejavnosti, vplivamo na koristnost, ki je posledica dostopnosti prebivalstva do storitev zdravstvenega varstva. Čim krajši je časovni interval dostopnosti do najbližjega izvajalca zdravstvenih storitev, tem večja je koristnost za prebivalstvo. Pri definiranju optimalnih lokacij in števila izvajalcev zdravstvene dejavnosti gre običajno za analizo in projekcijo prostorske dostopnosti do domnevno istovrstne, enako kakovostne in enako zmogljive zdravstvene infrastrukture, kar pomeni, da je merilo čas dostopnosti najrelevantnejše. Pri različnih časovnih intervalih se število in lokacije izvajalcev zdravstvene dejavnosti, ki so vključeni v mrežo zdravstvenega varstva, razlikujejo.

$\mathrm{V}$ četrtem koraku je pri raziskovanju mreže zdravstvenega varstva smiselno opredeliti tudi drugi vidik uspešnosti izvajalcev zdravstvene dejavnosti, ki prav tako kaže odnos med zdravstvenimi storitvami in koristnostjo, ki jo te zdravstvene storitve prinašajo posamezniku. Maksimalno koristnost je namreč mogoče doseči tudi z doseganjem kakovosti, ki jo prebivalec pričakuje od zdravstvenih storitev. Presojanje kakovosti obravnav bolnikov je tako pomemben dejavnik opredeljevanja mreže zdravstvenega varstva. Z zagotavljanjem opredeljene kakovosti zdravstvenih izidov namreč pomembno vplivamo na koristnost prebivalcev. Pri opredeljevanju kakovosti izvajalcev zdravstvene dejavnosti se običajno sklicujemo na nabor kazalnikov in kazalcev kakovosti, ki kažejo mero kakovosti obravnav bolnikov. Pregled in nadzor nad kakovostjo zdrav- 
stvenih izidov je ključnega pomena, ko se oblikovalci zdravstvene politike odločajo o meri kakovosti, ki jo morajo izvajalci zdravstvene dejavnosti dosegati znotraj mreže zdravstvenega varstva. 



\section{Sklep}

Osrednji cilj monografije je bil izoblikovati in preizkusiti model mreže sekundarne zdravstvene dejavnosti v Sloveniji, $s$ katerim je mogoče celovito in na spoznanjih sodobne ekonomske teorije učinkovitosti, mikroekonomske teorije podjetja in teorije lokacije pojasniti dejavnike mreže sekundarne zdravstvene dejavnosti ter $\mathrm{s}$ tem prispevati $\mathrm{k}$ poglobljenemu razumevanju mreže zdravstvenega varstva ne le v Sloveniji, ampak na področju preučevanja mrež zdravstvenega varstva na sploh v svetu. K temu nas je spodbudilo spoznanje, da do sedaj v literaturi mreža zdravstvenega varstva ni bila obravnavana celovito, ampak so bili pri tem uporabljeni zgolj posamezni parcialni pristopi. Skladno s tem smo v monografiji preučevali dejavnike mreže sekundarne zdravstvene dejavnosti, ki so bili v dosedanjih raziskovanjih zanemarjeni. Naš namen je bil na izviren način analizirati učinkovitost splošnih bolnišnic, optimalno velikost splošnih bolnišnic in optimalne lokacije ter število splošnih bolnišnic z namenom razvoja modela mreže sekundarne zdravstvene dejavnosti.

$\mathrm{V}$ ta namen smo $\mathrm{v}$ drugem delu monografije $\mathrm{z}$ analizo mer učinkovitosti, izmerjenih $\mathrm{z}$ metodo stohastične mejne analize, in mer učinkovitosti, izračunanih z metodo podatkovnih ovojnic, izračunali količnike tehnične, alokacijske in stroškovne učinkovitosti splošnih bolnišnic. Ti so bili merjeni tako s parametrično metodo stohastične mejne analize kot tudi z neparametrično metodo podatkovnih ovojnic. Rezultati metode SFA so pokazali, da je skozi celotno opazovano obdobje stroškovno najučinkovitejša slovenska splošna bolnišnica Splošna bolnišnica Celje. Ta podatek je skladen z dejstvom, da je Splošna bolnišnica Celje na eni strani znotraj metode SFA tehnično najučinkovitejša slovenska splošna 
bolnišnica, hkrati pa spada v skupino splošnih bolnišnic, ki dosegajo tudi najvišje mere alokacijske učinkovitosti. Rezultati metode DEA pa so pokazali, da je glede na celotno opazovano obdobje stroškovno najučinkovitejša Splošna bolnišnica Brežice, ki je znotraj metode DEA hkrati tudi tehnično in alokacijsko najučinkovitejša slovenska splošna bolnišnica.

$\mathrm{V}$ tretjem delu monografije smo za opredelitev optimalne velikosti splošne bolnišnice uporabili posamezne analitične koncepte dolgoročne stroškovne funkcije. Optimalno velikost izvajalca sekundarne zdravstvene dejavnosti smo analizirali z diskretnimi, zveznimi in grafičnimi analizami, pri čemer smo uporabili več različnih regresijskih modelov. Če bi bila tržna cena postavljena na raven minimalnih dolgoročnih povprečnih stroškov splošne bolnišnice, se najnižji stroški na enoto proizvodnje oziroma optimalna velikost slovenske splošne bolnišnice giblje med I 88.032 in 242.947 obravnavami bolnikov letno. Ob upoštevanju dejstva, da je povprečna cena storitve, ki jo plačnik zdravstvenih storitev plačuje izvajalcem zdravstvene dejavnosti nad minimalnimi dolgoročnimi povprečnimi stroški, je optimalna velikost splošne bolnišnice pri večjem obsegu proizvodnje, to je med $245.83 \mathrm{I}$ in 274.992 obravnavami bolnikov letno. $Z$ vidika vodenja splošne bolnišnice sta za vodstvo pomembni obe informaciji, torej tako informacija, ki pove, pri kateri količini proizvodnje ima splošna bolnišnica najnižje stroške na enoto proizvodnje, kot tudi informacija, ki opredeli točko maksimalnega dobička oziroma optimalne velikosti splošne bolnišnice.

$\mathrm{V}$ četrtem delu monografije smo skladno z namenom definirali optimalne lokacije in število splošnih bolnišnic znotraj mreže sekundarne zdravstvene dejavnosti. Pri tem smo uporabili klasične modele lokacija-alokacija skupaj z orodjem ArcGIS za mrežne analize. Projekcije prostorske dostopnosti izvajalcev sekundarne zdravstvene dejavnosti tako prikazujejo dva rezultata, pri čemer prvi rezultat predstavlja hipotetične lokacije optimalno lociranih splošnih bolnišnic, drugi rezultat pa ponazarja število takšnih lokacij oziroma hipotetično število splošnih bolnišnic, ki zagotavljajo osemdesetim odstotkom prebivalstva dostopnost do bolnišničnih storitev v različnih časovnih intervalih. Če definiramo 30-minutni časovni interval, v Sloveniji potrebujemo deset splošnih bolnišnic, ki morajo biti locirane v Celju, Murski Soboti, Ljubljani, Kranju, Ptuju, Mariboru, Novi Gorici, Kopru, Zagorju ob Savi in Novem mestu. Če sprejmemo sklep, da bodo bolnišnične storitve prebivalcem dostopne znotraj 45-minutnega časovnega intervala, potem v Sloveniji potrebujemo pet splošnih bolnišnic, ki morajo biti locirane v Celju, Ljubljani, Mariboru, Kopru in Novem mestu. Če definiramo 6o-minutni časovni in- 
terval, pa sta v Sloveniji dovolj zgolj dve splošni bolnišnici, ki morata biti locirani v Ljubljani in Slovenski Bistrici.

$\mathrm{V}$ zadnjem delu smo pokazali, kako lahko z analiziranjem učinkovitosti splošnih bolnišnic, definiranjem optimalne velikosti splošne bolnišnice in z opredelitvijo optimalnih lokacij ter števila splošnih bolnišnic oblikujemo učinkovito mrežo sekundarne zdravstvene dejavnosti. Pri tem smo sledili dvema ciljema vsake mreže zdravstvenega varstva, to je cilj maksimiranja učinkovitosti izvajalcev zdravstvene dejavnosti in cilj maksimiranja dostopnosti zdravstvenih storitev do posameznega bolnika. Na ta način smo oblikovali mrežo sekundarne zdravstvene dejavnosti, ki zagotavlja racionalno obliko delovanja splošnih bolnišnic, hkrati pa omogoča prebivalcem čim večjo dostopnost do bolnišničnih storitev. V končni fazi smo oblikovali tudi model raziskovanja mreže zdravstvenega varstva, ki je koristno orodje pri vseh nadaljnjih raziskovanjih na področju zdravstva. Model je uporaben za vse oblikovalce zdravstvene politike in za tiste, ki želijo preučevati ter oblikovati mrežo zdravstvenega varstva celovito oziroma na podlagi večjega števila dejavnikov, ki nanjo neposredno vplivajo. 



\section{Literatura}

Afriat, S. N. 1972. »Efficiency Estimation of Production Functions.« International Economic Review I3 (3): 568-598.

Aigner, D. J., C. A. K. Lovell in P. Schmidt. 1977. »Formulation and Estimation of Stochastic Frontier Production Function Models. «ournal of Econometrics 6 (I): 2I-37.

Alexandris, G., in I. Giannikos. 2010. »A New Model For Maximal Coverage Exploiting GIS Capabilities.« European Journal of Operational Research 202 (2): $328-338$.

Algharib, S. M. 20 I . »Distance and Coverage: An Assessment of Location-Allocation Models for Fire Stations in Kuwait City, Kuwait.« Doktorska disertacija, Kent State University.

Arcury, T. A., W. M. Gesler, J. S. Preisser, J. Sherman, J. Spencer in J. Perin. 2005. »The Effects of Geography and Spatial Behavior on Health Care Utilization among the Residents of a Rural Region.«Health Services Research 40 (I): 135-155.

Athas, W. F., M. Adams-Cameron, W. C. Hunt, A. Amir-Fazli in C. R. Key. 2000. »Travel Distance to Radiation Therapy and Receipt of Radiotherapy Following Breast-Conserving Surgery.« Journal of the National Cancer Institute 92 (3): 269-27 I.

Badunenko, O., M. Fritsch in A. Stephan. 2006. »Allocative Efficiency Measurement Revisited: Do We Really Need Input Prices? « Economic Modelling 25 (5): 1093-1109. 
Banker, R. D., A. Charnes in W. W. Cooper. 1984. »Some Models for Estimating Technical and Scale Inefficiencies in Data Envelopment Analysis.« Management Science 30 (9): 1078-1092.

Barzel, Y., in L. Kochin. 1992. »Ronald Coase on the Nature of Social Cost as a Key to the Problem of the Firm. The Scandinavian Journal of Economics 94 (I): 19-3I.

Basu, J., in B. Friedman. 2001. »Preventable Illness and Out-of-Area Travel of Children in New York Counties.« Health Economics Io (I): 67-78.

Basu, J., B. Friedman in H. Burstin. 2002. »Primary Care, HMO Enrollment, and Hospitalization for Ambulatory Care Sensitive Conditions: A New Approach.« Medical Care 40 (12): 1260-69.

Battese, G. E., in T. J. Coelli. 1992. »Frontier Production Functions, Technical Efficiency and Panel Data: With Application to Paddy Farmers in India.«Journal of Productivity Analysis 3 (I/2): 153-69.

Battese, G. E., in T. J. Coelli. 1995. »A Model for Technical Inefficiency Effects in a Stochastic Frontier Production Function for Panel Data.« Empirical Economics 20 (2): 325-32.

Bauer, P. W. 1990. »Recent Developments in the Econometric Estimation of Frontiers.« Journal of Econometrics 46 (I/2): 39-56.

Bauer, P. W., A. N. Berger, G. D. Ferrier in D. B. Humphrey. 1998. »Consistency Conditions for Regulatory Analysis of Financial Institutions: A Comparison of Frontier Efficiency Methods.«Journal of Economics and Business 50 (2): 85-I I 4 .

Berg, M., Y. Meijerink, M. Gras, A. Goossenesen, W. Schellekens, J. Haeck, M. Kallewaard in H. Kingma. 2005. »Feasibility First: Developing Public Performance Indicators on Patient Safety and Clinical Effectiveness for Dutch Hospitals. « Health Policy 75 (I): 59-73.

Berndt, E. R. 2000. »Medical Care Prices and Output.« V Handbook of Health Economics, ur. A. J. Culyer in J. P. Newhouse, I20-80. Amsterdam: Elsevier Science.

Besanko, D. A., R. R. Braeutigam in K. Rockett. 2015. Microeconomics. Hoboken, NJ: Wiley.

Blank, J. L. T., in E. Eggink. 2004. »The Decomposition of Cost Efficiency: An Empirical Application of the Shadow Cost Function Model to Dutch General Hospitals.«Health Care Management Science 7 (2): 79-88.

Bogetoft, P., in L. Otto. 201 I. Benchmarking with DEA, SFA and R. New York: Springer.

Bojnec, Š., Ž. Čepar, T. Kosi in B. Nastav. 2007. Ekonomika podjetja. Koper: Univerza na Primorskem, Fakulteta za management. 
Bosanac, E. M., R. C. Parkinson in D. S. Hall. 1976. »Geographic Access to Hospital Care: A $30-$ Minute Travel Time Standard.«Medical Care I 4 (7): 616-623.

Bowling, A. 2005. Measuring Health: A Review of Quality of Life Measurement Scales. Maidenhead: Open University Press.

Brabyn, L., in P. Beere. 2006. »Population Access to Hospital Emergency Departments and the Impacts of Health Reform in New Zealand. $\ll$ Health Informatics Journal I 2 (3): 227-237.

Buchmueller, T. C., M. Jacobson in C. Wold. 2006. »How Far to the Hospital? The Effect of Hospital Closures on Access to Care.«Journal of Health Economics 25 (4): 740-6I.

Bundesinstitut für Bau-, Stadt- und Raumforschung. 20I I. Bildung, Gesundheit, Pflege - Auswirkungen des demographischen Wandels auf die soziale Infrastruktur. Bonn: BBSR - Berichte Kompakt.

Busingye, D., A. Pedigo in A. Odoi. 20ı ı. »Temporal Changes in Geographic Disparities in Access to Emergency Heart Attack and Stroke Care: Are We Any Better Today? « Spatial and Spatio-Temporal Epidemiology $2(4): 247-223$.

Campbell, N. C., A. M. Elliott, L. Sharp, L. D. Ritchie, J. Cassidy in J. Little. 2000. »Rural Factors and Survival from Cancer: Analysis of Scottish Cancer Registrations.«British Journal of Cancer 82 (I I): I863-I 866.

Caudill, S. B., J. M. Ford in D. M. Gropper. 1995. »Frontier Estimation and Firm-Specific Inefficiency Measures.«Journal of Business and Economic Statistics I3 (I): I05-III.

Cervigni, F., Y. Suzuki, T. Ishii in A. Hata. 2008. »Spatial Accessibility to Pediatric Services.«Journal of Epidemiology and Community Health 33 (6): 444-448.

Chang, H., W. J. Chang, S. Das in S. H. Li. 2004. »Health Care Regulation and the Operating Efficiency of Hospitals: Evidence from Taiwan.«Journal of Accounting \& Public Policy 23 (6): 483-5 10.

Charnes, A., W. W. Cooper in E. Rhodes. 1978. »Measuring the Efficiency of Decision-Making Units.« European Journal of Operational Rese$\operatorname{arch}_{2}$ (6): 429-444.

Charnes, A., W. W. Cooper, A. Y. Lewin in L. M. Seiford. 1995. Data Envelopment Analysis: Theory, Methodology and Applications. Boston, MA: Kluwer Academic.

Chen, A., Y. Hwang in B. Shao. 2005. »Measurement and Sources of Overall and Input Inefficiencies: Evidences and Implications in Hospital Services.« European Journal of Operational Research I6I (2): 447-468. 
Cheng, Y., J. Wang in M. W. Rosenberg. 201 2. »Spatial Access to Residential Care Resources in Beijing, China.«International Journal of Health Geographics II (32): 32-43.

Chirikos, T. N., in A. M. Sear. 2000. »Measuring Hospital Efficiency: A Comparison of Two Approaches.« Health Services Research 34 (6): I389-I 408.

Christensen, L. R., in W. H. Greene. 1976. »Economies of Scale in U. S. Electric Power Generation.« The Journal of Political Economy 84 (4): $655-676$.

Christensen, L. R., W. D. Jorgenson in L. J. Lau. 1973. »Transcendental Logarithmic Production Frontiers. The Review of Economics and Statisti$\operatorname{cs} 55(\mathrm{I}): 28-45$.

Church, R. L., in A. Murray. 2009. Business Site Selection, Location Analysis and GIS. Hoboken, NJ: Wiley.

Church, R. L., in L. C. ReVelle. 1974. »The Maximal Covering Location Problem.« Papers of the Regional Science Association 32 (I): IOI-I I 8.

Church, R. L., in P. Sorensen. 1994. Integrating Normative Location Models into GIS: Problems and Prospects with the P-Median Model. Santa Barbara, CA: Simonett Center for Spatial Analysis University of California.

Ciocco, A., in I. Altman. 1954. U. S. Medical Service Areas and Distances Traveled for Physician Care in Western Pennsylvania. Bethesda, MD: U. S. Public Health Service.

Coase, R. H. 1937. »The Nature of the Firm.« Economica 4 (I6): 386-405.

Coase, R. H. 1960. »The Problem of Social Cost.«Journal of Law and Economics $3: 1-44$.

Cobb, C. W., in P. C. Douglas. 1928. »A Theory of Production.«American Economic Review I8 (I): 139-165.

Coelli, T. J. I995. »Estimators and Hypothesis Tests for a Stochastic Frontier Function: A Monte Carlo Analysis.«Journal of Productivity Analysis $6(3): 247-268$.

Coelli, T. J. 1996. A Guide to DEAP Version 2.I: A Data Envelopment Analysis (Computer) Program. Armidale: University of New England, Centre for Efficiency and Productivity Analysis.

Coelli, T. J., in D. Lawrence. 2006. Performance Measurement and Regulation of Network Utilities. Northampton: Edward Elgar.

Coelli, T. J., in S. Perelman. 1999. »A Comparison of Parametric and Non-Parametric Distance Functions: With Application to European Railways.« European Journal of Operational Research I I7 (2): 326-339. 
Coelli, T., S. Perelman in E. Romano. 1999. »Accounting for Environmental Influences in Stochastic Frontier Models: With Application to International Airlines.«Journal of Productivity Analysis I I (3): 25 I-273.

Coelli, T. J., D. S. Prasada Rao in G. E. Battese. 1998. An Introduction to Efficiency and Productivity Analysis. Norwell, MA: Kluwer Academic.

Coelli, T. J., D. S. Prasada Rao, C. J. O'Donnell in G. E. Battese. 2005. An Introduction to Efficiency and Productivity Analysis. New York: Springer.

Connor, R. A., S. D. Hillson in J. E. Krawelski. I995. »Competition, Professional Synergism, and the Geographic Distribution of Rural Physicians.« Medical Care 33 (I I): 1067-1078.

Cooper, W. W., L. M. Seiford in K. Tone. 2000. Data Envelopment Analysis: A Comprehensive Text with Models, Applications, References and DEA-Solver Software. Boston, MA: Kluwer Academic.

Cooper, W. W., L. M. Seiford in J. Zhu. 2004. Handbook on Data Envelopment Analysis. Boston, CA; Dordrecht; London: Kluwer Academic.

Copeland, R., in P. Jacobs. I981. >Cost of Capital, Target Rate of Return, and Investment Decision Making.« Health Services Research I6 (3): 335-34I.

Council on Graduate Medical Education. 1998. Tenth Report: Physician Distribution and Health Care Challenges in Rural and Inner-City Areas. Washington, DC: U. S. Department of Health and Human Services, Public Health Service, Health Resources and Services Administration.

Cromley, E. K., in S. L. McLafferty. 20 1 2. GIS and Public Health. New York; London: Guilford.

Dai, D. 20ı ○. »Black Residential Segregation, Disparities in Spatial Access to Health Care Facilities, and Late-Stage Breast Cancer Diagnosis in Metropolitan Detroit.« Health and Place I6 (5): 1038-1052.

Daraio, C., in L. Simar. 2007. Advanced Robust and Nonparametric Methods in Efficiency Analysis: Methodology and Applications. New York: Springer.

Dash, U., S. D. Vaishnavi in V. R. Muraleedharan. 2010. »Technical Efficiency and Scale Efficiency of District Hospitals.« Journal of Health Management $\mathrm{I}_{2}(3): 23 \mathrm{I}-248$.

Daskin, M. 2008. »What You Should Know about Location Modeling.« Naval Research Logistics 55 (4): 283-294.

Debreu, G. I95 I. »The Coefficient of Resource Utilisation.« Econometrica I9 (3): $273-292$. 
Deily, M. E., in N. L. McKay. 2006. »Cost Inefficiency and Mortality Rates in Florida Hospitals.« Health Economics Is (4): 419-43 I.

Delmelle, E. M., C. H. Cassell, C. Dony, E. Radcliff, J. P. Tanner, C. Siffel in R. S. Kirby. 2013. »Modeling Travel Impedance to Medical Care for Children with Birth Defects Using Geographic Information Systems.« Birth Defects Research Part A: Clinical and Molecular Teratology 97 (I0): 673-684.

Dietrich, M. 2008. Transaction Cost Economics and Beyond: Toward a New Economics of the Firm. Oxford: Taylor \& Francis.

Diewert, W. E. I971. »An Application of the Shephard Duality Theorem: A Generalized Leontief Production Function.«Journal of Political Economy 79 (3): $48 \mathrm{I}-507$.

Dixit, A. K. 1996. The Making of Economic Policy: A Transaction-Cost Politics Perspective. Cambridge, MA: The MIT Press.

Došenović Bonča, P. 20ı. »Inovacije kot dejavnik uspešnosti in učinkovitosti bolnišnic v Sloveniji.« Doktorska disertacija, Univerza v Ljubljani.

Došenović Bonča, P. 2014 . Opredelitev in merjenje učinkovitosti v zdravstvu. Ljubljana: Ekonomska fakulteta.

Dranove, D. 1998. »Economies of Scale in Non-Revenue Producing Cost Centers: Implications for Hospital Mergers.« Journal of Health Economics $\mathrm{I} 7(\mathrm{I}): 69-83$.

Drozg, V. 2005. »Koncepti policentrične ureditve Slovenije.« Dela 24 (I): I 47-I 57 .

Drummond, M., S. Boulenger, J. Nixon, P. Ulmann, J. Glanville in G. Pouvourville. 2003. »PHP8 the European Network of Health Economic Evaluation Databases Project.«Value in Health 6 (6): 712. https://doi. org/I0.1016/Sio98-3015(I0)6I816-5.

Dummer, T. J., in L. Parker. 2004. »Hospital Accessibility and Infant Death Risk.« Archives of Disease in Childhood 89 (3): 232-234.

Dutt, A. K, H. M. Dutta, J. Jaiswal in C. Monroe. 1986. »Assessment of Service Adequacy of Primary Health Care Physicians in a Two County Region of Ohio, U.S.A.« GeoJournal I 2 (4): 443-455.

Dyson, R. G., R. Allen, A. S. Camanho, V. V. Podinovski, C. S. Sarrico in E. A. Shale. 200I. »Pitfalls and Protocols in DEA.« European Journal of Operational Research 132 (2): 245-259.

Elesh, D., in P. T. Schollaert. 1972. »Race and Urban Medicine: Factors Affecting the Distribution of Physicians in Chicago.«Journal of Health and Social Behavior I3 (3): 236-250. 
Ersoy, K., S. Kavuncubasi, Y. A. Ozcan in J. M. Harris. 1997. »Technical Efficiencies of Turkish Hospitals: DEA Approach.« Journal of Medical Systems 2I (2): 67-74.

Esri. 2008. ArcGIS g: ArcGIS Network Analyst Tutorial. New York: Esri.

Evans, D. S. 1987. »Test of Alternative Theories of Firm Growth.«Journal of Political Economy 95 (3): 657-674.

Färe, R., in C. A. K. Lovell. 1978. »Measuring the Technical Efficiency Of Production.«Journal of Economic Theory I9 (I): I50-I62.

Färe, R., S. Grosskopf in J. Logan. 1983. »The Relative Efficiency of Illinois Electric Utilities.« Resources and Energy 5 (4): 349-367.

Färe, R., S. Grosskopf in C. A. K. Lovell. 1985. The Measurement of Efficiency of Production. Boston, MA: Kluwer Academic.

Färe, R., S. Grosskopf in C. A. K. Lovell. 1994. Production Frontiers. Cambridge: Cambridge University Press.

Färe, R., S. Grosskopf, B. Lindgren in P. Roos. 1994. »Productivity Developments in Swedish Hospitals: A Malmquist Output Index Approach.« V Data Envelopment Analysis: Theory, Methodology and Applications, ur. A. Charnes, W. W. Cooper, A. Y. Lewin in L. M. Seiford, 253-273. Boston, MA: Kluwer Academic.

Farrell, M. J. 1957. »The Measurement of Productive Efficiency.« Journal of the Royal Statistical Society 120 (3): 253-281.

Farsi, M., in M. Filippini. 2004. »Regulation And Measuring Cost Efficiency with Panel Data Models: Application to Electricity Distribution Utilities.« The Review of Industrial Organization 25 (I): I-I9.

Feldstein, M. S. 1967. Economic Analysis for Health Service Efficiency: Econometric Studies of the British National Health Service. Amsterdam: North-Holland.

Feldstein, P. J. 201 I. Health Care Economics. Clifton Park, NY: Thomson-Delmar Learning.

Ferrando, A., C. Ivaldi, A. Buttiglieri, E. Pagano, C. Bonetto, R. Arione, L. Scaglione, E. Gelormino, F. Merletti in G. Ciccone. 2005. »Guidelines for Preoperative Assessment: Impact on Clinical Practice and Costs.« International Journal of Quality Health Care 17 (4): 323-329.

Ferrier, G., in C. Lovell. 1990. »Measuring Cost Efficiency in Banking.«Journal of Econometrics 46 (I/2): 229-245.

Forsund, F. R., C. A. K. Lovell in P. Schmidt. 1980. »A Survey of Frontier Production Functions and Their Relationship to Efficiency Measurement.« Journal of Econometrics $\mathrm{I}_{3}$ (I): 5-25. 
Fortney, J., K. Rost in J. Warren. 2000. »Comparing Alternative Methods of Measuring Geographic Access to Health Services.« Health Services and Outcomes Research Methodology I (2): 173-I84.

Fortney, J., K. Rost, M. Zhang in J. Warren. 1999. »The Impact of Geographic Accessibility on the Intensity and Quality of Depression Treatment.« Medical Care 37 (9): 884-893.

Fortney, J. C., B. M. Booth, F. C. Blow in J. Y. Bunn. 1995. »The Effects of Travel Barriers and Age on the Utilization of Alcoholism Treatment Aftercare.« The American Journal of Drug and Alcohol Abuse 2 I (3): $391-406$.

Fortney, J. C., J. F. Burgess, H. B. Bosworth, B. M. Booth in P. J. Kaboli. 20II. \A Re-Conceptualization of Access for 2 ist Century Healthcare.« Journal of General Internal Medicine 26 (2): 639-647.

Fried, H. O., C. A. K. Lovell in S. S. Schmidt. 2008. The Measurement of Productive Efficiency and Productivity Change. Oxford: Oxford University Press.

Fryer, G. E., Jr, J. Drisko, R. D. Krugman, C. P. Vojir, A. Prochazka, T. J. Miyoshi in M. E. Miller. 1999. »Multi-Method Assessment of Access to Primary Medical Care in Rural Colorado.« The Journal of Rural Health I5 (I): II3-I2I.

Fryer, K., J. Antony in S. Ogden. 2009. »Performance Management in the Public Sector.«International Journal of Public Sector Management 22 (6): $478-498$.

Gannon, B. 2005. »Testing for Variation in Technical Efficiency of Hospitals in Ireland.« Economics Social Reviews 36 (3): 273-294.

Garnsey E., Stam E., P. Heffernan in O. Hugo. 2004. »New Firm Growth: Exploring Processes and Paths.«Industry and Innovation I3 (I): I-20.

Gauss, C. F. 2004. Theory of the Motion of the Heavenly Bodies Moving about the Sun in Conic Sections. New York: Dover.

Gesler, W. M. 1986. »The Uses of Spatial Analysis in Medical Geography: A Review.« Social Science \& Medicine 23 (10): 963-973.

Gesler, W. M., in M. S. Meade. 1988. »Locational and Population Factors in Health Care-Seeking Behavior in Savannah, Georgia.«Health Services Research Journal 23 (3): 443-462.

Gibrat, R. 1931. Les inégalités économiques. Pariz: Librairie du Recueil Sirey.

Giuffrida, A., in H. Gravelle. 2001. »Measuring Performance in Primary Care: Econometric Analysis and DEA.« Applied Economics 33 (2): I63-175. 
Gleason, J. M. 1975. »A Set Covering Approach to Bus Stop Location.« Omega 3 (5): 605-608.

Golany, B., in Y. Roll. 1989. »An Application Procedure for DEA.«Omega $17(3): 237-250$.

Goodman, D. C., E. Fisher, T. A. Stukel in C. Chang. 1997. »The Distance to Community Medical Care and the Likelihood of Hospitalization: Is Closer Always Better? « American Journal of Public Health 87 (7): I I 44 - I I 50.

Goodman, D. C., E. S. Fisher, A. Gittelsohn, C. H. Chang in C. Fleming. 1994. »Why Are Children Hospitalized? The Role of Non-Clinical Factors in Pediatric Hospitalizations.« Pediatrics 93 (6): 896-902.

Goodman, D. C., E. S. Fisher, G. A. Little, T. A. Stukel in C. H. Chang. 200I. »Are Neonatal Intensive Care Resources Located According to Need? Regional Variation in Neonatologists, Beds, and Low Birth Weight Newborns.« Pediatrics 108 (2): 426-431.

Goodman, D. C., E. S. Fisher, T. A. Bubolz, J. E. Mohr, J. F. Poage in J. E. Wennberg. 1996. »Benchmarking the US Physician Workforce: An Alternative to Needs-Based or Demand-Based Planning.«JAMA 277 (I2): I 8 II-I8I7.

Greene, W. H. 1990. »A Gamma Distributed Stochastic Frontier Model.« Journal of Econometrics 46 (I-2): 14I-I63.

Greene, W. H. 2003. Econometric Analysis. New York: Prentice Hall.

Greene, W. H. 2008. »The Econometric Approach to Efficiency Analysis.« V The Measurement of Productive Efficiency and Productivity Growth, ur. H. O. Fried, C. A. K. Lovell in S. S. Schmidt, 92-250. Oxford: Oxford University Press.

Griffin, R. C., J. M. Montegomery in M. E. Rister. 1987. »Selecting Functional Form in Production Function Analysis.« Western Journal of Agricultural Economics I2 (2): 216-227.

Grosskopf, S., D. Margaritis in V. Valdmanis. 200 I. »Comparing Teaching and Non-Teaching Hospitals: A Frontier Approach (Teaching vs. Nonteaching Hospitals).«Health Care Management Science 4 (2): 83-90.

Gruca, T. S., in D. Nath. 200I. »The Technical Efficiency of Hospitals under a Single Payer System: The Case of Ontario Community Hospitals.« Health Care Management Science 4 (2): 9I-IOI.

Gu, W., X. G. L. Wang in E. McGregor. 2010. »Optimization of Preventive Health Care Facility Locations.«International Journal of Health Geographics 9 (I): I-I6. 
Guagliardo, M. F. 2004. »Spatial Accessibility of Primary Care: Concepts, Methods and Challenges.« International Journal of Health Geographi$\operatorname{cs} 3(\mathrm{I}): \mathrm{I}-\mathrm{I} 3$.

Guagliardo, M. F., C. R. Ronzio, I. Cheung, E. Chacko in J. G. Joseph. 2004. »Physician Accessibility: An Urban Case Study of Pediatric Primary Care.«Health \& place ro (3): 273-283.

Gujarati, D. N., in D. C. Porter. 2010. Basic Econometrics. Boston, MA: McGraw-Hill.

Gulliford, M. C. 2002. »Availability of Primary Care Doctors and Population Health in England: Is There an Association? « Journal of Public Health Medicine 24 (4): 252-254.

Hakimi, S. L. 1964. »Optimum Locations of Switching Centers and the Absolute Centers and Medians of a Graph.« Operations Research I 2 (3): $450-459$.

Hansen, W. G. 1959. »How Accessibility Shapes Land Use.« Journal of the American Institute of Planners 25 (2): 73-76.

Hare, T. S., in H. R. Barcus. 2007. »Geographical Accessibility and Kentucky's Heartrelated Hospital Services.« Applied Geography 27 (3-4): I 8 I-205.

Harrison, J. P., M. N. Coppola in M. Wakefield. 2004. »Efficiency of Federal Hospitals in the United States.« Journal of Medical Systems 28 (5): 4II-422.

Heinrich, J. 2001. Health Workforce: Ensuring Adequate Supply and Distribution Remains Challenging. Report No. GAO-or-1042T. Washington, DC: General Accounting Office, Washington .

Henderson, J. W. 201 I. Health Economics and Policy (with Economic Applications). Samford, AL: Cengage Learning.

Hicks, J. R. 1935. »A Suggestion for Simplifying the Theory of Money.« Economica 2 (5): I-I9.

Higgs, G. 2005. »A Literature Review of the Use of GIS-Based Measures of Access to Health Care Services.«Health Service and Outcomes Research Methodology 5 (2): 1 19-139.

Hjalmarsson, L., S. Kumbhakar in A. Heshmati. 1996. »DEA, DFA and SFA: A Comparison.« The Journal of Productivity Analysis 7 (2-3): 303-327.

Hodgson, M. J. 1988. »A Hierarchical Location-Allocation Model for Primary Health Care Delivery in a Developing Area.«Social Science and Medicine 26 (I): 153-I6I. 
Hofler, R. A., in S. T. Folland. I991. »Technical and Allocative Inefficiencies of United States Hospitals under a Stochastic Frontier Approach.« Predstavitev na konferenci Midwest Economics Associations Fifty-Fifth Annual Meeting, St. Louis, MO, I99I.

Hollingsworth, B. 2008. »The Measurement of Efficiency and Productivity of Health Care Delivery.« Health Economics I7 (I0): I I07-I I 28.

Hollingsworth, B., in S. J. Peacock. 2008. Efficiency Measurement in Health and Health Care. London; New York: Routledge.

Holmes, J., F. Williams in L. Brown. 1972. »Facility Location under a Maximum Travel Restriction: An Example Using Day Care Facilities.« Geographical Analysis 4 (3): 258-266.

Huff, D. L. 2000. »Don't Misuse the Huff Model in GIS.«Business Geographies 8 (8): I 2.

Hunter, J. M., G. W. Shannon in S. L. Sambrook. 1986. »Rings of Madness: Service Areas of 19th Century Asylums in North America.« Social Science \& Medicine 23 (10): 1033-1050.

Jacobs, R. 200I. »Alternative Methods to Examine Hospital Efficiency: Data Envelopment Analysis and Stochastic Frontier Analysis.« Health Care Management Science 4 (2): I03-I I5.

Jacobs, R., P. C. Smith in A. Street. 2006. Measuring Efficiency in Health Care: Analytic Techniques and Health Policy. Cambridge; New York: Cambridge University Press.

Jain, T. R., in O. P. Khanna. 201 r. Microeconomics (for BBA). New Delhi: V.K.

Jarvis, E. I 852. »On the Supposed Increase in Insanity.« American Journal of Insanity 8 (4): 333-364.

Johnson, G. P. 1972. »The Estimation of a Long Run Cost Function for West Virginia Public.« Predstavitev na konferenci 57th American Educational Research Association Annual Meeting in Chicago, Chicago, IL, 3.-7. april 1972 .

Johnston, J. 1960. Statistical Cost Analysis. New York: McGraw-Hill Education.

Johnston, J. 1961. »Reviewed Work: Statistical Cost Analysis.«Journal of Farm Economics 43 (2): 477-480.

Joseph, A. E., in P. R. Bantock. 1982. »Measuring Potential Physical Accessibility to General Practitioners in Rural Areas: A Method and Case Study.« Social Science \& Medicine I6 (I): 85-90. 
Joseph, A. E., in P. R. Bantock. 1984. Accessibility and Utilization: Geographical Perspectives on Health Care Delivery. New York: Harper and Row Publishers.

Jovanovic, B. 1982. »Selection and the Evolution of Industry.« Econometrica $50(3): 649-670$.

Karanicolas, P. J., P. Bhatia, J. Williamson, R. A. Malthaner, N. G. Parry, M. J. Girotti in D. K. Gray. 2006. »The Fastest Route between Two Points is Not Always a Straight Line: An Analysis of Air and Land Transfer of Nonpenetrating Trauma Patients.« The Journal of Trauma 6I (2): $396-403$.

Khan, A. A. 1992. »An Integrated Approach to Measuring Potential Spatial Access to Health Care Services.« Socio Economic Planning Sciences $26(4): 275-287$.

Khan, A. A., in S. M. Bhardwaj. 1994. »Access to Health Care: A Conceptual Framework and Its Relevance to Health Care Planning.« Evaluation and the Health Profession 17 (I): 60-76.

Kinyanjui, G. K., P. M. Gachanja in J. M. Muchai. 2015. »Technical Efficiency of Hospitals Owned by Faith Based Organisations in Kenya.« The Journal of Pan African Studies 8 (6): 45-63.

Koop, G., J. Osiewalski in M. F. J. Steel. 1997. »Bayesian Efficiency Analysis through Individual Effects: Hospital Cost Frontiers.«Journal of Econometrics 76 (I/2): 77-105.

Koopmans, T. C. 195 I. »An Analysis of Production as an Efficient Combination of Activities.« V Acticity Analysis of Production and Allocation, ur. T. C. Koopmans, 359-373. New York: Wiley.

Koutsoyiannis, A. 1987. Modern Microeconomics. London: Macmillan.

Kristensen, T., K. R. Olsen, J. Kilsmark in K. M. Pedersen. 2013. Economies of Scale and Optimal Size of Hospitals: Empirical Results for Danish Public Hospitals. Odense: Institute of Public Health, Department of Health Economics, Faculty of Social Sciences.

Krugman, P., in R. Wells. 2013. Microeconomics. New York: Worth.

Kumbhakar, S. C., in C. A. K. Lovell. 2003. Stochastic Frontier Analysis. Cambridge: Cambridge University Press.

Kumbhakar, S. C., S. Ghost in J. T. McGuckin. I991. »A Generalized Production Frontier Approach for Estimating Determinants of Inefficiency in U. S. Dairy Farms.« Journal of Business and Economics Statistics 9 (3): $279-86$.

Langabeer, J. R., in J. Helton. 2012. Health Care Operations Management. Chicago, IL: Health Administration. 
Lau, L. J. 1986. »Functional Forms in Econometric Model Building.« V Handbook of Econometrics III, ur. Z. Griliches in M. D. Intriligator, str. 1515-1565. Amsterdam: North-Holland.

Lawrence, C. H. 2013. Statistics with Stata: Version I2. Boston, MA: Brooks/ Cole.

Lee, R. C. 1991. »Current Approaches to Shortage Area Designation.«Journal of Rural Health 7 (4): 437-450.

Levesque, J. F., M. F. Harris in G. Russell. 2013. »Patient-Centred Access to Health Care: Conceptualising Access at the Interface of Health Systems and Populations.« International Journal for Equity in Health I 2 (I): 18. https://doi.org/IO.II86/I 475-9276-I2-I8.

Li, T., in R. Rosenman. 200I. »Cost Inefficiency in Washington Hospitals: A Stochastic Frontier Approach Using Panel Data.« Health Care Management Science 4 (2): 73-8I.

Linna, M. 1998. »Measuring Hospital Cost Efficiency with Panel Data Models.« Health Economics 7 (5): 415-427.

Linna, M., U. Häkkinen in J. Magnussen. 2006. »Comparing Hospital Cost Efficiency between Norway and Finland.« Health Policy 77 (3): 268-278.

Lovell, C. A. K. 1993. »Production Frontiers and Productive Efficiency.«V The Measurement of Productive Efficiency: Techniques and Applications, ur. H. O. Fried, C. A. K. Lovell in S. S. Schmidt, 3-67. New York: Oxford University Press.

Lovett, A., G. Sunnenberg in R. Haynes. 2004. »Using GIS to Assess Accessibility to Primary Health Care Service.« V GIS in Public Health Practice: Opportunity and Pitfalls, ur. C. Massimo in M. Ravi, I87-204. New Cork: CRC.

Luo, W. 2004. »Using a GIS-Based Floating Catchment Method to Access Areas with Shortage of Physicians.« Health and Place Io (I): I-I I.

Luo, W., in Y. Qi. 2009. »An Enhanced Two-Step Floating Catchment Area (E2SFCA) Method for Measuring Spatial Accessibility to Primary Care Physicians.« Health and Place is (4): I I00-i I07.

Luo, W., in F. Wang. 2003a. »Measures of Spatial Accessibility to Health Care in a GIS Environment: Synthesis and a Case Study in the Chicago Region: Environment and Planning B.«Planning and Design 30 (6): $865-884$.

Luo, W., in F. Wang. 2003b. »Spatial Accessibility to Primary Care and Physician Shortage Area Designation: A Case Study in Illinois with GIS 
Approaches.« V Geographic Information Systems and Health Applications, ur. R. Skinner in O. Khan, 260-278. Hershey, PA: Ideal Group.

Luo, W., in T. Whippo. 2012. »Variable Catchment Sizes for the Two-Step Floating Catchment Area (2SFCA) Method.«Health and Place i 8 (4): 789-795.

Lyon, R. M., S. M. Cobbe, J. M. Bradley in N. R. Grubb. 2004. »Surviving Out of Hospital Cardiac Arrest at Home: A Postcode Lottery? « Emergency Medicine Journal 2 I (5): 619-624.

Mankiw, N. G. 2014. Principles of Microeconomics. Mason, OH: South-Western Cengage Learning.

Marianov, V., in L. C. ReVelle. 1994. »The Queuing Probabilistic Location Set Covering Problem and Some Extensions.« Socio-Economic Planning Sciences 28 (3): 167-178.

Marshall, A. 2013. Principles of Economics. Basingstoke; New York: Palgrave Macmillan.

Mas-Colell, A., M. D. Whinston in J. R. Green. 2012. Microeconomic Theory. New York: Oxford University Press.

McFadden, D. 1963. \Constant Elasticity of Substitution Production Functions.« Review of Economic Studies 30 (2): 73-83.

McGrail, M. R., in J. S. Humphreys. 2009. »A New Index of Access to Primary Care Services in Rural Areas.« Australian and New Zealand Journal of Public Health 33 (5): 418-423.

McGuigan, J. R., R. C. Moyer in M. F. Harris. 2008. Managerial Economics: Applications, Strategies, and Tactics. Mason, OH: Thomson Higher Education.

McGuirk, M. A., in F. W. Porell. 1984. »Spatial Patterns of Hospital Utilization: The Impact of Distance and Time.« Inquiry 2 I (I): 84-95.

McKay, N. L., M. E. Deily in F. H. Dorner. 2003. »Ownership and Changes in Hospital Inefficiency.« Inquiry 39 (4): 388-399.

McLafferty, S., in F. Wang. 2009. »Rural Reversal? Rural-Urban Disparities in Late-Stage Cancer Risk in Illinois.« Cancer I I5 (I 29): 2755-2764.

Meade, S. M., in R. J. Earickson. 2000. Medical Geography. 2. izd. New York: Guilford.

Medema, S. G. 1997. »Comment: The Coase Theorem, Rent Seeking and the Forgotten Footnote.«International Review of Law and Economics 7 (2): $177-178$.

Meden, T., C. St. John-Larkin, D. Hermes in S. Sommerschield. 2002. »Relationship between Travel Distance and Utilization of Breast Cancer 
Treatment in Rural Northern Michigan.«JAMA 287 (I): II I. https:// doi.org/I0.1001/jama.287.1.1 I I-JMSoro2-5-I.

Meeusen, W., in J. van den Broeck. 1977. »Efficiency Estimation from Cobb-Douglas Production Functions with Composed Error.« International Economic Review I8 (I): 435-444.

Mehrez, A., Z. Sinuany-Stern, T. Arad-Geva in S. Benyamin. 1996. »On the Implementation of Quantitative Facility Location Models: The Case of a Hospital in a Rural Region.« The Journal of the Operational Research Society 47 (5): 612-625.

Meliker, J. R., P. Goovaerts, G. M. Jacquez, G. A. AvRuskin in G. Copeland. 2009. »Breast and Prostate Cancer Survival in Michigan: Can Geographic Analyses Assist in Understanding Racial Disparities? « Cancer IIS (IO): 22I 2-222I.

Meliker, J. R., G. M. Jacquez, P. Goovaerts, G. Copeland in M. Yassine. 2009. »Spatial Cluster Analysis of Early Stage Breast Cancer: A Method for Public Health Practice Using Cancer Registry Data.« Cancer Causes Control 20 (7): 106I-69.

Messina, J. P., A. M. Shortridge, R. E. Groop, P. Varnakovida in M. J. Finn. 2006. »Pariwate Evaluating Michigan's Community Hospital Access: Spatial Methods for Decision Support.« International Journal of Health Geographics 5 (42): I-I8.

Messner, W. 2013. Making the Compelling Business Case: Decision-Making Techniques for Successful Business Growth. New York: Palgrave Macmillan.

Meyer, S. P. 201 2. »Comparing Spatial Accessibility to Conventional Medicine and Complementary and Alternative Medicine in Ontario, Canada.« Health and Place i 8 (2): 305-3 I 4.

Michigan Department of Community Health. 2015. »Certificate of Need (Con) Review Standards for Hospital Beds.« https://www.michigan. gov/documents/mdch/HB_Standards_399445_7.pdf.

Miller, R. L., D. K. Benjamin in D. C. North. 2014. The Economics of Public Issues. Upper Saddle River, NJ: Pearson Education.

Ministrstvo za zdravje Republike Slovenije. 2oro. Priročnik o kazalnikih kakovosti. Ljubljana: Ministrstvo za zdravje.

Ministry of Health - Province of British Columbia. 2002. Standards of Accessibility and Guidelines for Provision of Sustainable Acute Care Services by Health Authorities. Victoria: Ministry of Health - Province of British Columbia. 
Mitropoulos, P., I. Mitropoulos, I. Giannikos in A. Sissouras. 2006. »A Biobjective Model for the Locational Planning of Hospitals and Health Centers.« Health Care and Manage Science 9 (2): 17 I-179.

Mobley, L. R., in J. Magnussen. 2002. »The Impact of Managed Care Penetration and Hospital Quality on Efficiency in Hospital Staffing.« Journal of Health Care Finance 28 (4): 24-43.

Monnet, E., E. Collin-Naudet, S. Bresson-Hadni, A. Minello, V. Di Martino, D. Carel, V. Jooste, A. Cagnaire, P. Evrard, B. Obert-Clerc, J. P. Miguet in P. Hillon. 2006. »Place of Residence and Distance to Medical Care Influence the Diagnosis of Hepatitis C: A Population-Based Study.«Journal of Hepatology 44 (3): 499-506.

Morrill, R. L., R. J. Earickson in P. Rees. I970. »Factors Influencing Distances Traveled to Hospitals.« Economic Geography 46 (2): I6I-I7I.

Mortimer, D. S. 2002. Competing Methods for Efficiency Measurement: $A$ Systematic Review of Direct DEA vs SFA/DFA Comparisons. Melbourne: Centre for Health Program Evaluation.

Murawski, L., in R. L. Church. 2009. »Improving Accessibility to Rural Health Services: The Maximal Covering Network Improvement Problem.« Socio-Economic Planning Sciences 43 (2): I02-I Io.

Narula, S. C., U. I. Ogbu in H. M. Samuelson. 1977. »An Algorithm for the P-Median Problem.«Operations Research 25 (4): 709-713.

Nattinger, A. B., R. T. Kneusel, R. G. Hoffmann in M. A. Gilligan. 200 I. »Relationship of Distance from a Radiography Facility and Initial Breast Cancer Treatment.« Journal of the National Cancer Institute 93 (17): I344-I346.

Ngui, A., in P. Apparicio. 201 I. \Optimizing the Two-Step Floating Catchment Area Method for Measuring Spatial Accessibility to Medical Clinics in Montreal.« BMC Health Services Research I I (I): I66. https:// doi.org/10.1186/1472-6963-11-166.

Nixon, J., P. Ulmann, J. Glanville, S. Boulenger, M. Drummond in G. Pouvourville. 2004. »The European Network of Health Economic Evaluation Databases Project.« The European Journal of Health Economics 5 (2): $183-187$.

Nunamaker, T. R. 1983. »Measuring Routine Nursing Service Efficiency: A Comparison of Cost per Patient Day and Data Envelopment Analysis Models.« Health Services Research I 8 (2): I83-208.

Nyman, J. in D. L. Bricker. 1989. »Profit Incentives and Technical Efficiency in the Production of Nursing Home Care.« The Review of Economics and Statistics 7 I (4): 586-594. 
Onega, T., E. J. Duell, X. Shi, D. Wang, E. Demidenko in D. Goodman. 2008. »Geographic Access to Cancer Care in the US.« Cancer I I 2 (4): 909-9I8.

O'Neill, L. 1998. »Multifactor Efficiency in Data Envelopment Analysis with an Application to Urban Hospitals.« Health Care Management Science I (I): 19-27.

Openshaw, S. 1984. The Modifiable Areal Unit Problem. Norwich: Geo Books.

OpenStreetMap Wiki Contributors. 2016. »Beginners' Guide.« http://wiki.openstreetmap.org/w/index. php?title=Beginners\%27_guide\&oldid $=$ I 292649 .

Ozcan, Y. A. 2008. Health Care Benchmarking and Performance Evaluation: An Assessment Using Data Envelopment Analysis (DEA). New York: Springer.

Ozcan, Y. A., in R. D. Luke. 1993. »A National Study of the Efficiency of Hospitals in Urban Markets.« Health Services Research 27 (6): 719-739.

Ozgen, H., in A. Y. Ozcan. 2002. »A National Study of Efficiency for Dialysis Centers: An Examination of Market Competition and Facility Characteristics for Production of Multiple Dialysis Outputs.« Health Services Research 37 (3): 7 I I-732.

Pabst Science Publishers. 2010. »Wege ins Krankenhaus: Notaufnahme als 'verlängerte Sprechstunde' - Internet wichtige Entscheidungshilfe.« http://www.pabst-publishers.de/aktuelles/20100504.htm.

Panzar, J. C. 1989. »Technological Determinants of Firm and Industry Structure.« V Handbook of Industrial Organization, ur. R. Schmalensee in R. D. Willing, 3-56. Amsterdam: North-Holland.

Parchman, M. L., in S. D. Culler. 1999. »Preventable Hospitalizations in Primary Care Shortage Areas: An Analysis of Vulnerable Medicare Beneficiaries.« Archives of Family Medicine 8 (6): 487-491.

Parker, E. B., in J. L. Campbell. 1998. »Measuring Access to Primary Medical Care: Some Examples of the Use of Geographical Information Systems.« Health and Place 4 (2): 183-193.

Parker, L., H. O. Dickinson in T. Morton-Jones. 2000. »Proximity to Maternity Services and Stillbirth Risk.« Archives of Disease in Childhood 82 (2): I67-I68.

Pearce, J., K. Witten in P. Bartie. 2006. »Neighborhoods and Health: A GIS Approach to Measuring Community Resource Accessibility.« Journal of Epidemiology and Community Health 60 (5): 389-395. 
Penchansky, R., in J. W. Thomas. 198I. »The Concept of Access: Definition and Relationship to Consumer Satisfaction.« Medical Care I9 (2): I 27-I 4O.

Peng, Z.-R. 1997. »The Jobs-Housing Balance and Urban Commuting.« Urban Studies 34 (8): 1215-1235.

Penrose, E. 2013. The Theory of the Growth of the Firm. Eastford, CT: Martino Fine Books.

Perry, B., in W. Gesler. 2000. »Physical Access to Primary Care in Andean Bolivia.« Social Science and Medicine 50 (9): I I77-I I88.

Peters, D. H., A. Garg, G. Bloom, D. G. Walker, W. R. Brieger in M. H. Rahman. 2008. »Poverty and Access to Health Care in Developing Countries.« Annals of the New York Academy Sciences I 36 (I): I6I-I7I.

Petersen, H. C., in W. C. Lewis I994. Managerial Economics. New York; Toronto: MacMillan.

Phelps, C. E. 2012. Health Economics. Boston, MA: Addison Wesley.

Pindyck, R. S., in D. L. Rubinfeld. 2013. Microeconomics. Boston, MA: Pearson.

Pitt, M. M., in L. F. Lee. 1981. »Measurement and Sources of Technical Inefficiency in the Indonesian Weaving Industry.«Journal of Development Economics 9 (I): 43-64.

Plymouth City Council and Plymouth Hospitals NHS Trust. 2010. Derriford Hospital Accessibility Action Plan - Accessibility Strategy II 20Io2013. Plymouth, CA: Plymouth City Council and Plymouth Hospitals NHS Trust.

Posnett, J. 2002. »Are Bigger Hospitals Better?« V Hospitals in a Changing Europe, ur. M. McKee in J. Healy, ıоo-I8. Buckingham: Open University Press.

Pouvourville, G., P. Ulmann, J. Nixon, S. Boulenger, J. Glanville in M. Drummond. 2005. »The Diffusion of Health Economics Knowledge in Europe: The European Network of Health Economics Evaluation Database Project.« Pharmacoeconomics 23 (2): I I3-I20.

Pps Medico. 201 2. »Tipska regionalna bolnišnica - standardizirana.« Interno gradivo, Pps Medico, d. o. o., Ljubljana.

Prior, D., in M. Solà. 2000. »Technical Efficiency and Economies of Diversification in Health Care.« Health Care Management Science 3 (4): 299-307.

Probst, J. C., S. B. Laditka, J. Y. Wang in A. O. Johnson. 2007. »Effects of Residence and Race on Burden of Travel for Care: Cross Sectional 
Analysis of the 200 I US National Household Travel Survey.«BMC Health Services Research 9 (7): 40. https://doi.org/10.1 186/1472-6963-7-40.

Puig-Junoy, J. 1998. »Technical Efficiency in the Clinical Management of Critically Ill Patients. $\ll$ Health Economics 7 (3): 263-277.

Radke, J., in L. Mu. 2000. »Spatial Decompositions, Modeling and Mapping Service Regions to Predict Access to Social Programs.« Geographic Information Sciences 6 (2): I05-I I 2.

Rahman, S., in D. Smith. 2000. »Use of Location-Allocation Models in health Service Development Planning in Developing Nations.«European Journal of Operational Research I 23 (3): 437-452.

Rao, P. 2003. The Economics of Transaction Costs: Theory, Methods and Application. New York: Palgrave Macmillan.

Ravelli, A. C., K. J. Jager, M. H. de Groot, J. J. Erwich, G. C. Rijninks-van Driel, M. Tromp, M. Eskes, A. Abu-Hanna in B-W. Mol. 20I I. »Travel Time From Home to Hospital and Adverse Perinatal Outcomes in Women at Term in the Netherlands.«BJOG: An International Journal of Obstetrics \& Gynaecology i 8 (7): 457-465.

Rebernik, M. 2008. Ekonomika podjetja. Ljubljana: GV založba.

Reilly, W. J. I93 I. The Law of Retail Gravitation. New York: Knickerbocker.

ReVelle, L. C., in K. Hogan. I989a. »The Maximum Reliability Location Problem And Alphareliable P-Center Problems: Derivatives Of The Probabilistic Location Set Covering Problem.« Annals of Operations Research i 8 (I): 155-174.

ReVelle, L. C., in K. Hogan. 1989b. »The Maximum Availability Location Problem.«Transportation Science 23 (3): 192-200.

Rice, J. A. 2009. Mathematical Statistics and Data Analysis. Belmont, CA: Thomson/Brooks/Cole.

Rosenberg, M. W., in N. T. Hanlon. 1996. »Access and Utilization: A Continuum of Health Service Environments.« Social Science and Medicine 43 (6): 975-984.

Rosenblatt, R. A., in D. M. Lishner. 1991. »Surplus or Shortage? Unraveling the Physician Supply Conundrum.«Western Journal of Medicine I54 (I): 43-50.

Rosenthal, M. B., A. Zaslavsky in J. P. Newhouse. 2005. »The Geographic Distribution of Physicians Revised.« Health Services Research 40 (6): I93 I-1952.

Rosko, M. D. 200I. »Impact of HMO Penetration and Other Environmental Factors on Hospital X-Inefficiency.« Medical Care Research and Review 58 (4): $430-454$. 
Rosko, M. D. 2004. »Performance of U. S. Teaching Hospitals: A Panel Analysis of Cost Inefficiency.« Health Care Management Science 7 (I): 7-I6.

Rouse, P., J. Harrison in L. Chen. 2010. »Australian Accounting Review, Data Envelopment Analysis: A Practical Tool to Measure Performance.«Australian Accounting Review 20 (2): 165-177.

Salsberg, E. S., in G. J. Forte. 2002. »Trends in the Physician Workforce, 1980-2000.《 Health Affairs 21 (5): 165-173.

Samer, H. 2016. »Measuring Efficiency of Governmental Hospitals in Palestine Using Stochastic Frontier Analysis.« Cost Effectiveness and Resource Allocation 14 (3): I-I2.

Samuelson, P. A., in W. D. Nordhaus. 2010. Economics. Boston, MA: McGraw-Hill.

Samuelson, W. F., in W. F. Marks. 2010. Managerial Economics: International Student Version. Hoboken, NJ: Wiley.

Schilling, D., V. Jayaraman in R. Barkhi. 1993. »A Review of Covering Problems in Facility Location.«Location Science I (I): 25-55.

Schmidt, P., in T.-F. Lin. 1984. »Simple Tests of Alternative Specifications in Stochastic Frontier Models.«Journal of Econometrics 24 (3): 349-36I.

Schmidt, P., in R. C. Sickles. 1984. »Production Frontiers and Panel Data.« Journal of Business and Economics Statistics 2 (4): 367-74.

Schonfeld, H. K., J. F. Heston in I. S. Falk. 1972. »Numbers of Physicians Required for Primary Medical Care.« The New England Journal of Medicine 286 (I I): 57 I-576.

Schumpeter, J. A. 2008. Capitalism, Socialism and Democracy. New York: Harper Perennial.

Seiford, L. M., in R. M. Thrall. 1990. »Recent Developments in DEA: The Mathematical Approach to Frontier Analysis.« Journal of Econometrics 46 (I): 7-38.

Shannon, G. W., in G. E. A. Dever. 1974. Health Care Delivery: Spatial Perspectives. New York: McGraw-Hill.

Shen, Q. 1998. »Location Characteristics of Inner-City Neighborhoods and Employment Accessibility of Low-Income Workers.« Environment and Planning B: Planning and Design 25 (3): 345-365.

Shephard, R. W. 1970. Theory of Cost and Production Functions. Princeton, CA: Princeton University Press.

Sherman, H. D. 1984. »Hospital Efficiency Measurement and Evaluation: Empirical Test of a New Technique.« Medical Care 22 (I0): 922-938. 
Shi, L., in B. Starfield. 200 . »The Effect of Primary Care Physician Supply and Income Inequality on Mortality Among Blacks and Whites in US Metropolitan Areas.« American Journal of Public Health 91 (8): I 246-I 250 .

Shi, X., J. Alford-Teaster, T. Onega in D. Wang. 201 2. »Spatial Access and Local Demand for Major Cancer Care Facilities in the United States.« Annals of the Association of American Geographers IO2 (5): I I 25-I I34.

Shi, L., B. Starfield, B. Kennedy in I. Kawachi. 1999. »Income Inequality, Primary Care, and Health Indicators.« The Journal of Family Practice $48(4): 275-284$.

Simar, L., in P. W. Wilson. 2000. Testing Restrictions in Nonparametric Effciency Models. Louvain: Catholique de Louvain - Institut de Statistique.

Simon, H. A., in C. P. Bonini. 1958. »The Size Distribution of Business Firms.« The American Economic Review 48 (4): 607-6r7.

Souza, V. C., in D. P. Strachan. 2005. »Relationship between Travel Time to the Nearest Hospital and Survival from Ruptured Abdominal Aortic Aneurysms: Record Linkage Study.«Journal of Public Health 27 (2): $165-170$.

Spaulding, B. D., in R. G. Cromley. 2007. »Integrating the Maximum Capture Problem into a GIS Framework.«Journal of Geographical Systems $9(3): 267-288$.

Stevenson, R. E. 1980. »Likelihood Functions for Generalised Stochastic Frontier Estimation.«Journal of Econometrics I3 (I): 57-66.

Stiglitz, J. E. 2009. Selected Works of Joseph E. Stiglitz, Volume I: Information and Economic Analysis. Oxford; New York: Oxford University Press.

Straitiff, S., in R. Cromley. 2010. »Using GIS and K = 3 Central Place Lattices for Efficient Solutions to the Location Set-Covering Problem in a Bounded Plane.« Transactions in GIS I 4 (3): 331-349.

Street, A. 2003. »How Much Confidence Should We Place in Efficiency Estimates? « Health Economics I 2 (I I): 895-907.

Street, A., in R. Jacobs. 2002. »Relative Performance Evaluation of the English Acute Hospital Sector.« Applied Economics 34 (9): I ro9-I I 19.

Taaffe, E., H. Gauthier in M. O’Kelly. 1996. Geography of Transportation. Englewood Cliffs, NJ: Prentice Hall.

Tajnikar, M. 2006a. Mikroekonomija s poglavji iz teorije cen. Ljubljana: Ekonomska fakulteta.

Tajnikar, M. 2006b. Tvegano poslovodenje: knjiga o gazelah in rastočih poslih. Portorož: Visoka strokovna šola za podjetništvo. 
Tajnikar, M., in P. Došenović Bonča. 20I I. »Gradivo za predmet Osnove ekonomike zdravstvenega varstva.« Interno gradivo, Ekonomska fakulteta, Ljubljana.

Talen, E., in L. Anselin. 1998. »Assessing Spatial Equity: An Evaluation of Measures of Accessibility to Public Playgrounds.« Environment and Planning A 30 (4): 595-613.

Teitz, M. B., in P. Bart. 1968. » Heuristic Methods for Estimating the Generalised Vertex Median of a Weighted Graph.«Journal of the Operational Research Society of America I6 (5): 955-961.

Teixeira, J., in A. Antunes. 2008. »A Hierarchical Location Model for Public Facility Planning.« European Journal of Operational Research i 85 (I): 92-104.

Thanassoulis, E. 2001. Introduction to the Theory and Application of Data Envelopment Analysis: A Foundation Text with Integrated Software. Boston, MA: Kluwer Academic.

Thanassoulis, E., M. C. S. Portela in O. Despić. 2008. »Data Envelopment Analysis: The Mathematical Programming Approach to Efficiency Analysis.«V The Measurement of Productive Efficiency and Productivity Growth, ur. H. O. Fried, C. A. K. Lovell in S. S. Schmidt, 25I-420. Oxford; New York: Oxford University Press.

Tomintz, M., G. Clarke, J. Rigby in J. Green. 2013. »Optimising the Location of Antenatal Classes.« Midwifery 29 (I): 33-43.

Tommaso, M. R., in S. Dubbini. 2000. Towards a Theory of the Small Firm: Theoretical Aspects and Some Policy. Santiago: United Nations Publications.

Toregas, C., R. Swain, L. C. ReVelle in L. Bergman. 197 I. »The Location of Emergency Service Facilities.« Operations Research I9 (6): 1363-73.

Turrell, G., A. Kavanagh in S. V. Subramanian. 2006. »Area Variation in Mortality in Tasmania (Australia): The Contributions of Socioeconomic Disadvantage, Social Capital and Geographic Remoteness. « Health \& Place 12 (3): 29I-305.

U.S. Department of Health and Human Services. 2002. »Guidelines for Designation as a Dental or Primary Care HPSA.« http://bhpr.hrsa. gov/shortage/hpsas/designationcriteria/medicaldentalhpsaguidelines. html.

U.S. National Advisory Commission on Health Manpower. 1967. Report of the National Advisory Commission. Washington, DC: U.S. Government Printing Office.

»Uredba o kategorizaciji državnih cest.«201 2. Uradni list $R S$, št. IO2/201 2. 
Vining, D. R. 1976. »Autocorrelated Growth Rates and the Pareto Law: A Further Analysis.« Journal of Political Economy 84 (2): 369-380.

Wallis, J., in C. North. 1986. »Measuring the Transaction Sector in the American Economy, 1870-1970.« V Long-Term Factors in American Economic Growth, ur. S. L. Engerman in R. E. Gallman, 95-148. Chicago, IL: University of Chicago Press.

Wan, N., F. B. Zhan, B. Zou in J. G. Wilson. 2013. »Spatial Access to Health Care Services and Disparities in Colorectal Cancer Stage at Diagnosis in Texas.« The Professional Geographer 65 (3): 527-54I.

Wang, F. 201 2. »Measurement, Optimization, and Impact of Health Care Accessibility: A Methodological Review.« Annals of the Association of American Geographers IO2 (5): I IO4-I I I 2.

Wang, H.-J., in P. Schmidt. 2002. »One-Step and Two-Step Estimation of the Effects of Exogenous Variables on Technical Efficiency Levels.«Journal of Productivity Analysis 18 (2): 129-I 44.

Wang, L., M. Rosenberg in L. Lo. 2008. »Ethnicity and Utilization of Family Physicians: A Case Study of Mainland Chinese Immigrants in Toronto, Canada.«Social Science and Medicine 67 (9): I $410-1422$.

Watcharasriroj, B., in J. C. S. Tang. 2004. »The Effects of Size and Information Technology on Hospital Efficiency.« Journal of High Technology Management Research I5 (I): I-I6.

Wei, L., C. C. Lang, F. M. Sullivan, P. Boyle, J. Wang, S. D. Pringle in T. M. MacDonald. 2008. »Impact on Mortality Following First Acute Myocardial Infarction of Distance between Home and Hospital: Cohort Study.«Heart 94 (9): I I 4I-46.

Weinstein, J. N., D. Goodman in J. E. Wennberg. 1998. »The Orthopaedic Workforce: Which Rate is Right?« The Journal of Bone and Joint Surgery, Americn Volume 80 (3): 327-30.

Weis, L. I979. »The Structure Conduct Performance Paradigm and Antitrust.« Penn Law Journals I 27 (4): I I04-40.

Wennberg, J., in A. Gittelsohn. 1973. »Small Area Variations in Health Care Delivery.« Science I82 (I17): I102-8.

Wennberg, J. E., J. L. Freeman in W. J. Culp. 1987. »Are Hospital Services Rationed in New Haven or Over-Utilised in Boston? « Lancet I (8543): I I $85-89$.

White, K. J. 1993. SHAZAM User's Reference Manual Version 7.0. New York: McGraw-Hill.

Williamson, O. E. 1985. The Economic Institutions of Capitalism. New York: The Free Press. 
Williamson, O. E., in S. Winter. 1991. The Nature of the Firm, Origins, Evolution and Development. Oxford: Oxford University Press.

World Health Organization. 2014. World Health Statistics 2014. Ženeva: World Health Organization.

Yaisawarng, S., in J. F. Burgess. 2006. »Performance-Based Budgeting in the Public Sector: An Illustration from the VA Health Care System.« Health Economics is (3): 295-310.

Yang, D. H., R. Goerge, R. in R. Mullner. 2006. »Comparing GIS-Based Methods of Measuring Spatial Accessibility to Health Services.« Journal of Medical Systems 30 (I): 23-32.

Yang, J., in W. Zeng. 20I4. »The Trade-Offs between Efficiency and Quality in the hospital Production: Some Evidence from Shenzhen, China.« China Economic Review 31: 166-84.

You, J.-I. 1995. »Small Firms in Economic Theory.« Cambridge Journal of Economics I9 (3): 44I-62.

Zavod za zdravstveno zavarovanje Slovenije. 20I 4. »Splošni dogovor za pogodbeno leto 20I 4.«Interno gradivo, Zavod za zdravstveno zavarovanje Slovenije, Ljubljana.

Zhu, J. 2003.Quantitative Modelsfor Performance Evaluation and Benchmarking: Data Envelopment Analysis with Spreadsheeds and DEA Excel Solver. Boston, Dordrecht in London: Kluwer Academic Publisher.

Zuckerman, S., J. Hadley in L. Iezzoni. 1994. »Measuring Hospital Efficiency with Frontier Cost Functions.« Journal of Health Economics I3 (3): 255-80.

Zweifel, P., F. Breyer in M. Kifmann. 2009. Health Economics. Dordrecht; New York: Springer.

Žižmond, E., P. Dolenc, A. Delakorda in M. Novak. 2005. Uvod v ekonomijo. Koper: Univerza na Primorskem, Fakulteta. 


\section{Recenziji}

V monografiji avtorica obravnava oblikovanje mreže splošnih bolnišnic v Sloveniji, ki predstavlja eno izmed temeljnih iztočnic pri oblikovanju zdravstvene politike. Pri oblikovanju mreže zdravstvene dejavnosti je treba slediti cilju maksimiranja ekonomske učinkovitosti izvajalcev zdravxstvene dejavnosti in cilju maksimiranja dostopnosti izvajalca zdravstvenih storitev za posameznega bolnika. Osrednji cilj je bil razviti in preizkusiti teoretični model mreže sekundarne zdravstvene dejavnosti v Sloveniji, $s$ katerim je mogoče celovito in na spoznanjih sodobne ekonomske teorije o učinkovitosti, mikroekonomske teorije podjetja in teorije lokacije pojasniti dejavnike mreže sekundarne dejavnosti ter $s$ tem prispevati $\mathrm{k}$ poglobljenemu razumevanju mreže zdravstvenega varstva v Sloveniji in nasploh v svetu. Monografija dokazuje, da lahko na podlagi analiziranja mer učinkovitosti izvajalcev sekundarne zdravstvene dejavnosti, na podlagi definiranja njihove optimalne velikosti in na podlagi opredelitve optimalnih lokacij ter števila izvajalcev sekundarne zdravstvene dejavnosti oblikujemo učinkovito mrežo sekundarne zdravstvene dejavnosti. Raziskava prispeva rezultate in spoznanja, ki so pomembni tako pri poglobljenemu razumevanju mreže sekundarne zdravstvene dejavnosti kot tudi pri razumevanju mreže zdravstvenega varstva nasploh, kar je ključno za oblikovanje učinkovitega zdravstvenega sistema.

Monografiji je napisana $\mathrm{v}$ šestih poglavjih. V uvodnem poglavju avtorica predstavi uvodne misli in obravnavano tematiko. Drugo poglavje obravnava učinkovitost izvajalcev zdravstvene dejavnosti, kjer avtorica preučuje tehnično, alokacijsko in stroškovno učinkovitost slovenskih 
splošnih bolnišnic. V nadaljevanju se v tretjem poglavju avtorica ukvarja z optimalno velikostjo izvajalcev zdravstvene dejavnost, kjer na podlagi diskretne, zvezne in grafične analize določi optimalno velikost slovenske splošne bolnišnice. V četrtem poglavju avtorica preučuje optimalno lokacijo izvajalcev zdravstvene dejavnosti, kjer predstavi obstoječo mrežo sekundarne zdravstvene dejavnosti v Sloveniji in različne možne projekcije postavitve optimalnih lokacij ter števila splošnih bolnišnic v Sloveniji. V petem poglavju so podani ključne smernice postavitve optimalne mreže sekundarne zdravstvene dejavnosti in optimalni modeli mreže splošnih bolnišnic v Sloveniji. V zaključku petega poglavja je predstavljen tudi model raziskovanja mreže zdravstvenega varstva, ki je koristno orodje pri vseh nadaljnjih raziskovanjih na področju zdravstva. Monografija se zaključi s sklepnim poglavjem, v katerem so povzete ključne ugotovitve, kjer avtorica povzame, kako lahko $\mathrm{z}$ analiziranjem učinkovitosti splošnih bolnišnic, definiranjem optimalne velikosti splošne bolnišnice in opredelitvijo optimalnih lokacij ter števila splošnih bolnišnic oblikujemo učinkovito mrežo sekundarne zdravstvene dejavnosti. Pri tem sledi dvema ciljema vsake mreže zdravstvenega varstva, to je cilju maksimiranja učinkovitosti izvajalcev zdravstvene dejavnosti in cilju maksimiranja dostopnosti zdravstvenih storitev za posameznega bolnika. Na ta način je oblikovana mreža sekundarne zdravstvene dejavnosti, ki zagotavlja racionalno obliko delovanja splošnih bolnišnic, hkrati pa prebivalcem omogoča čim večjo dostopnost do bolnišničnih storitev.

Glavni izvirni prispevek monografije k znanosti je oblikovanje učinkovitega modela mreže sekundarne zdravstvene dejavnosti v Sloveniji. Pregled literature pokaže veliko pomanjkanje teoretičnih in empiričnih spoznanj pri raziskovanju mreže zdravstvenega varstva. Mreže sekundarne zdravstvene dejavnosti niso zasnovane na podlagi ekonomskih ocen učinkovitosti, optimalne velikosti, lokacije in števila splošnih bolnišnic, ampak zgolj na osnovi nekaterih posameznih ocen in smiselnosti obstoja določenih izvajalcev sekundarne zdravstvene dejavnosti. Nihče se ni lotil celovite analize ustrezne stopnje koncentracije izvajalcev zdravstvene dejavnosti, ki z doseganjem optimalne velikosti prispeva tudi k ekonomski učinkovitosti njihovega delovanja. Monografija predstavlja znanstveno delo, ki celovito opredeli mrežo sekundarne zdravstvene dejavnosti na podlagi različnih dejavnikov, ki nanjo vplivajo, pri čemer so ključni dejavniki prav analizirane mere tehnične, alokacijske in stroškovne učinkovitosti splošnih bolnišnic, optimalna velikost splošne bolnišnice ter optimalne lokacije in število splošnih bolnišnic.

Tema monografije je zelo aktualna, kar se kaže tudi v izrazito aplikativni vrednosti modela mreže sekundarne zdravstvene dejavnosti. Iz- 
oblikovane so konkretne rešitve, ki predstavljajo osnovo za optimizacijo in reorganizacijo sekundarne zdravstvene dejavnosti v Sloveniji. Model je zasnovan tako, da ga ni mogoče aplicirati samo v slovenskem prostoru, ampak tudi v svetovnem merilu, pri čemer predstavlja koristne teoretične in empirične iztočnice nasploh za vse oblikovalce zdravstvene politike.

Alojz Ihan

II

Monografija vsebuje šest glavnih poglavij. V uvodu avtorica predstavlja opis znanstvenega področja, opredelitev znanstvenega problema, namen ter cilje in izhajajoče predpostavke. V drugem poglavju predstavlja vsebinsko zaokroženo celoto raziskovanja učinkovitosti zdravstvene dejavnosti, tj. teoretične iztočnice preučevanja učinkovitosti, metodologijo za izračun učinkovitosti izvajalcev zdravstvene dejavnosti in seveda rezultate ocenjevanja mer učinkovitosti. V tretjem poglavju predstavlja zaokroženo tematiko optimalne velikosti izvajalcev zdravstvene dejavnosti, kjer prav tako najdemo teoretične iztočnice iskanja optimalne velikosti izvajalca, ustrezno metodologijo in rezultate. Četrto poglavje spet prinaša zaokroženo vsebinsko celoto, kjer si podobno sledijo podpoglavja teoretičnih iztočnic, metodologije in končno rezultatov projekcij postavitve splošnih bolnišnic v Slovenji. V petem poglavju avtorica predstavlja ključne ugotovitve raziskave in posebej opredeljuje ključni prispevek $\mathrm{k}$ znanosti in stroki, hkrati pa opiše tudi možnosti za nadaljnje raziskovanje. V šestem poglavju so podani sklepi, temu pa sledi še seznam uporabljene literature.

V monografiji avtorica obravnava oblikovanje mreže splošnih bolnišnic v Sloveniji, ki predstavlja eno izmed temeljnih iztočnic pri oblikovanju zdravstvene politike. Osrednji cilj je bil razviti in preizkusiti teoretični model mreže sekundarne zdravstvene dejavnosti v Sloveniji, s katerim je mogoče celovito in na spoznanjih sodobne ekonomske teorije o učinkovitosti, mikroekonomske teorije podjetja in teorije lokacije pojasniti dejavnike mreže sekundarne dejavnosti ter $s$ tem prispevati k poglobljenemu razumevanju mreže zdravstvenega varstva v Sloveniji in nasploh v svetu. Monografija dokazuje, da lahko na podlagi analiziranja mer učinkovitosti izvajalcev sekundarne zdravstvene dejavnosti, na podlagi definiranja njihove optimalne velikosti in na podlagi opredelitve optimalnih lokacij ter števila izvajalcev sekundarne zdravstvene dejavnosti oblikuje- 
mo učinkovito mrežo sekundarne zdravstvene dejavnosti. Raziskava prispeva rezultate in spoznanja, ki so pomembni tako pri poglobljenemu razumevanju mreže sekundarne zdravstvene dejavnosti kot tudi pri razumevanju mreže zdravstvenega varstva nasploh, kar je ključno za oblikovanje učinkovitega zdravstvenega sistema.

Monografiji je napisana v šestih poglavjih. Delo vključuje 23 preglednic in 45 slik, I 8 strani oziroma 325 virov literature. Avtorica je uporabljali tako domačo kot predvsem tujo literaturo. Uporabila je tri metodološke pristope glede na tri analitične in med seboj povezane dele raziskave. $\mathrm{V}$ prvem delu je z metodo deskripcije in vzročno-posledične analize ter metodami klasifikacije, primerjave in sinteze kritično podala pregled literature na področju empiričnega in teoretičnega preučevanja učinkovitosti v zdravstvu. V drugem delu je opredelila teoretične iztočnice, na osnovi katerih je v nadaljevanju postavila mikroekonomski model optimalne velikosti slovenske splošne bolnišnice. $V$ tretjem delu je izdelala pregled zasnov, metod in problemov prostorske dostopnosti izvajalcev zdravstvene dejavnosti. Avtorica je oblikovala optimalni model mreže sekundarne zdravstvene dejavnosti, s katerim se ustvarijo pomembni prihranki ne samo znotraj sekundarne zdravstvene dejavnosti, ampak tudi v celotnem sistemu zdravstvenega varstva.

Tematika je izjemno kompleksna in na tovrstnem področju tako obsežno zasnovanega dela še ni bilo, niti v svetu, še manj v Sloveniji. Osnovna teza je kompleksna in popolnoma izvirno postavljena, iz nje izhaja potreba po specifični metodologiji, ki je v Sloveniji doslej v tovrstnih raziskavah še niso uporabljali. Delo temelji na nekaterih popolnoma novih, ustvarjalnih in samosvojih rešitvah, ki omogočajo uporabo potrebnih podatkov na povsem nov in izviren način. $Z$ vidika metodologije raziskovanja monografija prinaša kar nekaj ključni izvirnih prispevkov k znanosti. Mednje prištevamo kompleksno metodologijo, s katero se je avtorica lotila raziskovanja problematike učinkovitosti, velikosti in lokacije izvajalcev zdravstvene dejavnosti. Izviren prispevek se kaže tudi skozi reševanje problemov definiranja kompozitnih spremenljivk, ki na nov način predstavljajo storitve izvajalcev zdravstvenega varstva in ponderirajo njihovo težo. Prav tako je izvirna metodologija za postavitev optimalnih lokacij. Na osnovi teh izvirnih prispevkov je avtorica postavila smernice za raziskovanje tudi nekaterih drugih fenomenov in storitev znotraj izvajalcev zdravstvene dejavnosti. Nenazadnje je izviren prispevek model mreže sekundarne zdravstvene dejavnosti, ki predstavlja čisto nov pristop $\mathrm{k}$ reševanju omenjene problematike. $\mathrm{Z}$ metodološkega stališča je poglavitni 
prispevek monografije definiranje mreže sekundarne zdravstvene dejavnosti, ki ga doslej ni bilo mogoče zaslediti nikjer na svetu. Seveda pa ima delo tudi veliko in zelo široko aplikativno vrednost za slovensko zdravstveno politiko.

\section{Gaj Vidmar}




$$
8
$$

